
From the collection of the

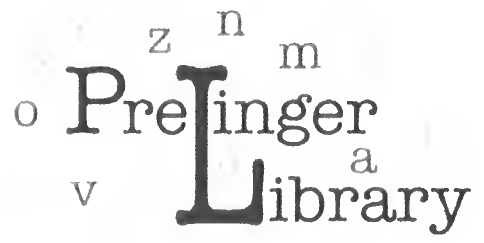

t

p

San Francisco, California 2006 
4.0

Mr. Frack

2425 Aroolacy st

Beskelén

Thrommall 1367

Parific States Sarnigst
form C. 145 Market St c. F. 

ELEMENTS OF THE MODERN BUILDING AND LOAN ASSOCIATIONS

\section{LAND ECONOMICS SERIES}

Edited by RICHARD T. ELY, PH.D., LL.D.

Director of the Institute for Research in Land Economics and Public Utilities, Professor of Economics, in the University of Wisconsin.

UNITED STATES LEAGUE OF LOCAL BUILDING AND LOAN ASSOCIATIONS

AMERICAN SAVINGS, BUILDING AND LOAN INSTITUTE

UNITED Y. M. C. A. SCHOOLS

INSTITUTE FOR RESEARCH IN LAND ECONOMICS AND PUBLIC UTILITIES

NATIONAL ASCOCIATION OF REAL ESTATE BOARDS 


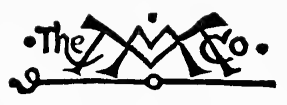

THE MACMILLAN COMPANY

INEW YORK - BOSTON - CHICAGO - DALLAS ATLANTA - SAN FRANCISCO

\section{MACMILLAN \& CO., Limited \\ LONDON - BOMBAY - CALCUTTA MELBOURNE}

THE MACMILlaN CO. OF CANADA, Lmo. TORONTO 


\section{LAND ECONOMICS SERIES}

The Law of City Planning and Zoning by Williams

*Principles of Real Estate Practice by Fisher

*Elements of Land Economics by ElyMorehouse

*The Appraisal of Real Estate by Babcock

A History of Public Land Policies by Hibbard

*Elements of the Modern Building and Loan Associations by Clark-Chase

*Books that have been approved for Standard Real Estate Course. 


\title{
ELEMENTS OF THE MODERN BUILDING AND LOAN ASSOCIATIONS
}

\author{
VOLUME IV in the \\ STANDARD COURSE IN \\ REAL ESTATE \\ Outlined by the \\ JOINT COMMISSION \\ Representing
}

The National Association of Real Estate Boards, The United Y. M. C. A. Schools

The Institute for Research in Land Economics and Public Utilities

and

The American Savings, Building and Loan Institute 


\title{
ELEMENTS OF THE MODERN BUILDING AND LOAN ASSOCIATIONS
}

\author{
BY \\ HORACE F. CLARK, Ph.D. (Wisconsin) \\ ECONOMIST, AMERICAN SAVINGS, BUILDING AND LOAN INSTITUTE \\ (FORMERLY WITH THE DEPARTMENT OF ECONOMICS, UNIVERSITY \\ OF WISCONSIN) \\ AND \\ FRANK A. CHASE \\ GENZRAL MANAGER, AMERICAN SAVITGS, BUILDING AND LOAN INSTITUTE
}

A text-book prepared as a part of the educational program of the American Savings, Building and Loan Institute.

\section{丹ew Fork}

THE MACMILLAN COMPANY

I927

All rights reserved 
COPYRIGHT, 1925,

By THE MACMILLAN COMPANY.

Set up and electrotyped.

Published May, 1925.

Printed in the United States of America by

J. J. LITTLE AND IVES COMPANY, NEW YORK 


\section{ACKNOWLEDGMENT}

This text-book has been prepared at the request of the United States League of Local Building and Loan Associations, and has been worked out under the direction of the Text-book Committee of the League. It is a part of the educational program which is being made available to building and loan people and students by the American Savings, Building and Loan Institute, a non-profit, educational corporation organized in coöperation with the League for this purpose. The book is the outgrowth of the movement started many years ago within the League by Henry S. Rosenthal, Mark D. Rider, H. A. Schroetter, James R. Moorehead, and others. The Text-book Committee, under whose direction it has been prepared consists of Ward B. Whitlock, Chairman, R. Holtby Myers, Franklin P. Stevens, and Prof. Richard T. Ely.

The extensive investigations which were necessary in compiling the material on which the text is based have been financed by voluntary contributions from many sources, and we desire to express our gratitude to the many friends who have made the work possible. Among those who have liberally aided us throughout the long period of preparation should be mentioned the following:

National Lumber Manufacturers' Association

Southern Pine Association

National-American Wholesale Lumber Association

Southwestern Lumbermen's Association

Northeastern Retail Lumber Dealers' Association

Hoo Hoo-the fraternal organization of lumbermen

Kansas, Nebraska, and Missouri State Building and Loan Leagues 
Many individual building and loan associations throughout the United States

All the officers of the United States League of Local Building and Loan Associations, and many officers of individual associations.

The work could not have been completed without the hearty support which has been extended to us by the many loyal and broad-minded building and loan men and women throughout the country. All of the officials of the United States League, many officers of the state leagues, officers of hundreds of individual associations, and the state supervisors of building and loan have given freely of their time in answering our questions and in correcting errors which have come to their attention in the manuscript and proofs.

Dr. Ely's staff in the Institute for Research in Land Economics and Public Utilities has rendered valuable assistance in research and editorial revision.

To name all the individuals to whom thanks are due, it would be necessary to print a roster of all the prominent people in the movement. Miss Ann E. Rae, president of the United States League, I923-24, Wm. R. Adair, president I $924-25$, H. F. Cellarius, Secretary of the League since its organization in 1893 , and Henry S. Rosenthal have been most generous in their help. Hon. Charles O'Connor Hennessy was among the number whose inspiration led to getting the work under way.

Dr. W. A. Scott, Professor of Economics of the University of Wisconsin, has read a large portion of the manuscript and made many helpful criticisms both of the material and the method of presenting it. Certain other economists have offered suggestions and criticisms of the outline of the book while it was under preparation. The suggestions of all these men have been considered and wherever possible they bave been incorporated in the text.

Three students of the University of Wisconsin, Eugene 
M. S. Shen, Walter T. Peterson, and Laurens G. Hastings, have written theses on certain phases of the work under our direction and the results of their studies have been incorporated in the text-book. Dr. Mary L. Shine has carefully revised the entire manuscript and assisted materially in getting it ready for the printer. Mr. E. G. Giessel has rendered help far in excess of that which came within the line of his duties as research assistant. The authors assume full responsibility, however, for all statements made in the book.

The Authors. 
- 


\section{PREFACE}

With the growing interest in building and loan associations on the part of students of finance generally, and especially among those who are already employed as officers and clerks of these associations, the need for an adequate text-book on the subject has been felt for several years. An increasing number of people have organized themselves into study clubs or "chapters" and have undertaken to develop complete courses of study which will perfect them in their future work. Colleges and universities are planning courses in the field, supplementing the traditional courses in finance. Correspondence courses are being arranged for those unable to meet with others for the purpose of undertaking such study.

For all of these purposes, this text-book is offered. It is based on the practical experience of the authors in the field and in the classroom. It is the first complete attempt at a text-book which covers the whole field and not merely a few specialized parts of it.

Our study of the subject makes no pretense of being the last word on building and loan associations. It is more in the nature of a survey, but we have tried to explain every essential part of the work. We pass in review every known phase of this most interesting and complex financial institution. Wherever space has compelled us to omit complete explanations, directions for finding further information are indicated.

These associations are of great value to hundreds of people besides wage earners, for whom they were originally started. The business man, safeguarding his future, may wisely estab- 
lish a reserve or sinking fund to meet a known or unknown future need, and the most reliable means of accumulating such a fund is through systematically setting aside a certain sum for this purpose. The housewife may frequently insure the realization of her desire for a real home in the same way. Even the child may be assured of educational advantages and business success by the practice of systematic saving, industry, and thrift. A knowledge of the operations of building and loan associations may contribute to this end.

In this book we have tried to lay the foundation, so that the man who is willing to spend a reasonable amount of time with it may go on to a complete understanding of the whole subject of building and loan associations with very little effort. If our work will set other men to clearing away the stumbling blocks that lie in the path of progress in some sections of the country, it will not have been in vain. Some of these obstacles are legal, some are economic, a few are accidental, but all of them are human. This big, vital, progressive institution is threatened with serious injury in a few states. When greed enters the door, philanthropic coöperation has a poor chance to survive under the same roof.

We have tried to prepare a text-book that will enable the association official who is desirous of improving the efficiency of his business to find the weak spots; one that will show the student who knows nothing of the subject just what these associations are, how they are organized and conducted, and how to become an effective worker in a field which is only partially developed. It can be used by individuals working alone or by correspondence, and in classroom and chapter meetings as a text-book for the course in building and loan associations.

Some of our conclusions are given in detail, but the complexity of association business in the United States is such that too many details would cover up the interesting and important ideas. The fundamental principles are comparatively few 
in number, and they may easily be understood by a little careful study.

A few parts of the book are designed to aid in highly technical matters, such as appraisal. Where the technical material is not needed by the student, it can be overlooked without destroying the continuity of the book.

By making use of the index, men who wish to start new associations on any particular plan, or to change from one plan to another, will find that the book offers many valuable suggestions in rather definite form. This information can be obtained without a complete study of the remainder of the book, if desired. The basis on which a particular plan should be selected will be found discussed concisely in Chapter III, and criticisms of each of the plans will be found toward the close of that chapter.

One particular part of our investigations has been directed toward clearing up the unnecessarily troublesome business procedure used by some associations. This detail work takes the time and energy of officials, when they might be developing and broadening the policies of their business. No one can prescribe remedies for economic difficulties without knowing the causes any more than for a physical disease. We have tried to find some of these causes, and in a few cases, at least, we seem to have been successful. Whenever we have found the cause, we have tried to show the methods that have aided some other associations in overcoming similar difficulties.

It is earnestly hoped that this volume may be helpful to thousands who wish a business career combined with a great service to humanity. In this sense only can the book be considered "propaganda" for the movement. On the other hand, we wish most effectively to discourage the activities of the get-rich-quick promoter and the fraudulent schemes operating under the guise of building and loan associations.

We are issuing this book as it is, in the belief that the representative building and loan associations of to-day have 
nothing to fear from the truth, and in the hope that it will help to eradicate many practices that have cast discredit upon them.

Horace F. Clark

Frank A. Chase

March $16,1925$. 


\section{EDITOR'S PREFACE}

The rapid growth in recent years of building and loan associations-both in number and in assets-has brought a demand for information concerning this particular form of financial institution from many quarters-from those who are engaged in finance, from the student of general economics, from the sociologist who has noted the social effects of their promotion of home ownership, and from the real estate dealer who finds the work of the association so closely related to his own.

Because of this intimate connection of the building and loan association with the work of real estate dealers and brokers, the present volume is appearing in the "Land Economics Series," in which several books are sponsored by the Joint Committee on Real Estate Education, representing the National Association of Real Estate Boards, the United Y. M. C. A. Schools, the Association of Collegiate Schools of Business, and the Institute for Research in Land Economics and Public Utilities. (Titles of the other books of this series are to be found on page iii.) It is intended to put the real estate man in possession of all necessary information about the use of this form of real estate credit, which, because of its use of the amortization principle, permits so great a liberality in the matter of loans without overstepping the boundary of sound financial policy.

Its appearance in this series does not mean, however, that the book has been written with the needs of real estate dealers solely in view. On the contrary, the writers have designed the book as a guide for those actually engaged in the building and loan business, as well as for those who are planning the 
organization of an association and are under the necessity of choosing the plan to be used and of working out details of the organization in such a way as to satisfy the law of the particular state in which the association expects to operate.

While parts of the book are designed to meet the needs of the two groups that have been mentioned, the general discussion will, it is hoped, supply the information on the subject that is desired by students of finance, general economists, sociologists, and others. Few people realize the economic significance or magnitude of building and loan associations as financial institutions. It has often been remarked that the American home, so largely owned by its occupants, is distinctive of our national life with its high standard of wellbeing. Yet it is not often understood that building and loan associations have played a large part in giving this distinction to our American way of life. As financial institutions, building and loan associations have assets of some four billion dollars built up by the savings of over seven million members. As institutions in our economic life, they give people of moderate means an opportunity of periodic saving and gradual acquirement of home ownership.

It is my great confidence in the building and loan association as a means of promoting economic welfare that makes me glad to present this work, which aims not only to explain the system but to lay down principles, observance of which will keep this splendid movement on a high plane.

RICHARD T. ELy, Editor. 


\section{CONTENTS}

Part I. Nature of the Building and Loan Association CHAPTER

I. What is the building and loan association? . . . . . I

II. The place of the building and loan association in the financial organization of the community . . . . 18

III. Different "plans" under which associations work . . . 32

IV. Kinds of shares issued . . . . . . . . . . 63

Part II. Planning the Buildirg and Loan Assoctatton

V. Starting an association: How? When? Where? Choice of plan for a given association: Meeting legitimate competition, etc.

Part III. Conducting and Developing the Business

VI. Organizing the personnel: (Selecting the "key" men, committees, staff, counsel, provision for surety bonds, etc.) 93

VII. Sources of funds: (a) From members, I 10; (b) Deposits I3I

VIII. General financial policy: Determining the interest rate, advantages and disadvantages of fees, fines, forfeitures, etc. . . . . . . . . . . . . . . . . I $\mathbf{3 4}$

IX. General financial policy (continued): Withdrawals . . 165

X. Making the loan . . . . . . . . . . . Igo

XI. Making the loan: Appraisals . . . . . . . 230

XII. The borrower and the association . . . . . 248

XIII. Accounting methods . . . . . . . . . . 267

XIV. Development of the business: (A discussion of successful methods of extension) . . . . . . . . 303

XV. The use of juvenile savings . . . . . . . . 323

Part IV. Earnings and Their Distribution

XVI. Earnings and expenses . . . . . . . . . . 334

XVII. Use of contingent-reserve fund . . . . . . . $34^{2}$

XVIII. Distribution of profits: Dividend policy . . . . 35 I 


\section{Part V. Regulation and Laws}

CHAPTER

XIX. State and federal regulation and audit . . . . 363

XX. State laws . . . . . . . . . . 385

XXI. Taxation . . . . . . . . . . . 4 415

Part VI. The Association as a Builder of National THRIFT AND HOME OWNERSHIP

XXII. Economic considerations in building and borrowing • 439 XXIII. History . . . . . . . . . . . . . $45^{2}$

Part VII. Cooperation as the Basis of Expansion

XXIV. Leagues, institutes, and systems . . . . . . . 476

$\mathrm{XXV}$. Trained leadership as the safeguard for the movement 489

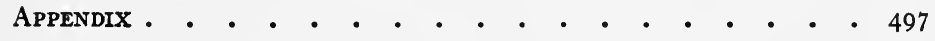

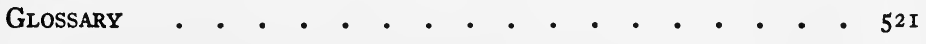

INDEX . • • • • • • • • • . • • • • 527 
ELEMENTS OF THE MODERN BUILDING AND LOAN ASSOCIATIONS 

UNITED STATES ACCORDING TO RECENT REPORTS

\begin{tabular}{|c|c|c|c|c|c|}
\hline STATE & $\begin{array}{l}\text { NUMBER } \\
\text { OF } \\
\text { ASSOCI- } \\
\text { ATIONS } \\
\end{array}$ & Assets & MEMBERS & DATE & $\begin{array}{l}\text { Estimated OR } \\
\text { REPORTED BY }\end{array}$ \\
\hline Totals & 11,854 & $\$ 4,660,809,495.19$ & & & \\
\hline $\begin{array}{l}\text { Alabama } \\
\text { Arizona } \\
\text { Arkansas }\end{array}$ & $\begin{array}{r}8 \\
5 \\
59\end{array}$ & $\begin{array}{c}\$ 6,000,000.00^{*} \\
2,698,158.30 \\
24,848,268.40\end{array}$ & $\begin{array}{l}\cdots \ldots \\
399,267\end{array}$ & $\begin{array}{l}\text { Dec. } 31,1924 \\
\text { do } \\
\text { do }\end{array}$ & $\begin{array}{l}\text { Clark and Chase } \\
\text { State Supervisor } \\
\text { Secretary of State }\end{array}$ \\
\hline $\begin{array}{l}\text { Callfornia : : } \\
\text { Colorado } \\
\text { Connecticut : }\end{array}$ & $\begin{array}{r}157 \\
52 \\
34\end{array}$ & $\begin{array}{r}127,500,000.00 \\
22,913,014.11 \\
17,784,862.56\end{array}$ & $\begin{array}{l}\dot{47}, \mathbf{3 2 1} 1 \\
33,877\end{array}$ & $\begin{array}{l}\text { do } \\
\text { June } 30,1924 \\
\text { Sept. } 30 \text { and }\end{array}$ & $\begin{array}{l}\text { League } \\
\text { State Supervisor } \\
\text { do } \\
\text { do }\end{array}$ \\
\hline Delaware . . & 37 & $6,201,168.00$ & .. & $\begin{array}{l}\text { Dec. } 31,1924 \\
\text { or fiscal years }\end{array}$ & do \\
\hline $\begin{array}{l}\text { District of } \\
\text { Columbia } \\
\text { Florida . . }\end{array}$ & $\begin{array}{l}23 \\
25\end{array}$ & $\begin{array}{l}40,467,000.00 \\
15,450,000.00 *\end{array}$ & $\begin{array}{l}57,234 \\
10,000 *\end{array}$ & $\begin{array}{l}\text { June 30, } 1924 \\
\text { Dec. } 31,1924\end{array}$ & Treasury Dept. \\
\hline Georgla 1 . & 8 & $1,000,000.00^{*}$ & . & do & $\begin{array}{l}\text { League } \\
\text { Securitles }\end{array}$ \\
\hline $\begin{array}{l}\text { Idaho } \cdot:: \\
\text { Illinols : : } \\
\text { Indiana : : } \\
\text { Iowa } \\
\text { Kansas } 2: \\
\text { Kentucky : : } \\
\text { Louisiana : } \\
\text { Maine } \\
\text { Maryland : : }\end{array}$ & $\begin{array}{r}9 \\
827 \\
380 \\
74 \\
143 \\
140 \\
80 \\
39 \\
1,100^{*}\end{array}$ & $\begin{array}{c}3,260,000.00^{*} \\
241,408,951.81^{*} \\
192,025,913.59 \\
33,309,994.62 \\
78,782,160.75^{2} \\
55,196,457.08 \\
106,931,401.24 \\
15,399,532.64 \\
180,000,000.00^{*}\end{array}$ & 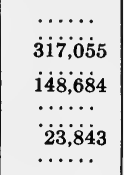 & \begin{tabular}{|c|}
$\begin{array}{c}\text { do } \\
\text { do } \\
\text { do } \\
\text { do } \\
\text { do }\end{array}$ \\
June 30,1924 \\
Dec. 31,1924 \\
do \\
do
\end{tabular} & $\begin{array}{c}\text { A. O. Rennison } \\
\text { State Supervisor } \\
\text { do } \\
\text { do } \\
\text { do } \\
\text { do } \\
\text { Wm. Pfaff } \\
\text { State Supervlsor } \\
\text { Samuel T. Rich- }\end{array}$ \\
\hline $\begin{array}{l}\text { Massachusetts } \\
\text { Michlgan : : } \\
\text { Minnesota : } \\
\text { Mississippi : } \\
\text { Missouri : : } \\
\text { Montana : : }\end{array}$ & $\begin{array}{r}213 \\
78 \\
84 \\
40 \\
216 \\
30\end{array}$ & $\begin{array}{c}311,962,791.49 \\
80,302,267.22 \\
20,839,953.65 \\
7,000,000.00 * \\
93,557,805.23 \\
11,649,271.62\end{array}$ & $\begin{array}{l}382,268 \\
\ddot{3} \dot{2} \dot{2} \dot{51} \\
\dot{1} \dot{5} \dot{4}, \dot{8} \dot{0} \\
\cdots \cdots\end{array}$ & $\begin{array}{l}\text { Oct. 31, } 1924 \\
\text { June 30, } 1924 \\
\text { do } \\
\text { Dec. 31, 1924 } \\
\text { Aug. 31, 1924 } \\
\text { End of fiscal } \\
\text { years 1924 }\end{array}$ & $\begin{array}{c}\text { ards, Baltimore } \\
\text { State Supervisor } \\
\text { do } \\
\text { do } \\
\text { W. O. Rae } \\
\text { State Supervisor } \\
\text { Secretary of State }\end{array}$ \\
\hline $\begin{array}{l}\text { Nebraska : } \\
\text { Nevada : } \\
\text { New Hampshire } \\
\text { New Jersey } \\
\text { New Mexlco : } \\
\text { New York } \\
\text { North Caroilna } \\
\text { North Dakota } \\
\text { Ohlo 3 : : } \\
\text { Oklahoma : } \\
\text { Oregon } \\
\text { Pennsylvania }\end{array}$ & $\begin{array}{r}82 \\
1 \\
28 \\
1,282 \\
11 \\
300 \\
225 \\
16 \\
822 \\
86 \\
30 \\
4,400 *\end{array}$ & $\begin{array}{r}123,021,650.27 \\
270,300.67 \\
7,330,534.34 \\
589,000,000.00 * \\
2,425,592.72 \\
217,007,141.00 \\
57,835,955.43 \\
6,175,157.45 \\
765,625,166.68 \\
77,788,006.42 \\
41,129,518.07 \\
741,539,681.02\end{array}$ & $\begin{array}{c}\ldots \ldots \\
i \dot{14}, 221 \\
900,000^{*} \\
\dot{408,996} \\
79,154 \\
1,966,128^{3} \\
121,442 \\
1,412,072\end{array}$ & $\begin{array}{c}\text { June 30,1924 } \\
\text { Dec. 31, 1924 } \\
\text { June 30,1924 } \\
\text { Dec. 31, 1924 } \\
\text { Dec. 31, 1923 } \\
\text { Dec. 31, 1924 } \\
\text { Dec. 31, 1923 } \\
\text { June. 30, 1924 } \\
\text { do } \\
\text { Dec. 31, 1924 } \\
\text { June 30, 1924 } \\
\text { Fisca] years }\end{array}$ & $\begin{array}{l}\text { State Supervisor } \\
\text { C. R. Carter, Reno } \\
\text { State Supervisor } \\
\text { do } \\
\text { do } \\
\text { do } \\
\text { do } \\
\text { do } \\
\text { do } \\
\text { do } \\
\text { do } \\
\text { do }\end{array}$ \\
\hline $\begin{array}{l}\text { Rhode Island } \\
\text { South Carolina } \\
\text { South Dakota } \\
\text { Tennessee. } \\
\text { Texas . . . . }\end{array}$ & $\begin{array}{r}7 \\
154 \\
22 \\
14 \\
108\end{array}$ & $\begin{array}{r}17,075,323.50 \\
20,000,000.00^{*} \\
4,860,146.21 \\
4,477,899.34 \\
23,014,683.87\end{array}$ & $\begin{array}{l}29,248 \\
21,000^{*} \\
\cdots \cdots \cdots \\
\cdots \cdots \\
\cdots \cdots\end{array}$ & $\begin{array}{l}\text { Dec. 31, } 1924 \\
\text { do } \\
\text { Dec. 31, } 1923 \\
\text { June } 30,1924 \\
\text { Dec. } 31,1923\end{array}$ & $\begin{array}{l}\text { do } \\
\text { E. O. Black } \\
\text { State Supervisor } \\
\text { do } \\
\text { From "Thrift }\end{array}$ \\
\hline Utah & 24 & $23,250,491.59$ & $65,000 *$ & Dec. 31,1924 & Secretary of State \\
\hline Vermont & 86 & $1,568,208.92 *$ & $3,200^{*}$ & $\begin{array}{l}\text { do } \\
\text { do }\end{array}$ & $\begin{array}{l}\text { Association Re- } \\
\text { ports and State } \\
\text { Supervisor } \\
\text { John A. Lesner, } \\
\text { Norfolk }\end{array}$ \\
\hline $\begin{array}{l}\text { Washlngton } \\
\text { West Virglnia } \\
\text { Wisconsin : } \\
\text { Wyoming : }\end{array}$ & $\begin{array}{r}61 \\
61 \\
155 \\
11\end{array}$ & $\begin{array}{c}59,774,836.12 \\
23,256,758.17 \\
118,182,354.19 \\
9,711,117.00^{*}\end{array}$ & $\begin{array}{r}160,000^{*} \\
168,613 \\
8,700^{*}\end{array}$ & $\begin{array}{l}\text { do } \\
\text { June 30, } 1924 \\
\text { Dec. 31, } 1924 \\
\text { do }\end{array}$ & $\begin{array}{l}\text { State Supervisor } \\
\text { do } \\
\text { do } \\
\text { M. A. Chapman, } \\
\text { Cheyenne }\end{array}$ \\
\hline
\end{tabular}

* Estimated. T. B. Conner, Chatrman, Georgia Securities Commission. Private organizations with bullding and loan features would run total to about $\$ 2,250,000$.

2 Kansas figures for 138 associations, 5 not reported.

Ohlo: Estimate as of January 1, 1925: Assets \$850,000,000

As of June 30, 1924: Stockholders 837,910

Depositors 851,776

Borrowers 276,442 


\title{
PART I
}

\section{NATURE OF THE BUILDING AND LOAN ASSOCIATION}

\author{
CHAPTER I
}

\section{WHAT IS THE BUILDING AND LOAN ASSOCIATION?}

The practical problems of building and loan associations; functions of building and loan associations-to promote thrift and home ownership; figures showing relative position in United States; success primarily due to use of the principle of amortization; the weakness of the lump-sum payment of a debt; amortization-its nature, its advantages, and its results; building and loan associations defined; example of loan operation; repayment before maturity; protection through foreclosure; source of funds; diversification of corporate title and terms used; slow vs. liquidating credits; advantages of association to the prospective home owner, the savings member, the employer, and the community.

It is sometimes said that the average American is more or less thriftless, and expects that his fortune will be made through a lucky chance. If this were true, there would be even a wider gap than now exists between those with fortunes and those without. But like many other half truths, it overlooks a most important part of our economic life. It is merely idle to talk about undue extravagance, for this does not coincide with the facts about our people's savings. Side by side with our large expenditures for luxuries and pleasures, we find a host of expenditures for capital goods that contribute to the progress of our time. And most of our capital is saved in comparatively small sums in institutions designed primarily to promote thrift and to accumulate a cash reserve.

Perhaps it may be said that we depend too largely upon 
chance for the larger rewards of life. But for the smaller things that make for a successful, progressive community, we do not take so many chances as popular opinion would have us believe. During the time that young men and women are watching for the great opportunity that will mean a competence for them, hundreds and thousands of them are putting aside small sums each pay day toward that unknown rainy day which is sure to be ahead. They may be looking toward the chance of big gains, suddenly achieved, but they have not forgotten the smaller things, as so many demagogues would have us believe. If they had, insurance companies would be out of business, investment companies would close their doors, and the general business life of our country would lag. All hese concerns help to furnish the capital with which business is carried on, and they get it principally in small amounts from individual customers, who have a limited store of savings.

Among the investment companies, the building and loan association has taken an inconspicuous but nevertheless important part. There is one of them for every 9,5 I4 of the people of the United States, yet comparatively few people know how they operate. There are more associations than the total number of national banks, and there are more than onethird as many as all the banks combined, including national, state, and private. In 1924 they had assets amounting to $\$ 3,94^{2}, 939,880$ or $\$ 37.30$ for every man, woman, and child in the entire United States in 1920, and they had a membership of $7,202,880$ persons. ${ }^{1}$

Most of the money of the modern building and loan association is invested in homes which members are buying through systematic payments. It is impossible to say how many homes have been purchased with the aid of building and loan associations during the past ninety-four years, but in a few districts more than half the home owners have been aided. In r923 one association in Michigan loaned $\$ 1,600,000$, which

${ }^{1}$ In 1923, national banks numbered 8,234, all banks 30,112 , and building and loan associations 10,009 . 
brought its total mortgage loans in 32 years up to $\$ 12,500,000$. This increased business was transacted at an average expense of less than one-half of one per cent of its assets. A Missouri association made 2,390 real estate loans in 1923, making a total of 14,366 since it was established. Probably 70 per cent of these loans were used for new construction, 15 per cent to aid in buying homes already constructed, and 15 per cent in taking up existing mortgages. More than $\$ 3,000,000$ was advanced to 542 families by one New York association in I923, for aid in home purchasing; one association in Ohio has made 34,000 loans since its organization; and in Nebraska there is a record of nearly 15,000 loans by one association in eleven years, amounting to approximately $\$ 39,000,000$. It has been estimated that 360,000 loans were made by building and loan associations in 1923 to aid in acquiring homes.

While one group of members of these associations is thus being aided to home ownership at reasonable rates of interest, another group is being aided to financial independence through the profits received on their savings. The building and loan association acts merely as a clearing house through which the savings of these members are made available to those who wish to borrow. The profits of the savings members are not large, but they are usually more than the rate paid by other safe types of investment, and the degree of safety is not less than that of the savings bank.

Thrift and Home Ownership as Community Ideals.When it is realized that there is perhaps a hoard of money to the extent of $\$ 400,000,000$ in cash put away by people in hiding places outside of the banks of the United States, ${ }^{2}$ it will be seen that there is a need for further development of institutions for the promotion of thrift.

Building and loan associations have been characterized in years past by such men as Judge Durack of New York, as: "An organized effort to extract concrete wealth from aggregated

\footnotetext{
2 Estimate of Joseph S. McCoy in the American Bankers' Association Journal.
} 
poverty." This phrase may be too concise, but it shows fairly well the real purpose of these associations.

A recent president of the United States League of Local Building and Loan Associations said that "Our associations are serving just two classes of customers: receiving the savings of thrifty and far-seeing people, and loaning these funds to members who wish to buy or build a home. Never was the need for building or owning a home greater than in the past few years, and as you well know, lack of sufficient funds has been one of our greatest problems." 3

Building and loan associations started as neighborhood clubs in most parts of the country. Neighbors wished to become home owners and began contributing a certain sum monthly to a treasurer. The aggregate of these monthly payments was soon sufficient to buy or build a home for one of the members. The fund was then loaned to one of them, and as other funds accumulated, others could borrow. The joint purposes of thrift and home ownership are inseparable and are of equal importance. There could be no coöperative building and loan association without both.

"Even in that neighborhood club, there were those who were able to pay more than others, and there were those who desired better homes than others, and to accommodate these varying capacities and desires, shares were introduced. The man who vas able to pay more money than his fellow members took more shares, and the one who wanted a better home than the average also took more shares, and thus obtained a larger loan and a second step in the upward climb." 4

The community ideals which are served by these associations are appreciated throughout the country. "A building and loan

${ }^{2}$ From the Report of Miss Ann E. Rae at the 35th Annual Convention of the New York State League of Savings and Loan Associations, 1922. Proceedings, 1922, p. 15. Miss Rae served as president of the New York State League 1921-22, and of the United States League 1923-24.

' From the address of James M. McKay, Manager, Home Savings and Loan Company, Youngstown, Ohio, before the New York State League of Savings and Loan Associations, 1922. 
association is not a philanthropy, it is a straight business proposition in which a valuable service is rendered to the borrower and is paid for by him at a rate which produces a reasonable profit on the investment. Thus the business is fair and beneficial to both sides. Such an association gathers up the savings of small investors and puts them to work by financing the building of homes. By reason of the installment plan of repayment spread over from five to ten years of monthly dues, the borrower is able to pay for his home out of his earnings." 5

Thrift is by no means as trite a subject for discussion as some would have us believe. "Thrift is a disciplinarian. It breeds virility. It strikes at sensuality, self-indulgence, flabbiness. It teaches the heroism of self-denial, temperance, abstemiousness, and simple living. It is the way to success and independence. It makes for happy homes, contented communities, a prosperous nation." 6 The value of home ownership for a ldrge portion of the population is not to be denied, in spite of many advantages of renting for persons whose work makes frequent moves necessary.

Amortization, a Method of Paying off a Debt.-The success of the building and loan association in promoting the two ideals is due primarily to the use of small periodic payments, or the so-called "principle of amortization." The term "amortization" means "killing off," and is used to signify the repayment of debts in periodical installments. Loans are due at some given time in the future, and when the amortization principle is not used, the borrower often has difficulty in finding the large sum of money to meet the lump payment when due. "Such loans are called "straight" mortgage loans. It is the common experience of lenders on straight loans that the debt is seldom paid in full except after several renewals. During the term of a straight loan (ordinarily from three to five years), the borrower pays the interest but usually makes little or no effort to accumulate a fund for the repayment of

${ }^{5}$ Editorial in the San Francisco Journal, 1922.

- From the Amcrican Building Association News, 1922, p. 453. 
the principal. As a result, when the mortgage is due, he is obliged either to renew it (that is, borrow the same sum for another period from the same lender), or "refund" it by borrowing from another lender on the same security a similar sum with which the amount due the first lender is repaid. Either of these processes leaves the borrower in the same position as before, if not in a poorer position. For the debt is still hanging over his head, and though he is paying the interest, he is hardly keeping pace with the debt because, as the property becomes older, its value probably declines. As a result, the lender prefers to renew the mortgage for a smaller amount, since he wishes the market value of the property to be continually greater than the amount of the loan; or if he is willing to advance the same sum on the renewal, he or his agent may ask a higher commission for placing the loan. In either event there will be an additional cost to the borrower.

Amortization avoids such difficulties. When an amortized loan is arranged for, the length of time which the loan has to run is determined by the number of installment payments or "dues" required to cancel the amount borrowed. Thus, the borrower may know in advance exactly where he will stand if he repays his loan according to contract. ${ }^{7}$

The term of the loan made by building and loan associations is somewhat shortened because, in addition to the dues which the borrower pays, he is credited with profits earned by the association from lending its dues to himself and other borrowers. When this additional sum is added to his principal, the amount of his loan is paid off much more quickly. As a

'This does not imply that all loans made through building and loan associations have a maturity of a definite number of months. Building and loan borrowers are also members of the association, and the profits which they receive upon their "dues" or installment payments will affect the number of payments they have to make. The laws of a few states permit building and loan associations to make contract loans for definite periods, but most of them prohibit this practice. Wherever it is permitted, some additional guarantee is required, usually in the form of a guarantee stock owned by a small number of shareholders. For a discussion of guarantee stock and permanent stock see Chaps. III and IV. 
result, the borrower succeeds in getting himself out of debt with little more trouble than is involved in the payment of interest under a "straight" loan contract. "As money must be borrowed, the monthly repayment loan is the cheapest and best, and the most certain of being paid, and each payment makes the security better for the association while month by month the borrower is accruing a greater interest in his property." 8

Definition of a Building and Loan Association.-The success of the building and loan plan appears to rest on the fact that, more than any other financial institution in the United States, it has enabled borrowers on homes to get out of debt. It happens that associations have no uniform methods of accomplishing this. This lack of uniformity does not obscure the work that they do, but it does make it difficult to define the term "building and loan association" briefly and accurately. It may be said that a building and loan association is that form of coöperative savings institution the funds of which are invested primarily in long-time amortized loans on real-estate security. Most of them are mutual savings institutions. Most of them loan only on homes. It is perhaps easier to define them by reciting their functions, purpose, and methods, and this is the method which has been used by most writers on the subject. Rosenthal's definition ${ }^{9}$ is as follows:

"A building association is a mutual coöperative financial institution usually operating under articles of incorporation issued by the state, and composed of members who have thus associated themselves together for their mutual benefit and financial advantage." 10

The Commissioner of Internal Revenue outlines the particu-

${ }^{8}$ C. W. Clausen, State Auditor of Washington, Report, 1919-20.

${ }^{\circ}$ Henry S. Rosenthal, Cyclopedia of Building, Loan and Savings Associations, Fifth ed., I923 (Cincinnati), p. 9.

${ }^{10}$ Joseph H. Sundheim gave a less complete definition in his Law of Building and Loan Associations (Philadelphia, 1922), p. 19, "A building and loan association is a private corporation for profit." This definition has now been revised for later editions of Mr. Sundheim's work. 
lar associations entitled to exemption under the Federal law as follows: ${ }^{11}$

"In general, a building and loan association entitled to exemption is one organized pursuant to the laws of any state, territory, or the District of Columbia, which accumulates funds to be loaned primarily to its shareholders for the purpose of building or acquiring homes. In order to be exempt the

OpERATION OF a MODERN

BuILDING and LOAN ASSOCIation

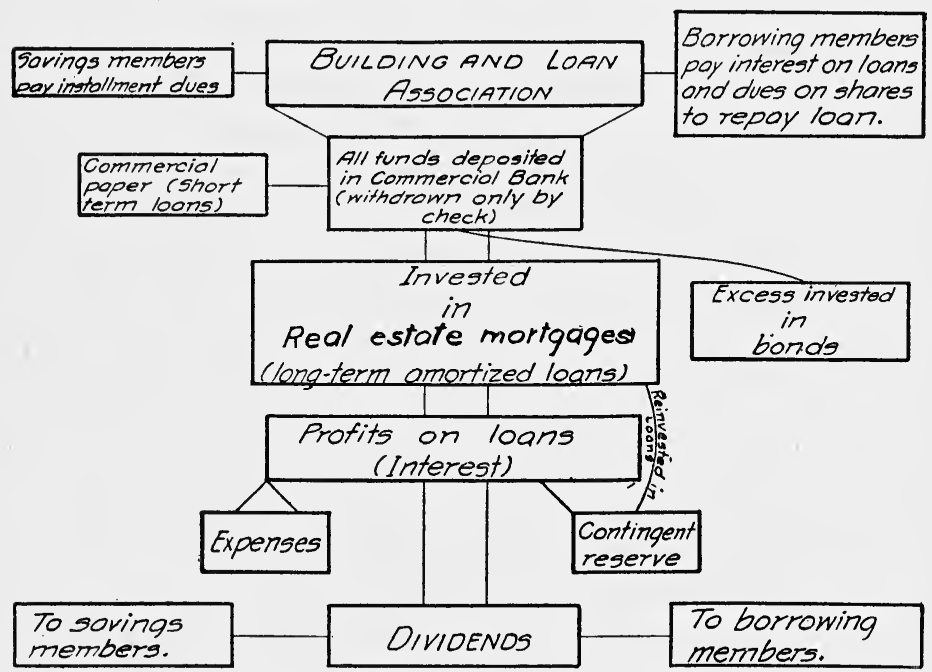

Chart I.-General plan of operation of a modern building and loan association.

association ( $\mathrm{I}$ ) must be mutual, that is, all of its stockholders or members must share in the profits on substantially the same footing; and (2) must be operated so that substantially all of its business is confined to the making of loans to bona fide shareholders."

It is probably impossible to formulate an acceptable definition which will include the activities of all these associations,

${ }^{11}$ Regulations 62, Bureau of Internal Revenue, Treasury Department, Article 515, Revenue Act of 1921. 
but their purpose, scope, and method are fairly well indicated in what has been said. The coöperative building and loan associations operating in the various states seldom undertake building operations, but lend their funds impartially either for the purchase or construction of residences.

Example of Building and Loan Operation.-In order to set forth clearly the work which is undertaken by these associations, the following illustration of their simplest operations is presented: ${ }^{12}$

A citizen who has saved, let us say, $\$ 1,800$, wishes to purchase or build a home, worth $\$ 5,000$, borrowing the remaining $\$ 3,200$. If he approaches a commercial mortgage company for a loan, it would be refused because a $\$ 2,500$ cash payment would be necessary. (Commercial or "straight" mortgages are usually limited to 50 per cent of the appraised value of the property.) A building and loan association can safely make a loan of the desired size because of the use of the amortization or partial payment principle, by which the borrower starts to repay his loan at once, thus making it to his own interest to continue his contract.

The citizen applies to the association for a loan of $\$ 3,200$, giving all the details of the proposed transaction of acquiring a home, including the amount he is prepared to pay in cash, his prospective income, etc. The applicant also agrees to pay the current rate of interest on the loan (say 7 per cent). Up to this point the procedure is the same as that for the straight loan, but after this point there is a difference. The association loan provides for the method of repayment as an essential part of the loan contract. The borrower agrees to subscribe for shares of "installment stock" in the association to the full amount of his loan, if the loan is granted. The payments on his shares are an investment of savings in the association which in turn can be applied to cancel the loan when the amount is large enough. He will pay for these shares, usually at the rate

\footnotetext{
${ }^{12}$ More detailed statements of operation will be found in later chapters in connection with the separate phases of the business.
} 
of fifty cents or more per month for each $\$ 100$ of loan, or, let us say, $\$ 16$ per month in the case before us. ${ }^{13}$ He also pays a small fee for the investigation of the security at the time of making the application, and some associations require that dues and interest for one month be paid at this time. Dues and interest are usually returned if the loan is refused.

The officials of the association investigate the claim, appraise the property carefully, search the title, see that insurance protection is provided, and if satisfied that the interests of the association are fully safeguarded, make the loan, A mortgage (or deed of trust) and a bond (or note) are then made out; the seller of the property, the borrower, and the secretary of the association meet at the office of the association, and the original deed of purchase, the mortgage, and all necessary papers are signed. This transfers the title from the seller to the borrower and at the same time pledges it by mortgage to the association as security for the loan. The deed and mortgage are recorded, and the borrower takes possession of the property. If the loan is not repaid, the association can proceed to foreclose the mortgage, have the property sold, and collect its debt from the proceeds.

The borrower then makes each month a payment of $\$ 34.67$ (in the case before us). Of this amount, $\$ 18.67$ is interest on the loan, while \$I 6 pays an installment of 50 cents each on 32 shares in the association. The shares, when they have been completely paid for by these installments plus the dividends that are credited to them, will pay off the debt.

The borrower thus automatically becomes a savings member as well as a borrower, and on his installment shares he is entitled to dividends, when the association makes a profit, just as any other savings member. These dividends are credited to his savings as they accumulate, usually at the end of each half year. An association charging 7 per cent interest can pay

${ }^{13}$ Monthly dues on shares vary greatly. The greater the periodic payment, the sooner the loan is paid off. Maturities tend to be shorter in the West than in the East, due to the larger payments demanded. 
dividends of approximately 6 per cent per annum, as its expenses are small. The borrower never receives as much in dividends as he pays in interest, since his dues never equal the loan until maturity.

At the expiration of six months, the \$I 6 monthly payments will amount to $\$ 96$ and the 3 per cent semiannual dividend will be added to this amount. ${ }^{14}$ By using the second method of computation shown in Chapter XVIII, this dividend would amount to $\$ 1.20$, making the total $\$ 97.20$. For the next six months, dividends are figured on the amount at the beginning of the period $(\$ 97.20)$, and on the accumulations as before, giving $\$ 197.3 \mathrm{I}$ at the end of this period. In this way compound interest adds to the payments made by the borrower and in approximately 139 months (if dividends continue at 6 per cent compounded semiannually) his "shares" will reach the total value of the loan, or $\$ 3,200$ (the actual accumulation in I 39 months will be $\$ 3,2$ I 8.04$)$. In the language of the association, the shares will have "matured" or reached their par value. The borrower then presents his stock certificate or pass-book to the association for cancellation, a check for the amount is made out to him, which he endorses at once and returns to the secretary as payment in full for his loan. ${ }^{15}$ Any balance is adjusted in cash or by check. A release is then executed for the mortgage and recorded. The mortgage is returned to the borrower who thus secures complete title to his property (except for liens subsequent to this mortgage).

In the above illustration, the borrower has paid a total $\$ 4,8$ I9.I3 (\$34.67 times I39) for the use and repayment of a loan of $\$ 3,200$ for I 39 months, besides the original fees (which are essentially the same for straight loans as under the building and loan plan). The net cost to him was, therefore, approxi-

${ }^{14}$ Dividends are figured on the average accumulation for the first six months. For three methods of making this computation, see Chap. XVIII, Dividend Policy.

${ }^{15}$ Many modern associations use a book credit to complete this transaction, merely canceling one amount with the other, and paying or receiving a small balance. 
mately 6.74 per cent for the actual time he used the money, and he is now out of debt.

An infinite number of variations from this method will be found, some using a monthly or quarterly reduction of principal and interest instead of the accumulation on shares; but while the mathematical solutions may vary, the essential amortization principle remains the same.

Repayment before Maturity.-Should the borrower care to repay the loan before it is due, he may do so, and the "withdrawal value" of his shares at the time of repayment is applied on the loan, thus reducing the cash payment necessary. The withdrawal value is essentially the book value of the shares at any given time, ${ }^{16}$ that is, the amount accumulated by his installments and the dividends credited to them.

As already stated, in case of default of payment by the borrower for a certain number of months the association can cause the mortgage to be foreclosed and sell the property in order to realize the amount of its loan. Foreclosure prccedure is essentially the same as under a commercial mortgage, but is less likely to happen where amortization is used because the borrower has more to lose, since his equity grows constantly greater each month. Also the association officials make it a practice to "nurse" delinquent loans along, encouraging the borrower to pay and so forestall trouble under foreclosure. (See Chap. X.)

Where the Money Comes From.-These lending operations are only possible because of a steady flow of income into the treasury of the association. This comes from the dues of savings members who are accumulating a sufficient fund to enable them to borrow, and more largely from the savings members who do not wish to borrow, but who wish to invest in the building and loan association. The amount which can be loaned depends directly upon the total amount received. Practically all receipts can be immediately loaned, with only a small amount of idle cash kept on hand, because some notice is

${ }^{10} \mathrm{~A}$ discussion of withdrawal practice will be found in Chapter IX. 
usually required before withdrawals are permitted. The amount available for loans constantly increases during the earlier years of the business, but tends to reach a maximum or an approximate equilibrium after a certain number of years. ${ }^{17}$

Name and the Use of Terms.-For convenience we are using throughout this discussion the term "building and loan association," but this is to be interpreted as including all institutions which have for their purpose the accumulation of a loan fund for use primarily to finance small home building. Actually I 43 different forms of corporate title are known to be in use in the United States. The various names used include the following:

Building and Loan Association. (Used in 47 states.)

Savings and Loan Association. (Used in 29 states.)

Building Association. (Used in 15 states.)

Loan and Building Association. (Used in 14 states.)

Building Loar and Savings Association. (Used in I4 states.)

Building and Savings Association. (Used in Io states.)

Savings Loan and Building Association. (Used in ro states.)

Coöperative Banks. (Used in Massachusetts.)

Homestead Associations. (Used in Louisiana.)

These associations are called by many other names in which the words "Savings," "Building," and "Loan" usually occur, but many other words are used as well. ${ }^{18}$

The plan used and the name by which these associations are called should not obscure their fundamental purpose. All are for savings. All are attempting to develop thrift and home-ownership among our people who, in the rush of modern life, are apt to overlook the value of the home.

Associations use not only different names but also different terms to describe the operations of their business. Practices do vary, but often when there seem to be variations in practice in different sections of the country, it will be found on exam-

${ }^{17}$ See Chapter VII for a discussion of this theoretical point of equilibrium.

${ }^{18}$ See Appendix for a complete list of titles known to be used by these associations. 
ination that the practices are the same and only the terms use is to describe them are different. Possibly one of the most important tasks which should be undertaken by association men is to standardize practices and terms throughout the country. This does not mean that only one method of doing business should be advocated for use in all parts of the country. One method is seldom adapted to all sections. But it does mean that when a given practice is in use, its name should indicate its content to men familiar with association work in other parts of the country. This applies both to the methods of lending money and to the distribution of earnings.

Slow vs. Liquidating Credits.-It is essential to remember that the amortized l a ans of the building and loan association belong to the slow-credit field and not to the commercialcredit field. That is to say, "self-liquidating credit" which is provided by the commercial banks is founded on the expectation that the goods purchased with the proceeds of the loan will be sold before the loan comes due; the receipts from the sale of the goods will be used to pay back the money borrowed. The slow-credit field on the other hand involves the ides that the money received from the loan will be invested in "fixed assets" or capital goods (including homes), and these capital goods will be used over a term of years. The money to repay the loan will come not from the sale of goods, but from the profits received from their use. Building and loan association loans are of the latter type, and run for a period of years.

\section{Objects of the Building and Loan Association}

For the Prospective Home Owner.-(I) The amortized loan offers the prospective home owner the opportunity to get out of debt when he borrows for the purchase of a home, where the straight mortgage loan offers much less definite opportunity. Under a straight loan the borrower must solve this problem of repayment for himself and build up a fund elsewhere. The installment payments of a building and loan mortgage care for that problem automatically. (2) A larger 
percentage of value can be borrowed. Not all borrowers wish to take advantage of this opportunity, but it is of advantage to every borrower to secure his loan at the most reasonable cost. If commercial loans are made for over 50 per cent of the value, first and second mortgages must be placed on the one piece of property. It usually happens that the rate of interest charged on the amount over 50 per cent of the value is greater than on the first 50 per cent.

For the Savings Member.-The outstanding advantage of the building and loan association for the savings member is safety. Funds saved through these associations are seldom lost. Some unfair methods were used by a few associations at times in the past, and these caused savings members to lose part of their money. Greed on the part of the officials perverted the movement to their own advantage, and lack of adequate state laws and supervision made such practices possible.

Ordinarily the promises of the associations have been scrupulously kept and the entire amount invested by savings members has been returned to them with the profits earned. The management of these associations has been extremely economical and dividends have been large. Many officers have served without pay or with much less pay than they are entitled to receive. Earnings have consequently run far in excess of the return expected on investments of as high a type as real-estate security. With the increased development of the movement, higher salaries will be paid to managing officials. This does not necessarily mean that the income of the savings member will be materially reduced, since these greater costs will be distributed over a larger amount of business, and the costs per unit will be less.

The flexibility which permits a savings member to put his funds away or withdraw them without difficulty is also an added advantage of the association. This is becoming increasingly true of all modern associations, regardless of the type of plan used. In the early development of the movement, only 
savings which remained until maturity received full dividends. Savers were obliged to "keep in step" with each other, and all had to go along together. More and more it is becoming true (even with those associations using the serial plan) that the member who withdraws within a few years can receive the maximum rate of return, provided only that he gives proper notice of withdrawal.

For the Employer.-The employer of labor often finds that these associations directly stabilize his labor turn-over or actually reduce it, but to be sure of these advantages he must reciprocate by providing continuous work. Since the funds of the association are loaned almost entirely for the purpose of home ownership, workmen who are certain of steady employment can make use of such loans and become better citizens. Their personal efficiency tends to increase, which very materially aids the employer in turning out a better class of product. Incidentally, stabilization of employment and increased efficiency aid business in general because they provide a steadier purchasing power for the people. Such advantages should not be overlooked by the business men of our nation. Thrifty workmen are our best citizens.

For the Community.-Probably no institutions do more for the development of community spirit than those which aid our people toward better housing. The old French maxim "A man will fight for his home but rot for his boarding house" is an eternal truth. If this is true for the nation as a whole, it is equally true for the individual community that desires to have the coöperation of all its people in its community activities.

One of the great lessons which associations teach the people is coöperation, a thing which the average man does not learn until it is forced upon him. When men have learned how to work together in small things, they become better citizens in large affairs. They have developed character and can see the point of view of the "other fellow."

The associations help to solve the housing problem, a thing 
which has been uppermost in the minds of many of our people for the past few years; and their contribution to this end has been recognized not only by government officials but by our most astute financial journals as is evidenced by the following quotation from the Wall Street Journal: "These associations promoting thrift and providing homes are really the only practical agency through which the housing situation can be solved, because they are nearer the working people and best understand their needs." 19

One of the former Presidents of the United States League of Local Building and Loan Associations has said: "I am fully persuaded that home ownership is to be one of the main factors destined to allay unrest, to establish contentment, and to create ambition for self-betterment along sane and practical lines. If we can thus supplant illegal, unreasonable, and destructive tendencies, which to-day threaten industry and society, with incentive for better attainments, with hope and encouragement and a rational assurance of success with effort, surely the work is worth while." 20

\section{SPECIAL REFERENCES}

Amortization. Kansas League Proceedings (1919), p. 62.

Purpose of building and loan. U. S. League Proceedings (1900), pp. 53-57.

Savings-advantages. U. S. League Proceedings (1901), pp. 93-100.

Social value of building and loan. U.S. League Proceedings (1922), pp. 86-103.

Thrift. Illinois League Proceedings' (1918), pp. I29-130; (1920), pp. 83-85. Iowa League Proceedings (1924), 84-87. Oklahoma League Proceedings (1923), pp. 81-84. Youngstown Institute Proceedings, March 23, 1923, pp. 5-8.

\section{GENERAL REFERENCES}

Rosenthal, Henry S. Cyclopedia of Building, Loan and Savings Associations (1923), pp. 8-9; I2-22； I I8-I2I；204-205.

Sundhetm, Josepri H. Law of Building and Loan Associations (1922), pp. I9-24.

${ }^{19}$ June, 1921, Wall Street Journal.

${ }^{20}$ E. L. Keesler of North Carolina, July, igrg. 


\section{CHAPTER II}

\section{THE PLACE OF THE BUILDING AND LOAN ASSOCIA- TION IN THE FINANCIAL ORGANIZATION OF THE COMMUNITY}

"The world knows little of its greatest institutions."-M. G. Glaeser.

"Financial organization of the community"-nature and scope; the position of the commercial bank in the financial world; short-time credit; intermediate credit; long-time credit; corporations dealing in long-time credit-savings banks, trust companies, insurance companies, mortgage companies, building and loan associations; the real-estate mortgage; nature of the mortgage used by associations; loan limitations; deposits among associations; continued growth of the building and loan movement.

When we speak of private finance or the financial interests of the individual, we mean the management of money income or money capital by individuals or corporations. In the financial and economic organization of to-day neither individuals nor corporations can carry on their activity without the cooperation of others, and a complex structure of financial institutions has been built up, in which each institution specializes in a given field.

By the phrase "financial organization of the community" is meant not merely the various forms of financial institutions as such, but also the methods by which they are organized, operated, and tied together. Therefore, to determine the rightful place of the building and loan association, it is necessary to consider some of the essential community financial requirements.

In the general conduct of business, whether in the production or the distribution of commodities, or in supplying services of people, it is almost always necessary to make use of greater 
capital than is possessed by the individual, firm, or corporation undertaking the work. In response to this need, financial institutions of various forms have been devised to assemble and make available to business the necessary funds.

To understand these institutions, we must know the source from which money capital is derived, the means of making it available where needed, and the methods by which its safe return with interest is insured so as to attract more capital in amounts sufficient to meet the community's growing needs.

In earlier stages of society, the private money lender, frequently an extortioner, was the only available source of financial aid. But with the development of coöperation, corporate organizations undertake this function. Capital is pooled for more effective general use by the community, and certain rules for the guidance of all financiers have been established.

The most common form of financial institution, taking this country as a whole, is the commercial bank, so designated because of the fact that it is primarily designed to provide funds for commercial or short-term use. Such credit covers all forms of business transactions which are promptly liquidated, as distinguished from those which constitute more or less permanent investment. It is foreign to our present purposes to attempt to outline the large and important subject of banking, but we would like to make clear the part banks play in making building and loan activity efficient, as all financial institutions are to-day tied together in one or more systems.

Commercial banks do not depend solely upon local depositors for funds, for in time of need they can draw upon "correspondent" banks in other cities. The latter furnish additional funds on demand and enable a local bank to tide over its temporary needs. In return for this service the local bank maintains a deposit account with the correspondent which is operated in the same way as the deposit account of any other individual or corporation. If the need should arise, the local bank will also extend credit to the correspondent bank. Since the inauguration of the Federal Reserve System, every "mem- 
ber bank" in the country is automatically in touch with every other member bank through its correspondence with the Federal Reserve Banks. In addition to being thus tied up in a national way, banks are, of course, joined together in each locality through their clearing houses, and they have many other interests in common.

Short-time Credit.-The commercial bank holds the current funds of the community, both commercial and private. These funds are not in any sense a permanent surplus, but are being used for current expenses in almost all cases. The depositor uses the checking account purely for convenience and safety, since it is ordinarily possible by the use of checks to make payments anywhere. Funds deposited in the checking account are withdrawable at the will of the depositor, and as a result, banks are obliged to keep sufficient cash in reserve to meet these demands. The bank can lend deposited funds for current business purposes because it knows that the loans will be repaid prior to the time that depositors call for them, but it must be sure that the money will be ready in case of need. As a result, the commercial bank can only lend its funds for "self-liquidating" needs. The goods which are bought with the proceeds of the loan must be sold before the loan comes due. To the business man such loans are a part of his "shortterm capital," or "working capital," and are never invested in f.xed assets.

In order to make certain that the banks do not abuse the privileges which have been granted them, legal restrictions have been imposed, which limit the types of security on which they may lend their money. It would manifestly be improper for commercial banks to lend funds on real estate to any large extent because the profits realized from real-estate operations come in only over a long period of years, and in time of stress the bank could not obtain repayment quickly. The large class of borrowers who wish to secure funds on real-estate security must, therefore, resort to institutions which specialize in this type of loan. When commercial banks lend a large proportion 
of their demand deposits on mortgages, they invariably get into trouble as shown by recent experiences of hundreds of banks in the Northwest. It is necessary to note, however, that all institutions, regardless of the type of investments which they handle, make use of the commercial bank for depositing their temporary funds.

Among the commercial banks which conduct checking accounts for individuals and corporations are national, state, and private banks, and some trust companies and savings banks. There are also a number of "credit unions," or cooperative institutions, which do a checking account and loan business on a small scale. ${ }^{1}$

Intermediate Credit.-Recently the term "intermediate credit" has been introduced into finance to cover the credit needs of borrowers who wish longer extensions of credit than are possible by the commercial banks, but do not wish to give mortgages or other long-term types of security. These needs, particularly for farm loans, are being taken care of by specialized institutions. The term intermediate credit does not concern us in the present discussion.

Long-time Credit.-We are primarily concerned with longtime credit on loans for investment in fixed capital; that is, the type of investment which will be repaid out of the profits of the business rather than from the entire proceeds of the sale of goods. These capital needs are of varying kinds, of which the most important are shown in the list on page 22 .

Many names are given to the various kinds of securities sold to the public by the borrowers for these different purposes, but they fall into the general classification of stucks, bonds, and mortgages.

Corporations Dealing in Long-time Credit.-Investment institutions which deal in long-time credit have as their principal function the collection of savings throughout the

"For a complete discussion of the credit union, see Coöperative Banking-a credit union book, by Roy F. Bergengren, Macmillan, 1923. 


\begin{tabular}{|c|c|c|}
\hline & MONEy BORROWED FOR & Securities Issued \\
\hline A. & $\begin{array}{l}\text { Governmental, state and municipal im- } \\
\text { provements. }\end{array}$ & Bonds, principally. \\
\hline B. & $\begin{array}{l}\text { Public utilities: Railroads, both steam } \\
\text { and electric; local utilities for supplying } \\
\text { electricity, gas, water, etc. }\end{array}$ & Bonds and stocks. \\
\hline C. & $\begin{array}{l}\text { Industries and commercial business de- } \\
\text { velopment. }\end{array}$ & $\begin{array}{l}\text { Stocks, bonds, and prom- } \\
\text { issory notes. }\end{array}$ \\
\hline & Private needs of individuals. & $\begin{array}{l}\text { Mortgages and promissory } \\
\text { notes. }\end{array}$ \\
\hline & Foreign governments. & Bonds. \\
\hline
\end{tabular}

community and the diversion of these savings to meet the needs of the community, because savings accrue to individuals and

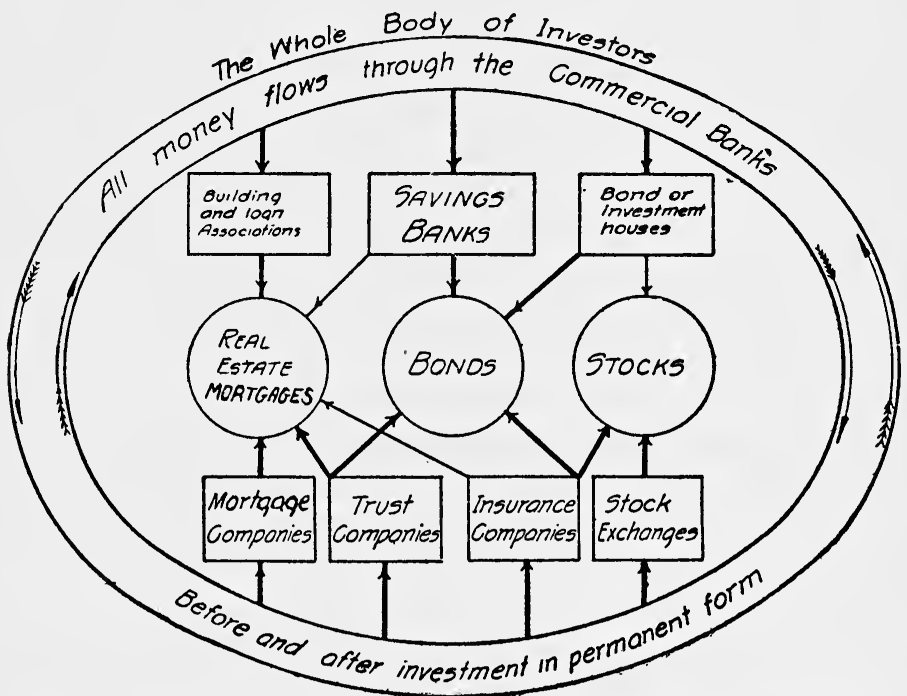

Chart 2.-The flow of money through our financial institutions intos permanent forms of investment.

corporations in so many forms that no one institution is equipped to handle properly all phases of the investment market. In fact, if one institution attempted to do so, the 
TABLE I

Princtpal Types of Investments of Various Financial Institutions

\begin{tabular}{|c|c|c|}
\hline $\begin{array}{l}\text { Financial } \\
\text { Institution }\end{array}$ & TyPe OF InVESTMENT & $\begin{array}{c}\text { Principal Class of } \\
\text { INVESTOR OR Depositor }\end{array}$ \\
\hline $\begin{array}{l}\text { uilding and loan } \\
\text { associations. }\end{array}$ & $\begin{array}{l}\text { 1. Real-estate mortgages (on } \\
\text { homes) } \\
\text { 2. State and government bonds. } \\
\text { 3. Other bonds. }\end{array}$ & $\begin{array}{l}\text { Small savers, princi- } \\
\text { pally wage earners } \\
\text { and salaried people. }\end{array}$ \\
\hline $\begin{array}{l}\text { avings banks and } \\
\text { trust companies. }\end{array}$ & $\begin{array}{l}\text { I. State and government bonds. } \\
\text { 2. Industrial bonds. } \\
\text { 3. Foreign bonds. } \\
\text { 4. Real-estate mortgages (on } \\
\text { business property and on } \\
\text { residences). }\end{array}$ & $\begin{array}{l}\text { Small savers and con- } \\
\text { servative investors. }\end{array}$ \\
\hline $\begin{array}{l}\text { Mortgage com- } \\
\text { panies. }\end{array}$ & I. Real-estate mortgages. & Large investors. \\
\hline $\begin{array}{l}\text { Investment com- } \\
\text { panies and in- } \\
\text { surance com- } \\
\text { panies. }\end{array}$ & $\begin{array}{l}\text { 1. Industrial bonds. } \\
\text { 2. State and government bonds. } \\
\text { 3. Foreign bonds. } \\
\text { 4. Stocks of industries, railroads, } \\
\text { and public utilities. } \\
\text { 5. Real-estate mortgages (on } \\
\text { farms, business buildings, } \\
\text { and apartments). }\end{array}$ & $\begin{array}{l}\text { Investors, salaried } \\
\text { people, and wage } \\
\text { earners. }\end{array}$ \\
\hline $\begin{array}{l}\text { Stock brokers and } \\
\text { stock exchanges. }\end{array}$ & $\begin{array}{l}\text { r. Industrial stocks. } \\
\text { 2. Industrial bonds. } \\
\text { 3. State and government bonds. } \\
\text { 4. Foreign bonds. }\end{array}$ & $\begin{array}{l}\text { Speculators and in- } \\
\text { vestors. }\end{array}$ \\
\hline Commercial banks. & $\begin{array}{l}\text { I. Commercial paper of all kinds } \\
\text { (promissory notes, accept- } \\
\text { ances, bills of exchange). } \\
\text { Short-time credit only. }\end{array}$ & $\begin{array}{l}\text { All persons and cor- } \\
\text { porations us ing } \\
\text { checking accounts. }\end{array}$ \\
\hline
\end{tabular}

work would not be completed, because no one institution has the capacity to reach all the very diverse elements in our modern society. Among the principal investment institutions are the following:
a. Savings banks (commercial and mutual).
b. Trust companies.
c. Insurance companies.
d. Building and loan associations. 
e. Mortgage companies.

f. Bond houses.

g. Stock exchanges (stock brokerage houses).

Each of these institutions has its particular place in the financial organization of the community and each deals with certain kinds of investments for which it is best equipped. The accompanying Chart I and Table I may give some idea of the activities of these institutions. In the table, investments are arranged in accordance with their importance in the business of the investment institution. The chart attempts to show the interdependence of all financial institutions as well as the types of securities which are most important to each.

Savings bank funds are usually protected to a greater or less extent by statute against excessive withdrawals without notice, and these banks are accordingly able to extend their field of lending beyond that of commercial banks. In the absence of statutory protection, their by-laws cover the same matter. In addition, they purchase outright many approved forms of such securities as bonds and stocks. They provide a large portion of the capital for industrial development and civic undertakings. They also provide substantial sums for realestate mortgage loans. This is particularly true of many of the mutual savings banks. ${ }^{2}$

Trust companies are quite generally permitted by law to qualify as savings banks, and in some cases as commercial banks; but to a great extent they largely specialize in the handling of trust funds of estates and individuals and in the transaction of many forms of business outside the ordinary field of banking.

Insurance companies perform a twofold function in our financial organization. They collect savings and they also

2 The only essential differences between commercial and mutual savings banks are the methods of distributing profits and of raising capital. In the commercial savings bank a comparatively small number of stockholders provide the capital funds with which they begin business. In the coöperative or mutual savings banks the depositors themselves provide most of the capital fund. 
assure the saver that the total fund which he has planned to accumulate will be forthcoming in case of his death or of some other contingency in his personal or business life. They invest these funds in various ways.

Mortgage companies, as their title indicates, make loans on the security of mortgages or deeds of trust on real estate, and in addition are usually purchasers of, and dealers in, such mortgages. For the conveniences of their investing customers, they have brought unit mortgages or mortgage bonds into general use. The single mortgage bond or note has been divided into parts commonly known as "mortgage bonds," each of which is equally protected by the terms of the mortgage, which is deposited with a trustee. Mortgage companies are not authorized to accept checking accounts. They act as selling agents for the securities in which they deal, in order to increase their usefulness; otherwise their business would be mainly dependent upon the amount of their own capital.

These various institutions dealing in long-term credit are alike only in the capital with which they deal. Each reaches a part of the people which others cannot reach, and by working together they enable our economic organization to function efficiently. It is true that there will always be a certain amount of overlapping in their functions, but this overlapping is of far less importance than the fact that they are making available money and credit which would otherwise not be used by industry and commerce.

The Real-Estate Mortgage, a Highly Specialized Type of Long-Term Credit.-When the commercial bank makes loans to its customers it does so primarily upon their business standing. The banker examines the balance sheet and income account. He knows the officers of the corporation and the kind of business which they are transacting. On the basis of his estimate of their ability to pay, the commercial bank extends them credit. Since the needs of commerce are largely short-term needs and because the bank official can keep in constant touch with the progress of the business, this form 
of personal credit without security can be successfully granted on a very large scale. A great deal of capital is needed for more than the short terms for which a commercial bank should lend; and when a considerable period of time must elapse before the loan is to be paid, many changes in the personal fortunes of individuals will occur. As a result, lenders who are extending credit for long periods of time wish to be assured of the return of their money by something more stable than individual credit. Hence, we have the development of the secured loan, of which the loan on real-estate mortgage is an outstanding type.

This mortgage is used by many different kinds of borrowers. Industrial corporations sometimes make use of it. It is very frequently used by hotel and apartment house owners, and it is particularly adaptable for residential loans. By the use of the real-estate mortgage on homes, many persons are enabled to purchase homes who would otherwise be unable to do so. This is possible because they are able to move at once into the house which they wish to purchase, after saving until they can make a first payment of a reasonable amount and borrowing the remainder. The money which they otherwise would have paid for rent is then used to help in paying off the mortgage.

Building and loan associations deal almost exclusively in mortgage-secured loans on residences. The other long-term credit institutions place their funds wherever the best interest rates are available. They must also consider the ease of reselling the securities in which they invest their money, since it is necessary at times to get their funds out of the investment quickly. A "close, quick market" is always a desirable asset for an investment house. By this is meant that the owner of the security may be able to sell it for approximately the quoted price without very much, if any, discount, and that a buyer may be obtained without undue delay. Real-estate mortgages on homes are not this kind of investment. There is no organized market where they may be quickly bought and sold. They are made out for considerable amounts, seldom being made 
for less than $\$ 500$, and the average is probably between $\$ 1,500$ and $\$ 2,500$. They range as high as the maximum amount that a man may care to borrow on an expensive residence.

In attempting to sell mortgages when funds are needed, therefore, considerable difficulty is encountered, because the average investor who is interested in them does not have so much ready cash to invest. The investor of large sums puts his funds away where they can be readily converted in case he needs money. This means that he uses securities for which there is an organized market. The mortgage business finds its customers among the type of investor who will not desire to withdraw his money suddenly. Building and loan associations are of the latter type and act as collectors of savings from many types of investors, but particularly from the small saver, who could not buy an entire mortgage alone. The association. through its lending operations, acquires mortgages and holds them until they have been paid off. Its members or sharel.olders enter and leave the business, not caring whose mortgages were purchased with their funds, because the association looks after all details for them.

No problem of a market, therefore, arises with the association. Savings members in the association may come and go. They put in funds and may withdraw them after a comparatively short period of years,--short, that is to say, as mortgage indebtedness runs. But as one set of savers withdraws, another takes its place, and the result is that the association has a fund continuously on hand which will allow it to retain the mortgage in its possession until it comes due. No uther institution is in a position to do this specifically for real-estate mortgages, not even the mortgage companies, for the latter must buy and sell continuously if they are to succeed. The particular service rendered by the associations is that of combining partial payments with profit sharing, because these institutions are organized primarily on a coöperative basis.

Many people who need homes are not in position to demand credit beyond the amount which can prudently be loaned on 
the basis of the value of their prospective homes. By making use of the periodical method of repayment it has been proved possible to make larger loans than could safely be made under ordinary methods, the gradual reduction of the principal taking care of possible depreciation or obsolescence of the property. At the same time the ultimate repayment of the original loan, without renewal, is assured by the fact that payments become habitual to the borrower, because of their frequency and regularity. It will be seen, therefore, that the building and loan association, which has always conformed to this principle, renders a dual and indispensable service in the greater liberality in size of loans made and in provision for their repayment.

No financial institution can lend more than it receives. Commercial banks and other institutions receiving deposits depend upon them as the source of their loanable funds. Their own capital acts as a safety fund and is not invested in the usual type of commercial paper, but in bonds and other permanen1 forms of securities. Also, the necessity of maintaining cash reserves with which to meet withdrawals tends to reduce their loans. Building and loan associations, except in certain states, including Ohio, are prohibited from receiving deposits, because a creditor and debtor relationship exists between the depositor and the institution receiving deposits. A subscriber for shares is not a creditor of a building and loan association, but a part owner of the business. Unlike shares in an ordinary corporation, building and loan shares may be withdrawn from the business under certain restrictions. The unequalled safeguards against embarrassment or injury to the association in this respect are the provisions of the state laws and the accepted practice that no association can be compelled to meet withdrawals beyond a prescribed portion of its current receipts. It will be seen that this provides safety for the association members who are savers, while at the same time it permits the lending of sums up to nearly the entire resources of the association.

All funds received by associations are at once deposited in 
commercial banks, and withdrawn only by voucher. When there are calls for more loans than car. be cared for, the association thus has an established credit position with the bank which enables it to borrow on very favorable terms. Such borrowing enables an association to care for all loans as they arise, and since the demand is greater than receipts of dues at certain seasons of the year, the bank finds the association a good customer.

The place of the building and loan association in the financial organization of the community is an important one. It is not a substitute for other financial institutions, but efficiently serves in certain fields not covered, or inadequately covered, by them. The limit of its usefulness is measured by the borrowing requirements of the community in the matter of amortized loans to enable every family to acquire a home free from debt. The savings of the many in building and loan shares provide an increasing sum to take care of the needs of the borrowers.

It is rarely the case that the limit of an association's usefulness is reached and that further development is inadvisable. The association is properly coördinated with other financial institutions of the community and each is committed to the faithful performance of its special functions. There is always room for growth without trespassing on the fieldis of other institutions. The activity resulting from such growth is reflected invariably in added general prosperity.

Comparison with Banks.-It is not proper to compare the amount of money subscribed to shares and paid into the associations with that paid into banks on account of capital stock.

The capital fund of the banks is merely a safeguard for the deposits and other liabilities which the banks incur. A bank's business is conducted largely with the money of its depositors, while that of an association is conducted almost entirely with the funds paid in by the stockholders or shareholders. The essential difference is that the shareholders of an association are virtually the only persons with whom the association trans- 
acts its business, while the stockholders of a bank are few in number and their relations with the bank are primarily those of owners rather than customers. The association does not establish a debtor and creditor relationship with its customers except in the small number of cases where "deposits" are used.

Deposits, an Overlapping Function.-The one important instance in which some building and loan associations perform the same functions as those rendered by banks is in the case of accepting deposits. No checking accounts are permitted, but the laws of a few states make it possible for building and loan associations to accept savings deposits, when the association becomes a debtor for the amount and the depositor a creditor. The depositor must have his funds recorded in a pass-book and may withdraw them only on presentation of the pass-book, as in the ordinary savings account conducted by banks.

The one difference between deposits as used by building and loan associations and the savings accounts in banks is that all funds received by building and loan associations are directed primarily into real-estate mortgages. In this way the associations raise large amounts of money which would not otherwise be put into residence ownership. Funds which are not available to banks are brought forth by savers and put into association deposit accounts in order to take advantage of the greater degree of safety and of the dividends which are usually greater than savings bank interest.

The justification of deposits, if they are to be justified, rests mainly upon the use to which the funds are put and not upon the debtor and creditor relationship. Building and loan associations have as their two coördinate functions the encouragement of thrift and the promotion of home ownership. If the practice of accepting deposits in certain localities adds to these great ends, their use would seem to be justified within the limits mentioned.

Should Building and Loan Associations be Encouraged?-No more beneficial use of money can be found than 
that involved in the building and loan method of meeting the normal demand for homes. Similarly, commercial and savings banks and trust companies can better and more beneficially handle the funds required for commercial and straight mortgage loans, and meet the requirements of those who desire to invest in stocks and bonds.

Through the building and loan association the home-building funds of each community are used primarily to meet local requirements, and outside investments are discouraged until local needs are adequately supplied. For this purpose, no agency has ever been presented that can more efficiently meet the situation than the local building and loan association. Its present preferential position whereby income on its shares is exempt from income tax aids in bringing this about. In several states, also, there is an exemption from other taxation, except the tax on real estate.

The association should not be considered a substitute for, nor in general a competitor of, other financial institutions, each of which has a distinct and necessary function to perform in the economic life of the community. When its scope and purposes are well understood and appreciated, coöperation between banks and building and loan associations will become a settled policy, whereby the financial resources of the community will be put to the best possible use in every individual instance.

\section{SPECIAL REFERENCES}

Need for an association in a particular community. Kansas League Proceedings, (1924), p. I3.

Place of building and loan. U. S. League Proceedings, (1915), pp. 120132.

Bank savings. Youngstown Institute Proceedings, March 23, 1923, p. 8. Status of building and loan associations as financial institutions. U.S.

League Proceedings, (1903), pp. 92-103. 


\section{DIFFERENT "PLANS" UNDER WHICH ASSOCIATIONS WORK}

Bird's-eye view of the "plans" used by an association; the terminating plan-general description, membership requirements, business transacted at meetings, premium, weakness of plan; the serial plan-evolution from terminating plan, methods of enforcing systematic payments (membership fees, withdrawal fees, fines, and forfeitures); regular permanent plan-eliminates the requirement to "get in line"; Dayton permanent plan-abolishes systematic payments, method of avoiding maturities, status of savings members; use of deposits and legal limitations and interpretation; guarantee-stock plan; Kansas "permanent" stock or "contingent-reserve" stock plan-origin, methods of issue, use, statistics; criticisms of all plans; distribution of plans geographically.

The distinctive feature of the building and loan association is the plan or method by which its business is carried on. Just as a commercial bank in the United States is distinguished by the use of the checking account as a fundamental process, so the building and loan association is set apart from other savings and lending institutions by the plan according to which it receives payments. The "plan" is the type of contract between the association and its members by which money is invested in the business. The contract is a subscription to shares of the capital stock of the association, on which the association agrees to distribute its earnings on a coöperative basis.

The "plan" resolves itself into ( $\mathrm{I}$ ) the method by which the subscriptions and payments for the shares are accepted, (2) the time and manner in which the shares are issued by the association, (3) the arrangements for distribution of earnings, and (4) the provisions for retirement of the shares, and paying the 
investment back to the members. Whether the member is using the association as a means of building up a savings fund for himself or is repaying a loan by installments, he makes use of that one of the plans which his particular association offers.

Four principal types of plans are now in use in the United States. They are:

(I) The serial plan. ${ }^{1}$

(2) The regular permanent plan.

(3) The Dayton permanent (sometimes called the "Ohio") plan.

(4) The terminating plan.

Modifications of each have been developed to meet particular local needs. One of these is the guarantee-stock plan used in connection with the serial and Dayton plans by some associations in California, Oregon, and Colorado. A variant of this plan is called the permanent-stock plan in Kansas, or as it probably should be known in the future, "the contingentreserve-stock" plan.

\section{Discussion of the Plans}

A large number of variations from each of the plans exist, but to attempt a discussion of many of them would needlessly complicate our task and would tend to confuse the beginner. Variations are sometimes added in order to meet a particular local condition, or because officers have failed to comprehend the real nature of a given plan and have started it improperly. Curiously enough, it has often proved easier to continue these variations than to readjust the books and make a fresh start. Hence the many variations continue in use. A thorough understanding of the more important plans will provide a background for the student, so that he can analyze any other with

1 The serial plan is the most commonly used plan in the United States to-day and is almost the universal plan used by associations in many states. 
which he may be confronted. To provide this background, we will consider the plans in detail in the order of their origin.

The Terminating Plan.-The terminating plan starts as a neighborhood group, club, or association which meets once each week or month to help each member acquire a home. The members start to save at the same time and make regular weekly or monthly contributions toward a common fund. This fund is represented by installment "shares," similar to shares of stock in a corporation (although the terminating associations are seldom incorporated). Each share has a certain matured or par value (frequently $\$ 200$ each), and members may subscribe to any desired number of shares. All members pay a stated amount of dues on each share at each meeting, and regularity is enforced by a system of fines for delinquency. Thus all members remain on an equal footing until the shares reach their matured or par value, when the contract is completed or "terminated" and the assets of the association are divided among them.

The dues paid in at each meeting are at once loaned to members. Each individual member expects to borrow from this fund in his turn, if there is money enough available for this purpose at the time he wishes to obtain a loan. Hence he usually subscribes for enough par value of shares to equal the amount he would like to borrow.

Borrowers pay interest on their loans (usually upon the whole amount for the entire time) and continue the installments on their shares until they reach par value. This value is then applied to the repayment of the loan and the loan is canceled.

Earnings on the fund consist principally of interest paid by borrowers and the fines charged for delinquency. These are divided among all the members on the basis of their total periodic payments. By adding the earnings to the periodic payments, the investment reaches the par value of the shares more quickly than if it depended upon the payments alone. 
Profits received by the borrowing members tend to reduce the actual amount of interest paid by them.

The club is organized for the sole purpose of accumulating this one fund and lending it to the original members or others who come in on the same basis. When the shares have matured, they are then ready to be paid to the investors. Those who have borrowed use their matured shares to cancel their loans. Other members receive the proceeds of their shares in cash. This terminates the association. It is the earliest application in America of the coöperative methods for financing home ownership which originated in Europe and the Far East.

There is no other capital than the installments paid in at each meeting. The members own the business and assume all the risk. Persons who wish to save for a home in this way become members of the association as follows: (I) By agreeing to abide by certain rules or by-laws (which have as their principal purpose the enforcement of regularity of payment), and (2) by subscribing to the desired number of shares of stock of the association, on which they must make stipulated payments.

Since there is only one group of shares issued, people who join after the first month find that older members already have some funds saved in the association, and they can only enter by putting in as much money for each new share as the old shares are then worth according to the books. For example, if one dollar is collected each month on each $\$ 200$ share, original members will have $\$ \mathrm{I} 2$ per share irvested at the end of one year. Earnings allotted to each share may amount to thirty or forty cents by that time. If a new member enters, he is obliged to pay enough to make his shares equal to this amount of about $\$ 12.40$, plus the current dues for the next month. Thereafter he would keep in step with the other members. As time passes, the required first payments become much larger for new members, and few are attracted to the association.

The business transacted at the meetings of the association 
consists of only two things: ( $\mathrm{I}$ ) the receiving and recording of payments, and (2) lending out the money received. It is the object of the officers to lend out all the funds received at each meeting, and their ideal is never to have a balance of cash that is not at work. (This is the ideal in all other plans as well as in the terminating plans.) The loan is secured by a mortgage on real estate, together with the customary note, and also by the pledging of the shares of the borrowing member. ${ }^{2}$

Premium.-Precedence in borrowing was originally determined by competitive bidding among those desiring funds. The man who wanted the funds the most, bid the highest sum (in addition to the regular interest) for the privilege of obtaining them. (In some of the very early associations, the premium bid was the only interest charge.) This bid was known as the "premium," and the name and the practice are still used in many associations throughout the country, regardless of plan used.

The premium may be paid in either of several ways: (I) It may be paid in installments as an addition to the regular periodic dues and interest; or (2) it may be paid as a lump sum at the time of making the loan. The latter is called "gross premium" and its amount is deducted from the face value of the loan, leaving only the discounted proceeds ${ }^{3}$ of the loan for the borrower. He is responsible to the association for the full face value of the loan, as well as for interest on the face value. Other premiums are in use, but all sorts of premiums are legalized methods of charging a rate of interest higher than the current legal rate.

Borrowers are on hand at all the earlier meetings of the terminating association. At later meetings the number dwindles because the amount available to the borrower after paying back dues and deducting the gross premium grows

${ }^{2}$ See Chap. $\mathrm{X}$ for details of security required for loans. The type of plan used in securing funds does not affect the security which may be offered by borrowers.

"The term "discounted proceeds" is here used in the ordinary commersial-hanking sense of face value minus charges. 
constantly smaller as the association grows older and the book value of the shares grows greater. The net proceeds are very small in proportion to the loan. For example, if a borrower wishes to secure a $\$ 1,000$ loan when the association is five years old, and monthly dues are $\$ 1$ for each $\$ 200$ share (with dividends averaging 6 per cent compounded semiannually) and gross premium is $\$ 30$ per share, he would be obliged to subscribe for at least $\$ 1,500$ shares, and possibly more, in order to receive his net $\$ 1,000$. He would then have to pay interest and dues on the full amount of $\$ 1,500$ until the termination of the association. The actual cost of the loan to the borrower soon becomes prohibitive at this rate.

Failure of the Terminating Plan.-It is expected under the terminating plan that all shall continue their membership (I) until all have secured loans, equivalent to their shares in amount, and (2) until their payments of dues and the earnings have matured these shares, but it does not work out that way. As stated by an earlier writer: ${ }^{4}$

"This plan is very simple and seems easy of accomplishment. Practice, however, proves that it is seldom, if ever, carried out to the agreed point of termination, the difficulty being that, after the fourth or fifth year, the accumulating capital increases beyond the demand for it. By this time most of the members who desire it have been supplied with loans; and persons who would become members and borrowers cannot do so, owing to the heavy back payments required to equalize new shares with old ones; the result is a deadlock. It thus becomes necessary to enter into some plan of liquidation by which non-borrowing members are required to retire from the association, taking their accumulated capital and such portion of the profits as may be mutually agreed upon; thus absorbing the fund that otherwise would accumulate beyond all control or use for the legitimate purposes of the association: so that in place of running nine or ten years, and dividing to each share $\$ 200$, as the theory promises, they are compelled to go into a liquidating process, and terminate in from six to seven years, giving to each share from $\$_{130}$ to $\$_{150}$. This is the natural and certain result of a plan based upon one issue of stock."

Like many theories which are wrecked because they depend upon the occurrence of some other events, this plan fails not

${ }^{4}$ Edmund Wrigley: How to Managc Building Associations (1872). 
because there are no savings, but because it is not possible to match the savings with loans at all stages of the process. Carried to its logical conclusion, the association would have to lend all of its receipts at each meeting right up to the last. There would be nothing to pay back to any member on the last meeting night (except to the last borrower and he would borrow the full value of his shares) because all the members would have received the value of their shares by borrowing on previous occasions, and the last payments would merely mature their pledged shares. The real obstacles to making this plan a success are, therefore, apparent. It would take as many borrowers as there were meetings to make the plan truly workable, and each would need to borrow at exactly the time when the money was available.

Modifications of the original plan still exist. Later success has been due to pooling funds among several associations. The terminating plan is of importance to us because it is the basis of the widely used and successful "serial" plan.

The Serial Plan. ${ }^{5}-$ The serial plan is obviously the outgrowth of the terminating plan under which early associations worked. It retains many of the basic principles of its predecessor, but by slight changes in method it escapes some of the manifest disadvantages. Instead of using a single group of shares, the serial association offers new groups, or "series," of shares of its installment stock for sale at periodic intervals. New series are offered as frequently as it seems desirable, annually, semiannually, quarterly, or even monthly. Dues begin when the stock is issued, and shares mature at different

${ }^{5} \mathrm{~A}$ thorough discussion.of many phases of the serial plan was presented at the meeting of the United States League of Local Building and Loan Associations at Cleveland in 1924, and these addresses were presented in full in the Proceedings. Ernest A. Hale, President of the Massachusetts Coöperative Bank League, presented the coöperative bank plan (see pages 122-129); James MacMaster, Chief of Building and Loan Division of New Jersey, discussed the New Jersey serial plan (see pages 13I-I4I); and George W. Cliffe, Secretary of the Reliance Building and Loan Association of Germantown, Philadelphia, discussed the Pennsylvania plan (see pages $145-150$ ). 
times, depending upon the date of starting, upon the amount of dues paid, and upon the earnings of the association.

All the members of the terminating association were on the same footing as far as the book value of their shares was concerned. Under the serial plan each member of a group is on the same basis, but the association has arranged the groups in successive series. It is in a sense an association of an indefinite number of associations of the terminating type, each series in turn going through the processes of starting, functioning to maturity, and then disappearing, as its loans are liquidated and its "free shares" 6 retired.

As each series matures, the association is obliged to pay back to the free shareholders the amount of their investment. This takes considerable sums at recurring intervals, and presents one of the problems of the business.

The serial pian is essentially the same in every state where it is in use. Statutory provisions, however, modify the actual practice in many essential respects. For example, in New Jersey there is no limit upon the number of shares that may be owned by an individual member in a particular association. In the case of Massachusetts, the coöperative banks operate on a modified serial plan, but there is a definite limit to the amount of investment for an individual shareholder. Most variations in the plan are the outgrowth of attempts to adapt it to local conditions in the many states where it is in use.

Enforcement of Systematic Payments.-A basic principle of the terminating and serial plans is the enforcement of systematic payment of installments (or dues) on shares, by means of fines and other penalties. The theory is that enforced thrift is necessary ( $\mathrm{I}$ ) to insure the receipt of anticipated

- "Free shares" are savings shares which have not been pledged as part cf the security for a loan. When such shares mature or reach their full par value on the books of the association by the payment of dues and the crediting of dividends, the holder of the "free shares" receives the value of the shares in cash. When "pledged shares" mature, their value is applied to cancel the loan. 
funds, ${ }^{7}$ (2) in order to apportion earnings "equally and ratably" to all shares in the series, and (3) because systematic saving is believed to be socially desirable. Keeping all members "in step" is supposed to accomplish these ends.

Three methods are used to promote regularity of payments and to induce the members to continue their payments until their shares reach par value: (I) membership and withdrawal fees, (2) fines, and (3) forfeitures. Some associations use only one or two of these; a few use all three. Membership fees, as indicated by the term, are imposed when a member joins an association, and they may be based ( 1 ) on the number of shares subscribed for, or (2) on the individual member regardless of the number of shares taken. They provide an additional fund to help cover the expense of conducting the association, and not infrequently yield a profit. ${ }^{8}$ Withdrawal fees are deductions from the book value when shares are withdrawn before maturity. Although these fees are an additional expense to the savings member, their use has been justified on the ground that members will be more likely to meet their obligation and continue their payments until their shares have matured because they suffer a loss by withdrawing. ${ }^{9}$ The operation of membership and withdrawal fees is essentially the same.

Fines are also employed for the purpose of enforcing promptness in making payments by both savers and borrowers.

7 The officers frequently make tentative arrangements to lend money several months in advance of the actual date of the loan, and can do so only when they are certain that the money will come in.

${ }^{8}$ Occasionally an association refunds membership fees after a certain number of years, but the practice is not common.

- In Chap. IX, pages 180 to $18 \mathrm{I}$, an analysis is presented of the arguments for and against the use of membership fees. In the earlier years of an association's existence, or where the state charges a "charter fee" which must be met from some source, there may be some justice in the use of membership fees. Small fees are not subject to criticism as an injustice, but merely because they annoy the member unnecessarily. Their place as an expense fund could more conveniently be filled from earnings.

Although disliked by many association officials, a diminishing withdrawal fee appears to have some effect in retarding early withdrawal. 
The amount is seldom more than a few cents per share for each monthly payment missed. "Pennsylvania perhaps uses this more than ary other state, the usual and maximum rate is 2 per cent on the amount due and unpaid no matter how caused." 10 Such fines are deemed necessary by many associations for the same reasons which prompt the use of fees,(I) in order to avoid such delinquency as would lead to withdrawals, and (2) to insure receipt of anticipated funds. Laws of many states limit the amount of fines that may be levied. Usually they may not be charged against more than six months' dues, after which time delinquent shares are segregated in the accounts of the association.

Forfeitures are of various kinds but most commonly are limited to the withholding of a portion of the earnings upon withdrawal of shares before their maturity. Where the forfeiture involves the absorption of all the value of the shares, the problem becomes serious, and legislation to prevent the use of the proceeds of forfeited shares as profits is in existence in several states. ${ }^{11}$

The Permanent Plan.-The regular permanent plan differs essentialiy from the terminating and the serial plans in this respect: Each shareholder has an independent ledger account and his own shares start and are matured without regard to others. Periodical payments are uniform in amount as under the serial and terminating plans. A considerable number of associations formerly operating under the serial plan now use the permanent plan in order to invite subscriptions to shares at any time without the necessity of "getting in line" with others. The designation of the plan has no

${ }^{10}$ Letter from George W. Cliffe, Secretary of the Reliance Building and Loan Ássociation, Germantown, Philadelphia, to American Savings, Building and Loan Institute.

${ }^{11}$ See Chap. IX. The most serious charge against associations using forfeitures as penalties is that it involves misrepresentation, especially to members who are unfamiliar with finance. Unless the association has suffered an injury through excessive withdrawals, forfeiture of principal is unwarranted. 
direct significance since this plan is no more permanent in character than the serial association. Its books are continuously open for subscriptions and in this sense it may be considered somewhat more available to new members. A large number of the associations operating under the permanent plan enforce systematic payments throughout the life of the shares through a system of fees and penalties as in the former plans.

Shares issued under the permanent plan may have all the characteristics of those issued by serial or terminating associations, but the essential difference is in the matter of grouping. There is nothing to prevent the issuance of shares on every business day of the association's life, instead of putting out a large number only at stated periods. The issuing of large blocks of shares at one time in the older associations is undoubtedly an outgrowth of corporate practice in selling shares of stock. Corporate stock is usually sold in large amounts, but the business of such institutions is quite distinct from the sale of stock, and the capital so raised is but a small part of their resources. With the building and loan association the sale of shares is one-half its business; the other being the lending of money so received. No other capital is used. Continuous subscription to new shares provides a regular flow of money. The demand for loans is greater at some times than others, but it is like the activity of any other business. A regular income makes it possible to meet the demand. It is desirable, however, for an association to sell as large a block of shares at the start as possible, so that it may begin lending money at once on a scale large enough to yield a substantial profit above expenses.

A new member can start to save in a permanent association with no more delay than in a savings bank. There is no necessity to "get in line" with another group. No back payments are needed. The member subscribes to the number of shares desired, pays the first month's dues, and his savings are under way. He receives at dividend periods his due pro- 
portion of the earnings, based on the length of time his dues have been in the hands of the association. These are added to his account, and together with his own regular payments will mature the shares in a given period, depending on the profits and provided no losses offset the profits. The association is able to keep a simplified set of books more like those of a bank, thus cutting down the expense for each account. Also there is no necessity of preparing to meet a large volume of maturities at given dates.

The Dayton Permanent, or "Ohio" Plan. ${ }^{12}$-Associations using the Dayton permanent plan avoid the method of enforcing systematic payment of prescribed dues on shares. In all other respects they are similar to the regular permanent associations. They permit each member to suit his own convenience in making payments, thus attracting people with irregular incomes as well as others. At each dividend-paying date earnings are credited to the shares on the basis of their book value in the current period, the rate of profits being the same for all shares of stock of one kind. ${ }^{13}$

In some associations using this plan all shares are assumed to be matured at all times. Each payment represents in turn a certain number of shares or fractional parts thereof. In other associations, maturity is always postponed. This is done by requiring the member to subscribe for a nominal additional amount of stock whenever his present credits equal the par value of a given number of shares. For eyample, if the nominal par value of shares is $\$ 100$ each and the member has previously subscribed for I 5 shares, the secretary will request him to increase his subscription to 20 or 25

12 The Ohio plan was ably discussed before the r924 Convention of the United States League of Local Building and Loan Associations at Cleveland by H. E. Buker, Secretary and Attorney of Equitable Savings Building and Loan Association of Zanesville (see pages I4I-144 of I924 Proceedings). See also Proceedings for 1903 , pages $7 \mathrm{r} \mathrm{ff}$.

${ }^{13}$ It is possible in most of the states of the Union for any association to have more than one kind of stock, regardless of the plan used (see Chap. IV). Each type will share ratably in earnings (see also Chap. XVIII for dividend disbursements, etc.). 
shares, or perhaps more, when his credits amount to $\$ \mathrm{I}, 475$. In this way his customary payments will never quite catch up with the amount of stock subscribed for. Maturity of shares is thus more or less a fiction. No advantage would accrue to the member who wishes to withdraw by paying in at any time the unpaid balance needed to mature any given par value of shares and then immediately withdrawing the entire amount, nor would it benefit the association. The member is encouraged to save as much as possible and to leave his savings with the association permanently. However, it is customary to permit additional payments and withdrawals without penalty, and practically at the will of the member. The shareholder's savings are represented by shares, as in the case of all other forms of associations, and they are subject to all the benefits and limitations imposed upon shares and shareholders.

Although membership fees are charged in some cases, mainly to provide for operating expenses during earlier years of operation, or to take care of heavy charter fees which are imposed by some states, the general policy of the Daytonplan associations is the elimination of all fees, fines, and forfeitures, upon the theory that such fees discourage rather than encourage saving.

It is supposed by many building and loan men that the Dayton plan is a development of very recent years, but it was well organized at least thirty years ago, as shown by the report on building and loan associations prepared in 1893 by U. S. Commissioner of Labor, Carroll D. Wright. On the basis of a statement made by A. A. Winters, general manager of the Mutual Home and Savings Association of Dayton, Ohio, the Commissioner showed that the Dayton plan had already been in use twenty years at the time of his report. It was not invented by any one man, and showed changes in each successive year of its growth. The main object of all the changes was to simplify methods so as to enable the association to adjust itself more easily to the needs of its customers. It is the 
definite intention of Dayton-plan associations to provide a type of membership that will accommodate all types of income, to eliminate cumbersome calculation of premiums and other charges, and automatically to protect borrowers against forfeiture during periods of misfortune without the necessity of special action by the officers or directors. Borrowers under the Dayton plan are pledged to the payment of stipulated periodic sums as under other plans.

Dayton-plan associations were among the first to lend funds at a rate of interest fixed by the board of directors to borrowers in the order of their applications, thus discarding all premiums. Money paid upon stock subscriptions acted as a sinking fund with which the loan was eventually canceled, as in earlier plans. The difference lay in the fact that the borrower could definitely determine almost the exact time and practically the exact amount required to repay his loan (it would vary somewhat with the earnings of the association); and he knew that at any time he might increase his payments if he desired to shorten the period of the loan. Interest is charged only for the actual period of the loan, whereas older plans originally charged interest for the whole period or for an arbitrary additional period in case of early repayment. The latter practice has now largely disappeared.

Under the serial and terminating plans, all dividends were calculated on the amount which should have been paid on each share at the dividend date. This made it essential that regular payments be enforced in order to keep the books straight. Even under the regular permanent plan, regularity is of great assistance to the accountant. But the Dayton plan bases dividends on the amount actually paid in according to the date of respective payments, which eliminates the necessity of keeping members in step with each other.

Deposits under the Dayton Plan.-Many of the Daytonplan associations in Ohio not only issue shares but they also accept deposits under a contract guaranteeing the depositor a definite rate of interest, and place a double liability upon 
the shareholder for this purpose. Interest is usually lower than the rate of dividends paid on shares in the same association. This practice lays them open to the charge of being savings banks, a term frequently applied as a stigma, because of the relationship of debtor and creditor between the association and its depositors, instead of purely coöperative share-holding among the members.

The comparison is possibly not unjust. However, this definite difference does exist: Such associations devote their funds primarily and almost exclusively to amortized loans on real estate, usually on equitable terms, while savings banks lend their funds on any type of safe security which is readily available to them when they are in the market for loans. When the mortgages are lucrative, savings-bank balance sheets will show an increase in mortgages; when government or industrial bonds are attractive, their loans will take this form. They even go into the market for foreign bonds at times when the price appeals to the investing officers. In other words, the whole field of investment is searched by the savings banks for the securities which best fit their scheme of doing business. There is no reason to suppose they would be either better or worse off if they increased their mortgage loans. The savings deposited in the Dayton-plan associations, however, go at once into the highly specialized business of mortgage loans, and these associations, therefore, are rendering a form of coöperative service of real value in aiding their customers to acquire homes.

Aside from the large development in Ohio, the receipt of deposits by associations does not seem to be as general a practice now as when U. S. Commissioner of Labor Wright issued his report on building and loan associations in 1893 . At that time there were $64 \mathrm{I}$ associations in thirty-one states and the District of Columbia, which received deposits. This was approximately eleven per cent of all associations reporting, $(10.979 \%)$. In I92 I, $45^{8}$ associations, or 5.3 per cent of 
all associations in the United States at that time, accepted deposits.

Depositors in building and loan associations in Ohio are in the same position as depositors in banks. "No depositor in an Ohio building and loan association assumes any liability as to any losses - rhich may occur. In case of liquidation, the depositors are all paid in full before the stockholders receive anything. ... The stockholder may be assessed the face value of the shares in addition to his stock credits, to prevent loss to the depositors." 14

It is to be noted, however, that the acceptance of deposits is not a necessary part of the Dayton plan. It merely happens that the Dayton associations are those which are more likely to open deposit accounts than those using any other plan. In most states the acceptance of deposits by any building and loan association is prohibited by law.

The Guarantee-Stock Plan. ${ }^{15}$ - The guarantee-stock plan $\mathrm{h}_{\text {ras }}$ for its main feature a basic stock which is not withdrawable and which is used to guarantee earnings on installment shares or investment certificates issued by the same association under the serial or permanent plans. Dividends on other kinds of stock thus become definite obligations of the company. The guarantee-stock is a fund of capital paid in at organization, just as in the case of an industrial corporation or a bank, on which the association begins business. It is used for the same purpose as the capital of a bank, and acts as a safety fund to guarantee the stipulated dividends, whether earned or not. Definite dividends or interesi and a fixed date of maturity can thus be contracted for, and the possibility of keeping the promises varies directly with the pro-

${ }^{14}$ Letter from J. W. Tannehill, Superintendent of Building and Loan Associations for Ohio, to the American Savings, Building and Loan Institute, September i 3,1924 .

${ }^{15}$ The guarantee-stock plan was very fully presented by R. Holtby Myers, Secretary-Treasurer of the Mutual Building and Loan Association of Los Angeles before the 1924 Convention of the United States League at Cleveland. (See pages 151-156 of 1924 Proccedings.) 
portion which the guarantee ${ }^{16}$ stock bears to the outstanding amount of installment shares. That is to say, if the amount of guarantee stock outstanding is small and the amouni of other kinds is large, the guarantee will be of small value. Building and loan associations have been so uniformly successful that no guarantee stock association has ever failed to make payments on all kinds of shares. But if for any reason, earnings should fall off in a particular association and installment shares outstanding amounted, for example, to $\$ 3,000,000$, the presence of only $\$ 100,000$ worth of guarantee stock would not in itself make it possible to meet an obligation of six per cent on the installment shares. The amount of the guarantee stock should be great enough to be of real assistance if the guarantee were ever needed. ${ }^{17}$

But in practice, even in periods of depression, the earnings have not dropped low enough to bother the guaranteeing shareholders. The presence of this additional capital enables the association to start lending operations promptly after organization, and to stabilize the amount of capital with which it operates. Its earnings are usually large from the very start.

The guarantee-stock plan meets the needs of the unstable population in newer sections of the country. People are mak-

20 Both spellings of the word "guaranty" and "guarantee" are used in building and loan practice. The word denotes that class of stock which undertakes the greater risk, and not that upon which the earnings are guaranteed. Hence the use of the spelling "guaranteed stock" is incorrect, as it conveys a wrong impression. The holders of this stock promise that the business will pay other shareholders a definite rate of return for a definite time. If the earnings should not be great enough, this stock "guarantees" the payment, and makes the installment shareholders secure against loss or damage. The State Building and Loan Department of California uses the spelling "guarantee." Since the older spelling "guaranty" is now regarded as obsolete except for legal usage, we also have adopted the form "guarantee." Guarantee stock is principally in use in California, Oregon, and Colorado.

${ }_{27}^{17}$ The California law recognizes the necessity of this relationship. Guarantee stock must equal yo per cent of the investment certificate liability up to $\$ 1,000,000 ; 7 \mathrm{I} / 2$ per cent up to $\$ 2,000,000$; and 5 per cent up to $\$ 5,000,000$. (Sec. 634 (e) of California Civil Code, Title XVI Building and Loan Associations.) 
ing new adjustments constantly, and they like to move about until they find a place to establish a home. Meanwhile they wish to put their funds to the most favorable use, but they do not want to leave them for any length of time. Because of the presence of the capital of the guarantee stockholders (a fund which remains permanently in the association business), the lending operations are not greatly affected either by the entrance or withdrawal of the temporary funds. If losses should occur before the contract with the temporary investors is completed, they could be absorbed by the guarantee stockholders. Installment shares, investment certificates, and certificates of deposit ${ }^{18}$ can be issued by such associations with full assurance that the earnings contracted for can be paid. Earnings in excess of the contract liabilities accrue to the benefit of the guarantee shareholders. Purely mutual building and loan associations, operating on the older plans, distribute all earnings on substantially the same basis to all shareholders. Owners of guarantee stock may participate in all earnings above those allotted to other shares. After the contract rates have been paid, if additional earnings remain which might by law be paid out to the guarantee stockholders, it is customary to retain part of the excess earnings in the business and issue stock dividends on the guarantee stock. The later shareholders of the association gain the protection of the larger guarantee, although it will have cost them nothing.

In the early years of a guarantee-stock association's life, the contribution which holders of this stock make is of far more importance than that made by the installment shareholders or other investors. They have assumed a larger risk, and a larger income is therefore justified. But as the asso-

${ }_{2}^{18}$ Deposits are prohibited under the California law, but the terms "certificates of deposit" and "investment certificates" are used interchangeably to denote the formal receipt given in exchange for temporary funds.

It is interesting to note that "shares" are distinguished from "stock" in California. Installment investors save on "shares," while "stock" denotes the permanent guarantee stock. 
ciation strengthens its position through years of service, the importance of the guarantee stock dwindles.

To adjust the dividend rates equitably among the different kinds of stock is difficult, but not impossible. Usually the holders of installment stock are asked to waive their right to all earnings, if any, in excess of their contract rate, in favor of the guarantors. ${ }^{19}$ The guarantee stock plan is probably used as a modification of the permanent plan to a much greater extent than in connection with the serial plan, although it may be used with any plan.

Kansas "Permanent Stock" or "Contingent Reserve Stock" Plan.-One of the reactions in Kansas against the old national associations ${ }^{20}$ of the 90's was the lack of public confidence in the old indefinite mutual plan of the serial association. It was felt that these mutual associations could not be safe because they had no reserve, and hence could not pull themselves out of difficulties in case of loss. Members of the old nationals of this period had suffered many losses and, as is usual in such cases, the blame fell upon a feature of the business which had little or nothing to do with the real situation. Actually the cause of most of the failures was lax state laws and poor supervision.

It was thought advisable to inaugurate a plan that would restore confidence in the institutions; and since the criticisms were being directed against the lack of a reserve, the suggestion was made that a new kind of stock be introduced which would provide a serial association with a fund which would act as a reserve. This stock was to be sold to the public like any other stock. The purpose of the stock was to make it possible for an association to sell series of shares upon which a definite contract rate of dividends could be promised, and which would mature at a definite date. The

${ }^{19}$ The statutes of none of these states appear to make any provision for a distribution of profits in excess of the contract rate. Provisions of the by-laws therefore govern.

${ }^{20}$ The national associations are discussed in Chap. XXIII, History of the Associations. 
presence of the additional amount of capital was expected to make the earnings large enough to meet the contract requirements on the serial shares, and no dividends were to be paid upon the new stock until the dividends on the series were first cared for.

The name given by law to this new capital was "permanent stock," but since there is no requirement that such stock shall remain permanently in the business, the name "contingent reserve stock" seems to be a term which more closely defines its purpose. ${ }^{21}$ After providing for the ordinary methods by which an association may collect capital, the Kansas law of 1899, as amended in 1919, states: "Any such corporation may also issue permanent stock, for which full par value shall be paid at time of issue or in monthly installments of five dollars per share, at the option of the purchaser, and upon which permanent stock a full dividend, or a definite dividend may be paid, which dividend shall in no case exceed the per cent of profit per annum acquired by any other class or series of stock at the time such dividend is declared. The balance of profits (if any) and the principal paid on said stock shall not be paid to the holders of the same until all lawful claims of every other class of stock in its series, as expressed in the certificate of such other classes, and all other liabilities of such corporations, shall have been fully liquidated and paid." 22

This new type of stock may be issued in either of two ways: (I) a small amount can be issued with each series of regular installment stock, in which case it is used to guarantee the

21 This term is offered by the present writers following the lead of W. L. Bowersox, president of the Kansas State League of Building and Loan Associations, who suggested the term "contingent stock" to replace the name "permanent stock" in Kansas. The term "contingent-reserve stock" seems exactly to define the character of this stock, and it has the approval of several Kansas building and loan men including L. E. Roush of Wichita, former state supervisor.

${ }^{29}$ Kansas Building and Loan Association Laws, Chap. 78 of laws of 1899, with amendments up to and including 1923, Section 6 (amended 1919). 
earnings upon the stock of that series only, or (2) all the new stock may protect all the serial shares without being allocated to a given series. The profits which accrue are put into a reserve account in the latter case, and if a profit over the dividends which had been guaranteed the shareholders remains in the reserve account when a series matures, this remaining amount becomes the property of the contingentreserve stockholders. The second plan seems to be the more practicable.

If the contingent-reserve stock is issued for a single series (as in the first case mentioned), it may be withdrawn when the other shares in that series have matured, if all the dividends have been met. The contingent-reserve stockholder may then withdraw not only the full value of his stock, but also all profits, if any, accruing to it after the liability for dividends and expenses has been met.

Where the contingent-reserve stock is not assigned to protect a given series, the excess profits from a single series may not be withdrawn when that series matures, according to a ruling of the Attorney General of Kansas, but stock dividends may be declared against the excess profits, leaving the money in the business. The new shares acquired as a dividend would then continue to draw further dividends, like any other part of the contingent-reserve stock.

The liabilities of the association which may be met with this contingent-reserve stock are definitely limited by law. The value of this stock is supposed to be kept intact and not used for meeting unusual expenses. Expenses must be paid from earnings only. If the earnings of the association are not large enough to meet the dividends promised upon the definitecontract shares, however, the contingent-reserve stock could be used to make up the amount required as far as it would go. This does not mean that it absolutely guarantees the full amount of the earnings, or that it protects the association against all losses. As in California and Colorado, the amount of protection which it supplies is dependent upon the size 


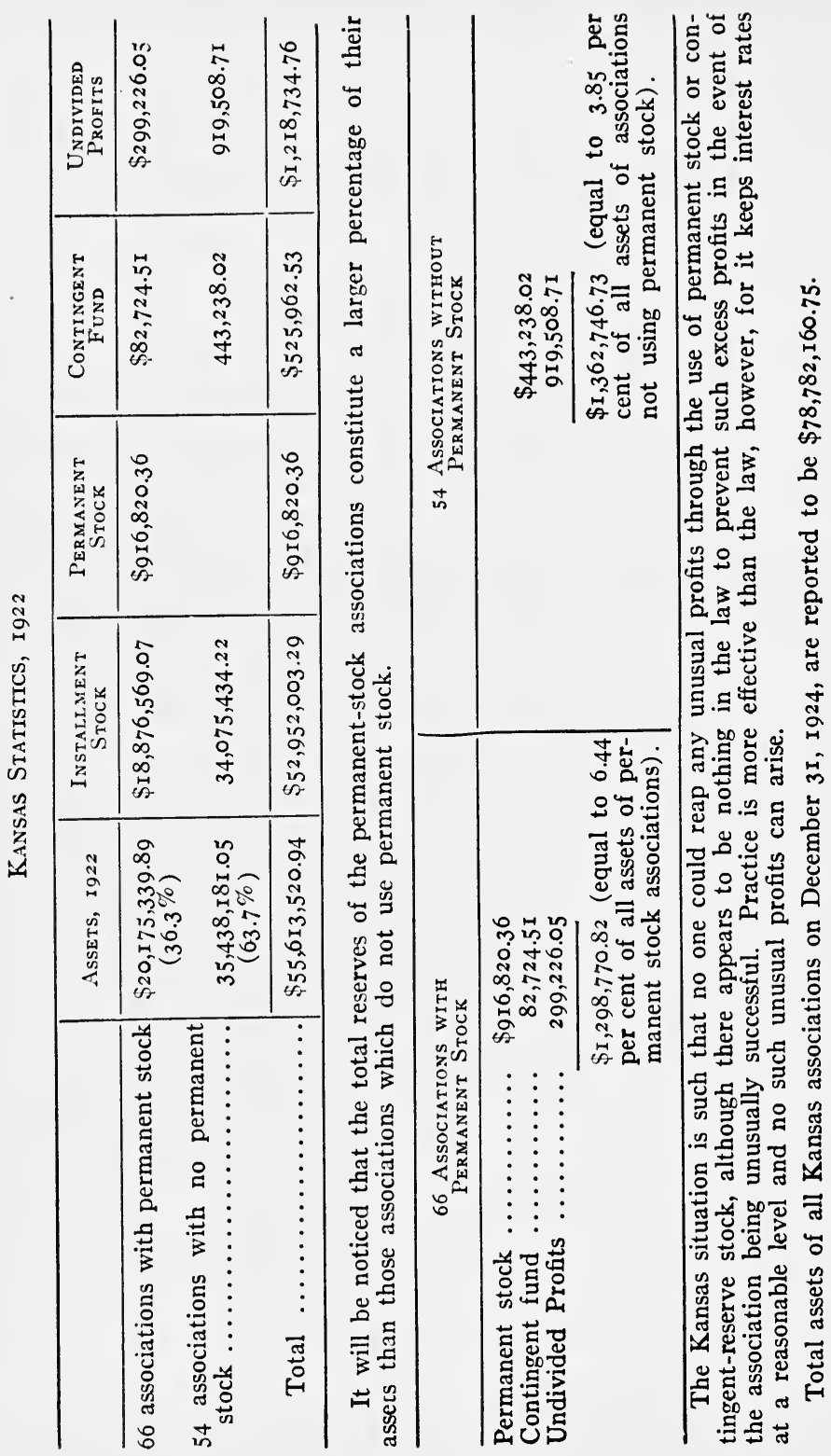


of the contingent-reserve stock fund as set over against the total amount of the shares on which it undertakes to guarantee the dividends. All contracts so far as known have been fully met and the dividends on all classes of stock have been liquidated.

In this connection it is interesting to note the accompanying statistics of the Kansas associations as reported by the state supervisor in the 1922 report. Of the associations reported, 66 were using permanent stock and 54 made no use of it. The 66 associations had about four-elevenths of the total assets reported by all associations, or 36.3 per cent. It should be noted that, on the average, associations using permanent stock in Kansas have been doing business for a much shorter length of time than those without such stock.

\section{Criticisms of the Plans}

To ascertain the comparative merits and demerits of the various plans outlined is a difficult undertaking. With the exception of the terminating plan, now largely a thing of the past, each plan has its enthusiastic supporters and its pronounced detractors. Many differences in plan have arisen in response to real or fancied differences in circumstances and environment. Differences in point of view have been reflected in changing laws, and, at times, the course of the business has had to change in response to unfriendly or ill-considered legislation; but with every change, the fundamental purposes of promoting thrift and home ownership have been retained. Efficient and largely altruistic service has been given by those intrusted with the direction of association activities.

The manifest limitations of the terminating plan and the further fact that it is no longer a facior of importance justify avoidance of further discussion of it. Because these associations wind up their affairs and go out of business when the shares have run their course people are apt to conclude that the association was not a success. It frequently happens that strangers are told that building and loan is not needed in 
a particular town because the one that tried it failed. On investigation it is often shown that the association reported as a failure was merely a terminating association that was obliged to discontinue when its purpose had been accomplished.

Criticism of the Serial Plan.-The serial plan is very much in evidence and it has had a longer period of unhindered growth and proved dependability than any other plan. It definitely recognizes the importance of systematic thrift as an economic asset and a builder of character. It inspires group enthusiasm in joint action at stipulated periods. It is particularly adapted to promote neighborhood friendliness and cooperation, especially in localities where industrial development provides a large number of people with assured, steady income, as it enables them to save systematically and to help each other in acquiring homes.

Those who prefer some other plan will say that the serial plan is out of date, meaning that newer plans have advantages not possessed by the purely serial plan, and citing their objections somewhat as follows:

(I) That it requires the association to accumulate large sums periodically to meet the maturity of free shares of a series. (The serial men answer this by saying that the association can borrow from banks or individuals when money is needed in excess of current receipts, and pay off the loans when receipts exceed demand. Installment payments of later series may thus be used in part to mature older series without disturbing current loans on mortgages. One series is thus in part replaced by another.)

(2) That, at such times, the association is unable to take care of the needs of all who wish to borrow. (Answer: "The credit of the association enables it to meet all legitimate demands.")

(3) That the accounting methods are complicated and burdensome. (Answer: "Modern serial associations have perfected their accounts along lines as simple and complete as any other plan.") 
(4) That many who might be induced to save are deterred when the lapse of time after a series is opened makes it necessary to pay an initial amount that is in excess of their means. (The answer of serial association men is that with the constant offering of new series this difficulty does not arise. Members may take one or more shares and increase the number gradually as their means permit.)

(5) Others will not join because they are not sure of having a steady income which will enable them to avoid the penalties for failure to meet all payments promptly. (Serial men claim that this objection is never heard by them.)

(6) The objectors feel that no person should be required to conform his saving to conditions imposed by a group of shareholders who organized the association in order to invest their money at good rates of income and who are manifestly in position to enjoy all the benefits and escape all penalties. Such men have a regular income and can make regular payments. (Pennsylvania officers answer this objection by saying that their associations are strictly mutual. The officers are elected by the shareholders, who have the right to attend all meetings. Therefore, any regulations in the by-laws or board rules that are irksome may be readily changed at any time.)

In spite of these criticisms, millions of people have found this plan thoroughly satisfactory and have profited by their membership in the serial associations, and millions more will continue to do so.

Criticism of the Permanent Plan.-Advocates of the permanent plan claim for it all the advantages of serial associations, and in addition they advance the argument that this plan eliminates the difficulty of meeting maturities and also simplifies accounting problems. It also allows shares to start at any time. It is the serial plan applied to a wider field through a small number of internal adjustments. Less criticism seems to be directed against this plan than any of the 
others, except where periodic payments are enforced by fines, in which case the advocates of the plan would probably reply, as in the serial plan above, that systematic saving is worth working for.

Criticisms of the Dayton Plan.-The Dayton plan is said to throw open the door to savers with every type of income, regardless of regularity, and makes its appeal particularly to those whose work is intermittent. This exposes the plan to the accusation that it is merely a bank. Originators of the Dayton plan proceeded on the assumption that saving should be made attractive. They abandoned the use of all fees and penalties, made savings funds readily withdrawable by members when needed, and usually required no forfeitures of earnings when shares were withdrawn before maturity. Every dollar received as savings they applied as dues on shares on a coöperative basis.

It is objected that the Dayton Plan lacks the characterforming quality of enforced, persistent, systematic saving. In answer, its adherents point out that penalties discourage saving at the very time when it should be most encouraged. Only the persons of strong will-power can continue paying dues when their income falls below its customary level, and, regardless of their determination, it becomes impossible to make payments when they are out of work. This plan, they say, makes it possible to reach greater numbers of savers, since it brings in both periodic and intermittent accumulation. The safety and profitableness of building and loan shares are thus made freely available to all who are in position to save to any extent and in any manner.

The Dayton-plan associations were the first to provide the convenience of well-equipped offices, open during business hours, thus facilitating the transaction of necessary business, and rendering a maximum service to all members. This practice is now coming into general use throughout the country for all types of associations. The serial associations of the 
East have been slower to adopt the regular office hours than any others. ${ }^{23}$

The great growth of assets of associations which charge ne fees or penalties but succeed in retaining the funds permanently is also cited as proof of the greater service which may be rendered by those which have followed the Dayton plan and abandoned these excess charges. The real test of merit of any association is the service rendered in the promotion of association ideals: thrift and home ownership.

Criticisms of the Definite-plan Associations.-It is claimed by those using both the guarantee-stock, and the permanent-stock or contingent-reserve-stock plans, that savings members prefer to know definitely in advance when their shares will mature, and that before they start to save they want to know what the exact number of payments will be. Borrowers, also, are believed to prefer a definite-contract loan, of which all costs are known in advance. This is provided by the guarantee-stock plan. But if one group of share-holders makes it possible for the others to avoid the ordinary risks of the business, those who provide the guarantee may reasonably expect to share in any unusual profits that happen to result from the operations of the business. They have provided a fund of money to protect the installment savers, and it is entirely possible that one or two bad years might wipe out the equity which they have built up by years of hard work. ${ }^{24}$ The guarantee-stock associations do not permit their members

\footnotetext{
${ }^{23}$ Regular business office hours are maintained by most of the associations in 27 states. In eight states the practice is irregular or absent. Connecticut, New Jersey, Pennsylvania, Delaware, and Maryland have practically no associations keeping regular business hours. In Minnesota only the associations in the larger cities keep them. In Maine and New Hampshire very few do, and in South Carolina not more than to per cent do.

24 "The advantages of the capital-guarantee stock plan are best appreciated and understood in the West where people are strange and strangers; in territory where few men of capital and leadership seem to have time and inclination to promote a form of coöperative financial institution, which promises little reward in either cash or appreciation,
} 
to withdraw their funds by means of checks, nor do they treat them in any other respect as a bank treats its deposit customers. They conduct their business on a genuine building and loan plan with all the usual safeguards and with the added advantages that (a) the members know definitely in advance the returns which their savings will yield, and (b) the borrower knows the exact time of maturity of his loan and therefore the exact total cost to him.

If there is any point at issue between the old-time building and loan men and the advocates of the guarantee plan, it would seem to be on the matter of mutuality. Can such associations, it is asked, claim entrance into the great family of building and loan associations when all the stockholders do not receive the same proportionate share of the profits? The question as to whether "mutual sharing" means that all shall receive the same returns will not be raised here. Each particular class of investors in these associations receive a rate of income uniform within the class. It might also be mentioned that no opposition of any real strength has developed against these associations. The advantages of purely mutual associations are not entirely lost by the use of guarantee stock. ${ }^{25}$

Argument as to the respective merits of the variolis plans is often wide of the mark. In spite of expressions of doubt of the soundness of certain plans (and all of them have their detractors), the fact remains that all have a most favorable record for solvency. ${ }^{26}$

"Those who do not know conditions may criticise. To many, some of our associations seem irregular and unorthodox. But any institution which teaches thrift and loans its money to promote home getting is justified, provided it operates upon ethical standards."

-R. Holtby Myers, in American Building Association News, 1921, page 555 .

23 "Because an association may have a paid-in guarantee capital does not, of necessity, preclude its operation as a "mutual," especially as regards its installment shares, which the law apparently contemplates it should also have." From Report of Geo. S. Walker, Commissioner of Banking, California, r92r.

${ }^{20} \mathrm{As} \mathrm{Mr}$. Charles S. Elliott well said, in his address before the 23rd 


\section{Geographical Distribution of the Various Plans}

The four principal plans are used by associations in practically all parts of the country.

32 states report that the serial plan is in use within their borders.

20 states report that the permanent plan is in use.

Io states report the Dayton plan.

9 states report the terminating plan.

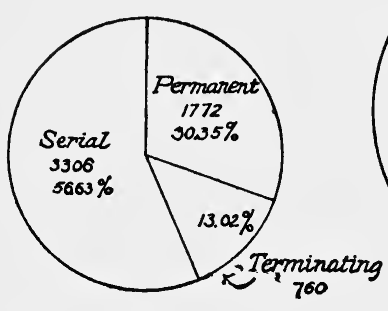

1893

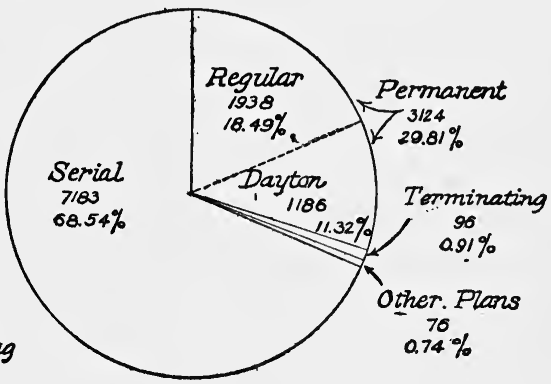

1923

Chart 3.-Changes in plans in use I893-1923, by building and loan associations in the United States. (Circle for 1893 represents the plans of 5838 associations, as shown in Wright Report. Circle for I923 represents the plans for 10,479 associations, as reported by state supervisors and others.)

Over the nation as a whole there are more than twice as many serial-plan associations as of any other type, even when all types of permanent plans are counted together. Next after the serial plan, in present organizations at least, comes the regular permanent plan of which there are 1938 in use. This annual convention of the United States League of Local Building and Loan Associations, at San Francisco, in 1915 :

"After all, it is not so much the style of the association, so long as it is kept up to date, as that you secure the confidence of the people. They will accept most any plan you offer, but the very fact that your plan has the elements of equity is what gains and retains their confidence." 
divides honors with the Dayton-permanent plan, for there are at least i 86 Daytons in the United States. The old terminating plan has now been superseded generally in all states, although there are nearly one hundred of these associations still operating. The accompanying table and chart show the changes in plans in use from 1893 to $1923 .{ }^{27}$

TABLE II

Changes in Building and Loan Plans in the United States, $1893-1923^{1}$

\begin{tabular}{|c|c|c|c|c|c|}
\hline \multicolumn{3}{|c|}{ Plans in $1893^{2}$} & \multicolumn{3}{|c|}{ Plans at Close of $1923^{3}$} \\
\hline Kind & $\begin{array}{c}\text { Num- } \\
\text { ber }\end{array}$ & $\begin{array}{c}\text { Percen- } \\
\text { tage }\end{array}$ & Kind & $\begin{array}{c}\text { Num- } \\
\text { ber }\end{array}$ & $\begin{array}{l}\text { Percen- } \\
\text { tage }\end{array}$ \\
\hline $\begin{array}{l}\text { Serial } \ldots \ldots \ldots \ldots \\
\text { Permanent } \ldots \ldots \ldots \ldots \\
\text { Terminating } \ldots \ldots \ldots\end{array}$ & $\begin{array}{r}3,306 \\
1,772 \\
760\end{array}$ & $\begin{array}{l}56.63 \\
30.35 \\
13.02\end{array}$ & 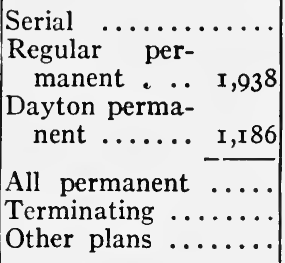 & $\begin{array}{r}3,124 \\
96 \\
76\end{array}$ & $\begin{array}{r}29.8 \mathrm{I} \\
0.9 \mathrm{I} \\
0.74\end{array}$ \\
\hline Total reported & 5,838 & 100.00 & Total reported .. & Io,479 & .00 \\
\hline
\end{tabular}

1 See Appendix, Table XXXI, showing complete classification of plans in use in United States 1923-1924, and Chart 13 based on that classification.

${ }^{2}$ Data from Report of Carroll D. Wright, U. S. Commissioner of Labor, I 894 .

${ }^{3}$ Data supplied by supervising officials and association officers, 1924 .

${ }^{27}$ A study should be made of the division of associations geographically and by plans, but on the basis of their assets. From the standpoint of the contribution to economic progress which the building and loan movement is making, the amount of business done is far more significant than the number of associations transacting it. The information on which such a study should be based, however, could only be obtained at present by very expensive investigation, since but a few supervising departments keep the statistics up to date and there are no collected data in the states where there is no supervision. As already suggested in another chapter, a complete investigation and report of this kind, along the line of Commissioner Wright's complete report of 1893 , should be undertaken by the U. S. Census Bureau. With this information to supplement the data compiled by the state leagues and the state officials there could be some uniformity in the interpretation of results and the figures given would have more value. 


\section{SPECIAL REFERENCES}

Building and loan in New Jersey. U. S. League Proceedings (1924), pp. I3I-I4I.

Building and loan in Ohio. U.S. League Proceedings (1924), pp. 142145 .

Building and loan in Pennsylvania. U. S. League Proceedings (IgI6), pp. 97-I20; (1924), pp. I45-150.

Coöperative banks in Massachusetts. U. S. League Proceedings (I916), pp. 40-48; (1924), pp. 122-I 29.

Dayton plan. Iowa League Proceedings (1916), pp. 25-26. U. S. League

Proceedings (I901), p. 140; (1903), pp. 7I-83; (1910), pp. 90-103.

Youngstown Institute Proceedings, March 8, 1923, pp. 7-8.

Dues. U. S. League Proceedings (I900), p. III.

Guarantee capital stock plan. U. S. League Proceedings (1924), pp. I5I-I 56 .

Kansas plan. U. S. League Proceedings (I9I5), pp. III-II5.

Permanent plan. Illinois League Proceedings (1918), pp. 55-59. Iowa League Proceedings (1916), pp. 32-38. North Carolina League Proceedings (1924), p. 57.

Polish associations. U. S. League Proceedings (I915), pp. I48-150.

Serial plan. Illinois League Proceedings (1918), pp. 55-59; (1920), pp. 85-89. Iowa League Proceedings (I916), pp. 30-32. U. S. League Proceedings (1900), pp. 109-110; (1910), pp. 90-103. Youngstown Institute Proceedings, March 8, I923, pp. 6-7.

Terminating plan. Iowa League Proceedings (I916), pp. 29-30. Youngstown Institute Proceedings, March 8, 1923, pp. 3-5; March 23, I923, pp. 3-4.

\section{GENERAL REFERENCES}

Rosenthal, Henry S. Cyclopedia, pp. 99-140. Sundheim, Joseph H. Law, pp. 25-29; 54-56. 


\section{KINDS OF SHARES ISSUED}

Purpose of capital among different companies:-industrial corporations, banks, and building and loan associations; essential difference between stock issued by building and loan associations and other corporations; the risk factor in association investment; sources of funds; types of stock issued; reasons for high dividend rate; installment stock; prepaid stock; paid-up or full-paid stock; guarantee stock; investment certificates; double-payment shares; juvenile savings; income bonds; certificates of indebtedness; differences in income, risk, and control.

While building and loan associations are essentially cooperative in their nature, the shareholders are not all on the same footing in each association. Capital stock is issued with a slightly different end in view from that of the ordinary business or financial corporation. In ordinary business, stock is sold in order to obtain only a comparatively small part of the capital which is used by the corporation. The money received from the stockholder is usually invested in a fixed plant, and this earns dividends by producing goods of some sort. It is a permanent part of the business structure. But most of the capital used by an industrial business is loaned to it by the creditors of the corporation. That is, the firm buys goods on credit of 30,60 , or 90 days. It sells the goods before payment becomes due, and thus has the money to make repayment, because the customers have completed at least a portion of their purchase in the meantime. Every business thus makes use of much capital belonging to others.

This is as true of banks as it is of industrial corporations, except that banks are buying and selling money and credit instruments instead of other types of goods. Stockholders' capital is but a small part of the bank's funds. The principal 
source from which a bank's loanable funds are derived is the deposits of its customers. People leave their money with the bank for short periods, drawing checks against it as they need it. The banker knows from experience about how long this money will remain uncalled for. $\mathrm{He}$ at once lends most of the money to his borrowing customers, knowing that it will be repaid by the borrowers before the depositors call for it or write checks against it. Thus the capital which is contributed by the stockholders of a bank or of an ordinary industrial corporation is but a small part of the fund with which that business is carried on. Actually the bank's capital is a fund used to guarantee the payment of the liabilities of the bank, including deposits.

In the case of a building and loan association, stockholders' capital plays a much more important rôle. Practically all the funds which the association has to lend come from its shareholders, who are the savings members and borrowers of the association. In most associations the borrowers become savings members at once on taking out their loans. The small periodical repayments by the borrowers constantly add to the loanable funds of the association. There are no "preferred creditors," except in the small number of associations operating on the guarantee-stock plan and in those associations which accept deposits. It is true that associations borrow temporary funds from the commercial banks to care for extraordinary needs, as do all other business organizations, and in such cases the lending banks become preferred creditors; but aside from these small borrowings the association depends on the constant flow of capital contributed by the shareholders and the earnings on this capital.

The essential difference between the stock issued by a building and loan association and that of any other corporation is (I) that building and loan stock constitutes practically the entire capital fund for the association's business, (2) that it may be withdrawn from the business when it "matures," and (3) that the owners of the shares are the principal customers 
of the association. The lenders are also the borrowers, although some associations lend to persons not members. In all other respects, building and loan shares are like similar shares of other financial and industrial corporations. Because of the regularity of their income and their high degree of safety, the best building and loan shares constitute as good an investment as bonds and high-class preferred stocks. But this does not mean that risk has been eliminated. Risk is always present in connection with stock ownership because all business has its periods of trouble. This risk is reduced to a negligible quantity in the building and loan associations, because (I) loans are made only on approved security of known value, (2) the margin of security behind the loan grows constantly greater, and (3) as coöperative organizations, the control of building and loan associations is in the hands of the members themselves.

Money invested in the shares of building and loan associations is at once re-invested by the association in permanent or semi-permanent form. It is loaned against mortgages on real estate, primarily, and will not be entirely repaid to the association until after a period of years, although part of it will be repaid each year in monthly or weekly installments. The shareholder owns an undivided interest in the whole group of mortgages which make up the association's assets.

The association aids all of its members in the accumulation of savings. But its shareholders receive their income from many sources and at different times, and they are not all ready at the same time to put their money into the association's hands. A few persons always have large sums in banks awaiting investment. Some have only occasional funds which they wish to invest. But the great majority of the people work on a wage or salary basis, and they have only a small surplus after each pay-day. It is in caring for the savings of the latter that the association movement has had its largest growth. In order to accommodate not only these, but all types of investors, the associations have issued many kinds of shares of stock. 
Most important among the kinds of stock issued is installment stock, but prepaid, full-paid (or paid-up), guarantee, double-payment, and juvenile shares are more or less common throughout the country, and investment certificates are used in California. It frequently happens that one association issues several kinds of stock. The rates of dividend on the different kinds of stock may be different, but there is usually some degree of similarity, and the intention is to make the return to each class of stock commensurate with the contribution which it makes to the life and success of the association.

Savings accumulated in building and loan associations differ from those accumulated in savings banks. It is not correct to class the two kinds of savings together. Ordinarily the dividend rate paid by building and loan associations is considerably higher than the interest rate paid by a savings bank. The building and loan member gets the higher rate because (a) the type of investment yields an unusually high rate of return, (b) the money is constantly employed, and (c) because the expenses are lower in all coöperative institutions than in banks, especially where earnings are divided on a mutual plan, due to the fact that many high-grade men contribute their time in aiding the management.

Instead of paying the profit to a group of people who have contributed only a small amount of capital stock, the building and loan association pays all the profits to its members. Each member is part owner of the business, assuming an ownership risk-a thing which must be assumed by someone in every business. The large profits go to the business man who is willing to assume a risk. In building and loan associations, the risk is negligible, it is true, but no emphasis on this fact should be allowed to cloud the issue. The building and loan member is an owner of the business and hence it is possible to pay him such handsome returns on the money saved. No savings bank, with.its large overhead costs, can afford to pay such high rates. 


\section{Explanation of Different Kinds of Shares}

Installment stock is readily understood. The subscriber undertakes to buy a given number of shares, usually with a fixed par value, or "matured value," 1 and instead of paying for them in a lump sum, as is customary in buying bank or industrial stock, he agrees to pay at regular intervals a given amount of money, usually the same amount at each payment. For example, if the par value is $\$ 200$ and the usual rate of profits in the association is 6 per cent, he may pay for each share $\$$ I a month. At the end of each six months he has paid $\$ 6$ per share. The association computes its profits and credits the proper amount to the series of shares in which his share belongs, (if the shares are issued in series). In only a minority of cases in serial associations are the profits credited to the shares directly, and they are rarely paid to the member immediately. ${ }^{2}$ In permanent-plan associations the profits are credited to each member's shares when dividends are declared. This money remains among the assets of the association and is re-invested at once. When the next dividend date arrives, the profits are computed not only on the installments of dues

1 The term "par value" is always a misnomer, and it is particularly unsatisfactory in connection with stock of the building and loan association. Irstallment stock is automatically wiped out or replaced by other stock when it matures, or becomes equal to its par value. The term "matured value" more nearly represents the idea involved.

In some associations operating on the Dayton permanent plan, eacl dollar deposited is regarded as $1 / 100$ of a fully paid share. This makes it possible to comply with the law if par value is required, while at ti:e same time it does not clutter up the accounting system with the record of par value.

"The depositing member subscribes for stock equal to the amount of money that he deposits, plus the dividends declared thereon, and each withdrawal from his account cancels a pro-rata amount of the stock." (Letter from James M. McKay, President of the Home Savings and Loan Company, Youngstown, Ohio.)

Par values of $\$ 100$ and $\$ 200$ are the most usual in the United States, but the range is from $\$ 10$ to $\$ 500$, with certain odd amounts sucl as $\$ 104$ and $\$ 130$ in some states.

A few associations in Kentucky pay full cash dividends on dues accumulations, and shares are eventually matured by dues only. 
paid by the member but upon the previous profits as well. The earnings are thus compounded every six months, and if the rate of dividend continues to be 6 per cent per annum in approximately II years and 7 months the book value of the share "matures" or becomes equal to its par value of $\$ 200$. It may then be withdrawn by the member (in which case the association pays back the total par value to the member) or re-invested according to the rules of the particular association. ${ }^{3}$

Not all associations compound the earnings on installment shares. One large serial association in Pennsylvania pays an average of 6 per cent dividends, but since these are not compounded, the average time of maturity is 147 months instead of 139 months on the monthly payment of $\$ 1$ for each $\$ 200$ share.

The term "deposit shares" is used in some states to indicate installment shares held under the Dayton plan; to which credits may be added or from which withdrawals may be made at will. The use of the term arises from the accounting

${ }^{3}$ Payments and time of maturities for installment shares of $\$ 100$ par value at different dividend rates are shown in the following table, computed on the basis of dues paid on the first of the month with dividends credited semiannually.

TABLE No. III

APPROXIMATE MATURITy OF INSTALlMENT SHARES OF \$IOo PaR VALUE, AT VARIOUS PAYMENTS PER MONTH

\begin{tabular}{|c|c|c|c|c|c|c|c|c|c|c|c|c|c|c|}
\hline \multirow{3}{*}{$\begin{array}{l}\text { Pay- } \\
\text { ments } \\
\text { per } \\
\text { month }\end{array}$} & \multicolumn{14}{|c|}{ Per Cent of Earnings per Annum } \\
\hline & \multicolumn{2}{|c|}{$5 \%$} & \multicolumn{2}{|c|}{$51 / 2 \%$} & \multicolumn{2}{|c|}{$6 \%$} & \multicolumn{2}{|c|}{$61 / 2 \%$} & \multicolumn{2}{|c|}{$7 \%$} & \multicolumn{2}{|c|}{$71 / 2 \%$} & \multicolumn{2}{|c|}{$8 \%$} \\
\hline & Years & Mo. & Years & Mo. & Years & Mo. & Years & Mo. & Years & Mo. & Years & Mo. & Years & Mo. \\
\hline$\$ 0.50$ & 12 & I & II & 10 & I I & 7 & I I & 4 & I I & I & 10 & IO & IO & 7 \\
\hline .6 & 10 & 7 & 10 & 4 & IO & 2 & 9 & I I & 9 & 9 & 9 & 6 & 9 & 4 \\
\hline I.00 & 7 & o & 6 & Io & 6 & 9 & 6 & 8 & 6 & 7 & 6 & 6 & 6 & 5 \\
\hline
\end{tabular}

If the dividends are compounded monthly, the period will be shortened somewhat; if compounded only once a year, it will be slightly lengthened. When dues are paid at the end of the month, instead of at the beginning, this also will postpone maturity approximately one month. This might make an important difference to a borrower. 
practice involved. The account resembles that for the deposits of a bank, and the member has only the passbook as evidence of his membership. These are true building and loan shares which are subject to all the rights and liabilities of shareholders generally and are not deposits in the sense of establishing a debtor and creditor relationship with the association. A better term for these shares would be "optional installment" shares.

Prepaid stock calls for a lump sum to be paid when the stock is subscribed for, and this sum is determined by calculating the present worth of the par value of the share at the expected dividend rate for a given number of years. It is the sum which at the current rate of dividend, compounded at each dividend payment, will amount to par in a certain time. Thus, for a share of $\$ 200$ par value, maturing in II years and 9 months, with the dividend rate of 6 per cent compounded semiannually, the amount to be prepaid would be $\$ 100 .{ }^{4}$

Paid-up or full-paid stock is distinguished from prepaid stock in that the full par value of the share is paid by the member at the time of subscription. This stock usually draws

4 The amount prepaid on any share can be varied at will. If each share has a par value of $\$ 100$, the periods of time which will be required for various payments to mature are shown in the following table, ( + and signs being used to denote approximate periods):

TABLE No. IV

TIME REQUIRED FOR MATURITY OF A \$IOO SHARE OF PREPAIT STOCK AT VARIOUS DIVIDEND RATES

\begin{tabular}{|c|c|c|c|c|c|c|c|c|c|c|c|c|}
\hline \multirow{2}{*}{$\begin{array}{l}\text { Amt. } \\
\text { Pre- } \\
\text { paid }\end{array}$} & \multicolumn{2}{|c|}{$5 \%$} & \multicolumn{2}{|c|}{$6 \%$} & \multicolumn{2}{|c|}{$7 \%$} & \multicolumn{2}{|c|}{$8 \%$} & \multicolumn{2}{|c|}{$9 \%$} & \multicolumn{2}{|c|}{$10 \%$} \\
\hline & Years & Mo. & Years & Mo. & Years & Mo. & Years & Mo. & Years & Mo. & Years & Mo. \\
\hline$\$ 25$ & 28 & $1-$ & 23 & $5+$ & 20 & 2 & 17 & 8 & I 5 & $9-$ & 14 & $0+$ \\
\hline 40 & 18 & $7-$ & 15 & & I 3 & 4 & I I & $8+$ & 10 & 5 & 9 & $5-$ \\
\hline 50 & 14 & $0-$ & I I & $9-$ & 10 & I & 8 & I0 & 7 & $10+$ & 7 & $0+$ \\
\hline 60 & 10 & 4 & 8 & 8 & 7 & 5 & 6 & $6+$ & 5 & $10-$ & 5 & $3-$ \\
\hline 75 & 5 & Io & 4 & $10+$ & 4 & 2 & 3 & 8 & 3 & $3+$ & 2 & $5+$ \\
\hline
\end{tabular}

The amount of prepayment necessary to mature a $\$ 100$ share in a given time at a given rate of dividend, compounded semiannually, is shown in following table: 
its dividend in cash at each semiannual (or other) dividend period. Members purchasing paid-up shares are required by many associations to waive dividends in excess of a stipulated rate. Practice varies widely as to the payment of earnings on shares of this type. In some associations the same rate is paid as upon installment shares. Where the dividend on paid-up shares is lower, any excess earnings are used first to meet the expenses of running the business. Then if any further amount remains, it is placed in the contingent-reserve fund, to protect the association against loss in the future. ${ }^{5}$

Where both installment shares and paid-up shares are issued by the same association, many fathers and mothers are providing for the education of their children by buying paid-up shares and using the dividend checks to keep up payments on another

\section{TABLE No. V}

NECESSARY AMOUNTS OF PREPAYMENT TO MATURE \$IOO SHARE IN VARIOUS TIMES, AT DIFFERENT RATES OF DIVIDEND

\begin{tabular}{|c|c|c|c|c|c|c|}
\hline $\begin{array}{c}\text { Time } \\
\text { (Years) }\end{array}$ & $5 \%$ & $6 \%$ & $7 \%$ & $8 \%$ & $9 \%$ & $10 \%$ \\
\hline $6 \ldots \ldots \ldots \ldots$ & $\$ 74.35$ & $\$ 70.14$ & $\$ 66.18$ & $\$ 62.46$ & $\$ 58.97$ & $\$ 55.68$ \\
\hline $7 \ldots \ldots \ldots \ldots . . .$. & 70.77 & 66.11 & 61.78 & 57.75 & 54.00 & $50.5 \mathrm{I}$ \\
\hline $8 \ldots . . . . . . . .$. & $67 \cdot 36$ & 62.32 & 57.67 & 53.39 & 49.45 & $45.8 \mathrm{I}$ \\
\hline $9 \ldots \ldots . . . . .$. & 64.12 & 58.74 & 53.84 & $49 \cdot 36$ & 45.28 & 41.55 \\
\hline $10 \ldots . . . . . . . . . .$. & 61.03 & $55 \cdot 37$ & 50.25 & 45.64 & 41.46 & 37.69 \\
\hline $11 \ldots \ldots . . . . .$. & 58.08 & 52.19 & 46.92 & 42.20 & 37.97 & 34.18 \\
\hline $12 \ldots \ldots \ldots \ldots$ & 55.28 & 49.19 & 43.80 & 39.01 & 34.77 & 31.00 \\
\hline
\end{tabular}

Prepayments for shares of other par values are proportional to the figures given above; that is, for $\$ 200$ par value they would be twice as great; for $\$ 50$, one-half, etc.

In estimating the payments, it is better to err on the side of conservatism. That is, maturities should be slightly overestimated, because the saver will be pleased to receive his money before the promised date, but will resent delay. So also with the amount of prepayment: a slightly increased amount at the start will not be missed, and it will make earlier maturity possible. For example, to mature $\$ 100$ in ro years at 6 per cent, instead of taking the exact amount $\$ 55.37$, it might be well to take $\$ 55.50$ or even $\$ 56.00$. "Even up, instead of even down." The larger the amount to start with, the earlier the maturity.

${ }^{5}$ For a complete discussion of contingent-reserve funds, see Chap. XVII. 
lot of installment shares. For example, when a son is six years old, the father or mother buys outright $\$ 1,000$ worth of 6 per cent paid-up stock. At the end of six months a dividend of $\$ 30$ is paid on this stock. The $\$ 30$ check is turned in to the association as payment for the first six months' installments on $\$ 1,000$ worth of installment stock. When the next dividend check is received, it is similarly applied, and when the boy is ready to enter college, the $\$ 1,000$ has grown to $\$ 2,000$, which is an ample fund for the first two years. Associations are glad to take care of the bookkeeping necessary, since it keeps the funds in the business. Therefore, the secretary is frequently instructed merely to credit the earnings on the other shares and no dividend check need be issued.

Guarantee stock, used principally in California, Oregon, and Colorado, does not differ essentially from the shares in a bank, a trust company, or other financial institution of the ordinary type, but is quite different from ordinary building and loan stock. These shares are used to guarantee to savings members a definite profit on their investment. No dividends may be declared on guarantee stock until contract dividends on other shares and other liabilities have been paid. If the association is flourishing, there is an opportunity for large earnings upon the guarantee shares, far in excess of that paid upon installment shares. Actually the rate is not much greater than dividends on other stock, since these shares must absorb possible losses in periods of depression. Also it is customary to build up large contingent reserves in associations using guarantee stock in order that the dividends on this stock may be stabilized as much as possible. Guarantee stock in California may not be withdrawn. It constitutes a permanently invested capital fund. "Shares" (usually installment shares) in the same associations differ from the guarantee stock in that they may be surrendered under reasonable terms. In Oregon this guarartee stock is known as "reserve fund" stock, but, unlike the California guarantee stock, the Oregon reserve fund 
stock may be withdrawn when the liabilities for which it was pledged have been discharged. ${ }^{6}$

"Permanent" stock or "contingent-reserve" stock, as used in Kansas, is similar in all respects to guarantee stock except that it may be withdrawn when all contract liabilities for which it is pledged have been liquidated, and these

- The law of the State of Washington permits the use of guarantee stock (called reserve fund stock) up to 5 per cent of the total capital of an association, provided the association was using such stock at the time the law was passed. This law was designed to permit the Equitable Building and Loan Association of Portland, Oregon, to continue business in the State of Washington on that basis, as it had been conducting part of its business there prior to the adoption of the law. Additional dividends are permitted on this stock in consideration of the guarantee against loss to other shareholders. (Washington Savings and Loan Association Laws, Chapter I69, I919, Section 6.)

In Oregon (Sec. 6935, Corporation Laws of Oregon) this reserve-fund stock may be paid for in full or in installments and the method of participation in the earnings is left to the by-laws. Reports from Oregon indicate that all associations operating in the state use the regular permanent plan. The few associations which use reserve-fund stock, therefore, use it in connection with the permanent plan. This type of stock appears to have more in common with the Kansas permanent or "contingent-reserve stock" than with the California guarantee stock.

The use of guarantee stock in Colorado is not specifically provided for in the statutes, but appears to be possible under paragraph 952 of the laws as revised in 1919 (Sec. I08). In part, this section reads as follows : "Every such association ... may issue and sell its shares of stock ... with or without full participation in the earnings of such association, or partially in limited dividend-bearing stocks as may be provided by the by-laws."

Guarantee stock is also permitted by law in the state of South Dakota (see Sec. 907I of Building and Loan Law of South Dakota) and in Rhode Island, with the approval of the Bank Commissioner (see Sec. 3903 [7], Chapter 265, General Laws), as well as in Utah. No associations using this plan are reported to be in existence in these states.

Two associations in Idaho are reported to use a form of guarantee stock. Although there is no direct statutory permission for guarantee stock in this state, the laws provide that the constitution and by-laws of the association shall govern the kinds of shares to be issued.

A form of guarantee stock is also in use by a few associations in Louisiana under Section 4, Act I 20 of 1902 , but it is not looked upon with favor by many of the older and stronger homesteads (the name under which building and loan associations are known in Louisiana), especially those with large contingent-reserve funds. 
liabilities are limited by law as stated in the preceding chapter.

Investment certificates are issued in several parts of the country, particularly in the newer sections where the population is not as familiar with the building and loan idea as in the older settled portions. Their most common use occurs in California, but they are also found in Pennsylvania in a few associations. The certificates may only be issued where there is another fund which guarantees the contract rate of earnings on the certificates. This may be the guarantee stock already referred to, or if the law permits the use of a contingent fund for this purpose, the latter may provide the guarantee. They are comparable with the ordinary bank certificates of deposit.

Double-payment shares are used in a small number of associations, principally in New Jersey, for the purpose of maturing a given sum more quickly. A simple computation will show that the time of maturity is always more than half that of the shares using payments of the regular size. (Compound interest is not proportional to time.) An easy rule to remember is that the longer the period, the greater will be the influence of compound interest. Hence, when double payments are used, the time of maturity will always be greater than one-half that of the regular shares, although a larger sum is receiving interest in each of the earlier years. For example, 50 cents a month will mature one $\$ 100$ share in approximately I 39 months if dividends continue at the rate of 6 per cent compounded semiannually, and it will take somewhat over 8I months to mature the same amount if $\$ \mathrm{I}$ is paid each month.

Juvenile savings ${ }^{7}$ are not permitted in all states, but they are a real incentive to thrift, and the present writers feel that a larger development of such savings is justified. The actual amount of money paid in by a child may not be large, and

'An able discussion of the whole subject of juvenile savings, their use and abuse, was made by Edwin M. Einstein before the 1924 Convention of the California League of Building and Loan Associations. (This is reported in the Proceedings of the Convention, pages 38 to 44.) See also Chap. XV of the present text-book. 
hence the profit to the association will be small. But the contact thus established may be nurtured through the years, so that when the shareholder becomes of age his knowledge of the benefits of compound interest will cause him to continue his savings in this same form. The benefits to his character need not be dwelt upon; much good will result both to the association and to the growing citizen. These savings are almost without exception in the form of installment shares, but they differ in that no fees, fines, or penalties are enforced against them. The children have no regular source of income, and it would be an easy matter to take away their savings if fines were levied when they failed to appear on time with their dues. The association protects itself from injury in some cases by allowing profits at a slightly lower rate on juvenile shares. The difference is small, and ranges from $1 / 2$ per cent to I per cent less than the rate paid on other shares.

Obviously these savings must be accounted for separately from the others, but this is a minor disadvantage when examined from the standpoint of the life and success of the association over a period of years.

Income bonds, with a special "subscription agreement" and "investor's receipt," are used by a few associations in the State of Washington. These appear to have the characteristics of the usual investment certificate, with a stipulated rate of dividend, and call for no additional comment.

Certificates of Indebtedness.-The certificate of indebtedness is in use in a few states, notably in Missouri. This is a method of indirect borrowing from a bank or private individuals, and if improperly used may lead to considerable trouble. When a loan has been approved and the association is short of ready money, it issues a certificate of indebtedness to the borrower for the amount of the loan. $\mathrm{He}$ in turn disposes of the certificate to anyone else who will supply the money. He may turn it over directly to the contractor who is building his house, or he may discount it at the bank. In either case, the borrower receives a smaller net loan than he 
is entitled to and in consequence he is really paying a higher rate of interest.

The danger in the use of the certificate of indebtedness is that it is a direct obligation of the association, and its owner is a preferred creditor. If issued in amounts larger than the income of the association for a few months, the certificates may put the association in the position of being unable to pay its debts and may cause insolvency. These certificates are not sold to investors who expect to leave the funds in the association for any length of time as is the case with ordinary shares. They are only a method of temporary borrowing. For this reason the prudent association official limits their amount to a sum which will never place the officers in an embarrassing position.

Differences in Shares Due to Income, Risk, and Control.- Shares of stock issued by building and loan associations are varied in type in order to fit the income of various classes of savings members. With the exception of guarantee and permanent stock and juvenile savings, all kinds share equally in risk and control of the association's affairs. By-law provisions of individual associations sometimes place different classes of stock upon an unequal basis of control, but this is not a common practice. By control is meant the voting power which attaches to the stock. Shareholders may vote for directors of the association at the regular meetings, and in most states they may vote for changes in the by-laws. Since the directors choose the officers and the staff of employees, the vote of a stockholder is important in determining the policy and the actual conduct of the business. Voting is usually by shares, that is, one share is entitled to one vote, but in many serial associations the voting is by members, regardless of the number of shares held.

Income (or dividend rate) paid upon different classes of shares varies according to the contribution which the stock is alleged to make toward the success of the business. Where all shares have an equal degree of risk and control there is no 
justification for varying the dividend rate. If one kind of stock shoulders the larger portion of the risk, this stock may justly be entitled to a slight increase of income, dependent upon the additional risk involved. Other factors may also justify different dividend rates for different kinds of stock. For example: full-paid stock is usually held by people of means, rather than by saiaried people or wage earners. They invest in the associations because of a desire to gain a reasonable rate of income as well as to promote the ownership of homes in their community. The investment seldom remains in the association as long as the maturity period of installment shares. It is possible for the officers to induce investors to buy such full-paid stock at a lower dividend rate than that paid on installment stock by offering the following advantages:

(I) The rate paid is as high as any other equally secured investment (and often higher).

(2) The shorter time for which the money is used hardly justifies the association paying a rate as high as that paid on long-time shares.

(3) The investor can afford to take a lower rate because of the rapid turnover of his investment.

(4) The holder of full-paid shares has no liability on unpaid subscriptions, while the holder of the same amount of credits which have accumulated on installment shares is liable to the association for the remainder of his unpaid subscription.

It is customary for associations which have been earning 6 per cent or 7 per cent dividends on installment stock to ask full-paid stockholders to waive dividends in excess of $5^{\mathrm{T}} / 2$ per cent or 6 per cent.

Larger Dividends for Borrowers.-The borrower is the backbone of the association, for without him there would be no incoming profits. In certain parts of the country some of the newer associations are meeting the competition of older concerns, both of other building and loan associations and of commercial-mortgage companies, by paying the borrowing member a higher rate of dividend on his shares than the amount 
paid the savings member. In this way they are enabled to charge a higher interest rate on the loan, while keeping the borrower satisfied through his increased credits. The statement is frequently made that it makes no difference what interest rate is paid so long as the dividend rate is essentially the same as the interest rate, since the borrower "gets back all that he pays in." If this were true, there would be nothing for the savings member who has not borrowed against his shares.

It will be noticed that for the period of the loan the borrower has the use of and is required to pay the association for a sum of money larger than the average amount of his repayments to the association during that period. Therefore, the difference between the amount of interest he pays on his loan and the amount of dividends credited on his stock is the important part of the income of the association. The excess interest provides the dividends for the non-borrowers, for it is their money of which the borrower has had the use, more than of his own. A higher dividend rate to the borrower has its usefulness as an advertising measure, but in itself it does not justify higher interest rates. The modern ideal of the building and loan association is toward constantly lowered rates as the supply of mortgage money becomes more plentiful; and since the associations are primarily organized for mutual coöperative service, the benefits of fair rates would seem to be deserved by all members alike.

Exceptions to the Rule of Equal Sharing.-Guarantee stock and permanent or contingent-reserve stock assume more risk and are exceptions to the rule that all kinds of stock should share alike. The owners of this stock have undertaken to guarantee to other savings members of the association that a given rate of dividend will be paid on their stock during the life of the contract. This throws an additional risk burden upon the guarantee shareholders, and in return for assuming it, they are entitled to a higher dividend rate. It happens that the high degree of stability of earning power which the average association attains gradually removes this element of risk. 
Many associations with guarantee stock in their plans have been paying steady dividends upon all shares for years. Such differences as occur between the various rates, therefore, should be as small as is consistent with the true investment position of the different kinds of stock.

Juvenile shares, as already mentioned, do not share in control of the association. These shares never suffer a loss of principal except in the event of actual failure, and the possibility of this is remote. Their only interest in the association is therefore the matter of income. Since they are in a preferred position as to risk, there is some justification for paying a smaller dividend rate. The distinction is more theoretical than real, however, since no building and loan shareholder is assuming enough risk to keep him awake at night.

\section{SPECIAL REFERENCES}

Certificates of deposit. U.S. League Proceedings (IgoI), pp. II7-II8. Certificates of stock. Missouri League Proceedings (I92I), pp. 26-28. Guarantee stock. Nebraska League Proceedings (1923), pp. 38-40. Joint and survivor accounts. U. S. League Proceedings (I9i4), pp. $80-83$.

Paid-up stock. Nebraska League Proceedings (1924), pp. 19-20. U. S. League Proceedings (1900), p. 115.

Permanent stock. Kansas League Proceedings (1920), pp. 28-32. U.S. League Proceedings (1901), p. I4I.

Prepaid stock. North Carolina League Proceedings (1924), p. 34.

Matured shares. U. S. League Proceedings (1920), p. 152.

Savings accounts. Iowa League Proceedings (I916), p. Io; (IgI6), pp. 42-43.

\section{GENERAL REFERENCES}

Rosenthal, Henry S. Cyclopedia, pp. II7-I18; I90-195.

Sundheim, Joseph H. Law, pp. 45-53. 


\title{
PART II \\ PLANNING THE BUILDING AND LOAN ASSOCIATION
}

\author{
CHAPTER V
}

\section{STARTING AN ASSOCIATION}

Economic factors to be considered before starting a new association in a particular community; existing associations; decision to organize; preliminary methods; selecting organizing committee; publicity; securing charter; conditions determining the choice of plan; first regular meeting; directors-their selection, qualifications, oath of office, term of office, compensation; importance of coöperation with large employers of labor; company associations; dangers of associations for single subdivisions; legal limitations as to territory served; branch offices.

The question of the advisability of starting a local building and loan association or a group of associations in a city is not as easily decided as it would seem. If it is to be a success, a new association must serve a real economic need. Its primary purpose is to provide homes by encouraging local thrift, but there must be a real need for homes as well as a need for home owning, which may be a very different thing. There must also be a shortage of funds for home building in institutions which supply such funds. In growing American communities this condition of shortage is normal, and there is usually room for further development, especially if this highly specialized form of finance is not being provided by existing institutions.

On the other hand, if the associations in the community are meeting the local need for loans, further organization would merely add competitors to the field without serving a real economic need. In the states where building and loan associa- 
tions have been well developed for many years, there may be fewer associations during the rext few years, rather than an increase. This should result from consolidations and by the weeding out of those which do not fit the needs of the community. But or $r$ the country as a whole, the number should continue to increase for many years to come. An increase in the assets of all associations, moreover, is more than likely to continue indefinitely in all sections of the country.

The following table may be used as a rough guide in estimating opportunities for further development in the various states of the Union. Only the actual numbers of institutions are shown in this table, and before making a decision to start a new association, it would be well to ascertain the assets of associations already in the field. Little attention need be paid to the authorized capital of associations already at work, since this usually bears no relation to the business transacted. One association with assets of $\$ \mathrm{I}, 000,000$ r.ay be serving the community better than a dozen struggling associations of smaller size. But mere size is not a true index when taken alone, for the primary consideration is the degree of community service which is being ren.ered.

In order to present this situation more clearly, the information in the table has been grouped according to geographic sections of the country and the totals are presented in Chart $4 \cdot \cdot^{1}$

Already there are more than one-third as many building and loan associations as there are banks in the United States. The Comptroller of the Currency reports the aggregate asset: of all the banks for June, r 923 , as $\$ 54,034,9$ I I,000. Building and loan associations had approximately $\$ 3,942,989,880$ assets at the end of the fiscal years r923-24. (State supervisory departments require reports as of different dates. More 1923 dates than 1924 are included in this figure.)

Greatest development has naturally taken place in the Middle

1 The figures for each state are shown in a complete table in the Appendix. (See Table XXXII.) 
Atlantic States and the states immediately to the west because of the early start in this district and the remarkable record for safety of money invested in the associations. Over the country as a whole, the average number of people to each association

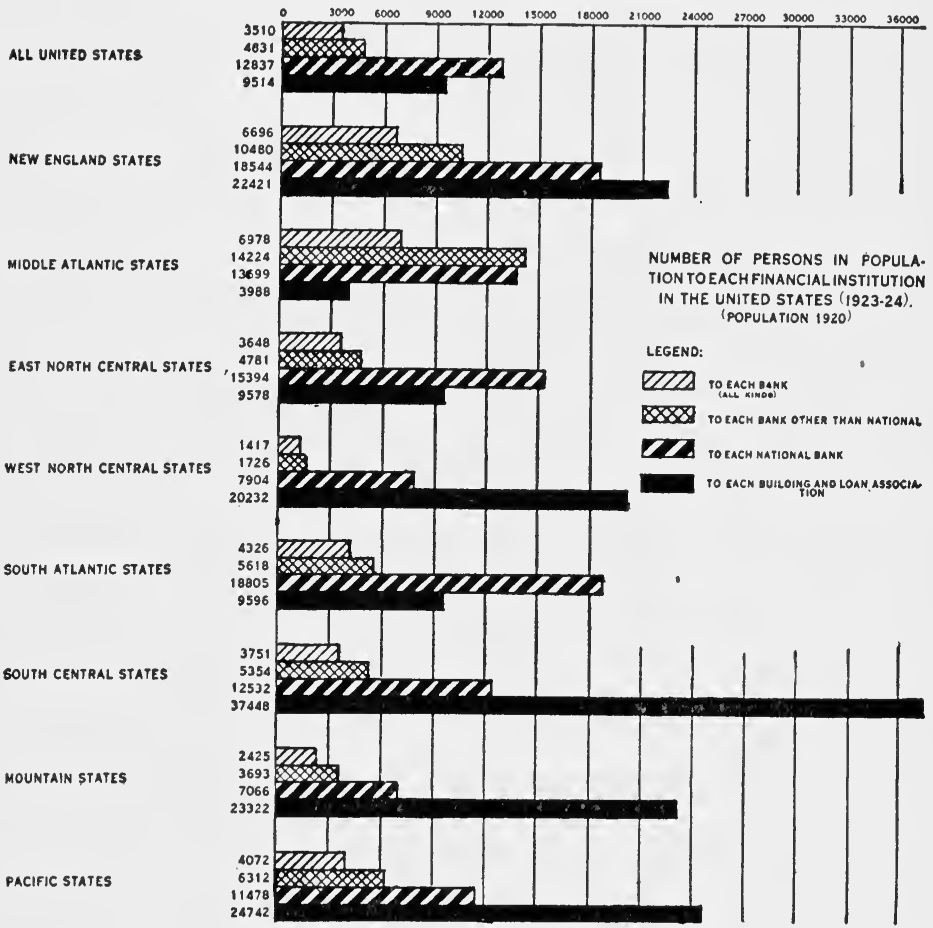

CHART 4.-Comparative number of persons in the United States for each existing financial institution.

is shown to be 9,5 I4. If averages are to be trusted, it would seem that, if there is a population of ro,000 in a given com. munity who are not now served by a building and loan association, an opportunity may exist for starting a new association. However, there are many known cases of thriving neighborhood associations in towns having two thousand population or less 


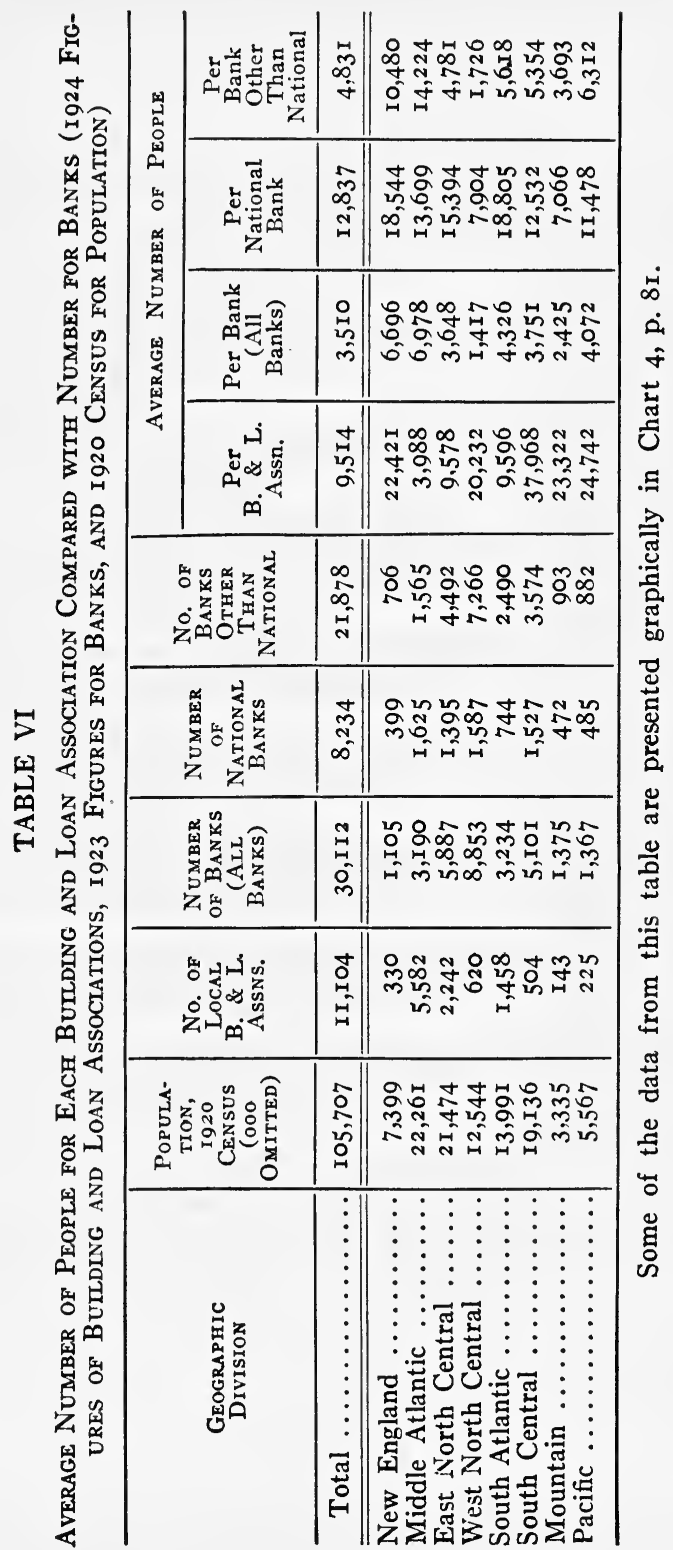


(In many states there are towns of one thousand or less with a serviceable building and loan association which is meeting a real local need.) When a new association supplements existing institutions instead of trying to supplant them, it has the greatest chance of success. Business diverted from a competitor is of no value in promoting home ownership. Creating new business is of real assistance.

Making the Decision.-The usual occasion for starting another association is an evident lack of funds for home building or home buying by a certain group of people who do not seem to be served by existing associations. Recognizing this need, the members of the group get together and canvass the situation. If they believe that they can reach others like themselves who are not members of any association and so get new funds that are not now available for the purchase of homes, they organize and go after those funds. The group may be made up of home seekers and business men. It may include a real-estate man whose loan applications are not now accepted by existing institutions as frequently as he feels they should be. It may include a lumber dealer who believes he is not getting enough of the business that arises from loans by other associations. It may include other dealers and merchants who think that the building and loan movement is not as active as it might be in their city, and who feel that they are in a position to influence a certain number of people to begin systematic saving. In other words, in most communities to-day it comes from the desire of business men to promote thrift and increase the development of their city, rather than from the savings members who are seeking interest on their money.

Preliminary Organization Methods.-When organization is decided upon, it is necessary to entrust to an organizing committee the preliminary details essential to complying with the law. Most states have printed copies of the law relating to building and loan associations, and these may be obtained from the state supervisor or other state officers. The law should be studied carefully, for each state has its own ideas 
on the subject. So much depends upon the organizing committee that it is safe to say that the first few steps will determine the success or failure of the undertaking.

This committee should consist of representative people who are firmly convinced of the desirability of the undertaking, and who are sufficiently informed about details to guide the initial procedure. This community service is most successful when men and women with a zeal for such service have the time and the determination to "put it across."

The members of the committee may be selected because of their connection with certain groups of people, either industrial, racial, or other groups with common interests. If they live in the district to be served, or if they are widely acquainted in the neighborhood, so much the better. This committee may be appointed as a result of a preliminary mass meeting held for the purpose, or may be selected in any other legitimate manner. If it is to be a success, every precaution must be taken to make the committee truly representative. Its size will depend upon the amount of work to be done. An important part of the work will be to secure a considerable number of association members at the start, for the larger the initial fund, the sooner the association can begin to lend considerable sums of money. This preliminary selling work takes time, but proper organization of the committee, and the adoption of right methods of procedure will expedite it.

Publicity at this time is of great importance, and newspaper advertising and special write-ups should be used freely. In many cities where campaigns are put on for new associations by the business men, many columns of space are gladly contributed by the press because of the real news value of the undertaking. ${ }^{2}$

The expenses of preliminary organization are frequently borne by interested civic organizations or private individuals, but this money must be arranged for in advance. The committee should be supplied with subscription blanks setting

'For a discussion of such campaigns and other successful development methods, see Chap. XIV, 
forth in brief the proposed methods of operation, including (I) the plan on which the association will conduct business, (2) the kinds of shares offered, (3) the par value of shares, and (4) the payments to be made on each class of shares. The subscription blanks should be in such form as to be available for attaching to the proposed articles of incorporation in applying to the state for a charter. The services of a competent lawyer should be secured to insure that all forms used comply with the laws of the state.

Application for a State Charter.-Up to this point, the organization is merely tentative. The law usually requires that a minimum number of shares must be subscribed for before a charter will be granted. If it should not be possible to complete the arrangements, all money paid on account of subscriptions is returned to the subscribers. If it is a success, the charter should be applied for as soon as the advance subscriptions are in. The Secretary of State issues corporation charters in many states, but other officials sometimes perform this duty. In any event, if a state supervisor of building and loan exists, he should be consulted at this time, as his approval of the plan must first be secured in some states, and his coöperation is always a desirable asset. $^{3} \quad$ No business can be transacted (except taking preliminary subscriptions to stock) until the charter is issued. Until that time the association has no legal existence.

Choice of Plan.-The association may use more than one plan of collecting savings if it so desires. 'The choice of plan depends upon the habits and income of the people from whom membership will be drawn. Where the income of most of the community is regular and steady work is constantly available, the serial and regular payment plans, which enforce systematic

${ }^{3}$ Approval of the supervisor is required by law in the following states: Arizona, California, Colorado, Connecticut, Delaware, Idaho, I'linois, Kansas, Kentucky, Louisiana, Maine, Massachusetts, Minnesota, Montana, Nebraska, Nevada, New Hampshire, New Jersey, New York, North Carolina, North Dakota, Ohio, Oklahoma, Oregon, Rhode Island, Utah, Virginia, Washington, West Virginia, and Wisconsin. 
payment, are most useful in developing habits of thrift and in directing savings into home-owning investment. In communities where work is intermittent, the Dayton permanent plan, which does not require regular payments, has proved the best. It permits the savings member to make payments as his income is received, and gives him the maximum earnings upon them.

The size and make-up of the community also have a direct effect upon the plan selected. The newer the locality, the more is difficulty experienced in establishing a purely mutual association. People are not willing to risk their savings in the hands of strangers unless some measure of assurance can be given in regard to income. For this reason, the guarantee-stock plans and the permanent or contingent-reserve stock plans have been developed. In general it may be said that the smaller or older the community, the greater is the chance of success on a mutual basis; the larger or newer the community, the more the need arises for guarantees. It takes many years of successful operation to establish a reputation which needs no guarantee.

By combining two or more plans it is possible to care for all the elements of any community, and while this process may tend to encumber the books at the start, the added service may make the effort worth while.

First Regular Meeting.-When the plan has been selected and the charter secured, the association has the right to transact business, and the first regular meeting should be held to effect permanent organization.

Following the selection of a chairman and secretary, the report of the organization committee should be submitted for discussion and adoption or correction. The next order of business should be the consideration and adoption of constitution and by-laws, ${ }^{4}$ to be followed by the election of such directors,

1 In some states, where by-laws must be submitted to a state official for approval, it is necessary to decide upon these at a prior meeting, and this work may then be delegated to the organizing committee. Most associations use no constitution, as the charter is considered as taking its place. The expressions charter and articles of incorporation are used interchangeably to cover the official document by which the state creates the associa- 
officers, and committees as the by-laws may provide. The organization committee is thereupon disbanded, although the same men frequently continue to act as a soliciting committee to secure additional memberships.

Other things being equal, members of this committee may well be selected as association officers and directors because of their interest in the success of the association. This is strengthened by their experience in the preliminary work of the committee.

Selecting Qualified Directors.-Nominations for directors should not be so restricted as to prevent a free exercise of choice by the members, and anything like unsavory politics will react unfavorably later. Some associations go so far as to permit cumulative voting to insure adequate representation of minorities. ${ }^{5}$

An active building and loan man points out that "it is of prime importance that building and loan associations elect to membership on their boards only persons who are known to be live, active, and aggressive, yet conservative men of business affairs, - men who can and will study and become familiar with the principles and operative plans of building and loan associations, so that they may become well qualified by reason of their discretion and good judgment to direct the business entrusted to their care by the associations."

Directors should be men or women of intelligent enthusiasm, with a full realization of the possibilities of the building and loan movement and a full appreciation of the real opportunity for public service their position affords. They should be

tion as a legal person. A set of by-laws which cover most of the essential points will be found in the Appendix. These suggestions do not attempt to conform to all the varying state practices, but they contain no provisions which would prove objectionable.

${ }^{5} \mathrm{By}$ cumulative voting is meant the privilege of casting as many votes as one has shares, multiplied by the number of directors to be elected, but instead of casting an equal number of votes for each candidate to be elected, the total number of one member's votes may be cast for any one or more candidates. 
people of such character and influence as will add strength to their association.

The laws of some states require that each director take the oath of office upon assuming his position, and such a requirement should be made mandatory in all associations, even where the law is silent on the point. No director who fails to perform his full duty should be permitted to retain that position, for the welfare of the entire movement requires that "directors shall direct."

The term of office of directors has usually been one year, but the present tendency is toward a three-year term. The directorate is frequently divided as nearly as may be into three equal parts, holding office for one, two, and three years, respectively, in the first instance. One-third the number must then be elected at each annual meeting thereafter. This plan insures greater continuity of the personnel and policy of the management than is possible where the whole board is elected each year.

The compensation of directors is subject to no fixed rule, but in the smaller associations throughout the country it is the custom to serve without charge. In the main, the association has received a faithful service for which it could not have adequately paid. In the larger associations with sufficient resources to permit such expenditure without serious reduction of dividends, and with added responsibilities and duties for the directors, it is perfectly proper to pay the directors a reasonable compensation, and this should be made a permanent policy.

\section{Prerequisites to Success}

Avoiding an Improper Start.-It is difficult to correct a mistake after it has been made. If the new association cannot attract savings, or cannot get a substantial membership, the question naturally arises: Has it merely used the wrong plan; or was the whole project wrong? Dormant associations are scattered over the entire country to-day. In some cases they 
would require radical changes in some details of their business policies and of their rules, in order to be made successful. In others, the personality of the officials chosen has not been of the right type to secure the desired result. A little careful planning of the start will often avoid such later trouble. Above all, the right men must be secured.

A substantial aid to the organization of any building and loan association is found at times in the active interest of some large employer of labor. His assistance is not given by coercion of his employees but through creating the spirit of emulation. If the employer himself subscribes liberally to shares of stock, this is a splendid recommendation. If he allows some of his men to use "company time" to solicit every employee on the payroll, they are more likely to put real enthusiasm in the work, because they do not lose any of their income while doing it. The employer is justified in encouraging such work, as there is no influence that will more effectively stabilize his labor turnover and increase the efficiency of his men than the provision of means whereby they become contented home owners and thrifty savers. The employer must supply continuous employment, if the plan is to be a continued success.

Company Associations.-The question is often asked: Should the employer actually start his own association, or should he put his effort towards building up another association in the community? Generally speaking, existing local associa. tions should be patronized. Probably no association should be started by a single industrial corporation where the number of employees is less than, say, 5,000. Of course, if no other associations are available for the use of the employees, the number is of small importance. This does not mean that the whole 5,000 must be members of the association, for the average number of members for each building and loan association in the United States to-day is approximately 670, while in 1893 it was 301 . But where a large number of employees have no adequate building and loan facilities, the employer 
will find a company association a valuable aid in promoting industrial good-will. It fits in well with other forms of humanitarian activity on behalf of the workmen. In these plant organizations it is customary for the company to provide suitable offices for the association, and usually the secretary is on the general payroll of the company, without expense to the association. All the profits then accrue to the members, and the association can make loans at a most reasonable cost. Keeping both the interest rate and the dividend rate low is a necessary ideal for all successful associations. One reason for the success of many company associations has been that the men themselves run the association's affairs, and they do not feel "patronized" by their employers.

Dangers of Associations for Single Subdivisions.Where building and loan associations are projected by subdividers of real estate, adjacent to large or small cities, they are almost always developed with the idea of profit for the real-estate dealer rather than for the savings member. There is always danger that a subdivision is not in conformity with sound economic principles. If the loans are limited to the single subdivision, the financial stability of the association rises and falls with the success or failure of that subdivision.

The future value of the property in a new suburb is necessarily more problematical than that of any given locality already developed in the same community. Another difficulty with many subdivisions is that people buy lots who will not build homes. They expect to make money by the increase in the value of the lots. Yet the lots will increase in value only as homes are built around them. To avoid the troubles of such speculation, the loans of an association should be distributed over an entire community. This will spread the risk over all the desirable areas of the city on the usual principle of insurance.

Legal Limitations as to Territory Served.-Any "domestic association" beromes a "foreign association" when it goes beyond the boundaries of its own state. It will thus be 
seen that the terms "foreign" and "national" are practically synonymous. If there is a distinction between the two words, the national association covers a wider territory. It is not always possible for an association organized in one state to do business in another state, and before starting an association the organizers should examine the legal and economic conditions under which they would be obliged to operate.

Laws of various states treat building and loan associations somewhat differently from ordinary corporations because of their coöperative character. In 17 states and the District of Columbia, locally formed associations may not transact business outside the state boundaries. In at least 8 states the business is limited to the county in which the associations are organized. Together these states include well over half of all associations in the country. The laws of 22 states appear to permit associations organized within their boundaries to transact business in other states if they wish. ${ }^{6}$

Branch Offices.-Nineteen states permit branch offices, but

- The 17 states which prohibit associations from doing business outside the state are: Alabama, Arizona, Connecticut, District of Columbia, Illinois, Indiana, Iowa, Kentucky, Louisiana, Maine, Massachusetts, Minnesota, New Jersey, South Carolina, South Dakota, Tennessee, Vermont, and Wisconsin.

The 8 states which are known to limit the business to the single county in which the association was organized are: Florida, Iowa (domestic local associations), Louisiana, Maine, South Carolina, South Dakota, Tennessee, and Vermont. The law is hazy on this point in several states, but Georgia (among others) appears to use the county limit.

In some states there is a provision limiting business to the county but under certain circumstances associations may reach a wider territory. These include: Iowa (domestic associations), Kansas, Minnesota, New Hampshire, New Jersey, New York (50 mile radius), North Carolina, Oregon, Pennsylvania, Texas, Washington, and Wisconsin (50 mile radius).

The 22 states which appear to permit associations to go outside the state for business are: Arkansas, California, Colorado, Delaware, Kansas (under certain restrictions), Maryland, Michigan, Missouri, Montana, Nebraska, New Hampshire, New York (fifty-mile radius of home office), North Carolina, North Dakota, Ohio, Oklahoma, Oregon (consent of state supervisor necessary), Pennsylvania, Texas (by license), Utah, Washington, and West Virginia. 
very little use seems to be made of the privilege. If branches are located so that loans may be limited to property not more distant than a single day's round trip journey from the home office and back, branches are frequently successful. Then the principal officers can inspect any property offered as security, and so check up the opinion of the local agent with their own mature judgment. Branches too distant to permit close supervision are seldom a success.

\section{SPECIAL REFERENCES}

Branch offices. Illinois League Proceedings (I $1 \mathrm{I} 8$ ), pp. I24-1 25.

By-laws. Oklahoma League Proceedings (1924), pp. 20-23. Youngstown Institute Proceedings, April 13, 192.3, pp. 2-13.

Constitution. Youngstown Institute Proceedings, April $\mathrm{r} 3, \mathrm{1} 923, \mathrm{pp}$. 2-I3.

Directors. New York League Proceedings (1923), pp. 28-33. U. S. League Proceedings (1903), pp. 66-70. Youngstown Institute Proceedings, April 13, 1923, pp. 6-7; April 20, 1923, pp. I-5.

Location. Kansas League Proceedings (1919), pp. 75-79. New York League Proceedings (1922), pp. 40-41. Youngstown Institute Proceedings, June 15, 1923, pp. 2-3.

Management. Illinois League Proceedings (I918), pp. I23-125. U.S. League Proceedings (I901), pp. 50-56; (I901), pp. 79-84; (I903), pp. Iо9-гіо.

New associations-their troubles. Kansas League Proceedings (I920), pp. 64-66.

Organization-by-laws, constitution formulation, kind of people necessary, lawyer, and name. Youngstown Institute Proceedings, March 6, 1923, pp. 2-6.

Voting powers. U. S. League Proceedings (I916), pp. II2-I14.

\section{GENERAL REFERENCES}

Rosenthal, Henry S. Cyclopedia, pp. i67-187.

Sundheim, Joseph H. Law, pp. 31-44; 82-90. 


\title{
PART III \\ CONDUCTING AND DEVELOPING THE BUSINESS
}

\author{
CHAPTER VI
}

\section{ORGANIZING THE PERSONNEL}

(Selecting the "key men," committees, staff, counsel, provision for surety bonds, etc.)

Duties of directors-selecting officers, passing upon loans, etc.; relation of dividend rate to expenses; president-qualifications, duties; vice-president; secretary—qualifications, duties, salary; treasurer; other officers; bonding; group life insurance; vacations and working conditions; appraisal committee-compensation, duties; auditing committee; other committees-membership, promotion, finance or business policy, legal counsel.

The personality of an institution is expressed by the people who represent it with the public. This personality can be no more effective than that of these men and women. On their ability, tact, and courtesy hinges the respect of the customer for the association. This becomes increasingly important as the business grows beyond the limits of a small neighborhood, ard loans are placed throughout a city. Savings members begin to come in from a wider and wider area, and the secretary or clerk who meets them and accepts their savings is the only person they may know in the organization.

Duties of Directors.-As a result, it is the duty of the directors to select the type of officers and employees who shall represent exactly the ideals of this particular institution. The duties of the directors involve not only the selection, but also 
the bonding of officers and employees. They must also see that the assigned duties of each position are faithfully performed. This is in addition to the duties of the directors in shaping and adopting the general policies of the association which are not covered by the charter and by-laws. Of course, they will also look after such matters as office arrangements and equipment, and they should have a full and exact knowledge of the business transacted.

Their most important function, however, is passing upon all applications for loans and making sure that every loan is safe. A director of a building and loan association who fails to safeguard faithfully the funds of his association is not only recreant to an important trust, but also, if actually negligent in the performance of such duties, may have to assume direct financial responsibility for losses which result. ${ }^{1}$

The scope of the directors in selecting the office stafi is necessarily limited by the amount of money which may be spent for salaries. Fortunately, not many people are needed to conduct the office routine. This is true of even a large building and loan business. Seldom are more than two active full-time officers needed.

3 The director of a building and loan association is personally liable in many states in protecting the patrons from losses. For example, Section 9670 of the Revised Statutes of Ohio blankets this liability as follows:

"Directors... shall be individually liable for any loss to members, caused by their neglect to comply with the provisions of this section or any other provisions of law prescribing their duties."

This liability does not extend beyond neglect and fraud.

"Directors who keep within the limits of their authority and act in good faith are not liable for their errors in judgment, provided ordinary diligence is exercised. They are liable personally to shareholders for losses occasioned by fraud, willful neglect, misconduct or breach of trust for their own benefit provided suit is brought within reasonable time after discovery.

"They are not liable for mistakes of judgment honestly made and within the scope of their powers even though they may be so gross as to appear to us absurd and ridiculous, nor for want of skill or knowledge."

(Address of Robert T. Corson, Philadelphia, Pa., before the 1903 convention of the United States League of Local Building and Loan Asso:intions.) 
One clerk working full time, with modern office equipment, may be able to handle all the regular office work of a good-sized business if part time help is available a few days each month. But the day has passed when competent people can be obtained for a pittance.

Too frequently in the past, associations have undertaken to pay such a high dividend rate to their savings members that there was no money for expenses. In many cases the dividend rate was the same as the interest rate charged to the borrower. This was possible because it was expected that most of the officers would work for nothing, and such expenses as could not be avoided would be paid out of other income. This "other income" was a highly flexible and uncertain item. It consisted in part of fines and fees of various types, and penalties which were assessed against savings members who withdrew before the end of the regular period for their shares.

The more equitable solution is to anticipate a dividend rate somewhat less than the interest rate, making the difference great enough to care for necessary expenses, including reasonable salaries. Annual expenses need not be more than one per cent of assets, and can usually be less. ${ }^{2}$

Necessary Officers.-When the amount of money that may be spent for officers is known, it is a task requiring real business judgment to apportion this money in such a way that at least one "key man" will be obtained. On him will hang the success or failure of the institution. This man needs to have the quiet, steady, irresistible enthusiasm of the power house. Without such a man, the work will "hang fire." With the proper man, a high degree of coöperation from other business houses is realized from the start. It is true that an association may exist with only a small measure of such cooperation, but if it is to have a healthy, worthwhile growth, the help of other related businesses is indispensable.

Importance of the President.-In the selection of a

${ }^{2}$ An extended discussion of the sources and use of expense funds will be found in Chap. XVI. 
president, the board of directors should realize that this position needs more than a figurehead and should choose a man of real standing in the community, a man with genuine ability. He should appreciate the importance of building and loan work to the community. The choice of such a man will insure the conduct of the business along the most modern lines. He may not be required to do any of the detailed daily work, but he should be so thoroughly familiar with every phase of building and loan procedure and the affairs of his association that he could do it if called upon. His knowledge will enable him to exercise a strong if not controlling influence over the association's general policies.

The duties of the president include those of the ordinary presiding officer and the execution of such authorized acts as the board of directors and the by-laws may provide. Among the latter may be mentioned the signing of all checks, notes, share certificates, security releases, and other documents issued by the association in the transaction of its business. He is frequently made the custodian of the fidelity bonds given the association by other officers and employees. In some cases, he may be the managing official in active charge of the business of the association, although this practice is far from general. In some of the larger associations the constant attention of an executive is required, and he should be unhampered by the burdensome details which usually devolve upon a secretary.

The time required for this work in the arerage association is very limited, and may not interfere with his other business life. Where this is true, the president frequently serves without pay, receiving his reward in dividends on his own shares like any other savings member. If the duties take all of his time, he deserves and should receive a salary like that of the president of any other financial institution of similar size.

Vice-President.-The vice-president she ald possess qualifications equal to those of the president and he must be ready to assume the duties of the president whenever his superior officer is absent or unable to serve. 
Type of Man Needed for the Secretary.-In most associations the secretary is in active charge of the business, and is not infrequently elected treasurer as well. It is he, therefore, more than any other officer, who should be the "key man." In the Massachusetts coöperative banks the treasurer is usually the active officer in charge.

To be qualified for the position, the secretary must have a sufficient knowledge of business procedure to enable him to handle efficiently every unusual development that arises in conducting the association. Important decisions must be made frequently. without consulting other officers. He cannot afford to make mistakes. In no other business is it more essential that advisory service be available to the clientele than in the building and loan association. The secretary must be well informed, therefore, regarding every phase of the business of investment and finance.

The secretary should know especially the details of household budgets, and the methods of acquiring and maintaining homes. Many homes are purchased without an increased income after slight readjustments of household expenditure, with the resulting savings. The family must be shown how it can "buy its home while it lives in it." It must not be "milked dry" in the process. The ordinary living expenses go on just the same. The only way to acquire a home is to save it.

If the secretary really knows his job, he can help every patron of the association over the rough spots that are always cropping up in the course of the years, and keep them satisfied and actively interested in promoting the association business. It is not sufficient for him to be a zealot in promoting thrift and home ownership and the growth of sound civic conditions, although it is important that he possess this attribute. He should have, or be able to acquire, complete information regarding residential development in his own city. He should have such knowledge of insurance, taxation, and title procedure. and of real-estate values, as will enable him to safeguard 
the interests of both the association and its members. $\mathrm{He}$ must also be able to apply this knowledge to the correct solution of every problem that may arise. If he does not at first possess this knowledge, he should at least have the willingness and ability to acquire it. ${ }^{3}$

The character and standing of the secretary must be above reproach, in order that the association which he serves may have the complete confidence of the community. On his honesty depends most of the safety of the association. $\mathrm{He}$ must be capable of giving sound advice to the board of directors and his fellow officers, and at the same time be ready and willing to yield his opinion in deference to the judgment of the board. The secretary should also be a man of vision, one who really understands the meaning of the word "service" and who is himself willing and anxious to serve.

Duties of the Secretary.-The duties of a secretary are outlined as follows in a copy of the by-laws of a building and loan association selected at random:

"It shall be the duty of the Secretary and Treasurer to record the proceedings of the meetings of the Association and the Board of Directors; he shall receive all moneys paid to the Association and deposit the same in the bank unless otherwise instructed by the Board of Directors; he shall keep accurate accounts between each member and the Association, and sign all orders and issue all notices authorized by Board of Directors; he shall have the custody of all books and papers pertaining to his office; he shall take charge of all mortgages and policies of insurance on property on which the Association has advanced or loaned money, together with all securities for the payment of money belonging to the Association, and when authorizad by the Board of Directors give receipts of acquit-

$\mathbf{8}$ "The average secretary is so close to his work, and so hedged about with technical phrases, intelligible to himself, but Greek to the layman, that he cannot tell the building and loan story intelligibly. It requires a trained, experienced man to put it over as it should be." (R. Holtby Myers, American Building Association News, Nov., 1921.) 
tance for all and every sum or sums of money paid him for the Association by any person whomsoever upon any bond, bill, note, mortgage, or upon any other security or account whatsoever. He shall provide a suitable box, marked with the corporate name, in which to keep all papers of the Association, which he shall deposit in the bank for safekeeping if so required by the Board of Directors; he shall submit to the Association at each yearly meeting a statement of the affairs of the corporation, and shall at all times be prepared to inform the Board of Directors and stockholders of the financial affairs of the Association. The money deposited in bank shall be drawn only upon checks bearing the signature of the Secretary and Treasurer and countersigned by the President; or in his absence by the Vice-President."

It will be observed that this outline enumerates duties that are primarily concerned with handling the business after it has been developed, and serves as a definite guide to correct procedure in accordance with the general policies of this particular association. It is invaluable for the purpose but necessarily omits much that may be said with relation to the duties of the secretary.

He should not only handle the business that comes in his office but should create business. This includes both saving and lending business, with emphasis on either or both as occasion may require. Sufficient funds must be made available to meet the legitimate needs of borrowers, and there should never be an excess of idle funds in the treasury of the association. If loan applications exceed available funds, he should develop the savings business. If idle money lies in the treasury he should search for and secure sufficient additional, desirable loans to restore the balance. So long as the association is unable to serve every worthy borrower to the extent he deserves, there should be no slackening of business solicitation.

Whether new business is secured through outside personal solicitation, or attracted by advertising or a well-located office, 
the entrance of a new customer or member calls for the performance of duties too often ignored and which deserve some consideration here. The secretary, who is animated by a real love for his work and a sincere desire to render real service to his new client, should seek to know all pertinent facts which will enable him to give sound advice in any proposed business transaction. If the proposal includes an investment or a savings program, he will of course urge a maximum use of the association's facilities. But he should take care to warn the customer against undertaking more than can be readily carried out with his income through ordinary persistence in industry and thrift. If the proposal includes the securing of a loan for purchase or construction of a home, the secretary should attempt to determine the soundness of the investment and whether the applicant is keeping within his means and ability to accomplish his purpose. Service of this sort is invaluable.

If the secretary is to attain the maximum of usefulness to his association and to his community, he must be willing to take an active interest in all helpful local activities, yet never to the point where such work interferes with the full performance of the prescribed duties of his office. If he is not required to devote his entire time to the work of the association, as is frequently the case in neighborhood associations, his own business should be of such a nature and so conducted as to further, and not to retard, the work of the association.

Two plans of paying the secretary are in vogue: one, the definite salary, and the other, a salary based on business done by the association. Which is best, from the standpoint of the secretary himself, depends upon the man. Some men are so constituted that they are not able to do their best work unless they have a certain assured income. Other men will do their best work when there is the incentive of a possible increase through their own activity. Associations sometimes readjust their policy for that very reason. One secretary might be employed on a stated salary basis, but if a change were made and a different man secured, he might be of a type who does his 
best work under the other plan of compensation. Again, associations that have been using the percentage plan have been known to change it if it returned to the secretary a compensation which the directors felt was unwarranted. A similar change in policy has caused much criticism of "big business" - too many men have been reduced to a stated salary the moment they began to make more than a reasonable compensation on a commission basis. The same criticism can be made of association officers or directors who adopt this policy.

Treasurer.-The treasurer should be a person of tried integrity and with sufficient knowledge of financial affairs and of accounting to handle safely all funds entrusted to his care, and account for them properly. It is customary for the board of directors to designate one or more commercial banks as depositories, and all funds are deposited, as received, in these banks. The secretary is frequently made ex-officio treasurer, thereby combining in one position all the duties of receiving, depositing, disbursing, and accounting for all cash. The usual provision is made that all checks shall be countersigned by the president or other designated official in addition to being signed by the secretary or treasurer. In all cases where provision is made for the separate position of a treasurer it is very essential that he should merit and receive the unqualified confidence of that part of the community which will have business dealings with the association. Not only should all money received be deposited immediately to the credit of the association, but all accounts should be complete and in balance at all times. Under no circumstances should funds be deposited with the personal account of the treasurer. The compensation of the treasurer is usually nominal in amount and in many cases his services are gratuitous.

Serious consideration should be given to the advantages of choosing an officer of a trust company or other financial institution to serve in this capacity. The trust company is especially designed and equipped to render service of this kind and its officers are always at hand when needed for the transaction of 
business. Another treasurer might be engrossed in his own business and not be so readily available. Furthermore, it will be found in many cases that using an officer of another popular financial institution as treasurer of the association will prove of substantial advantage in attracting business.

Whatever system is adopted with regard to the handling of the funds, it is the duty of the board of directors to see that fidelity bonds, proportionate to the risk involved, are required from all who have access to these funds or authority over their expenditure. In many cities "hold-up" and burglary insurance are now taken out in order to protect the association against this kind of loss. Its usefulness depends largely upon local conditions, but the officers should make sure that their funds are adequately protected before deposit as well as afterwards.

Other Officers and Office Staff.-During the early period cf an association a very limited staff, if any, will be required in addition to the officers above noted, but it must be borne in mind that if an association is to function effectively it must have enough help to make the work run smoothly. Additional employees should be added from time to time to keep pace with the association's requirements.

It is very commonly the case that the first official added to the roster is an assistant-secretary. Provision is sometimes mause in the by-laws for the election of this official in the same manner and at the same time that other officers are elected. The assistant-secretary is frequently given the power to act as secretary in event of absence or incapacity of the latter. For this reason he should possess the qualifications requisite to the secretary's work. He also should provide an adequate surety bond in favor of the association for its protection.

Since the employees meet the public more directly than the officers themselves are able to, their mental attitude toward the business will be reflected by the members and will accordingly do much to advance or retard the growth and usefulness of the association.

The Bonding of Officers.-As already stated, all officers 
and employees handling funds of the association should provide adequate protection to the association in the way of surety bonds. These must be made out in favor of the association in such amounts as will fully protect it in case of defalcation. For this purpose either personal or corporate surety bonds may be employed, as may be directed by state law, or if it is silent, by the board of directors or the by-laws. The amount of such bond is usually decided by the board of directors, but in some states the supervisor of building and loan associations has the right to order an increase in the amount in any case where he deems it necessary.

Personal suretyship should be avoided as a general rule. In any event no director or other officer of the association should be accepted as surety on any bond issued in favor of the association (even if this is permitted by law). The cost of corporate bonding is not excessive; it obviates all questions of personal interest in the adjustment of any shortage or defalcation; it provides a certainty of recovery to the extent of the full value of the bond. Unfortunately, this is not always true in the case of personal suretyship. Being so directly to the interest of the association, payment of the cost of bonding is very properly a charge to be met as a regular expense by the association rather than by the individual officers. But this payment in no way relieves the officer of responsibility for his own future conduct.

If the bonds are to be kept by the association itself, those of the secretary, assistant-secretary, and other officials should be deposited with the president, and the president's bonds, in turn, should be deposited in the custody of the secretary or treasurer, as the by-laws may provide. Where the state law requires the bonds to be deposited elsewhere, it must, of course, be complied with.

Such bonds are usually issued on an annual basis and care should be exercised in the matter of securing their prompt renewal at expiration. The amount of the bond should be readjusted whenever necessary, and the responsibility rests with 
the directors to see that no defalcation has alrea ly occurred, before the renewal of a bond. In order to be certain of recovery in the event of loss arising under a bond, it is essential to meet all requirements of the surety company. Questions submitted either prior to the issuance of a bond or on its renewal, covering the existing relations between the officer and the association, involving his indebtedness to the association, the proper auditing of his accounts, the correctness of the audit, should be fully and carefully answered.

No surety company will issue a bond or renew it unless it is convinced that the existing state of affairs justifies it. The courts hold that the surety company is not liable for losses arising on bonds issued when incorrect or misleading replies are furnished by an association. Negligence on the part of the directors may thus prove a serious matter in case of trouble.

The directors must bear in mind that they are required by the law of most states to see that officers are properly bonded. Probably it is more difficult to misappropriate funds from the modern association than it was in the past because of the many safeguards which have been provided. But human ingenuity in breaking a regulation is at least as great as that wnich makes the regulation in the first place, and constant vigilance on the part of all directors is the only genuine safeguard. Most of the losses which associations have sustained in the past have been the result of the defalcation of officers improperly bonded.

Group Life Insurance.-It has become the custom for some associations to carry group life insurance policies on their officers' lives, especially for the secretary, treasurer, the active directors, and members of permanent committees, and all others who handle important parts of the work. This practice has come over into the associations from other financial and industrial companies, and it has proved a great help in increasing the interest of the employees. This insurance is usually payable at the event of death or total disability of the employee to a beneficiary selected by the employee. In some cases the 
amount paid would be $\$ 500$ after three months' service, increasing $\$$ roo each calendar year of continuous service until a maximum of $\$ I, 000$ is reached. The total is seldom large, but the receipt of even a small sum by a deceased employee's family is always appreciated, and the interest thus shown by the association operates to increase its business among their friends. An association should set an example as an ideal type of employer. If it fails to encourage home ownership and better citizenship among its own people, the officers may have lost their vision of the association ideals.

Insurance can also be carried by the association for its own protection in the event of the death of the active directing hoad, if that seems desirable. The personal element will always be important in a business which deals primarily with credit. If the "key man" is lost by death, the resulting setback could well be partly covered by such insurance.

Vacations and Proper Working Conditions.-As an ideal employer, the building and loan association cannot afford to neglect its working force. The hours of labor should be the same as those maintained by institutions using similar types of employees. As soon as earnings permit it, regular vacations should be provided for the entire staff.

Committee Organization.-In addition to the duties of management pertaining to particular official positions, there are certain other details in the operation of building and loan associations which are intrusted to committees.

Individual officers or employees attend to the transaction of such business as has to do with receiving funds, selling of shares, receiving application for loans, completing loans when they are approved, and securing performance by the borrower of the terms of loans. They also look after all necessary accounting processes in the transaction of the general business of the association.

To committees, on the other hand, are usually intrusted such matters as (I) the appraisal of real estate offered as security for loans by prospective borrowers and (2) the auditing of 
acrounts. The use of conmittees is designed to safeguard the association and to maintain public confidence, both of which purposes are essential to the success of the business.

Appraisal Committee.-The appraisal committee ${ }^{4}$ is usually composed of three members of the board of directors, selected because of their special fitness to determine the value of the security offered for loans. Their findings in each case are submitted to the board in writing and made a part of the proceedings in approving the loan. ${ }^{5}$

Members of the appraisal committee are usually compensated for the work of inspecting and appraising properties, the fee most frequently charged the borrower being $\$ 3$, allowing $\$ \mathrm{I}$ to each appraiser for this service. The work of the appraisal committee, although of great importance, is merely advisory to the board of directors. The directors are responsible for the final decision in approving or rejecting applications for loans.

It is essential that the members of the appraisal committee be conversant with real-estate values, and they should be sufficiently informed concerning the various economic factors involved in urban-land utilization to determine in any given case whether the project is sound from a business standpoint. This committee may also be called on to judge whether the applicant is in a position to carry out his undertaking. In some of the larger associations an expert professional appraiser is kept constantly employed, in lieu of the usual appraisal committee.

The duties may include the frequent inspection of a mortgaged dwelling in course of construction, although this duty is sometimes assigned to a special Building Committee or to an inspector for the association. Many associations specialize in making loans for new construction; many make no distinction as to the purpose of the borrower in securing a loan; while some decline all loans for construction purposes because of the added

${ }^{4}$ The particular designation of this committee varies among the associations. Other terms used are "real estate committee," "security committee," "finance committee," etc.

${ }^{5}$ See Chap. XI for the material covered in these reports. 
labor incident to guarding against special prior liens, etc. The work of the appraisal committee varies greatly among the different associations due to this difference in business policy. Auditing Committee.-The chief purposes of an audit are to determine (a) that the business is being conducted in strict conformity to the state laws, and to the by-laws, the rules, and the regulations of the association, (b) that the association's assets are intact and adequately safeguarded, and (c) that the accounts of the association are clearly and properly kept. It follows that the auditing committee should possess such qualifications as will enable them to intelligently inspect the records in detail and not make a merely perfunctory examination of the books. A favorable report from an ignorant committee may be positively harmful to the business by creating a false sense of security that sometimes leads to disaster. The defalcations of officers which have caused most of the building and loan failures would have come to light in time to avoid disaster if the association's affairs had been properly audited.

It is customary in smaller associations for the auditing committee to inspect the accounts of the association at stated periods, at least once a year. These committees usually consist of three members elected by vote of the entire membership. The laws of the various states usually provide for examination by a representative of the state department having supervision of building and loan associations. In most of the states this duty is inadequately performed and an independent audit is demanded by business prudence. In the larger associations, the employment of a competent certified public accountant is deemed necessary. ${ }^{6}$

Other Necessary Committees.-Special conditions may make it desirable to have other committees appointed from

\footnotetext{
- The states in which no provision has been made for such examination are as follows: Alabama, Georgia, Idaho, Maryland, Mississippi, Nevada, New Mexico, South Carolina, Virginia, and Wyoming. Certain other states have inadequate supervision (including examination), due to lack of provision for the payment of expenses incurred in such examination by a state official. These include Florida and Texas.
} 
time to time, as, for instance, a membership committee, a promotion committee, or a committee on finance or business policy. Since each is designed for a particular purpose it should be composed of those board members best qualified to meet the particular need. Each member should be in a position to give the required amount of time to the special work in hand.

The membership committee, for instance, should include those who possess the widest acquaintance, are public minded and public spirited, and realize to the full the mutual advantages to be derived from the greatest possible increase in membership of the association.

The promotion committee should be composed of those who are experienced in business development in general, and are familiar with effective forms of advertising and trade development through successful experience in their use. They should possess such complete knowledge of the affairs of the association as will enable them to develop their activities along lines that are most expedient at the time.

The members of the committee on finance or business policy should be men of wide financial experience, who are able to plan the general policies of the association in such matters as the determination of the territory in which loans shall be made, the question of borrowing from banks to meet an excessive demand for loans, the matter of granting or restricting loans when conditions change, and such other questions of financial policy as may develop from time to time.

Legal Counsel. ${ }^{7}$ - The attorney of the association may well be a member of the board. In this close contact he can safeguard the association against any action of doubtful legality or one that might be deemed inadvisable in a given case. $\mathrm{He}$ should possess not only the necessary legal qualifications, but in addition should have a vision of the opportunities for service in a building and loan association which will lead him to

7The terms "counsel," "solicitor," "attorney," "conveyancer," are used interchangeably among associations to designate the legal officer. 
protect and advise the association and its individual members in such a way as to broaden the scope of the whole movement. This service should be performed for a reasonable compensation, derived mainly from fees paid by borrowers for title search or examination of abstracts. Occasion should seldom arise for court proceedings in connection with ordinary association business. The right man will not seek personal gain at the expense of either the association or the borrower.

It would seem to be sound policy for the attorney to limit his service to a single association, or at the most to a very few. The temptation to play one against the other is very great when the same solicitor attempts to act for several associations.

\section{SPECIAL REFERENCES}

Attorney. Youngstown Institute Proceedings, May 1 I, I923, pp. I-7. Auditing. U. S. League Proceedings (IgIo), pp. 34-38; (Igr4), pp. rog-Ir4. Youngstown Institute Proceedings, June I, I923, pp. I-I8. Bonding. California League Proceedings (1924), pD. 71-74. Nebraska League Proceedings (1924), pp. 24-25.

Committees. Youngstown Institute Proceedings, April I3, 1923, p. 8. Directors. Kansas League Proceedings (1920), pp. 72-74. New York League Proceedings (1923), pp. 28-33. U S. League Proceedings (1903), pp. 66-70. Youngstown Institute Proceedings, April I3, I923, pp. 6-7; April 20, 1923, pp. I-5.

Management. Illinois League Proceedings (I918), pp. I23-125. U. S. League Proceedings (I901), pp. 50-56; (r901), pp. 79-84; (1903), pp. IO9-I IO.

Officers. Missouri League Proceedings (1921), pp. I8-22; (т922), pp 64-68. Kansas League Proceedings (1916), pp. I2-13. Youngstown Institute Proceedings, March 6, 1923, p. 7; April 13, 1923, pp. 6-7. Surety bonds. Missouri League Proceedings (1924), p. 4I. U. S. League Proceedings (1910), pp. 50-57.

\section{GENERAL REFERENCES}

Rosenthal, Henry S. Cyclopedia, pp. 232-254; 296-324.

Sundheim, Joseph H. Law, pp. 65-Io6. 


\section{SOURCES OF FUNDS}

Safety and reasonable dividend rate, factors in attracting capital; sources of funds-regular salaries or wages, hoard's of money, re-investment of interest and dividends; advantages of compound interest; tendency toward equilibrium of savings and loans; typical receipts and disbursements of an association, showing operations over a period of years; repayment of loans before due; operations of an association using paid-up stock; premium-origin, present use, increasing disfavor; fines, fees, and forfeitures now passing away; borrowing by associationpurpose, limits, security; tying up insurance with savings.

\section{(a) From Members}

The methods by which money may be attracted into the treasury of the association are of as many varieties as the ingenuity of the officers can provide. Ever since the early "terminating" plan associations ran into difficulties after a few years' operations, new schemes have been developed. The problem is to discover the hiding places of money, and find ways to convert it to the investments which the association has to offer.

"Money is not so churlishly diffident as had been supposed. It is apt indeed to hold back distrustfully at first. Coöperative credit is to it what the newly painted gate is to the cow. But show it that its money will be safe, and it will come in readily enough to the tune of only a moderate dividend. It is important that money should not be over-remunerated, in order that there should not be two interests . . . - the lender's and the borrower's, with a temptation to the former to exploit the latter." 1

${ }^{1}$ Henry W. Wolff, Coöperative Credit for the United States, p. 65. 
In attracting capital, the dividend rate is only one of several considerations of which safety is of first importance. The man with money to invest, whether it is much or little, wants to be sure that he will be repaid at some later time. He is willing to take the slight risk involved in building and loan investment when he knows that past members of the association have received their funds promptly at maturity. An established reputation is the surest attraction to money.

Regular Wages and Salaries.-Wages and salaries are of course the big source of association funds. As has already been indicated, it is possible for the officers to encourage their members to make slight readjustments in their household budgets and so save larger portions of their income. Most people make no plans for using their wages or salaries. When the money is received, it is paid out with no thought of getting the greatest net good for its owners. A few minutes' study will often result in decided changes which will make it possible for them to carry more building and loan shares. Money from small savers is the steadiest type of association income, resulting in small "turnover"- that is, there is less withdrawal.

Hoards of Money.-There is the considerable accumulation of money actually kept on hand by those who do not understand our modern system of finance. Often there is an unreasoning distrust of the whole group of banks and bankers. Perhaps it is due to the losses which some member of a family has sustained in the remote past. Scarcely a month passes without the disclosure of hoards of money which have been accumulating for years in the hands of such people. On the death of an old man a short time ago, his widow called in some of her trusted neighbors to count the money which they had put away in an old trunk over a long term of years. The amount found was something over $\$ 8,000$, and it represented the savings of some fifty-five years. The tragedy is not that the money was kept out of productive use during such a long period, but that the interest was lost. One of the items was a sack of $\$ 500$ in gold, received when the husband, then 
a young man, was discharged from the army at the close of the Civil War. In the 55 years which had elapsed since it was stored away, this $\$ 500$ alone might have earned enough to equal $\mathrm{I} / 2$ times the entire hoard. ${ }^{2}$

It is difficult to locate such hoards, and still more difficult to induce their owners to invest the sums in a building and loan association, but the task is by no means impossible, and the resulting good to the community as well as to the owners of the money will more than offset the trouble involved.

Re-investment of Interest and Dividends.-Interest on investment is a larger item in our national income than most people realize. The capitalist is as anxious to take advantage of maximum return as any other member of our population, and building and loan officials can prove to the most astute handler of money that the dividend return and the degree of safety which are realized through affiliation with the association movement are well worth while.

The prompt re-investment of dividends or interest makes it possible to gain the advantages of compound interest, but the average man often neglects such opportunities. He lets the funds lie in a bank account until he finds another profitable place for them. The building and loan association undertakes this responsibility for him, so that he automatically receives compound interest on his savings.

Advantages of Compound Interest.-Most of us have not thought of the difference in income between simple and compound interest, but the following illustration may make it clear:

In five years,

$\$ \mathrm{r}, \infty 0$ placed at 6 per cent simple interest $=\$ 1,300.00$ at 6 per cent compounded annually $=\mathrm{I}, 338.2 \mathrm{I}$ at 6 per cent compounded semiannually $=\mathbf{I}, 343.92$ at 6 per cent compounded four times each year $=1,346.87$ at 6 per cent compounded monthly

$=1,348.83$

At $6 \%$ compounded annually, $\$ 500$ amounts to $\$ 12,175 \cdot 3^{i}$ in 55 years. 
When it is possible to take advantage of this great difference (nearly I 5 per cent for semiannual compound in five years) it will be understood how attractive the building and loan method of saving can be made to men who desire the maximum return on their investment.

The Tendency Toward Equilibrium.-After a reasonable number of years of operation, all modern associations have more money constantly available for loans, although the amount tends to reach a point of equilibrium after the first maturities. When this point is reached, the directors must use great care in arranging for the repayment of the principal of maturing shares. This is especially true of the serial associations. The sums to be loaned new borrowers will be decreased (unless there is a progressive increase in the sale of new shares) because part of the sums previously available for loans must now be paid out as matured savings.

Practically, this is only a tendency toward equilibrium, because many causes operate to cause a fluctuation of withdrawals. When money is "tight" in the general credit market, some savings will be withdrawn before maturity in order to secure higher interest rates elsewhere. When interest rates for other securities fall, and money is "easier," the opposite tendency is noticeable. Yet some of the largest gains in assets have occurred in periods of depression because both safety and large returns are secured in the building and loan association.

Expected Income for a Serial Association.-In order to illustrate more clearly the actual situation for a new building and loan association, the following tables have been prepared showing the flow of income and expenses in a hypothetical serial association which we will call the Alpha Building and Loan Association.

The only essential difference between this fictitious company and the average serial association is that provision has been made for a contingent-reserve fund. The use of the contingentreserve is increasing throughout the country, and will eventually be a recognized practice in all associations. With the 


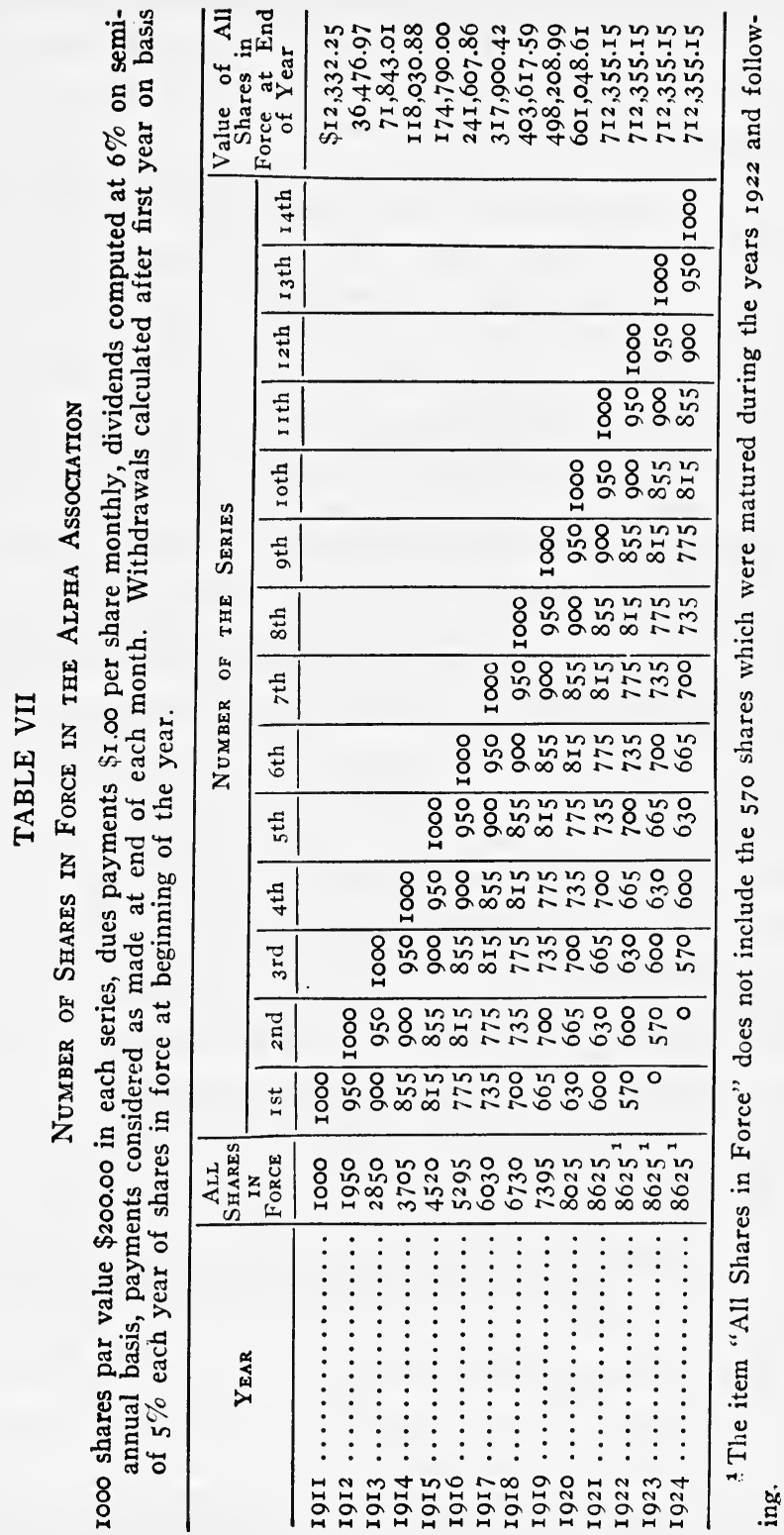


exception of the serial arrangement, the following figures might apply to any new progressive association, regardless of plan used.

The first of these tables (Table VII) shows the number of shares in force for a 14 -year period, assuming the number of shares sold each year to be 1,000, and the number of withdrawals each year as 5 per cent of shares outstanding at the close of the preceding year. ${ }^{3}$

It will be noted that in the first series (during the first year) funds were available for loans on 60 shares only. As later series are introduced, an increasing proportion of shares may be borrowed upon as funds become more plentiful. The actual numbers for the ten series are as follows:

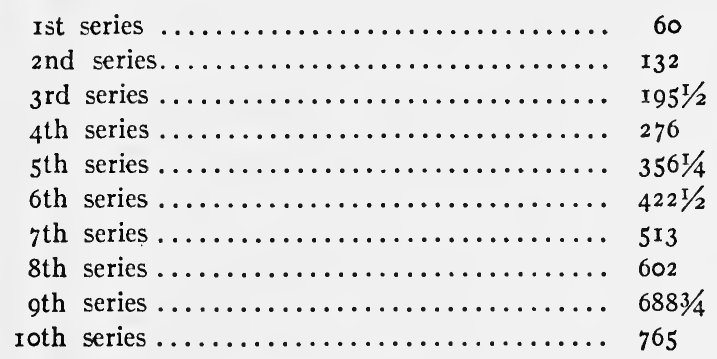

These figures will be more readily understood by referring to Table VIII, which shows the typical receipts and disbursements of the Alpha Association. To obtain the number of shares against which loans may be made, divide the third item of "disbursements" (loans made) by $\$ 200$, the par value of one share, the resulting figure is the maxinum number of

${ }^{3}$ Withdrawal of shares before maturity seldom is less than 50 per cent, and the average perhaps is 65 per cent over the country as a whole. In serial associations there is a tendency for withdrawals to be less than under the regular permanent plan and much less than under the Dayton permanent plan. The latter associations do not use the idea of maturity, but shareholders enter and withdraw at will. Since associations which pay 6 per cent dividends mature shares in about $11 \frac{1 / 2}{2}$ years, 5 per cent of withdrawals each year is probably not very different from actual conditions. 


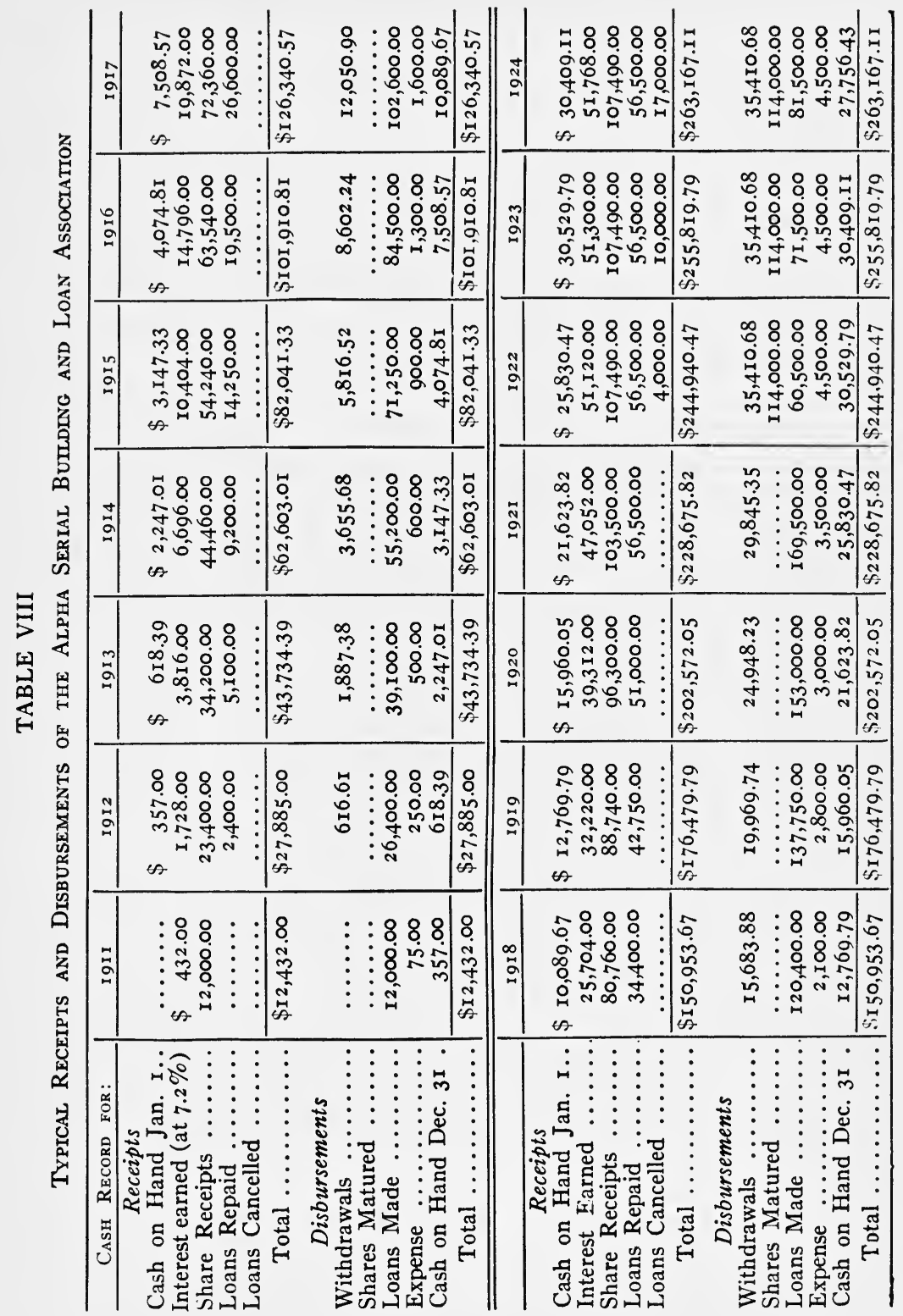




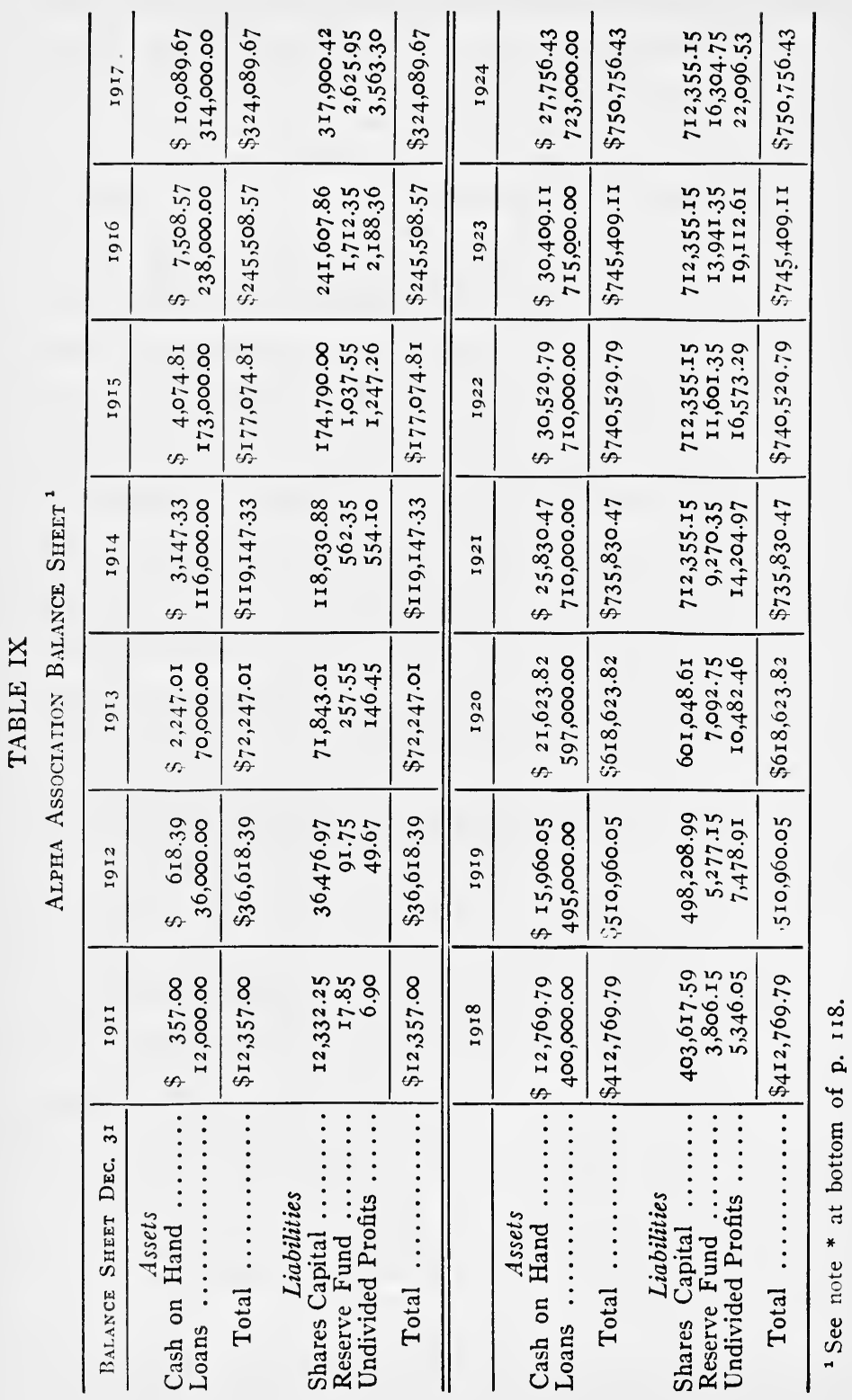


shares which borrowers have available for their use during the given year.

The maximum number of shareholders, if each held 5 shares of $\$ 200$ matured value each, would be 1,725 in all series in force. If each family in a community of 10,000 is represented by one member, the total available memberships would be something over 2,000 , but the figure 1,725 is a fair index of actual conditions.

The tendency toward equilibrium after the tenth year, when we have assumed that 8,625 shares will remain continuously in force, is not to be understood to mean that growth is impossible beyond that point. Progressive associations will always continue to grow. They would grow if for no other reason than that the reserve fund and undivided profits give additional sums which are added to the loanable funds.

Receipts and disbursements of the Alpha Association have been calculated according to the number of shares stated to be in force in Table VII. These figures were obtained by a careful analysis of the receipts and disbursements of a large number of associations, and are based on percentages obtained from this study, due allowance being made for the early period of growth.

No allowance has been made for the use of paid-up shares, since at this point it is desired to present only the conditions which may be expected from the use of installment shares. Paid-up shares may be advantageously used by all associations, but their introduction adds a new element, especially to the rapidity of "turn-over," or number of times a given amount of money is received or paid out. If the matured value of the installment shares is used to buy paid-up shares, the money

* A very interesting method of comparing a series of balance sheets similar to those shown in Table IX has been worked out by Stephen Gilman. Let the figure for any year equal $100 \%$. Then divide the figure for any later year by the figure for the first year, and the later figure is thus turned into a percentage of the first. In this way a sort of index number is developed, which tells at a glance the relationship between any desired series of figures. 
remains in the association and no cash is needed to meet maturities. If the savings member demands his money and withdraws, the officials are confronted with several alternatives. Finding the cash to retire "free shares" is a real problem.

The break in the flow of new money for loans first occurs at the year 1923 in the table, at which time many shares must be retired. Those shares which are pledged for loans will merely be applied on the loan at maturity and the mortgage released. Table VIII shows that $\$$ I 4,000 shares will mature in 1922 and each year thereafter. That is, 57 per cent of the shares which entered the series are assumed to remain until maturity. Of these 570 shares, 60 were pledged for loans and will be canceled. The remaining 5 ro shares, valued at $\$ 102,000$, must be paid off. Receipts during the year were as follows:

Interest earned ................. \$ \$ II,I20.00

Share receipts ................. $107,490.00$

Loans repaid (before maturity) ...... $56,500.00$

$\$ 215,110.00$

From this income, expenses must be paid as well as other items. These include:

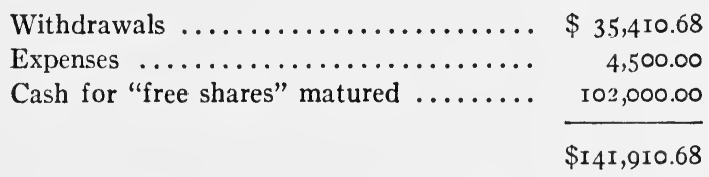

When these deductions have been made, a total of $\$ 73, \mathrm{r} 99.32$ is available for all other purposes, including loans. Whereas, in the previous year, it was possible to lend $\$ 169,500$, the association must now restrict its lending to approximately onethird of its former activity, unless more savings can be secured.

Reflection will show that the money for retirement of shares can be obtained from one of several sources.

(I) The entire income from all series could be set aside 
for approximately 13 months before the expected maturity date in order to have on hand a sufficient amount.

(2) Part of the loan repayments and interest received could be so used. If the officers do not desire to set aside all income, it can be accumulated over a longer period by using only part of the receipts each month.

(3) The money may be borrowed from the bank when the shares are due, and repaid out of later receipts. (This is reported as common practice in many of the Pennsylvania serial associations.)

(4) When the state laws permit, and the by-laws of the association specifically provide for it, matured shares may be paid off gradually after the date of maturity, interest on the amount withheld being paid from maturity until the total is paid. This gives the association a chance "to catch its breath," and relieves it from the strain of large cash payments at one time.

The balance sheet of this Alpha Association is shown in Table IX. In the interest of simplicity many items which might normally appear in such a balance sheet have been purposely omitted. Such items as real estate (office building), furniture and fixtures, bonds of all kinds, etc., will occur in many statements. But such omissions will not impair the essential facts which this table is designed to show.

Repayment of Loans Before Due.-Loans will be repaid during every fiscal year, many of them before they are due. Experience shows that about half as many loans are repaid every year as the amount of new loans for that year. These repayments, together with the interest received, may offset all withdrawals and maturities in some years. This is especially true in a period of real-estate activity, but it would be unwise to depend upon such a source of income in periods of inactivity. In certain years, repayments of loans are very rapid. Loans which are expected to run for ten or twelve years frequently are paid in full at the end of three or four years. Early repayments of this sort have a marked effect on the 
cash balance of the association. They present a problem for the officers in finding new loans as well secured as the old. They may increase the income of the association materially, especially when fees based on longer periods are used. They also affect the borrower, since early repayment may greatly change his interest rate, particularly if he has paid a lump-sum premium.

Introduction of Paid-up and Prepaid Shares.-The maturity of installment shares and the necessity of providing cash to meet such maturities are often the incentives which lead to the adoption of paid-up shares by an association. Withdrawal by individuals will occur as before.

In Table $\mathrm{X}$ the receipts and disbursements are shown for an association which started business at the same time and on the same basis as the Alpha Association but which introduced paid-up shares, upon maturity of shares in the first series. For convenience this is referred to as the "Omega Association." Since its problems for the years I9II-I92I exactly duplicate those of the "Alpha Association," only the later years (I922-1924) are shown. In 1922 the loans made by the Alpha Association dropped from $\$ 169,500$ to $\$ 66,500$. The Omega Association, however, continues to increase its loans steadily through every year of its existence, even after reaching the so-called point of equilibrium. After the introduction of paid-up shares, cash dividends (on full-paid shares) become a regular part of the disbursements. This plan makes possible a wider service by the association for the community in which it is located.

The use of paid-up stock not only enables the association to retain maturing shares, but it also provides a means of obtaining large amounts of capital from investors to whom installment saving is no object.

Prepaid stock also attracts those with larger sums to invest and this stock is even more permanent than full-paid shares, since it is designed to accumulate certain sums during an 
extended period and the holder is less inclined to withdraw for investment elsewhere.

\section{TABLE X}

Recerpts and Disbursements of the Omega Assoctation Using PaId-Up Shares

\begin{tabular}{|c|c|c|c|}
\hline Cash Record for & 1922 & 1923 & 1924 \\
\hline \multicolumn{4}{|l|}{ Receipts } \\
\hline Cash on Hand Jan. I & $\$ 25,830.47$ & $\$ 30,749.79$ & $\$ 30,447.6 \mathrm{I}$ \\
\hline Interest Earned .... & $52,440.00$ & $56,508.00$ & $60,654.00$ \\
\hline Share Receipts (Installment)... & ro7,490.00 & ro $7,490.00$ & $107,490.00$ \\
\hline Loans Repaid .... & $56,500.00$ & $56,500.00$ & $56,500.00$ \\
\hline Loans Cancelled ........... & $4,000.00$ & $10,000.00$ & $17,000.00$ \\
\hline Share Receipts (Full Paid)... & $55,000.00$ & $5^{2,000.00}$ & $48,500.00$ \\
\hline Total & $\$ 301,260.47$ & $\$ 313,247.79$ & $\$ 320,59$ I.6I \\
\hline \multicolumn{4}{|l|}{ Disbursements } \\
\hline Withdrawals & $\$ 35,410.68$ & $\$ 35,410.68$ & $\$ 35,410.68$ \\
\hline Shares Matured & I I $4,000.00$ & I I $4,000.00$ & I I $4,000.00$ \\
\hline Cash Dividends Paid & $1,100.00$ & $4,389 \cdot 50$ & $7,500.85$ \\
\hline Loans Made ........ & I I 5,500.00 & I $23,500.00$ & $130,500.00$ \\
\hline Expense $\ldots \ldots \ldots \ldots \ldots \ldots \ldots$ & $4,500.00$ & $5,500.00$ & $6,500.00$ \\
\hline \multirow{2}{*}{$\begin{array}{c}\text { Cash on Hand Dec. } 3 \mathrm{I} \ldots \ldots \ldots \\
\text { Total } \ldots \ldots \ldots \ldots \ldots \ldots\end{array}$} & $30,749.79$ & $30,447.6 \mathrm{r}$ & $26,680.08$ \\
\hline & $\$ 301,260.47$ & $\$ 3$ I $3,247.79$ & $\$ 320,59 \mathrm{I} .6 \mathrm{I}$ \\
\hline
\end{tabular}

Table XI shows the balance sheets for the Omega Association.

\section{TABLE XI}

Balance Sheets of the Omega Assoctation

\begin{tabular}{|c|c|c|c|}
\hline & I 922 & 1923 & 1924 \\
\hline \begin{tabular}{l}
\multicolumn{2}{c}{ Assets } \\
Cash on Hand Dec. $3 \mathrm{I} \ldots \ldots \ldots$ \\
Loans $\ldots \ldots \ldots \ldots \ldots \ldots \ldots \ldots$
\end{tabular} & $\begin{array}{r}\$ 30,749.79 \\
765,000.00\end{array}$ & $\begin{array}{r}\$ 30,447.61 \\
822,000.00\end{array}$ & $\begin{array}{r}\$ 26,680.08 \\
879,000.00\end{array}$ \\
\hline Total $\ldots \ldots \ldots \ldots \ldots$ & $\$ 795,749.79$ & $\$ 85^{2,447.6 I}$ & $\$ 905,680.08$ \\
\hline $\begin{array}{l}\text { Liabilities } \\
\text { Shares Capital (Installment) .. } \\
\text { Shares Capital (Paid-Up) } \ldots \ldots \\
\text { Reserve Fund } \ldots \ldots \ldots \ldots \ldots \ldots \\
\text { Undivided Profits } \ldots \ldots \ldots \ldots \ldots\end{array}$ & $\begin{array}{r}\$ 7 \text { I } 2,355.15 \\
55,000.00 \\
\text { I I }, 667.35 \\
\text { I } 6,727.29\end{array}$ & $\begin{array}{r}\$ 7 \text { I } 2,355.15 \\
107,000.00 \\
14,217.75 \\
\text { I } 8,874.7 \text { I }\end{array}$ & $\begin{array}{r}\$ 7 \text { I2,355.15 } \\
\text { I } 55,500.00 \\
16,925.45 \\
20,899.48\end{array}$ \\
\hline Total . & $\$ 795,749.79$ & $\$ 85^{2}, 447.6 \mathrm{I}$ & $\$ 905,680.08$ \\
\hline
\end{tabular}


Income and outgo of funds of an association can be balanced by officers who know their business. Absolute balance is not necessary. It is even considered desirable to have an excess of funds constantly flowing in because the officers must then be active in finding suitable loans. It keeps them interested in promoting the affairs of the association.

Income Under Other Plans.-The foregoing discussion of the methods by which funds are acquired is designed to show what may be expected in an average association when shares are issued on the serial plan, and particularly to point out the difficulties which arise when the association is obliged to retire large blocks of shares within a comparatively short period, as well as the methods of avoiding such difficulties.

Many of these difficulties will not arise except in serial associations, or if they come up, they will present themselves from a slightly different angle. For example, it is much less likely that the permanent or Dayton permanent associations will have to meet large blocks of maturities at one time.

The possible number of shares which may be sold dur.ng the early life of an association is about the same under the other plans as in the serial plan. As a result, the foregoing tables may be considered a fair index for the business that may be expected in any type of building and loan association. Such differences as exist between different plans lie in the fact that new members may enter at any time under both permanent plans, and therefore it is possible to induce new money to enter quickly when needed. It is possible that the incentive of group movement may offset this tendency in the serial association. A lot of people take out new shares at the same time when each new series is opened, and this is believed to encourage still others to join at the same time.

Under all plans, therefore, the total amount of new money which may be expected from shareholders will be essentially the same as that which has been shown in this chapter, although the methods of handling the accounts may be somewhat different. Also, this new money will be forthcoming from the 
same classes of persons who invest in all building and loan associations. No separate discussion seems needed to cover the other plans at this point.

Interest and Premiums.-The association is mainly dependent upon interest for its earnings. Combined with interest is the peculiar use of a "premium," which has persisted since the earliest building societies. The premium was the only cost of the loan in some very early associations. The man who was most anxious to get into his own home would bid the highest premium, and priority in borrowing was determined in this way.

In the modern association, the use of the premium as a means of determining priority is seldom of any importance. It is one legalized method of securing a higher interest rate for the association's funds, and is so recognized by the officials of the associations which use it. The laws of the various states were originally framed to allow the priority premium to be used, and these laws have been changed but little since interest became the more important part of the charge. As a result it is still possible, by the use of premiums, to charge considerably more than the highest contract interest rate in some states.

Fortunately this usurious practice is on the decline, as legislators are recognizing that the statutes have been used for private advantage in the past. As a result there appears to be a definite trend in legislation to provide a maximum beyond which the total premium and interest may not go.

One reason that it has been possible in the past to collect the premium in addition to the interest is that the offsetting credits on the accumulating principal have materially reduced the actual cost. The building and loan plan gets the borrower out of debt, and accomplishes this by charging a total monthly payment which is within reach of his income. The sum demanded per week or month is of more importance to the average wage earner than the total amount to be paid over a long period of years. A few additional payments make no essential difference to him. 
The premium is probably destined to be merged into the regular interest charge, when our people are more familiar with the operation of the associations, but until they understand more about finance, there is small likelihood of the abandonment of the premium.

Fines, Fees, and Forfeitures.-Fines have never been an important source of income for building and loan associations and are gradually disappearing, since other methods of eliminating delinquency have proved more efficacious. Fees of all kinds continue in use as a source of expense funds, and penalties such as withholding a part of the earnings on shares in case of early withdrawal constitute an important part of income. The latter are properly called "forfeitures," but forfeiture of principal is now largely a thing of the past.

One type of income which falls within the general class of "fines," but which aids the conscientious member, is used by some associations. ${ }^{4}$ When the periodic payments of the borrower are made prior to a certain day each month (for example, by the fifteenth), the rate of interest accepted for the month is less than the contract or stipulated rate. That is, if the loan were made on a 7 per cent basis (or any other rate) the note would call for this amount per annum, and the association retains the right to collect this amount. Whenever interest payments are made before the fifteenth of the month, the borrower is allowed to pay a rate approximately I per cent per annum less; for example, 6 per cent instead of 7 per cent ( $\$ 5$ per $\$ 1,000$ per month, instead of $\$ 5.83$ ). The higher rate thus penalizes the tardy borrower, and is an additional source of income for the association. At the same time the borrower who is systematic in his payments, is regularly rewarded by the remission of a part of his agreed-upon interest.

Borrowing.-It has been mentioned several times that an association may profitably borrow money when it needs additional funds to meet unusual demands. Both home building

4 These include the Home Savings and Loan Company of Youngstown, Ohio, of which James M. McKay is president. 
and home buying are more active at certain seasons of the year than at others. Much of this activity takes place in the spring, and there is a renewal of it in the fall, due to the effort to get into a home and become settled before winter. In most parts of the country, there is little demand for money for new construction during the winter, although this does not apply to the south and west, where outdoor operations can be carried on successfully every month in the year.

If these seasonal demands are not cared for, there may be periods when the income of the association is greater than the demand for loans. Such an excess of funds provides opportunity for the exercise of the business ability of the officers, and one method of meeting the situation is to anticipate the arrival of the funds by borrowing when the demand is in excess of current income and repaying when the demand has fallen off.

No association should borrow an excessive amount of money. In some states borrowing in excess of a certain percentage of the assets of the association is prohibited. A ro per cent limitation is not unreasonable. As loans of this character are strictly short-term or commercial loans, it may be unwise to borrow more than the amount of known revenue for a few months, but. this depends largely upon the general situation of the business. Where the association is an established institution and conditions are normal, it can count on a reasonable increase of income aside from that which has been determined by its loan contracts. If, however, an association borrows in excess of its known income, there is the possibility of inflation, and if the income is not received before the loans are due, the association itself might be forced into liquidation.

Security for Borrowing.--There is no necessity for an association to give any security such as mortgages for these loans from the bank. Only a note is needed. The board of directors adopts a resolution specifically naming the bank from which borrowing is authorized, the amount of money which is desired (or the maximum that may be borrowed within a given 
time), the term of the loan, and the interest rate to be paid. This resolution also authorizes the president and secretary (or other officers) to apply for the loan and to issue the note of the association therefor. This note, with a certified copy of the resolution, is turned over to the bank when the loan is secured. No mortgages or other evidences of indebtedness are required, because the note and certificate constitute one of the very small group of preferred claims, or probably the only preferred claim which may exist against the entire assets of the association. Sums borrowed in this way take precedence over the savings of members. The commercial bank is ordinarily the only real creditor of the association, and for this reason associations' notes bear a preferential rate over any other type of bank paper. Most banks are eager for such loans, not only because of their ultimate safety, but also because prompt repayment is assured. The systematic revenues of the association make this possible.

The larger associations which make a practice of borrowing money whenever it is expedient to do so, sometimes authorize the loans by means of "blanket" resolutions of the directors. That is, the board authorizes its officers to borrow as needed up to a specified limit. As funds are needed, the officers issue notes under this authorization, each note being accompanied by a certified copy of the resolution as before. The plan has many advantages where directors' meetings are infrequent. It has the objection of handing over control of the process to the officers, however, and many building and loan men believe the plan is unsound. They prefer a method whereby no blanket authorization is used, but the specific amount desired at a given time is passed upon by the directors. The latter plan is desirable where the officers are not sufficiently experienced to make a success of the blanket system, but it limits the action of the association when unusual demands occur between meetings of the directors. Many associations have such relations with their banks that they average more of money borrowed from the bank than they do cash on hand. 
Insuring the Receipt of Savings.-Since it is true that many savings members withdraw their investment before the maturity of their shares, many schemes have been devised by building and loan men to keep money in the association. The old plan of fining a delinquent member or charging him fees of various kinds has not always resulted in complete satisfaction. Various kinds of insurance plans have been attempted in different states, some of which have met with success and others with failure. Since it is to the interest of the savings member to continue his contract with the association for a considerable period when the investment is tied up with a lifeirsurance contract, the matter would seem to merit the attention of a greater number of building and loan men.

Probably failure has resulted where the association has overemphasized the insurance feature to the detriment of the sarings feature. Tying a life-insurance contract to a savings plan definitely encourages the savings member to accomplish the goal which he has set for himself, since he knows that even in the event of his death he would leave his family the amount of money which he had set out to accumulate.

Life-insurance contracts for borrowers have long been required by many associations, the insurance being assigned to the association during the life of the loan. When a borrower has objected to purchasing an ordinary life policy for this purpose, it is easy for the association to show that while the property may be good for the amount of the loan, the association is not concerned with that so much as with the income from which its money will be paid. The officers want to know who is going to pay the debt in the event of a man's death, and if they are required to take over the property and sell it, this may leave the widow and children destitute, with no basis on which to begin life again. The possession of a home free of debt is often the best means for keeping a family together, so life-insurance contracts in connection with loans have always been found satisfactory, since the insurance money repays the loan when a borrower dies before his contract is completed. 
Life insurance for savings members must be sold on a somewhat different basis. The laws of some states prohibit associations from acting as life-insurance agents, but there is usually nothing to prevent individual officers from so acting if they care to do so. It is possible to sell various kinds of insurance in connection with savings shares, but the ordinary-life type appears to work best, since it does not contain any savings feature, and the money which the member saves draws the maximum building and loan dividend, instead of the limited dividend provided by a life-insurance company on its endowment policies (usually not more than 3 or 4 per cent). One association which has successfully operated the "assured savings plan" reports that it has been received with great satisfaction by its members. The association has provided a table of costs, showing total monthly payments for each age from twenty to fifty-eight, and in extended columns the following items into which the monthly payment is divided:

Annual life-insurance premium, amount of surplus in insurance fund account at end of ten years, optional surrender value of policy in ten years, value of shares in ten years, total cash value of shares and surrender of policy in ten years, total cost including insurance, and the cash profits at the end of ten years.

This plan works as follows: If the member is thirty-five years of age when he starts to save, he pays the association $\$ 8$ per month for each $\$ \mathrm{I}, 000$ of shares. The association pays the life-insurance premium yearly in advance, collecting this monthly from the member. Should the member die on the last day of the first year, there would be paid to his beneficiaries the following:

For membership share account, including interest... $\$ \quad 73.55$

From insurance-fund account, a surplus of....... $\quad 2.16$

From life insurance company ............. $1,000.00$ 
The amount of insurance would continue the same throughout the life of the contract, but the value of the membership shares would continually grow, and the surplus from the insurance fund would also grow. Should the member be living at the expiration of the ten-year term, there would be available in cash to the member $\$$ I, I 53.59 if he chooses to withdraw. The association also provides an option whereby it agrees to continue to pay the life-insurance premium as long as the member lives (costing them $\$ 2 \mathrm{I} .84$ per year) and also to pay an annual dividend to the member of $\$ 40$ as long as he lives, and at his death the beneficiary receives the savings on shares and the life-insurance money, making a total of $\$ 2,028.43$.

Not all associations will be able to offer such favorable contracts as this. It will depend upon the operations of the state law in any given case. ${ }^{5}$

A similar plan has also had successful operation among a number of associations in the state of Kansas. It has been criticized on the basis of its cost to the association, and it has been said that it detracts from the purely mutual building and loan idea. It would be well to consider, however, the advantages which accrue from such an insurance contract before arbitrarily stating that it is not a satisfactory method of promoting continuous saving in the building and loan association. It distinctly encourages thrift in its broadest sense, assists a savings member to create an estate, and relieves the suffering of widows and children. This type of community service has considerable merit in itself, but from the selfish standpoint of the association, the higher percentage of maturities which results from the use of such a plan should not be overlooked. ${ }^{6}$

The plan above mentioned is quite different in its scope from the plan which has been tried out in Massachusetts, and a few other states, whereby the coöperative bank has opened an

${ }^{B}$ The plan mentioned above is in use by the Los Angeles Mutual Building and Loan Association of which R. Holtby Myers is the efficient secretary.

"See "The Assured Investment Combination," by L. E. Roush, Kansas League Proceedings, 1924, pp. I16-122. 
insurance department by providing an expense and guarantee fund of considerable amount. ${ }^{7}$

\section{(в) Deposits (Used Principally in Ohio)}

In recent years the practice of accepting deposits on the same basis as those in a savings bank has become more or less common in a few states where this practice is sanctioned by the statutes. ${ }^{8}$ This grew out of the practice of accepting members whose share payments were purely optional, and where the idea of maturity was practically eliminated. It was seen that the procedure of handling this business was essentially the same as in a savings bank. Shareholders, however, undertook the usual risks pertaining to share ownership, and this risk tended to keep many persons away who were unable to assume any responsibility for the debts of others. The introduction of the depositor as a preferred creditor followed, the same as in a savings bank.

The use of deposits in Ohio has been found to attract a class of investors who could not otherwise be reached, and the largest growth of the business has come in the associations which collect a part of their funds on this plan. After an experience of a number of years, the state supervising department of Ohio is satisfied that the plan as worked out in their state is a success. In commenting on the situation, the present Superintendent of Building and Loan Associations, J. W. Tannehill, writes as follows:

${ }^{7}$ A discussion of this plan will be found in the 1909 U. S. League Procecdings, pp. 42 to 50 , by William F. Winter, Fall River, Massachusetts. The Massachusetts plan was devised in order that the coöperative banks might supply insurance to their members (who are supposed to be largely working men) at lower rates than the premiums charged on industrial insurance by old-line companies.

${ }^{8}$ The statutes of Arizona, Montana, and Ohio appear to permit huilding and loan associations to accept regular savings deposits. The majority of the state laws are silent as to deposits, but certain states definitely prohibit their use. Among those prohibiting deposits are California, Michigan, New Jersey, and Rhode Island. 
"While the strictly mutual building and loan association is the ideal organization and is exempt from national taxation, experience has shown that in most large cities, as Dayton, Cincinnati, Cleveland, Toledo, Akron, and Columbus, the growth of strictly mutual companies is too slow to meet the needs of home builders. Only in exceptional cases do the mutual companies obtain large assets. Both classes of savings and loan companies are absolutely essential in Ohio. Probably three-fourths of the business in the State is done by associations that accept deposits.

"In Ohio, all stockholders-running, paid-up, and permanent-receive the same rate of dividerid. The rate of interest on deposits depends, in some associations, on whether the money is left on deposit a specified length of time, the rate on long-time deposits being higher than on money left on deposit for a shorter period.

"The loss to stockholders in the few Ohio associations that have failed during the past quarter of a century has been smaller in proportion to assets than any other business corporations in the state. The percentage of loss is much lower than banks, either state or national. No loss to depositors in building and loan associations has been reported to this Department at any time since its organization." ${ }^{9}$

Building and loan associations operate on such a small expense budget that they can consistently pay a higher interest rate on deposits than that paid by savings banks. As a result there has been in the past considerable friction with the banks when the association accepts deposits. With the growing mutual understanding between the officials of banks and associations, however, this feeling of antagonism is passing away. Both institutions are filling a needed place in the community. Each specializes in its own field, and the success of one contributes to the success of the other by encouraging a larger

${ }^{9}$ Letter from J. W. Tannehill, Superintendent of Building and Loan Associations for Ohio, to the American Savings, Building and Loan Institute, September I3, 1924 . 
number of people to save a portion of their income and invest these funds where they will benefit the community.

\section{SPECIAL REFERENCES}

Cash balances. Youngstown Institute Proceedings, April 23, I924, pp. 5 and 7 .

Deposits. New York League Proceedings (1922), pp. 37-38. Ohio League Proceedings (1922), pp. 106-108. U. S. League Proceedings (1902), pp. 65-69; (I918), pp. 75-78. Youngstown Institute Proceedings, April 13, 1923, pp. 9-II. 


\section{CHAPTER VIII}

\section{GENERAL FINANCIAL POLICY}

Regular building and loan plan; periodical reduction plan-restriction, advantages; cancel and endorse plan; provision for early repayment of loan, crediting full book value, return of unearned premium; reasonable dividends; factors affecting the interest rate; necessity for stating complete loan costs to borrower; legal and contract interest rates; split loans meet straight mortgage competition; computing the actual interest rate; advantages of lower interest rates; treatment of expenses; reserves for contingencies; investment of idle funds.

Regular Building and Loan Plan.-The regular building and loan method of charging the borrower for his loan is already understood from what has been said in previous chapters. It involves the lending of a given sum against real-estate mortgage security, to be repaid by maturing shares to the value of the loan. The borrower may receive the face value of his loan or the face value minus certain charges. In either event he pays interest upon the full amount of the loan for the entire time until it is paid off, but receives credit for earnings on his shares which offset the interest in part. Periodical payments are made by the borrower which involve three things: (I) the payment of interest, (2) the paymert of other charges (such as premium), and (3) the payment of dues on the stock subscribed for. The shares of stock of the borrowing member are matured in most associations in the same way as those of any other savings member. At maturity the shares are paid off by the association by the simple process of canceling the shares against the loan. ${ }^{1}$

${ }^{1}$ In practice, many associations write a check for the matured value of the shares in favor of the borrower. The borrower presents his share certificate for cancellation, endorses the check, hands it back to the association officials, and the endorsed check is entered as payment for the loan. 
The dividends received upon shares, or the part of the loan already repaid, constitute an essential part of the regular building and loan method. ${ }^{2}$ The borrower has the use of a larger

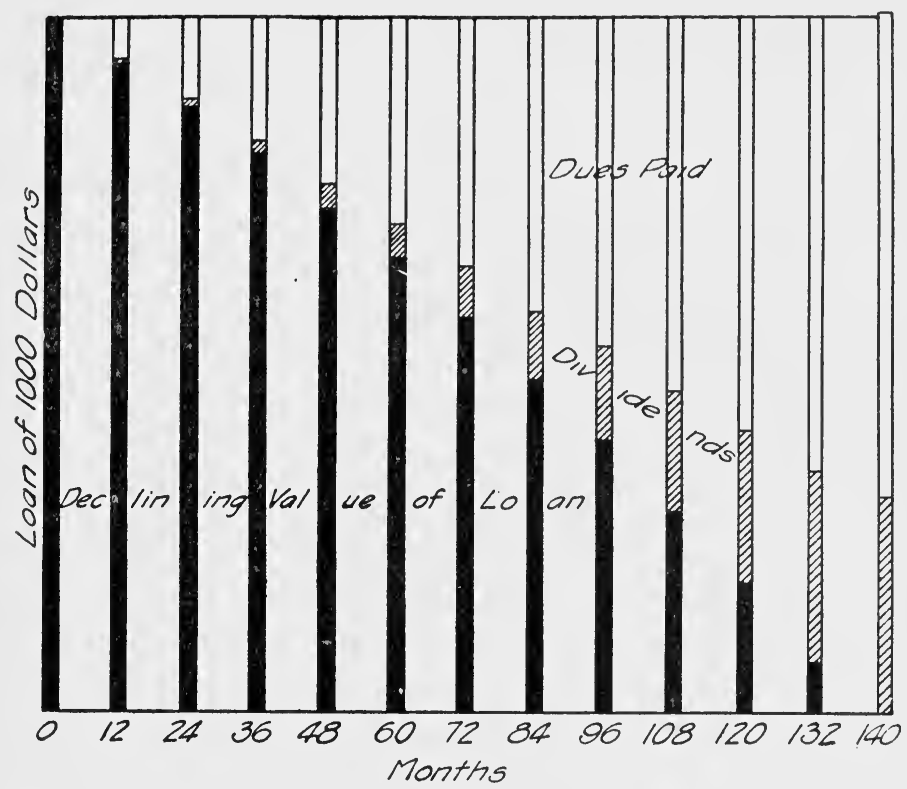

Chart 5.-Repayment of loan by building and loan plan. Dues and dividends gradually build up a fund which is used to wipe out the debt. Place a card along the tops of the black bars and note the increasing effect of compound interest toward the end of the period. Also note that the total accumulation at 140 months is greater than the loan.

This archaic bookkeeping procedure is rapidly disappearing from association practice and the value of the shares is credited upon the loan on the books of the association, a check being issued only where a balance is due the borrower.

${ }^{2}$ It is not customary to speak of share accumulations as the repayment of a loan, since the two transactions are more or less independent, and a loan may be repaid before the maturity of shares, if desired. Shares are accumulated as a "sinking fund" from which to pay the debt when due. For comparative purposes, however, the book value of shares may be considered as partial repayment of the loan. 
amount of the association's money than the amount of dues which he has paid to the association, as will be seen from Chart 5 and Table XII. The borrower always pays more

\section{TABLE XII}

Repayment of Loan Through Dues and Dividends, Showing Net Loan on Which Interest is Actually Paid (Loan \$1,000, Dues Payments \$5 Per Month, Paid at End of Month, 6 per Cent per Annum Dividends Credited Semiannually)*

\begin{tabular}{|c|c|c|c|c|}
\hline Month & $\begin{array}{c}\text { Total Dues } \\
\text { Paid }\end{array}$ & $\begin{array}{l}\text { Dividends } \\
\text { EARNED } \\
\text { TO DATE }\end{array}$ & $\begin{array}{c}\text { Book Value } \\
\text { OF Shares }\end{array}$ & $\begin{array}{l}\text { Net Loan } \\
\text { Outstanding }\end{array}$ \\
\hline I 2 & $\$ 60$ & $\$ \quad$ I. 66 I 5 & $\$ 6$ I.66I5 & $\$ 938.3385$ \\
\hline 24 & I 20 & 7.0775 & I 27.0775 & 872.9225 \\
\hline 36 & I 80 & I 6.4780 & I 96.4780 & 803.5220 \\
\hline 48 & 240 & 30.1045 & 270.1045 & 729.8955 \\
\hline 50 & 300 & 48.2155 & 348.2155 & 651.7845 \\
\hline 72 & 360 & 71.0830 & 431.0830 & 568.9170 \\
\hline 84 & 420 & 98.9970 & 518.9970 & 481.0030 \\
\hline 96 & 480 & 132.2655 & 612.2655 & 387.7345 \\
\hline 108 & 540 & 171.2135 & 711.2135 & 288.7865 \\
\hline 120 & 600 & 2 I 6.1875 & 816.1875 & 183.8125 \\
\hline I32 & 660 & 267.5545 & 927.5545 & 72.4455 \\
\hline 140 & 700 & 305.6390 & 1005.6390 & -5.6390 \\
\hline
\end{tabular}

* In compiling the figures on which this table and the accompanying chart are based, Robinsonian Table No. 23 was used for $\$ 5$ monthly payments and 6 per cent per annum dividend rate, payable semiannually.

interest to the association than the dividends which the association pays to him. But the amount of these dividends in the course of a long-term loan is a very appreciable item in reducing the costs of the loan.

Much has been written about the great savings of interest under the building and loan plan, but like the advertisements on the subject of climate in our celebrated resorts, the truth is so satisfactory that exaggeration in the long run causes more harm than good. Many men have said that it makes no difference how high an interest rate the borrower pays, since he gets it all back in dividends. The chart shows how absurd such a statement is. The borrower receives dividends on every dollar paid in, but at no time is this sum as great as the amount 
of the loan. Dues and dividends together equal the loan at maturity. The borrower actually pays interest on the net amount of the loan over the book value of his shares. The chart clearly shows how this net loan continually grows less until it finally disappears.

The greatest benefits of compound interest are realized when the time element is great. "Book value" of shares increases much more rapidly toward the close of the period. This in general represents the situation for all dividend rates, the changes which would occur being largely due to the relative influence of larger or smaller dividends and longer or shorter periods of time.

Principal and Interest Reduced Monthly or Quarterly.-The second important method of crediting dues and interest on loans in building and loan practice is similar to that in use by some savings banks. That is, a fixed monthly payment is required from the borrower throughout the life of the loan, but while the interest rate remains the same throughout the life of the loan, the amount of interest paid continually decreases, the remainder being applied directly in reducing the loan. Thus, instead of using the excess installment payment (over the interest) as dues to pay for a given number of shares as in the first instance, the excess is used to reduce the principal periodically. The method works out as follows: if a member borrows $\$ \mathrm{r}, 000$ at 6 per cent interest, he may be required to pay \$ro per month as under any other building and loan method. The first month's interest on $\$ 1,000$ amounts to $\$ 5$, leaving $\$ 5$ to apply on the principal. This $\$ 5$ at once reduces the $\$ 1,000$ loan to $\$ 995$, and the next month the interest on the loan will be one-twelfth of 6 per cent of $\$ 995$, or $\$ 4.98$. Out of the $\$ 10$ monthly payment, $\$ 5.02$ is applied upon the principal, reducing the amount on which interest is charged to $\$ 989.98$ for the following month. This process is continued until the loan is wiped out. The use of shares to mature a loan is thus unnecessary although nominal share ownership may be required. 
Practice varies among associations using this method as to the time at which the principal will be reduced. The majority of them reduce the principal and interest monthly, but some reduce the principal quarterly and a few reduce it semiannually. For the borrower the monthly reduction offers some advantage over quarterly or semiannual reduction.

Comparison with Regular Building and Loan Plan.In order to show the relation between interest costs and length of time required to repay a loan under the monthly-reduction plan and the regular building and loan plan, the following tables have been compiled, based on actual experience. In Table XIII the interest rate and dividend rates are both 6 per cent per annum.

It will be seen that where the building and loan dividends are the same as the interest rate, there is no essential difference between the two plans in cost of loan to the borrower. The time of maturity will also be the same where payments are made at the same time each month under the two plans.

The reasons for this similarity can be discovered by subtracting the dividends credited in each period under the building and loan plan from the interest paid in the same period, and comparing the result with interest paid in the same period under the monthly reduction plan.

The differences between the monthly reduction plan and the regular building and loan plan occur where the dividend rate on building and loan shares is less than the interest rate, as shown in the next table. Here we have compared loans bearing 7 per cent interest. As in the former case, where the dividend and interest rates are the same, the costs and maturities do not differ substantially, but such differences as occur are seen to favor the monthly reduction plan.

The important variations arise when the rates differ. With the interest rate at 7 per cent and the dividends 6 per cent (comparing the first two columns with the last three), it takes much longer to mature shares to repay the loan. Since interest at 7 per cent must be paid throughout the entire period, while 


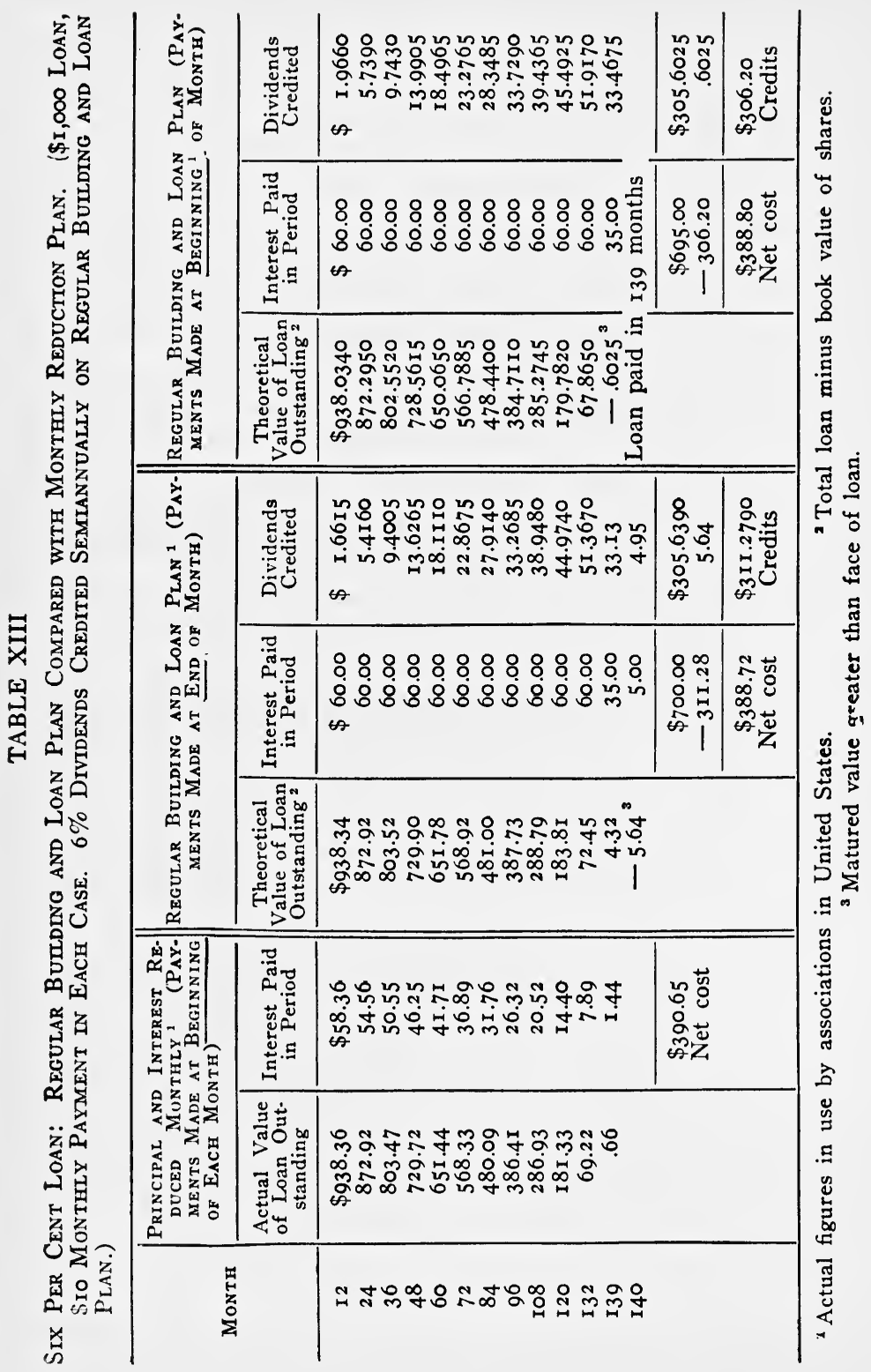


dividends and share payments are being accumulated, the cost of the loan increases considerably. (See Table XIV.)

The use of the regular building and loan method is thus shown to produce a larger revenue for the association than monthly reduction, when dividend rates are less than interest rates. Later in this chapter we discuss some 233 reports on loan costs made to us by individual building and loan associations. Of these, 24 use a monthly reduction plan, 4 adjust principal and interest each six months, 7 use the plan called "cancel and endorse" (see p. 143), and the remaining 198 associations use one of the regular building and loan plans.

Comparison of Actual Rates.-If it is desired to compare the actual rate paid by borrower using the monthly reduction method with the regular building and loan method, the following procedure might be used:

(I) With total uniform monthly payment and number of months known, calculate interest charge for first month and assume that this proportion holds true throughout period. Then proceed with the dollar-month computation discussed later in this chapter.

(2) Where reduction of interest is semiannual instead of monthly, use the regular savings-bank plan. Tables and formulas for this plan can be obtained from any standard textbook on the mathematical theory of investment.

Restriction of Use of Periodical Reduction Plan.The method of reducing principal and interest periodically is not legal for building and loan associations in all states, since most states require the association to lend only to members. In a few states the strict requirement is that shares to the full amount of the loan must be subscribed for by the borrower. This effectively prevents the use of the periodical reduction plan.

In order to comply with the provisions of the law in a few states, all borrowers subscribe for shares in the association, but in the absence of statutory restrictions as to amount, this subscription is at times merely nominal. For example, a borrower 


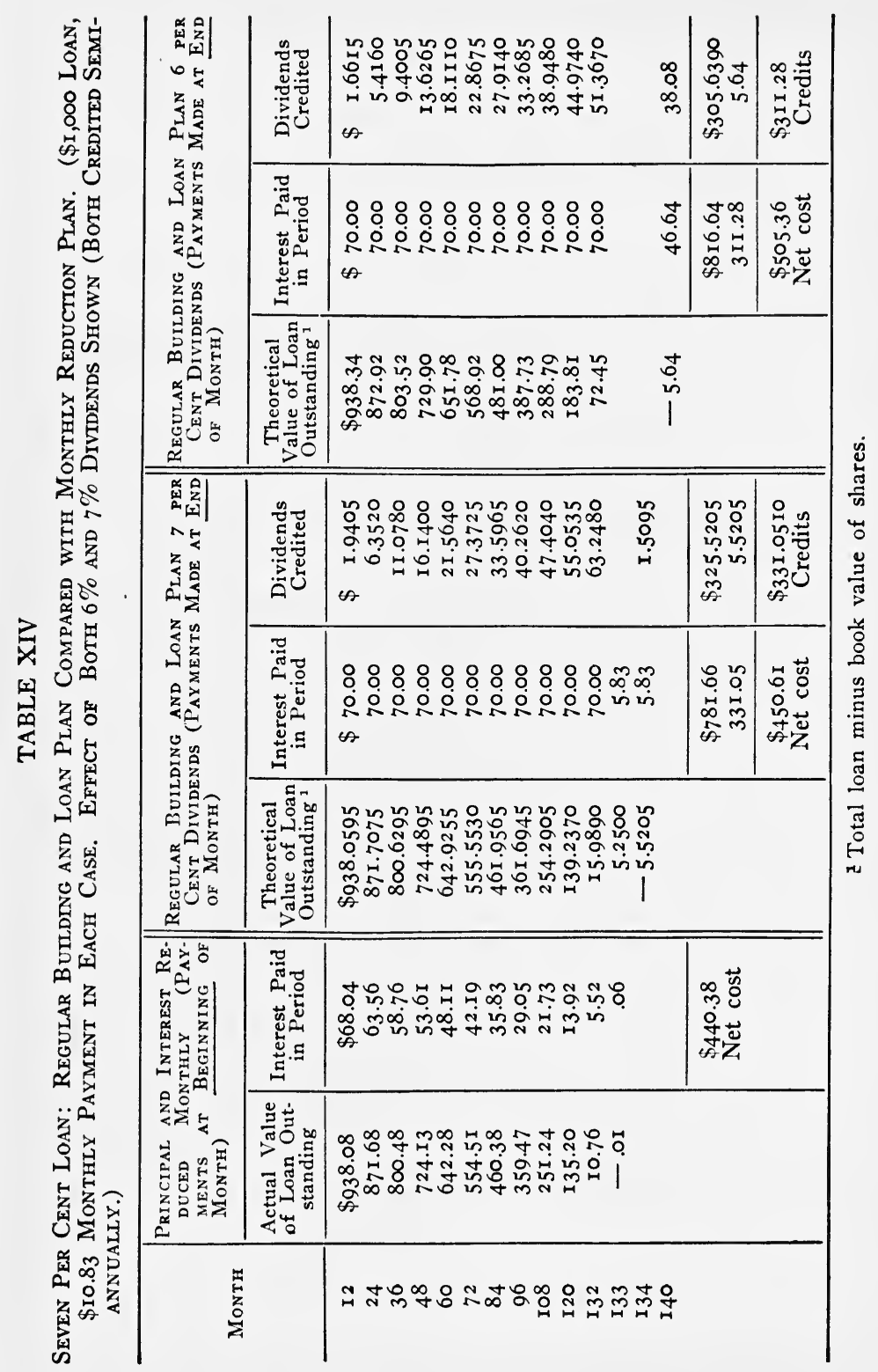


of any sum, large or small, may subscribe for.only one share of stock. Obviously, this practice is a mere subterfuge, and, while it is countenanced, the nominal membership can hardly be regarded as of any value to the association in case of trouble. ${ }^{3}$

The tables shown above prove that the periodical reduction plan is as "mutual" as any other building and loan plan. Mutuality depends upon profit sharing, and periodical reduction distributes profits which are close to the interest rate charged on the loan.

The theory on which membership for both borrowers and savers is required in ordinary building and loan practice is that each member assumes a proportional liability in the association's business. In case of financial difficulties of any sort, the member must bear his share of the losses. The borrower, therefore, who has merely a nominal membership in the association would bear only an insignificant part of the losses. Hence he would not be subject to any real financial liability.

Advantages of Periodical Reduction.-The periodical reduction plan has this advantage for the borrower: In the event of failure of the association at any time after he has started to repay the loan, the borrower's liability (except his nominal share holding) is constantly growing less. If the

${ }^{3}$ The Solicitor of Internal Revenue in a recent Ohio case has decided that such nominal subscriptions to stock do not destroy the mutual feature of building and loan associations, where the borrower receives credits on his loan which reduce the amount due in substantially the same way as under the building and loan method. "The holder of any part of the capital stock of a building and loan association must be regarded as a member thereof in the same way as a holder of the capital stock of any other stock corporation is a member of such corporation. The extent or character of membership in a building and loan association is not prescribed by law, but that matter must be deemed to be left to the discretion of each association.... Anyone who shares in the profits of an association and through the ownership of any amount of its capital stock is entitled to participate in the management of the association must be regarded as a member within the meaning of the law. (S. M. 1469, Bulletin III-10, 9.)" For a full report of this decision, see American Building Association News, June, 1924, pp. 252-5. 
affairs are thrown into liquidation, the borrower can only be held for the reduced amount of principal which remains charged to him on the books on the date of the receivership. Under the regular building and loan plan, the full amount of the loan stands constantly on the books against the borrower. His share accumulation is in a separate account. It is possible in the event of a failure under the regular plan that all shares might lose their book value and the borrower would still be responsible for the total amount of his loan. Several courts have taken the progressive stand that share credits should reduce the liability for the borrower. The liability in either case is negligible in view of the small number of failures and it does not often deter the borrower from assuming the slight obligation involved.

Cancel and Endorse Method.-A few associations still use a method which came into vogue many years ago which is similar in many respects to the periodical reduction just referred to. Uniform monthly (or weekly) payments are made as before. Instead of applying the excess payment directly upon the principal, however, payments are accumulated until they (with dividends) equal the value of one share. The par value of these shares is usually $\$$ roo. When the par value of one share has been accumulated, the borrower's note and certificate are endorsed to that effect by the officials of the association, and one share is thereby canceled. Interest is thereafter due, not upon the full amount of the loan, but upon the reduced loan. The periodical payments remain the same, but as in the case of periodical reduction, the amount set aside for interest constantly grows less and the amount to be applied to the remaining shares increases with each successive cancellation. As a result the periods between such cancellations grow progressively less.

Policy Regarding Early Repayments.-A proper financial policy includes provision for early repayment of loans. If every borrower allowed his loan to continue on the books of the association for the entire period originally agreed upon, 
there would be little opportunity for misunderstanding. Bui as a practical matter, borrowers repay their loans whenever it is convenient and if there is no provision in the contract showing the obligations of both parties before maturity, it is possible for misunderstanding to arise. Surreptitious profits may be taken, and such profits are not good policy. The association expects to be in business many years. The good-will of prospective borrowers is a more valuable asset than such small amounts of money as might accrue by exacting more from the borrower than the association is entitled to receive.

Reasons for Early Repayment.-(I) The borrower may receive an unexpected income. (2) He may sell the property within a few years. (3) The new owner may pay cash and desire to have the mortgage discharged. (4) He may wish to borrow but may not care to continue the mortgage with the same building and loan association. This might be due to any one of many reasons, perhaps cheaper rates of interest or better service are offered by other lenders. But in any case it offers an opportunity for the officers to work for the improvement of their own business and so shape their financial policy that they may keep these loans on the books.

Proper Credit for Payments.-The borrower is entitled to the full book value of his shares if he pays his loan before maturity, and applies the value of the shares upon that loan. He has contributed substantially to the business by paying interest during the life of the loan, even though only for a few years. There is no justification for treating him as a ne'er-dowell savings member who withdraws because of the lack of the "will to persist." Withdrawal of shares by a borrower before he has repaid his loan is never permitted, but on early repayment, shares can be withdrawn and applied as part payment of the loan. Most associations make no distinction between the withdrawal value of the shares of a borrower and that of free shares. This practice results unfairly for the borrower where withdrawal fees are charged. He has accumulated his savings for the purpose of repaying the loan, and it is a 
mistaken policy which allows him to be penalized. $\mathrm{He}$ is entitled to credit for the full book value of his shares, even though a savings member is taxed for failing to persist. Taxing the savings member in this fashion is consciously done by directors of some associations in order to increase their revenue. In the next chapter, actual practices in regard to withdrawal a:e treated in detail.

The borrower is interested not only in the withdrawal value of his shares, if he pays his loan before maturity, but also in the policy of the association in the matter of refunding other charges when early payment is made. He should be informed in the beginning regarding both. If a gross premium has been deducted in advance, for example, this premium has not been earned by the association if the loan is repaid before maturity. The borrower is entitled to a return of the unearned amount. Installment premiums will, of course, be canceled automatically, and so will cause no difficulty. If the original loan contract is so worded as to show the borrower where he stands at all times, uncertainty and disappointment can be avoided.

In this connection it might be well to call attention to the fact that there is no essential difference between a "forfeiture" and a "withdrawal" of shares at less than their book value. Forfeiture may be interpreted to mean cancellation of all value, including the principal. Common practice in associations to-day has eliminated the forfeiture of principal. Forfeiture commonly means, therefore, the loss of part of the profits which are withheld because of the failure to conform to certain rules. Two states of the Union, Washington and California, definitely prohibit forfeiture of principal.

Reasonable Dividends to Borrowers and Savings Members.-Any consideration of financial policy would be incomplete which would not mention probable dividends. (A complete discussion of dividends occurs in a later chapter of this text-book.) It would be well to keep in mind at this time that large dividends are only possible when there is a large 
income. An association's income is dependent upon interest and other charges upon loans. The smaller the interest rate charged (and any premium charged must also be included as "interest"), the smaller the dividends which may be paid to savings members. As society progresses, interest rates have a tendency to decrease, the accumulation of capital not only making this possible but necessary. The size of the dividend is one element in the time required to mature shares.

Selecting the Length of Maturity.-In selecting the approximate period in which it is desired to mature shares, the income and the saving habits of the community must be considered along with probable dividend and interest rates. In general, the more stable the community, the longer the period which may be used with success; the newer the community, the shorter the period. The mean average maturity of shares in the United States is I 4.8 months. Western communities tend to select shorter periods than those used in the East. ${ }^{4}$

Determining the Interest Rate, the Use of Fees, etc.The prime consideration which must always be in the mind of the directors when they are determining the financial policy of their association is the community's needs for funds for home ownership. These needs change from time to time and it is necessary that the association's policies change to meet each new condition. This does not mean that all the good which has already been accomplished by an association will be thrown over and a complete reversal of all methods made, but merely that slight adjustments must continually be made to keep the association in step with the progress of the community. The interest rates and other charges must always be kept in line with the rates charged by other financial institutions in the same territory.

" "Selecting the period" is not to be understood as guaranteeing definite maturity at a given date. But when the prospective earnings can be estimated, the amount of the periodic dues payment can be adjusted to bring about the desired result.

By consulting the Robinsonian Building-Loan Tables, the approximate maturities can be determined with great accuracy. 
The association is a clearing house. It collects savings wherever they may be found and directs them into the highly specialized residence mortgage. It makes possible the continuous use of money in a profitable way, since real-estate loans yield as high a rate of return as is consistent with sound investment. Where the individual lender finds himself at a considerable disadvantage in re-investing his particular amount of money when a loan comes due and is repaid, the association is known to be constantly in the market for new loans and this makes it possible to keep its money continuously employed.

The Need for Equitable Rates.-Competition with other institutions lending on real-estate mortgages determines only to a slight degree the financial policy which an association must follow. The ostensible interest rate is determined competitively. Other charges vary with each association. The organizers of an association are interested first of all in securing a sufficient dividend rate upon their own shares to make the investment profitable to themselves and to other investors. Therefore, they attempt to fix an interest rate as high as "the traffic will bear," knowing that the borrower can see his way out of debt through the amortization principle in spite of the excessive rate.

Conscientious directors realize that fair interest rates are absolutely necessary if the business is to continue successfully, and the influence of such men tends to lower the interest rate asked. It is impossible to carry on a lending business if there are no customers for loans. Whatever the charges are, they must be within the reach of the income of the class of borrowers who can make use of the association. Unscrupulous directors have at times taken advantage of borrowers by keeping the monthly payment low, while requiring an excessive number of payments, thus accomplishing the same thing as charging a higher rate in the first place.

The rates must be equitable. The poor man's money is entitled to purchase as much as the rich man's money in a given set of circumstances. Where the desire of the organizers 
of an association for large returns upon their own investment is the only means of determining the entire financial policy, trouble often ensues. Charging too high a rate in the past has obliged some associations to liquidate their assets and go out of business, because the high rate was boycotted by borrowers and the money of the savings members could not be invested according to plan.

Charges Should be Easily Understood.-The interest rate to be charged should be so plainly set forth in the printed matter of the association that there is no opportunity for the borrower to misunderstand it. The average building and loan secretary has not taken the trouble to sit down with the borrower and figure out the total cost of a loan. It has been the custom to tell the borrower the rate of interest, and to refer to the premium and such other costs as may be imposed as unimportant details. The borrower is expected to pay the cost of preparing papers, searching the title (or title insurance) and some other fees. In most cases, these additional charges have been no greater than the cost of a straight mortgage loan made by other lenders in the same community. In a few cities, these additional costs are much greater than necessary.

An increasingly popular plan is that whereby a clear statement of every item of expense involved in making a loan is clearly set forth, usually in a printed circular. The average borrower from a building and loan association is making the only big loan of his life, and misleading or incomplete statements may make it possible to exact an exorbitant total price for the loan.

Limiting the receipt of money in order to maintain a higher rate of interest than is warranted by the existing supply of capital is a degree of monopoly control not warranted for associations of a coöperative character. An outlet for such money is usually available at a slightly lower rate.

The ostensible interest rate charged is seldom the actual price which the loan costs. It is merely a starting point on which other items may be computed. To discover the actual 
rate, it is necessary to know the total monthly or weekly payment, the number of times this amount must be paid, and whatever other expenses are involved.

Determining the Interest Rate (Including the Premium).-Every state in the Union has a legal interest rate. Most of them also have what is known as a "contract rate." The difference between these two rates is this: in the absence of an agreement for a specific amount of interest, but where a promise to repay a loan "with interest" has been made, the creditor can enforce collection at the legal rate of interest in the courts. The contract rate is invariably higher than the legal rate, ranging from $\mathrm{I}$ to 3 or 4 per cent above it. This contractual limit makes it possible for debtor and creditor to agree upon a rate in excess of the legal rate, but not above this maximum "contract rate," provided the rate is stated in the contract. These rates vary from state to state.

It is necessary for building and loan associations, as for other corporations, to comply with the statutory provisions regarding rates which may be charged. It happens, however, that many of the states have passed special acts which permit the associations to charge more than either the legal or the ordinary contract rate in the form of premium and interest. These special laws directly exempt the premium of the building and loan association from attack as usury.

Development of the Premium.-By I 886 the most usual amount of premium was I 5 cents per share of $\$ 200$ in Massachusetts, according to Edward W. Bemis, although the range of premium paid was from 5 cents to 50 cents per share. This amount was paid monthly in addition to the dues and interest. ${ }^{5}$ The usual interest rate at that time was 6 per cent and dividends were at the same rate. It was common for the borrower to bid as high a premium as necessary in order to secure his loan, and later, when funds were more plentiful and bidding

${ }^{5}$ Edward W. Bemis, "Coöperative Banks in Massachusetts," Chap. 7 of a History of Coöperation in the United States (Vol. 6, Johns Hopkins University Historical Studies, 1886), p. 95. 
less keen, he would attempt to borrow the same amount again. If he could obtain it at a lower premium, he would use the second loan to pay off the first, and so pay the smaller premium to maturity. In some cases, he would retain the original shares and in other cases not. It was necessary that he pay interest and premium on both loans for the month in which the transfer was made. It was also customary to have a new mortgage made out and the old one discharged.

The present use of the premium is largely as a lever to obtain a higher total rate from the borrower in order to give a bonus to the member saving on free shares. Sometimes it is used to take advantage of the excessive need of a prospective borrower. The latter use, however, is definitely becoming obsolete. It is possible to induce a borrower to make this additional payment on a loan because the association is crediting him with earnings upon the installment repayments. For example, when the dividend rate and the ostensible interest rate are both 6 per cent, the borrower may not realize that when a premium of $\$ 5$ per month per thousand is added to the cost of his loan he is paying approximately 12 per cent interest. The credits of dividends on the installments appear to be large, and the borrower who is unskilled in finance may be led to believe that he is paying much less than the real rate.

The question of premium must be considered in each individual case. A ro per cent premium deducted but once from the face of the loan may prove actually less expensive to the borrower than a premium which appears to be smaller, but which is paid as an addition to the monthly installments throughout the life of the loan.

Forms of Premium.-There are almost as many possible ways of charging premiums as there are associations which charge them. When U. S. Commissioner of Labor Wright published his report in 1893 , the discussion of premiums occupied thirty-nine pages. ${ }^{6}$ Sixty-eight such plans were found to

- Report of U. S. Commissioner of Labor, Carroll D. Wright, I893, pp. 385-424. 
be in vogue, but all of them could have been included under the general classification of (I) payment as a lump sum or "gross premium," or (2) payment in installments. The gross or lump-sum premium is deducted when the loan is made. The borrower gives a mortgage for the full amount of the loan, say $\$ \mathrm{I}, 000$, but receives in cash this amount minus the premium bid. The amount of premium reported varied with competition, so that it is impossible to determine from the report the averages for 1893 . It was by no means uncommon for premiums of $\$ 200$ and $\$ 300$ per thousand to be deducted from the loan at that time. "Net premium" and "interest premium" are less common now than formerly and need not be considered here.

When an association was operating on the terminating plan, the large profits received from the use of gross premiums were only possible during the early years of the association's life. This situation does not arise in the modern association because the continuous issuance of shares makes it possible to issue loans of ordinary maturity at any time.

Where a gross premium is used and the borrower repays his loan before maturity, the association must be prepared to return a proportionate part of the "unearned premium." The amount deducted is supposed to cover the full term of the loan, for example, 120 months. If the borrower were to repay in five years, without credit for the unearned premium, he would be paying $12 \%$ or twice as much as the supposed amount. The increase in the rate of interest is even more than this, since the amount paid should yield compound interest. The laws of certain states require the return of the unearned gross premium in the event of early repayment.

The installment premium overcomes this difficulty, since it is merely an addition to the interest paid each month or week. As previously stated, if the installment is larger than a proportionate share of a similar gross premium, the actual cost to the borrower might be more. Care should be exercised in setting the rate, therefore, whatever the type of premium used, 
so that both the borrower and the association will know where they stand. ${ }^{7}$

Is Recent Legislation Effective?-It would be interesting to know what effect recent statutes of some states have upon the situation. Under the law of these states, if the association changes its interest rate, it is obliged to make this new rate effective upon all borrowers. Does this requirement apply to the premium as well as to the ostensible interest rate? The present writers are unable to find any proof that it changes the premium, but a study should be made to discover what the real situation is. The use of the premium in any form, even where it is merely a method of complying with the law regarding usury, is simply a cumbersome means of extracting more money from the borrower and is destined to disappear from association practice.

Competition a Factor in Determining the Interest Rate.-The ostensible rate of interest charged by an association is usually competitive with rates charged by other mortgage houses in the same district. When the building and loan association rate varies from the rate charged by other institutions it appears to average not more than I per cent above competitive rates. When the higher rate is charged, it is possible for the building and loan association to meet the competition of a lower rate for several reasons.

Competing with Straight Loans.-In competing with "straight loans" the association has the decided advantage of "getting the borrower out of debt." The one mortgage continues in force until it is paid off. There are no renewal costs

${ }^{7}$ In addition to the discussion in the Wright Report, premiums are discussed in the following:

Rosenthal, H. S., Cyclopedia of Savings Building and Loan Associations, pp. I59-160, 2 I7, 2 I8.

U. S. League Proceedings:

1900-C. D. Wright, pp. 88-89, 100-106.

I $900-H o n$. Seymour Dexter, pp. I I I-I I5.

190I-J. E. Huffman, pp. 140-14I.

Dexter, Seymour, Coöperative Savings and Loan Associations, pp. 23, 77-91, 159. 
as in the case of an ordinary commercial straight-loan mortgage. Commercial mortgage loans ordinarily run from three to five years, although the amortized commercial loan is becoming increasingly more common. On the straight loan the lender expects the borrower to make a lump-sum payment when it is due, thus reducing the face of the mortgage somewhat, even if he desires to renew the balance. Search of the title is again necessary because the law is usually interpreted to protect the original mortgagee only for the life of his mortgage. A second title search costs the same as the first. In an association loan, all renewal costs are avoided, and the actual expense and trouble which are saved to the borrower are important items.

In addition to this, the association is able to make a loan representing a larger percentage of the value of the property because of the use of the amortization principle, and second mortgages for amounts above 50 per cent are thus avoided. (Commercial mortgage houses commonly restrict their lending to 50 per cent of the appraised valuation, a margin which is necessary in their particular business, since the principal is not reduced during the life of the loan. If the borrower, therefore, desires a loan of more than 50 per cent of the value, he must resort to a second mortgage, which invariably carries a higher rate of interest and may involve a large commission as well.)

Another advantage of the association loan is that the borrower finds himself in the hands of his friends who will exert every effort to help him through any tight place. While the association is not a philanthropic institution, the officers make it a practice to assist the borrower in every way toward meeting his obligation.

These advantages are all useful in inducing the borrower to pay more interest. Again, the borrower is sometimes convinced that the additional bookkeeping involved in caring for the frequent periodical payments justifies some additional cost. This inducement is not legitimate, since with modern bookkeeping systems this cost is negligible. 


\section{Split Loans to Meet "Straight" Mortgage Competi-} tion.-At times the borrower desires a loan of such a large percentage of property value that it can only be handled by two mortgages. Perhaps it is not possible to make a down payment of more than Io per cent on the purchase price of a piece of property. A "split loan" can be used, whereby the total loan is split into two parts which are then secured by first and second mortgages respectively. Heretofore such loans have been troublesome because of the excessive payments required. A split loan with a uniform payment of moderate size has been worked out to cover such cases by Franklin P. Stevens of Kansas City. This obviates the former difficulties. ${ }^{8}$ The major portions of the payments are applied to the second mortgage until it is paid off, then all are applied to the first for the remainder of the term.

Competing With Other Associations.-Competition with other building and loan associations is another matter, and this also becomes of importance in determining the interest rate. The best weapon for one association to use in competing with another is "service." This much overworked word plays an increasingly important part in all modern business activity. In the case of the building and loan association, it means supplying something which is not available from any commercial house. It means aiding the borrower to avoid the pitfalls which his inexperience may cause him to overlook. It means being ready to help him at every stage of his relations with the association. If he is borrowing in order to construct a home, it means giving him advice (I) as to successful plans, (2) as to contractors who will deal honestly with him, and (3) as to the proper method of avoiding unnecessary expenditures. It especially means doing something for him which will make him a better citizen in his financial relations with his neighbors.

Some new associations have found it necessary to charge a higher rate of interest than older associations in the same city

${ }^{8}$ This plan is discussed in detail in Chap. $\mathrm{X}$. 
which are already established. At first thought, this seems to be an impossibility, but by giving more in the way of service, as well as a correspondingly higher rate of dividend to the borrowers and savings members alike, borrowers are attracted in spite of these higher rates.

Actual Rates in Use.-The ostensible rate is seldom the actual rate of interest which the borrower pays. Many other items of cost affect the rate. Most of these items are the same as for straight loans. Others are unusual and hence subject to misinterpretation by people unfamiliar with building and loan practice. In order to set forth the actual situation in use to-day, we have asked association officers in all parts of the United States to tell us their exact charges and have made a careful study of these reports from practically every state in the Union. Of the 233 reports which were complete enough to be used in making a statistical study, ro6 stated that their ostensible rate was between 6 and 7 per cent. (See Appendix Table XXXIII.)

Computing Actual Rate, When Ostensible Rate is Known.-There are many ways of computing the actual rate charged, all of which give slightly differing results. The computation which is most readily understood by the average man is based on "dollar months," or the number of months that the borrower has the use of one dollar. (Obtained by multiplying the number of dollars in his possession by the number of months, see formula on following pages.) This formula has the objection that it fails to show some of the advantages of the compound-interest principle when applied to long periods. For short periods, the effect of compound interest is not as noticeable as for periods of eight years or more. For periods up to about eight years, therefore, the "dollar month" formula $^{9}$ is satisfactory, and above that it will provide an answer that is a close approximation of the real rate.

- This method of presenting the loan costs to the borrower is in use in several parts of the country, and was called to our attention first by Harry C. Jones, Secretary-Treasurer, the Manchester Building and Loan Association, Manchester, New Hampshire. 
The Dollar-Month Formula.-From the total monthly payment is subtracted the monthly interest charge. This gives the amount which is applied toward the repayment of principal (or the maturity of shares). Since this sum is paid each month for the duration of the loan, the amount paid the first month is in the hands of the association the full period, the second payment is there for the entire period less one month, the third payment is there for the entire period less two months, and so on. Instead of computing this by the long arithmetical process, the formula for arithmetical progression will give a "coefficient." When this coefficient is multiplied by the amount of dues paid per month, the total number of dollar months for which the association has the use of the borrower's money will be obtained. (See "Lender's dollar months" in formula.)

The formula for arithmetical progression is as follows:

$$
\frac{\mathrm{N}}{2} \times(\mathrm{N}+\mathrm{I}) \text { or } \frac{\mathrm{N}(\mathrm{N}+\mathrm{I})}{2}
$$

where $\mathrm{N}$ is the number of monthly payments. ${ }^{10}$

This formula is the method of computation under " $B$ " in the accompanying "work sheet." Other parts of the sheet are self-explanatory. It will be noticed that before the actual rate is found, the total amount of the fees and charges paid but once are deducted from the total loan. Regardless of the

$z^{2}$ This can be quickly proved for a short period, and the same result would apply to longer periods :

Example: What is the number of months that the association uses \$I when the borrower pays $\$ \mathrm{I}$ dues each month for 7 months?
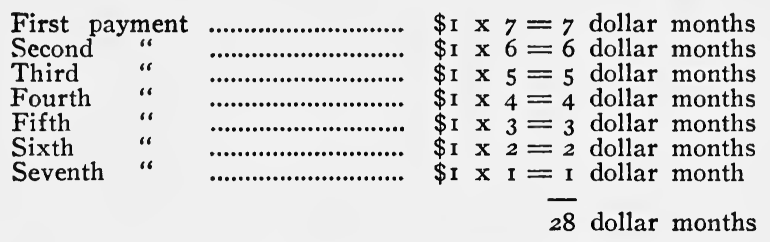

$$
\frac{N(N+1)}{2}=\frac{7(7+1)}{2}=\frac{56}{2}=28 \text { dollar months }
$$


name by which such charges are called, the amount which remains in the hands of the borrower is all that he actually uses, but he pays interest on the total face value of the loan.

Work Sheet for Computing Actual Rate of Interest When Payments and Periods are KNOWN

A. Total amount paid each month..... \$10.00

Interest at $6 \%$ equals $\ldots \ldots \ldots \ldots \ldots \quad 5.00$

Net dues applied to principal each month ....................... \$5.00

B. Total number of months, $139 \div 2=69.5$

Multiply by number of months plus I $=\mathrm{I} 40$

"Coefficient" ................. 9730

Multiply by (I) dues per month....\$5

Gives the number of months during which the association has the use of $\$ I$ of the borrower's money:

Lender's dollar months (gross) ....... 48,650

C. Total amount of loan ........... \$1,000

Subtract fees and all charges paid but

once $\ldots \ldots \ldots \ldots \ldots \ldots \ldots \ldots \ldots \ldots \ldots . .30$

Net loan $\ldots \ldots \ldots \ldots \ldots \ldots \ldots \ldots . . \ldots 970$

Multiply by number of months..... I 139

Gives the number of months that borrower

has the use of $\$ I$ of the association's money:

Borrower's dollar months (gross) ...... I $\quad 134,830$

Subtract (2) from (4):

Net borrower's dollar months.........

Divide by 12 :

Net borrower's dollar years......... $7, \mathbf{I} 8 \mathrm{I}$

86,180

D. Number of months $\ldots \ldots \ldots \ldots \ldots$ I 39

Multiply by total payment per month.\$ ro

Gives total amount paid by borrower.....

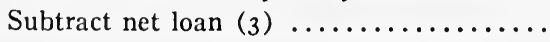

Actual cost in dollars ................

$\begin{array}{r}\begin{array}{r}\$ 390 \\ 970\end{array} \\ \hline \$ 420\end{array}$

E. Divide (6) "Actual cost in dollars," by (5)

"Net borrower's dollar years":

Gives actual rate per cent paid by borrower 
In accepting the rate found by this method, it must be borne in mind that the figure is only approximate, since the earnings on the borrower's monthly payments of dues have been compounded semiannually and compound interest is not proportional to time, hence the shorter the period, the better the approximation which will be obtained.

It will be noticed that the borrower pays back the full amount of the net loan $(\$ 970)$ and in addition $\$ 538.15$ as interest and initial expense. This is an average of $\$ 3.87$ a month, although the actual amount paid as interest is $\$ 5.85$. The reason for this is that the borrower receives credit for earnings on the dues paid in, so that these earnings reduce the actual cost to a figure less, in this case, than the ostensible rate. Where the association operates on a purely mutual plan and distributes all of its earnings, and where the expenses are negligible, this is the usual situation in regard to cost. But where considerable portions of the earnings are retained in the business, or paid out in large expense accounts, the amount which can be credited to the borrower is correspondingly reduced, and the actual rate becomes as great as, or greater than, the ostensible rate. ${ }^{11}$ Actual rates in use to-day are almost invariably higher than the ostensible rate.

Actual Rate in Use.-We have computed on the dollarmonth basis the actual rate in each of the 233 reports previously referred to, and a summary of this study will be found in the appendix. Only one figure is given for each item for each state, and this has been selected with great care by the use of various averages. (See Table XXXIII in the appendix.)

Selecting the Total Rate.-To meet the needs of borrowers, it is not sufficient that funds are at hand. They must be available on such terms as the borrower can meet, and at

13 For example, if in order to pay 6 per cent dividends and mature its shares to repay the loan in 139 months, an association finds it necessary to lend at 7 per cent, the actual rate computed by the foregoing method will be 7.5 per cent, provided the loan expense was $\$ 30$. If the borrower received the full $\$ 1,000$, without any expense, the rate would be 7.1 per cent. 
such an actual cost that he can afford to keep up his payments. The importance of this phase of the building and loan business has not been fully realized in the past, and in order to call attention to it, we have computed the rates just mentioned. Selecting a proper rate necessitates a most careful study of the borrowing requirements of the community if equity is to be accorded the borrower and safety assured for the funds of the association. It is especially important that guesswork be eliminated.

In only three instances out of the 233 reports studied were the actual rates the same as that which was stated as the ostensible rate; 196 associations were charging more than the stated rate, and 37 were charging less. Probably none of the officers who deal with the borrowers are purposely misrepresenting the situation in regard to the costs of loans. The actual rates charged vary from a figure I per cent less than the published ostensible rate to more than twice the published rate. The latter instances occur where no earnings are credited to dues paid by the borrower, the borrower thus paying the full amount of the loan in dues, and interest on the full amount for the full time as well.

On the average, over the whole United States, the actual rate is more than 2 per cent greater than the ostensible rate. To state this fact is to indicate the remedy, which is that the actual cost of the loan should be determined by the association officers and then this cost should be stated in their published circulars.

Lower Rate Indicates Greater Safety.-It is a commonplace in financial circles that lower interest rates usually accompany an increase in safety. It would not be well to place dependence upon this item alone, because there are on the market unsafe securities bearing very low rates of interest. But as a general rule this is true: the lower the interest rate, the better will be the general character of the security.

In the case of a building and loan association, the lower rates accompany added strength because the amount of the monthly payments necessary to care for a loan are propor- 
tionately reduced. The terms of the loan are thus brought within reasonable reach of the borrower. If the making of every payment is a strain upon his income, he will be continually in trouble, and the officers of the association will be obliged to spend much time and trouble in "nursing along" his loan, with a constant danger of foreclosure. Loans made by the building and loan association are exceptionally safe and they are usually paid up even when the rate is extortionate. This argument, however, cannot be used to support a policy which keeps the borrower continually in "hot water" through the requiring of an exorbitant monthly installment.

Expenses as a Part of Financial Policy.-An association expects to pay all of its expenses from its earnings, and while this may be difficult during the first year or so of its life because of certain heavy organization charges, it is the only sound policy upon which an association can survive. Efficient and economical management is a prime necessity. The association tries to teach its members to cultivate the habits of personal economy and it should keep its own house in order. Undue expenses cast discredit upon not only the association involved, but upon all others. The essential basis of the movement is coöperation, and coöperation always involves economical management or it fails of its main purpose.

A necessary expense is the business office. Old time building and loan men condemn the practice of opening expensive downtown business houses. It is claimed by some that the large expense involved offsets any possible gain. The argument in favor of the expensive downtown location is that any legitimate activity which aids the association to carry out its purpose of securing funds which will be devoted primarily to promoting home ownership and cultivating thrift is justified. Well-located business places attract a class of savers who would never find an association which is located in an out-of-the-way place. As a result, the amount of business transacted offsets the added cost.

Some associations maintain open house throughout the busi- 
ness day and their clerks are ready at all times to receive payments and loan applications after the manner of the best conducted banks. This situation was unknown to building and loan men in the days when the association was merely a neighborhood club. The extension of activity which is indicated by such procedure reacts to the benefit of the home-owning part of the community.

It would not be wise for all building and loan associations to endeavor to establish their business in downtown locations. In the parts of the country where hundreds and even thousands of associations are centralized in a single city or courty, the business can be most efficiently transacted on the neighborhood plan with occasional meetings. ${ }^{12}$ In cities where a single association is doing business, it would be lost in a neighborhood location. At either extreme the expense of location should be proportional to the business done.

Reserves for contingencies are as much a legitimate deduction from earnings as salaries or office rent. A more complete discussion of this matter is included in a later chapter. It is, however, an item which should be considered by the directors in laying out their financial plan.

Fees, Fines, and Forfeitures.-It is well known that fees, fines, and forfeitures were originally designed to encourage persistence in saving. They serve a useful purpose in promoting punctuality. Real thrift, we are told, is dependent upon system in saving or setting aside a "cash reserve," as our California friends call it. Since the building and loan association was organized primarily to encourage thrift, any device was sanctioned which was designed to serve this end. The borrower must, of course, be punctual in meeting the terms of his contract. Otherwise his loan becomes due in full upon defauit for

${ }^{12}$ It should be noted that the larger number of associations are located in the states where periodic meetings are held. These include Pennsylvania, New Jersey, Maryland, and Delaware. Many of the associations in these states are comparatively small in size. While conclusive statistics are not available, it is probably true that the highest average assets will be found among those associations maintaining regular business hourg 
a few months. In case of default, however, it will be no easier for him to pay the original amount after fines have been added to it than without such fines. The possibility of losing his property would appear to be as effective a lever as the use of fines. If any "fine" is ever justifiable it would appear to be a regular interest charge upon delinquencies.

In many associations, if the savings member fails to make his payments on installment shares promptly, fines are assessed against his share credits. Such procedure is limited by law to six months in some states. At the end of that time, some other arrangement must be made. Ordinarily the member is notified of his delinquency, and the book value of his shares at that time (less the accumulated fines) is set aside for him. ${ }^{13}$

The only reason forfeitures are continued to-day is that in twelve states the law permits their use as an additional source of revenue. In some states forfeitures are used surreptitiously. The withdrawal of shares before maturity is such a common practice that the use of fines on free shares is of small importance in promoting persistence. Only in case of "forfeiture" do the fines become an important source of earnings.

All classes of savings members are entitled to the benefits of the building and loan association. It is possible and profitable to have more than one kind of shares in one association on some of which fines may be charged, if desired, but on others where there is no such penalty. Provision for the setting aside of savings in lump sums such as prepaid and full-paid shares, and the use of shares under the Dayton plan make this possible.

The Purchase of Securities.-Every building and loan association is faced by the necessity at times of investing some

${ }^{2}$ In the case of accumulations which are uncalled for by delinquent members, practice varies as to the use of the proceeds. The term "forfeited shares" is usually applied to such proceeds, although the term is not adequate. Four states, Delaware, Indiana, Ohio, and Oregon, provide that such proceeds escheat to the state. Connecticut requires that the proceeds of forfeited shares be listed with the banking department. Twelve states permit the application of such funds to the earnings of the associations. 
of its funds in a temporary way. At times not enough applications for sound loans are available. At others a fund is being accumulated to retire a considerable number of shares in a few months. Several expedients are possible in using the temporary surplus. (I) Arrangements can be made with the bank of deposit whereby interest will be paid upon balances in the checking account. Banks, however, are unable to pay much interest on such balances. Certificates of deposit, bearing better rates, may be purchased if the probable term they can be carried will warrant their use. (2) Securities of an approved type can be bought on the open market. Rates as high as the interest on mortgages cannot be expected from such securities, if safety is to be maintained. Relative marketability of the securities purchased is of great importance, since the income received would be considerably reduced if loss must be suffered in case of quick sale. The state laws frequently restrict the type of investment which associations may use for temporary needs and before an officer makes such an investment he must be careful to ascertain the present law and to consult his state supervisor upon the subject. A very interesting development of recent years is the issuance of lists of approved securities by the various state supervisors. Association officials, while skilled in their highly specialized calling, are seldom familiar with the general investment market, and the use of such approved lists (when wisely compiled) is a service of great value to the associations.

\section{SPECIAL REFERENCES}

Date when interest begins. Youngstown Institute Proceedings, March 30, 1923, pp. 5-6.

Delinquency. Nebraska League Proceedings (1924), pp. 48-49. Oklahoma League Proceedings (1923), pp. 38-46. Youngstown Institute Proceedings, March I2, I924, pp. IO-I6.

Fees-membership. California League Proceedings (1924), pp. 28; 30; 75-84. Iowa League Proceedings (I916), p. 25. Minnesota League Proceedings (1924), pp. 17-20. Youngstown Institute Proceedings, April 13, 1923, p. 9. 
Fines. Iowa League Proceedings (1915), pp. 23-24; (1916), p. 39; (1918), pp. 21; 26-29. Ohio League Proceedings (1914), pp. 48-49. U. S. League Proceedings (I916), pp. III-II2.

Interest rates. Minnesota League Proceedings (1924), pp. 4-5. Nebraska League Proceedings (1924), pp. 14-15. Ohio League Proceedings (1920), pp. 104-108. Youngstown Institute Proceedings, March 12, 1924, pp. 5-10.

Loan costs. California League Proceedings (1924), pp. 29-31. Missouri League Proceedings (1919), pp. 61-69.

Premium. Iowa League Proceedings (1915), p. 24. Ohio League Proceedings (1914), pp. 50-51. U. S. League Proceedings (1900), pp. 88-89; I00-106; III-II5; (I90I), pp. 140-14I.

Principal and interest reduced periodically. Iowa League Proceedings (1915), pp. 24-26; (1918), pp. 21-22. Ohio League Proceedings (1914), pp. 5I-52. Youngstown Institute Proceedings, March 5, I924, pp. I2-I4.

Quick Azsets. U. S. League Proceedings (1902), pp. 77-87.

Repayment of loan. California League Proceedings (1924), pp. 30-31.

\section{GENERAL REFERENCES}

Putnam, T. M. Mathematical Theory of Finance (1923).

Robinson, J. Watts. Robinsonian Building-Loan Interest Tables (1909). Rosenthal, Henry S. Cyclopedia, pp. 121-122; 159-163; 206-207; $217-$ $219 ; 334-438$.

SkINNER, ERNEST Brown. Mathematical Theory of Investment (I924). SundheIm, Joseph H. Law, I32-147; 159-I62.

Wright, Carroll D. Ninth Annual Report of the Commissioner of Labor (1893), 387-424. 


\section{GENERAL FINANCIAL POLICY (Continued)}

\section{WITHDRAWALS}

Reasons for charging a withdrawal fee-to encourage thrift, to cove; expense; reasons for early withdrawal; factors affecting number of withdrawals; withdrawal charges; withdrawal and membership fees; results of charging withdrawal fees; notice of withdrawal.

When an association member withdraws his savings before his shares have matured, he faces a situation which he may not always understand. Usually his profits are reduced by various fees, so that he does not receive the full book value of his shares. Opinion varies radically as to the justice of withdrawal fees. Many association men (including James R. Moorehead, one of the strong advocates of fees and fines) have believed that penalizing the withdrawing member by withhoiding a portion of the earnings would encourage him to persist in saving until his shares are matured. The argument presented is that people will persist provided withdrawal causes them to suffer loss. Taking the opposite view, other officials state that they have yet to see the member to whom a reduction of earnings makes any difference when he has made up his mind to withdraw funds.

Only by an examination of the facts, however, may any conclusions be drawn about it. The present writers sent questionnaires to a number of representative associations throughout the United States and an analysis of their replies is the basis of the following discussion.

Reasons Given for Charging a Withdrawal Fee.-The case in favor of charging withdrawal fees is supported by at least three important reasons. 
(a) The one most frequently given is that of encouraging the thrifty. This desirable object needs no comment.

(b) A reason of more importance to the association is the matter of covering the expense of conducting the business. Expenses must come from some source. If the member withdrawing in a comparatively short time is granted the same earnings as the one who remains constantly with the association through many years, the real burden of the expense must be borne by the latter. It is true that losses and consequent reduction of earnings may occur after the early withdrawal has taken place, and these necessarily fall on the remaining members.

Many officials believe that "The man who is in to-day and out to-morrow is of no benefit to himself or the association," and hence he should be obliged to pay a fee for withdrawing. Of course, it would be worth while to distinguish between the "ne'er-do-well" and the member who withdraws because of financial difficulties; but it is almost impossible to make any fixed rule that will distinguish between these two classes of patrons. Association officials may be given some degree of latitude in penalizing the one or benefiting the other, but such power should be exercised with great care to prevent its being abused. It does not appear right to tax the persistent, thrifty, and continuous saver in order that the thriftless may gain an additional benefit, and in a really coöperative institution the "pound of flesh" should not be exacted.

(c) Withholding a certain percentage of the earnings (which might otherwise accrue to the withdrawing member) may tend to make the association stronger. That is, an association becomes stronger financially if its funds are increased, and any method of retaining earnings will contribute to this end. As a result, those remaining in the association will benefit and the soundness of the institution is thus supposed to be increased. The position is not well taken unless the earnings withheld are put into a reserve for the permanent protection of the association. 
The reasons just stated are presented from the standpoint of the association. Unless the reasons which prompt the member to withdraw are taken into consideration, however, all sides of the problem will not be understood.

Reasons Which Prompt the Member to Withdraw.Aside from the always present temptation to spend whatever money one has on hand, there are legitimate reasons for withdrawing funds from the building and loan association before shares have matured. Members do not use the association for philanthropic purposes, but for the purpose of reaching a higher financial position in the community. Among legitimate reasons for withdrawal are:

(I) Higher Rates Elsewhere.-The few people who have developed a "financial consciousness" withdraw their funds in times when money is "tight," and put them into more speculative investments where higher returns are possible. Whenever money is "tight," interest rates rise and the possibility of gaining through speculative investments is materially increased. As a result, association officials must face the fact that some withdrawals will occur in such times due to this factor. With "easy" money, interest rates are low elsewhere. Investment in building and loan shares then takes on an added attraction to such investors and they put some money into shares. The average investor, however, is found to prefer the building and loan investment in times of tight money because of the possibility of loss elsewhere, and as a result many associations have their most rapid growth and render their best service during straitened times.

(2) Desire to Buy or Remodel a Home.-Another reason for withdrawal which should not be overlooked by the association is that presented by the member who has accumulated a sufficient sum to enable him to purchase or remodel a home. It is true that the association has heretofore gained nothing in interest paid by such a member, but on the other hand he has made a substantial contribution to the success of the association during the years when his savings have been a 
part of the loanable funds, and in many cases withdrawal of accumulated savings is coincident with his becoming a desirable borrower. Also, each new home added to a community's development is just that much more opportunity for the growth of community spirit.

(3) Moving Away from a Community.-As the placing of one's savings may be easily done by mail, this reason loses its force if the association is known to be ably and conservatively conducted, provided also that the member has no immediate need for his savings. It happens many times that heavy expenses are encountered when moving and the use of savings for such purposes is amply justified.

(4) Emergencies of all sorts.-Real withdrawal needs call for no comment.

Educating the Member to Longer Investment.-If savings members are encouraged to recognize building and loan shares as a permanent type of investment, they will gradually allow their money to remain longer with the association. Also, as the association grows older and safety has been proved, the securities offered will make a wider and better appeal. In the terms of the investment banker, the shares will have been "seasoned," by which is meant that all payments of dividends have been promptly credited and paid at maturity.

A few associations have adopted the policy of re-instating a withdrawing member if he returns within a few months, and returning to him a credit equal to the withdrawal fee on each share, not exceeding the total amount deducted when he withdrew. This practice would seem to mitigate the loss to withdrawing members, and is an added incentive to become a member again as soon as the immediate financial difficulty has passed. One association uses a "certificate of reëntry," which is given to the withdrawing member, to be sold if the member cannot use it himself. In this way it is possible to recover a part of the fee paid on withdrawal.

Percentage of Withdrawals. - The number of with- 
drawals from different associations is found to vary with several different factors.

(a) The type of association is of great importance in affecting withdrawals; that is, the plan on which membership is handled. Associations using the Dayton permanent plan or any modification of it customarily repay to withdrawing members the full book value of their investment or at least a larger percentage than is paid by associations working on any other plan. As a result, members come and go, and very little can be said about "persistence." Other plans, however, contemplate maturity of shares, and it seems to be true that where the loss is considerable when shares are withdrawn before maturity, there is a slight tendency to continue saving instead of withdrawing. (See Table XIX, p. I82.)

(b) The length of time which shares run seems to play a most important part in determining the percentage of withdrawals that will take place before maturity. Shares which mature in a very short time, such as three or four years, are reported to have withdrawals of only about 5 per cent. Very few associations use shares of such short terms. As the average time of maturity lengthens, the withdrawals become greater. When maturity requires ten years or more, the average withdrawal is between 50 and 60 per cent.

(c) The least important of the factors affecting withdrawal is the geographic district in which the association is located. Newer districts are less stable than old and hence would seem to suffer heavier withdrawal. On more careful analysis, the difference which seems to be caused by location, however, is usually found to be due to other factors. For example: In an old-settled state like Pennsylvania we find associations reporting their percentage of withdrawals all the way from 50 per cent to 90 per cent, while in the equally old adjoining state of Delaware it appears that withdrawals before maturity do not exceed 50 per cent of those who originally subscribe for shares. In the comparatively new state of Kansas, withdrawals are reported to be from 70 to 80 per cent on the 
average, whereas in the adjoining state of Missouri they run between 35 and 40 per cent.

Evidently, there is a need to educate people to the longer term of investment in order that the capital funds may become more stable. The actual amount of withdrawal of installment shares before maturity is very great. The smallest known percentage of withdrawals for shares maturing in approximately ten years is 35 per cent. Many associations report from 35 to 60 per cent withdrawals, but a very large number of associations to-day have to face the fact that from 60 to 90 per cent of their savings members will withdraw before the shares have matured.

\section{TABLE XV}

Percentage of Withdrawals

\begin{tabular}{|c|c|}
\hline Percentages & $\begin{array}{c}\text { States fRom Which Individual Associations } \\
\text { Reported }\end{array}$ \\
\hline 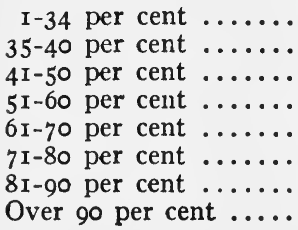 & $\begin{array}{l}\text { No record } \\
\text { Missouri, Maryland } \\
\text { Delaware, Pennsylvania } \\
\text { West Virginia, Kansas } \\
\text { Illinois, Tennessee, Wisconsin } \\
\text { Kansas, Wisconsin } \\
\text { Nebraska, Oklahoma, Pennsylvania, Washington } \\
\text { Oklahoma, Pennsylvania }\end{array}$ \\
\hline
\end{tabular}

\section{Types of Withdrawal Charges in Use}

Whether any other charge is made for withdrawal or not, it seldom happens that earnings are paid by any association if the dues are withdrawn during the first year. The dues are returned with no profits. A few notable exceptions to this rule are found, but this is the usual practice, except for associations operating on the Dayton plan.

After the first year, charges vary all the way from no deduction of either principal or dividends up to the return of no earnings and an actual deduction of part of the principal paid in. The latter practice, fortunately, is limited to a constantly 
smaller number of associations, and in time will undoubtedly be entirely abandoned. In those states where withdrawal fees are prohibited, ${ }^{1}$ association officials refusing to return the amount of principal which the member has paid might be subject to criminal prosecution.

A. No Charge.-A development of outstanding importance in this whole matter is the adoption of a new principle by a small number of associations. They return to the member not only all his dues and earnings, but add to this a portion of the contingent reserve fund which has been accumulated while his shares were on the books. The statutes of South Dakota and Washington favor this practice. In the past, the accumulation of a contingent reserve has always been regarded as a legitimate expense of the association, as for any other corporation, and this accords with good accounting practice. Therefore, the costs of accumulating such a reserve are chargeable against the profits before dividends are credited to any share. It is true that the accumulation of a contingent reserve builds up an additional capital fund for the business which increases the profits of the association later on. This particular benefit does not accrue to the savings member, except in cases where the contingent reserve is so large as to add materially to the earnings. It will aid later shareholders, probably after the present momber has withdrawn from the business. The encouragement of the distribution of the contingent reserve by state law, therefore, seems to be based upon the assumption that the man who has helped to build up the fund should be entitled to participate in it. ${ }^{2}$ This practice is wholly new to everyday business experience and should be carefully studied before being, adopted or rejected.

B. Reduction of Earnings. - The most common withdrawal fee is a reduction of earnings credited to the withdrawing shares. The methods by which this is brought about are

1 A summary of state laws covering withdrawal charges will be found on pages 186 and 189 of this chapter.

" See Chap. XVII on Contingent-Reserve Funds. 
so varied that association officials appear to be uncertain as to the proper procedure. Four specific plans of reducing earnings at early withdrawal are in use, but there are modifications of each of them.

( I) Earnings paid in full to last dividend date plus allowance for the estimated earnings for current period. Credits allowed between dividend dates are based on the assumption that the association will continue its former rate of earnings. Several instances are reported where the amount credited is one-half of the earnings for the previous period. This practice is of advantage to the member and gives him the maximum return that can reasonably be secured, but it is open to the serious objection that dividends are not the property of shareholders until they have been earned and also declared by the board of directors. The association may expose itself to loss by granting such credits. Where the additional credit allowed is less than the regular rate, this objection is less serious. The coöperative character of the business makes it necessary for associations which pay the dividends on savings at the same rate as the interest charged on loans to guard this matter carefully, particularly in the absence of a contingent reserve. Expenses and losses must be determined before profits are known. In associations which pay a smaller dividend on shares than they charge to the borrowing member, this matter is less likely to cause trouble, since it is expected that the difference between the two rates will be ample to care for such losses and expenses as occur.

(2) No Earnings After the Last Dividend Date.-This is the most usual form of caring for withdrawals. Earnings are credited either (a) semiannually or (b) annually. Perhaps more dividends are credited semiannually than otherwise. This plan is essentially the savings-bank plan. Under this method, the pass-book at all times shows the withdrawal value of the stock, but the member receives no profits on his savings between dividend dates. For this reason the association makes an appreciable profit when withdrawals occur between dividend 
periods, since it has the use of money after the last dividend without having to pay for such use. Where thirty days' notice is required before withdrawal is permitted, the association is holding the money, and hence interest earned in this period is lost to the member.

The member can avoid loss of earnings by borrowing against his shares until the next dividend date, if he cares to do so. For example, if the association is charging $6 \mathrm{~T} / 2$ per cent interest and paying 6 per cent dividends, a member with a credit of $\$ 525$ on May ist could borrow $\$ 450$ until the dividend date (June 30 ) and save $\$ 10.57$ by not withdrawing the entire credit on May rst. ${ }^{3}$

(3) Percentage of Total Earnings Reduced.-Where the withdrawal charge is determined by reducing the rate of dividends, the member is subject to a considerable reduction of earnings. Two methods are in use:

(a) A uniform reduction of earnings regardless of the length of time that the shares have been in force. The rate of earnings paid on withdrawn shares is the same under this plan

s Savings realized through stock loans instead of withdrawal.

Loan against stock on May $I$, withdrawal June 30 :

Credit January I (with dividend)................................. \$500.00

Dues January-May ........................................................ 25.00

June dues ........................................................................ 5.00

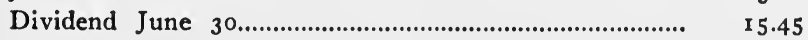

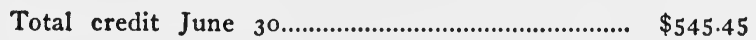

Less interest on $\$ 450$ at $61 / 2$ per cent for 2 months...... $\quad 4.88$

Net credit June 30.

Withdrawal on May $I$ :

Credit Jan. I (with dividends)....................................... \$500.00

Dues January-May .............................................................. 25.00

Withdrawal value May I.................................................................... 525.00

Gross balance in favor of loan........................................................ 15.57

Less June dues (not paid)............................................................ 5.00

Net gain by borrowing............................................................ \$10.57

Other rates and payments would show proportionate gains. 
whether the shares are withdrawn soon after they are subscribed for or at any later time before maturity. For example: Earnings on shares which are continued to maturity, 7 per cent compounded semiannually. Shares withdrawn prior to that time, 5 per cent dividends compounded semiannually for the length of time that the respective payments are held by the association.

(b) A varying rate of reduction of earnings dependent upon time. For example, 7 per cent dividends if shares remain to maturity, 6 per cent for three-fourths the time, 5.5 per cent for one-half the time, and 5 per cent for less than half the expected time.

A rough approximation seems to show that associations which vary the percentage of earnings according to the length of time, usually reduce them about 20 per cent on the average for withdrawal during the last few years, and 25 to 30 per cent when withdrawal occurs before that time. A more equitable method can undoubtedly be worked out which would base returns to all members on the actual contribution which they make toward the success of the association.

(4) Simple Interest Instead of Compound.-When simple interest is credited to the withdrawn shares instead of compound interest, the real situation tends to be obscured. Six per cent compounded for I 40 months on $\$ 5$ monthly dues is equivalent to approximately 7.5 per cent simple interest for the entire time. By paying only 6 per cent simple interest to the withdrawing member the association has a clear gain of I.5 per cent. The loss to the member grows greater as the term increases. Therefore, he may suffer approximately as great a loss of earnings when he is credited with simple interest for a long period as in case 3 (a) mentioned above. ${ }^{4}$

4 Payment of simple instead of compound interest in the event of withdrawal may possibly be the outgrowth of the Pennsylvania law of 1859 (Sec. 2). This section required legal interest to be paid to the legal representative of the shareholder in the event of his death.

The right to withdraw was stated in the Act of 1859 , Section 2, of the State of Pennsylvania as follows: "When he or she shall be entitled to 
TABLE XVI

Simple Interest Rates Equivalent to Semiannual Compound Rates FOR VARIOUS MONTHS

\begin{tabular}{|c|c|c|}
\hline Number of Months & $\begin{array}{l}6 \text { PER CENT CoMPounded } \\
\text { SEMIANNUALLY EQUIVA- } \\
\text { LENT TO: } \\
\end{array}$ & $\begin{array}{l}7 \text { PER CENT CoMPOUNDED } \\
\text { SEMIANNUALLY EQUiVA } \\
\text { LENT TO: } \\
\end{array}$ \\
\hline $\begin{array}{r}36 \\
72 \\
84 \\
108 \\
\text { I } 20 \\
\text { I } 34 \\
\text { I } 40\end{array}$ & $\begin{array}{l}6.10 \\
6.58 \\
6.73 \\
7.05 \\
7.21 \\
7.40 \\
7.49\end{array}$ & $\begin{array}{l}7.17 \\
7.82 \\
8.03 \\
8.47 \\
8.69 \\
8.97 \\
9.09\end{array}$ \\
\hline
\end{tabular}

C. Portion of Principal Retained as a Fee.-Very $\mathrm{f} \in \mathrm{w}$ associations specifically report that they withhold any part of the principal paid by the member if he withdraws before maturity. On the other hand, when a large membership or withdrawal fee is charged to all alike, it is possible for the association to retain part of the principal of the investment, when shares are withdrawn in their early years. If the membership fee is not returned (and most associations make no pretense of returning it) the prospective saver who is not certain that he can continue his contract to maturity should calculate the exact return which he would receive on his investment in case of early withdrawal. Advance calculations based on some of the tables in this text-book may save considerable misunderstanding and disappointment. (See Tables XVII and XVIII.)

receive the amount paid in by him or her, and such portion of the profits as the by-laws may determine, less all fines and charges. Provided, that at no time, shall more than one-half of the funds in the Treasury be applicable to the demands of withdrawing stockholders, withcut the consent of the Board of Directors and that no stockholder shall be entitled to withdraw whose stock is held in pledge of security. Upon the death of a stockholder, his or her legal representative shall be entitled to receive the full amount paid by him or her and legal interest thereon, first deducting all charges that may be due on stock. No fines shall be charged upon a deceased member's account from and after his or her decease, unless the legal representative of such deceased assume the future payment on the stock." Edmund Wrigley, The Workingman's Way to Wealth $(1872)$, p. 45 . 


\section{Uniform Withdrawal or Membership Fee.-Where a} uniform withdrawal fee is used, this is similar to the membership fee, except that in some associations it does not apply to the man who remains with the association until maturity, but affects only the member who withdraws before maturity. The amount which appears to be most commonly used as a withdrawal fee is 2 per cent of the par value of the shares.

In this connection it is well to note that some associations pay commissions for the sale of their shares. Where the members withdraw before maturity, the deduction of the fee offsets the commission paid, and creates a surplus for the association (inasmuch as the fee is usually greater than the commission). If all members withdraw before maturity, the association suffers no loss, but where the fee is returnable to the member at maturity, the association must build up from earnings an amount large enough to make this repayment. In other words, the full matured value of the shares must be accumulated while the fee itself is being amortized. Thus, with a two per cent fee, the association must collect and earn a total of $\$ 1020$ for every $\$$ rooo matured value of shares. This can be done by computing on an actuarial basis the dues necessary to mature the total amount in the desired time at the proposed dividend rate, and by setting up reserves to cover the full potential loss. Otherwise a deficit is created for every share matured. A similar procedure is involved where an association abates a part of the withdrawal fee at the end of a certain number of months or years.

Effect of Uniform Withdrawal Fees (including entrance or membership fees).-Uniform fees to all members are so farreaching in their results that a more extended examination of them is necessary at this point. Comparatively few persons who start to save systematically, either in building and loan associations or elsewhere, are able to continue for long periods of time. Emergencies arise which demand money, and they withdraw their savings to meet the need. The dividends received in early years are often not as great as the uniform fee. The difference constitutes a loss of a portion of the principal. This applies particularly to the first and second years. 
When an association claims to pay a certain rate of dividends but at the same time penalizes withdrawals, the average rate of dividends will be far less than the advertised rate because withdrawals before maturity outnumber the shares carried to maturity. Particular care is necessary in the preparation of truthful advertising in such a case.

The following tables show the variation in actual earnings on shares due to the use of a fee of $\$ \mathrm{r}$ per $\$$ roo shares, if the member withdraws before maturity. Computations are based on the more common dividend rates, for shares of a par value of $\$ 100$, with monthly dues of $\$ .50$ and $\$ I$ per share respectively. Dividend rates are compounded semiannually, the figure given at the head of the column being the annual rate. Fees are deducted from the first payments. (Larger membership or withdrawal fees would involve greater losses.)

Losses of capital are indicated in the tables by minus signs, or negative figures. For example, if a member has paid dues of 50 cents a month for one year, of which the first $\$ \mathbf{r}$ per share is considered a membership fee (or a total of \$6), his earnings for the period would be 19 cents, if the dividend rate were 7 per cent per annum compounded semiannually. ${ }^{5}$ If no other fees are charged, he would receive on withdrawal at the end of one year $\$ 5.19$ instead of $\$ 6.19$, the total amount paid in plus the dividends. As a result he has lost nearly 13.5 per cent (13.433). In small amounts this is not serious, although inequitable. It becomes of great importance when the amounts are large or when the member is not properly informed of his rights and obligations at the time of subscription. It opens up a wide opportunity for misrepresentation.

The member who remains with the association until the maturity of his shares may not be penalized, but at any time before maturity there is likely to be some loss involved, as these

- Dividends have been computed on total paid in, including the fee. Where the dividends are not computed on the fee, the loss becomes greater. 
tables show. By comparing the expected maturities with the actual rates received, a fair idea of the loss may be obtained.

Varying Withdrawal Fee.-An interesting recent development is the varying withdrawal fee, which rewards the member who stays with the association. One association has worked out its plan as follows: A withdrawal fee of 2 per cent of the par value is charged on the books of the association against all shares as subscribed and issued. This fee is intended to cover the expense of handling the business. The shares of this association normally mature in something over eight years. If the member continues to pay his installments for the entire period, the withdrawal fee is canceled or "absorbed" by the association. The association can afford to absorb this expense

\section{TABLE XVII}

Rate of Earnings on Each \$ioo Share of Building and Loan Stock With a Membership Fee of \$r, When Savings Are Withdrawn Before Maturity, With No Other Withdrawal Fees or Penalties. Monthly Payments of $\$ .50$ Per Share.

\begin{tabular}{|c|c|c|c|c|c|c|}
\hline \multirow{2}{*}{$\begin{array}{l}\text { TIME OF } \\
\text { WITH- } \\
\text { DRAWAL }\end{array}$} & \multicolumn{6}{|c|}{ Actual Rate of Earnings When Annual Dividend Rate Is: } \\
\hline & 5 & 6 & 7 & 8 & 9 & Io \\
\hline At end of: & & & & & & \\
\hline $\begin{array}{l}\text { I year. } \\
2 \text { years. }\end{array}$ & $-14.362 *$ & & - I3.433* & - I $2.967^{*}$ & - I $2.499^{*}$ & - I $2.03 I^{*}$ \\
\hline S.. & $\begin{aligned} 3.439^{*} \\
1.331\end{aligned}$ & {$\left[\begin{array}{r}2.435^{*} \\
2.350\end{array}\right]$} & $\begin{array}{l}1.423^{*} \\
3.386\end{array}$ & -0. & 29 & I.665 \\
\hline & 2.985 & 4.007 & $\begin{array}{l}3.380 \\
5.029\end{array}$ & 4.414 & 5.440 & 6.467 \\
\hline & 3.737 & 4.755 & $\begin{array}{l}5.029 \\
5.773\end{array}$ & 0.050 & 7.072 & 8.093 \\
\hline $\begin{array}{l}5 \text { years. } \\
6 \text { years. }\end{array}$ & $4 . \mathrm{I}$ & $\begin{array}{l}4.75 \\
5.15\end{array}$ & $\begin{array}{l}5.773 \\
6.71\end{array}$ & $6.79 \mathrm{I}$ & 7.809 & 8.826 \\
\hline 6 years.. & 4.28 & 5.150 & 6.171 & 7.186 & $8.20 \mathrm{I}$ & 9.215 \\
\hline 7 yea & & 5.394 & 6.407 & 7.420 & 8.432 & 9.445 \\
\hline 8 years.. & 4. & 5.546 & $6.55^{8}$ & 7.569 & 8.580 & $9.59 \mathrm{I}$ \\
\hline 9 ye & 4.639 & 5.649 & 6.660 & 7.670 & 8.679 & 9.689 \\
\hline ro years.. & $4.7 \mathrm{I} 3$ & 5.723 & 6.732 & $7.74 \mathrm{I}$ & 8.749 & ... \\
\hline $\operatorname{Exp}$ & & & & & & \\
\hline months & 146 & I39 & I33 & 128 & I 23 & II 9 \\
\hline
\end{tabular}

* Withdrawals during the first two years when a membership fee of $\$ \mathrm{I}$ is charged on shares requiring a monthly payment of 50 cents will result in an actual reduction of principal. The starred figures indicate this percentage of loss. Other figures are annual rates with semiannual compound earned up to the time of withdrawal. 


\section{TABLE XVIII}

Rate of Earnings on Eacii \$roo Share of Building and Loan Stock With a Membership Fee of $\$$ i, When Savings Are Withdrawn Before Maturity, With No Other Withdrawal Fees or Penalties Monthly Payments of \$i Per Share.

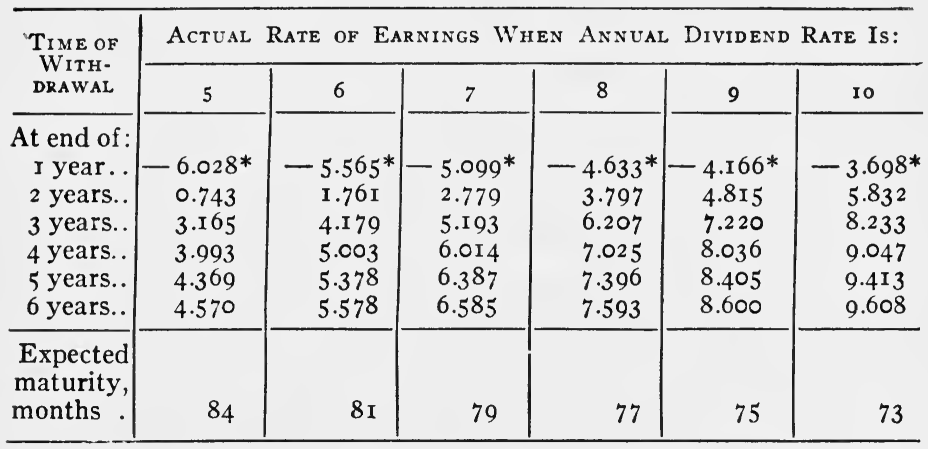

* Withdrawals during the first year when a membership fee of $\$ 1$ is charged on shares requiring a monthly payment of $\$ 1$ will result in an actual reduction of principal. The starred figures indicate this percentage of loss. Other figures are annual rates with semiannual compnund earned up to the time of withdrawal.

because, if the shares persist until maturity, earnings upon them are sufficient to cover this item. If they are withdrawn before maturity, the fee is expected to cover the difference between the actual earnings on the amount paid and the cost of handling the business in the earlier years of the transaction.

This fee is varied as follows: (a) It disappears and is charged off the books when the shares mature. (b) If the savings member withdraws between the fourth and eighth year, onehalf of the fee remains as a charge against the withdrawal value. (c) Should the member withdraw in less than four years, the entire withdrawal fee becomes effective. It is claimed that instead of charging all members the same fee for putting the business on the books, this withdrawal fee allows the money invested by the savings member to earn a sufficient amount above the dividends to cover this cost. Perhaps this plan might be improved by changing the rate each two years; that is, 
charging the maximum fee for withdrawal during the first two years, three-fourths of that amount for withdrawal during the next two, one-half the next two years, and one-fourth for the remaining period until maturity, when it disappears. Compare this method with the varying rate of reduction of earnings in 3 (b) above, p. I 74 .

Arguments in Support of the Use of Fees.-In spite of the fact that the use of fees will result in loss in the various cases shown in the foregoing tables, there are many association officials who believe that their use is justified on other grounds, especially in the encouragement of persistent thrifty saving. Among the reasons assigned may be mentioned the following:

( I) Fees supply the association with a larger income, especially in its earlier years, and enable it to take care of unusual expense.

(2) They permit the employment of a staff of experts who give legal aid and advice to members, or who can supply definite information concerning building sites and construction costs.

(3) They make it possible for the association to render many additional services which could not otherwise be undertaken, such as maintaining a clearing house of information regarding employment for its members.

(4) The entrance of a new member calls for a considerable amount of work such as indexing, entering, and making up the pass-book. The expense of this work is a proper charge against the member's earnings, and if paid at the start in the shape of a fee there is no burden thrown on other members.

(5) The early years of an association's life show a very small growth until a reputation for honesty and safety have been acquired. Earnings during this period are limited, and fees are tolerated by some officials at this time in order to show carnings when this would otherwise be difficult or impossible.

Where the fee is of moderate size, the question of its use seems to depend largely upon the convenience of the members and of the association. The 738 associations reported in 
Illinois in 1922, for example, collected $\$ 440,468.24$ during that year from "fees, fines, and pass-books," but this sum was less than $\$ 50$ per month per association and was but $1 / 300$ $(0.35 \%)$ of the amount collected as interest and premium. Such an insignificant sum can scarcely be important to the life and success of the average association, and probably constitutes merely an irritating nuisance to the members.

Arguments Against the Use of Fees.-While there is no general agreement among association men as to the advisability or inadvisability of the use of fees, able arguments in support of both sides of the question are advanced by their respective partisans. Some of the more important objections which are presented are as follows:

(I) In general such fees are felt to be penalties which discourage the habit of saving, even though they may apply only to those savers who fail to persist a specified length of time. To the extent that this is true, it is a contradiction of one of the purposes of the building and loan association.

(2) Banks do not charge a fee to open a savings account, and people who are unwilling to pay for the privilege of saving will naturally turn to the competing institutions which make no such charge.

(3) The income from fees is not worth the annoyance and expense which they cause.

(4) The use of fees robs an association of its staid business air and gives it the appearance of an institution belonging to the agency class.

(5) Fees may become a fruitful source of dissatisfaction and ill-feeling when not properly understood by the members. The trouble would be minimized if all carried their shares to maturity, but a large percentage withdraw earlier.

The excessive fee, not the small fee, is the source of trouble. Until prohibited by statute, a few associations have waxed fat on fees as large as 5 per cent of the par value of the stock, and such fees have tended to discredit the whole movement where they have been in effect. Unfortunately, legislation does not 
reach all the cases and some associations are still charging these exorbitant fees. It is only a matter of time, however, until such practice is checked.

Results of Charging Fees.-Do more members persist when withdrawals are penalized? This question has been asked time and again and has never been satisfactorily answered. It would be well to demonstrate what percentage persists until maturity where withdrawal fees are charged and where none are charged. A positive direct relationship between withdrawal fees and the percentage of withdrawals might thus be estab-

\section{TABLE XIX}

Relations Between Fees Charged on Withdrawal and Percentagrs of Shares Carried to Maturity

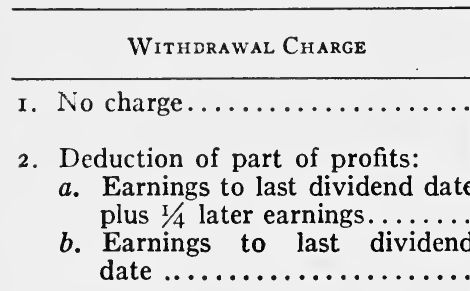

c. Percentage of earnings reduced (amount not stated)...

d. Simple interest instead of compound

3. Reduction of principal:

a. Membership fee to all alike..

b. Uniform withdrawal fee.....

c. Varying withdrawal fee (amount absorbed at maturity) $\ldots \ldots \ldots \ldots \ldots \ldots \ldots$
Percentage of Stock Matured* (REPORTED AVERAGES)

$10 \%$

$35 \%$

(Plan of most Dayton associations -but no record kept since maturities are disregarded.) For other associations:

$$
\begin{aligned}
& 10-22 \mathrm{~T} / 2-30-50 \% \\
& 2 \mathrm{~T} / 2-20-33 \mathrm{~T} / 3-55 \%
\end{aligned}
$$

I assn.: Shares maturing in less than 3 years, $95 \%$

I assn.: Shares maturing in 4-9 years, $80 \%$

I assn.: Shares maturing in ro years, $47 \%$

$$
18-20-40 \%
$$

(No data available)

$$
5-15 \%
$$

$65 \%$

* Compiled from questionnaires answered by individual associations. 
lished. In Table XIX are shown the various percentages of maturities which associations have found under different withdrawal charges.

It will be seen that where no charge is made, a very small number of members persist to maturity. At first glance this would appear to support the use of withdrawal fees. But it will also be seen that where a membership fee is charged to all alike, the number of members who stay with the association is very limited. This is also true in some cases where a reduction in the rate of earnings credited to withdrawn shares is used.

As a general rule, the largest number of shares remaining at maturity is found in those associations using a withdrawal fee. Those where the shares have a maturity somewhat shorter than the average also find that their members remain for a reasonable time. If there is any relationship, therefore, between number of shares matured and withdrawal charges, it would seem to be based upon these two things: short maturities and a reasonable fee. A further study is necessary, however, before any definite conclusion can be reached on this mooted point.

Borrowing to Avoid Withdrawal Fee.-It would be interesting to know how many associations permit shares to be withdrawn without penalty in order to make it unnecessary for the shareholder to borrow against his shares. It has been shown earlier in this chapter (page 173) that it is usually cheaper for the member to borrow from the association against his stock at the regular rates of interest than it is to accept the reduced value at which shares may be withdrawn between dividend dates. This is even more important when a fee is assessed in case of withdrawal before maturity.

Withdrawals Under the Dayton Plan.-Since the problem of maturity does not arise in the Dayton plan association, the matter of withdrawal before maturity is of less importance than in any other case. Officials make no special effort to induce members to persist for considerable periods. The plan provides for entering or leaving at will. The size of the dividends is expected to attract savers. The association is prepared 
for withdrawals, but as it is also constantly active in gaining new members, the new business more than replaces whatever withdrawals occur.

There are great differences in the methods of crediting profits to withdrawing members even under this plan.

(a) The most common method follows the savings-bank plan as in case (2) above (see page I72). Profits are credited semiannually. Should withdrawal occur between dividend periods, the full amount credited at the last dividend date is returned to the member together with whatever payments have been made in the meantime. He receives no additional earnings between dividend periods.

(b) A few Dayton plan associations credit the profits annually, instead of semiannually, in the belief that this encourages stockholders to remain with the association longer. It may happen, however, that such a practice also encourages withdrawals just after the dividend-paying date. If this is true, the association would be forced to guard its cash supply carefully in order that it may care for the heavy withdrawals at this particular period each year.

Practices in Washington Associations.-The plan under which many associations in the state of Washington operate in recent years is similar to the Dayton plan. These associations use several methods of crediting dividends in case of withdrawal.

(a) Some of them use the mutual-savings bank plan. Interest is allowed on monthly balances under this plan, provided the amount is not entirely withdrawn between dividend periods.

(b) Dividends credited only semiannually. This is the more usual practice. Associations in the state of Washington must use $\$ 100$ as the par value of their stock. In order to comply with the law and at the same time operate under the Dayton plan, these associations consider that each dollar paid in represents I/IOO of a full-paid share. It is the general custom to "allow their door to swing both ways" and probably not over ro per cent of the members in Washington persistently 
save for the period which would be required to mature their shares.

California Guarantee-Stock Associations.-In the newer sections of the West, associations have had some difficulty in encouraging their members to remain with them for long terms of years. This is particularly true of those towns which are growing rapidly in population. Installment stock with a definite maturity date is issued and an increasing percentage of the business is being done in full-paid investment certificates bearing a definite rate of interest. This satisfies the demand for a high interest return, but at the same time makes it possible to withdraw the money quickly and take it elsewhere. As a result, the percentage of withdrawals is very high.

Notice of Withdrawal.--Some period of notice is required by the by-laws of all associations before withdrawal may be made mandatory, even in the limited sense in which a demand can be made by one who is a member of an association and not a creditor. This period is thirty days in most cases, just as it is for savings banks. Even with this period of grace, the law provides an additional safeguard. A building and loan association is not required to pay withdrawing members more than a portion of the receipts for a given month, and in case of stringency, withdrawals are usually paid in the order in which applications therefor are filed. Many modern associations do not ask this period of grace when a member wishes to withdraw his shares. The practice of promptly returning a member's money when asked for is growing, but such a system requires a large amount of current receipts or a larger cash reserve than is carried by some associations; otherwise there will not be sufficient ready funds to satisfy withdrawing members without seriously interfering with the business of lending.

The question may be asked: Why not require a building and loan association to pay withdrawals on demand and without limitation? It is a sufficient answer to say that the association does not do a banking business and carries no demand 
deposits. Requiring thirty days' notice before withdrawal can be demanded effectually prevents "runs" and consequent forced liquidations, and makes it unnecessary to carry a large cash reserve. Cash in reserve would be idle and unproductive, and notice of withdrawal is required so that funds can be loaned to aid more borrowers and increase the net earnings of every member. There have been many periods of "tight money" when demands could not be readily met, and such periods will recur with every swing of the business cycle. It is particularly necessary to grant an association time because its investments are not self-liquidating as are those of a commercial bank. The association which makes these matters clear to all its members will have no difficulty in the matter of meeting withdrawals.

State Laws Regarding Withdrawals.-Examination of the laws of the various states shows a remarkable lack of uniformity in the United States in regard to the provisions which protect the thrifty citizen from the machinations of men who would betray their trust. Where the statute allows the association to provide in its by-laws for withdrawals, stating that such amount of the dues and profits may be returned on withdrawal before maturity "as the by-laws provide," it throws the field wide open and permits unscrupulous men to misappropriate any amount of money which has been paid in. In several states where this is allowed, a few associations have taken advantage of the statute and allow nothing to be withdrawn during the first three years of the shares' life, either of principal or of interest. Such unjust practices would subject the officers to criminal prosecution in the states where the law seeks to protect the savings member. It must be said in justice to association men that the vast majority of them would never consider such practices whether the statutes permitted them or not, and they are now bringing pressure to bear on the few remaining associations practicing such injustice, so that they will be driven out of business within a few years or compelled to work out a more equitable system.

In Table $\mathrm{XX}$ are grouped the more important statutory 


\section{TABLE XX}

\section{Statutory Provistons Covering Withdrawals Before Maturity}

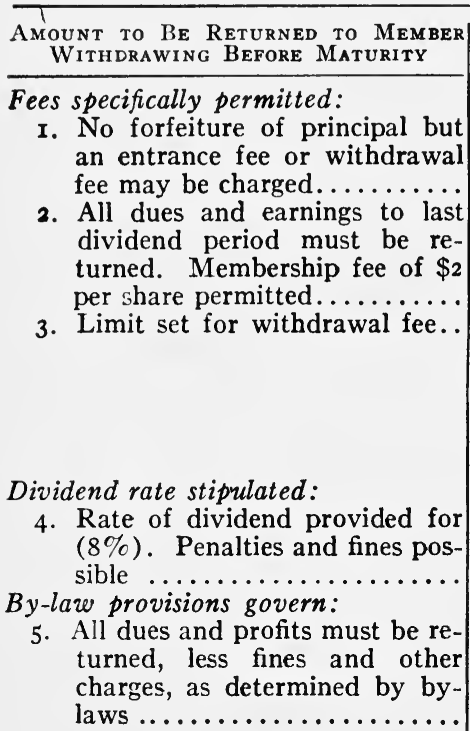

California.

Washington.

Colorado \$2, maximum $\$ 10$ in one transaction.

Rhode Island not to exceed one per cent of maturity value. Membership premium and fines also may be deducted.

\section{Alabama.}

Florida, Indiana, Kentucky, Louisiana, Maine, Massachusetts, Michigan, Nebraska, New Jersey, Ne.v York, Ohio, Oklahoma, Oregon, Vermont, Wisconsin, and District of Columbia.

6. Withdrawal provisions left to by-laws ...................

Connecticut, Kansas, Mississippi, Missouri, Montana, Nevada, Pennsylvania, South Dakota, Utah, Virginia, West Virginia, and Wyoming.

Directors determine amount:

7. All dues and portion of profits to be determined by directors.

8. Withdrawal provisions left to directors...$\ldots \ldots \ldots \ldots \ldots$.

\section{Principal:}

9. All dues, except share of losses,

if greater than loss fund......

ro. All dues, less fines $\ldots \ldots \ldots \ldots$...... in any fiscal year............

No mention of withdrawals:

Illinois and New Hampshire.

North Carolina.

Iowa.

Minnesota and Texas.

elaware.

Arizona, Arkansas, Georgia, Idaho, Maryland, New Mexico, North Dakota, South Carolina, and Tenne:see. 
provisions covering withdrawal of shares before maturity. It will be seen from this that only two states have attempted to prohibit forfeiture of principal. Even in these two states, fees may be charged, and a fee might cause a member withdrawing in the first year or so to suffer some loss of principal, as we have already shown.

It will be seen that 16 of the states provide that all dues



Charr 6.-Statutory provisions covering amount which may be withdrawn on building and loan shares before maturity.

and profits up to the last dividend period must be returned, but fines and some other charges are possible in these states. The withdrawal provisions are left "to the by-laws" in twelve states, and three others give the directors considerable discretion in the amount which will be returned. In at least two states (and probably in four) there is no effective provision for the payment of any profits on withdrawal, and, in two of these, fines may be used to reduce the actual amount of dues paid in. The accompanying map indicates the withdrawal provisions of the state laws.

This whole withdrawal problem is one that needs to be more thoroughly investigated and carefully worked out by the asso- 
ciations which are interested in promoting the best interests of the business, in order to protect the legitimate interests of both the member and the association.

\section{SPECIAL REFERENCES}

Withdrawal fees. California League Proceedings (1924), pp. 28, 30. Withdrawals. California League Proceedings (1924), pp. 28, 30. U.S. League Proceedings (rgor), pp. I42-I44; (1910), pp. 57-71. Wrigley, Edmund, The Working Man's Way to Wealth (1872), p. 45.

\section{GENERAL REFERENCES}

Putnam, T. M. Mathematical Theory of Finance (1923).

Robinson, J. Watts. Robinsonian Building-Loan Interest Tables (1909). Rosenthal, Henry S. Cyclopedia, pp. I54-156; 210-212 ; 334-438.

Skinner, Ernest Brown. Mathematical Theory of Investment (I924). SundHetM, Joseph H. Law, pp. 57 ; I48-158.

Wright, Carroll D. Ninth Annual Report of the Commissioner of Labor (1893), pp. 465-489. 


\section{CHAPTER $\mathbf{x}$}

\section{MAKING THE LOAN}

Mortgages used to protect lender; first and second mortgages; split loans-nature, difficulties, uniform payment plan; adjusting split loan to fit any interest rate; who may borrow; no loans to officers or "straw men"; credit bureaus; loan application-content, handling; examination of title; legal form of mortgage; the bond or note; the warrant; the trust deed; tax notices and tax receipts; insurance-fire, tornado; construction loans; refunding straight mortgages; stock loans; repayment before maturity; foreclosure procedure; farm loans.

Before discussing the actual procedure of making the loan, it is necessary that we recall the type of loan which may be made by a building and loan association. Savings received by the associations are relatively long-time funds, and they should not be invested in short-time self-liquidating paper, since this matures quickly, making it necessary to reinvest frequently, and funds would often be idle.

Association loans are neither short-time commercial loans, nor the form of coöperative credit used by our "credit unions." They are not made against personal or business standing, but are a form of coöperative credit generally based upon realestate security. Both the period of time and the type of security for the loan differ from those used in banking practice. From the standpoint of the savings member, the loans are "group loans," in the sense that each member puts his funds into the association without knowing the particular mortgage on which they are loaned. It might be said that the member shares in the benefits of a blanket mortgage which is split up into many parts.

From the standpoint of the association, there is no blanket 
mortgage in the technical sense of this term, but a large group of individual mortgages on which it loans the money of its members, and for which it has assumed responsibility for safety and the details of collection. The managing officers of the association judge the type of security which they will accept; they determine the margin between the value of the property and the amount of the loan. Their selection of risks will determine the safety of the investment and upon this safety and the record of the association for prompt payment of its obligations will depend the final verdict of public approval or disapproval of the association.

First mortgages on improved real estate are the foundation of the building and loan business. A mortgage may take any one of several forms, but in substance it is a contingent conveyance of the property from the man borrowing the money (the mortgagor) to the building and loan association (the mortgagee), given as security for a loan, and this conveyance becomes void when the debt is paid. The essential difference between a first mortgage and any other mortgage is that its claim comes first in case the property must be sold to pay the debt (aside from taxes and other claims of the government against the property, such as street improvement, etc.). In those states having a mechanics' lien law, claims of mechanics for wages, etc., may sometimes wedge their way ahead of the first-mortgage claim. This makes it necessary to know before lending money upon a property what other claims are in existence against the property or what claims may later be recorded that take precedence of a mortgage.

A mortgage becomes a first claim by being recorded before any other claim is placed on record against the same property in the county office provided for that purpose. Practice as to the place of recording and the rights which are secured through the record, vary throughout the country; but the purpose of all recording acts is fundamentally the same. (It is well to keep in mind that where the recording act recognizes that all subsequent mortgagees have "constructive notice" of the first claim 
filed, the priority of claim of any mortgagee can be defeated if the mortgagor makes a later mortgage which is recorded before the first mortgage is placed upon the county records.)

Under the term "first mortgage" is included any first lien upon the property which is used to secure a debt, regardless of its name. Real estate loans may be called "first mortgages," "first liens," "first deeds of trust," "vendor's privilege and first lien" (as in Louisiana), etc. The purpose of all these instruments is the same: to enable the lender to get title to the property in case the borrower fails to meet his obligation.

Second Mortgages.-The use of any mortgage other than a first lien is disappearing from building and loan association practice. Such use is both unnecessary and dangerous, especially where the first mortgage is held by a party other than the first mortgagee. In the past second mortgages have been used in three or four states of the country, and the law in ten states would still permit their use. It has been possible to use such mortgages successfully at times because the periodical payments constantly reduce the risk. However, periodical payments do not always offset the other dangers of this type of mortgage, and it is not looked on with favor.

They have been most widely used in Pennsylvania, and the state banking commissioner of that state has long recognized their inherent evil, especially as they have often been used for private advantage. With second mortgages it is possible to cover up the profits of dealers, and such use should be prohibited in association practice. ${ }^{1}$

"Second mortgage" is the name given to any lender's claim to a piece of property which is secondary or "junior" to the claim of another lender on the same security. Frequently the so-called "second" mortgage must follow the claims of several other lenders, in which casc it is really a third or later mort-

1 See 1919 report of John S. Fisher, state banking commissioner of Pennsylvania. Also reprinted in the American Building Association News, January, 1921, p. 33. 
gage, as the case may be. The only safe claim is a first claim, as in case of sale the value of the property may be absorbed for the benefit of the first mortgagee before the junior obligations are paid off.

Where the association holds both the first and second mortgage against one piece of property, the matter of priority of lien is of no importance.

Split Loans.-A "split loan" can be made by an association on two mortgages, a first and second, in order to care for unusual needs of a borrower, without unduly burdening him. The loan is "split" between the two mortgages, which differ only in priority of claim, and where the association holds both mortgages priority is of minor importance. For example, on a piece of property worth $\$ 15,000$, the borrower wishes a loan of $\$ 12,000$. The association is unwilling to lend on first mortgage for that amount. It may be willing to lend up to $\$ 9,000$ or $\$ 10,000$ on first mortgage. Were it to lend $\$ 12,000$ on one mortgage, the periodical payment of dues and interest under the regular building and loan plan might be greater than the borrower could meet regularly out of his expected income. By using two mortgages, requiring payment of interest on both and of dues on the second, the postponement of payment on the first makes the deal possible. Therefore, the split loan is used in order to bring the payments within reach of the borrower's income. The amount which is placed upon the second mortgage depends upon the expected income of the borrower, or the size of the periodical payments which he can make without difficulty. From two-thirds to three-fourths of the loan would be put under the first mortgage, and the balance under the second. When the borrower has completed the repayment of the amount covered by the second mortgage, this instrument is released, and the periodical payments are then applied to pay off the remaining first mortgage.

The principal difficulties which have arisen in connection with the split loan in the past are that the required payments have been too large. Franklin P. Stevens, Vice-President and 
Secretary of the Safety Savings and Loan Association of Kansas City, Missouri, has worked out for the split loan a plan of uniform payments of moderate size which, with slight modifications to fit various interest rates, will be of great practical importance to every association in the country.

Uniform Payments Applied to Split Loan.-The plan worked out by Mr. Stevens contemplates that the association shall hold only the first mortgage, the second to be carried by the vendor of the property. In Kansas City it has been possible to secure a 6 per cent interest rate on the second mortgage in spite of the fact that the association charges 6.6 on its first mortgages. Vendors are primarily interested in disposing of their properties, hence this interest concession.

Under this plan, \$95 a month for $\mathrm{r} 35$ months will pay off $\$ 9,000$ in two loans (\$6,000 on first mortgage, $\$ 3,000$ on second). The borrower makes all payments to one of the officers of the association, who divides the money between the two mortgagees. For the first 74 months, $\$ 48.50$ of each payment is applied to interest and principal of the second mortgage, on the monthly reduction plan. (That is, the proportion going to interest grows steadily smaller, while the amount applied to principal steadily increases, and interest is charged only on the actual balance.) At the end of 74 months, the $\$ 3,000$ second mortgage is paid in full. Beginning with the $75^{\text {th }}$ month, the entire monthly payment is applied to the first mortgage. Throughout the period, $\$ 33$ a month interest must be deducted from the $\$ 95$ as interest on the $\$ 6,000$ first mortgage. For the first 74 months this leaves $\$ 13.50$ to be applied each month on shares to repay the first mortgage, and for the remaining period $\$ 62$ each month will be so applied. Dividends at a 6 per cent rate added to the payments make it possible for the entire loan to be paid off in 135 months. Where shares for the full amount of the loan must be issued, it is necessary for the association to waive payment of dues on a portion of these shares until after the second loan is paid off. In most 
states the law permits such practice, if sanctioned by the association's directors or by the by-laws. ${ }^{2}$

At the end of the period the borrower has paid for his home, with a regular payment that he can afford, and without the cost or necessity of any new financing.

Application of the Split Loan Plan to Various Interest Rates.-The size of the monthly payment and the time required to pay off a split mortgage will vary somewhat with the interest and dividend rates. (a) By considering the s.um of the two mortgages as one, it is possible to determine from the Robinsonian tables how long it will take various monthly payments to mature this total at the current dividend rate (ignoring for the moment the interest rate). (b) Interest can then be added to the various periodical payments, and when the amount is found that appears most satisfactory to borrower and to the association, this payment can be divided between the two mortgages on any desired percentage. Fifty per cent or more of the periodical payments will usually be applied to the second mortgage, since it is desirable to get this paid off quickly. As much more may be so applied as desired, so long as there is a small balance above the first-mortgage interest which may be applied to the repayment of the first mortgage. (Fifty-one per cent was so applied in the plan shown above.)

Example: Find payment and maturity of $\$ 9,000$ loan $(\$ 3,000$ on second, $\$ 6,000$ on first) when dividend rate is 6 per cent, interest on first is 6.5 , and interest on second is 7 per cent.

At 6 per cent dividends, $\$ 9,000$ can be paid off in the following way:

2 The changes made in the by-laws of the Safety Savings and Loan Association in order to care for the split loan were as follows:

"Sec. I 7a, Monthly installment shares of the par value of Two Hundred (\$200) Dollars to be known as 'Security Shares' may be issued in whole or in half shares on the same terms as provided in the case of Savings Shares, except that the holders shall pay to the Association on or before the fifteenth day of each month, the sum of Ninety (90) cents per share (or such amount per share, and in such periodical installments or otherwise as the directors shall by resolution authorize or provide), instead of One (r) Dollar per share, as provided in the case of Savings Shares," 
\$40 dues per month in approximately 151 months.

$\$ 50$ dues per month in approximately 129 months.

$\$ 60$ dues per month in approximately i1 2 months.

$\$ 70$ dues per month in approximately 99 months.

$\$ 80$ dues per month in approximately 89 months.

$\$ 90$ dues per month in approximately $8 \mathrm{I}$ months.

With interest at $\$ 50$ per month, payments would be $\$ 90, \$ 100, \$ 110$, $\$ 120, \$ 130$, or $\$ 140$. Suppose that the maturity of 129 months and the amount $\$ 100$ appears to be most satisfactory, in comparison with present payments required on shares. Of this payment, one-half will be absorbed as interest on the two mortgages for the first month. The amount to be applied on first-mortgage shares must be arbitrarily chosen, and we will assume that $\$$ Io is the choice.

The $\$ 100$ monthly payment will then be divided as follows:

Interest on $\$ 6,000$ first mortgage.......... $\$ 32.50$

Dues on part of $\$ 6,000$ shares (balance of dues to be waived until later)............... I0.00

Amount applied to interest and principal of $\$ 3,000$ second mortgage............... 57.50

Total monthly payment.............. $\overline{\$ 100.00}$

Payments are divided as above for 62 months; at which time $\$ 22.57$ will remain due on the second mortgage. $(\$ 57.50$ per month repays $\$ 3,000$ principal and interest at 7 per cent, on the monthly reduction plan in about 63 months.) The 63rd monthly payment will be divided so that $\$ 22.70$ is applied to the final payment on the second mortgage, thus paying it in full and cancelling it.

Meanwhile payments have continued on first mortgage at the rate of $\$ 32.50$ interest each month, \$10 per month toward shares for 62 months, $\$ 44.80$ in the 63 rd month, and $\$ 67.50$ thereafter, with the following result:

Payments on First Mortgage (I)

Amount of first mortgage........................ $\$ 6,000.00$

$\$$ ro per month at 6 per cent semiannual compound dividends for 62 months $\ldots \ldots \ldots \ldots \ldots \ldots \ldots \ldots$ \$ $\$ 723.45$

One month's dividend on $\$ 723.45 @ 6$ per cent per annum ............................. 3.61

Payment toward first mortgage made in 63rd month $\quad 44.80$

Accumulation to date toward repayment of first mortgage (but not so applied until end of total period) ......... 771.86

Balance due on first mortgage when second mortgage is fully paid off (at $63 \mathrm{rd}$ month) $\ldots \ldots \ldots \ldots \ldots \ldots \ldots \ldots \ldots \ldots \ldots \ldots \ldots \ldots \ldots, 228.14$ 
Payments continue at a uniform rate of $\$ 100$ per month as before, and in a total of about 126 months (depending on the regularity of the dividend rate) the entire debt is paid off.

\section{Payments on First Mortgage (2)}

Accumulation of $\$ 771.86$ at 63 rd month draws dividends in association for balance of period, amounting in 126 months

(@6 per cent semiannual compound dividends) to...... $\$ 67.50$ dues per month for remaining 63 months, (@6 per cent semiannual compound dividends) $\ldots \ldots \ldots \ldots \ldots \ldots$.

Total credits at I 26 months................. $\$ 6,027.8 \mathrm{I}$

Deduct amount of first-mortgage loan............ $6,000.00$

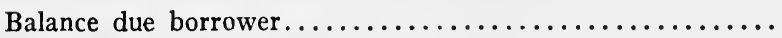

$\$ 1,052.88$

$4,974.93$

$\$ 27.8 \mathrm{I}$

It will now be noticed that the debt is paid in full in 126 months instead of the 129 predicted. By referring to the original statement of the problem, it will be seen that 129 months was obtained from the Robinsonian tables on the basis of a 6 per cent dividend rate. A considerable portion of the payments made during the period have received the equivalent of a 7 per cent dividend rate. This is due to the periodical reduction plan. Wherever a uniform monthly payment is applied to the repayment of a loan by the monthly reduction of principal and interest, the loan will be repaid in the same time as that required to accumulate the amount of the loan at a dividend rate equal to the interest rate, with the same total monthly payments. As a result, several months are saved to the borrower by the process. By this method of calculation the predicted time should always be in excess of the actual time, - a conservative procedure.

By the use of the above method, the Stevens' UniformPayment Split-Loan Plan can be applied to any desired combination of interest and dividend rates. It should be mentioned that this is the first time that such a method has been worked out in a practicable way and offered to association men.

Deciding the Amount of the Loan.-The amount of the loan which may be advanced against a given property is in all cases decided only by the directors and officials of the association. This is not a matter which can be left to subordinates, as the safety of the operations of the association largely depends upon sound appraisal and loan limitations imposed by 
law and business experience. The association loan is reduced slightly with every periodical payment ${ }^{3}$ and, therefore, safe loans of higher percentages of the property can be made under the amortization plan.

Permitted Types of Investment.-Loans are not limited to real-estate security, although this is the principal type. (I) Loans may be made upon the book value of unpledged stock of the association, and the shares are pledged for repayment. (2) Certain types of bonds may be purchased by the associations in some states, especially government or state bonds or bonds secured by real estate. In those states where there has been established a clearing house for building and loan associations, such as the Land Bank of New York, ${ }^{4}$ bonds issued by this clearing house are legal investments for the member associations. Clearing houses make savings available for home ownership in parts of the state where they are needed when the accumulation of capital elsewhere is not immediately in demand at home. Investments in bonds are generally regarded by building and loan men as merely temporary expedients until the flow of capital is balanced with the demand for it.

In a few cases, building and loan associations have attempted to lend money upon leaseholds. A leasehold is a long-term contract for the use of land, running perhaps for ninety-nine years. These contracts have come into use in parts of the country (I) where the value of land is very high, and (2) where the tendency has developed of separating the ownership of the land from that of the building. Landlords making a leasehold contract take practically no risk. The tenant undertakes to construct a building upon the land, to pay either all

${ }^{3}$ Where loans are repaid by the accumulation of shares, the share account and the loan account are ordinarily kept separate, and in this sense the loan is not directly reduced with each payment. However, the value of the shares is increased each month or week, and as the shares are pledged as collateral security for the loan, the statement that "the amount of the loan is reduced with each payment" is essentially correct.

- See Chap. XXIV. 
or most of the taxes thereon, to make all required street and other improvements to the property, and he pays to the landlord a stipulated rent for the use of the site for the term of the contract. New Jersey building and loan associations are definitely prohibited from making loans on leasehold property, according to an opinion rendered by Attorney General McCran in 1922. No other opinion on this has been found by the present writers. In the few states which limit the size of the loan which may be made to individuals by building and loan associations, this problem does not arise because loans on leaseholds are ordinarily for business property construction and the amounts involved are very large.

The types of security which are permitted by the various state laws are summarized in the following table. This refers to the regular funds of the associations. The law in most cases makes additional provision for the use of surplus funds, permitting the purchase of bonds, etc., as just discussed.

Who May Borrow.-Loans of building and loan associa-

\section{TABLE XXI}

Krnds of Security Which Buiteding and Loan Associations Are ReQUired or Permitted by State Law to Accept

\begin{tabular}{|c|c|}
\hline State & Types of Security \\
\hline Alaban & To be provided in by-laws. \\
\hline Arizona & $\begin{array}{l}\text { "Adequate security on real or personal property, or per- } \\
\text { sonal security with at least two endorsers." }\end{array}$ \\
\hline$r$ & Law silent. \\
\hline California & First mortgage or deed of trust with note or obligation. \\
\hline Colorado & First mortgage or trust-deed liens upon real estate. \\
\hline otiot & First mortgage on Connecticut real estate. \\
\hline Delaware .. & $\begin{array}{l}\text { Bonds and mortgage against real estate and "other suf- } \\
\text { ficient security." }\end{array}$ \\
\hline Dis & First mortgage or deed of trust upon real estate. \\
\hline Florida . & Mortgage on real estate and note or bond. \\
\hline Georgia & "Mortgage with waiver of exemption, or title, or both." \\
\hline Idaho. & Law silent-custom requires first liens on real estate. \\
\hline Illinois .. & $\begin{array}{l}\text { Unencumbered real estate "except by prior lien of same } \\
\text { association." }\end{array}$ \\
\hline Indiana & $\begin{array}{l}\text { First lien on Indiana real estate, except that personal } \\
\text { security may be accepted when no other demand for } \\
\text { loans exists. }\end{array}$ \\
\hline
\end{tabular}


TABLE XXI-continued

\begin{tabular}{|c|c|}
\hline State & Types of Security \\
\hline Iowa & Real-estate security. \\
\hline Kansa & $\begin{array}{l}\text { First liens on real estate, non-negotiable and non-assign- } \\
\text { able, except for taxes and special assessments. }\end{array}$ \\
\hline Kentucky & Note secured by first mortgage. \\
\hline Louisiana & Vendor's privilege and first mortgage on real property \\
\hline $\begin{array}{l}\text { Maine .... } \\
\text { Maryland }\end{array}$ & Note secured by first mortgage of real estate. \\
\hline Massachusetts & First mortgage on real estate. \\
\hline Michigan & First mortgage on real estate. \\
\hline Minnesota & Non-negotiable note or bond secured by first mortgag \\
\hline ississippi & Appears to require real-estate security. \\
\hline Missouri & First mortgage or deed of trust. \\
\hline Montana .. & To be provided in constitution and by-laws. \\
\hline $\begin{array}{l}\text { ebraska } . . \\
\text { evada } \ldots\end{array}$ & First mortgage on real estate. \\
\hline evada & $\begin{array}{l}\text { Ample real-estate security, unencumbered except by } \\
\text { prior loans from the association. }\end{array}$ \\
\hline
\end{tabular}

New Hampshire. "Satisfactory security." (Association "may purchase houses or may purchase land and erect houses thereon, and may sell or lease the same to its shareholders.")

New Jersey..... First-lien mortgages. (Association may purchase "lands or building lots, erect buildings and improvements thereon or purchase lands already improved" when it

New Mexico.... Law silent.

New York..... First mortgage on real estate.

North Carolina. First mortgage on real estate.

North Dakota.. Law silent.

Ohio ......... First mortgage on real estate.

Oklahoma ..... Real-estate security.

Oregon ........ First mortgage on real estate.

Pennsylvania ... Bond and mortgage or other security.

Rhode Island... Non-negotiable note or bond secured by first mortgage on real estate.

South Carolina.. Law indefinite.

South Dakota... First mortgage on real estate.

Tennessee ...... Trust deed or mortgage and note on real estate.

Texas ......... First mortgage on real estate.

Utah ......... Real-estate security.

Vermont ...... First mortgage on real estate.

Virginia ....... Personal security, promissory notes or bonds, or mortgage or deed of trust upon real or personal property.

Washington .... First mortgage on real estate.

West Virginia... Personal security, real-estate mortgage, or deed of trust (Association may buy, improve, lease, or sell real estate.)

Wisconsin ..... First mortgage on real estate.

Wyoming ...... Real-estate security, also by unanimous consent of trustees may loan on bonds and personal property. 


\section{TABLE XXII}

Summary of Kinds of Security Permitted or Required by State LAWS

\begin{tabular}{|c|c|}
\hline Types of Security & States \\
\hline $\begin{array}{l}\text { Pirst mortgage on real es- } \\
\text { tate or equivalent re- } \\
\text { quired } \ldots \ldots \ldots \ldots \ldots \ldots\end{array}$ & $\begin{array}{l}\text { California, Colorado, Connecticut, District of } \\
\text { Columbia, Illinois, Indiana, Kansas, Ken- } \\
\text { tucky, Louisiana, Maine, Massachusetts, } \\
\text { Michigan, Minnesota, Missouri, Nebraska, } \\
\text { Nevada, New Jersey, New York, North } \\
\text { Carolina, Ohio, Oregon, Rhode Island, South } \\
\text { Dakota, Tennessee, Texas, Vermont, Wash- } \\
\text { ington, Wisconsin. }\end{array}$ \\
\hline $\begin{array}{l}\text { First mortgage required by } \\
\text { custom-not by law..... } \\
\text { Other types of real-estate } \\
\text { security (including sec- } \\
\text { ond mortgages) permit- } \\
\text { ted .................... }\end{array}$ & $\begin{array}{l}\text { Arizona, Delaware, Florida, Georgia, Missis- } \\
\text { sippi, Oklahoma, Pennsylvania, Virginia, } \\
\text { West Virginia, Wyoming. }\end{array}$ \\
\hline $\begin{array}{l}\text { Other security permitted } \\
\text { (kind not stated) ....... }\end{array}$ & $\begin{array}{l}\text { Delaware, Indiana, New Hampshire, Pennsyl- } \\
\text { vania. }\end{array}$ \\
\hline $\begin{array}{l}\text { Personal property per- } \\
\text { mitted .................. } \\
\text { Personal security permitted } \\
\text { No provision, left to by- } \\
\text { laws } \ldots \ldots \ldots \ldots \ldots \ldots \ldots\end{array}$ & $\begin{array}{l}\text { Arizona, Virginia, Wyoming. } \\
\text { Arizona, Virginia, West Virgiria. } \\
\text { Alabama, Arkansas, Maryland, Montana, New } \\
\text { Mexico, North Dakota, South Carolina. }\end{array}$ \\
\hline
\end{tabular}

tions are made principally to members of these associations, but "membership" in some states is a very flexible term. Oldtime building and loan men have criticized the "loose" practices of the newer states where anyone may be considered a member when he subscribes for one or more shares of stock in an association, and then borrows a considerable sum. Early practices required that a borrower should subscribe for shares equal in amount to the value of his loan and this practice continues to be used in most states of the Union. ${ }^{5}$ Membership is defined by (I) the statutes of the various states, and (2) by the by-laws of each association. Anyone complying with the rules

'See Rosenthal's Cyclopedia, 1923 edition, Chap. XII, pp. 204 ff. 
there provided and making the necessary payments to the association may become a member.

It is not so important for loan officers to worry about the technical meaning of term "member" as it is to discover the character of the borrower. Loans, however made, must be repaid if the association is to be successful. In case the borrower should fail to meet his obligation, the association has the right to take over the property and dispose of it to the best advantage possible, but no association wishes to burden its officers with the care of real estate. Their business is lending money and not the renting or selling of houses; but such property as comes into the hands of officials because of bad loans must be disposed of, of course. The value of the property is a prime consideration, but there never will be such a thing as the elimination of the consideration of the character of an applicant for a loan. A man of high character without proper security will be unable to secure a loan; but if an applicant has a good reputation, the association is justified in lending a higher percentage than otherwise upon whatever security is offered.

Loans should never be made to officers, even where the state laws are silent on this point. Such loans are not ethical, and have led to abuses in the past. Few persons are capable of maintaining an unbiased point of view when considering the value of property they desire to offer as security for a loan.

Loans to "strawmen" are exceedingly dangerous. A "strawman" is either a fictitious person or an applicant who is acting for the real borrower. Men of shady reputation have been hnown to use upright young mechanics who, in applying for a loan, can give evidence to the association that they hold regular positions. A mechanic complies with all the requirements and applies for a loan in his own name. When it has been made, however, a plausible story is concocted to show that the mechanic has transferred his interest in the property to another party. The association is not obliged to make the loan to the new party, and can cancel the negotiations at any time it sees fit. If the contracts have been signed, and the mortgages 
recorded, it is usually possible to hold up the transfer if fraud is clearly shown. A clause could be inserted in the mortgage preventing the title of property from being changed without the consent of the association. This would eliminate the possibility of transferring it to an irresponsible party. ${ }^{6}$

Credit Bureaus.-For avoiding the wrong type of borrowers, associations in some cities have developed credit bureaus, which are similar to the credit bureaus established by other business houses or groups of business men. The records of all borrowers can be exchanged through such bureaus and the possibility of borrowers playing one association against another can be eliminated. In Cleveland, for example, the credit bureau lists all borrowers of associations subscribing to the bureau; and the letters E, excellent, P, poor, and N, no good, indicate previous experience of other associations with each individual. Where prompt and truthful reports are made to a central bureau, many difficulties are avoided.

Allotment of Loans.-The bidding process to determine priority has been practically eliminated to-day, and the practice is growing of caring for loan applications in the order in which they are filed. This would appear to be the only just method. Some associations set a maximum amount for individual loans for each month in order to bring about an adequate distribution of the available funds. The board of management occasionally tries to avoid complications when funds are adequate by fixing a maximum amount for a single mortgage (for example, in one month not more than $\$ 3,500$ to one individual). In this way they aim to help the small home owner, who as a rule needs it most, and they also get in touch with a greater number. ${ }^{7}$

Steps in the Process of Making the Loan.-The neces-

- This suggestion was made by Dr. J. F. Rybak, President of the Cuyahoga District, before the 3 and Annual Meeting of the Ohio Building Association League, held at Cleveland, Ohio, September 21-22-23, 1920 ( 1920 Ohio Proceedings, p. 97). See also Chap. XII.

'See Bulletin No. 3, New York State League of Savings and Loan Associations, September 22, 1922. 
sity of prompt action on all loan applications and of advising the borrower as to the result of his application at once is being impressed upon building and loan officials more forcibly every day. Slack methods which allow an application to be accepted and action withheld for days or even months bring criticism upon the association's way of conducting business. An applicant is entitled to know promptly whether he will secure his loan or not. With the development of efficient procedure, less time is consumed in the actual handling of the loan.

A complete application form may include the following items:

General (for all loans):

Applicant's name.

Name of wife (if married).

Address.

Legal description of property.

Size of lot.

House number, block, subdivision, and ward in which located.

Below or above grade.

Street improvements, in and expected.

Condition of house.

Age of house.

Amount of taxes:

a. General.

$b$. Special.

Encumbrances, including judgments or other liens.

Assessed value.

Purchase price.

Improvements including heating system, type of plumbing, bath, toilet, stationary laundry tubs, etc., whether connected with sewer, whether piped for gas, whether wired for electricity.

Occupied by tenant or owner.

Amount of loan desired.

Use to be made of borrowed money.

Proposed improvements.

Agreement to bring abstract down to date (or insure title), and have title certified under one certificate.

Agreement to pay examination and recording fees.

Statement that all taxes are paid to date, with exceptions, if any. Tax statement to cover personal property taxes for the past three years. 
Personal information regarding borrower:

Age.

Health.

Occupation.

Where employed.

How long in that employment.

Income.

Other property owned.

Amount of indebtedness carried.

Fire and other insurance carried on this property.

Amount of life insurance.

Special (if loan is for construction purposes):

Size of the building.

Material of which to be built.

Estimated cost of construction.

Whether contract or day labor.

Name of architect.

Name of contractor.

Name of company bonding contractor for satisfactory completion, and protection against mechanics' liens.

Not all of these items appear in all application blanks, but in general this is the information desired. Some associations include many other items, leaving space for the report and recommendation of the committee on appraisal, certificate by the attorney, etc. The inclusion of such statements on a loan application, however, tends to crowd the blank and may restrict its use. Throughout the Middle West and Far West, the application is usually separate from other reports, although all such reports would naturally be filed in the same office jacket.

At the next meeting of the association's board of directors the secretary presents the accumulated applications. If the board considers them satisfactory in a general way, it calls for a report by the appraisal committee, and an examination of title by the attorney. The appraisal committee then makes a minute and detailed examination of the property, and its members state their opinion either upon the application blank or upon a special report blank provided for that purpose. This report is then returned to the secretary. The success or failure 
of an association in a large city depends primarily upon the skill with which the appraisals of property are made. It is such an important subject in the success of this work that a separate chapter has been devoted to it in this text-book. (Chap. XI.)

If the loan has been approved by the appraisal committee, the attorney of the association is next called upon to examine the title. In lieu of a personal examination by the company's attorney, the certificate of a title company is accepted in some sections, or a policy of title insurance is taken out. In this connection, it has often been suggested that very few titles in the United States are clear of defects. Fault could probably be found with the character of almost any title. These defects are usually of such a character that they do not constitute a serious danger; occupants of the property have been undisturbed in their possession for many years, and a mortgagee may have nothing to fear in lending money on such security. When the amount of the desired loan is much less than the value of the property, the cost of remedying ancient defects may be an unnecessary expense. It is a matter of nice judgment, therefore, for the attorney to know when to press for the perfection ef title in all respects and when to be lenient. The final criterion in all cases is the safety of the association's funds when loaned against a given piece of property.

The abstract of title is a history of the title to the piece of property from the earliest known records. This usually extends back to the United States government (in this country) and it is necessary that this abstract be brought down to date. A good abstract of title will show all parties who have had any interest in the property for the past twenty years. ( $T$ wenty years, because in most states twenty years' undisturbed possession gives clear title.) Many associations also require that the abstract show a copy of the official plat of the property, and its relation to streets, alleys, sewers, and the like. Abstract companies specializing in this business are found in all states where this practice is in vogue.

Title problems are by no means easy of solution. "There 
are many complications arising over titles, or over abstracts, relating to the abstracts themselves, over contracts, sales, heirs, wills, succession judgments, illegal corporations, recording of instruments, deeds which carry a suspicion of possible invalidity, innocent purchasers, heirship, time when titles may not be questioned, the 'tolling' of statutes of limitations, and suspension by disability of affected persons, as to what are merchantable titles, taxation, tax titles, re-sale titles, which are unsettled." 8 Title difficulties are perhaps more numerous in the West than in the East, but the subject is of such importance that it cannot be overlooked. ${ }^{9}$

Advance Provision for Collection.-A few associations forestall trouble in making prompt collections by securing the signatures of their borrowers to cards authorizing a bank to honor the draft of the association upon the borrower for the amount of the monthly payments as due. One such form which has been in successful use for some time is shown on p. 208. It is printed on a $3 \times 5$ card.

Making Out the Mortgage.-When the various steps up to this point have been completed and approved by all necessary officials, the mortgage or trust deed and the bond or note must be made out. The more progressive associations specialize in reaching this poini promptly. The executive committee often meets daily; all loan applications received since the previous day are acted upon at once; the committee leaves at the close of the meeting to examine all property. Meanwhile, the title is under examination, and the president and secretary are authorized to close the approved loans as soon as the necessary papers can be drawn. Loans are sometimes closed within twenty-four hours. Such prompt action has had a marked influence on the growth of the business.

${ }^{8}$ From address by F. L. Boynton, Kingfisher, Oklahoma, before the Tenth Annual Session of the Oklahoma State League, held at Shawnee, Oklahoma, May 25-26, 1922 (I922 Proceedings, pp. 42-43).

- The student is advised to consult attorneys in his own locality as to title procedure. A list of general books upon this subject will be found at the end of the chapter. 


\section{Draft AUthorization}

Loan number

Stock number

Bank

\section{Address}

Until otherwise notified by me, you are hereby authorized to honor draft on me for $\ldots \ldots \ldots \ldots$. Dollars $(\$ \ldots \ldots \ldots \ldots)$ by the Federal Savings and Loan Association of Oklahoma, as drawn each month hereafter, and also to charge said draft to my account with your bank, and thereby oblige.

Signature

Telephone

Street and number

Witness

Town and state

The mortgage is designed to secure the transfer of the property to the lender (the building and loan association) in case of the borrower's failure to meet the terms of his contract. It appears to be a deed of absolute transfer, but it contains a "defeasance clause." This defeasance clause means that the absolute transfer of the property may be "defeated" or avoided if the borrower pays his debt. The conveyance can only become effective, therefore, in the case of default, and it requires court action to make the transfer of title effective.

The essential points are alike in all mortgages, although the wording varies greatly in different states. Forms have been shortened in many jurisdictions by eliminating useless duplication of clauses which were originally inserted by scriveners who received pay for their services on the basis of the number of words in the written document. 
The following explanation of various forms is arbitrarily arranged. Lack of space prohibits the reproduction of forms in full, although such reproduction could serve no useful purpose since mortgages which may be legal in one state are generally useless elsewhere. The student should procure copies of current forms from a local stationer (they sell for only a few cents), marking the various clauses so that the explanations can be referred to at a glance.

\section{The Mortgage}

I. The Parties.-It is customary when the borrower is married to include the names of both husband and wife as comakers.

(Made the ..... day of $\ldots \ldots \ldots \ldots \ldots$ between, etc.)

2. Preamble.-Recites the consideration (that is, the amount of debt).

(In consideration of $\ldots \ldots \ldots .$. )

3. Legal Description of the Property.-(This must agree with the recorded description.)

(The following described real estate $\ldots \ldots \ldots \ldots \ldots$.

4. Granting Clause.-This clause gives the mortgage the appearance of an absolute conveyance.

([The borrower $]$........ does ....... grant, bargain, sell, etc. ...........)

5. Habendum Clause.-This clause defines the legal title that the mortgage would convey if the courts construed it literally; in other words, the size of the legal estate granted. Usually this would be a "fee simple" title, or the most complete title that can be granted in the United States.

(To have and to hold......... )

6. Defeasance Clause.-If the debt is paid under the terms agreed upon, this clause provides that the mortgage shall be canceled and the full title to the property restored to the borrower. It "defeats" or nullifies the habendum clause. This 
right to regain the title is known as the borrower's "equity of redemption."

(Provided always, that if the said ..... shall pay to $\ldots \ldots \ldots$. then these presents shall be void, etc. ........)

7. Conditions of Repayment.-This clause is sometimes combined with the preamble which recites the amount of the debt. It provides for the amount of interest, how this is to be paid, size of the monthly payment of dues on shares, responsibility for taxes, insurance, interest on prior mortgages (if any), and length of time the contract is to run. In the case of most association mortgages, the length of time is determined by the maturity of shares to the amount of the mortgage.

$(\ldots \ldots \ldots$ to pay interest thereon, and also the sum of $\ldots \ldots \ldots$ dollars per month as dues ........... etc.)

8. Provision that the entire debt becomes due upon default of payment of principal, interest, taxes, or insurance.

$(\ldots \ldots \ldots$ if default is made...$\ldots \ldots$. etc.)

9. Signing and sealing, which may be done before a notary if desired.

The Bond or Note.-A bond or note usually accompanies a mortgage. This is the personal promise of the borrower to repay the loan with the interest and other agreed charges. The mortgage shows that the obligation is secured by the value of the physical property in case the borrower fails to pay, while the bond or note evidences the personal liability of the borrower for the whole sum. In case of default, the association may ask the court to have the property sold to protect its interest. Should it bring less than the amount of the loan, a "deficiency judgment" may be recovered on the bond against the borrower, for the amount of the deficiency.

The bond differs from a note in that it is always executed by the borrower under a formal seal, while notes may or may not be sealed. A sealed instrument was recognized by the ancient law as a document entitled to greater consideration than a similar instrument not sealed. 
Bond: (Know all men by these presents that $\ldots \ldots \ldots$ is held and firmly bound unto ......... etc.)

Note: (For value received, I promise to pay, etc.)

Warrant.-Accompanying the bond is sometimes a form of "warrant." This is an authorization signed by the borrower and directed to the attorney of the association. It expressly provides that suit may be brought in case of default, and "confesses judgment" or release to the association of all rights which borrower had before default. It is designed to shorten the court procedure.

The warrant recites in considerable detail the conditions of the loan and its method of repayment, authorizing the association's attorney to sue in case of default, and formally "quits claim" of the borrower in the property.

The tendency in all formal documents is toward simplification. The lawyers have found that essential provisions of the loan contract will be recognized by the courts regardless of the exact wording, provided the latter is clear and explicit. As a result, the older forms are being shortened and simplified as occasion makes it possible.

The Trust Deed.-The deed of trust differs from the mortgage only in the method by which the title to the property is conveyed in case of default. The purpose of the two instruments is the same. The trust deed has been adopted in order: (I) to simplify the mortgage process, (2) to secure possession more promptly in event of default, and (3) to avoid cumbersome restrictions in areas where titles were not always adequately recorded in pioneer days. It will be noticed that in some trust deeds, the bond which accompanies it is recited in full, although the bond is also executed as a separate instrument at the same time.

\section{The Trust Deed}

I. The Parties.- The trust deed differs from the mortgage principally in providing for a trustee, an outside party who 
holds the title during the life of the debt. The borrower (with his wife, if he is married) is the first party. The trustee is named as the second party. The association acts as third party.

(THIS DEED OF TRUST, made and entered into ....... by and between ......... etc.)

2. Granting Clause.-As in the mortgage, the trust deed appears to convey all the borrower's rights in the property to the trustee. The nominal consideration of one dollar mentioned in this clause is purely fictitious and will eventually disappear from the document.

(........ that the said party of the first part ........ does grant, bargain, sell, convey, etc.)

\section{Legal Description of the Property.}

(........ the following described land and improvements .....)

4. Habendum Clause.-Stating whether all the title passes under this instrument or whether part is reserved.

(To have and to hold ........... etc.)

5. The Trust Clause.-Creating a trust or confidential relationship recognized by law for the benefit of the association which lends the money.

(........ have concurrently herewith executed and delivered their bond to the third party ......... etc.)

6. Quoting the bond in full, setting forth the amount of the loan, the method of repayment, etc. This bond is a separate sealed instrument, as in the case of the mortgage. By incorporating it in the trust deed, all of its provisions are made a part of the county record, which becomes the most important part of the legal proceedings in case of trouble.

(Know all men by these presents, that $\ldots \ldots \ldots$ is held and firmly bound to ......... etc.)

7. Covenants.-Deeds ordinarily have additional promises or assurances added for the purpose of protecting the grantee in the estate which is being conveyed. The grantor thus agrees to protect the grantee in case the title to the estate is not as 
represented. These additional promises are called "covenants." (Mortgages sometimes omit such covenants.) Ordinary covenants in trust deeds are: to protect against prior encumbrances, to pay taxes, to protect against prior liens, for fire and tornado insurance, for completion of building construction. for repairs and against waste, for reimbursement of expense of the association in enforcing compliance with terms of loan, etc.

8. Defeasance Clause.-Providing for the release of the claim of the association when the obligation is met as agreed.

(........ if the conditions, provisions, and agreements above recited..$\ldots \ldots$ shall be...$\ldots$ fulfilled...$\ldots$. the property herein conveyed shall be released .........etc.)

9. Debt Becomes Due in Full on Failure to Pay dues and interest for six months. (The association has the option of enforcing or postponing this provision.)

$(\ldots \ldots \ldots$ but if default is made ....... etc.)

ro. Provision for appointment of successor of trustee in event of his death or other disability to act.

II. Permission to trustee to sell the property at public sale after .... days published notice, in case of default.

I2. Right to execute and deliver a deed of conveyance to purchaser is given to trustee.

13. Provision that proceeds of sale are to be divided in payment of the various portions of the debt, and remainder, if any, to be returned to the borrower. If proceeds of sale do not cover items due, then the withdrawal value of shares is to be applied to debt. Deficiency, if any, will be met by borrower. Borrower also agrees to pay certain other costs of foreclosures, etc.

I4. Leasing Clause.-The trustee by this clause regrants to the borrower the right to use the premises during the life of the loan, thus legally arranging for the borrower's occupancy of his own premises in spite of the apparent conveyance by the trust deed.

(....... party of the second part hereby lets the said premises to said parties of the first part $\ldots \ldots \ldots$. ) 
I 5. Fictitious consideration of lease mentioned in order to comply with all statutes.

16. Covenant of trustee to perform his trust faithfully.

I7. Signing and Sealing.-Proper signature, duly acknowledged as in other legal documents.

Choosing Between the Trust Deed and the Mortgage. - Statutes of the various states differ so markedly in their provisions concerning the instruments which may be used that forms used successfully in one state may be wholly outlawed in another. The student should familiarize himself with the forms actually in use in his own state, learning particularly which instruments will be legally recognized and the reasons for choice between them.

\section{Other Necessary Loan Papers}

Tax notices and tax receipts are collected in the loan jacket with the other papers, and it is necessary to see that these papers are kept up to date in all particulars during the life of the loan.

Wherever it is possible for personal property taxes to be "extended" upon real property if unpaid, the association must guard itself against these as in the case of other taxes. Large personal property taxes becoming a lien against property of small value might wipe out an association's equity in such property.

Insurance.-If the present building is not already insured, a policy must be written when the loan is made and a "loss payable" clause included, so as to protect the equity of the association in the property. This clause is also inserted in any policy already in force. Fire insurance is universally employed, and in large areas of the Middle West wind or tornado insurance is likewise insisted upon.

Association officials who wish to be of greatest service make it a point to learn all essential details of the needed types of insurance. Many standard text-books have been written on the 
subject, and, in addition, the insurance companies continually print up-to-date and authoritative pamphlets, on all phases of the business. These are most useful in avoiding trouble. The "New York Standard Form of Fire Insurance Policy" is in use in many states. Several interesting booklets have been issued which explain each of the clauses in this policy in detail. If a fire-insurance policy is to be a real protection, all of its conditions must be complied with.

Borrowers dislike to carry both fire and tornado insurance to the full value of the property. They feel that destruction by wind is so much less likely to occur than loss by fire that the amount of tornado insurance carried should be reduced. This argument overlooks two important points: (I) That, although losses by fire occur more frequently and the risk of loss by tornado is proportionately less, yet in a given number of losses by fire and the same number of losses by tornado the latter will show a much larger proportion of total losses; (2) that the rate of premium is reduced in accordance with the smaller risk. When a policy in force is less than the full value, the owner is "carrying his own insurance" for the balance, which may mean that he has assumed a risk of a very considerable loss, if destruction through windstorm occurs.

The interest of the association in the continuance of these policies is so great that the borrower is made to understand at the time of making the loan that they must be kept in force. If he fails to provide a renewal prior to expiration, the association must procure it. In case of failure on his part to pay the premiums promptly, the association will advance the money, adding this to the amount due, and charging interest on such advances. Since the insurance policies are made payable to the association for its protection, they must be filed in its office. To guard the interest of the association and the borrower in the matter of maintaining ample and valid insurance protection is one of the most important duties of an association executive.

Signatures.-When all the papers relating to a loan are 
drawn up, the borrower is notified to call and affix the necessary signatures. A great deal of time may be saved for the borrower by arranging to have all papers ready at the same time.

Special Procedure for Construction Loans.-A few building and loan associations refuse to provide for construction loans, since the procedure necessary requires more attention on the part of the officers than where the property is already constructed. Such associations are willing enough to advance money against property when the building is completed, after some one else has assumed the trouble and risk incident to building. This practice subjects an association to severe criticism, for the reason that it is not extending all possible service to its community.

Much more careful attention to detail must be made in case of construction loans, particularly to the matter of costs. The same careful appraisal must be made of the lot as in other cases, but estimates of construction must be carefully checked. Collusion between the contractor and the borrower may cause an over-extension of credit. It has happened in the past that in order to secure an excessive loan the contractor and the borrower have made out a contract for a fictitious sum (for example, where the actual cost was $\$ \mathrm{I}, 600$, a contract for $\$ 2,400$ was made), in the hope that the association would extend credit on the basis of the larger amount, thus making it possible for the borrower to put in a minimum of his own money.

A service of great importance can be rendered by the association in directing its members to honest contractors who can be depended upon not only to charge an equitable sum for the work which they undertake, but also to deliver a completed house with the type of construction that the borrower expects. It has been said in the past that more than 25 per cent of the persons making applications for building loans come in later and ask for additional sums, because they were misinformed 
as to the building costs. ${ }^{10}$ When care has been used in estimating the amount of the costs such later increase of loan will be unnecessary. Also by requiring that all payments be made through the office of the association, a great deal of trouble can be avoided.

In avoiding liens of mechanics and material men, the association can arrange for the borrower to "accept" the bill for material from the dealer. This "acceptance" is merely a signature of the borrower on the face of the bill, and it is accompanied by an order to the association to pay the bill when due out of the proceeds of the loan. In this way the association obtains a valid first lien without injustice to the other creditors involved in the same transaction.

Ordinarily no work is allowed to be done on the construction of a house prior to the approval of the loan and filing of papers by the association, not even hauling material to the site. This is important in all states where a mechanic's lien law is in force or where the building-supply men may obtain such a lien for material delivered. Any mechanic's lien or material lien would otherwise come before that of the association. The careful association official, of course, makes sure that all bills incurred for labor and material are paid, regardless of priority of lien, since he wishes in common fairness to see that the borrower does not become encumbered in outside obligations and also to make sure that the association is fully protected against prior liens.

If work has been started on construction before application for the loan, great care must be taken to discharge any existing liens of this character or claims for building material. Borrowers sometimes undertake construction expecting to obtain money from other sources, only to find it necessary to resort to the associations before the work is completed, hence the need for caution.

${ }^{10}$ See also address of Arthur H. Murdock (Omaha, Neb.), before United States League, I9I I (Proceedings, p. I I3). 
Before any work is undertaken, some associations make a practice of taking pictures of the lot and nearby buildings and filing these with the loan application as a permanent part of the records in the office. During construction and when the building is completed, other photographs are made, which also become a part of the permanent record. In this way the officers are enabled to check up, without the necessity of a personal visit to the site, in case the details have escaped their minds.

A serious error that has been made by a few associations is to advance all the money upon a construction loan in one sum. Where the borrower's character is unimpeachable, this process has not proved particularly harmful, but for even the best men there is a temptation to pay other debts out of a lump sum rather than to keep it all for the purpose intended. A common plan is to divide the loan into several parts, usually ninths. When the foundation is completed, one-ninth of the total is paid. When the building has reached the second floor joists or is ready to roof, another ninth is paid; when the roof is on, another ninth; when lathing is completed, another; when the plaster is thoroughly dry and a workmanlike job has been completed, another. Two-ninths can be advanced when the interior trim is approximately completed, and the remaining two-ninths when the decorating is finished and the lighting fixtures hung, the sidewalk completed, and the grading done.

Another method provides that biweekly or monthly certificates must be filed with the association stating the actual expenditure for material and labor during the preceding period. The association, under authorization of the borrower, then pays 90 per cent of such amounts, withholding the remaining ro per cent until the period within which liens may be filed has expired, after the completion of the building.

The contractor is usually required to give bond guaranteeing that he will complete the building in accordance with the plans and specifications, and that no mechanic's liens or material men's liens will be filed against the property. The bond is made out to the borrower, but is filed with the association and 
specifically referred to in the loan papers so as to protect the association's mortgage. The use of such bonds depends entirely upon the custom of the locality and the relative size of the loan. Bonds may seem expensive to the borrower, and their cost at times may be too great a burden to insist upon, but the added protection is usually found to be worth the cost. The advisability of their use depends upon the given situation and is determined by the officers of the association in each case.

It is particularly important to guard against the desire of small contractors to secure work for an entire winter. Buildings started in the fall can be completed as promptly as those started at other times in the year. The tendency to "string the work out" works a hardship on the borrower, as interest goes on just the same whether the building is ready for occupancy or not. A clause for a definite date of completion can easily be inserted in the contract, which will prevent misunderstanding and consequent disappointment. The contractor is penalized for delay in such a case, while at the same time the owner will pay a slightly higher price which includes a premium for definite delivery.

Refunding Straight Loans.-The borrower who has discovered after using a straight loan that he has no means of paying it off when it becomes due, of ten resorts to the association to help him out of his difficulties. The method of handling the refunding operation is similar in all respects to that involved in making an original loan on a building already constructed, as set forth above, except that great care must be taken to see that the association's lien is fully protected at the time of the transfer. Ordinarily the association will not pay the money for the loan to the borrower, but will put the papers of the loan in "escrow." 11

The owner of the old mortgage likewise deposits his papers.

11 The term "escrow" refers to the temporary deposit of papers (or the title which those papers represent), in the hands of a third party for delivery upon the completion of some contingent act (which in this case means when the consideration is paid). 
The money ${ }^{12}$ is also turned over by the association to the escrow officer (or trustee). The escrow officer acts as a clearing house. He uses the association check to pay off and cancel the original mortgage. In return for the original claim, the borrower has given the association a new claim. The new mortgage is substituted on the records for the old one. The borrower transfers his obligation by this process from the original lender to the association and makes his future payments under the new conditions.

The safeguards necessary in refinancing a straight loan are the same as for an original loan made by the association. All details of procedure mentioned at the beginning of this chapter must be followed for the protection of the association. Of especial importance is the search of the county record for liens which may have been recorded since the straight loan was first placed upon the books. Any such liens which are not discharged would have a prior claim to that of the association.

The necessity of refunding straight loans arises from the failure of the borrower to provide a fund for repayment when these loans become due. When no money has been accumulated for the purpose, the straight loan must be renewed in three or five years from its date, and a commission and other expenses must be paid upon renewal. At the end of the next period there is usually the same inability to pay off the debt, and it is said that because of this the average life of a straight mortgage loan is seventeen years. In such cases, the building and loan association renders a great service in substituting the installment-payment method which assists the borrower in getting out of debt.

Stock Loans.--Savings members who find themselves ready to purchase a home, or who wish to pay off a debt or to undertake a new business, have the privilege of borrowing their own accumulations from the association by pledging their stock as security for the loan. Stock loans usually may be made up to

1s The check may be made out by the association to the previous lender or to any desired third party. 
90 per cent of the withdrawal value of the shares. The ownership of shares does not change when they are pledged as collateral for such loans. The borrower does not part with the title to this security. He transfers to the association only the right to be indemnified through selling the shares in case of his own failure to pay the sum due.

The procedure in making stock loans is much simpler than in mortgage loans. A personal note is executed by the borrower for the amount of the loan, and this note recites that certain shares of the association are pledged as collateral security. The stock certificate is endorsed over to the association for that purpose, to be returned when the loan is paid. The only action on the part of the officers of the association is to check up the amount of the loan with the withdrawal value of the shares. Since the borrower is merely making temporary use of his own accumulated funds, a minimum of trouble is involved.

Clear Explanation to the Borrower.-Regardless of the type of loan desired, it is of prime importance that all the facts in connection with the loan are fully explained to the borrower when the loan is made. These include: (a) the terms and conditions of carrying the loan through to maturity; (b) his rights regarding repayment before the loan is due, that is, whether notice of repayment is required or not (usually no such notice is required), whether repayment must be made in full or if partial repayment of large sums is permitted; (c) the amount of share credits which will be applied to the loan at any time; and (d) possible changes in interest rate if this is adjusted on all loans outstanding. In the past, few building and loan secretaries have been able to figure out quickly the exact value of a retiring borrower's shares when they are to be applied to the repayment of a loan. The withdrawal value of shares of a borrower is the same as the withdrawal value of the same class of shares of a savings member.

Releasing Mortgage Before Maturity.-In case of early repayment of a loan, the credit procedure is as follows: The total amount of the loan plus unpaid interest to date is charged 
to the borrower. The withdrawal value of his accumulated shares is calculated by the most equitable method. (If a withdrawal fee is charged, this is figured at the minimum rate.) Any advance payments which he may have made which the association has not yet earned ${ }^{13}$ are computed. These credits are added together and deducted from the total amount due. The borrower is then asked to pay the difference in cash. This done, his mortgage is released and returned to him together with the canceled note. The release is next entered on the official records of the county where the mortgage was originally registered, and the title is thereby restored to the borrower.

Protecting the Association by Foreclosure.-In case the borrower defaults in meeting his periodical payments for a certain number of months (usually six), the association has the opportunity to force the collection of its funds through legal foreclosure under the terms of the mortgage.

Foreclosure procedure is only resorted to by a building and loan association after all other methods of securing payment have been tried without success. Actual experience shows that on the average only one loan is foreclosed for every I 53 loans

${ }^{13}$ For example, if he has paid a lump-sum premium when the loan was made, this total amount was calculated as a part of interest rate for the entire period. The number of months that have already expired is used as the numerator of a fraction, the total number as the denominator. The lump-sum premium is multiplied by this fraction and the resulting figure is the amount of the premium which the association has earned. For example: A loan was made January 1, I9I7, on which a $\$ 100$ premium was charged, dividends on shares averaging 6 per cent compounded semiannually, and monthly payments of $\$ .50$ per month per $\$ 100$. Maturity in $: 39$ months. If this loan were repaid on April 1 , 1924, premium earned was

$$
\begin{aligned}
& \frac{87}{139} \times \$ 100=\$ 62.59 \\
& \$ 100.00 \text { total premium } \\
& 62.59 \text { earned premium } \\
& \$ 37.4 \text { I credit }
\end{aligned}
$$

The borrower is also entitled to dividends on the credit of $\$ 37.4$ I for 87 months, but this is usually overlooked.

The laws of some states require the absorption of lump-sum premiums in a definite number of months. 
made by associations which need to use this process, which is less than I per cent $(0.653 \%)$ of all loans made by these associations. This is the record for the nation as a whole. For individual associations the record is much more favorable, for nearly two-fifths of the associations which reported their experience for twenty years in reply to questionnaires on the subject stated that they had never foreclosed a loan. A table summarizing the foreclosure experience of associations which reported from forty-one states and the District of Columbia is given in the appendix. (See Table XXXIV.)

Steps in the Foreclosure Process.-When it becomes apparent that the debt will not be paid except by the use of the foreclosure process, the attorney for the association files the necessary papers with the court, asking that the borrower be "foreclosed" from exercising any further right of title in the property and requesting that the same be sold for the benefit of the creditor. After hearing the cause (at which time the borrower has a right to present his side of the case), the court enters an order in accordance with its judgment. The property is then advertised as subject to sale for debt, and the advertisement is continued for a certain number of weeks, according to the law. If the borrower does not redeem the property within this period, the sheriff (or other county officer) sells it at public sale to the highest bidder.

In most cases, the property is bought in by the association or its agent. Purchase gives the association the opportunity to dispose of the property at a more favorable price, instead of the lower price which must always be taken at a forced sale. Frequently the transaction results in a slight profit, but since the handling of property consumes time which the officers might better spend in the extension of their business, such profit is not always desirable.

It should be noted that if the borrower's equity in the property is of any importance, he will not allow the association to foreclose. If he is in trouble or out of work, he will endeavor to borrow elsewhere and take up the mortgage on different 
terms or transfer the property to some one else who can meet the required payments.

Association officials make every reasonable effort to aid the borrower under these circumstances, finding work for him, advising and encouraging him through his period of trouble, and granting extensions of time. So long as interest payments are met, installments on the principal may be foregone for any reasonable period. Sometimes the officers negotiate sales of mortgaged property in order to relieve the original mortgagor and substitute one better able to go on with the contract. This is in keeping with the coöperative character of the institution, for the officers are interested in keeping their own expenses as low as possible in order to make a maximum profit for their membership (of which the borrowers are a part), and at the same time they wish to save their borrowers all possible expense in connection with the loans.

When borrowers get into trouble, it is generally because they become entangled in outside affairs, but by strict attention to possible delinquencies, and close check upon missed payments, the association may keep its record of collections much higher than that for straight mortgage loans, where the borrower is not regarded as an integral part of the institution making the loan.

Farm Loans.-The benefits of the amortization principle for loans on real-estate mortgages have been extended to rural credits in a considerable number of states. It makes no particular difference to the association whether the borrower makes his periodical payment once each week, each month, each quarter, each half year, or even once each year. It is sufficient that the repayment be periodical and in accordance with the borrower's income. Whatever may be the time of the year at which this income is received, the association is able to arrange for the acceptance of payments to coincide with it. Since the farmer has produce for sale only at the end of his crop year, July I and January I commonly suit his convenience for making payments upon any loans that he may make, but these 
dates of payment will be varied according to the needs and income of the farmer in each locality. Payments for both principal and interest should be carefully arranged to meet the receipt of income. Monthly payments for farmers are not likely to be successful.

When the system of lending upon farm loans was started by a small association in Ohio about 1902, there was considerable misgiving on the part of the association officials as to the outcome. Prior to that time all borrowers had made payments at shorter intervals than the half year. The association officials, however, placed a considerable number of loans on rural property surrounding their town, and the idea soon became so popular that surplus funds became a thing of the past with that particular association. As long ago as I92 I, building and loan associations in the state of Ohio had outstanding loans against farm property to the amount of $\$ 42,709,568.07$. There were I 2,955 separate mortgages that year, averaging $\$ 3,296.76$ each. This was about 9 per cent of the total assets of the building and loan associations in Ohio for that year.

Indiana made it possible for associations to lend upon farm mortgages by passing a special rural loan act. This provided for associations with a form of guarantee stock which corresponds in every way to the stock of a bank, and is similar to the guarantee stock already discussed. It is a permanent fund of capital which cannot be withdrawn; if the owner desires to sell it he must sell it to another investor. The guarantee stockholders under the Indiana law are jointly and severally liable, which means that if suit needs to be brought against them to collect any liability, it is brought against all of the guarantee stockholders. Judgment can be taken against all, so that each stockholder is thus liable for the whole amount of any indebtedness of the association. This system eliminates the mutual feature of the ordinary building and loan association, and was inaugurated in order to make building and loan credit attractive to farmers who were previously unfamiliar with the plan.

It is possible for an association to pass on the guarantee for 
its farm loans to the State of Indiana, if desired, although in practice this does not seem to be done to any great extent. The guarantee is passed on by posting with the State Auditor (as trustee) mortgages in multiples of $\$ 15,000$ on farm land of the state otherwise unencumbered, provided the mortgages do not exceed 50 per cent of the value of the real estate. Bonds can then be sold against these mortgages to secure money for further loans, both the association and the state being responsible for their payment.

Rural loan associations are not required to restrict their mortgages to farm loans, however, and it has become customary for them to extend their lending operations in the cities, where it is usually possible to charge a higher rate of interest. ${ }^{14}$

Kansas and Nebraska have also made considerable use of farm loans, although in Kansas the requirement of the state constitution that every species of property be taxed at its actual cash value in money has caused some dissatisfaction with this form of credit, since money is available from other sources that seems to be exempt from such taxation. Almost any method of assessment which will comply with the Kansas constitution will result in the borrower paying such high taxes on the combined value of the property and the loan that the cost of the loan made by a building and loan association under the circumstances is prohibitive. The tax would ordinarily be paid by the holder of the loan (the association), but would be passed on to the borrower through a higher interest rate.

The law in Kansas authorizes associations to issue ruralcredit shares, both installment and full-paid, the proceeds from the sale of which must be loaned to farmers at an interest rate not exceeding by $\mathrm{I} / 2$ per cent the dividend rate paid on such shares. Such loans may run for any period up to twenty years, and the interest and installments must be paid semiannually. Whenever the borrower desires to make payments upon the principal, he is allowed to do so, and interest ceases on the

"H. P. New, "The Indiana Rural Loan Association," in U. S. League Proceedings, 1920, pp. 198-208. 
amount so paid at the time of payment. When the loan runs for ten years or longer, it must contain a clause obligating the borrower to reduce the principal at least a certain amount semiannually or annually. No commissions or any charge other than standard fees for abstracting and recording are permitted.

The building and loan plan can be made useful to farmers by merely adjusting it to fit their needs, and the above cases illustrate a few of the methods now in use in the United States. They do not pretend to represent all of the possible opportunities for such service. Wherever the farmer can secure his loans at a lower interest rate and on equally favorable terms for repayment from other lenders, he will have small reason to resort to the building and loan association. To be successful in the rural-credit field, association loans will have to compete on equal terms with the agencies already established in the field. ${ }^{15}$

\section{SPECIAL REFERENCES}

Assignment of stock as collateral security. U. S. League Proceeding: (1916), pp. 102-108.

Construction loans. California League Proceedings (1924), pp. 29-30, 32-35. Ohio League Proceedings (1920), pp. 94-98. Youngstown Institute Proceedings, March 30, 1923, pp. 4-5; March 5, 1924, pp. IO-I 2 .

Date when interest begins. Youngstown Institute Proceedings, March 30, 1923, pp. 5-6.

Deeds. Youngstown Institute Proceedings, F-bruary 20, 1924, pp. 2-4. Excess funds. Iowa League Proceedings (I916), pp. 23-24; (I918), p. 22. Ohio League Proceedings (1916), pp. 72-80.

Farm loans. Hedrick, W. O. Building and loan associations the solution of the rural credit problem, Scientific Monthly, May, I916, v. 2, pp. 453-459. Herrick, Myron T., Rural credits, land and coöperative, New York (I9I4). Herrick, M. T., and Ingalls, R., Building and loan associations (in their "How to finance the farmer, private enterprise, not state aid"), (I915), pp. I6-23. Cleveland, Ohio, state committee on rural credits and coöperation. Iowa League Proceedings (1915), pp. 12-13, 20; (1916), p. 29; (1918), pp. 12-13. Minnesota League Proceedings (1923), pp. 23-24. Ohio League Proceedings ${ }^{15}$ T. B. Brown, "Rural Credits," in U. S. League Proceedings, 1916, np $69-71$. 
(I9I4), pp. 52-53; (I9I5), pp. I05-I2I; (I9I6), pp. 98-106; (I920), pp. 78-81. U. S. League Proceedings (I913), pp. 106-120; (I915), pp. I35-I40; (I916), pp. 60-83; (I920), pp. I98-208.

Foreclosure. Illinois League Proceedings (I918), pp. 59-6r. Iowa League Proceedings (I9I8), pp. 63-64. Mason, G. N., Redemption and foreclosure of mortgages, Chicago Law Notes, (I898-I899), v. 3I, p. I08. Youngstown Institute Proceedings, March 30, 1923, p. I4; May II, 1923, pp. 7-9.

Insurance-fire. U. S. League Proceedings (I900), pp. I30-I3I; (I9I6), pp. I49-153. Ohio League Proceedings (I9I6), pp. I9-22.

Insurance-life. Illinois League Proceedings (I920), pp. 70-74. Iowa League Proceeding (1916), pp. 43-45, 49-53. Nebraska League Proceedings (1924), pp. 51-55. U.S. League Proceedings (1909), pp. 42-52; (I9I2), pp. I26-I34; (I9I8), pp. I45-I49; (I923), pp. I63-I 76. Insurance-tornado. Iowa League Proceedings (I9I6), pp. 77-78. Kansas League Proceedings (1924), pp. I44-146. North Carolina League Proceedings (1924), pp. 52-56. Youngstown Institute Proceedings, March 30, pp. 15-16.

Interest rates. Minnesota League Proceedings (1924), pp. 4-5. Nebraska League Proceedings (1924), pp. 14-I5. Ohio League Proceedings (1920), pp. I04-108. Youngstown Institute Proceedings, March I2, I924, pp. 5-10.

Land contracts. Youngstown Institute Proceedings, May II, I923, pp. I3-I4.

Leases. Youngstown Institute Proceedings, February 20, 1924, pp. 9-10. Loans. U. S. League Proceedings (Ig03), pp. I07-I08; (I9II), pp. IIOII8; (I9I4), pp. I35-I39.

Loans-application. Youngstown Institute Proceedings, March 30, 1923, pp. 3-4; January 30, 1924, pp. I-I 2.

Loans-limitation. Iowa League Proceedings (I918), pp. 22-26.

Loans-procedure. Youngstown Institute Proceedings, March 30, I923, pp. 8-9.

Loans-recording. Youngstown Institute Proceedings, May II, I923, pp. 9-II.

Loans-straight. Kansas League Proceedings (I918), p. 15. Youngstown Institute Proceedings, March 5, 1924, pp. 8-10.

Loans-split. Youngstown Institute Proceedings, March 5, I924, pp. I-8. Mechanic's lien. Illinois League Proceedings (1918), pp. 61-63, 64-68. Ohio League Proceedings (1914), pp. 56-88; (1915), pp. 69-83; (I916), pp. 43-53. Youngstown Institute Proceedings March 30, I923, pp. 6-7.

Mortgages-forfeiture clause. Youngstown Institute Proceedings, May II, I923, pp. I4-I5. 
Mortgages-scope. Ohio League Proceedings (I920), pp. 72-73; (1921), pp.' 15 -I6.

Priority of liens. Youngstown Institute Proceedings, February 20, 1924, pp. 8-9.

Repayment of loan. California League Proceedings (1924), pp. 30-31. Second mortgages. Stern, Samuel, Second mortgage loans by building and loan associations, National Real Estate Journal, February 26, I923, v. 24, pp. 27-29. Youngstown Institute Proceedings, March I2, I924, pp. I6-20.

Sccurity. U.S. League Proceedings (1900), pp. 86-87, r30-13r. Youngstown Institute Proceedings, March 23, I923, p. II.

Title. Iowa League Proceedings (I9I6), pp. 59-74; (I922), pp. 22-40. Kansas League Proceedings (1924), pp. 50-63. Ohio League Proceedings (1914), pp. 97-100. Oklahoma League Proceedings (1922), pp. 4I-52. U. S. League Proceedings (1902), pp. 89-93, 102-107; (I910), pp. 72-75; (I9I3), pp. I87-243; (I916), pp. I16-II7; (I920), pp. 79-101. Youngstown Institute Proceedings, May II, I923, pp. 3-5, 9-II; February 20, 1924, pp. I-25.

Torrens system. Iowa League Proceedings (I9I5), pp. II-I2; (I9I6), pp. 16-21. Ohio League Proceedings (1914), pp. Ior-II4. Kansas League Proceedings (1916), pp. 22-26. U. S. League Proceedings (I9I3), pp. 223-243.

\section{GENERAL REFERENCES}

Rosenthal, Henry S. Cyclopedia, pp. 198-204; 216-229; $270-274$.

Sundheim, Joseph H. Law, pp. I07-132; I63-I74; 21 I-230.

Dumas, Jacques. Registering Titles to Land. (Callaghan \& Co., I900) Maupin, Chapman W. Marketable Title to Real Estate. (Baker Voorhis \& Co., I92I)

SHeLdon, THEOdORE. Land Registration in Illinois.

VIELe, Dorr. Land Title Registration Act of the State of New York. Cameron, Arnold G. Torrens System. (Houghton Mifflin, I9I5) 


\section{CHAPTER XI}

\section{APPRAISALS 1}

Appraisal-by committee or by individual; necessity of personal inspection; appraising the lot-street improvements, estimating cost of future improvements, effect of surrounding property upon value, capitalization of economic rent; appraising the house-points to be considered, use of symbols, conformity of property to standards of community, determination of depreciation, occupancy by tenant or owner, checking estimates of value, the one per cent rule, cubic-foot comparison; appraising buildings before construction-character of contractor, necessity of investigation; complete plans and specifications, periodical inspection during erection, use of base prices; zoning; consideration of intangible items in appraisal.

The whole subject of appraisal is of such fundamental importance in building and loan work that the fortunes of an association may rise or fall with changes in appraisal policy. The efficient officer or employee should study many of the books which deal especially with this field. This chapter merely attempts to summarize the more important elements of the subject as it affects the building and loan association.

Officers Who Make the Appraisal.-Before considering any details of the appraisal process, it is necessary to know upon whom the burden of the work will fall. Shall an individual officer or a committee conduct the appraisals? In the small neighborhood association of the past, appraisals have always been conducted by a committee, usually composed of three members. With the growth of the large modern association, practice is about equally divided between the use of committees and of individual appraisers. There appears to be

${ }^{1}$ We are indebted to Fergus Mead and K. Lee Hyder of the American Appraisal Company, Milwaukee, and R. Holtby Myers of the Los Angeles Mutual Building and Loan Association, for valuable criticisms and suggestions concerning this chapter on appraisals. 
no one best method. Choice will depend largely upon the difficulty of making the appraisal, the class or type of property offered as security for a loan, the customs in the individual community, and the men who are available for the purpose. Support is frequently given to a committee of three chosen from the association's board of directors instead of a paid special appraiser, on the ground that the board committee is felt to be more in accord with the true coöperative idea. ${ }^{2}$

An equally strong stand in favor of appraisal by individuals can be taken on the ground of greater efficiency acquired under specialization. Who makes the appraisal does not seem to matter so much as how it is done. The problem is so technical that a new profession of real estate valuation is growing up. It is being developed by "the gradual merging of the practical business man's knowledge and observation of real estate with the scientific method of thought and analysis."

The men who undertake the work must be conscientious, thoroughly acquainted with local conditions, and well trained in values. No "offhand" opinions are of any use. "The appraiser must be a student and analyst, capable of relating evidences of value and weighing them by consistently organized, logical reasoning. . . Haphazard, unorganized habits of thought do not lead to correct appraisals." 3

Personal Inspection Absolutely Necessary.-It is impossible to appraise a property properly without personal inspection and attention to many details. Committees have been known to drive up to property upon which a loan was desired and, without having left the seats of their automobiles, report their estimate of the valuation of that property. Such a committee might better have stayed at home. One of the easiest things for a builder to do is to produce an outside appearance of value when in fact he has skimped and slighted

${ }^{2}$ See address of Fremont Wood before California League Convention, American Building Association News, June, 1918, p. 256.

A careful and painstaking analysis of the subject will be found in The Appraisal of Real Estate by F. M. Babcock (Macmillan, 1924). 
many structural parts of a house. For example, the small amount saved by the use of $2 \times 2$ or $2 \times 4$ inch timbers in place of $2 \times 6$ or $2 \times 8$ material is more than offset by the structural weakness which results. On the other hand, items of especial importance in giving value to a property are the built-in features, the interior trim, the plumbing, and the heating system. No casual glance at the outside of a property can provide any adequate basis for the valuation of such objects. It is necessary to enter the house and inspect it from cellar to garret. A personal inspection often discloses evidences of thrifty habits and character which may be of as great importance to the association as the property value. ${ }^{4}$

It is not our purpose to discuss in detail all the various influences which enter into values, as lack of space prohibits such a discussion. The appraiser must be familiar with the fundamental influences governing city growth and he should make an especial study of his own city to determine what has caused movements of population and resulting values in each section of the city.

Appraising the Lot.-From the standpoint of the building and loan association, the appraiser needs to know first the fundamental things which influence the value of given lots and he should know how to check this value with that of nearby

${ }^{4}$ Men who are thoroughly experienced in the appraisal field are careful to stress this personal note. The interested student will find much of interest along this line in the writings and addresses of men like C. C. Knox, Vice-President and Appraiser of the Home Savings and Loan Company, and C. C. Pennock and C. F. McCall, all of Youngstown, Ohio; John J. Wagner of Cedar Rapids, Iowa; John A. Moore, of Kansas City. Missouri; and F. M. Babcock, of Evanston, Illinois.

In addition to the books listed at the close of this chapter, reference should be made to Mr. Knox's article in Rosenthal's Cyclopedia, pp. 223227, and transcripts of the addresses of Messrs. Knox, Pennock, and McCall delivered before the Youngstown Chapter of the American Savings, Building and Loan Institute on February 6, 1924, May 25, 1923, and March 19, I924; the address of Mr. Moore before the Kansas City Chapter of the same Institute (Moorehead Chapter No. I), February 26, 1923, and that of Mr. Wagner before the r924 Convention of the Iowa Building and Loan League. 
property, both vacant and improved. Before he leaves the office, the following things should be noted on his transcript of the loan application:

Size of lot.

Number of lot in plat.

Corner or inside.

Above or below grade.

Between what streets.

How many lots to the nearest corner.

Distance from car line.

Assessed value of lot.

In case of doubt as to the size or shape of the lot, a survey should always be made. This is of importance where lots are increasing in value and in districts closely built-up. When "foot-frontage" is high in price, a difference of a few inches may greatly alter value. Odd shaped lots, lots of unusually small size, hillside or filled-in lots, or lots in a hole call for very careful treatment. Unless they are conservatively valued, difficulties will arise.

Location is of primary importance, for the home buyer will not pay high prices in an unattractive neighborhood. Cities originate where they have a point of contact with the outside world, but they grow along lines of least resistance, according to topography and soil structure. If the lot is located within convenient reach of downtown, with a pleasing route of approach, it will be regarded with more favor than sites which can only be approached through an unattractive portion of the city or over a hill.

Street improvements are of almost as much importance as the lot itself. Their condition must be carefully considered, especially in newly developed residence districts. Should the improvements not be in, the householder will be obliged to pay for them when they are installed, and if they are added during the life of a loan and paid for by means of street improvement bonds, the claim of the bondholders for the cost of such improvement precedes the lien of the association against the 
property. Payment of street bonds is generally distributed over a long term of years, and a certain amount of supervision is required to make sure that no default in payments may occur. The association is in an advantageous position to exercise such supervision.

Improvements to be noted by the appraiser include (among other items) :

Kind and condition of sidewalk, curbing and gutter.

Type of street paving.

Sewer.

Water.

Gas.

Electricity.

Telephone. (This is of much less importance than the preceding items, because telephone connection is usually made by private companies and can not burden the property itself.)

Estimates of street paving are usually figured on a squareyard basis. Sewer installation may be figured on the foot frontage or upon the number of square feet contained in the lot, depending upon local custom. When reduced to the footfront basis, the probable assessment is more easily compared with the lot value, as the depth of the lot or the number of square feet thereon are of less importance than the width. ${ }^{5}$

Instead of attempting to study and measure each element in the value of a lot, the modern appraiser lists each "point" in its favor or to its disadvantage, and compares these points with the effect which similar points have had on recent sales of nearby property. He attempts to arrive at a price which might be the basis of a forthcoming sale of the property-a fair cash market value which could be realized at some time in the future.

s This can be seen from the comparative ease with which street-widening projects can be put through. Houses and business buildings may have a very long potential life, but they are torn down and replaced by more modern structures whenever occasion demands. When a city undertakes the widening of a business thoroughfare by moving the buildings back a few feet, it takes but a few years in modern American cities to accomplish this result for entire city blocks. 
Our courts have often attempted to define this term. "The fair cash market value of a piece of real estate is the price which a seller who is willing and able but not compelled to sell will accept for his property from a purchaser who is willing and able but not compelled to buy." This is one recent well-known definition. It applies both to the total value of the house and lot together as well as to either alone.

The type and character of the improvement increases or decreases the value of the total of land and improvements, and the value of the whole is frequently more than the sum of the values of the lot and the house considered alone. This implies that the type of improvement must fit the lot. An expensive house on an inexpensive lot is a mistake, and vice versa. In the few cases where a lot is improved to its highest and best utility, and where surrounding property is in the same condition, the value of the building has little or no effect upon the value of the lot. The aggregate value of all the buildings in a neighborhood has a definite effect upon the value of each individual lot because the type of buildings determine the character of a neighborhood.

The value of the lot may also be found by capitalizing "cconomic rent" plus expectation of its future value and income at the current rate of interest. That is, if the gross rent paid for a given building and lot is known, all costs can be deducted from it, such as charges for service, commission for collection of rent, all taxes, insurance, repair costs, allowance for depreciation, and interest on capital actually invested in the building. The remainder is approximately economic rent as nearly as this figure can be determined. (Economic rent is the price paid only for the use of the site itself.) Dividing this figure by the current rate of interest will give a value which may be used to check appraisal made under the "point" system mentioned above.

For example, if the monthly rental of a house is $\$ 75$, commission for collection 5 per cent, yearly taxes $\$ 200$, insurance $\$ 35$, repairs $\$ 75$, de- 
preciation 3 per cent, interest on capital 6 per cent, and cost of construction $\$ 5,000$, we have the following:

\begin{tabular}{|c|c|c|c|}
\hline Rent & $75 \times 12)=$ & & $\$ 900.00$ \\
\hline Deduct: & Commission. & $\$ 45.00$ & \\
\hline & Taxes ..... & 200.00 & \\
\hline & Insurance .. & 35.00 & \\
\hline & Repairs ... & $: 5.00$ & \\
\hline & Depreciation & 150.00 & \\
\hline : & Interest $\ldots$ & 300.00 & 805.00 \\
\hline Net & en & & $\$ 95.00$ \\
\hline
\end{tabular}

Capitalizing economic rent at current interest rate of 6 per cent:

$$
\frac{\$ 95}{.06}=\$ 1,583.33=\text { value of lot. }
$$

Wide differences in the rate of income from land occur in the same city, due to different uses. A growing neighborhood is always a safer place in which to lend money than one which is deteriorating. The direction of growth must be carefully noted, and when a city is found to be growing away from a site, the percentage which may be loaned safely will be much less than when the population is moving toward a given site.

A check upon the value of the lot may be made by estimating the value of the house in the usual way and subtracting this from the total price asked for the house and lot, and comparing this with the value of other lots nearby. Although the figure obtained is not accurate, it answers very well as a check.

When all of these elements have been taken into consideration, the appraiser is in a position to place a valuation upon the lot, which may be expressed either as so much per front foot or so much per square foot. As already remarked, the frontfootage basis is usually the more satisfactory figure. The resultant figure should be checked with the estimate of other appraisers, if possible.

Appraising the House.-The building which is most suited to its location is the one which will yield the largest and most certain net return for the longest term of years, 
provided it will not be subject to supercession by other uses. "Tax payers" (small temporary structures) are sometimes true economy. Few residences answer this description, but the appraisers must always keep in mind the best possible standard as a "norm" ${ }^{6}$ from which to measure other houses.

The value of a house is determined only after consideration of many items which do not affect the value of the lot. These would include:

Size (to be obtained by actual measurement).

Total height.

Height of each floor, including basement.

Number of stories.

From these figures can be obtained the cubic content and if the appraiser makes use of appraisal tables he can save much time in calculating the actual size. ${ }^{7}$

Symbols make it very much easier for the appraiser to record the items inspected than it would be if he attempted to write out in long hand each detail in a house. There is no uniformity in the use of symbols, but a system is gradually being developed by which single letters of the alphabet denote certain items, with figures to modify each letter. For example: "A" may mean oak and pine finish on first floor, pine finish upstairs, hardwood floors, wired and piped for gas; "B" might refer to brick; "S" to stone; "C" to tile or cement. The first symbol might be modified by using " $\mathrm{A}$ " alone for standard oak and pine finish and the figures " $\mathrm{"} \mathrm{if} \mathrm{oak} \mathrm{and} \mathrm{pine} \mathrm{were} \mathrm{used} \mathrm{down-}$ stairs, " 2 " if pine upstairs, " 3 " hardwood floor, " 4 " wired, and " 5 " if piped for gas, etc. A standardized set of symbols can be worked out which will add greatly to the convenience of appraisers.

6 "Norm" is an abbreviation of "normal," a standard, or point of reference, from which other values are measured.

${ }^{7}$ Complete appraisal tables prepared by C. C. Knox of Youngstown, Ohio, are issued in book form, Principles of Real Estate Appraising, published by Robert C. Knox. Youngstown, Ohio, 1924. 
Other items which the appraiser must note are:

Type of construction and material used.

Age of building and improvements.

State of repair.

Built-in features.

Untinished rooms.

Plumbing: kind and condition, including number of baths, toilets, etc.

Heating system: kind and condition.

Wiring for electricity.

Piping for gas.

Garage, single or double, separate or part of house.

It will thus be understood that a definite attempt is being made to examine all the factors which give the property value. The design of the house is also of great importance, as it will not bring as much as its cost if it is built along unusual lines. Room arrangement must be similar enough to customary usage to avoid criticism. Wasted space, obsolete or freak "lay-outs," and poorly placed windows and doors definitely reduce values.

View, exposure of house, soil, trees, shrubs, lawn, garden, hedges, and arbors, all have their effect upon value, and must be considered. When the district is changing in character, the neighborhood elements play a large part, but religion, race, and standards of living of the neighborhood, density of population, parks, churches, clubs, and schools are integral elements of all settled districts and have little direct effect upon the value of individual properties.

Prices which people are willing to pay for their homes are determined by many factors:

(a) Costs of building construction at the time of purchase.

(b) Level of salaries and wages.

(c) Level of apartment rents.

(d) Number of home seekers.

(e) Supply of houses for sale.

(f) Possibility of resale in case of necessity.

(g) Desirability of the neighborhood. 
The relative importance of each may only be guessed, but each plays some part. "The appraiser must weigh all such factors, ... [and observe] their effect upon the actual sales of similar properties." 8

In general it may be said that the total price of a home should never exceed three times a man's annual income, and few can carry so large a burden. If it can be kept within the range from one and one-half to twice the income, no difficulty should be experienced by a borrower in completing the purchase.

The improvements on a given lot must be suited to the neighborhood. A more favorable appraisal and a higher value can be given where the house is not more elaborate than the average of surrounding houses. Neighborhoods where the character of property is above the average always attract other citizens anxious to get into this class. As a result, if the house is somewhat smaller than the average (but not too small), it will be idle less of the time than if it is larger than the average, and it can generally be sold with little or no loss in case a sale becomes necessary. The reason is that the average resident will be unable to support a more expensive house than other residences nearby, for people who can afford to keep up such a property will move into neighborhoods where properties of greater value abound. Capital can very easily be wasted, therefore, by erecting homes too expensive for the neighborhood; and the appraiser must take this into consideration in his estimates.

After the principal figure has been computed, the rate of depreciation and the actual amount of depreciation according to the life of the building must be carefully computed. Average depreciation on a home is considered to be 2 per cent per year throughout the United States. This figure, however, must not be adhered to too closely, as true depreciation will depend upon the type of material from which the house is

${ }^{8}$ See the well-developed discussion by Babcock, in his "Appraisal of Real Estate," especially pp. 207-212. 
constructed and the degree of skill used by the builders. A 2 per cent rate assumes that the building will last fifty years, which is much too long for the average American home. The shorter the prospective life of the building, the higher the rate of depreciation should be. Cheaply constructed houses as in some parts of California and the South will last scarcely twenty years. This makes a 5 per cent figure for depreciation absolutely necessary for such houses. Thirty year houses call for $3 \frac{1}{3}$ per cent depreciation; forty year houses, $2 \frac{1}{2}$ per cent; fifty years, 2 per cent. The U. S. Treasury Department allows income tax payers to deduct 5 per cent on wooden structures and $2 \frac{1}{2}$ per cent on brick. When the depreciation rate is too low, a loss of value occurs in excess of this rate and this results in too high an appraisal.

The appraiser should also inquire whether the house is occupied by a tenant or by the owner. Houses occupied by tenants are abused much more than houses occupied by owners. If the owner lives in the same neighborhood, he will be able to oversee necessary repairs promptly, but if he lives in another part of town or in another city, destruction may exceed repairs. This may not be due to willful neglect on the part of the owner, but because of the difficulty of having repairs made at a reasonable cost when the owner is at a distance from the properties.

It is well to check the estimates of value in every possible way. Items which may be used for checking purposes include the number of vacant houses in the community, prospective or possible vacancies, the rental value (the annual rent that might be received from the property), cost to the present owner, date of purchase, present selling price if different from cost. It of ten happens that a house and lot may not sell for their true value due to the differences in the relative position and bargaining power of the buyer and seller. If either is forced to complete the deal quickly, he must accept a sacrifice. A buyer who is required to secure accommodations in a hurry may pay more than the property is worth. This is particularly true at a time 
of real-estate activity, such as has been experienced in the past few years. Residences have been known to sell for from 50 to 100 per cent more than their appraised values. Such unusual selling prices are of small practical importance because they do not represent conditions which will exist in the future. Every precaution should be taken to discover the actual cost of construction and the real value if possible. It should be recognized that real-estate values are subject to the same fluctuations as those of other commodities.

There is a so-called "one-per-cent rule" for appraising residence property in certain parts of the country. If a house rents over a term of years for $\$ 50$ a month, or $\$ 600$ a year, the one-per-cent rule applied to the monthly rent would indicate that the value was $\$ 5,000$. This figure is based on the assumption that when taxes, insurance, and repairs have been paid, and depreciation allowed for, the net return to the owner will be approximately 6 or 7 per cent. ${ }^{9}$ This again is only a check against value, because with rapidly rising taxes and other costs, rents do not always keep pace with the expenses and they also lag when values are falling.

In apartment houses the figure must be very much higherprobably between 15 and 20 per cent per year of the value of the property must be received as rental in order to net 6 or 7 per cent to the owner. The reason for this is the added operating expenses of keeping up apartment buildings. Water, heating, and janitor service run very much larger per occupant in apartment houses than in a home. Painting, papering, and repairs to plumbing must be made at frequent intervals. Sometimes these items must be cared for every year, whereas in the private house, painting is done only once in two years or more. Loans made upon apartment houses are usually too speculative for the average building and loan association, and in addition they fail to encourage home ownership.

"A less conservative estimate is the "ten-per-cent rule" which is applied to the yearly rent. Under this rule, the value of the above property, renting for $\$ 600$ a year, would be $\$ 6,000$, instead of $\$ 5,000$. 
Valuations are frequently reduced to a cubic foot basis for comparative purposes. The cost of construction in one part of the country can not be used in estimating values in other places, but it is useful in a particular city. Bungalow construction runs from perhaps 20 cents per cubic foot (or even less) to as high as 45 cents or 46 cents per cubic foot. The difference in these figures is due largely to weather conditions. Buildings in the north must, of course, be more resistant to cold, must provide efficient types of heating plants, large storage space for fuel, etc. The great variations in structure make comparative figures impracticable. The large appraisal companies, which maintain specialized field forces for the appraisal of every sort of property, never attempt to compare buildings on a cubic-foot basis. One of these companies writes: "Without exception, our appraisers list and describe all elements entering into building construction as well as fixed building equipment, such as heating, lighting, plumbing, sewerage, etc., and upon receipt in the office, unit costs are compiled based on actual local conditions, also prices of material and labor which are applied direct to the bill of quantities." 10

Many things affect cost. In certain parts of the country, it is not the custom to build cellars, strange as this may seem to most people in the United States to-day. The housewife is obliged to put up with makeshift accommodations in place of cellar storage space. Labor conditions vary greatly in different parts of the country, hours of work being similar in many cases, but wages varying greatly, and the quantity of finished product expected of the workman shows even a greater difference. Cost of materials in this day when many nearby products have been exhausted depends largely upon transportation. Lumber which is used in the district which centers in Chicago travels a minimum distance if it is produced in the South, but there has been adjustment of railway rates and competitive conditions to put the Pacific Coast producers practically on a par with those in the South, so that the cost of every thousand

${ }^{20}$ Letter from the American Appraisal Company, Milwaukee, Wisconsin. 
feet of lumber delivered in the Middle West is essentially the same, regardless of its point of origin. A glance at any map showing lumber production will show the present relative importance of areas producing lumber and the part which transportation plays in such a situation. ${ }^{11}$

In 1922 , the distribution of lumber production, according to the U.S. Forest Service, ${ }^{12}$ was as follows:

\begin{tabular}{|c|c|c|}
\hline & $\begin{array}{c}\text { Thousand } \\
\text { FEET }\end{array}$ & $\begin{array}{l}\text { Per Cent } \\
\text { of Total }\end{array}$ \\
\hline Northeastern States .. & $1,423,377$ & $4 \cdot 5$ \\
\hline Central States ........... & $1,762,298$ & 5.6 \\
\hline Southern States ... & I I $, 974,77$ I & 37.9 \\
\hline N. Carolina Pine States............... & $2,408,540$ & 7.6 \\
\hline Lake States $\ldots . \ldots \ldots \ldots \ldots \ldots \ldots \ldots$ & I,944,236 & 6.2 \\
\hline North Pacific States.................. & $8,860,045$ & 28.1 \\
\hline South Pacific States................. & $\mathrm{I}, 720,556$ & 5.4 \\
\hline North Rocky Mountain States.......... & I,I6I,039 & 3.7 \\
\hline South Rocky Mountain States.......... & 268,843 & .9 \\
\hline All Other States...................... & 45,183 &.$I$ \\
\hline Total & $31,568,888$ & 100.0 \\
\hline
\end{tabular}

\section{Appraisement of New Buildings Before Construc-} tion.-The appraiser faces several contingencies when he attempts to estimate the value of a house before construction is undertaken. Of prime importance in this connection is the character of the builder. Private owners are misled at times into the belief that the lowest bid offered by contractors is the cheapest for them. This is a correct assumption if all the contractors bidding upon the job do equally good work. Differences in price among contractors are likely to depend more upon methods of construction than anything else. Therefore, when an appraiser attempts to discover the probable value of a house before it is built, he must know whether the particular contractor builds average type of construction, or above or

"See map, Figure 64, page 114, Whitbeck and Finch Economic Geography (Prepared by the U. S. Forest Service).

"Figures of the U. S. Forest Service as published by the National Lumber Manufacturers Association 
below the average. For example, if the average cost of residences in the town is 28 cents per cubic foot, certain contractors will erect buildings which fall into the 28 -cent class, others will put up 26-cent houses or less, and another group will erect the type worth 30 cents or more. The type of construction which will be used must be known in advance of anything else.

The same tests of desirability as were mentioned in connection with the appraisal of a house already built should be applied to the contemplated improvements on a given lot. Sizes, material, etc., can be determined from accurate and carefully prepared blue prints and specifications, but reliance solely upon the contract may bring in a large element of error. Detailed plans and specifications of the entire house are indispensable if an accurate appraisal is to be made. These should include basement and foundation plans, floor plans, front and side elevation details, etc., and definite specifications for all material to be used. A copy of the blue prints and specifications (initialed for identification) and all contract prices should be included among the records of the association before construction is undertaken.

The appraisal of a house during construction includes inspection at each step in erection. Not less than six personal inspections are necessary, and many associations use nine or even ten inspections between the application for the loan and the final completion of the house.

Prices of material vary so much from year to year that the only safe method is to find a base price of all standard material for some previous year, or else a ten-year average. Local material men should have such information on their books, or it can readily be obtained from many national associations of material producers. It has become the custom in recent years to adopt I9I3 prices as base prices. The reason for the use of I9I3 is that it is the last complete calendar year prior to the opening of the World War. By taking this year as a base, no influences due to the war were included. Other influences which affected price in that year may be disregarded for pur- 
poses of comparison. If a ten-year average is adopted, it is necessary to select years which include a full swing of the business cycle, otherwise the resultant figure will not be satisfactory. By a full swing of the business cycle is meant a period which involves price changes from a minimum to a maximum, a period long enough to give price influences time to work out (for example, I9I4-I92I). In case the prices fluctuate violently in a single year due to unusual causes, an average must be carefully selected in order to avoid these extraneous influences.

When the base price has been adopted, the prices of materials for the current year can be compared with the base and the appraiser can use his own judgment as to the difference between these prices; that is, he can estimate from his experience in the city whether or not the new prices would be a safe basis for evaluating a piece of property. In determining the safety of using a given price, the appraiser must constantly bear in mind possible changes in value in the future. The value to-day is based more directly upon the probable price of the property ten years in the future than upon anything else. No rule can be laid down for making such estimates, as it all depends upon a given situation. The essential thing to remember is that the new building must be completed in accordance with the plans and specifications and that the material which the appraiser used in his estimate must actually be used in the construction.

Zoning.-City ordinances restricting the type of construction which may be used in given areas are designed to protect property values. Areas which are occupied essentially for residence, retail business, wholesale business, or manufacturing, are set off from each other. This is not done arbitrarily, as is sometimes supposed, but only after careful expert investigation. Experts differ among themselves as to method, but their purpose is the same. The principal difficulty which has arisen with zoning ordinances in the past is that after property owners have undertaken a certain type of construction in a given 
neighborhood, the ordinance has been changed in too short a time, permitting detrimental construction nearby.

Vast areas in every city in the United States are in an intermediate stage, in which they are ripening into a higher use. At first glance one wonders why old residences remain on streets which are being invaded by retail stores. If the neighborhood is a good retail neighborhood, why should not all owners find it profitable to tear down residences at once and erect business blocks? The reason is obvious. The time has not yet come when it would be profitable to do so. Residents are astonished when business houses are established near them, but business moves very slowly. A house changed into a store may or may not presage retail development in that particular block. It is sure to have an effect, however. When a store is opened in a residence block, a period of waiting occurs. People hesitate to undertake either purchase or new construction nearby until they know whether or not the district is to change from residences to stores. Local retail stores almost always reduce nearby residence values. New buyers fear the change may affect their investment.

A zoning ordinance which is properly designed and adequately enforced is of great advantage in protecting property values. It tends to restrict the use to which property may be put, and thus keeps out undesirable elements. Residence districts cannot be invaded by gasoline filling stations or unsightly stores in basements or in the first floors of houses. Garages, funeral or undertaking parlors, and factories are not allowed among apartments or high-class stores. The ordinance tends to stabilize values, and since property values are more of the future than of the present, it gives a distinct protection to the appraiser and the association for which he is working.

Unappraised Values.-In addition to the physical characteristics which admit of appraisal, many other items add to the safety of residence loans. With the development of the family, the home acquires a sentimental value which may prove 
to be the strongest influence in maintaining regular payments on the loan. The monthly payments constantly reduce the amount of the loan, thus increasing the margin of safety. In those states where the home is exempt from execution, or may be declared exempt in case of financial difficulties, the character of the security is thereby enhanced. The careful appraiser will consider these and other intangible items before placing a final value on any property.

\section{SPECIAL REFERENCES}

Appraisal. Iowa League Proceedings (1924), pp. 61-73. Ohio League Proceedings (I9I6), pp. 8I-83, I06-108; (I9I7), pp. 74-80; (I920), pp. 73-74; (1922), pp. I46-149. Oklahoma League Proceedings (1922), pp. 46-53. Youngstown Institute Proceedings, March 30, I923, pp. 7-8, IO.

Building costs. California League Proceedings (1924), pp. 50-53. Building material. Missouri League Proceedings (1919), pp. 33-46.

\section{GENERAL REFERENCES}

Rosenthat, Henry S. Cyclopedia, pp. 223-228. Babcock, Frederick Morrison. The Appraisal of Real Estate (1924). KNox, C. C. Principles of Real Estate Appraising (1924). Estimating Building Costs and Appraising Buildings. (Ist ed. N. Y., I924). 


\section{THE BORROWER AND THE ASSOCIATION}

Basis of credit; securing the borrower's coöperation; importance of borrower recognizing his obligations and responsibilities; adjustment of payments in accordance with borrower's income; rights of member withdrawing to build home; compound-interest accumulations; single-family vs. multi-family houses; advantages of the high percentage loan; calculation of loan costs; straight mortgage loans; reasons for use of bords or notes in addition to mortgage; transfer of loan.

Probably there is as much of accident as of conscious choice in the selection of a lending institution when a borrower starts his search for a loan, but the loan will be granted because it comes within the type of credit which the lending institution has found satisfactory, or refused because it does not meet the requirements. The "essence" of credit is the same, regardless of the institution that creates it, for the term has a meaning so definite that when people say that a particular man's credit is "good," or "fair," or "poor," all who are financially minded know just what this means. Credit always varies with the individual. It has its foundation in the fundamental ideas of (a) ability to pay, (b) willingness to pay, and (c) the social means of enforcing payment. ${ }^{1}$

There is nothing disgraceful in a mortgage when it is used for the purpose of acquiring a home that the family can afford. It is no longer a thing "to be raised and then dramatically burned." After some sacrifices in setting aside a fund with which to make a first payment, a family can live in its home while paying for it, and the money which formerly was ab-

3 For a clear-cut, thorough analysis of the foundations of credit, the reader is referred to W. A. Scott, Money and Banking (1916 ed.), pp. 99-102. 
sorbed by rent now pays a major portion of the installments on the purchase price. The development of such a system is due to the economic use of coöperative credit. Without the borrower to use the accumulating funds, there could be no building and loan association.

The borrower that the building and loan association is seeking is one who has such a high regard for the sacredness of a contract that, with him, only the first two of the elements mentioned above are important. Character is often of far more importance than property, but character backed up by property is the safest type of security.

When the association is obliged to resort to legal process to collect its money, the expenses of operation mount very quickly, and one of the greatest advantages of the association is lost. As expenses increase, profits decline or rates of interest must advance. At times, of course, borrowers fail to pay, and the provisions of the mortgage must be enforced against their property; but the number of foreclosures is much smaller than it is for other institutions which lend on mortgages.

Another great difference between associations and other lending institutions lies in the fact that there is a personal relation between the borrower and the association officers. They are neighbors first, and business associates afterwards. They are interested in the welfare of the community, and they recognize that a community is not well off when its institutions are in financial difficulties.

Gaining the Coöperation of the Borrower.-A vital element in the situation is the fact that the borrower himself becomes a member ${ }^{2}$ of the association. He is a part owner of the business, and because he is an owner he cannot afford to let anything go wrong with it. "One of the greatest cures for radicalism that has ever been devised is to give the reins of government to the man who advocates radicalism," Professor Stephen W. Gilman is fond of pointing out. A man may con-

${ }^{2}$ We asked a number of associations about their practice in selecting borrowers, and out of 256 reporting, 247 required that their borrowers be 
demn management by the "other fellow," but let him assume an office and he may become the most conservative of the conservatives. So with the borrower. If the loan is merely a cold-blooded business proposition in which the terms are ironclad, any borrower will meet it in the spirit in which it was made, so long as he is able. But in times of adversity - (and all borrowers face trouble at some time during the life of a loan) - he will not make any unusual effort to restore the loan to a paying basis. Perhaps he assumes that the lender stands to lose more in case of default, in which case he may not grasp the lender's point of view.

This is different in the case of a building and loan association. On taking membership the borrower has assumed a risk of ownership. He is no longer an outsider with the "other fellow" making all the profit. He pays interest on the money borrowed, but he also receives credit for the profits which his dues have earned. Should he fail to meet his obligations, he would lose his property and forfeit the esteem of his neighbors, and fellow-members in the association.

Arrangement of Repayment.-No loan, whether it is from the building and loan association or any other institution, is safe unless the method of repayment is definitely arranged members, and 9 made no such requirement. These were divided geographically as follows:

Section

\begin{tabular}{ccc}
$\begin{array}{c}\text { Number } \\
\text { Report- }\end{array}$ & $\begin{array}{c}\text { Requiring } \\
\text { Membership }\end{array}$ & $\begin{array}{c}\text { Not Requiring } \\
\text { Membership }\end{array}$ \\
25 & of Borrowers & of Borrowers \\
37 & 25 & None \\
52 & 37 & None \\
55 & 52 & None \\
59 & 53 & 2 \\
28 & 56 & 3 \\
\hline 256 & 24 & 4 \\
\hline
\end{tabular}

Totals

Northeastern States

Eastern States

Southern States

247

9

In 1893 , according to U. S. Commissioner Wright, 26.25 per cent of the members in the building and loan associations in the United States were also borrowers. The current percentage is unknown. 
by the borrower at the time the contract is signed. Probably more borrowers fail because they do not compute the cost and the exact method which they propose to use in repaying a loan than for any other reason. The man buying a home in which he expects to live is in no different position in this respect than any other borrower. The new home yields its owner many other satisfactions beside the mere saving of rent. But in spite of this fact, many unforeseen payments must be taken care of or serious trouble will result. These include not only interest and installments on the principal, but also taxes, repairs, and contingencies of many kinds. Many have failed to acquire their homes because they did not calculate and arrange for the payments that must be met in the first few months. The family must live during the transition period. Rent or other charges must be paid on the old home. A first payment of considerable size must be made on the new home. Interest on the loan accrues from the day it is made.

In order to care for all contingencies, the borrower should anticipate his needs by becoming a savings member and build up a "cash reserve" as large as possible in advance of his application for the loan. He can then approach the association with a definite proposition, wanting to buy or build a house of a certain kind for a definite price, and desiring a loan of the balance of the purchase price. When the size of the loan is known, and the amount of the periodic payment has been determined, the problem becomes one of merely adjusting the payments to the borrower's income. It is fatal to rely upon a hoped-for income about the realization of which there is the least doubt.

If the borrower has been a savings member before contracting for a loan, he should be allowed in all cases to withdraw his accumulated share holdings in order to apply their value on the purchase price of his home. He is entitled to receive the full amount of both dues payments and profits in such a case, regardless of regular practice of the association, because his 


\section{THE BORROWER AND THE ASSOCIATION}

loan will keep him as a member of the association until it is paid off.

In case a withdrawal fee is demanded, and the shares are nearing maturity, it is usually possible to avoid the penalty for withdrawal by borrowing against their book value. ${ }^{3}$ For example, in an association where maturity is expected in I I years and 9 months, \$200 shares may have reached a book value of $\$ 196.30$ in I I years and 6 months, at which time they could have a withdrawal value of $\$ 184.64$. It is usually possible to borrow up to 90 per cent of the withdrawal value of savings shares, which in this case would be $\$$ I66.18. Interest on this sum at 6 per cent would be $\$ 2.50$ for the remaining period of three months. If the member borrows instead of withdrawing, he can make a net profit of \$9.I 6 per share on the transaction. It would be necessary to pay the regular dues for the remaining three months, but this money would be returned when the shares matured, together with the balance over the loan.

Many of us fail to realize the possibilities of compound interest in aiding accumulation. It happens that $\$ 43.65 \mathrm{a}$ month for twenty years will create a fund of $\$ 20,000$, if dividends average 6 per cent compounded semiannually. Or in ten years the same monthly payment will amount to $\$ 7, \mathbf{1} 25 \cdot 32$ :

Putting $\$ 20,000$ at 6 per cent compound interest, the investor can have:

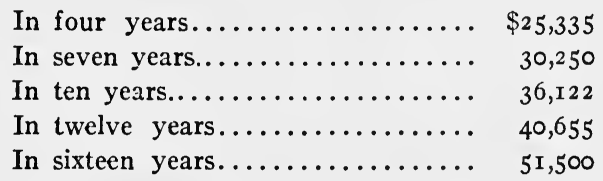

The principal cause of poverty in old age is found in the unwillingness of people to recognize the advantages of consistent effort in saving for a definite purpose in a definite time, and the determination to accomplish that end.

s This practice is also suitable for regular savings members who wish to withdraw before maturity. See also Chap. IX. 
Ambitious young men always want to provide for their families homes which will be thoroughly up-to-date and suited to the class in which they live, but this ambition frequently outruns their income and it has caused many to undertake far more than they can complete in the purchase of a home.

A new home should cost not more than three years' income, and it is a safer proposition if it costs less, especially if it keeps within the income of two years. Telling a young man with a $\$ 2,500$ salary that he must live in a $\$ 5,000$ house may bring scorn on the advisor's head, for other men on the same salary are living in better homes. In a period when economic conditions are more or less upset, there may be some justification for building a more expensive house, but regardless of the size chosen, the cost must not become a burden. Interest, taxes, repairs, and depreciation are real items of cost, and while depreciation is not an "out of pocket" cost, it is none the less a thing that must be provided for in any scheme of financing.

Income-producing houses may sometimes prove an acceptable solution of the housing problem. A house for two or three families can be designed with all the dignity and charm of a separate home, and such houses are not a detriment to any neighborhood. Rents derived from the other apartments in a well designed home may very well be used by a young man of small income to offset the high cost of building a larger house than he needs for his own family. The multi-family house provides each family with a home at less cost than if they live in separate buildings.

The amount that can safely be borrowed against a given property can only be discovered by careful investigation. In the older settled districts of the East where values are stabilized, associations make a practice of lending a large proportion of the value of the property, but as we pass westward across the country, we find the proportion which an association is willing to lend grows very much smaller. A principal reason for this is the instability of values in the newer portions of the country. A value determined upon unsound principles is always 
a gamble (the boom days of the West are not so far past that prices which arose in those days may be forgotten), and as a result a 50 per cent loan in some parts of the West may be as liberal as a 75 per cent loan in the Northeastern States.

One decided advantage in the use of a high percentage loan is the fact that it renders second mortgages unnecessary. That is to say, the average borrower may not have accumulated a cash reserve of 50 per cent of the value of his prospective home. If he places a first mortgage for 50 per cent, pays 25 or 30 per cent out of his own money, and borrows the balance on a second mortgage from some one else, the costs of the second mortgage may actually be the greatest part of his expense. Not only is the interest rate high, but the commissions or discount to which second mortgagors must usually submit sometimes make the cost prohibitive. A heavier single mortgage, therefore, may not only cost the borrower less in the long run, but also may be to the advantage of the lender, because smaller costs of the one large loan enable the borrower to keep his promises without trouble.

Where the percentage desired is higher than the association cares to lend on its first mortgage, the "split" loan already described has been used with success and satisfaction to the association and the borrower, as well as to the seller of the property. ${ }^{4}$

Advantages of the Association Loan.-(a) The outstanding advantage of the building and loan association is its use of the principle of amortization. By small monthly or weekly payments the loan is "killed off" over a period of time so that at the end of the contract it has completely disappeared. For example, the man borrows a thousand dollars from an association at 6 per cent interest, and by paying \$10 each month for about 138 or 139 months he will have accumulated a fund of a thousand dollars with which to pay the debt, besides paying interest on the loan in the meantime. This sum comes

${ }^{4}$ See Chap. X, pp. 193-197. 
not alone by his payments, but by the addition of profits which the association has earned.

The practice of crediting on the loan each of the separate payments, thus reducing the principal each month, instead of applying the payments on shares, may make a difference to the borrower from a legal standpoint in case the association fails. It makes little practical difference because of the small likelihood of failure. The legal difference hinges upon the liability which attaches to the borrower. The mortgage and note call for the repayment of the full amount of the loan, and the shares which are accumulating a sinking fund to pay off the loan constitute a separate part of the transaction. If the association should fail at any time during the life of the loan, the books would show that the borrower owes the full amount originally borrowed. They would also show that he has a credit of the present book value of his shares. But these are no longer worth their book value, owing to the failure. ${ }^{5}$

They are worth their proportionate share of the total assets, but no more. The borrower is, therefore, liable to the association for the face value of his loan while the offsetting credits depend upon other matters. As a result, the legal responsibility is greater than where the loan is periodically reduced on the association's books, either through the method of "cancel and endorse" or by direct application of payments to the loan. The periodical reduction plan leaves the borrower responsible in case of the failure of the association only for the remaining portion of his loan and whatever amount of shares appears on the books to his credit.

(b) Of almost equal importance with the principle of amortization is the fact that the long-time contract avoids all renewal troubles and costs. The average loan made by a commercial lender upon a real-estate mortgage is supposed to be of three or

- The laws of North Dakota specifically provide that in the event of failure the borrower will receive the full amount of credit on his loan as shown by the book value of his shares. Court decisions in some other states make the same rule effective. 


\section{THE BORROWER AND THE ASSOCIATION}

five years' duration. Actual duration is much longer, due to renewals. Loans for longer periods are sometimes made on straight mortgage, but the average lender does not wish his funds tied up too long. This may be due to the fact that we have not yet developed a real "investor's conscience" about such things in America. Mortgage loans are investment loans, and as such are not supposed to be self-liquidating in any sense. ${ }^{6}$

The investment loan is usually paid off from profits and requires the lapse of a considerable period of time before a fund large enough to retire the obligation can be accumulated. Therefore a mortgage loan running only for three years is an anomaly, for at the expiration of the term (unless the borrower sells the house or has income from some other source to apply on the loan) it will be a financial impossibility for him to pay back the amount borrowed. He can not obtain a sufficient sum in so short a time from renting or using the property.

The ordinary commercial mortgage lender insists upon as rigid an investigation before renewal of a loan on a given piece of property as was made in the first place. The property must be appraised, its present value compared with that of the previous appraisal, the title must be examined again and brought down to date, new loan papers must be drawn up, and all instruments must be recorded in the usual way. Frequently commissions are charged on renewals which are as large as those paid in the first place. All such renewal charges are eliminated by the use of the amortized loan, because the single loan contract provides for its ultimate repayment.

(c) Premiums charged by associations are used as an adjust-

'The term "self-liquidating" applies where the proceeds of a loan are used to purchase goods which will be used or sold by the borrower before the loan is due, and the proceeds of the sale pay back the loan. On the other hand, investment loans never contemplate the sale of the property itself in order that the loan may be repaid. The property is used over a period of time and the profits from its use are supposed to be large enough to pay not only the interest charges but to repay the principal as well. 
ment to increase the published interest rate. The ostensible rate advertised by an association is largely determined by competition with other lending institutions in the same city. If it is customary for commercial lenders to charge six per cent, it would be unwise for a building and loan association to ask more than seven. In order to charge a higher actual rate, many different forms of "premium" have crept into use. These premiums are called by different names (as already discussed in a previous chapter), but their purpose is the same. An association cannot charge interest and premium at a rate higher than the "contract" rate allowed to associations in the state where it is located, unless the premium is specifically exempted from the law relating to usury. ${ }^{7}$ Such a contract would be illegal and in case of default no remedy could be had at law. The building and loan statutes sometimes provide specifically that interest and premium are not to be considered usurious, which means that any rate agreed to between the association and the borrower could be collected in the courts.

At first glance it seems that the charges of a building and loan association may be very much higher than those for loans secured from other sources, but as a matter of fact, this is not always the case. In some cases the actual interest cost is less because the borrower receives credits of dividends on all amounts paid towards the principal of his loan. These credits of dividends tend to offset the interest and premium paid. The saving in other charges is also very great.

Calculating the Loan Costs.-The only correct way to compare costs of a loan secured from a building and loan association with that secured from any other lending institution is to eliminate costs which are the same in both cases. For example, if a home is being purchased and the abstract of title has not been brought down to date for a number of years, the costs of bringing this abstract down to date will be the same whether the purchaser borrows money to finance the transaction or not. Costs of that kind are not true loan costs, nor are the fees and

7 See the summary of state laws, Chap. XX. 
commissions paid to real estate agents, although both must be paid when a house is purchased.

Associations differ very remarkably in regard to the fees, fines, penalties and forfeitures which they use. These items are of primary importance to the borrower and he should carefully examine the practice of the association from which he expects to secure a loan before he actually signs a contract. If these items are merely nominal, they will make no appreciable difference, but where they become exorbitant (as they do in a few associations), the borrower should be sure that they are used for the benefit of the association itself, rather than as a perquisite of some individual, before he undertakes an obligation which includes the possibility of such charges. If he is regular in his payments and remains with the association until the loan is repaid, he would only be affected by an original membership fee, if one is used; but should he for any reason fail to make regular payments under his contract, fines and forfeitures may become a serious matter. The borrower has considerably more at stake than the ordinary savings member, and for this reason it is much more important for him to know about such extra charges than for the savings member.

The method of offsetting interest paid with dividends received should be carefully examined by the borrower. The dividends are earnings on his own money, which he is saving for the purpose of repaying the loan. This money is not idle and, therefore, the dividends are in no sense a gift. The association has put the money to work, and the borrower as a saver is entitled to the profits made from the use of his money. ${ }^{8}$

In some states, including Michigan, a statement to a borrower by an association secretary that the interest cost is less than the actual rate paid (using dividends as an offset) may lead to trouble. The courts will not enforce a higher rate than the amount originally agreed upon. ${ }^{9}$

${ }^{8}$ Methods of calculating actual rates paid when all charges are known were discussed in Chap. VIII.

- See the article of W. C. Sheppard of Grand Rapids in the March, 1918, American Building Association News. 
Effect of Fees on the Cost of a Loan.-Membership and loan fees act as an additional cost to the borrower for the use of money advanced to him by an association. If he pays off his obligation by maturing shares equal in par value to his loan, the influence of the fees on the total cost of the loan is small. But if the loan is repaid before maturity of the shares, a fee becomes of considerable importance. Property is frequently sold a few years after a loan is made. The new owner may not care to continue the mortgage or may wish to place another mortgage elsewhere. Or a borrower may be tempted to secure a loan elsewhere by the offer of a lower rate of interest, forgetting that the fees he has already paid may be called for again in making the new loan. In either event, the borrower repays his loan to the association before it is due.

When fees are charged it may pay better in some cases to carry the loan for a slightly longer period in order to take advantage of reduced costs. The following table shows the actual rate of interest paid by the borrower for a loan of $\$ 1000$ at 6 per cent, 7,8 , and 9 per cent when fees of $\$ 10, \$ 25$, and $\$ 50$ are charged.

The Straight Mortgage Loan.-The man who borrows from a building and loan association seldom makes a straight mortgage loan. This is usually confined to loans on real estate secured from commercial lenders. Only the mortgage and its accompanying bond or note evidence the transaction. No method of repayment is specifically provided. It has the advantages of simplicity and lack of red tape, but the disadvantage is that the only real security behind the mortgage in case of default is the property itself since no "sinking fund" has been established. The lender protects himself by requiring a wide margin between the amount of his loan and the value of the property. As has already been pointed out, this may be a disadvantage to a man with few savings, since it practically forces him into the hands of a second mortgagee in order to secure the difference between his sav- 


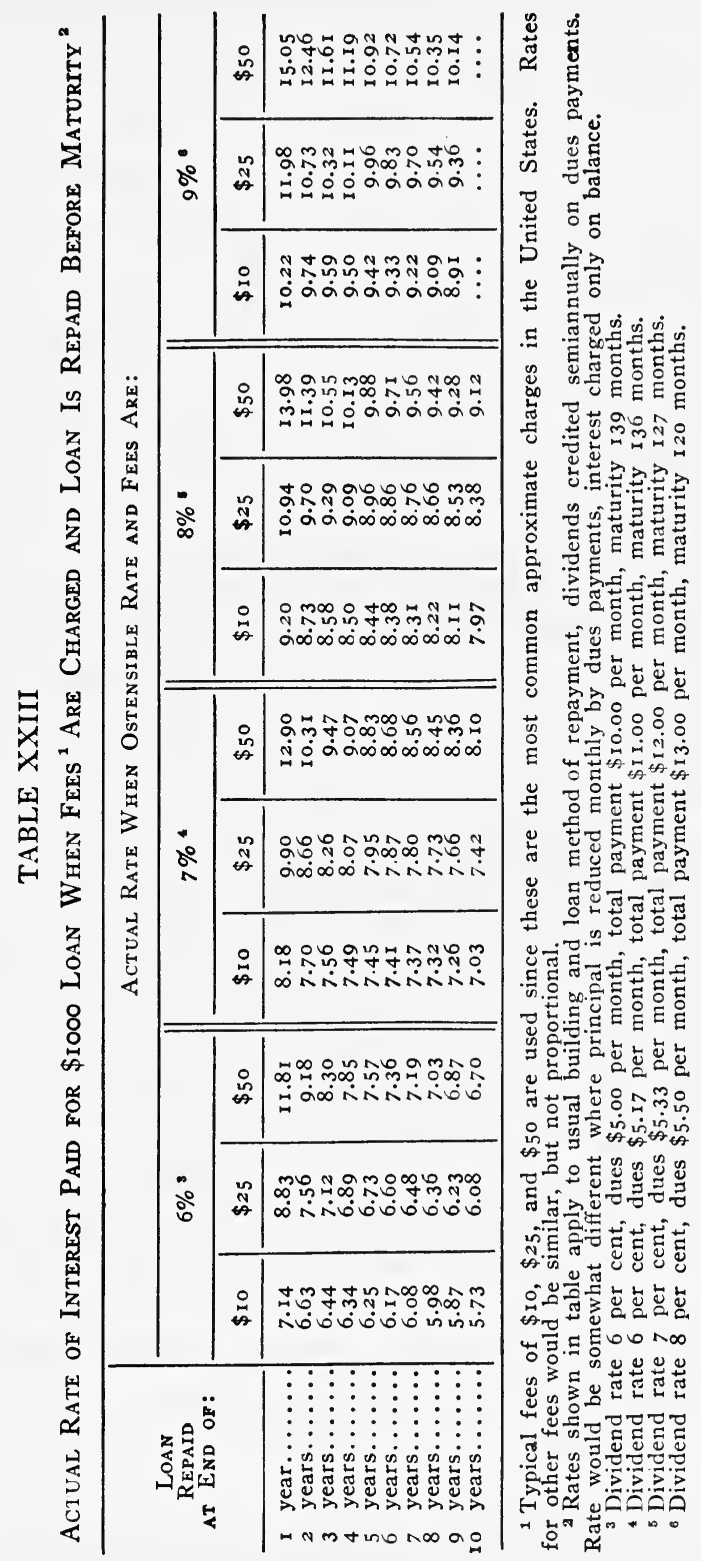


ings and the amount of his investment not covered by the loan under first mortgage.

Reasons for Use of Bonds or Notes in Addition to Mortgage.-Real-estate loans are almost always secured by a bond or note in addition to the mortgage. The primary purpose of such an added instrument is to make the borrower personally responsible for the loan. Few borrowers from the building and loan associations are continuously making loans in their daily business experience, but they are entitled to consideration as are other business men. The building or buying of a home is an event that happens but once or twice in the average man's lifetime. A few careless borrowers think of the mortgage as merely resting upon the security of their property, but these are given a wider grasp of the situation when they see that the loan is not only secured by the property mortgaged, but by an additional personal promise. They know that their honor is at stake when they have signed a note promising to pay a given sum of money.

Foreclosure Possibility.-If the mortgaged property must be attached by the association, it will be sold for the highest possible price under foreclosure proceedings, probably being bid in by the association to protect its own interest. If it does not yield a sufficient sum to meet the principal of the loan, the bond or note gives them the right to sue the borrower and recover judgment for the balance. It is an added protection to both the borrower and the association, because it results in a more conservative attitude toward the obligation on the part of each.

Practical Conditions of Construction Loans.-It is necessary for a borrower who undertakes a construction loan to make a much more careful arrangement beforehand than is needed in purchasing a house already built. The particular reason for this is that mechanics' liens must not be allowed to attach to the property before the association's papers are recorded. Before any preliminary work is done upon the lot, even in the matter of excavation or the delivery of materials 
to the site, all details should be worked out with the association, and all papers drawn up and signed.

The old practice of extending loans in lump sums for construction purposes has largely been abandoned. The borrower has no need of funds until payment for construction is due, and were he to receive the entire loan in advance, interest would be charged upon money for which he would have no immediate need. By making advances only as construction proceeds and paying the contractor directly, the association is assured that the money will be used for the purpose intended and will not be diverted by the borrower to some other use. The temptation is almost always present when a large sum is suddenly added to a checking account to pay the most pressing bills with that money.

Of equal importance with this protection is the assurance that the house will be completed according to plans and specifications. The borrower, being usually inexperienced in construction, may easily be misled. Small but unlooked for items of cost enter at each stage of the process. This is particularly true if alterations are made in the plans. The association can well afford to develop a corps of skilled officers to assist the borrower in selecting satisfactory plans in the first place. We have abundant examples of improperly designed homes that have stood incomplete, sometimes for several years, until the owner could secure funds to put on the finishing touches. These mistakes are so costly that every precaution should be taken to avoid them.

Refunding or Re-financing of Previous Mortgages.When a householder has borrowed from a commercial institution on a straight mortgage, this may be "refunded" or "refinanced" into a building and loan association amortized plan with very little difficulty. An investigation will have to be made by the association before such a loan is taken over, but this will cover the remaining life of the loan, and its cost will be no greater, and perhaps less than the cost of renewal. Refunding does not constitute repayment, but merely 
the substitution of one lender for another-the same borrower is the obligor in both cases.

One of the evils that arise in refunding a previous mortgage is the usual desire of the borrower to increase the amount loaned instead of paying a part of it. Money should be borrowed for a specific purpose, and the methods of repayment should be known in advance, but many times when these straight mortgages come due, new needs have arisen. The borrower wants to spend a sum on new furniture or other equipment for his home, and bullding and loan associations throughout the country have found that these temptations are hard to resist, whenever there is a prospect of refunding a loan instead of paying it off. For the benefit of the borrower himself (to say nothing of the safety of the funds of the association), when a straight mortgage loan made by some one else is refinanced by an association, the safest policy seems to be to loan only an amount sufficient to redeem the prior obligation.

Transfer of Loan.-The right of a borrower to sell his home subject to the mortgage cannot be denied by a lender, but a sale does not release the original mortgagor from personal liability under his note. In this sense the transfer of a mortgage cannot be made without the consent of the association. If the purchaser does not assume the mortgage and make a formal agreement to pay it, the association will have no opportunity to hold him personally liable for the balance of the debt in case of foreclosure and sale at a value below the debt, according to decisions of the courts in certain jurisdictions. ${ }^{10}$

In order to safeguard its loans, one prominent association in Ohio now requires all purchasers of property upon which it holds a mortgage to sign the following application for transfer of a loan:11

${ }^{10}$ Ohio Circuit Court of Appeals has decided at least one case on this basis.

${ }^{31}$ Developed by J. E. Kinney, former president of the Buckeye State Building and Loan Company. 
No loan will be transferred unless (I) all interest and payments due on such loan and (2) all taxes and assessments due on the property, are paid, and (3) al! insurance policies are assigned to the new owner and filed with the loan papers.

\section{APPLICATION FOR TRANSFER OF LOAN}

(Where mortgaged property is sold and the buyer assumes the loan)

Columbus, Ohio, ..............

To the Buckeye State Buinding \& Loan Company,

22 West Gay Street, Columbus, Ohio.

I (or we) hereby make application to your Company to have your mortgage loan No........ for $\$ \ldots . .$. . (original amount), dated ............. covering property commonly known as .......... now owned by ................., transferred on your books to the name.. of ...

(As written or to be written in the deed)

I (or we) have purchased the real estate described in the mortgage securing said loan and will and do hereby assume and agree to pay said loan and to comply with all the terms and conditions thereof, provided you consent to this transfer.

I (or we) also agree to cause to be assigned to me (or us), immediately upon delivery of the deed, and delivered to you, all insurance policies covering buildings involved in said loan, or to supply you with new insurance. I (or we) further agree that all insurance policies now in force or hereafter issued, covering said buildings, shall be and remain in your possession until said loan is fully paid.

I (or we) further agree to pay at once all interest or payments now delinquent on said loan, if any.

I (or we) hereby certify that all taxes and assessments which were due on said property on the last settlement date, to-wit: $\ldots . \ldots \ldots \ldots \ldots$, have been paid to the County Treasurer, except.................. WitNESSES: 


\section{APPROVAL OF TRANSFER}

Columbus, Ohio, ...................

The Buckeye State Building and Loan Company hereby consents to the transfer and assumption of the above loan as requested, without, however, releasing from personal liability anyone already liable for payment thereof.

\section{The Buckeye State Building and Loan Company}

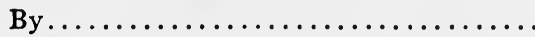

Through the use of such an application, all the parties better understand their relations, and a possible cause of friction is removed. The association will seldom be obliged to resort to the courts for judgment against the original borrower, but it could do so if necessary. The new borrower is not put to any disadvantage, since he has received full value for the obligation which he assumes. Signature of the transfer application merely recognizes an existing liability.

\section{SPECIAL REFERENCES}

Assignment of stock as collateral security. U. S. League Proceedings (1916), pp. 102-108.

Borrower-classification. Kansas League Proceedings (1920), pp. 68-71.

Youngstown Institute Proceedings, March 30, I923, p. II.

Certificates of stock. Missouri League Proceedings (I92I), pp. 26-28. Citizenship and thrift. U. S. League Proceedings (I92I), pp. 74-77.

Construction loans. California League Proceedings (1924), pp. 29-30, 32-35. Ohio League Proceedings (1920), pp. 94-98. Youngstown Institute Proceedings, March 30, 1923, pp. 4-5; March 5, 1924, pp. IO-I 2.

Credit bureau. Youngstown Institute Proceedings, March 30, 1923, p. 4. Date when interest begins. Youngstown Institute Proceedings, March 30, 1923, pp. 5-6.

Delinquencies. Nebraska League Proceedings (1924), pp. 48-49. Oklahoma League Proceedings (I923), pp. 38-46. Youngstown Institute Proceedings, March I2, 1924, pp. I0-16.

Fees-membership. California League Proceedings (1924), pp. 28, 30, 75-84. Iowa League Proceedings (I9I6), p. 25. Minnesota League Proceedings (1924), pp. 17-20. Youngstown Institute Proceedings, April 13, 1923, p. 9.

Fees-withdrawal. California League Proceedings (1924), pp. 28, 30. 


\section{THE BORROWER AND THE ASSOCIATION}

Fines. Iowa League Proceedings (1915), pp. 23-24; (I916), p. 39; (1918), pp. 21, 26-29. Ohio League Proceedings (1914), pp. 48-49. U.S. League Proceedings (I9I6), pp. III-II2.

Foreclosure. Illinois League Proceedings (1918), pp. 59-6r. Iowa League Proceedings (1918), pp. 63-64. Mason, G. N., Redemption and foreclosure of mortgages, Chicago Law Notes, 1898-I899, v. 31, p. 108. Youngstown Institute Proceedings, March 30, 1923, p. I4; May II, I923, pp. 7-9.

Interest rates. Minnesota League Proceedings (1924), pp. 4-5. Nebrasha League Proceedings (1924), pp. 14-15. Ohio League Proceedings (1920), pp. 104-108. Youngstown Institute Proceedings, March 12, 1924, pp. 5-10.

Loan costs. California League Proceedings (1924), pp. 29-3r. Missouri League Proceedings (1919), pp. 61-69. Youngstown Institute Proceedings, March 12, 1924, pp. I-4.

Loans. U. S. League Proceedings (1903), pp. 107-108; (19II), pp. I IO-II 8.

Loans-limitation. Iowa League Proceedings (rgr8), pp. 22-23, 25-26. Mechanic's lien. Illinois League Proceedings (1918), pp. 61-68. Ohio League Proceedings (I914), pp. 56-88; (I915), pp. 69-83; (I9r6), pp. 43-53. Youngstown Institute Proceedings, March 30, 1923, pp. 6-7.

Repayment of loan. California League Proceedings (1924), pp. 30-31.

Services it is possible for a building and loan association to render. U.S. League Proceedings (1918), pp. 97-104.

Taxes. Ohio League Proceedings (I9I7), pp. 42-46. Youngstown Institute Proceedings, February 20, 1924, p. 14.

\section{GENERAL REFERENCES}

Putnam, T. M. Mathematical Theory of Finance (1923).

Robinson, J. Watts. Robinsonian Building-Loan Interest Tables (1909).

Rosenthal, Henry S. Cyclopedia, pp. 121-122; 161-163; 198-200; 213$229 ; 262-267 ; 334-438$.

SkINNER, ERnest Brown. Mathematical Theory of Investment (I924). SundheIM, JosepH H. Law, pp. 107-132. 


\section{CHAPTER XIII}

\section{ACCOUNTING ${ }^{1}$}

The prime requisites of accounting; problems of the building and loan accountant; elimination of unnecessary expense in handling the accounts; classification of receipts and disbursements; recording procedure; cash book; general ledger; "debit" and "credit" defined; ledger accounts; asset items; liability items; use of vouchers and checks; controlling accounts; balancing ledger accounts; combined cash book and journal; trial balance; reports; the "explained balance sheet"; methods of accounting for dividend distribution; other records.

The three prime requisites of accounting which are always borne in mind by those who wish to have their books represent the true condition of a business are: accuracy, adequacy, and simplicity. Modern accounting systems have met the criticism that they are not easily understood by the layman, by eliminating from their practices many cumbersome methods. After passing through a period of complexity they have now reached a desirable point of simplicity. On the other hand, it is possible to carry simplicity too far, so that the records are not adequate. The best set of books is the one which is easily understandable by anyone who cares to examine them. The problems which the accountant of a building and loan association faces include:

(r) Showing the flow of receipts and disbursements.

(2) Showing the actual conditions of the affairs of the association (the value of all that it owns, the contributions of its shareholders, and the amount of its debts). This finally

¿ Only an elementary summary of building and loan accounting practice can be included in the present text-book. The student is referred to standard accounting texts for the finer points of technical detail and more complete explanation. 
resolves itself into a summary such as appears in the balance sheet.

As important subdivisions of the second problem, there are several additional matters which the accountant should attempt to present. These include:

(3) The gross and net earnings.

(4) The value of any share at any time.

(5) The value of any loan at any time.

The desirability of simplicity as well as inexpensiveness must never be forgotten in setting up the books. Records must be in such shape that they can easily be continued when a change of officers occurs. If it is necessary to revise the system completely because the new men cannot understand the books, the system is a failure.

Economy may be achieved for small associations by keeping several types of records in a single binder. On the other hand large associations may find it most economical to invest in large, expensive machines and elaborate records in order to keep similar accounts. The true measure of efficiency is not the cost of the equipment but the cost per unit of business done. Simplified accounts contribute greatly in keeping expenses low. Building and loan associations are first of all cooperative institutions, and the profits belong to the stockholders. When the total cost runs over one per cent in an association which has made a reasonable growth, something is fundamentally wrong not only with the accounts, but with other phases of the association's business as well.

Economy can be achieved at many points. Fancy "cut-out" cards which fit only certain expensive files are always interesting to the accountant who is a novice, and they may be useful to the experienced accountant under certain conditions; but the expense of such cards and files is unnecessary in most cases. The association is not run for the accountant, but the accountant's function is to present a continuous and 
accurate record of the business, and he should accomplish this in the easiest possible way.

Records are of Distinct Classes.-The records of an association include many things in addition to the ordinary bookkeeping entries. For convenience, they may be grouped as:

(I) The money records.

(2) The auxiliary records.

(a) Stock register.

(b) Loan applications.

(c) Appraisal record.

(d) Title reports.

(e) Fire and other insurance records.

(f) Tax receipts.

(g) Minute book for directors' and shareholders' meetings.

Many of the auxiliary records can be grouped together, and the importance of grouping all essential facts should never be overlooked. The custom of assembling in compact form all the loose papers in connection with each loan should be extended into the accounts wherever practicable. Loose papers are always a nuisance and cause much difficulty. Separate records for money items which could be combined likewise cause unnecessary delay when the records need examination.

The Money Records. - The accountant's problems deal with the money records primarily. Many books used in ordinary corporation accounting can be dispensed with in building and loan association work. It is desirable to eliminate the journal except for a few "closing entries," or it may be combined very satisfactorily with the cash book.

The general set of books found in most associations in the United States includes:

(I) Cash book.

(2) Journal. $\}$ Or a "cash journal."

(3) Individual ledger.

(4) General ledger. 
The cash book frequently takes the form of a cash receipts book and a cash disbursements book. Other records are kept by some associations, depending upon the kind of business undertaken.

When the set of books includes only the four types mentioned, the process of recording is easily carried out. If we suppose that a new association is about to begin business and that a small fund has been raised among the local business men for preliminary expenses, such as advertising, charter fees, a set of books, etc., the first entries in the cash book might be somewhat as follows: ${ }^{2}$

\section{Cash Book}

\section{Receipts}

Mar, I Contributions for preliminary expenses from the following firms:

A \& Company

B \& Company

C \& Company

$\begin{array}{r}\$ 25.00 \\ 50.00 \\ 30.00 \\ \hline \$ 105.00\end{array}$

\section{Disbursements}

Mar. Io State charter fees * ....... \$10.00

II Books and stationery ...... 25.00

II Balance on hand (a pencil notation) $\ldots \ldots \ldots \ldots \quad 70.00$ $\$ 105.00$

* State charter fees vary considerably, the usual amount for a medium sized association being perhaps $\$ 250$ in many states. It is permissible in some states to carry this item as an asset, if receipts from members have been used to pay for it. The amount should be "written down" each year or each fiscal period as for any other depreciating asset. Thus it will eventually disappear from the books. In other states the necessary amount can only be paid from earnings or from contributions. If earnings are relied upon, none will have accrued, and the money for the fee will have to be "advanced" to the association by those interested, until it gets upon its feet and begins to realize earnings. The men who advance the money trust to good faith and association success for later reimbursement.

${ }^{2}$ In some cases the contributions for original expenses are not entered on the books in the regular way, but are treated as a personal expense of the organizers. Later on, if the association has sufficient earnings to enable it to repay such contributions without impairing earnings, a memorandum of the organizing expenses is presented for approval and reimbursement.

Where the contributions are treated as a loan from the business men, 
The small association is then in a position to carry on some business, and if the campaign for membership has been successful, funds will begin to arrive. As the members pay in their dues, the cash book entries will become numerous.

\section{Cash Book (Repeated and Extended)}

\begin{tabular}{|c|c|c|c|c|}
\hline \multicolumn{2}{|l|}{ Receipts } & \multicolumn{3}{|c|}{ Disbursements } \\
\hline $\begin{array}{r}\text { Mar. I Contributions. } \\
\text { Mar. Io Dues on Share } \\
\text { to 30 Certificates No. I } \\
\text { (itemized) No. } \\
\\
\text { No. } 3 \\
\text { No. } 4 \\
\text { etc. }\end{array}$ & $\$ 105.00$ & $\begin{array}{r}\text { Mar. IO } \\
\text { II } \\
\text { 3I }\end{array}$ & $\begin{array}{l}\text { State charter } \\
\text { fees ........... } \\
\text { Books \& Sta- } \\
\text { tionery } \ldots \ldots \ldots . . . \\
\text { Balance on Hand } \\
\text { (a pencil nota- } \\
\text { tion) }\end{array}$ & $\begin{array}{r}\$ 10.00 \\
25.00 \\
1580.00\end{array}$ \\
\hline & $\$ 1615.00$ & & & $\$ 1615.00$ \\
\hline
\end{tabular}

The dues received are usually itemized in the cash book, each item being labeled with either the name of the member or the number of his share certificate, or both. For convenience we have summarized them here. If deposit slips are used, this summary is the only actual book entry, and the slips themselves must he carefully filed in order to check up mistakes. The safest system provides for each item to be entered in full in the cash book so that it may later be "posted" to the proper account in the ledgers.

The association is now in a position to make a loan and when the application has been approved, the entries shown on p. 272 may result.

Many new items have now appeared in the accounts and the need for summarizing the different items by means of ledger accounts is at once apparent. That is, the dues paid by each member must be credited to him individually, so that the total amount he has paid can be seen at a glance. The for which the association is liable, the share credits should be given preferred status over such claims in the event of early dissolution or giving up of the project. It should be noted that impairment of capital results when these contributions are classed as loans and then spent for items which will not appear on the balance sheet as tangible assets. 
Cash Book (Repeated and Extended)

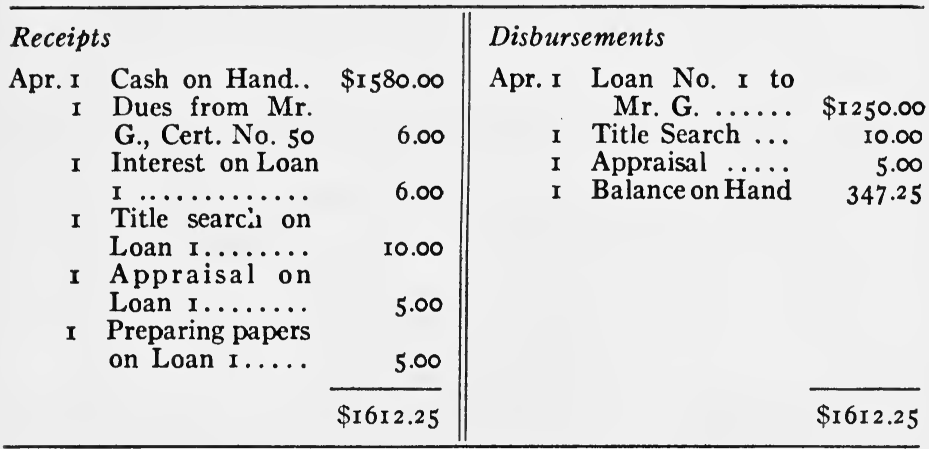

loans must be properly entered. Interest is an item of earnings and this must be recorded as such to show what the association is doing, and many other items must be taken care of.

One reason for itemizing so many of the transactions is to enable the officers to present a summary of the receipts and disbursements to the Board of Directors, to the stockholders, or to a state supervising official at any time that this may be called for. Such statements may include the following items, hence the necessity for accounts in the books which will produce figures for each by merely totaling the entered items:

\section{RECEIPTS}

(Cash balance in hands of treasurer at last report)

Dues received on installment or running stock.

Full-paid stock issued.

Pr paid stock issued.

Interest.

Premium.

Fees.
(a) Membership.
(b) Withdrawal.
(c) Transfer. 
(d) Satisfaction.

(e) Appraisal committee.

(f) Attorney.

Fines.

Mortgage loans repaid.

(a) Secured by mortgage and stock pledged.

(b) Straight mortgage.

Credits on mortgage loans.

Stock or pass-book loans repaid.

Taxes received from borrower.

Fire-insurance premiums received from borrower.

Bills payable (money borrowed).

(a) From banks.

(b) From other building and loan associations.

Bills Receivable repaid (money loaned to other building and loan associations).

From sale of bonds.

From judgments (after foreclosure).

Rent from association real estate.

Real estate sold.

(a) Outright.

(b) On contract.

Matured installment stock transferred to paid-up stock (a bookkeeping entry).

Credit from contingent reserve to meet loss.

Life-insurance premiums received from borrower.

\section{DISBURSEMENTS}

Loans on real estate (with stock pledged).

Straight mortgage loans.

Loans on other security.

Loans on association stock or pass-book.

Advances on loans previously approved.

Payments on stock withdrawn.
(a) Installments repaid.
(b) Profits. 
Payments on paid-up stock.
(a) Principal repaid.
(b) Profits.

Payments on prepaid stock.
(a) Principal repaid.
(b) Profits.

Payments on stock matured.
(a) Installments repaid.
(b) Profits.

Bills payable repaid.

(a) To banks.

(b) Other building and loan associations.

Interest paid on borrowed money.

Expenses.

(a) Salaries.

(I) Officers, directors, and legal counsel.

(2) Clerical help.

(b) Stationery and printing.

(c) Postage.

(d) Telephone and telegraph.

(e) Rent.

Taxes paid by association.

(a) On property.

(b) Charter and examination fees.

(c) Other taxes.

Taxes advanced for borrower.

Fire-insurance premiums advanced.

Real estate purchased.

Expenses on real estate owned by association.

Furniture and fixtures.

Foreclosure costs.

Bonds purchased.

(a) United States.

(b) Other bonds.

Losses paid and charged against contingent fund.

Life-insurance premiums advanced for borrowers. 
Mortgage credit transferred to repaid loans.

(Balancing item: Cash on hand: in bank or with treasurer.)

Some of these items are given in greater detail than are required for public reports, but it is vital that the directors know at all times where the business stands, especially when operating under a plan where receipts and disbursements fluctuate from month to month. Old established serial associations which can predict their flow of income with a high degree of accuracy have less need for detailed information, but where the condition of the business is well reflected by the books, the association tends to be in a stronger position in the community.

Recording Procedure.-The next logical step in the discussion would be the matter of ledger posting. Before proceeding to it, however, it will be well to call attention to the many details of recording procedure which are necessary to insure absolute accuracy of the records.

Verification of the Amount Paid.-When a member pays any money to the association, the first duty of the receiving officer is to verify the amount paid. It must agree with the amount stated by the member or entered by him on the slip. The sum paid is first entered in the books of the association before it is credited to the pass-book of the member. The reason for this is that the average member comes in contact with the officers only when he is making his periodical payment. He may have some questions to ask, and the officer's attention may be diverted by such conversation. As a result, it is possible that an amount entered first in the member's pass book may not be properly entered elsewhere. At the end of the day an improperly recorded cash item may be "over" or "short" and unaccounted for, for it may have been entered as a receipt but not credited to the proper account, or an incorrect amount may have been entered.

If the teller or other receiving official makes sure that the 
proper entry has been made on the books of the association first, and then credits the amount to the pass-book of the member, this difficulty will not arise. In small associations where entry is made directly into the cash book or on a teller's blotter, the difficulty of verification is much greater than in associations where the members fill out deposit slips. When the amount paid has been verified, the number of the share certificate must be checked and the proportionate amounts for dues (principal) and interest or other charges must be extended. A deposit slip which avoids much of the trouble of checking is as follows:

\section{DEPOSIT SLIP*}

Westerleigh Building-Loan and Savings Association Westerleigh, Staten Island, New York

Name

\begin{tabular}{|c|c|c|}
\hline \multirow{2}{*}{$\begin{array}{l}\text { Series No........... } \\
\text { Certificate No......... }\end{array}$} & Dollars & Cents \\
\hline & & \\
\hline Dues & & \\
\hline Interest $\ldots \ldots \ldots \ldots \ldots \ldots$ & & \\
\hline Premium $\ldots . . . \ldots \ldots$ & & \\
\hline Fines $\ldots \ldots \ldots \ldots \ldots \ldots$ & & \\
\hline$\cdots \cdots$ & & \\
\hline Total $\ldots \ldots$ & & \\
\hline
\end{tabular}

* The use of a slip makes it possible to do a certain amount of direct advertising to the members by calling their attention to the need for promptness, stating office hours, announcing the opening of new series, or making suggestions regarding the service rendered by the association. Unusual items can be readily inserted on the blank lines, such as advance payments, etc. 
If the member is made responsible for filling out this slip himself, he will soon learn to be careful and to extend the proper items. Payments made by borrowing members are accounted for in the same manner as those of savings members, except that interest items occur only in borrowers' payments.

The object of the cash book is to record the flow of cash. If the receipts and disbursements are recorded directly in this book, it is a book of "original entry" and, therefore, becomes the "key book" of the system. If a dispute should arise between a member and the association, the book of original entry will be recognized by a court as evidence of a given transaction. If the original records are made on deposit slips either by the borrower or the receiving officer, the slips then become the book of original entry and must be carefully filed.

Ledger Entries.-With this outline of the cash book entries, we are now in a position to take the next step of separating the many cash-book items and recombining them in groups that will be easily understood. This process is called "posting." Each entry in the cash book is copied into an account in one of the ledgers.

(a) Posting Receipts to General Ledger.-The original entries on deposit slips or the teller's blotter, or in the cash book, must find their way promptly to the separate accounts in the ledger in order that the business record may be complete. This may be done in several ways. (I) One method involves entering the original items directly in the cash book, from which they are transferred later to the ledger account. (2) Under another method the bookkeeper first posts the deposits slips to the cash book and then sorts them into either alphabetical or numerical order and posts the items from the slips directly to the individual ledger. The method which is more likely to avoid mistakes posts from the slips to the cash book and then to the ledger. The student unfamiliar with accounting should 
refer to standard texts for methods of checking up inaccurate posting.

By referring back to the cash book entries already discussed, it will be seen that the following accounts in the general ledger will be required: Cash, Charter Fees, Expense, Contributions, Installment Shares (a summary of items in the individual ledger), Loans, Interest, Attorney, Appraisal Committee, and Miscellaneous Income. Some accountants would open ledger accounts in addition to the items already shown, but. there is no immediate need for a larger number.

In making the original cash-book entries, we have placed the items of receipts on the left-hand page and of disbursements on the right-hand page. This is the usual practice, but the entries might be entered on opposite pages if desired. The side of the page on which the debit and credit are placed is of no importance, but when a position has been selected it is necessary to continue it. The task of the accountant is to so record his information that every one can understand it.

By the term "debit" is meant that the party or the account has assumed an obligation, or becomes the "debtor" of the association for the amount of the obligation. When an account is "credited" with a given sum, this amount is deducted from the obligation, which the party named at the head of the account has assumed. This system was developed for individual accounts and has been continued for the summary accounts (or "controlling" accounts) in the general ledger, even though these accounts seldom refer to individuals. For every debit entry there must be a corresponding credit.

The first group of cash-book items on page 270 will be posted to the ledger as follows (with appropriate reference to date, page, etc., of original entry):

Cash (Account No. r)

$(\mathrm{Cr})$

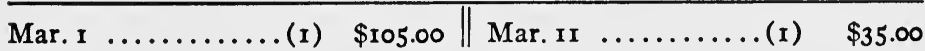

These items are merely the totals of the various cash-book entries and are posted to the same sides of the ledger account 
as in the cash book. When distributed to the other accounts, their position is changed to the opposite side, because a charge against cash is also a credit to some other account, or vice versa.

$$
\text { Charter Fees (Account No. 2) }
$$

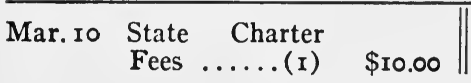

(Dr)

Expense (Account No. 3)

Mar. I Books and Stationery ......(I)

$\$ 25.00$

(Dr)

Contributions (Account No. 4)

Mar. I ..............(I) $\$ 105.00$

To those who have never studied bookkeeping it may appear that the above arrangement is purely arbitrary. By totaling the debit and credit columns of the four accounts, however, it will be seen that they are equal.

\section{Debit $\$$ I 40.00}

Credit $\$ 140.00$

In essence, this indicates both the method and the purpose of double-entry bookkeeping - a balancing of one account with another or another group. This matter of balance will become clearer as we proceed.

Receipts from members constitute the largest income of the association, and it is important that the receipts on each certificate be kept separate. Many of the members will withdraw their savings prior to the maturity of their shares. The association records these accounts in the individual ledger just as deposits are entered by a bank. A "controlling" account in the general ledger summarizes these individual accounts. 
This item is balanced by the debit entry of $\$ 1,510.00$ to Cash, making that account appear as follows:

Cash (Account No. I)

Mar. I $\quad \ldots . \ldots \ldots$ (I) $\$ 105.00$ $10-30 \ldots \ldots \ldots$ (I) 1510.00

Mar. II

(I) $\$ 35.00$

With the making of a loan, the items connected with it begin to appear. When the loan on page 273 has been posted, the ledger entries will be as follows:

(Dr)

Cash (Account No. I)

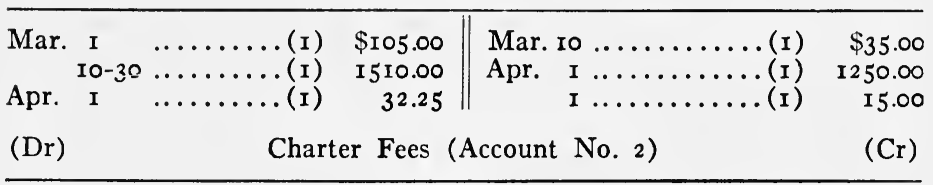

Mar. 10

(I) $\$ 10.00 \|$

(Dr)

Expense (Account No. 3)

$(\mathrm{Cr})$

Mar. 10.............(I) $\$ 25.00 \|$

(Dr)

Contributions (Account No. 4)

$(\mathrm{Cr})$

Mar. I ............. (x) $\$ 105.00$

(Dr)

Installment Shares (Account No. 5)

(Cr)

Mar. 10-30 .......... (I) \$1510.00

Apr. I .......... (I) 6.00

(Dr)

Loans (Account No. 6)

(Cr)

Apr. I ........... (I) \$1250.00

(Dr)

Interest (Account No. 7)

(Cr)

Apr. I Loan No. I...(I) $\$ 6.2$ I

(Dr)

Attorney (Account No. 8)

Apr. I Loan No. I...(I) $\$ 10.00 \|$ Apr. I Loan No. I.. (I) $\$ 10.00$

Appraisal Committee (Account No. 9)

$(\mathrm{Cr})$

Apr. I Loan No. I...(I) $\$ 5.00 \|$ Apr. I Loan No. I...(I) $\$ 5.00$ 
Totals of all accounts now stand as follows:

Debit $\$ 2947.25$

Credit $\$ 2947.25$

The purpose of the general ledger is to provide a recapitulation of the business by means of these summary accounts. They are distinct from the individual accounts. Each group of shares, if the association issues more than one kind of stock, will have a separate account in the general ledger. Practically every general ledger will contain at least the following types of accounts:

\section{Asser Items ${ }^{2}$}

Loans on real estate (with pledge of stock).

Loans on real estate (on straight mortgages).

Loans on stock.

U. S. and other bonds (not usually carried except as a convenient liquid asset, or in aid of the guvernment).

Bills Receivable (money due the association on promissory or other notes).

Accounts Receivable (money due association on open account-not as customary in building and loan associations as in commercial business).

Furniture and fixtures.

Books and stationery.

Real Estate (including allowance for depreciation).

Insurance advanced for borrowers.

Taxes advanced for borrowers.

Charter fees (may be carried as an asset until authorized capital on which fee was collected has been issued and earnings have absorbed same).

Cash in treasury.

${ }^{3}$ Other items are sometimes included, but the list here shown is essentially complete. It is not good accounting practice to include among the assets, items such as installments on stock which are "due and unpaid". Such items are mere memoranda and not true assets. Other items due on contract such as interest "due and unpaid" are true assets. Uncollected interest can not be listed as an asset in some states. 


\section{LIABIITY ITEMS *}

Installments on running stock.

Installments on running stock (in advance).

Paid-up stock.

Prepaid stock.

Permanent, guarantee, or other stock with extra liability.

Matured stock (not withdrawn by members).

Loans (incomplete and due borrowers).

Interest (owed not yet due).

Bills payable (borrowed money evidenced by notes).

Accounts payable (current unpaid open accounts).

Profit and loss.

Contingent reserve.

School savings (used only in certain parts of the country).

Christmas savings (used only in certain parts of the country).

(b) Posting to the Individual Ledger.-From what has already been said about the general ledger, the purpose and scope of the individual ledger will be understood by the student. Each individual with whom the association is dealing has a separate account in the individual ledger. These accounts are usually headed both by the name and the certificate number of the individual member.

The individual ledger is designed to show the exact condition of each member's account at all times without cluttering up the general ledger with many small items. The simplest form of this ledger is like that used by banks for an ordinary deposit account. A successful type of this form is reproduced on p. 283 .

This form has been developed for use with a bookkeeping machine and is easily posted by any clerk. Skill on modern machines is readily acquired and is largely a matter of practice. Associations which feel that they cannot afford to purchase a bookkeeping machine of any kind will find that this form can be readily adapted to a loose leaf or bound volume for hand posting.

- Balancing items are occasionally added to the liabilities side of the balance sheet to cover assets not actually in the possession of the association. These items do not belong in a balance sheet. 
THE INDIVIDUAL LEDGER

283

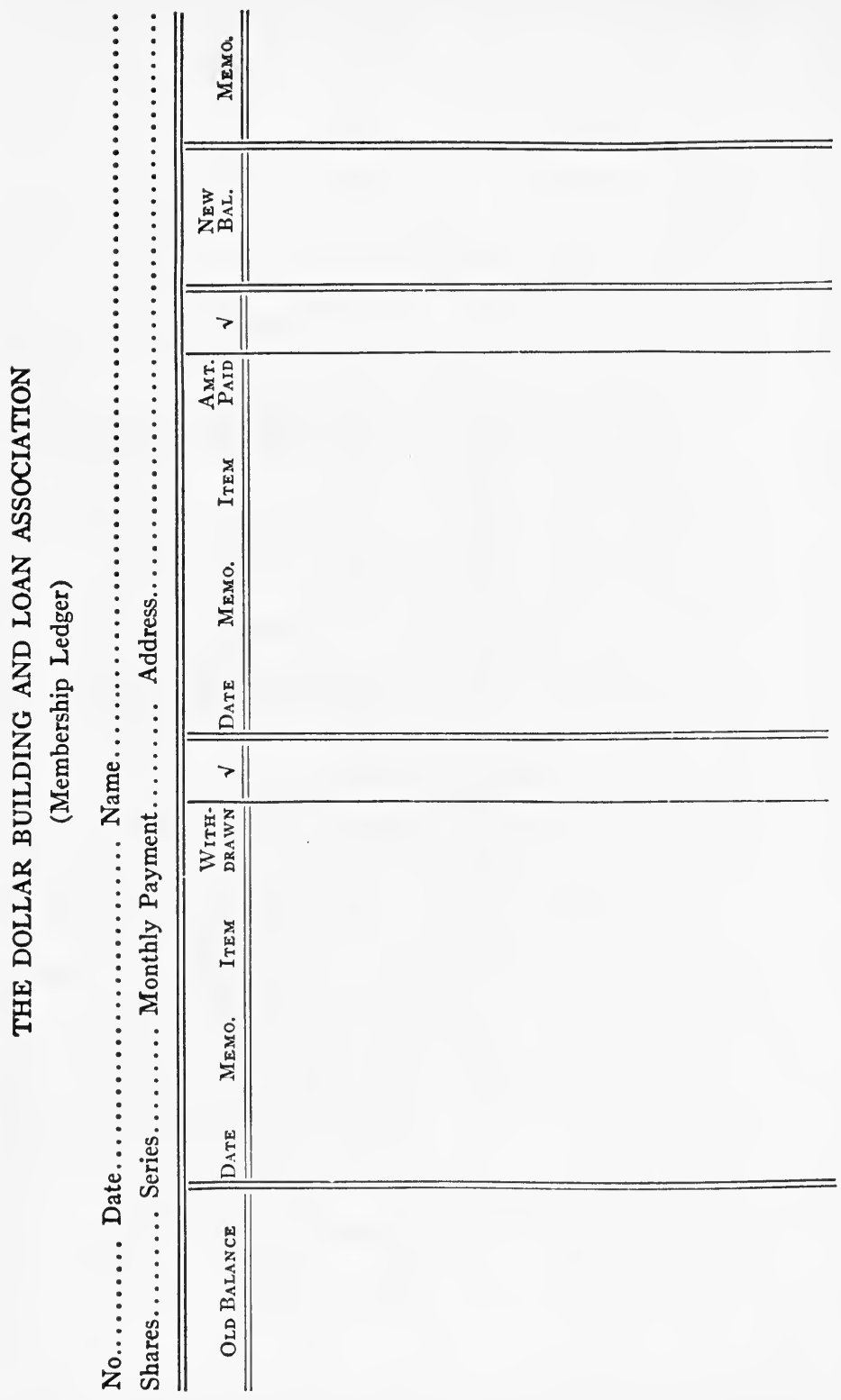


By using a separate scheme of recording for these many small items, the size of the general ledger is very much reduced and made easier to handle. In large associations, several clerks may be required to take care of the individual ledger, each having one part of it. A summary of the various individual accounts is posted to the controlling accounts in the general ledger. These controlling accounts are handled usually by the head bookkeeper only. When they are balanced with all other accounts in the general ledger, the resultant figures are transferred to the profit and loss account as explained below.

The individual ledger is coming into general use in serial associations to-day, thus avoiding the necessity of tracing entries across wide books which were originated in a past generation. Geo. W. Cliffe, Secretary of the Reliance Building and Loan Association of Germantown, Philadelphia, has perfected the ledger sheet which appears on p. 285 and which serves admirably for this purpose.

Posting Disbursements.-All disbursements must be authorized by the Board of Directors unless the by-laws provide for other authorization. Associations seldom pay out cash directly, finding it much more accurate and convenient to deposit all their moneys at a bank and pay by check. Where cash payments are necessary, debit slips (similar to deposit slips) should be filled out or a disbursements blotter should be- kept by the paying officer. This practice is not satisfactory, since most of the payments made by an association run into large figures and the opportunity for checking the actions of officers does not exist when cash is handled. Cash payments encourage misappropriation of funds.

Checks should be signed by at least two officers in all cases, and the best practice is to use formal vouchers for this purpose. The voucher itemizes the purposes for which the fund is expended, and there can never be any question regarding the receipt for a given item. Voucher forms are sometimes made in duplicate, but more often the size of the check is 

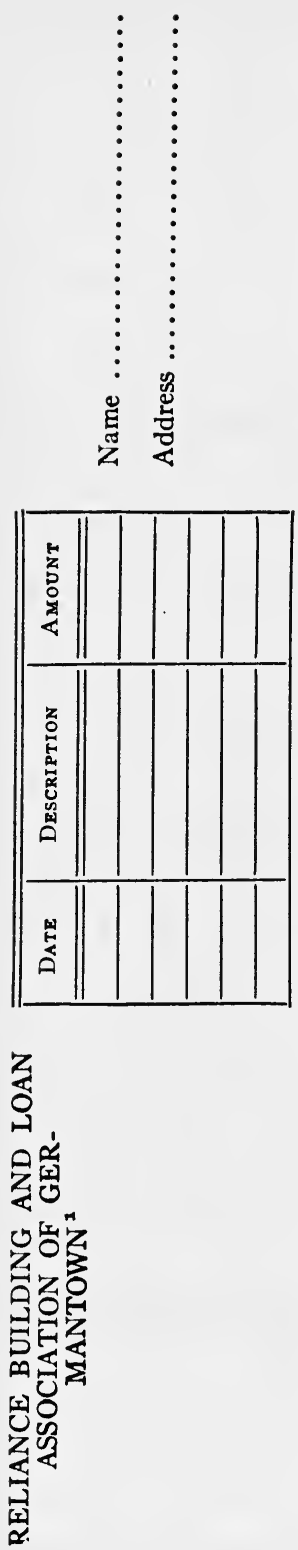
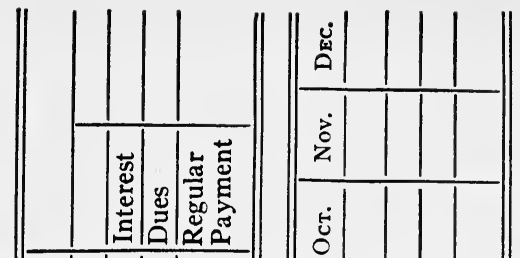

焉焉

율

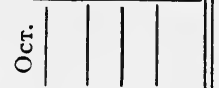

造 年

물

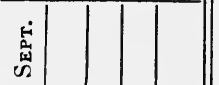

造

क०

0

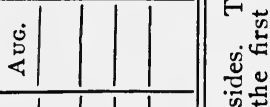

弪运

피시 싯
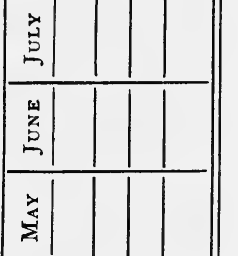

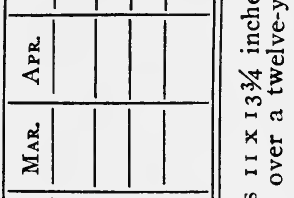

as

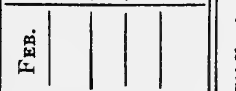

$\stackrel{\dot{z}}{\llcorner}$

\&

出

占占

ते

تृ

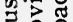

के 앙

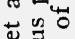

这焉

.

इन क

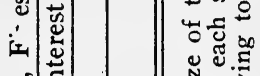

艺烍

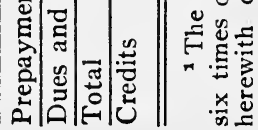


simply increased to provide additional space. When made in duplicate, the second copy can be used as a debit slip for posting. If not so used, the additional papers tend to clutter the records.

No "stubs" are needed for association checks, as they introduce an element of chance. Checks can be assembled in pads, a practice sanctioned by long use in banks for cashier's checks. The check-book stub is not a good permanent record and is not easy to handle or summarize. If used, it should be used only as an auxiliary record.

By entering the item of disbursement directly in the cash book at the same time that the voucher is made out, trouble is avoided. Or if a voucher separate from the check has been issued, this voucher form may be used in the same way as a deposit slip and posted direct to the cash book or individual ledger. The important thing is to make sure that the item is properly entered before the check is issued. In selecting a method for this purpose, as for any other, simplicity and accuracy should be the guiding motives.

Each item of disbursements must be posted to either the individual ledger or the general ledger, as in the case of receipts. A summary of the day's business, if totals are posted each day, can thus be prepared and presented to the officers promptly. Nothing contributes to the efficiency of a business more than accurate, summarized knowledge in the hands of the officers every day. They should be able to know at a glance where they stood when business opened in the morning. The form used by a prominent association in Kansas is shown on p. 287 , the items being stamped on with a rubber stamp

This form permits the balances for an entire week to be seen at a glance.

Controlling Accounts.-As has been mentioned in connection with the general ledger, certain accounts are opened on the books for the purpose of summarizing many individual accounts. It would be impracticable to present all the totals of hundreds of accounts in an intelligent way. The statis- 
DAILY SUMMARY OF ASSOCIATION BUSINESS ${ }^{\text {s }}$

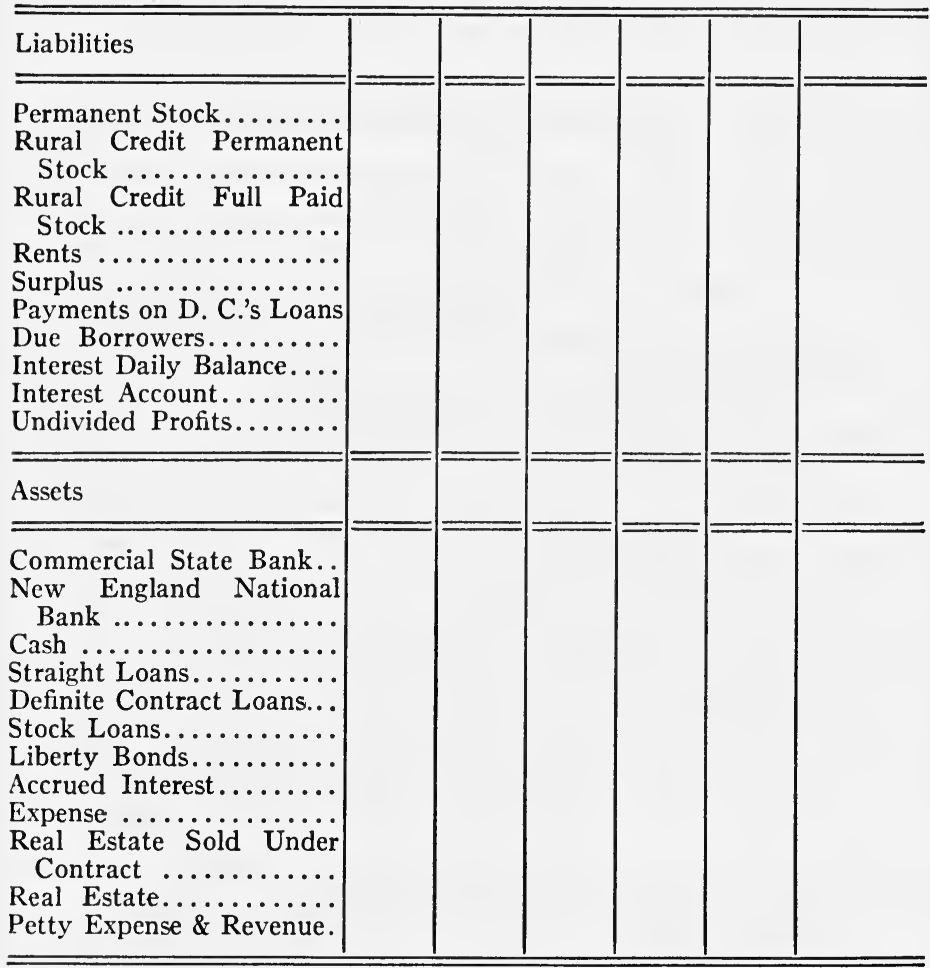

tician long ago adopted the policy of averaging large groups of figures and presenting a single figure as representative of a large group. The controlling account serves the accountant in a similar way. Adjustments must be made at the end of every fiscal period and sometimes more frequently. Profit and loss must be determined. By "closing" groups of accounts into one controlling account, the actual amount of profit or loss is shown and this one figure can be transferred to the profit and loss account. Profit and loss will thus show a small number of items all of which mean something. As soon as

${ }^{5}$ Form used by the Mutual Building and Loan Association, E. C. Ryan, Secretary, Emporia, Kansas. 
the profit and loss account can be balanced, whatever profit has been realized is the "undivided profits" from which the distributions of earnings to shareholders and to the contingent reserve are made.

The Journal.-Assuming that the business of our association has now been .running six months and that the end of the fiscal period has arrived, it is necessary to close the books and determine the profits. The balances of the several ledger accounts are now as follows:

(Dr)

\section{(Dr)}

(Dr)

Cash (Account No. I)

$$
\$ 3000 \|
$$

Charter Fees (Account No. 2)

$$
\text { \$10 } \|
$$

Expense (Account No. 3)

$(\mathrm{Cr})$

$\$ 750 \|$

(Dr)

Contributions (Account No. 4)

$(\mathrm{Cr})$

$\$ 105$

(Dr)

Installment Shares (Account No. 5)

(Cr)

$\$ 100,000$

(Dr)

Loans (Account No. 6)

(Cr)

$\$ 98,000$

(Dr)

Interest (Account No. 7)

(Cr)

$\longrightarrow \quad \$ 2800$

(Dr)

Attorney (Account No. 8)

(Cr)

$\overline{\|}$

(Dr)

Appraisal Committee (Account No. 9)

(Cr)

(Dr)

Miscellaneous Income (Account No. IO)

(Cr) 
As now arranged, these entries are meaningless for the business as a whole. It is necessary to assemble the balances into a single account, and the Profit and Loss Account is used for this purpose. No receipts or disbursements of cash will occur, and hence no cash-book entries are needed. The journal is used to make the necessary transfe: as follows:

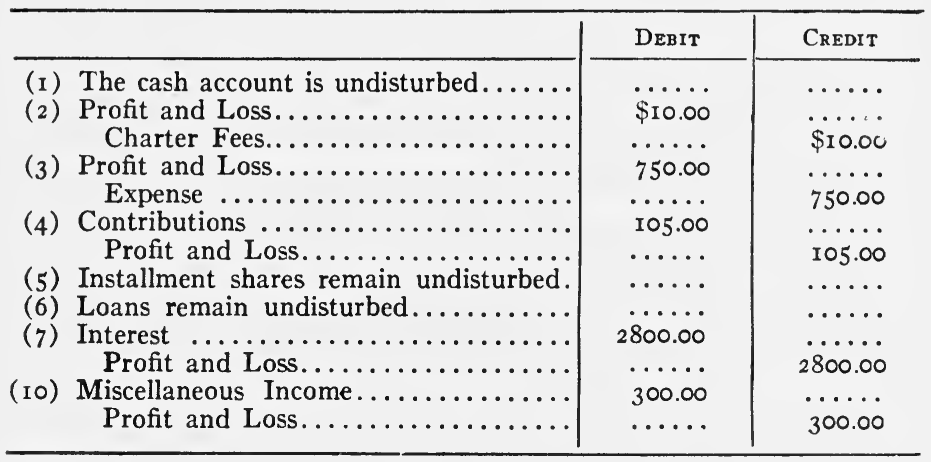

These items are now posted to the various ledger accounts which results in leaving the Profit and Loss Account in the following condition:

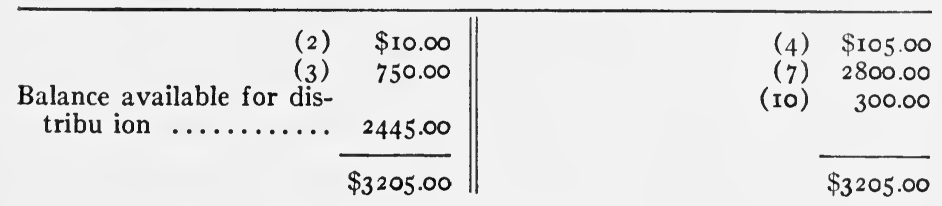

The balance of this account is the net earnings for the period,- the available fund from which the contingent fund and dividends are derived.

The closing entries just described are the only entries for which a journal is actually needed. By combining the cash 
book and journal, it is possible to eliminate the journal entirely, as shown hereafter.

If a dividend policy of a given rate has been adopted, it will only happen by accident that the exact amount of money necessary to meet this rate remains as undivided profits after setting up necessary contingent and other reserves. As a result, a few dollars may be carried in the Profit and Loss account from one dividend period to the next.

In our illustration, the $\$ 100,000$ of installment shares are entitled to a dividend, but few of these shares have been in the business exactly the same length of time. We may assume that five per cent of the net earnings (or \$125.00) are set up as a contingent-reserve account. The balance can be distributed to the $\$ 100,000$ shares on the basis of their relative age. Probably $\$ 150$ will remain in the Profit and Loss account after such distribution.

Surplus Account.-Building and loan practice differs so much from ordinary corporation practice that there is no need for an account entitled "surplus." A few associations use a surplus account in addition to contingent reserves and profit and loss, but where a surplus is used it has essentially the function of the contingent-reserve account.

Contingent-reserve accounts are explained in Chapter XVII. The laws of certain states require that before profits can be distributed to shareholders, a certain percentage must first be set aside from the profits and put in the contingent-reserve account to provide for possible losses. The contingent-reserve account, therefore, becomes a permanent part of the business structure. It is not the property of any individual shareholder, but is a capital account from which losses may be paid. $^{6}$ The purpose of such an account is to enable the association to establish a continuous and uniform dividend policy and to protect the members in case of loss.

- Statutes of certain states permit the distribution of a proportionate share of this account to members at maturity of their shares, but the practice is by no means common. 
Combined Cash Book and Journal.-The ordinary journal discussed above can be dispensed with except for the "adjusting" or "closing" entries. Years ago, bookkeepers "journalized" all transactions which entered their books-a very laborious and time-consuming system. By ruling the cash book so that items are distributed across the page a much better result may be obtained with a minimum of effort.

A book ruled in this fashion is generally called a "combined cash book and journal" since it provides two columns which act as an ordinary debit and credit journal and as many other columns as desired for distributing and summarizing the entries. In posting these entries to the ledger, only the column footings need be transferred at the end of each day, except for the general items, which will be posted as before. Small associations frequently find it convenient to post footings only once each month.

Both receipts and disbursements are entered in this combined book. Every item will appear either in detailed form or as a summary in combination with other similar items, depending upon the way in which the books are kept.

A workable form of combined cash book and journal is shown on p. 292.

This form is not suggested as the only one possible, but it is a type which has been successfully used. The explanation column has been placed on the left-hand page near the center because there are usually fewer items to debit than there are to credit, and this leaves ample space on the right-hand page. Those entries which cannot be classified into the separate columns are grouped into the general columns. A further convenience in this form is numbering the lines on each side of each page so that the proper place of entry may be readily found. With the growth of an association's business, additional columns may be required and some that were earlier thought necessary may be discarded. The items which previously went into these columns will now be entered into the general columns. It is well to leave several columns blank, 


\section{ACCOUNTING}

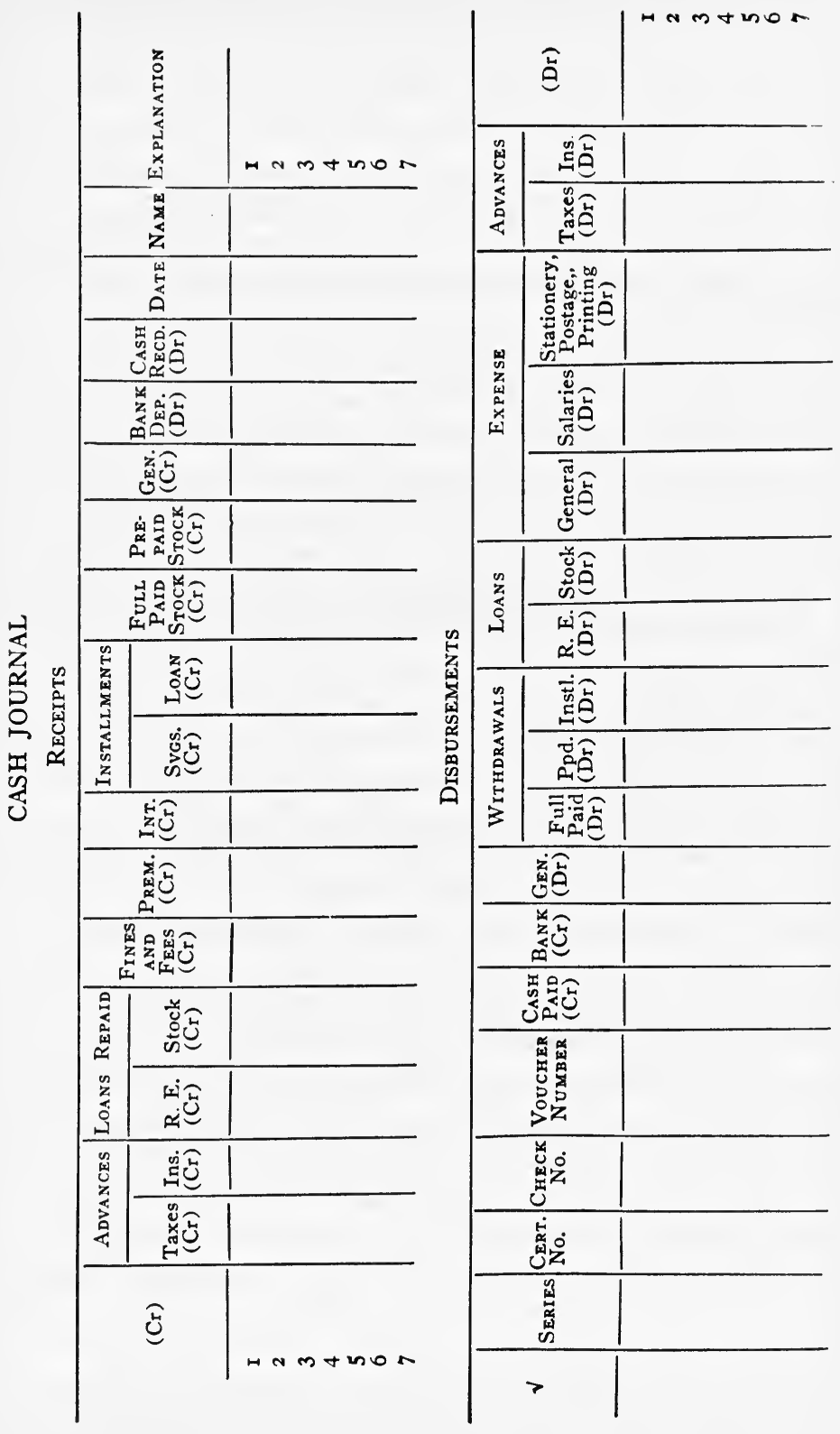


without headings, so that they will be available when an account acquires prominence enough to warrant a separate column. Only experience can show which items can be omitted from a given association's books.

Trial Balance.-Unless all the accounts are in balance, the books of an association are useless. In order to prove their correctness between fiscal periods, accountants resort to a "trial balance." This involves taking off the totals of both sides of all accounts and proving them to be equal. Simple as the process is, it must be done with great care, for errors easily creep in. A regular trial balance sheet is ordinarily used, which may be bound in book form as a permanent record, if desired. It may be worked out so that one sheet contains the balances of one week or one month or six months. The use of such a form makes it possible to check up all operations frequently and is useful as a daily report to the directors such as that shown earlier in this chapter. This trial balance must show the footings of all accounts in the general ledger, together with balance of each account. The form on p. 294 used by the Home Savings and Loan Company of Youngstown, Ohio, is typical of the best form of trial balance.

Reports.-Periodic reports must be made by all associations to some one who is interested in the conduct of the business. The directors need not be informed of all the details of each day's transactions, but they want to see summaries of the business. These summaries should be clear enough to fully explain the actual condition of the organization. Reports to stockholders can be made on a skeleton form, since the members are more interested in the result than in the method by which it is secured. They want to know at all times that the business is being safely and profitably conducted. Other than this they seldom make inquiry.

Reports to a state officer are another matter. Each state supervising department demands a certain type of report, and the student should procure the form required in his state and carefully study it in the light of principles laid down in this 
The Home Savings and loan Company, Youngstown, Ohio General Ledger and Daily Statement

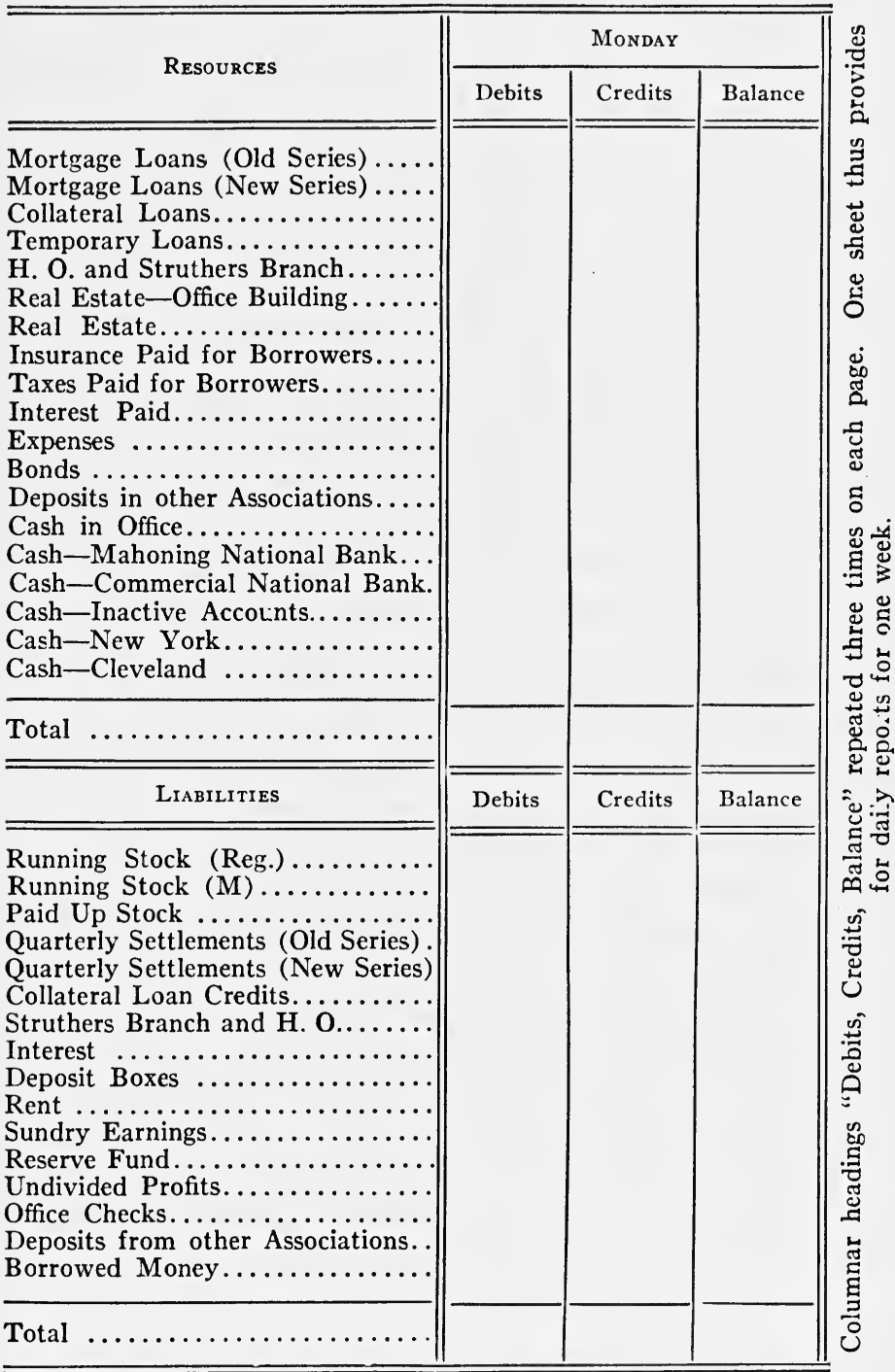


chapter. In states where these reports have been well worked out, they provide a convenient form for making reports to directors and shareholders as well as to supervising officials, thereby saving much time and labor in duplicating the information.

Unusually complete reports are required in some states, and many of these requirements contain suggestions that are well worth while. For example, one department requires the separation of loans into "loans for purchasing homes," "loans for residence construction," and "other loans." Another suggests that loans be separated so that total urban and total rural loans of each type can be found. Where the additional information is secured without burdening the association offcials, the method has much to recommend it.

An interesting balance sheet for use as a report has been worked out with each item explained by E. R. Partlow, Secretary of the Equitable Building and Loan Association of Danville, Illinois, a copy of which is reproduced herewith.

\section{FORTY-FOURTH ANNUAL STATEMENT}

February 29, 1924

\section{RESOURCES}

Loans on Real Estate and on Contracts......... \$1,864,072.06

This sum is composed of First Mortgages on Real Estate, at about 60 per cent of the value of the security as appraised by our Loan Committee and approved by a majority of the entire Board of Directors; all buildings upon the mortgaged premises are fully protected by both fire and wind storm insurance. Loans are made for the purpose of buying homes, building homes, paying existing mortgages or debts-in fact for any legitimate purpose.

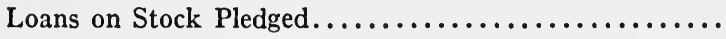

A holder of "Free Stock" may borrow at any time any portion or all of the book value of his shares, giving a note with his certificate as security. This provides ready money at any time, and avoids the neces- 
sity of losing earnings if money is needed between statement or withdrawal periods.

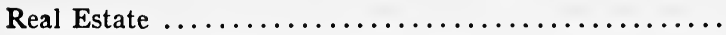

No Association can avoid having to foreclose some mortgages. Unforeseen circumstances will arise during the lifetime of a few borrowers, making it impossible for them to meet their payments on loans. The percentage of failures in an Association is very small. The few losses sustained on foreclosures are more than made up in the profits of others.

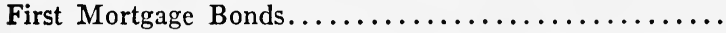

These were purchased when there was no demand among our members for the funds on hand. They are first class security, and provide an available fund at any time should necessity arise.

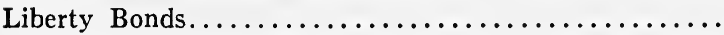

Obligations of the United States. Like the First Mortgage Bonds, they provice an Emergency Fund.

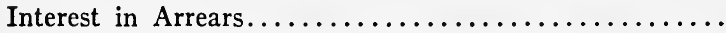

There are always some borrowers who cannot, or do not, pay the interest on their loans promptly. This item is secured under the mortgage given. Fines are charged for delinquency.

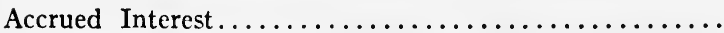

Interest earned, not yet due and payable, upon mortgages, First Mortgage Bonds, and Liberty Bonds.

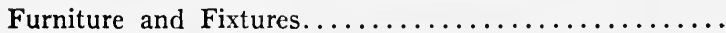

Equipment used in the Association's office.

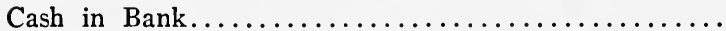

Needs no explanation, as all of us know what "Cash in Bank" means.

$20,230.75$

$33,400.00$

10,3II.3I

$2,500.00$

I 30, I 20.46

$\$ 2,134,985.00$

LIABILITIES

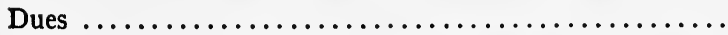

The savings of all our members, whether accumulated by regular weekly or monthly payments, or the investment of "lump sums."

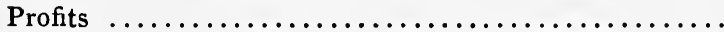

$\$ 1,903,573.06$

Total divided profits. The earnings apportioned to the members upon the amounts invested by them. They 
are never disturbed in the future, even though losses to the association might occur. Many withdraw their earnings every six months, in order to use the money.

Reserve $13,500.00$

Under the laws of Illinois governing Building Associations, we are obliged to set aside a certain portion of the earnings or net profits at each statement period, to be placed in "Reserve." This fund is an additional protection for our members, as it can only be used to meet losses sustained by the Association.

$\$ 2, \mathrm{I} 34,985.00$

Methods of accounting for dividend distribution vary according to the plan on which the association conducts its business. Usually such distribution is made in one of three ways:

(a) At a fixed rate which seldom varies for a term of years.

(b) At a varying rate dependent upon earnings in each fiscal period.

(c) On the partnership plan whereby no reserves are set up, but all profits are apportioned to the shares according to the length of time the shares have been in the business.

The methods by which distribution is made are discussed in a later chapter. The proper procedure for accounting in such distribution is similar in all essential respects to the method of posting already shown.

Permanent Plan Accounts.-The necessary accounts of the permanent plan are the same as already shown. All installment stock is combined in a single account in the general ledger, and such other types of stock as are issued may be entered in the usual way.

Serial Associations.- It is necessary to keep separate the various series of installment stock issued by a serial association. Each series will, therefore, require a separate account in the general ledger. It is entirely possible to keep a separate ledger in order to record the various series, letting each series 
open, function to maturity, and be repaid, while only totals for each series are posted to the one controlling account in the general ledger. This plan has certain advantages, among which are the division of labor in keeping the records and the freeing of the general ledger of much unnecessary detail.

Serial Associations Dividing Earnings on the Partnership Plan.-Where all income is divided among the members on the partnership plan and the business has reached a stage of equilibrium, there is less necessity for elaborate separation of the various parts of each payment. Members of such associations do not expect such information from their officers since they never have had it, and the books may, therefore, be greatly simplified. All that the members ask is that the business be conducted on a sound basis and series be opened frequently enough to care for their savings. A considerable saving in time and in book space is realized by crediting payments in a lump sum, but when detailed information of the present condition of the business is needed, it cannot be obtained from such books. It would appear, therefore, that wherever the business fluctuates from month to month and it is practicable to divide the items in the accounts, the advantage of the more complete information should offset the cost in time and trouble.

Dayton Plan Bookkeeping.-Since payments are made under the Dayton plan at any time, the books may be kept on the plan of the deposit records in a bank. All records are made as previously explained, except that the installment stock is grouped in a single account. These records are perhaps kept more easily than those under any other modern plan, where complete information is desired. Greater simplicity may be achieved only at the expense of accuracy.

Guarantee and Permanent Stock Plans.-Except the method of dividend distribution, the bookkeeping process of associations which guarantee dividends on certain kinds of shares does not differ from those already outlined. Ledger accounts for the shares which act as a guaranteeing fund and 
for their dividends must be kept separate. Dividends are added to other share accounts at each dividend period with only a formal motion by the directors. The earnings of the guarantee stock itself depend directly upon the amount left after the regular dividends have been paid.

Uniform Accounting Systems.-Progress in formulating uniform accounting systems has been very slow in the United States. State supervising departments have recommended in many cases that their associations adopt uniform systems; but in the absence of legislation these recommendations have not met with universal success and unqualified support.

In 1924, uniform accounts were prescribed by the supervisory departments of Arizona, California, Connecticut (for new associations only), Indiana, New Hampshire (Eldridge forms), and North Carolina. Certain other state departments recommend the adoption of uniform accounts, but do not require such adoption. These include Kansas (Hall Lithographing Company forms), Louisiana, Missouri (Hugh-Stephens forms), New York, and Oregon. The West Virginia supervisor believes that uniform systems should be required in his state.

It is too early at this time to suggest complete systems of uniform accounts which would be universally acceptable, but building and loan men can well afford to undertake a thorough study of this whole project, to the end that associations using each main plan and principal modifications may soon have a standard set of books which will guide them in keeping their own.

\section{Auxiliary Records}

Stock Register.-The laws of several states specifically require that a stock register be kept, but this requirement may usually be met by entering the essential information on the individual ledger accounts. If shareholders' accounts are carried in numerical order, this record is adequate. The essentials include the name and address of the shareholder, number of certificate series (if any), the kind or class of shares issued, 
number of shares, and date of issuance. The records should likewise show any transfers of ownership and the ultimate disposition of the certificate, whether by voluntary or involununtary withdrawal, or by cancellation at maturity.

Loan Applications.-Although the regular minute book will show what loan applications have been acted upon, it often happens that a surplus of applications is received. Where the by-laws specify that loans shall be considered and made in the order in which applications have been filed, it is wise to keep a permanent record, showing the date of filing, name of applicant, amount of loan desired, and any other facts that may be pertinent. It is not necessary, however, to enter in such record more than a small portion of the information contained in a complete application.

Appraisal Record.-An appraisal record may well be made a part of the record of "Loan Applications Received" through inclusion of space therefor. It often happens that loans which are otherwise acceptable must be declined because of unfavorable report by the appraisers as to the value of the property. In such case it will do no harm to have on file an appraised valuation of such properties for future reference. When a loan is made, the appraised value may well be included in the information given at the top of each loan ledger sheet.

Title Reports.-The evidence of title, in whatever form, is usually filed with other loan papers in individual jackets numbered to correspond with the numbers assigned to the respective loans. Where abstracts of title are in use, these may be so bulky as to necessitate separate filing. In this connection, it should be urged as a precautionary measure that, except where dependence is placed on personal search of the records, the mortgage contract should provide that all evidences of title such as abstract, and certificate of policy of title insurance, shall remain in the custody of the lending association until the loan is cancelled. Furthermore, it is advisable never to permit such instruments to be removed from the files, as in pending transfers of real estate, except upon written 
order of the borrower and written receipt by the party in whose favor such order was written. Otherwise, an association may not only find itself lacking evidences of title, but may even be required to pay for reproduction of the same by the liquidating borrower.

Insurance Records.-No association office can safely do otherwise than maintain an up-to-date filing system whereby all insurance policy expirations can be easily and systematically noted and renewals provided. It is not sufficient that a memorandum entry be made on the individual loan-ledger sheets. An insurance policy in event of casualty is of importance equivalent to the note and mortgage which are so scrupulously guarded. An expired policy is worthless, and the only way to be constantly protected is to watch expirations and see that renewals are always made. The checking of insurance expirations a month in advance is to be commended.

Tax Receipts.-Receipts or certificates covering taxes paid by the association for its borrowers are tangible evidences of indebtedness and require proper listing and also safekeeping. The record should show the date, amount, loan number, with spaces for inserting date of payment by borrower, amount of principal payment, and the interest thereon.

Minute Book.-In every association a complete record of the proceedings of all meetings of shareholders and directors must be kept. Many are still using bound books for the purpose and laboriously writing the minutes thereon in long hand. More, perhaps, are now using loose-leaf books for the purpose so that the notes may be typewritten. A third method which saves time and trouble provides that portions of the minutes which are repeated at each directors' meeting be printed on the loose-leaf sheets with blank spaces provided for such items as: date and place of meeting, those present, the presiding officer, minutes of previous meetings read, reports read, action taken thereon, loan applications received (including respective items usually inscribed in the minutes and space for data on each), action taken on each loan, bills 
allowed and ordered paid, unfinished business, new business, adjournment. The use of such printed minutes saves the secretary's time as well as insuring that no essential part of the regular procedure shall be overlooked.

\section{SPECIAL REFERENCES}

Accounting. American Institute of Accountants, Building and loan associations (in their Accountants' Index, I921, pp. 200-201, New York, The Institute). Bennett, R. J., Building and loan associations, Journal of Accountancy, February, 1924, v. 37, pp. 81-90. Illinois League Proceedings (1920), pp. 88-89; (1920), pp. 93-94. Iowa League Proceedings (1914), p. I9. Kansas League Proceedings (1920), pp. 77-78. Montgomery, R. H., Building and loan associations (in his "Auditing Theory and Practice," 3rd ed., rev. and enl., I922, v. 2, pp. 76-85, New York, Ronald Press). Oklahoma League Proceedings (1924), p. 38 . Youngstown Institute Proceedings, June I5, I923, pp. 6-7, II-18, 20-23; June 22, I923, pp. I-2I.

Equipment. Youngstown Institute Proceedings, June 15, 1923, pp. 3-23; April 23, I924, p. 6.

\section{GENERAL REFERENCES}

Gordon ANd Lockwood. Modern Accounting Systems (1924) pp. 7-50. Newlove, George H., and Pratt, Lester A. Specialized Accounting (I923), Chapter X.

Rosenthal, Henry S. Cyclopedia, pp. 276-282; 325-333; 454-464.

Yeo \& Lukens Company. Building and Loan Association Accounting (Philadelphia). 


\section{CHAPTER XIV}

\section{DEVELOPMENT OF THE BUSINESS}

Diversified methods in use; opportunities for enlarging the association; coöperation of members and directors; circular distribution through mail of commercial and industrial plants, pay-envelope advertising; size of advertising appropriation; newspaper advertising-nature of copy; personal solicitors; importance of selling influential people first; problem of over-selling; community coöperation-enlisting the aid of a disinterested party from outside, conferences of business men, coöperation with bankers, putting the plan into effect; direct mail solicitation-advantages and disadvantages; national coöperative advertising.

Methods of obtaining new business vary with the service which an association has to sell. Purely mutual associations whose members share all risk have generally found that it is unsatisfactory to employ paid solicitors, because a salesman urges only the advantages of the article he is selling; and possible trouble is stored up when a new member is led to believe that the association is doing business on the same basis as a bank or upon any other than its actual basis. Because of misrepresentation, statutes have been passed in several states ${ }^{1}$ which prevent the employment of paid solicitors to sell shares in building and loan associations on a commission basis. On the other hand, definite contracts can be sold by paid solicitors with small opportunity for misunderstandings, and where the law permits such contracts (either for loans or savings) the paid salesman has made a place for himself. ${ }^{2}$ Very little can be accomplished by broadly generalizing about

3 Paid solicitors are prohibited by law in Connecticut, New Jersey, New York, and Ohio.

${ }^{2}$ Definite contracts are used principally in California, Colorado, and Kansas. 
methods which might be successful under various conditions. Therefore, we have obtained direct from associations in every part of the country a statement regarding methods which have proved most satisfactory to them, and this chapter is based largely upon their replies.

Replies were received from $22 \mathrm{I}$ associations, and a wide variety of development methods were reported, ranging from "obtaining the coöperation of members," or of directors, through advertising, printed circulars, personal solicitation, and "community campaigns," on down to billboards and window displays.

There was almost as much diversity of opinion expressed in regard to the value of the different methods as there were associations reporting. Here is a summary of the opinions:

\begin{tabular}{|c|c|c|c|c|c|c|c|}
\hline \multirow{2}{*}{ METHOD } & \multirow{2}{*}{ REPORTED } & \multirow{2}{*}{\multicolumn{2}{|c|}{ IN USE }} & \multirow{2}{*}{$\begin{array}{c}\text { Associa- } \\
\text { TIONS } \\
\text { REPORTING }\end{array}$} & \multicolumn{3}{|c|}{ Opinion of Results } \\
\hline & & & & & Good & Fair & Poor \\
\hline \multicolumn{4}{|c|}{ Coöperation of members........ } & $2 \mathrm{I} 2$ & 124 & 56 & 32 \\
\hline \multicolumn{4}{|c|}{ Coöperation of directors.......... } & 215 & 160 & 40 & I5 \\
\hline \multicolumn{4}{|c|}{ Newspaper advertising ............ } & I 77 & II 4 & 48 & 15 \\
\hline \multicolumn{4}{|c|}{ Printed circulars, etc........... } & I65 & II 3 & 37 & 15 \\
\hline \multicolumn{4}{|c|}{ 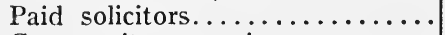 } & 71 & 39 & 9 & 23 \\
\hline \multicolumn{4}{|c|}{ Community campaigns........... } & 67 & 29 & I5 & 23 \\
\hline
\end{tabular}

The number of associations using other methods to develop their business were as follows:

25 Personal solicitation by officers and members.

24 Direct mail solicitations.

8 Civic club, school and factory talks.

7 Window displays.

8 Blotte:s, calendars, and novelties.

6 Bill boards and bulletins.

5 Emphasize safety, courtesy, service, and promptness.

4 Individual savings banks.

3 Street-car advertising.

2 Moving-picture theater slides.
2 House plans and photos.

2 Payroll envelopes.

2 School savings clubs.

I Personal solicitation by life insurance salesman selling life insurance and building and. loan.

I Factory clubs.

I Follow real-estate transactions.

I Feature the annual meeting.

I Est:.blished agencies.

I Personal interviews.

I Solicitation by members on a paid basis. 
Opportunities for New Business.-The association secretary who recognizes the fact that his business is one of real community service and that it offers the possibility of increasing not only loans, but also savings at the same time, can make a life career for himself and his fellow workers which is as amply satisfactory as the career offered by any other type of business. Too many associations in the past have felt themselves "overwhelmed with business" when new applications for loans came in greater amount than could be satisfied with available funds. Instead of going out after more funds from savings members, secretaries closed their doors to new applications until funds should be available in the future. Such a business offers small opportunity for the secretary who is ambitious to keep in step with modern development, although it would supply a life position with a moderate reward for anyone who enjoys caring for many details of a business which serves his fellow men.

Probably the limit of size of the business which can be cared for by the average association secretary is $\$ 1,000,000$ in assets. Up to a certain point in any association, increasing the business reduces the percentage of overhead expense. For example, in an association with $\$ 200,000$ assets, the expense of management is approximately as high as for a larger association. Perhaps no additional expense is involved as the business is increased to $\$ 400,000$. To increase size beyond this point calls for more expense, but without necessarily increasing the ratio of expense to amount of business transacted. The associations of most rapid growth are those which are inclined to use a generous percentage of their revenue for the promotion of additional business and improvements in the service rendered. The smaller association, because it does not spend so much money for development, can sometimes pay a higher dividend return than the large association, but this is not invariably true. Very few of the more progressive associations have expense accounts greater than one per cent per annum of their assets. Many association secretaries who are 
active in developing new business feel that if a surplus remains after paying all expenses out of this allowance they are justified in expending the balance for promotion purposes.

Coöperation of Members and Directors.-When an association secretary has made up his mind to increase the business, he finds that contact with people entering his office forms the basis for most of this increase. Members and directors coming in on their own business sometimes bring their friends and business associates with them. Much new business can be developed right in the office through such personal contacts between the officers and the visitors. This is particularly true where associations maintain regular business offices, open throughout the day. The personal contact can be brought about by the effective use of attractive printed matter. While the visitor is waiting for his friend to transact business, his attention and interest can be attracted by having printed matter conveniently placed on writing stands or nearby shelves. Desire for safe investments with attractive dividends can be aroused in such leisure moments, and if the secretary's desk or window is so placed that he seems accessible, a casual conversation may frequently turn a chance visitor into an active member. Many associations in the past have failed to realize the effectiveness of properly placed printed matter. Attractive, well-kept displays mean a great deal more than is commonly supposed.

Perhaps one of the most effective forms of printed circulars is the small folder which presents the "explained balance sheet," such as that of the Equitable Building and Loan Association of Danville, Illinois, which we have reproduced in Chapter XIII, (see pages 295-297). This statement is free from technical terms and even the person who knows nothing of finance can visualize the business and grasp something of its methods. He needs no understanding of the technical principles of accounting. 
Attractive Office.-Where the association has its office with another firm, such as a real-estate firm, it is easily possible to make the building and loan section of the room the most attractive part of the premises. It should not be necessary for a new customer to search for advertising matter. On the outside of every folder should be a short concise statement of the purpose of building and loan associations, one on each folder. Many people know nothing about the associations, nor will they take the time to read long statements of their origin and history. Three or four folders of six or eight pages each, neatly printed and concisely arranged, are ample for the average association. If the wording of the folders can be as concise as the wording of a telegram, they are much more likely to be read and remembered.

Circular Distribution.-In addition to attracting members into the office, members and directors can frequently be induced to coöperate by further distribution of such literature through their own business offices or industrial plants. Every business house has a mailing list, and every name on a mailing list is a potential savings member for a building and loan association. If the folders issued by an association are small enough to slip inside an ordinary business envelope, and light enough to avoid increase in postage, considerable distribution of such folders may often be obtained through the mail of local business houses. This is usually looked upon as a form of community service rather than the promotion of business for a rival concern, and good results are frequently obtained by such means. Pay envelopes can often be supplied to local business houses, which will carry a single business-building sentence directly under the amount of pay and the name of the employee.

A few associations have spent too much money in advertising before the community had been definitely "sold" upon the building and loan idea. Possibly the average association can obtain for $\$ 50$ to $\$ 75$ a year a sufficient number of folders for its early life. By this we do not mean to imply that larger 
advertising expenditures are unwise. This depends largely upon the attitude of the community. Selling the building and loan idea costs money, and the expenditure will bring good effects in the long run.

Newspaper Advertising.-Of the $22 \mathrm{I}$ associations which reported their advertising methods, 177 use newspaper advertising; of these II4 (or 64 per cent) found the results very satisfactory. Fifteen associations (or less than 9 per cent) were not satisfied with such results, and 48 associations considered the results fair. To be effective, newspaper advertising must have news value and it must be continuous. No one is attracted by a bare statement of facts unless they are seeking such facts. New members who can be reached through the newspapers must be caught and held by the attractiveness of the statements presented. If a small card simply stating the name, the assets, and the current dividend rate of the association is continuously carried in at least one of the local newspapers, this may form a background for further advertising effort at certain specified times of the year. Such a card continuously before the public will undoubtedly bring in an occasional new member, even if nothing else is done. Whether or not it brings in enough to justify its expense will depend upon the follow-up methods which are used with it. Many associations have found it exceedingly profitable to carry such cards in connection with large advertisements in another part of the paper at weekly or monthly intervals. In each of these larger advertisements they bring out some striking phase of their business, changing copy with each insertion. It is easy enough for an advertisement writer to assume that the business of lending money is too prosaic to admit of striking advertising and kill his words by platitudes. To be effective, advertising must first of all be truthful. The most striking thing that can be said about a building and loan association may not be the same in any two localities in the country; but in times when the association is "overwhelmed with loans" the secretary should advertise so as to appeal to new savings 
members and bring in new funds. When he is "overwhelmed with money" he can advertise for first-class loans. Advertising for loans may seem somewhat bizarre to old-established associations whose portfolios are usually filled with applications in advance of available funds, but in newer parts of the country where the building and loan idea has not been thoroughly "sold" to the people, it is as essential to advertise for good loans as for persistent savings members. The supply of second and third rate loans is always larger than the demand, but the number of first-class risks is always limited, and this is the only type of risk that a building and loan association should consider.

The cost of newspaper advertising varies widely between small towns and large cities. If an association in a large city attempts to do merely a neighborhood business, it will find that newspaper advertising is rather expensive for results obtained. If on the other hand, it is attempting a city-wide business and expects to attract all possible capital and make loans wherever possible, the additional expense of metropolitan newspaper space will in the long run be repaid. Because of the expense involved, however, the directors invariably give considerable thought to their campaign before actually undertaking it, unless they have a fund for such purpose obtained in some previous period.

Personal Solicitors.-When the laws permit the new association to develop business by means of paid solicitors, or through personal solicitation by officers and members as an extra part of their daily work, it is essential that plans be laid so that the building and loan idea is definitely presented first to the most influential people of the community. The association movement was established to enable the "common people" to assist each other coöperatively in financing their homes, and the record of membership of modern associations conclusively proves that the movement has not departed from this original pian. Workmen and salaried people constitute a major portion of the membership in most associations to-day, 
but if these people are to be attracted to an association, it is usually necessary to attract first the business leaders and professional men who are regarded most highly in the community. These men may be regarded as "capitalists," but their influence in attracting other savings members is of incalculable importance, and their funds are as necessary and as useful to an association as those of anyone else.

This chapter is not intended as a treatise on selling methods. Many valuable books have already been printed upon that subject, some of which are listed at the close of the chapter. It is, however, necessary for us to present something of the problem of reaching people who do not come to the office. When prospective customers enter a business house, it is comparatively simple to get them into the frame of mind to entertain a business proposition. Reaching the same people in their own homes or offices is quite a different matter.

The problem of employing paid solicitors has never been satisfactorily settled. As mentioned at the beginning of this chapter, there is constantly a tendency for the man who is selling goods to overlook their disadvantages. Another fault of the salesman of investment securities is the tendency to "oversell" his prospects. Bond houses do not have as much trouble with this as building and loan or life-insurance companies. Investors who buy bonds do so for the most part with accumulated funds. Investors in building and loan shares and in life insurance pay their installments out of current income over a term of years. Salesmen sometimes accept subscriptions for such large sums that all of the member's accumulated savings are required as a first payment leaving him with no funds for future payments. In such cases, the members are very likely to give up the attempt to meet their payments in a rather short time. The difficulty arises in the fact that the solicitor received as a commission a considerable portion of the first payment. The association probably regarded this as a membership fee, purposely set aside to cover the cost of putting the business on the books. The remainder, if any, was applied 
in the ordinary way to shares. Where the member remains with the association until maturity, earnings would be more than sufficient to offset the expense of original solicitation, and a reasonable rate of dividend can be paid upon the entire investment. By very early withdrawal, however, the savings have not earned enough to cover the cost of the fee (see tables in Chapter IX), or if the earnings have been great enough for this purpose, they may not leave a reasonable margin of profits to the member for the time the association has used the money.

Paid solicitors must receive a sufficient sum for their services to enable them to live. An agreement is reached between the management and the solicitor based principally upon the relative ease or difficulty of placing business in a specific locality in a given length of time. A reasonable membership fee may be used under such conditions, but this fee should yield the solicitor only as much as his service is worth. To be ultimately successful with paid solicitors, an association should develop a corps of men who remain continuously in a given locality for a considerable period of time. The use of high-pressure methods never brings permanent business. Members who are "rushed off their feet" by over-enthusiastic salesmen tend to become dissatisfied not only because of the misrepresentation, but because they do not have the time or opportunity to learn many details of the business in which they are making their investment before they have actually parted with their money.

The successful salesman needs to be a real building and loan man, educated to understand the type of community service which these coöperative institutions are rendering. The better type of building and loan associations consistently weed out their force of solicitors so as to get a type of man who will sell the right quantity of business to each prospect and sell it on a basis that will be permanent.

Community Coöperation.-Where an association is actively competing with many others in the same town, the idea 
of community coöperation for the promotion of business seems at first glance to be impossible. How, the question might be asked, can all associations work together to develop business, when a few might get most of the benefit? The immediate answer is that new members will select the association best adapted to their needs in any case. If a promotion campaign is paid for jointly by a number of associations, all should benefit thereby, and the cost per unit of business written will be comparatively small.

Growth of all the associations definitely aids in community development, and it is to the advantage not only of all association men but to other business men as well to aid in such growth. There are few American communities which do not need more homes, especially homes owned by the occupants. Efforts to promote a home-owning citizenship need no defense. With people owning their own homes and living in them, business conditions tend to become more stable than where the population is largely of the tenant class. It usually takes some disinterested person from the outside, however, to bring together all of the various business people in a whole-hearted support of the community association movement. Only in this way can a hearing be secured and public interest created in the project.

Little Preliminary Organization Needed.-Very little preliminary organization work is necessary if the right man carries on the work. More damage than good has at times been done by the wrong kind of preliminary work. Public interest cannot long be sustained, and the more quickly a project of community coöperation is carried through, the better. If the newspapers carry stories in advance, the subject has ceased to be news when the campaign starts. If newspaper coöperation is gained and the story is withheld until the campaign actually starts, the reporters will have new reading material each day of the campaign to keep the public informed. Two or three days of intensive community coöperation in showing the advantages of the building and loan plan, and a selling 
campaign of perhaps an hour or so at the end of the time will accomplish more than an ordinary salesman can accomplish in several years.

Conference of Business Men.-The most effective method of bringing about a community campaign is to unite the business men at a preliminary conference. Bankers, real-estate men, merchants, plant officials, the leading men in each business and professional group, should be brought together at the first meeting. An alert newspaper reporter should be called in at the same time. If the organization is effected in quick businesslike fashion, the reporter will be "sold" on the idea. He sees the chance to get live news for his paper and he has been known to prepare the story as a "scoop," with an exclusive article covering the conference and the plans which were worked out. The reporter has thus been brought in contact with the building and loan work in an important way, and it makes more of an impression upon him than any written material which might have been furnished in advance. An advance article based upon printed matter is apt to be "flat" and more harmful to the campaign than complete lack of notice.

It is possible to avoid antagonism of other lending agencies by securing the sponsorship of representative business men at the preliminary meeting. The chamber of commerce, the luncheon clubs, and the banks are all interested in the growth of building and loan associations. An immediate meeting of the clearing-house banks secures their coöperation, because such an invitation recognizes the important part they play in any financial undertaking of the community. Their opinions are listened to with respect because they understand the ebb and flow of money through the town. They know that all money taken in by the associations must flow through their banks and then be invested in homes within the community. The meeting serves to call attention to the fact that local resources so used are not being diverted to outside investments in bonds and other securities. 
Coöperation with Bankers.-The competition which a building and loan association sets up with the savings department of the banks is of much less importance than might at first be believed. People invest their savings in the building and loan association because of safety and higher rates offered, and they recognize that their dividends are higher than those paid on savings deposits because of the much larger overhead expense of the banks, because of the more gainful investment in real estate mortgages, and because of the profit-sharing system employed by the association. Proper building and loan development does not interfere with savings bank deposits, because two different classes of investors are attracted. In fact, by increasing the habit of thrift on the part of the people, the savings in both institutions will increase.

Where a building and loan secretary lacks a high conception of his duty and attempts to divert business from the time deposits of a bank to his own association instead of stimulating new business, the immediate sympathy of bankers cannot be obtained. Nor is the banker less mistaken when he fails to recognize that withdrawals from his own time deposits for the purpose of meeting the housing situation actually result in greater ultimate profit to himself than the commission which he makes on the sale of outside bonds to his depositors. Amounts withdrawn are usually deposited again by the sellers of the houses or the contractors or material men who construct them. Where selfishness and ignorance of the work of these coördinate institutions exist, both sides need education. An outside man familiar with the development of the building and loan business elsewhere is often able to point out and correct many mistaken conceptions.

Putting the Plan into Effect.-Following the first conference, the plans developed there are put into effect. If the promotion of a new building and loan association is considered desirable, a larger meeting of representative men of the community is arranged, preferably at an evening dinner when they will have a certain amount of leisure afterward for dis- 
cussion. If this larger meeting agrees with the plan, soliciting committees are appointed including representatives of each industry or type of business.

At this meeting information concerning the meetings of other groups is sure to be available. The committees are delegated so that every meeting of local business men occurring while the campaign is in progress may be attended by the representatives of the building and loan campaign. For example, if a labor representative is present and knows that a meeting of the joint labor council will occur the following day, arrangements can be completed at once for representatives to appear at that meeting. The managers of different plant organizations may be ready and willing to arrange for noon meetings with their employees. School superintendents may arrange for thrift talks at the schools. It is possible that moving-picture men can furnish the opportunity to present the subject between two parts of the program. All of these different groups can be enlisted to provide the opportunity for a brief address of vital community importance. If the groups are allowed to elect or appoint their own representatives on several joint committees so that the solicitors can be organized into opposing teams with leading men as team captains, a genuine spirit of rivalry can be developed. Possibly they can arrange for the losing team to give a dinner for the other team's benefit. It is absolutely essential that the coöperators shall be able to get a genuinely good time out of the whole thing if their enthusiasm is to be maintained for the several days of the campaign.

Selling the building and loan idea by many local men in this quick, "snappy" way is most effective in reaching the people vitally interested in its development. A surprising degree of permanent enthusiasm is frequently aroused by such campaigns; people continue to put their funds into the associations and to leave their present savings there for long periods of time. Association officers also catch the spirit and contirue the search for new business. A sudden decline of interest is 
unusual, but this may occur when the right kind of enthusiasm has not been aroused by the campaign director.

Successful Men as Committee Members.-The best men to get on the various committees are the busy men of the town. Men who have no leisure can always undertake one more task. Their consent to act on these committees can be obtained usually because they recognize a civic obligation to take part in anything that promotes community well-being. Employers of men have unusual capacities for enthusiasm and leadership in such campaigns.

It is absolutely necessary to emphasize at the start that the leader has no personal interest in the amount of business transacted during the campaign. $\mathrm{He}$ is usually paid on a daily basis, and is hired simply to outline an opportunity for members of the community to coöperate for their own mutual advantage. If his arguments are sound and his manner frank and convincing, the action of the participants is inspired, and they can go ahead with their own plans. The committee men can show their own sincerity by substantial contributions at the first meeting, if this seems to be desirable; but many communities will need no such stimulus until the closing hour of the campaign when new memberships are asked for. Men who undertake at the end of a two or three day campaign to talk building and loan for one hour to their friends may be converted to the idea for life. The basis of a community campaign appeal is the development of homes; the old type of appeal was on the basis of savings and the profit realized from savings. The modern appeal is one of self-interest in presentday things, the help and joy that come from self-enforced thrift.

Direct Mail Solicitations.-The most expensive method of obtaining membership is through an unsupported campaign by mail. The large mail-order houses report that only three to five per cent of the people whom they solicit by mail can be sold merchandise, even with the highest type of advertising. The cost of their follow-up system is enormous. This refers to 
the kind of business which can be most easily done by mailthe selling of merchandise.

The experience of one building and loan association indicates that not over one per cent of the people solicited by mail can be interested to the point of investing in shares by direct mail solicitation unsupported by other campaigns. Only a few associations have made the attempt. The experience indicates that a new association would make a mistake in depending upon such methods, because of the delay and expense involved. If a direct mail campaign is undertaken following a campaign of community coöperation, the immediate effects are much more certain than where no preliminary work has been undertaken. Whatever is put forward in the mail campaign must be presented from a new angle. The material used must have a personal appeal, and like the folders spoken of earlier in this chapter must be in concise "telegraphic" form if it is to be read with interest by the persons addressed.

Probably the best mailing lists which can be obtained by an association are those furnished by employers of labor. After this, telephone directory lists probably rank highest; but since telephone subscribers are so regularly solicited for all kinds of merchandising projects, they become more or less hardened to this sort of advertising matter. Lists of people who are not regularly solicited are much better.

Carefully prepared form letters, personally signed, can be sent out only at considerable expense; but men who have studied the results believe that the kindly feeling which is engendered in a new member by the personal note in these letters makes them a profitable investment. Some associations make it a point to send cordial personal letters to everyone who opens, closes, or reopens an account, or transacts any other outstanding business.

The success of mail solicitation depends upon the degree of sincerity behind the effort; probably a letter betrays the writer's feelings more than any other type of literature. The prospective customer is more interested in the safety of his 
funds than in any other phase of the business. Next after this, he wants to know that, should he need a loan, his record of persistence as a saver will be established so that he can receive favorable consideration. After these two points are made clear in preliminary correspondence with a prospective customer, it is possible to take up the comparative advantages of the association over other iypes of institutions for savings. At this point it is entirely feasible to add the record of dividend payments and other outstanding features of the business. The dividend rate, however, is of less importance than most other features, as has already been shown in an earlier chapter. It would ordinarily be possible to reduce the dividend rate one, two, or even three per cent below some rates at present in force without appreciably diminishing the flow of money into the treasury.

Other Methods. - In addition to the five principal methods of business development which have just been discussed, many other opportunities are open to the progressive association, and none of them should be discarded without consideration. In the opinion of the writers, all advertising methods have their value, and variety results in a wider appeal to the people of the community.

Blotters and window displays may attract some people, but others might better be reached through small advertisements on pay envelopes or slides in moving-picture theaters. Small savings banks in the home undoubtedly help some people to lay aside part of their funds, but others might be reached more effectively through short talks before clubs, schools, or factory meetings. The immediate method to be selected depends upon the nature of the people whose business is sought more than upon any other one thing.

National Coöperative Advertising.-There is probably enough similarity among building and loan practices throughout the nation to make a national advertising campaign profitable. This is the conclusion reached from a study of the reports of $22 \mathrm{I}$ associations, ro5 of which stated that they be- 
lieved that such a campaign would be beneficial to their local associations. Forty-six others reported that they did not believe such a campaign would be successful, and 33 were undecided. The relative gain which these reporting associations had made between I9I9 and 1923 is shown in the following tabulation:

\begin{tabular}{|c|c|c|c|}
\hline $\begin{array}{c}\text { Associations } \\
\text { REPORTING }\end{array}$ & Assets I9I9 & AssETS 1923 & $\begin{array}{c}\text { Gain } \\
\text { Per Cent }\end{array}$ \\
\hline $\begin{aligned} \text { ro5 } & \text { Yes } \ldots \ldots \ldots \\
46 & \text { No } \ldots \ldots \ldots \\
33 & \text { Undecided . . } \\
37 & \text { Did not answe }\end{aligned}$ & $\begin{array}{r}\$ 108,698,976.73 \\
49,015, \text { ro2 } .44 \\
53,441,213.74 \\
\text { his inquiry. }\end{array}$ & $\begin{array}{r}\$ 229,973,084.91 \\
89,486,782.46 \\
85,990,027.49\end{array}$ & $\begin{array}{r}111.5 \\
82.5 \\
60.9\end{array}$ \\
\hline
\end{tabular}

221 Total

The assets of all the associations in the United States showed a gain of 76.6 per cent in the same period. The associations believing in advertising on a national basis showed an excess percentage of gain over the average association of 34.9 per cent. If all the associations in the United States had made an equivalent gain, the total assets for 1923 would have been $\$ 4,0$ r $4,998,29$ I instead of $\$ 3,342,530,953$ as actually reported.

The outstanding success of the coöperative advertising campaigns conducted nationally by the paint manufacturers, the flooring manufacturers, the raisin growers, and others have been so successful that there is little reason to believe that building and loan associations would not be equally benefited. It is true that a local association is not selling its goods on a national basis, but neither is the local paint store. Yet, the latter is definitely in favor of the national campaign conducted for its benefit.

It is interesting to note that many of the associations which reported a dislike for national coöperation favor local cooperative advertising because of the similarity of methods in a given locality. One hundred and nine associations stated that they believed local coöperative advertising would be more satisfactory than that conducted on a national basis; 45 stated 
that both were needed; 2 I disliked local coöperative advertising; and 2 favored neither. Local coöperative advertising in Kansas City and New Orleans has produced excellent results. The same is true of the state-wide coöperation of Ohio associations, with emphasis on general publications of live news items in the local press.

Selling Loans and Refinancing.-It is probably more important in developing the business of the association to secure new savings members than to make new loans, but everyone in contact with an association should be given some definite information regarding the process of getting a loan and the advantages of the amortized loan. Undoubtedly, more people come into the association movement on the recommendation of their friends and neighbors than for any other reason.

No real campaign for selling loans is necessary. It should be a matter for the individual officers to find the proper loans in order to place their accumulated funds whenever they have an excess. As before explained there are four types of building and loan association loans: ( 1 ) For the purchase of buildings already constructed, (2) financing new construction, (3) refinancing old straight mortgage loans, and (4) simple borrowing for private purposes other than home ownership. The first three are the primary objects of the association's business, and should always be given preference, but the last named is legitimate so long as the character of the applicant is satisfactory and the security ample.

Probably refinancing calls for more straight newspaper advertising than any other type of loans which may be offered. An equitable loan plan and an announcement that the association has enough funds on hand to refinance straight mortgages on favorable terms are likely to place such excess very promptly.

When a town seems to be built to about its limit, when there are no applications for any construction loans, the secretary must use his ingenuity in placing his money in first-class loans. Some have even made use of lists of unsatisfied mortgages ob- 
tained from the public record of their counties. Any legitimate method that results in promptly disposing of accumulations may be used, and the success of a given method will depend almost entirely upon the psychological factors in a given community.

\section{SPECIAL REFERENCES}

Advertising. Connecticut League Proceedings (1922), pp. 20-23. California League Proceedings (1924), pp. II3-IIg. Illinois League Proceedings (I920), pp. 47-5I, 74-80, 90-93, I2I-I25; (I922), pp. I6-I 7, 45-47, 72-75, 76-82. Iowa League Proceedings (1915), pp. 30-33; (I916), pp. 29, 45-47; (I922), pp. 72-75; (I923), pp. 65-70. Kansas League Proceedings (I919), pp. 67-70; (1920), pp. 32-36, 546I ; (I924), pp. I7-I8, 31-33, I03-107. Missouri League Proceedings (IgI9), pp. 46-53; (I92I), pp. 22-26; (I924), pp. 9, II. New York League Proceedings (1922), pp. 38-39, 63-79; (1923), pp. 38-45. Ohio League Proceedings (I 155 ), pp. 35-4I ; (I9I6), pp. 100-102; (I92I), pp. 64-7I, I06; (I922), pp. 69-74, I25-I27, I28-I3I, I35-I39; (1923), pp. I06-II9. Oklahoma League Proceedings (1922), pp. 2023. U. S. League Proceedings (I90I), p. I44; (1902), pp. 55-59; (I9II), pp. I63-I70; (I915), pp. 75-I09; (I9I6), pp. 92-95; (I9I8), pp. I05-II5; (I9I9), pp. I36-I40; (I920), pp. IOI-II2, I55-I57; (I92I), pp. 90-92; (1923), pp. 196-203. Youngstown Institute Proceedings, June 15, 1923, p. 20; April 16, 1924, pp. I-15; April 23, I924, pp. 2-3.

Banker's viewpoint. Ohio League Proceedings (1916), pp. I24-134.

Banks vs. building and loan associations. Kansas League Proceedings (I918), pp. I4-I5. Ohio League Proceedings (I92I), pp. 86-II3. Oklahoma League Proceedings (1924), pp. 28-29.

Branch offices. Illinois League Proceedings (I918), pp. I24-I 25.

Community development. U. S. League Proceedings (Igor), pp. 44-50.

Education of public. U. S. League Proceedings (I914), pp. I53-I79; (I9I6), pp. I37-I48.

Members-obtaining. Iowa League Proceedings (1922), pp. I6-I7.

Press and building and loan relationship. U. S. League Proceedings (I900), pp. 44-52.

Promotion. Minnesota League Proceedings (1924), pp. I6-I7. Ohio League Proceedings (1922), pp. 22-23.

Salesmanship. Kansas League Proceedings (1924), pp. 43-49. Nebraska League Proceedings (1924), pp. 44-46. Oklahoma League Proceedings (1922), pp. 58-67. 


\section{GENERAL REFERENCES}

Hilliard, Wm. How to Sell Building and Loan Investments.

Myers, R. Holtby. Ten Lessons-Selling the Building and Loan Idea, (1922).

Rosenthal, Henry S. Cyclopedia, pp. 472-477. 


\section{CHAPTER XV}

\section{THE USE OF JUVENILE SAVINGS}

Juvenile savings yield future profits, not present income; full participation in earnings desirable; early experience in New Jersey and New York; methods in use in Corning, New York-pass-book and portable bank; envelope system used in Elmira, New York-size and regularity of savings; experience in Chicago; success of the plan in Fresno, California; machine deposits; coöperation with the teachers; New Jersey League leaflets; school-savings banking.

By training the young citizen to use the association in accumulating his savings, the officers can establish for themselves a definite basis of future business that cannot be obtained cheaply in any other way. Whether the child is reached through the school (on some plan which relieves the teacher of all burden in connection with the work), or directly from the office of the association, the future profits which may arise from such business are the incentive which leads officials to sacrifice all present profits in developing the business.

Not all states allow associations to accept the savings of minors in their own name, but the laws are gradually being changed to permit this practice. Whether the savings are considered as shares or as special savings accounts, their essential purpose is the same: to get the child into the habit of transacting business with the association. The child gains much more information about the conduct of economic affairs by means of such savings than is realized by the average adult. $\mathrm{He}$ is made independent at once to the extent of his savings, though the sum is seldom large; and this development of the spirit of independence and self-reliance justifies to a great extent the expense attendant upon the development of the busi- 
ness. Also, the added expense to the association is made up in later years through increased business. Immediate returns can well be overlooked in view of the remote ends which are sure to benefit both parties. A special teller's window with a platform above the floor of the lobby is provided by many associations to-day, so that the child can easily see through it. A sympathetic officer behind such a window soon gains a child's confidence.

Juvenile Savings Paid Full Earnings.-When the managers understand and appreciate this branch of the business, the child is never penalized, regardless of the system of fines that may be imposed upon adult savings members for delinquencies. In all respects juvenile savings are, or should be, a preferred claim against the assets of the association. These savings are returnable in full with earnings up to the last dividend date, and sometimes up to the date of withdrawal, at any time the child chooses to withdraw. The child is entitled to full earnings upon his savings; but, because of preference over other members, there may be some justification for paying dividends upon juvenile shares at rates from one-half per cent to one per cent less than those paid upon adult shares.

Early Experience in New Jersey and New York.-The juvenile-savings business has had a large growth only where sympathetic officers have been placed in charge of the work. As a result, not all associations undertaking the business have been equally successful, even when the provisions of the state law were the same. William Flemming is probably the father of the juvenile-savings movement, having started a "juvenile annex" of the East Rutherford, New Jersey, association in December, 1896, which attracted an unusual number of children. Frank Kingsbury, a former president of both the United States League and the New York League of Savings and Loan Associations, became interested in the work, and made a pilgrimage to East Rutherford to learn of Mr. Flem. ming's plans. He then attempted to introduce a juvenile annex 
into his association at Corning, New York, but met some diffculties with the State Banking Department. To remedy this situation, a bill was framed by the legislative committee of the New York State League which passed the legislature and enabled the New York associations to accept juvenile savings. The plan was put into effect after some delay, and has since met with remarkable success.

Methods Used in Corning, New York.-The Corning association issues a pass-book when the child opens his account, and lends him a portable bank as soon as the amount reaches one dollar. Banks may be brought in to the association office, and their contents deposited, between the hours of two and five on the Saturday afternoon immediately preceding the third Monday of each month. This time is selected because the third Monday is the regular deposit day on installment shares. The association asks five or six of its friends to assist the regular office staff in receiving these deposits. They are seated at small tables along one side of the room, and each clerk is supplied with distinctly colored slips and a check sheet. The number of the bank and the amount taken from it are listed on both records. The colored slip, the bank, and the book are returned to the child, who presents the pass-book to the secretary, who makes the proper entry in the pass-book and on the ledger card. The secretary also lists it on another proof sheet. At the end of the afternoon the cash and the various check sheets are balanced, and the ledger entries compared with the tally sheet.

Dividends in the Corning association are paid on even dollars for even months. At the close of each six months' period, the ledger cards are footed, the interest computed (the amount being entered in the proper space on the card in red ink), and the balance is carried forward. Withdrawals are allowed any time upon application, but one dollar is retained by the association until the small savings bank is returned in good order. The Corning association has always been much pleased with the success of this business, since it not only teaches the child 
to save money but also teaches him banking methods and business practices.

Envelope System Developed in Elmira.-It remained for Clay W. Holmes, President of the Chemung Valley Mutual Loan Association of Elmira, New York, in I910, to modify the system by the use of small deposit envelopes, so that the children of the public schools could be reached on a large scale with a minimum of trouble to the school authorities and a maximum of accuracy in conducting the business. In 1905 Mr. Holmes had been influential in securing the passage of the juvenile-savings amendment to the New York law, which permitted associations to issue juvenile shares to any minor, which should be free from the control or lien of any other person. The law also permitted the association to pay the accumulated savings on shares to the minor and accept his receipt as an acquittance and sufficient release.

Before that time, systems of school savings banks had been introduced in many schools in the United States, but few of them had been successful, due to the great amount of bookkeeping which was expected of the teachers. Mr. Holmes did not originate the envelope idea, as it was suggested to him by a friend; but he put it into effect in rgro in coöperation with the Elmira Superintendent of Schools, Don C. Bliss, and the ease with which this plan works has resulted in a tremendous development of the business.

In Elmira on Monday morning the pupils in each school room are permitted to hand to their teacher an envelope containing any amount. If old enough to write, the child writes his name on the envelope, notes the amount it contains, and then seals it. The teacher takes the envelopes to the principal, who turns them over to the janitor for delivery to the association office at noon. The secretary of the association, or an assistant, opens the envelopes and credits each child with the amount contained. The responsibilities of the teachers and the principal end when the envelopes are delivered. A simple form of receipt is used so that each person connected with the 
handling of the money is released when he passes it on to the next.

Simplified Bookkeeping for Juvenile Savings.-The details of the association bookkeeping in Elmira are as follows: A check-sheet for the ten schools with rooms properly numbered is first used. The envelopes of each room are counted, the amounts added up on an adding machine, and the result noted on the check sheet. This total shows how much money should be found in the envelopes. The envelopes are then opened, the money counted, and checked off on the sheet. The amounts on the envelopes are then posted on the weekly sheet of each room to the credit of the individual pupils. Each sheet is then totaled, and the sum must agree with the check sheet. At the end of the month the weekly deposits are totaled for each pupil, posted to a regular ledger card, and entered on the child's pass-book. The entire total of the month's receipts from all the schools is then entered upon the regular books of the association as one item. This simple and easy method of bookkeeping checks back at every step and prevents errors.

Withdrawals are allowed at any time, and the bookkeeping process is again simplified to the last degree. The child comes in, puts down the number of his pass-book on a simple blank, and states the amount he wishes to withdraw, signing his name on a sheet provided for that purpose, if he is old enough to write. Otherwise, the mother or father, or someone else signs for him. All juvenile withdrawals are entered on the one sheet and the association is supposed to know nothing about them until the end of the month. Then the secretary adds up this sheet, and draws one voucher for the entire amount to reimburse the cash drawer. One item at the end of the month on the regular books of the association thus covers all juvenile withdrawals for that month. On the sheet and the ledger cards, the whole system goes by number. The originals are carefully preserved and filed away so as to avoid mistakes.

This association issues pass-books to the child for any sum 
from one cent up. Simple pass-books are used, which cost very little, but which give the child a feeling of independence. ${ }^{1}$

It might be mentioned that pass-books have now been designed which contain detachable, numbered coupons as well as permanent sheets. When the teacher enters a deposit in the pass-book, it is at once recorded by carbon paper on the coupon. The coupon is detached and goes with the money direct to the association. No other record need be made at the school. Since the coupons are numbered the same as the pass-books, the keeping of the record at the office is very much simplified and there is small chance of error.

Size and Regularity of Juvenile Savings.-A study of this type of deposits is interesting. More than half the children of the Elmira schools made deposits every week during the first year, mostly small in amount. The remainder put in larger amounts once or twice a month. It was found that the younger children depositing smaller sums were more regular than the older children who deposited larger sums. As the age increases into adolescence, regularity decreases. Seventyfive per cent of all receipts came from pupils of ten years or under. Withdrawals were made mostly by pupils from eleven years up. The total amount withdrawn was very slight, most of the complete withdrawals being occasioned by removal from the city, death in the family, or sickness. Partial withdrawals were in nearly every case to procure some article of apparel or other legitimate necessity.

The high-school students have not been solicited under this plan in Elmira because of the discovery that children averaging over fifteen years are less likely to be continuous savers than younger children.

\footnotetext{
${ }^{1} \mathrm{Mr}$. Holmes continued actively in this work until his death in 1919, since which time it has been conducted by his successors. G. V. R. Merrill took charge of the work until his death in November, 1924. The present association officials intend to continue the policies which have been so successful in the past as the new president, Fred M. Howell, has had ample experience and training for this work under Mr. Merrill.
} 
Experience in Chicago.-At least one association in Chicago had started the school-savings plan as early as the East Rutherford association in New Jersey. Originally they mailed a small pass-book with a little circular to each child in the grammar schools. This brought many children to the association office, where they were taught to fill out the deposit blank, and the officers never needed to show them more than once. In the course of a few years, this department of the business contained some $\$ 25,000$ of deposits. This particular association will not accept $t$ an individual deposit of less than five cents. The officers feel it is one of the best methods of advertising the association and teaching the children something of business methods before family cares are forced upon them.

Juvenile Savings Elsewhere.-Of recent years there has been a large development of the school-savings plan in many other parts of the country. Many towns in Ohio have associations which accept juvenile savings. In Oklahoma, Geo. E. McKinnis at Shawnee and J. L. Coffman at Nowata have developed a large business among school children; and Walter F. McDowell has had remarkable success in the State of Washington. Wherever permitted by law there are increasing numbers of juvenile accounts.

In California, the banking law specifically reserves to the state banks the right to collect the savings of school children. As a result, building and loan associations have been at a considerable disadvantage in attempting to install such systems. After several years of planning and negotiations between the Fresno Guarantee Building-Loan Association and the various school and state officials, solicitation of subscriptions to the shares or certificates of the association among the children in the twenty-five schools of the city was begun in March, I924. The plan was carefully worked out in advance by the secretary, Edwin M. Einstein, and the directors of the association, along the lines of a modern advertising campaign. They followed 
the approved method described in School Savings Banking by the American Bankers Association. ${ }^{2}$

Bulletins fully outlining the workings of the system were sent to each of Fresno's five hundred school teachers. A few days later, thirteen thousand circulars were distributed to all the school children, while the teachers explained the plan verbally, as a part of the instruction in thrift required by the California law. On the following Monday a card reading "Tomorrow is School Thrift Day" was hung in each classroom. The teachers also gave each child two signature cards to take home for their parent's signature-one yellow for the association's files, the other white, which also contained an authorization to the school principal to deliver the children's money to the association. Tuesday morning the classroom cards bore the legend "To-day is School Thrift Day," and as soon as classes opened, the children were given the opportunity of opening accounts with a minimum of 25 cents. Each teacher listed each name and the amount deposited on a separate manila envelope, sealed the money and the yellow signature card in the envelope, and sent them at once to the principal's office, where association officials gathered them up.

Procedure at the association office was similar to that used in Elmira, New York. Envelopes were verified and cash was checked; individual ledger cards and pass-books were made out; and the pass-books were returned to the schools as soon as possible. The large amount of work and the small office force made it impossible to get all the pass-books back before the second "Thrift Day," a week after the first. For the first few weeks this juvenile business nearly swamped the staff and made it necessary to work nights and Sundays. After the accounts were well under way, the pass-books were taken back to the schools on Thursday following the Tuesday collection. As in earlier experiments with school savings, the cost of

2 School Savings Banking, Chap. VIII, pp. 83-102, published for the American Bankers Association, Savings Bank Division, by the Ronald Press, New York, 1923. (174 pp. \$1.25.) 
installation of the Fresno system was large. The initial printing bill was $\$ 530$, and the monthly operating expense about $\$ 85$, not including the amount of time spent by the secretary, and about one-half time for one assistant. The association is so well satisfied with results that they expect to continue the work whether or not it ever shows a profit. The first week, r,326 new accounts were opened, and in ten weeks there were 2,257 accounts with $\$ 5,857$. I I paid in. By the end of 1924 the accounts numbered 2,640 , with credits of $\$ \mathrm{II}, 436.24$, to which profits of $\$ 2 \mathrm{I} 5.76$ were added on December $3 \mathrm{I}$.

The great care necessary in complying with all legal restrictions was illustrated in the Fresno case when a careless reporter for a local paper printed a news story of the plan stating that a representative of the association would call at the schools and collect savings of the children which would bear interest. The Superintendent of Banks at once proceeded to interfere, as the news story implied a violation of the law. Mr. Einstein was able to show him, however, that the plans and the printed matter of the association complied with the law and had already been approved by the State Building and Loan Commissioner, the State Superintendent of Public Instruction, the Fresno Superintendent of Schools, and the local District Attorney; and the Superintendent of Banks withdrew his objections. $^{3}$

Machine Deposits.-Machines have been perfected which have proved fairly satisfactory for the acceptance of school savings in states where devices of the "slot machine" type are in use for legitimate purposes. They are automatic stamp sellers, very similar to the postage stamp machines now commonly found in drug stores and other general retail stores, except that school-savings machines sell savings stamps. An association official secures permission from the school authorities to visit the schools at certain stated times each month. He makes a short address (and it must be very short), and

- See address before California Building Loan League, May, 1924, by Edwin M. Einstein, Proceedings 1924, pp. 38-44. 
gets the children to put their savings in the machine. For each penny, nickel, dime, or quarter-dollar a stamp of the same denomination is delivered by the machine. The child pastes this on a card. When the card is filled, he takes it to the office of the association, where it is duly exchanged for a credit in a regular pass-book. This process entirely relieves the school authorities of responsibility, and throws the burden where it belongs-upon the shoulders of the association officials. One difficulty with the use of stamps is that the method is quite unlike the ordinary deposit method used in connection with adult savings, and what the child learns here may be forgotten later.

Coöperation with the Teachers.-It is necessary to mention at this point that none of these plans can meet with success without the whole-hearted support of the school authorities. Indifference is fatal. The results of the plan depend almost entirely upon the spirit of competition and emulation which is fostered in the minds of the children. They like nothing better than to do the things which the other fellows are doing. If shown that every penny invested in the association will be returned on demand with whatever earnings the association can afford to pay, the child can often be converted into a building and loan saver for life. With equitable treatment of children's savings, the future possibilities are infinite, but any attempt to produce immediate profit from the use of juvenile savings has always resulted in disaster. The expense is approximately as great as the possible earnings from the investment until the total reaches a considerable size, and during the early years may be greater. It is a matter of the future, rather than of present reward.

New Jersey League Leaflets.-The New Jersey League of Building and Loan Associations has prepared two pamphlets for use in the public schools of the state in teaching the subject of building and loan to the students. This is an extension of the juvenile-savings plan, intended to encourage the young people of the state to investigate the safety and high 
earning power attained by building and loan investment. Wherever introduced, these pamphlets have met with enthusiastic success; they have been written in simple terms so as to reach the average student of the seventh, eighth, and ninth grades, and copies of the pamphlets are available for free distribution upon application. ${ }^{4}$

School Savings Banking.-Competition of the banks for school savings is proving a real incentive to thrift, and the recent report of the American Bankers Association shows that only seven states fail to report the use of some form of school savings. The banks have now adopted a practice long used by building and loan associations of segregating juvenile accounts from other assets. A joint thrift campaign on a nation-wide scale might well be undertaken by the building and loan associations in coöperation with the banks, in order to increase the interest of the children in the process and at the same time to develop new methods of handling juvenile savings in the future.

\section{SPECIAL REFERENCES}

Education of children on thrift. Illinois League Proceedings (1920), pp. $92-93$.

Juvenile savings. California League Proceedings (r924), pp. 38-44, 7r. Iowa League Proceedings (1915), p. 27. Kansas League Proceedings (1920), pp. 87-93. Ohio League Proceedings (1921), pp. 8I-90. U. S. League Proceedings (rgIr), pp. I32-146; (1920), pp. I37-144. Youngstown Institute Proceedings, June 22, 1923, pp. 2 I-25.

\section{GENERAL REFERENCES}

School Savings Banking, Ronald Press (1923).

- Inquiries should be addressed to the Secretary of the New Jersey League, whose present address is: H. R. Heydon, Clinton Buflding, Newark, N. J. 


\title{
PART IV
}

\section{EARNINGS AND THEIR DISTRIBUTION}

\author{
CHAPTER XVI
}

\section{EARNINGS AND EXPENSES}

True earnings and unrealized profits; avoiding unequal maturities; accounting for advance payments; treatment of unearned premium; handling membership fees, interest, penalties; excess earnings on full-paid stock; profits on deposits; forecasting net earnings; source of funds for expenses; salaries; advertising.

Building and loan profits are so easily secured that it sometimes happens that secretaries do not recognize the difference between true earnings and profits on hand not yet earned. These include advances of interest, lump-sum premiums, etc. Failure to account separately for advance payments is a possible source of trouble. It eventually leads to paying dividends out of the capital of the association. All capital is supposed to be invested in mortgages and other long-time loans for the purpose of earning profits.

Earnings the Only Source of Dividends.-When dividends are paid out of capital, it results in unequal maturity of different shares. This is especially noticeable when shares are issued in series, but inequality results regardless of the plan used. If large advance payments (such as gross premium) are paid in one year, while in another such payments are small, these profits should always be set aside until earned. If they are allocated at once to the shares in force, these shares may mature more quickly than would be indicated by their regular dividends, which depends upon their average 
earnings for a considerable period of time. If such large payments are credited for several successive years and there is a falling off later on, the difference in length of maturity may be quite marked, sometimes extending the period from I05 to I 6 months, I 20 to 126 months, or 130 to 138 months.

Such unequal maturities cause criticism of the methods of the association, and savings members fail to understand why it is possible for one share to mature in so much less time than another. Where the profits are divided on the partnership plan, these errors tend to be covered up, but they are nevertheless present regardless of the plan of the distribution of profits.

Improper accounting not only inflates the earnings, but it is possible for such practices to cause insolvency. An association has no right to distribute as its profits anything except true earnings. Instances are known where very large "dividends" have been paid from gross premiums, and several state leagues have recently taken steps to curb the practice, as it would tend, if continued, to discredit the association movement.

Advance payments which may cause these difficulties include (I) the old-fashioned gross premium, (2) advance payments on shares, and (3) membership fees. Of the three, the advance payments on shares are least likely to cause trouble, since they are ordinarily credited directly to the installment shares and cannot find their way into any account which might be distributed to earnings.

Accounting for Advance Payments.-There is a definite need for a complete understanding of the accounting processes involved. All unearned income which is in the hands of the association should be kept separate from the ordinary interest and other profits accruing to the association. This may require the addition of such ledger accounts as "interest advanced," "unearned premiums," and "unadjusted fees." These accounts should receive credit respectively for all such advances, and should be debited with each item as settlement is made or when it becomes a real profit. At each periodical adjustment of accounts (annual, semiannual, or otherwise), all 
such special accounts should be carefully inventoried and adjusted.

It has long been the custom of secretaries to work out their calculations by means of simple arithmetic as the need arose. This answers very well when the types of income are very limited. So long as all income belongs to the current period, it can be credited at once as profits. Secretaries would do well to study with care many of the compilations presented in the Robinsonian Building-Loan Interest Tables, for these when properly applied would solve many of the problems in connection with maturities and distribution of income.

The methods of accounting for such payments should be standardized along the lines already worked out for ordinary reserve accounts in a commercial business. No publication has heretofore attempted to explain the character of these payments, and the following suggestions are made after a study of nation-wide conditions. The checks and balances of a particular set of books must be clearly understood in order to prevent the distribution of unearned money. It is the duty of every officer of a building and loan association to take his interest tables and figure the natural maturities of his shares on the basis of the periodical payments and the usual dividend rate. This is not a hard task, and it will lay a good foundation. For example, if the dividend rate averages 6 per cent compounded semiannually, and payments of 50 cents are made each month on each \$roo share, the natural maturity would be about I 39 months. If borrowers from this association are charged 6 per cent interest payable monthly and a gross premium of $\$ \mathrm{I} 6.8 \mathrm{I}$, payable when the loan is made, this is the equivalent of one per cent premium paid in installments of I $62 / 3$ cents per month for each $\$ 200$ of the loan. A computation will show that $\$ \mathrm{I} 6.8 \mathrm{I}$ is the present worth of $\mathrm{I} 62 / 3$ cents monthly plus 6 per cent interest compounded on this payment for I 39 months.

The association has not earned this prepaid premium at the time it is entered on the books. It is entitled to $162 / 3$ cents 
from this amount each month. If the premium were not earning any dividends, monthly deductions of $162 / 3$ cents from this fund could continue only for $92 \frac{1}{4}$ months, but the correct method of accounting for such troublesome figures requires that the $\$ \mathrm{I} 6.8 \mathrm{I}$ be included as an earning asset of the association so that dividends may be credited upon it at each dividend period, while deductions of $162 / 3$ cents per month are being made from the original fund and the dividends. In this way $162 / 3$ cents can be credited to profits from this fund throughout the life of the shares. In no other way is the gross premium properly entered upon the books.

There may be divergencies in the practice of accounting for this sort of income among associations using this old-fashioned plan, ${ }^{1}$ but if it is desired to represent the situation truthfully, the division should be made along this line. If no attention is paid to the probable maturity of the shares, the bookkeeping becomes merely a haphazard record which can mean nothing to anyone who is really interested in the business.

Returnable Fees.-Where membership fees are used, the difficulty of properly accounting for them is not so noticeable, since the frank purpose of such fees is to provide an expense fund for conducting the business of the association. If the fee is uniform in amount and none of it is returnable to the member on withdrawal, there is nothing to prevent the adding of this fee to the earnings. If the membership fee is returnable to a member at a later time on the basis of length of

1 Many state laws require that a proportionate part of gross premium be returned to a borrower when he repays his loan before maturity. In Missouri the law provides for a return of the gross premium on the basis of its being absorbed or earned in 120 months. That is, if a borrower repays his loan in 100 months, he shall be credited with $20 / 120$ of the gross premium paid. (Sec. I4, Building and Loan Laws of Missouri, effective after June 25, I923.) Other states requiring that proportionate parts of the gross premium be returned include: District of Columbia (by-laws determine), Florida, Illinois, Indiana, Kansas, Michigan, Nebraska, New Jersey, New York, Oklahoma, Pennsylvania (by-laws determine), Texas, Virginia (by-laws determine), West Virginia (by-laws determine), and Wyoming. 
his connection with the association, a separate account is necessary, as in the case of the gross premium mentioned above.

Appraisal and other loan fees which are merely collected by the association and turned over at once to the parties for whom they were collected should, of course, never reach the earnings account of the association.

\section{True Earnings for Installment Shares.}

(I) Interest. The largest source of earnings for the ordinary running stock or installment shares of a building and loan association is the amount derived from interest. Borrowers' payments should be promptly separated on the books of the association in such a way as to show the amount of the repayment of the loan (or dues on shares), the amount paid as interest (including premium), and such penalties as may be imposed.

(2) Fees and Penalties. The proper disposition of membership fees has just been referred to, and this applies with equal force to withdrawal and other fees imposed upon both borrowers and savers. The disposition of fines is another matter. Where they are used, they are ordinarily credited directly to earnings. A few associations early in their growth allowed fines to be paid over to officers who collected delinquencies. This practice has been abandoned by practically all progressive associations as a step in the simplification of the accounting process and the elimination of unnecessary annoyances, since it placed a premium on the delay of officers in notifying members of delinquency.

A careful examination of the receipts of many associations has shown that the total income derived from fines is a negligible factor in the building and loan association work. Their preservation is due to the momentum given by an early start more than to any actual need. Where penalties are necessary to enforce systematic payments by borrowers, interest charged upon delinquencies at the same rate as for the original 
loan is ordinarily found to be an ample spur to prompt resumption of regularity.

\section{(3) Excess Earnings on Full-paid Stock over Stipv.}

lated Dividends. Full-paid stock is ordinarily introduced into the building and loan plan on the understanding that a fixed dividend rate will be continued on this stock for an indefinite time in the future. The contract with the shareholders ordinarily states that dividends earned by such stock above 6 per cent (or whatever rate is used) are waived by the subscriber. Such a clause in the purchase contract is not the equivalent of a guarantee of earnings to this amount, but it is commonly accepted as a moral obligation on the part of the association to pay the rate named, if possible. As a result, when the proceeds of full-paid shares are invested in loans, whatever earnings are realized over the stipulated dividend rate accrue to the benefit of the installment shareholders. That is, if all loans outstanding bear 7 per cent, and full-paid stock is earning 6 per cent, this difference may make it possible to pay more than a 6 per cent dividend rate on installment stock.

(4) Profits on. Deposits. In states where deposits are permitted to building and loan associations, a profit from their use is realized exactly as for full-paid stock. All of these items thus become a part of the earnings from which expenses and dividends for installment shares may be paid.

Forecasting Net Earnings.-An established association, well known in the community, can predict its net earnings with little difficulty. The saving habits of the people of the community become settled with the continued success of an association, and the flow of income and the demand for loans can be predicted very closely. As a result, an association is enabled to establish a definite dividend policy which may frequently be continued for many years at a time.

As has already been stated in another connection, the increasing accumulation of building and loan funds points to a continued reduction in the interest and dividend rates. It is 
not necessary to maintain high dividend rates in order to attract savings. In fact, for every dollar so attracted, some other dollars are probably repelled in the belief that institutions which pay too high a rate of earnings cannot be particularly safe.

Expenses.-The desirability of keeping expenses as low as is consistent with efficient management cannot be overemphasized, and the source of funds to meet these expenses can be but a single thing: the true earnings of the association. Expenses should bear a definite relation to the income and to the service which an association is prepared to render. There is no need for either extravagance or parsimony.

In the early days of an association, the expense may be paid by contributions from interested parties, where the law permits such practice, in order that the institution may not be rendered insolvent by using its capital for expenses. Where the law prohibits the acceptance of contributions for such purposes, membership or other fees seem to be justified until the earnings of the association can take care of necessary expenses without further help.

Reasonable salaries are now recognized as an essential part of the movement, although, as pointed out earlier, most associations will need the full-time service of only one or perhaps two officials. Voluntary service which has been rendered in the past by many devoted and public-spirited men could not have been paid for on a satisfactory basis with the income and dividend rates formerly maintained by most associations, but such voluntary service is hardly consistent with the continued growth of the association movement. The services of an efficient secretary and other officers should be paid for as in any other business. In a well-established association, good salaries can easily be paid while the expense ratio is being kept within one per cent of the total assets. Many devoted and publicspirited men will continue as in the past to supply their services gratis because of their love of the work, and this is as it should be. But the tendency for better salaries and 
greater efficiency is definitely recognized throughout the movement.

The advertising appropriation for the extension of the business is a legitimate expense that is being recognized by practically all modern associations. It is true that when the business reaches a certain point, the profits of the individual member are not increased by such appropriations. On the other hand, by coöperating with other associations locally or throughout the state or the nation, the services of the association are extended to a wider and wider audience. Because of the greater public service thus rendered, the additional expense is justified in spite of the fact that the individual member is not directly benefited.

The expenditures for business office and proper accounting and other office equipment have already been discussed in an earlier chapter and will not be referred to here further than to say that the proper housing of an association contributes much toward the service which it is enabled to render, and the extension of such service justifies the reasonable additional costs which may be involved.

\section{SPECIAL REFERENCES}

Earnings. U. S. Lecgue Proceedings (I912), pp. 6I-74.

Expenses. Iowa League Proceedings (1922), pp. I8-19. Ohio League Proceedings (1922), pp. 89-90. 


\section{CHAPTER XVII}

\section{USE OF CONTINGENT-RESERVE FUND}

Need for a contingent reserve; treatment in the accounts; created from earnings; importance in serial associations; benefits derived from the fund for all associations; sources of the fund; use of the reserve; size; difference between contingent reserve and undivided profits; separation of special securities.

The remarkable record for solvency of the building and loan associations may lead the overoptimistic to believe that there never is a rainy day, and hence there is no necessity to prepare for it. But even if the risk is comparatively small, the wise association still carries its umbrella of insurance. In any commercial enterprise, the manager who helps himself to all the earnings of his business at the end of each fiscal period will one day find no profits in the till.

Need for a Contingent-Reserve.-A growing surplus on the credit side of the balance sheet is usually a sign of a healthy business. But to regard all surplus as profit is to neglect one of the primary canons of accounting. Wherever there is a possibility of risk, there is a possibility of loss, which means that something should be set aside to provide for this loss before it occurs.

Many possible contingencies in the ordinary business with a large fixed investment are of no concern to the building and loan official. But contingencies such as foreclosures and consequent acquisition of real estate or the shrinkage in the market value of other securities, may cause a depletion of the assets.

It is true that associations seldom fail, but serious crises may occur, in which failure is averted only by the most careful nursing of loans. When the demand for real estate disap- 
pears, as it does at recurrent intervals, foreclosures tend to multiply. Many an association has found itself with several times the normal amount of real estate on its books during dull years. It is to provide a "buffer" for these bad years that the practice of setting up contingent-reserve funds has come into existence, following the usual business practice. ${ }^{1}$

Contingent-Reserve Funds Not Separate from Other Assets.-While known as "funds," these reserves are not items separate from the other assets of the association. No specific mortgages or securities are set aside as the reserve. They are merely reserve accounts which have been created out of profits and appear on the liability side of the balance sheet in order to show that they are not owned by any one member, but are a protection for all. The accountant does not use the term "fund" unless there is a specific amount of some asset set aside for the purpose, but the term is used in place of "account" almost universally by building and loan associations. It should be borne in mind, of course, that the technical name for the contingent-reserve fund would be "reserve account."

Reserves Created from Earnings.-The contingentreserve fund is created by setting aside at each dividend period a definite percentage of net earnings before the profits are distributed to the shareholders. In some states the minimum amount is prescribed by law. In others, the maximum which may be so applied is provided for. The association thus makes certain that both its shareholders and itself are protected in case of losses. Not infrequently, such other amounts of undivided profits as remain after declaring the dividends are added to the reserve. The inclusion of such additional amounts is perfectly proper when lawful, provided rightful earnings are not withheld from members thereby.

Contingent Reserves Useful but Not Necessary in Serial Associations.-In the serial and terminating types

¿ The words "reserve" and "contingent fund" are used interchangeably by building and loan associations. This fund is sometimes called a "guarantee fund," but this designation is by no means common. 
of associations, these reserve funds are seldom found. In both these types of associations, profits are allotted to shares in a group or series, and are at once reinvested by the association in exactly the same way as all other available funds. In case of loss by reason of foreclosure or failure to collect a given debt or part of a debt, the loss is charged against current earnings. Any loss in excess of current earnings must be charged directly against the book value of all the shares. In such associations, therefore, the need for a separate reserve to meet losses is not as apparent as in associations operating on the permanent or Dayton plans. No individual member has any specific right to a part of these undivided profits in a serial association any more than in the case of the reserve account in other plans. Where serial associations adopt a regular dividend policy contingent reserves are as useful as in other plans. The savings member never has any specific right to the fund unless it is granted by law. ${ }^{2}$

${ }^{2}$ On April 10, 1916, in the friendly suit of the Bohemian Mutual Building and Loan Association of Milwaukee vs. Hon. A. E. Kuolt, Commissioner of Banking, the Circuit Court of Wisconsin held that the contingent fund should be kept intact and not distributed piecemeal to withdrawing shareholders.

"The apparent function of this fund is to insure the stockholders against losses. Its purpose is not unlike that of the various forms of insurance now in such common use. If the state had required this contribution to be made in the form of premiums paid to some company to insure against losses, no question could be raised but that this contribution was a proper item of expense. Instead of requiring these associations to pay this premium to some other company the legislature has provided that the association shall insure itself against loss by setting aside definite contributions to the contingent fund. This contribution is as legitimate an item of expense as are the premiums paid on any insurance policy. . . .

"But it does not follow that the legislature may [require the association to] set aside as high as fifty per cent of the profits for the purpose of establishing a sinking fund. The limit of its power is that the sum set aside shall be such as may reasonably be required to accomplish the protection of shareholders against loss." (See p. 22, U. S. League Proceedings, 1916.$)$

The New York courts have held similarly in the case of a reserve fund maintained by insurance companies. (Griff vs. Equitable Life Assurance Society, I6o N. Y. 16; 73 Am. St. Rep. 659). No case appears for 


\section{Benefits Derived from Contingent Reserve.-The} savings member has always an undivided equity in the contingent reserve during membership, and his earnings are increased somewhat because this fund is loaned in the usual way. Members at the time of final dissolution of the association participate in the distribution of this fund just as in the division of any other asset, but since there is no reason for an association to discontinue business so long as it is prospering, this is of no practical importance.

When the fund has been built up to a reasonable size, losses are seldom greater than its income, so that there is seldom any necessity to use the principal of the fund in meeting such losses. This also leaves current earnings on regular assets intact. If an association is obliged to liquidate because of insolvency, this fund would aid in paying claims against it. With an adequate contingent reserve, insolvency seldom occurs.

There is some justice in the contention of the withdrawing member that the reserve will enrich others later on. On the

building and loan associations in New York, though this decision would probably be followed.

In South Dakota and Washington, the law permits associations to adopt by-laws providing for a distribution of part of the contingent reserve in the case of withdrawal of shares.

"Any such association may adopt by-laws providing that any person whose stock shall be full-paid or withdrawn, may receive credit on his final payment for the amount he has as such shareholder contributed to the contingent fund or surplus account after making deduction for his share of the losses of the association paid out of such contingent fund or surplus account during the time he was such shareholder. And such credit may be allowed notwithstanding any provision in this article restricting the use of such contingent fund or surplus account to the payment of losses of the association." (Section 9086, Statutes of South Dakota.)

In case of forced withdrawal in Washington, Section 16 of the law provides that by-laws shall clearly state the manner in which such forced withdrawal of shares shall take place, including the proviso "that the holders thereof shall be paid the full value of the shares, including, in such case, their proportion of the contingent fund." (Sec. 10, Chap. 169, Laws of 1919, printed in Sec. 16 of 1921 pamphlet.)

No court decision construing these provisions appears to have been rendered. 
other hand, during membership he has been benefited by the fund because it has protected his earnings. The opinion that payments to the reserve are merely insurance premiums for the protection of members would seem to be the sounder conclusion.

There is little to be said in favor of building up a very large reserve fund. Since it is an insurance matter, its size should be carefully adjusted so that it bears a definite relation to the total assets of the association. It is unfair to inflate the contingent reserve unduly if it can be done only at the expense of those who are present members of the association.

Sources of the Fund.-It is possible, as already stated, to create a contingent reserve from any assets which the association may possess. (I) The customary method of determining the fund is to set aside a certain percentage of the earnings each fiscal period after all expenses have been deducted. For example, if the association has earned $\$ 6,000$ gross, and expenses are $\$ 1,000,5$ per cent of the remaining $\$ 5,000$ or $\$ 250$, could be added to the reserve fund.

There is an advantage in basing the percentage upon earnings instead of upon the total amount of loans outstanding. If the loans are used, a figure determined upon that basis might be more stable, but it may not represent the actual operations as closely as the reserve based upon earnings. Earnings fluctuate with the fortunes of the business, but it has been the custom to use them as a base, and most of the statutes provide for a continuance of this practice.

(2) It has long been the custom for certain banks to require their stockholders to pay a premium for their stock which is at once set aside as a surplus. The bank's surplus has almost exactly the same object as the contingent reserve of a building and loan association: it acts as an additional safeguard against loss. In addition, it also makes quickly possible a regular dividend rate. This practice has been carried over into the building and loan association movement in the use of 
permanent, contingent-reserve, or guarantee stock in certain states. These types of stock create a reserve fund at once. Any type of stock might be sold at a premium for this purpose, if desired, but the practice is seldom used in connection with installment stock.

It would be a cumbersome process to ask members buying shares on the installment plan to pay a premium into a reserve fund. Whatever slight advantage would result would be offset by the troublesome accounting involved. Only a few cents would be recorded at each monthly or weekly payment of dues, and it would require much time and trouble.

Use of the Contingent Reserve Fund.-The money accumulated for the reserve fund is invested by the officers in exactly the same way as are all the other assets of the association, that is, principally in real-estate mortgages. The presince of the fund increases the earning capacity of the business.

Size of the Contingent Reserve.-The accumulation of this fund during the earlier years of the business, when earnings are comparatively low, may cause the association to pay a slightly lower rate of dividends than if no fund were being set aside. If there is any loss to members in the earlier years, it works against both borrowing and savings members alike, but the time will arrive when the interest yield on the contingent reserve is as great as the deductions from net earnings toward this fund. When this time arrives, the reserve fund ceases to be a burden and becomes a definite advantage.

There is a definite limit to the size of the reserve which may be called its point of equilibrium. This point is reached when the earnings of the contingent reserve exactly equal the amount added to the reserve from net earnings during any fiscal period. Take as an illustration an association with assets of $\$ 1,000,000$, in which a sufficient percentage has been regularly set aside for the contingent reserve, so that the reserve amounts to 5 per cent of the total assets. This gives a reserve fund of $\$ 50,000$, leaving $\$ 95^{\circ}, 000$ to be represented by shares of members. 
The association proposes to regularly set aside 5 per cent of earnings for contingent reserve.

\section{Case I:}

Where dividend and interest rates charged on loans are equal (at 6 per cent) and expenses of the association are met by fees and other revenues, with dividends declared semiannually:

Gross earnings $(\$ 1,000,000$ at 3 per cent $) \ldots \ldots \ldots \ldots \ldots \ldots$. $\$ 30,000$

Deduction for contingent reserve fund (5 per cent) ...... $\quad{ }_{1,500}$ ?

Earnings on contingent reserve $(\$ 50,000$ at 3 per cent).. 1,500$)$

\section{Case 2:}

An association with the same amount of assets as before with interest rate of 7 per cent, dividend rate 6 per cent, and expenses of 1 per cent per annum:

Gross earnings $(\$ 1,000,000$ at 3.5 per cent).......... $\$ 35,000$

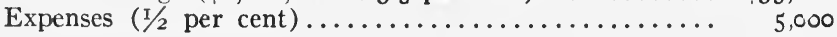

Net earnings ......................... 30,000

Deduction for contingent reserve fund (5 per cent).... I I,500

Earnings on contingent reserve $(\$ 50,000$ at 3.5 per cent less expenses of $1 / 2$ per cent $) \ldots \ldots \ldots \ldots \ldots \ldots \ldots \ldots . .1,500\}$

Case 3:

If the interest rate is 7 per cent, dividend rate of $6 \mathrm{~T} / 2$ per cent, and expenses one-half of one per cent per annum:

Gross earnings $(\$ 1,000,000$ at 3.5 per cent $) \ldots \ldots \ldots \ldots . \$ 35,000$

Expenses $\left(1 / 4\right.$ of one per cent) $\ldots \ldots \ldots \ldots \ldots \ldots \ldots,{ }_{2,5} 00$

Net earnings ............................. 32.500

Deduction for contingent reserve fund ( 5 per cent)... I, 1,625

Earnings on contingent reserve $\left(\$ 50,000\right.$ at $3^{1 / 2}$ per cent less expenses of $1 / 4$ of one per cent) $\ldots \ldots \ldots \ldots \ldots \ldots, \quad \mathrm{r}, 625$

Case 4:

If the interest rate is 9 per cent, expenses are usually higher and may be as much as 2 per cent per annum:

Gross earnings $\left(\$ 1,000\right.$ at 4.5 per cent) $\ldots \ldots \ldots \ldots \ldots \ldots \$_{45,000}$

Expenses (one per cent)................... ro,

Net earnings ........................ 35,000

Deduction for contingent reserve fund ( 5 per cent).... I,750

$\left.\begin{array}{c}\text { Earnings on contingent reserve }(\$ 50,000 \text { at } 4 \mathrm{~T} / 2 \text { per cent } \\ \text { less expense of one per cent }) \ldots \ldots \ldots \ldots \ldots \ldots \ldots \ldots \ldots \ldots \ldots \\ \mathbf{I}, 750\end{array}\right\}$

Difference between Contingent Reserve and Undivided Profits Account.-Many accountants in the building 
and loan associations do not know the difference between a contingent reserve account and the undivided profits account, but the two funds are quite separate. Undivided profits are merely temporary items, which are placed either in an account called by this name or left in profit and loss until the directors have made some disposition of them. This would include all earnings not specifically allotted to given shares. The reserve fund, on the other hand, is a permanent account to protect the association from loss. It is true that both funds arise from the same source, but the directors may exercise some discretion with the undivided profits account, whereas no such discretionary power rests with them in connection with the reserve fund when it is on the books.

All the net profits of a given year should first be accounted for in the profit and loss account or in the undivided profits account. From this account it is a simple matter to make whatever distribution is desired to the contingent reserve, to dividends, etc. The purpose of maintaining this undivided profits account for all profits is that it acts as a clearing house, centralizing all items of profits under one heading, and so giving a better picture of the business than if the items are kept in many separate accounts. Nothing should be put in this account, however, unless it is really earned, because anything which tends to throw suspicion upon this or any other single account in the books causes suspicion to be directed at all of the accounts, and no amount of explanation can wipe away the difficulties which arise in such a manner.

Separation of Special Securities. - While it is true that practically no association maintains a distinction between its ordinary assets and its contingent-reserve fund, it is also true that a few associations attempt to carry a small portion of their capital in the form of very liquid funds. In a small number of cases this separate portion of the capital equals in amount the reserve fund, probably more by accident than by design. 


\section{SPECIAL REFERENCES}

Contingent fund. Iowa League Proceedings (1922), p. 19. North Carolina League Proceedings (1924), pp. 34-35. Ohio League Proceedings (1922), pp. 96-97. U.S. League Proceedings (I901), p. 142; (1914), pp. I28-129; (I917), pp. 50-5I.

Decisions. Wisconsin Circuit Court, April 10, 1916-contingent fund 5 per cent of net profits upheld. U.S. League Proceedings (I9I6), pp. 2I-22.

\section{GENERAL REFERENCES}

Rosenthal, Henry S. Cyclopedia, pp. 156-159; 267. SundHeIM, Joseph H. Law, pp. 63-64. 


\section{DISTRIBUTION OF PROFITS: DIVIDEND POLICY}

Fallacies concerning dividend and interest rates; importance of a uniform rate; source of dividends; limiting the individual investment; effect of contingent-reserve fund; undivided profits; determination of net from gross earnings; methods of dividend distribution; equated time; partnership plan; Dexter plan; pass-book credits and their effect on withdrawals.

Capital will be attracted to building and loan associations regardless of the rate of dividends paid so long as safety of principal is continuously assured. Investors are interested first of all in knowing that their funds will remain intact and that under reasonable restrictions these can be withdrawn without unnecessary delay.

One fallacy which still persists in the minds of many association officials is that dividends must greatly exceed the current rate on other investments of equal and comparable safety. This fallacy is responsible for another one: that the interest rate on loans should be the maximum that can be exacted from any borrower. The coöperative and semi-philanthropic character of the association movement makes it imperative that both interest and dividend rates be equitable. Instances are by no means rare where extortionate interest rates are charged in order to inflate the dividend rate.

No association can honestly claim to be operating on a truly mutual plan when it discriminates against any class of its members in favor of another class. In some cases borrowers are misled to believe that the increased dividends which result from high interest rates offset the excessive payments. As already shown in an earlier chapter, this statement is false. The net amount paid by the borrower is seldom less than the ostensible interest rate, and it is generally higher. 
If an association is to continue to attract new capital, it is of importance to establish a fairly uniform dividend rate rather than a high dividend rate. The general public rightly believes that safe investments yield a low income. This is the universal experience outside of the building and loan ficld, and it is now coming to be recognized in this work as well. In England where the movement has had its largest growth outside the United States, dividend rates are scarcely higher than sav-

PERFECT ELASTICITY

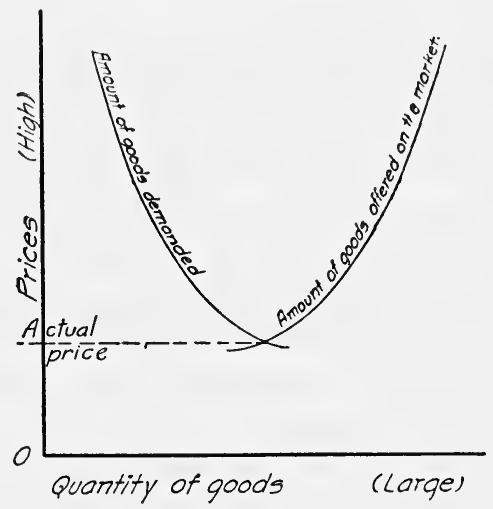

CharT 7.-Demand and supply curves for certain commodities under competitive conditions.

ings bank interest in the United States, ranging from 3.5 to 5 per cent. Even in the eastern section of this country, many successful associations can be found which pay an average of only five per cent dividends while savings banks are paying three and four per cent.

Persons who are familiar with the customary supply and demand curves plotted by economists will find the two accompanying diagrams of some interest in a study of this problem. For many commodities the demand and supply are both elastic. That is, as price increases, demand falls off; but potential supply increases. Actual price is set where market demand ap- 
proximately equals market supply. This is illustrated by Chart 7. The supply of capital does not vary in the same way as the supply of goods, although demand is fairly elastic, increasing as price (interest rate) falls. Chart 8 illustrates the probable supply and demand curves of capital at various rates of interest. It will be noted that for a considerable range of interest rates, the amount of capital offered on the market remains practically stationary. Saving is not increased mate-

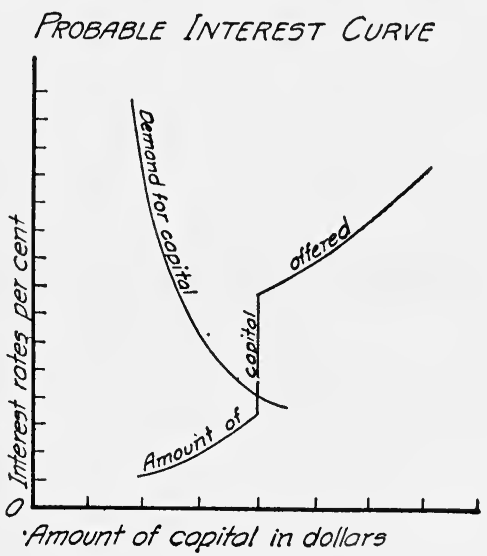

Chart 8--Probable demand and supply curves for capital. Amount of capital offered changes somewhat with changes in interest rate, but is relatively unaffected by a considerable range of rates.

rially by higher rates, nor does it fall off appreciably until the rates become very low. In fact, some associations have found that when the rate has been lowered from a fairly high figure, more funds have been freely offered to them for investment than before. This is probably due to the fact that most people consult a banker or other financier before making any substantial investment, and these men associate low dividend yields with security and hence would favor investment in an association with a conservative dividend policy.

Regardless of the rate, it is important for officials to remem 
ber that dividends must be paid only from current earnings. Money collected in advance is not profit, as has been previously shown. These advance funds must be retained in a separate account until earned. Likewise, dividends must not be paid from capital. That is, the savings of the members must not be given back to them under the title of dividends when the association has earned no such funds. This policy would render an association insolvent. It has been practiced in the past by "wild-cat" stock promoters in an attempt to attract new capital, and they have not always been detected. Nor are directors permitted to advance money to an association for the purpose of paying dividends. A few associations have attempted this policy in the past, also in order to attract new capital, but this practice is forbidden by law in many states and in all cases would be a direct violation of the confidence of the members.

Regularity Desirable.-No greater attraction can be offered for the savings of new members than a regular dividend rate when safety has once been assured. This is possible as soon as the business has progressed to the point where the total flow of money can be predicted with some accuracy. It tends to build up the confidence of a community in the integrity of the officers, and insures a permanence of the savings which have been invested in association shares. Fluctuations in the dividend rate cause a feeling of uncertainty, especially when the change is made abruptly without due notice to the shareholders and before the association has built up a permanent business. However, this should not prevent the lowering of an unjust interest rate after due notice to borrowers and savings members alike. Equitable rates are of even more importance than regularity.

The practice of limiting the amount of investment which may be made by individual shareholders may be of some assistance in securing a regular dividend rate, since members are less likely to withdraw large amounts suddenly when they have comparatively small holdings. Sudden withdrawals in large 
amounts interfere with earnings. The statutes of several states definitely limit the amount of investment which may be made by individuals. ${ }^{1}$

There is an opinion among some association officials that statutory limits should be low enough to prevent individuals from "dumping" money into the association for a short period, only to withdraw it after six months or so. The determining factor should be existing conditions in the given locality. When all funds needed to provide adequate housing are available, reasonable limits may be imposed without resulting in harm.

Effect of Contingent-Reserve Fund.-From the previous discussion of the use of a contingent reserve as a "buffer"

${ }^{1}$ Statutory limitations in the United States in 1924 are as follows: Iowa : $\$ 10,000$ unless assets exceed $\$ 1,000,000$, when limit is I per cent.

Kentucky : $\quad$ Association with capital of :

$\begin{array}{ll}\text { \$100,000 or less } & \begin{array}{l}\text { Not to exceed } 21 / 2 \% \\ \text { of shares. }\end{array} \\ \begin{array}{ll}\$ 100,000-\$ 500,000 & 2 \% \\ \$ 500,000-\$ 1,000,000 & 11 / 2 \% \\ \text { Over } \$ 1,000,000 & 1 \%\end{array}\end{array}$

Massachusetts: $\$ 8,000$ as follows: for joint accounts, deposits up to $\$ 4,000$, which may be allowed to accumulate up to $\$ 8,000$. For individuals, total deposits must not exceed $\$ 4,000$, even though part is in a joint account, and can not accumulate to more than $\$ 8,000$. Ten shares of matured and ten of paid-up stock at one time, or not more than forty unmatured.

Nebraska: $\quad \$ 5,000$ limit on investment stock to one person.

One borrower limited as follows:
Assets of $\$ 200,000-\$ 500,000$ $\$ 10,000$
$\$ 500,000-\$ 1,000,000$ 15,000
Over $\$ 1,000,000$ 25,000

New Hampshire: Fifty shares (of $\$ 200$ par value, total $\$ 10,000$ ).

Vermont : Forty shares (of $\$ 200$ par value, total $\$ 8,000$ ).

Wisconsin :

Installment stock not to exceed $\$ 10,000$.

Paid-up stock not to exceed $\$ 10,000$.

If loan is made which is greater than $\$ 10,000$, stock to cover may be issued.

In two jurisdictions (District of Columbia and Maryland) the statutes specifically permit by-laws to limit the investment of individual members. In all others, by-laws may do so if desired. 
to absorb losses, it will be seen that this account aids the association in establishing a regular dividend rate. When losses occur, the existence of the contingent-reserve account permits interest and other income received on current loans to remain intact as earnings. The fund represented by this account is invested in mortgages of the association in the usual way, and when no losses occur, interest received on this account increases the total amount of earnings.

Undivided Profits.-An additional safeguard is provided when a small amount is left in undivided profits or the profit and loss account after each dividend distribution. The purpose of this account is different from the contingentreserve fund, but it acts as an added temporary protection.

Determining Net from Gross Earnings.-When the total income of the association has been found, all the items which constitute the actual "out-of-pocket" expenses, such as salaries, office expense, rent, depreciation of equipment, etc., are deducted. If an office building is owned or there is other real estate permanently held by the association, depreciation reserves of the ordinary commercial type should be deducted and set up on the books. These will care for the ultimate replacement of these buildings and charge against the current income the proper cost of this item for the period. In case the association has borrowed money, interest paid for the use of this money must also be deducted. The resulting figure may be called "net earnings," and from it the contingent reserve allowance is first made, after which the dividend distribution can be determined.

Methods of Dividend Distribution.-Many secretaries have found it difficult to compute the dividends which should be allotted to the various shares. A casual survey of methods in use would lead one to believe that cumbersome and artificial methods have been purposely selected. The simplest method within each plan which results in equality of distribution to the various shares is desirable, yet convenient, simple 
and equitable methods and short cuts are unfortunately conspicuous by their absence.

The problem of dividend distribution contains two general factors: the total amount of net earnings available for dividends, and the total average capital employed during the dividend period. The amount of net earnings available for dividends, as has been shown, is the remainder after deducting from actual net earnings the amount to be set aside for contingent reserve. This remainder is to be distributed among the shareholders according to their respective contributions of earning capital during the dividend period.

Equated Time.-It is necessary to determine not only the amount of investment which each shareholder has made, but also the average length of time that this investment has been held by the association. This average is usually known as "equated time." The total amount of dues and dividends to the member's credit at the beginning of a fiscal period remains' to his credit throughout the time, unless withdrawn. No average is needed in determining this figure. The equated time average is required for computing dividends on monthly payments made between the dividend dates.

Three methods of making this computation are in use, which may be illustrated with uniform monthly payments of $\$ \mathrm{I} 6$ and 6 per cent dividends. (The same methods may be applied to weekly payments.)

(I) Payments considered as made at the middle of the month. This represents the actual situation in most associations, and gives a quick and convenient method of calculation.

Monthly payment $\$ 16 \times 6=96$ dollar months.

Divided by $2=\$ 48$, or the average on which the dividend is based. $(\$ 48 \times 3 \%=\$ 1.44$.

(2) Payments considered as made at the end of the month. (Used in compiling Robinsonian Building-Loan Interest Table No. 23.) 
First payment $\$ \mathrm{I} 6$ (Association uses for 5 months) $=80$ dollar months Second payment \$I6 (Association uses for 4 months) $=64$ dollar months Third payment $\$ 16$ (Association uses for 3 month $\left._{3}\right)=48$ dollar months Fourth payment Si $_{1} 6$ (Association uses for 2 months) $=32$ dollar months Fifth payment $\$ 16$ (Association uses for 1 month) $=16$ dollar months Sixth payment\$I6 (Association uses for o months) $=0$ dollar months 240 dollar months

Average amount in possession of association: 240 dollar months divided by 6 equals 40 .

3 per cent dividend on 40 equals $\$ 1.20$.

(3) A third method computes the payments as made at the beginning of the month, an ideal situation, but one seldom realized in practice.

First payment $\$ \mathrm{I} 6 \times 6=96$ dollar months
Second payment $\$ \mathrm{I} 6 \times 5=80$ dollar months
Third payment $\$ \mathrm{I} 6 \times 4=64$ dollar months
Fourth payment $\$ \mathrm{I} 6 \times 3=48$ dollar months
Fifth payment $\$ \mathrm{I} 6 \times 2=32$ do'llar months
Sixth payment $\$ \mathrm{I} 6 \times \mathrm{I}=\underline{\mathrm{I} 6}$ dollar mon'hs

Average amount in possession of association is 336 dolar months divided by 6 equals $\$ 56$. This gives the largest accumulation of the thrce. $\$ 56 \times .03=\$ 1.68$. (This is the method on which Robinsonian Table No. 25 is based.)

Under the first method all fractional months or fractional weeks are eliminated. The assumption is made that the dues are in the possession of the association about one-half of the period. In most associations it happens that dues are paid on the average about the middle of the month, and as a result the first method is probably the most practicable. Where dues are paid at other times in the month, the first method may still be used with slight changes, if the second and third methods are undesirable. If made at the beginning of the month, add one-half month to the calculation; where paid at the end, onehalf month must be deducted. 
Partnership Plan.-An excellent explanation of the partnership p'an is given in Newlove and Pratt's Specialized Accounting, Chapter $\mathrm{X}$, and we reproduce it here in its original form:

"Under the partnership plan the profits are distributed on the assumption that all profits constitute a common pool for all series alike. This assumption may work to the serious disadvantage of particular series of shares if the profitableness of the enterprise varies from year to year, viz., the old series gain at the expense of the new series if the rate of profit increases, and lose if the rate declines.

"Illustrative Problem.-A building and loan association, whose monthly dues are $\$ I$ issued I,000 shares and 2,000 shares of its stock during its first and second years of operation, respectively. Assuming that the net profits were $\$ 390$ and $\$ \mathrm{r}, 890$, respectively, during the first and second years, find the book value of the stock at the end of the second year."

\section{SOLUTION $^{2}$}

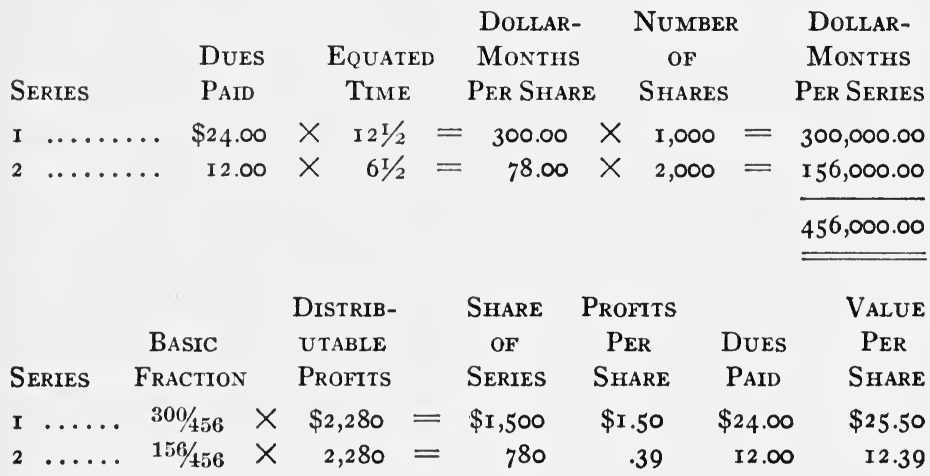

Dexter Plan.-A slight modification of the partnership plan known as the "Dexter plan" treats past distribution as

${ }^{2}$ Spccialized Accounting, by G. H. Newlove and Lester A. Pratt, 1923, The White Press. 
definitely belonging to each series. As a result, the earnings on shares which have remained in the association for some time are not disturbed, but current earnings are allotted on the total accumulations. In this way older shares are not penalized in case the rate of earnings varies from year to year.

Varying Rate.-Since it is only possible for an association to distribute the earnings actually received, it is sometimes necessary to vary the rate each year in accordance with income. Due to the fact that interest rates do not change more often than once in several years, the variation in dividend rate tends to be less marked than it would be in ordinary commercial practice.

In recent years, it has become a quite general practice to credit each share account with its due portion of each dividend. In such case the determination of (a) dividend rate, and (b) dividend distribution, is effected in the following manner:

To the amount of dues and dividends on each shareholder's account at the last dividend date, add the equated value of payments made since that date. The average investment of cach shareholder during the period is thus determined. These items should be listed for convenience and their sum is the total average investment for the period. The dividend rate is obtained by dividing the net earnings by this total average investment. (It is customary to retain in "undivided profits" any excess remaining above an even per cent or half per cent.) The dividend due each shareholder in the list is then readily computed by multiplying his average investment by the determined dividend rate. To prove the correctness of these computations, it is only necessary to compare the sum of all individual dividends with the product obtained by multiplying the total average investment by the dividend rate used. With all the individual dividends determined, each is transcribed from the list to the ledger account and pass-book of each shareholder. 


\section{ILLUSTRATION :}

Shareholders' List Showing Average Investment During Period

\begin{tabular}{|c|c|c|c|c|}
\hline $\begin{array}{l}\text { Certifi- } \\
\text { CAte No. }\end{array}$ & $\begin{array}{l}\text { BALANCE AT } \\
\text { BEGINNING } \\
\text { OF PERIOD }\end{array}$ & $\begin{array}{l}\text { EQuated } \\
\text { VALUE OF } \\
\text { INTERVENING } \\
\text { PAYMENTS }\end{array}$ & $\begin{array}{l}\text { Total Average } \\
\text { INVESTMENT }\end{array}$ & $\begin{array}{c}\text { DIVIDEND } \\
\text { (INSERTED } \\
\text { AfTER RATE } \\
\text { DETERMINED) }\end{array}$ \\
\hline 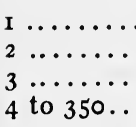 & $\begin{array}{r}\$ 342.61 \\
685.22 \\
3,426.10 \\
580,237.56\end{array}$ & $\begin{array}{r}\$ 7.50^{1} \\
15.00 \\
75.00 \\
40,395.50\end{array}$ & $\begin{array}{r}\$ 350.00^{2} \times .03 \\
700.00 \\
3,501.00 \\
620,633.00\end{array}$ & $\begin{array}{lr}\$ \quad 10.50 \\
21.00 \\
105.03 \\
18,618.99\end{array}$ \\
\hline & & & $\$ 625,184.00 \times .03$ & $\$ 18,755.5^{2}$ \\
\hline
\end{tabular}

$\frac{\text { Net earnings }}{\text { Total investment }}=\frac{\$ 20,416.45}{\$ 625,184.00}=.03$, with remainder of $\$ 1,660.93$

Hence dividend rate is 3 per cent.

Proof:

Average investment multiplied by rate

$$
\begin{array}{r}
\$ 625,184 \\
.03 \\
\hline \$ 18,755.52
\end{array}
$$

\begin{tabular}{|c|}
\hline Dividends \\
\hline $\begin{array}{r}\$ 10.50 \\
21.00\end{array}$ \\
\hline $\begin{array}{l}\begin{array}{c}105.03 \\
18,618.99\end{array}\end{array}$ \\
\hline
\end{tabular}

How Pass-Book Credits Affect Withdrawals.-Savings banks invariably credit the interest paid their depositors directly on the pass-book at or near each dividend period, and many building and loan associations have adopted this practice in crediting dividends in order to keep their members informed of the progressive increase of the value of their shares. Where all earnings are paid to the members in case of withdrawal before the shares mature, this policy results in definitely increasing the esteem of the member for the association. But where a part of the earnings are withheld or "forfeited" in

1 "Equated value" is determined on the basis of average time as already shown on page 357 . The first, or simplest method, is used in the above calculation. If payments are irregular, each must be computed separately, multiplying the respective payments by the number of remaining months in the period, and dividing the sum of the respective products by the number of months in the period.

${ }^{2}$ Minor fractions of $\$ I$ are disregarded. 
case the shares are withdrawn before the full pa: value has been reached on the books, the member sustains a considerable shock when he sees this deduction from his pass-book entries. As a result, the disadvantage in such cases would probably offset the advantage. Withdrawal charges should always be as low as consistent with sound association practices; and regardless of their size, the pass-book itself should fully set forth the details of these costs so that the member may be at all times informed of his rights and obligations in case of withdrawal.

\section{SPECIAL REFERENCES}

Dividend computation. Youngstown Institute Proceedings, June I5, I923, pp. 8-9.

Dividends. Youngstown Institute Proceedings, April 23, I924, pp. 5-6.

\section{GENERAL REFERENCES}

Gordon and Lockwood. Modern Accounting Systems (1924), pp. 38-44. Newlove and Pratt. Specialized Accounting (1923), Chapter X.

Putnam, T. M. Mathematical Theory of Finance (1923).

Robinson, J. Watrs. Robinsonian Building-Loan Interest Tables (Igog). Rosenthal, Henry S. Cyclopedia, pp. 209-210; 268; 274-276; 334-438. S KinNer, ERnest Brown. Mathematical Theory of Investment (I924). Sundherm, Joseph H. Law, pp. 58-62.

Wright, Carroll D. Ninth Annual Report of the Commissioner of Labor (1893), pp. 427-46I. 


\title{
PART V \\ REGULATIONS AND LAWS
}

\author{
CHAPTER XIX
}

\section{STATE AND FEDERAL REGULATION AND AUDIT ${ }^{1}$}

Dangers of sudden growth of an association; bank failures in the United States; building and loan failures; general survey of building and loan supervision in the United States; methods of supervision; "certificate of necessity"; approval of by-laws, of bonds; uniform accounts; examination-two types, procedure, fees; salaries of supervisors; income of the departments; reports; coöperation with supervising department; separate department for supervision-advantages, disadvantages; proper department for supervision.

When a business shows a large and sudden growth, almost without outside encouragement, it is sure to attract to itself men who wish to take personal advantage of its resources. The rapid rise of the building and loan association has exposed it to this possibility. It is comparatively easy for an official to twist a by-law or a constitutional provision to his own advantage. This is especially true if he is in a responsible executive position and has won the confidence of his board of directors. The directors of our strongest banks have occasionally been lax in controlling their officers, though bank directors are supposed to devote a considerable portion of their time to the duties of their directorate.

It can be readily understood, therefore, how a board which meets infrequently, as is the case in many building and loan associations, may drift into the habit of placing too much re-

${ }^{1}$ Part of the material on which this chapter is based, appeared in the Journal of Political Economy for December, 1924. Thanks of the authors are due the editors for permission to introduce some of the data here. 
liance upon the judgment of the appointed officers. In most associations reliance will be placed particularly in the secretary or the officials who appraise the security offered for loans. Decisions regarding the moral risk represented by the borrower, the security for the loan, and the use to which the proceeds of each loan are put, must be left to some one. If the officer has a record of honest service, the directors are justified in placing the burden upon him and in relying on his judgment. It is a remarkable testimonial to the men who have officered these associations in the past that the losses have been practically negligible. From the meager data available, it would appear that the record of safety is better than that of commercial banks. Most of the losses which have occurred have been due to defalcation by officers who were improperly bonded and who took advantage of their position.

\section{Comparative Solvency of Financial Institutions}

Bank Failures in the United States.-The Annual Report of the Comptroller of the Currency for 1923 gives the following information:

During the year ending June 30, 1923, 202 state (commercial) banks failed, 17 savings banks, 7 loan and trust companies, and II private banks, making a total of 237 state and private institutions. There we:e also 37 national-bank failures, making a total of 274 . Liabilities of the 237 state and private banks were $\$ 64,550,000$ and of the 37 national banks $\$ 20,076,000$, a total of $\$ 84,626,000$. (Actual losses can not be determined until the receiverships have been wound up.) ${ }^{2}$

"In the years covered ky the operations of the national banking system, I 863 to I 923 , the number of national banks organized was 12,455 , of which 8,264 are in active operation. Of the 4,I9I not in existence, some 3,530 were closed by voluntary liquidation, generally for the purpose of reorganizing or amalgamating with other banks, national or state. In this sixty-year period, the number of failures was only 711 , or $5.7 \mathrm{I}$ per cent of the total number chartered. . . .

"It is of further interest to note that as a result of careful supervision

${ }^{2}$ Report of the Comptrollcr of the Currency, dated December 3, 1923, p. $5 \mathrm{Ir}$. 
and of directorial management, etc., the assets and other resources of these failed banks paid to their creditors average returns of approximately 83 per cent as indicated by the final reports of fully liquidating receiverships, these closed receiverships representing nearly 90 per cent of the total." ${ }^{3}$

"From the date of the first failure of a national bank in 1865 to October $3 \mathrm{I}, 1923$, the number of banks placed in charge of receivers was $7 \mathrm{II}$. Of this number, however, 50 were subsequently restored to solvency and permitted to resume business." 4

"The collection from the assets of the 587 national banks, the affairs of which have been finally closed, amounted to $\$ 193,097,245$, and together with the collections of $\$ 26,006,848$ from assessments levied against the shareholders, make a total of $\$ 217,104,093$, from whicn on claims aggregating $\$ 196,786,558$ dividends were paid amounting to $\$ 146,779,303 . \ldots$

"The average rate of dividends paid on claims proved was 77.66 per cent, but including offsets allowed, loans paid, and other disbursements with dividends, creditors received on an average 84.03 per cent. . .

"The book or nominal value of the assets of the 124 national banks that are still in charge of receivers amounted to $\$ 92,480,144$," against which $\$ 37,060,907$ had been coliected by October 31 , $1923 .^{5}$

On June 30,1923 , there were the following banks in operation in the United States:

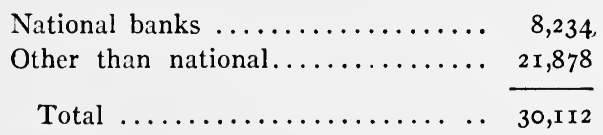

Building and Loan Failures.-In the fiscal year ending June 30 , 1923, five failures of building and loan associations are known to have occurred in the United States. ${ }^{6}$ The aggregate loss from these failures is reported as less than $\$ 250,000$, but complete figures are not obtainable. The total number of associations in existence on June 30, 1923, was 10,009 with

${ }^{3}$ Report of the Comptroller of the Currency, dated Dec. 3, 1923, p. 81 .

${ }^{4}$ Ibid., p. 73.

"Ibid., p. 74 .

- All state departments having supervision over building and loan associations participated in this inquiry, and in those states wher: there is no supervision, reliable individuals who are in close contact with the movement furnished information. 
assets $^{7}$ amounting to approximately $\$ 3,342,530,953$. The percentage of failures among building and loan associations for I923 was, therefore, one-twentieth of one per cent, and assuming the losses to be as stated, they amounted to seven thousandths of one per cent of the total assets of all the associations.

From the earliest record to March, 1924, failures of building and loan associations were reported as follows:

I4 states reported a total of 87 failures.

I7 states reported "No building and loan failures."

I state reported "None for I5 years."

I state reported "None since department was created in IوI9."

I state reported "None for 25 years."

I state reported "None since r899."

I state reported "None since department was created in I909."

I state reported "None for more than I5 years."

I state reported "None for 20 years."

District of Columbia reported no failures since July I, I9I3.

No other record shown.

8 states reported "No record."

2 states did not report (South Carolina and Nevada).

One additional failure was reported during the spring of I 924 , making a total of 88 failures reported from the earliest record to date. The total number of associations organized in the United States is not known, but 88 is less than one per cent of 10,009, the number existing June 30, 1923. No record of the actual losses sustained is available, but the amount appears to be comparatively small, since considerable sums are invariably realized on liquidation of well-secured loans.

In several cases these failures were reported to be enforced liquidations, due to enactment of better laws. Some of the associations that failed were the "nationals" of an earlier day.

It should be borne in mind in considering this record of solvency that many "terminating" associations have wound up

${ }^{7}$ Official figures for building and loan associations compiled by $\mathrm{H}$. F. Cellarius, Secretary of the United States League of Building and Loan Associations. 
their business and have later on been referred to as failures hecause of the fact that they are no longer in existence. As a matter of fact, these terminating associations, in the natural course of events, wound up their operations upon the maturity of their only series.

\section{The Problem of Regulation}

The Need for Regulation.-Losses sustained by building and loan associations have been small, but with the continued growth of the movement, there is a growing need for more adequate regulation and supervision to provide "rules of the game," so that the record of the past will at least be maintained. To-day 37 states and the District of Columbia have some measure of supervision over the associations which are doing business within their boundaries. No department exists in Alabama, Georgia, Idaho, Maryland, Mississippi, Nevada, New Mexico, South Carolina, Virginia, and Wyoming, although in some of these states the activities of associations come within the provision of the "blue-sky laws" or inadequate special laws which are administered by a securities commission or one of the other state departments. In Florida and Texas the supervisors are unable to carry out the provisions of the law because of lack of funds. Virginia is in the unfortunate position of being the victim of a "joker" section which nullifies a law which would provide adequate supervision. The repeal of this one section would place Virginia in a much stronger position. No supervision is exercised by the federal government except over associations in the District of Columbia, other than such attention as is necessary in the collection of taxes.

Where an overworked state banking commission has been asked to shoulder this additional burden of supervision with no extra provision of funds, it is easy to understand why the duty is not always properly fulfilled. But there is a changing sentiment in favor of regulation, due to the mushroomlike 
growth of this movement everywhere. Officials of even the so-called "backward" states have begun to act. For some years the annual meetings of the state supervisors for discussion of their problems have found an increasing number of states represented, showing that there is a definite movement under way to solve the complex problems which constantly arise.

The following study of the supervising situation has been made possible largely because supervising officials have themselves contributed so generously of their time and assistance in supplying the necessary data. In those cases where supervision is lacking it has been necessary to rely upon information obtained from other sources, but care has been taken to select sources capable of supplying accurate information.

Methods of Supervision.-To be properly effective, supervision must extend to all phases of an association's activities, from organization to dissolution, and should encourage the use of efficient and equitable practices and prevent fraud and injustice, while leaving to the officers the widest possible latitude in the conduct of their business. It is best brought about by administrative rather than legislative control. That is, detailed laws for all phases of the business fail of their purpose. The state laws which lay down the broad principles or rules which regulation is to follow, and then provide competent, well-paid supervisors to see that the law is carried out, have been found most practicable. By framing a statute in this way, it can be administered in the light of existing conditions, changing as conditions change, without the necessity of waiting for another session of the legislature to alter the law to meet each new situation, as is now so often necessary. ${ }^{8}$

Certificate of Necessity.-In a few states, organizers of new associations are now required to prove to the supervisor

- An analysis of present statutes and the essential provisions of supervision will be found in Chap. XX. 
that their proposed organization is needed in the locality where they expect to operate. ${ }^{9}$ When the supervisor is convinced of the validity of the project he issues a permit, usually called a "certificate of necessity," which grants the right to form an association after compliance with the law. Properly administered, the granting or withholding of permits may work for the elimination of much duplication of effort and prevent men with unsavory records from perverting the work to their own advantage.

Approval of By-laws.-Since the actual conduct of an association is determined largely by its by-laws, their formal approval by the supervisor would seem to be imperative, in order to assure conformity with the statutes and with their interpretation by the supervisor and the courts. ${ }^{10}$

Approval of Bonds by Supervisors.-Where the law requires that the state supervisor must approve bonds before an association may purchase them with the surplus funds of an association, the supervising official usually publishes at frequent intervals a list of bonds so approved. This obviates the necessity of special correspondence when surplus funds are on hand, and makes it possible for the association to act with a high degree of independence while still keeping within the provisions of the law.

Uniform Accounts.-Progress in prescribing uniform accounting systems has been slow. Probably this is because it has been felt that the individual association should not be hampered in its business any more than is necessary. With continued development and the constant introduction of new people into the business, however, those progressive super-

${ }^{9}$ States including Arizona, Maine, Massachusetts, Ohio, and Wisconsin require such certificate, although not always called by this name.

to States requiring approval of by-laws by supervisor before association may begin business include: California, Colorado, Connecticut, Delaware, Georgia, Illinois (Attorney General), Indiana, Iowa (Executive Council), Kansas, Kentucky, Maine, Michigan (Secretary of State), Minnesota, Missouri, Montana, Nebraska, New York, Ohio, Oklahoma, Texas, Washington, West Virginia and Wisconsin. 
visors who wish to make their own work effective are requesting the associations which come under their control to use more standardized types of accounting systems. In this way many cumbersome methods are being eliminated and the time of secretaries can be devoted to developing their business instead of to detailed clerical work. ${ }^{11}$

Examination.-Thirty-four of the states require an annual examination, although in the case of Texas and Florida this cannot be carried out because of the failure of the legislature to appropriate sufficient funds. Two states, Minnesota and West Virginia, require two examinations annually; North Carolina examines only once in three years; and in the District of Columbia the Comptroller of the Currency is authorized to examine associations "whenever he may deem it useful," but he actually examines semiannually.

It is necessary to distinguish carefully between an examination and an audit in association practice. An audit is designed to prove the technical correctness of the books, and is usually made by a committee of members instead of by accountants. In making an audit, the books are assumed to be correct up to a certain point, and the report covers merely entries made from that time on to the date of the audit. An examination differs from an audit in that nothing is assumed or taken for granted. It is usually made by a competent state official or a certified public accountant, or by both. All activities of the association between the periods of examination come up for review. Not only is the technical correctness of the books proved, but the minutes of all official meetings are examined, and these are compared with the expenditures, the loans granted, the special accounts which are called for, etc. Only in this way can the examiner know that nothing has been over-

11 States which now prescribe uniform accounts for all associations include Arizona, California, Indiana, and North Carolina. Connecticut prescribes accounting systems for all new associations. Missouri, New Hampshire, and Oregon are attempting to bring about uniformity, and Kansas, Louisiana, and New York recommend uniform accounts but have no authority to prescribe them. 
looked. After such a thorough search, a certification carries the weight of authority.

Where an audit includes all this procedure, it becomes a true examination, but in too many cases the work of an unskilled auditor is merely perfunctory, and hence of no value. Even where the supervising department is not required by law to make an examination, the association finds it of advantage to obtain the services of a competent official of the department for that purpose, if possible. The advertising value of the phrase "regularly examined by the state building and loan supervisor" is not to be overlooked. In addition, a certified public accountant is often called in whenever it is desired to check up the condition of the books between examination periods.

Examination Procedure.-The Massachusetts law presents a concise statement of the duties of the banking department in conducting periodical examinations of associations (coöperative banks).

"In the examination of every coöperative bank, inquiries shall be made as to the nature and resources of the corporation in general, the methods of conducting and managing the business, its affairs, the actions of its officers, the investment of its funds, and whether the administration of its affairs is in compliance with its by-laws and with statutory requirements. At each visitation, a thorough examination and audit shall be made of the books, securities, cash, assets, liabilities, income, and expenditures, including a trial balance of the shareholders' ledgers for the period elapsed since the preceding examination." 12

A proper examination includes a complete balancing of all accounts on the association's books, including those with each individual shareholder. The pass-books are called in and compared with the association's records. Where this is done regularly, errors are promptly discovered and corrected before

${ }^{12}$ Chap. I7o, General Law's of Massachusetts, Sec. 46. 
they become serious. If improper entries are not checked at once, they tend to become cumulative, and may cause trouble in later years.

Whether conducted by a state official or a commercial accountant, the purpose of the examination is always the sameto prove that every part of the business is efficiently and legally conducted and that the association is solvent.

Fees.-In order to carry state supervision into effect, most of the states ( $3 \mathrm{I}$ in all) charge a fee for the periodical examination. Six of these charge the actual expense of examination, and one of these, Rhode Island, sets a maximum of $\$ 50$ per year on such expense, evidently to prevent oppression of an association by some future official who may happen to be antagonistic. The fee based on assets is rapidly becoming the predominant type. Nineteen states at present use it, although Arkansas combines it with a per diem fee for the inspector. Seven states make an examination charge on a per diem basis. This fee ranges from $\$ 7$ to $\$ 25$ per day, and the expenses of the examiner usually are paid by the association in addition to the fee. Five states are reported as making no charge for examination. An annual license fee which is used for the maintenance of the department is charged in Washington and California. This license fee evidently answers the same purpose as the examination fees in other states.

A glance at the accompanying map will show the present state of supervision, the cross-hatching indicating the base on which examination fees are charged. It is of particular interest to trace the way in which customs move over adjacent state boundaries and run for considerable distances. For example, the southeastern states have no adequate supervision, but proposed legislation would provide it in at least two states (Georgia and South Carolina).

Poorly paid supervisors are not of much help in promoting the healthy growth of the movement, and the salaries seem to be gradually increasing in order to attract qualified men. An occasional high-grade man will work for small pay from 
a sense of duty, but the profession must pay well if it is to continue to attract the only kind of men who will really supervise.

Salaries have been held down in the past because legislatures have ignored the willingness of associations to pay for thorough examination. Well-paid supervisory service is being provided in only a few states. Legislators contend that raising

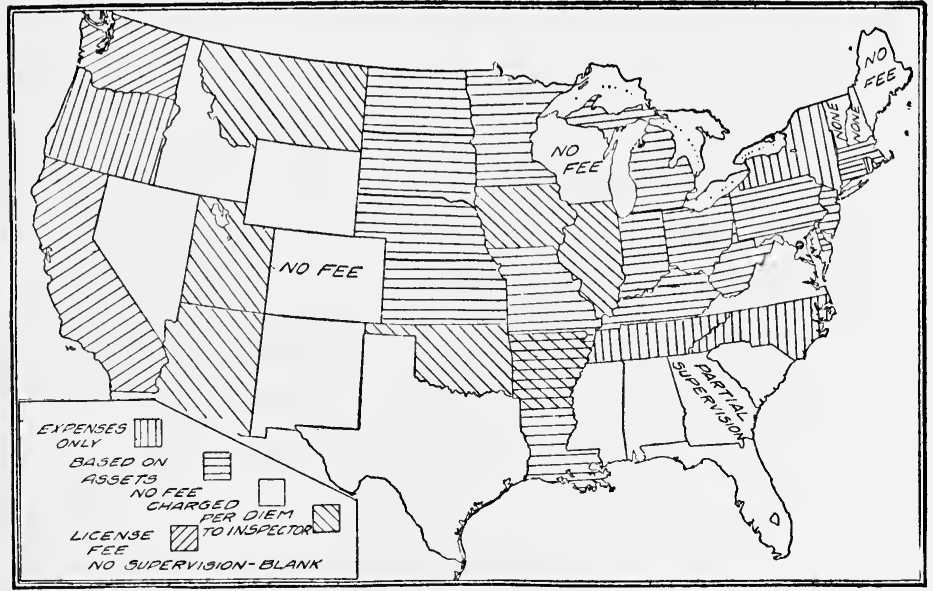

Chart 9.-Methods used by the states in charging examination fees, indicated by shading.

the salaries of examiners (even though the revenue of examiinations leaves a surplus for other purposes) would cause all other state officials to demand similar increases and thus tend to burden the state with expenses. As a matter of fact, examination fees in most states are already great enough to provide adequate examination and general supervision without imposing a tax burden on the people. The money received from fees is considered a part of the general revenue of the state in twenty cases, and it is segregated in eleven others. In only eight cases, however, is this money used directly for the support of the supervising department. In others it is paid into 
the state treasury and a general appropriation is made to cover expense.

Since the examination definitely aids the associations in conducting their business along sound and up-to-date lines, it would seem that those states which charge fees large enough to cover all the expense of supervision and then see that the work is properly done are working to the best interests of their people. For example, in 1922 the Ohio supervisor received $\$ 78,799.5 \mathrm{I}$ in fees, of which $\$ 55,722.00$ was spent in the operation of the department, leaving a balance for the general revenue fund of the state of more than $\$ 23,000$. In return for this, the state furnished offices, janitor service, heat, light, supplies, and printing, including the printing of the annual report. The latter items are often overlooked in computing the cost of government service. Other states show a similar surplus.

Reports.-In addition to the regular examination by the supervisors, periodical reports are required by every state which maintains a supervising department. These reports are supposed to show the true condition of the association, but many of them are so incomplete that they are of no real value.

In an earlier chapter ${ }^{13}$ we have pointed out the use which may be made of periodical reports and the items which should be included. Strange and unusual items are still to be found in some reports, but the tendency toward simplicity and a true presentation of the business condition is distinctly noticeable.

One important step has recently been taken in certain states by requiring that the "loans outstanding" must be reduced in accordance with the credits on shares to the various borrowers. This removes the objection against inflation, which has frequently been heard in the past. Loans shown among the assets should be the net amount now due the association, after offsetting credits have been deducted. All items should reflect the actual condition of the business without exaggeration.

${ }^{13}$ Chap. XIII, "Accounting." 
Coöperation with the Supervising Department.Prompt replies to inquiries sent out by the supervising departments of the states materially aid state officers in handling association affairs. There is a tendency upon the part of association secretaries to regard official inquiries as a necessary nuisance, to be answered only when there is nothing else to do. Such delays add to the expense of supervision and, where fees are directly based on the cost of the supervising department, the association pays for the neglect, since all delays involve extra correspondence. Business courtesy calls for prompt replies and the filing of reports as soon as the books are closed.

Separate Department for Supervision.-In the past, when regulating statutes were passed, it has been customary for legislatures to ask the state banking department to assume the supervision of building and loan associations along with their other duties. The theory on which this is based seems to be that since the associations are financial institutions, they should be supervised by the official who oversees the banks. There is a marked difference of opinion as to who is the proper officer for this purpose, and the main arguments on both sides are here presented.

( I) Opposed to One Department. Supervision and control of both banks and building and loan associations by one department is said to be inadvisable because:

(a) The bank examiner and deputies are seldom informed about the principles of long-time investments.

(b) Sound investment practice differs fundamentally from banking, in such matters as proper cash reserves to meet withdrawals, the margin between value of property and loan for amortized loan as contrasted with straight mortgage loans, etc.

(c) The banking department is usually organized to restrain rather than to promote.

(d) It cannot effectively encourage the organization of 
associations, or assist materially in meeting the obstacles which arise.

(e) Since association finance is coöperative, the sympathies of the banking department may be antagonistic because it may fear that association activity will interfere with the work of the commercial and savings banks and trust companies which command most of the attention of the department.

(2) Favoring One Department. The state banking department is often urged as the logical supervising department because:

(a) The longer experience of the bank examiner in the conduct of public affairs gives him a check on the newer activities of the building and loan examiners.

(b) When the building and loan examiner works under the bank examiner, the higher official acts as a court of appeal for associations who are dissatisfied with the work of their examiner.

(c) All financial institutions are essentially alike, whether their profits are distributed coöperatively or otherwise. Hence their problems are the same, and when centered in one state department, all will be treated with equal fairness.

(d) The associations do not compete with the banks, but supplement their service. They make the same use of the commercial banks as do all other business houses, depositing all funds as received and borrowing as the need arises.

(3) Opposition to Supervision by Other State Departments. The objections to other state departments, such as that of the corporation commissioner, or the securities commission, acting as supervisors of associations are: 
(a) Official time is largely occupied with other administrative matters, which interfere with proper supervision of associations.

(b) The fact that supervision is so radically different from regular duties may result in inadequate regulation.

Proper Department for Supervision.-The crux of this controversy seems to be in the attitude of the banking department. Unfriendly officials often fail to understand the place of the association in the financial organization of the community. If adequately provided with funds, which come from the associations, and controlled by men who are interested in promoting the movement, there can be no adequate objections to combining the supervision of the two types of institutions. This is especially true so long as the associations in the state are few in number and relatively small in assets. On the other hand, where the traditions of the department are definitely opposed to coöperative institutions, or where the associations are so numerous that supervision of both banks and associations becomes difficult or impossible, a separate department is the only satisfactory solution of the problem.

Finally there appears to be no adequate defense of the policy of placing building and loan associations under either a corporation commissioner or a securities commission. The tendency is definitely in the direction of a separate department for the supervision of building and loan associations. 


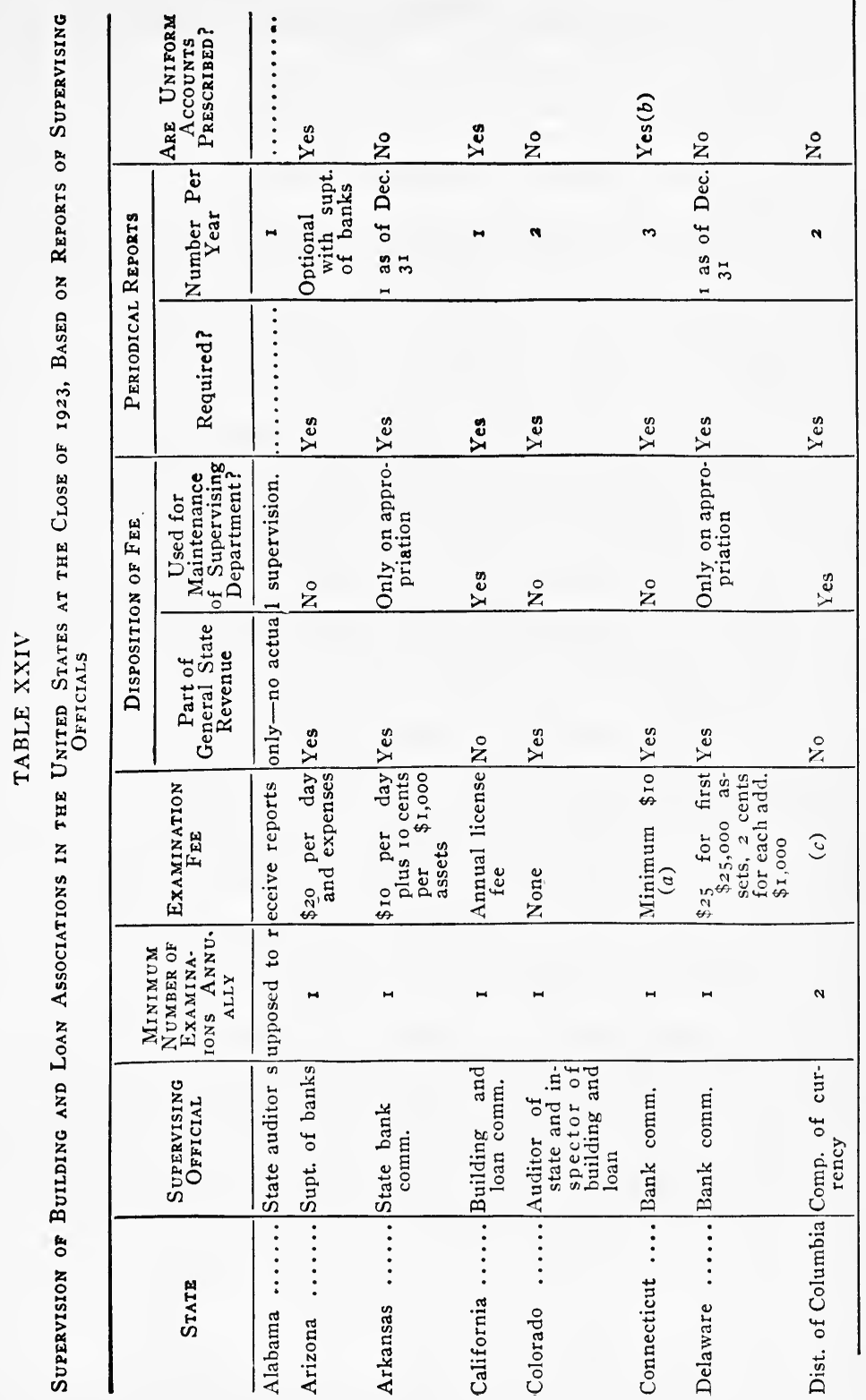




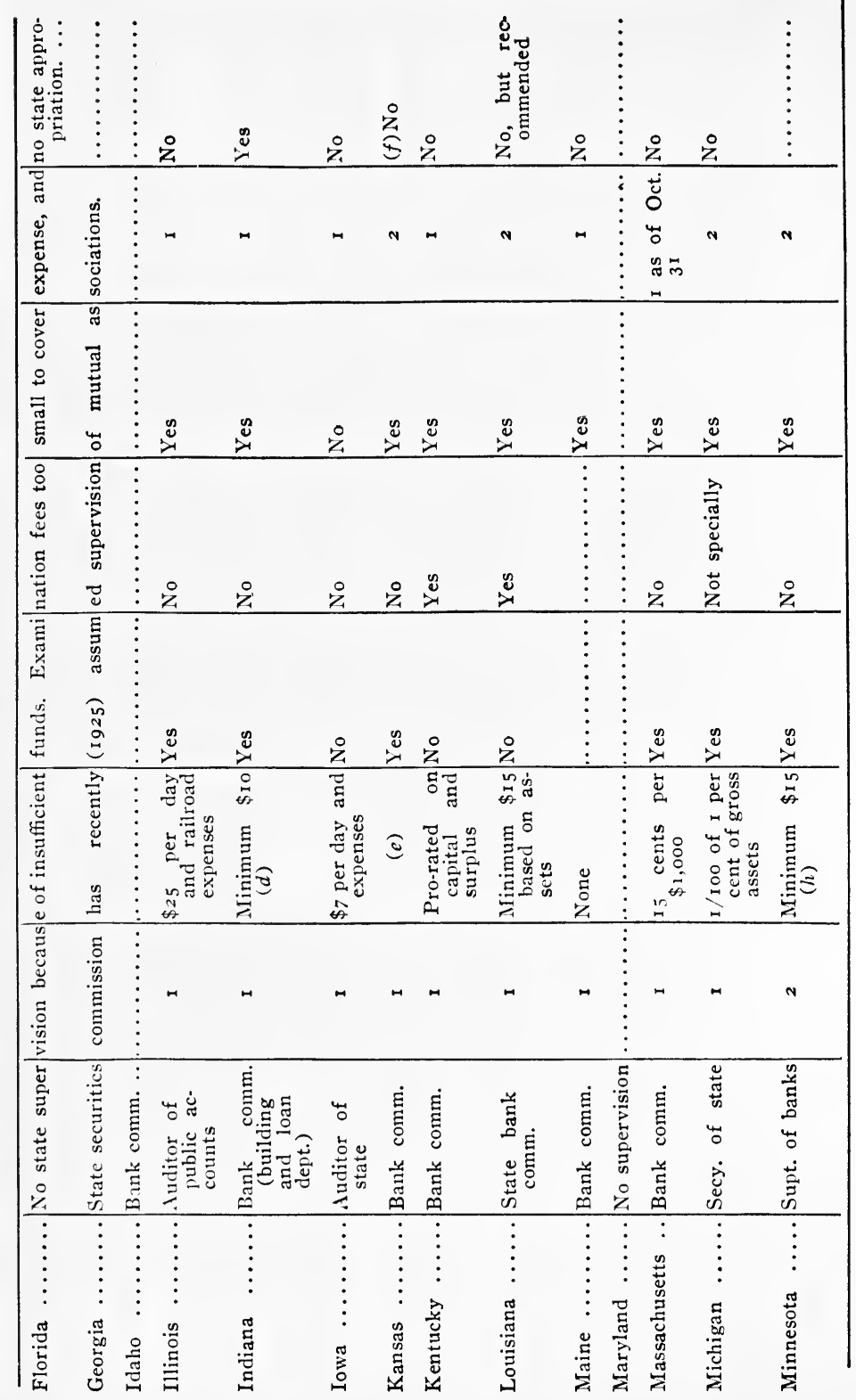




\section{STATE AND FEDERAL REGULATION}

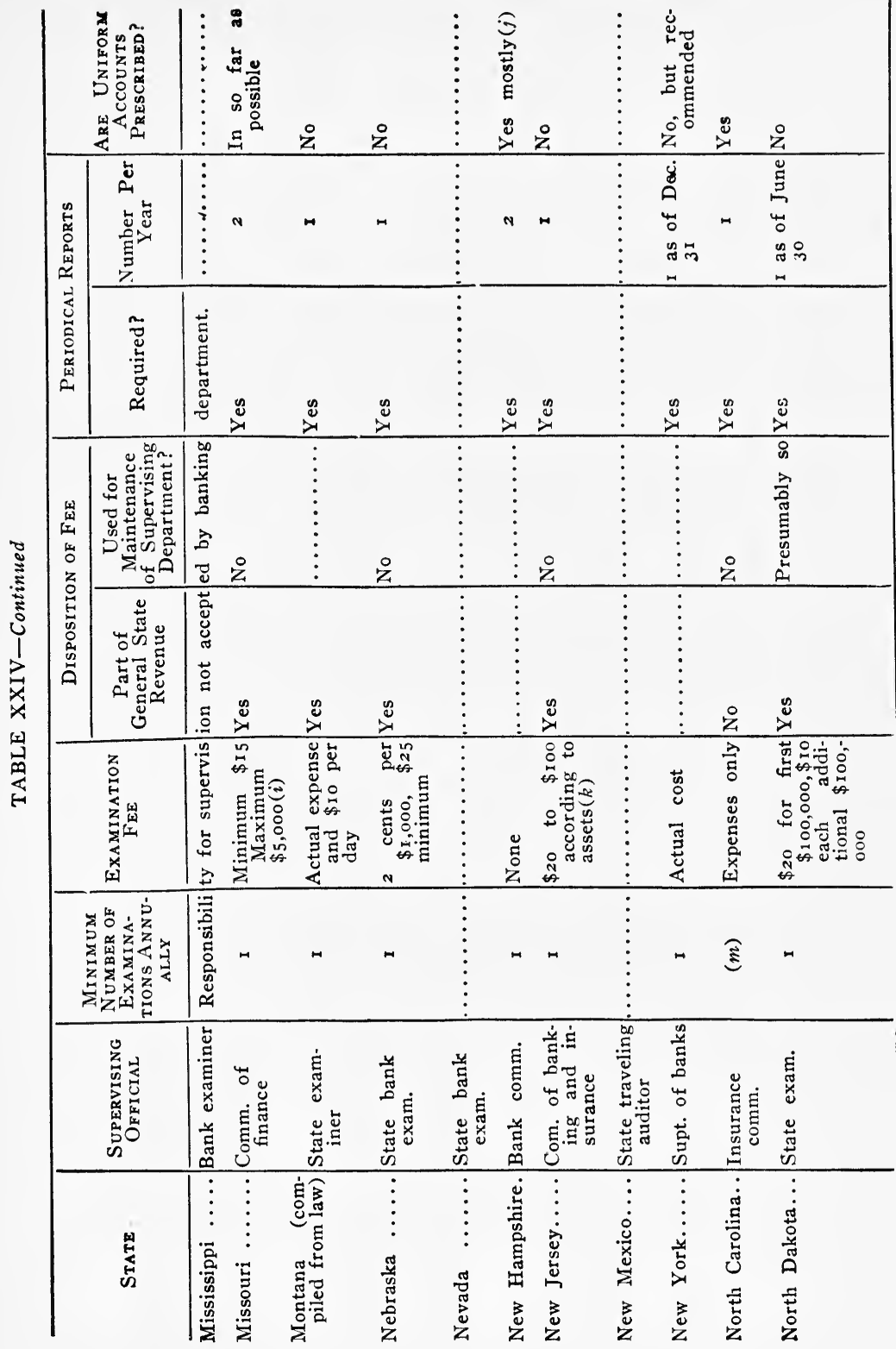


CURRENT PRACTICE IN SUPERVISION 381

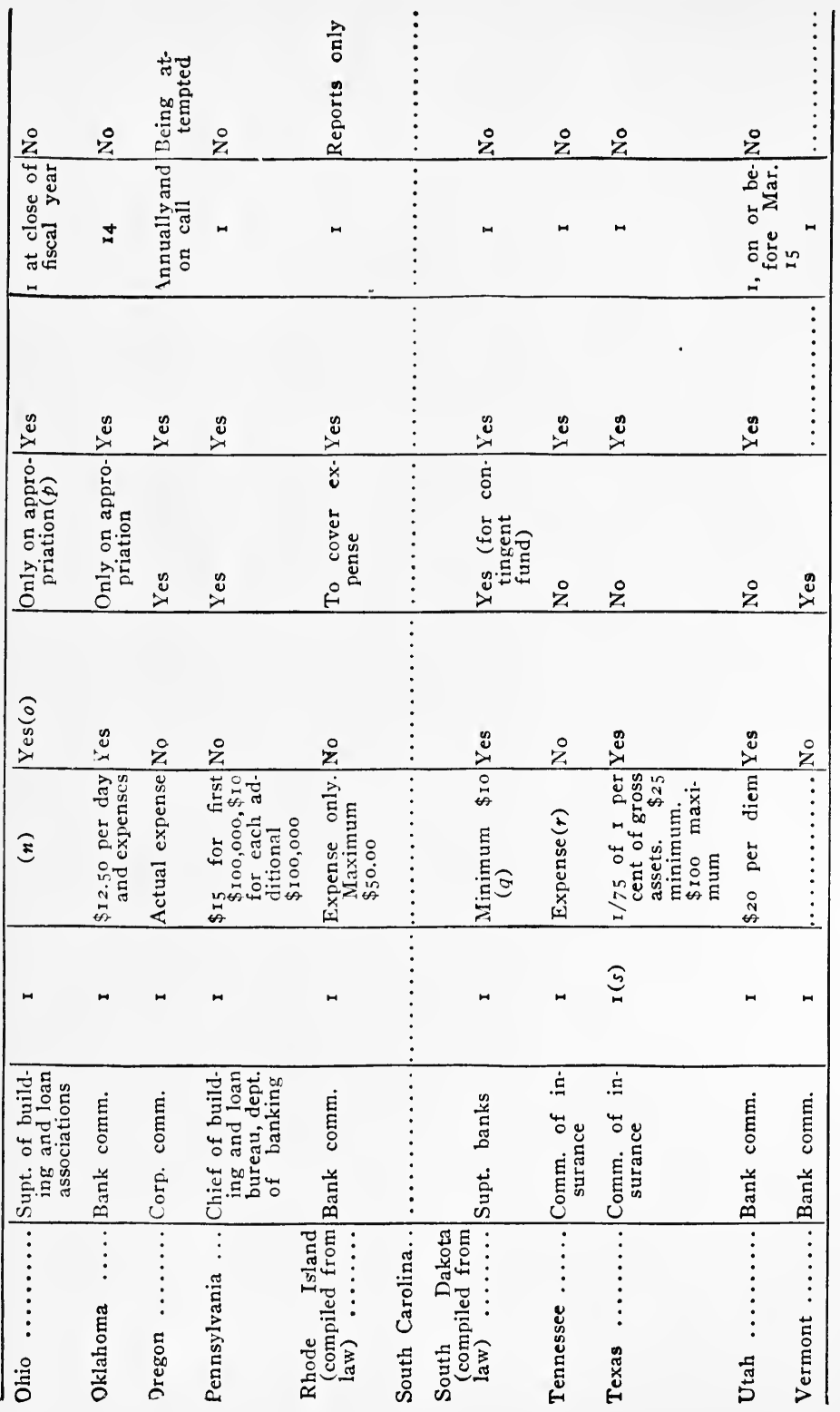




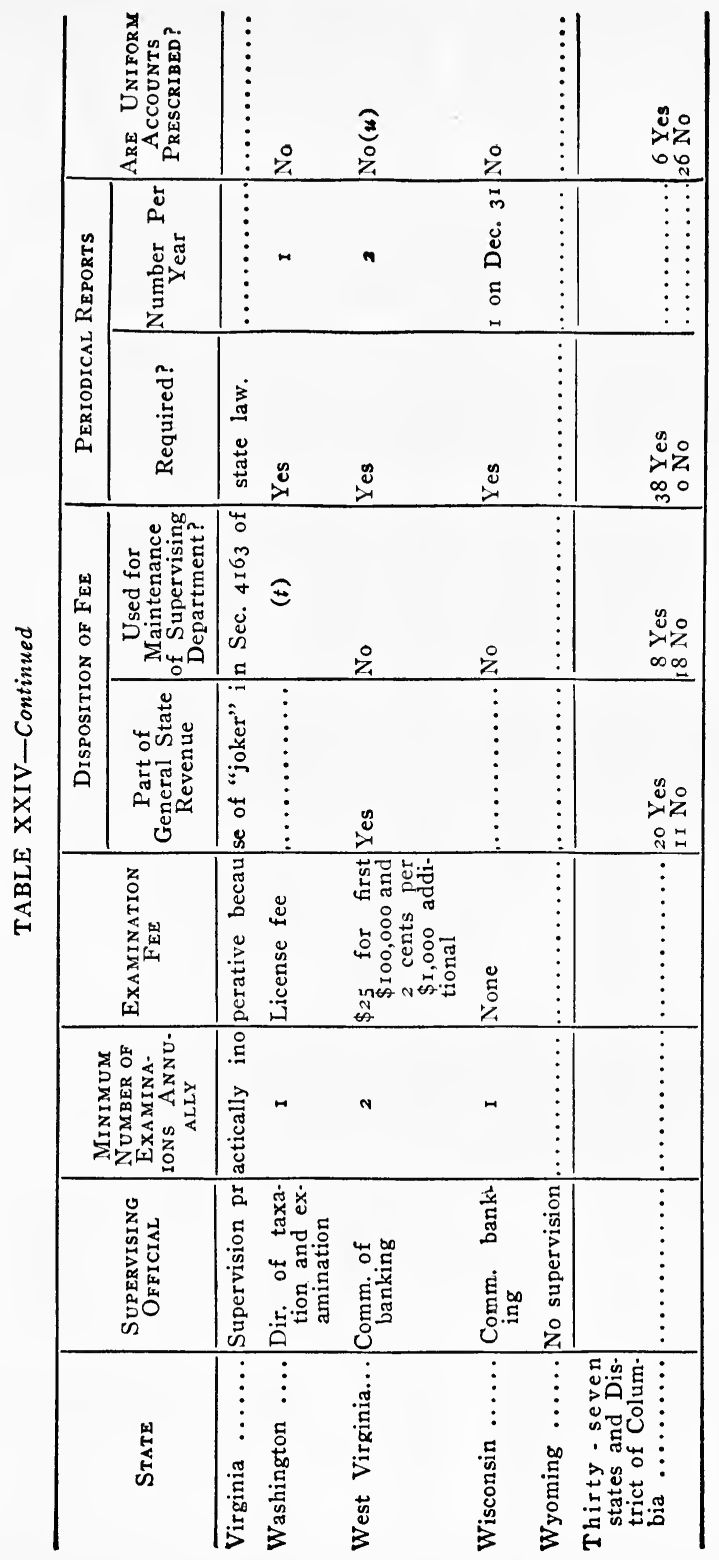




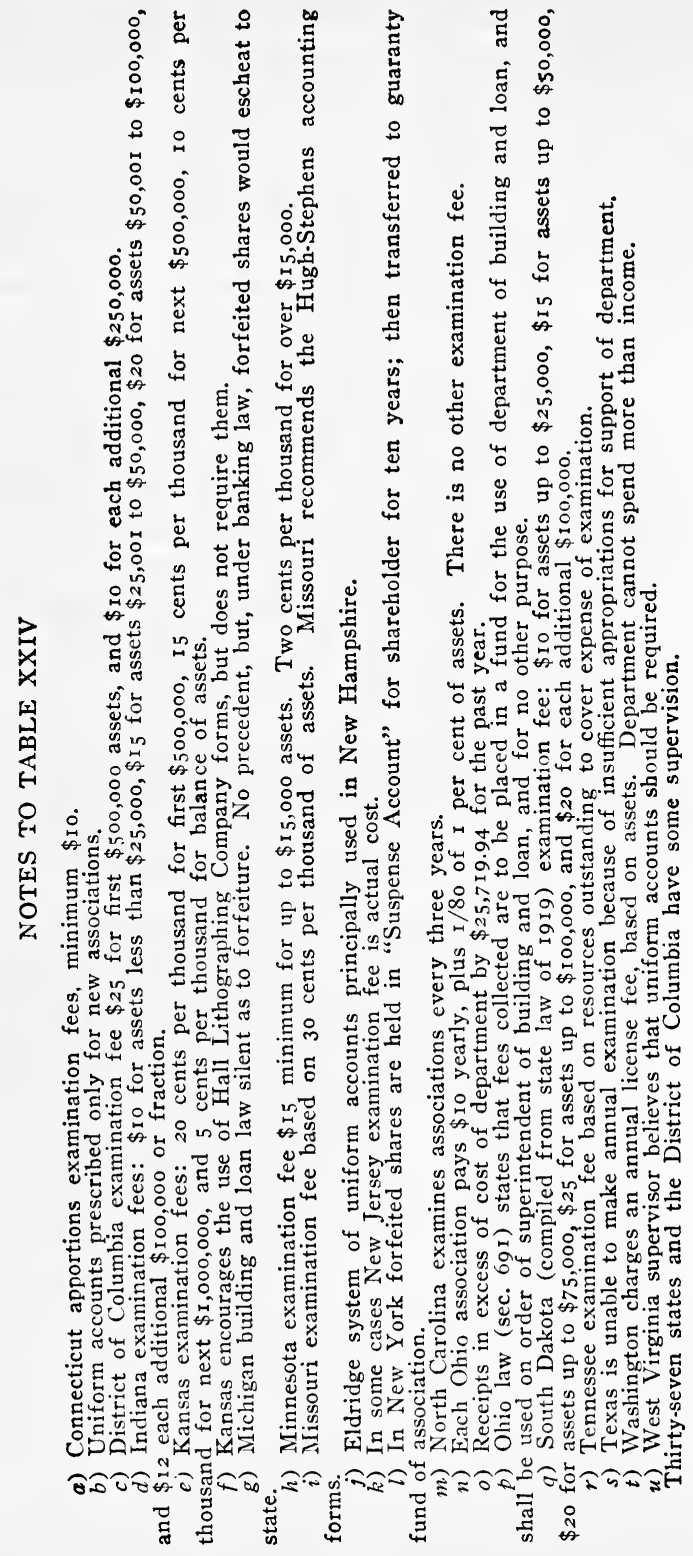




\section{SPECIAL REFERENCES}

Examination. Iowa League Proceedings (I914), pp. 16-19; (Igr8), pp. 20-21. North Carolina League Proceedings (1924), pp. 33-34.

Failures. Minnesota League Proceedings (1924), p. 14. U. S. League Proceedings (1909), pp. I26-I 29.

Losses. Ohio League Proceedings (1922), pp. 90-91; 104-106.

Receiverships. Dyer, H. C., Receiverships of Building and Loan Associations, Cent. L. J., 1899, v. 48, p. 369. Robbins, A. H., Rule of Distribution as Between Borrowing and Non-borrowing Members upon the Insolvency of Building and Loan Associations, Cent. L. J., Igor, v. 52 , p. 313 .

Regulation. U.S. League Proceedings (I9II), pp. 83-97.

Reports. U. S. League Proceedings (I909), pp. II4-rI9.

Standardization. Iowa League Proceedings (I916), p. 28. Nebraska League Proceedings (1924), p. 47. Ohio League Proceedings (1914), pp. 53-54. U. S. League Proceedings (I9I7), pp. 80-94. Youngstown Institute Proceedings, March 23, 1923, p. 2.

Supervision. Illinois League Proceedings (1922), pp. 43-44. Iowa League Proceedings (1913), pp. 9-12; (1914), pp. I2-20. Oklahoma League Proceedings (1922), pp. 35-40. U.S. League Proceedings (1903), pp. I23-139; (I9I4), p. I32.

\section{GENERAL REFERENCES}

Rosenthal, Henry S. Cyclopedia, pp. I49-I53; 2/9-23I ; 285-296; 325333.

SUNDHETM, JOSEPH H. Law, pp. I79-I87. 


\section{STATE LAWS ${ }^{1}$}

The first impression that one receives on making a careful study of the laws relating to building and loan associations in the United States is that the safety of the movement has been brought about by the spirit of sound common sense of the men in charge of the associations rather than by the state laws which have been provided for their regulation.

The "rules of the game" which are so necessary to ultimate success have been built largely on the basis of experience, but matters of grave importance have been omitted from the laws of many states. Only a few states have complete modern statutes on the subject, and further intensive study is needed to determine what should be included in a modern statute on the subject.

The most noticeable trend in legislation is the opposition shown toward the old national associations. Associations having their home office in another state are known as "foreign" associations, and restrictions have been placed upon them in the states where the bad effects of the nationals were most pronounced. The advantages provided for the local association, on the other hand, show that this type of coöperative finance is distinctly favored by the lawmakers.

Instead of presenting a detailed discussion of all the state laws, space for which is lacking in the present text-book, we have prepared the series of tables which are shown herewith. In these tables we have made the first grouping ever attempted of the building and loan provisions of the laws of all the states of the Union. The lack of uniformity is at once apparent, but a close comparison will show that provisions are frequently

${ }^{2}$ Notes for the tables in this chapter will be found on the pages opposite the respective tables. 
TABLE XXV (A)

Statutory Provisions, January I, I925, Covering Building and Loan AssoCiations in the United States

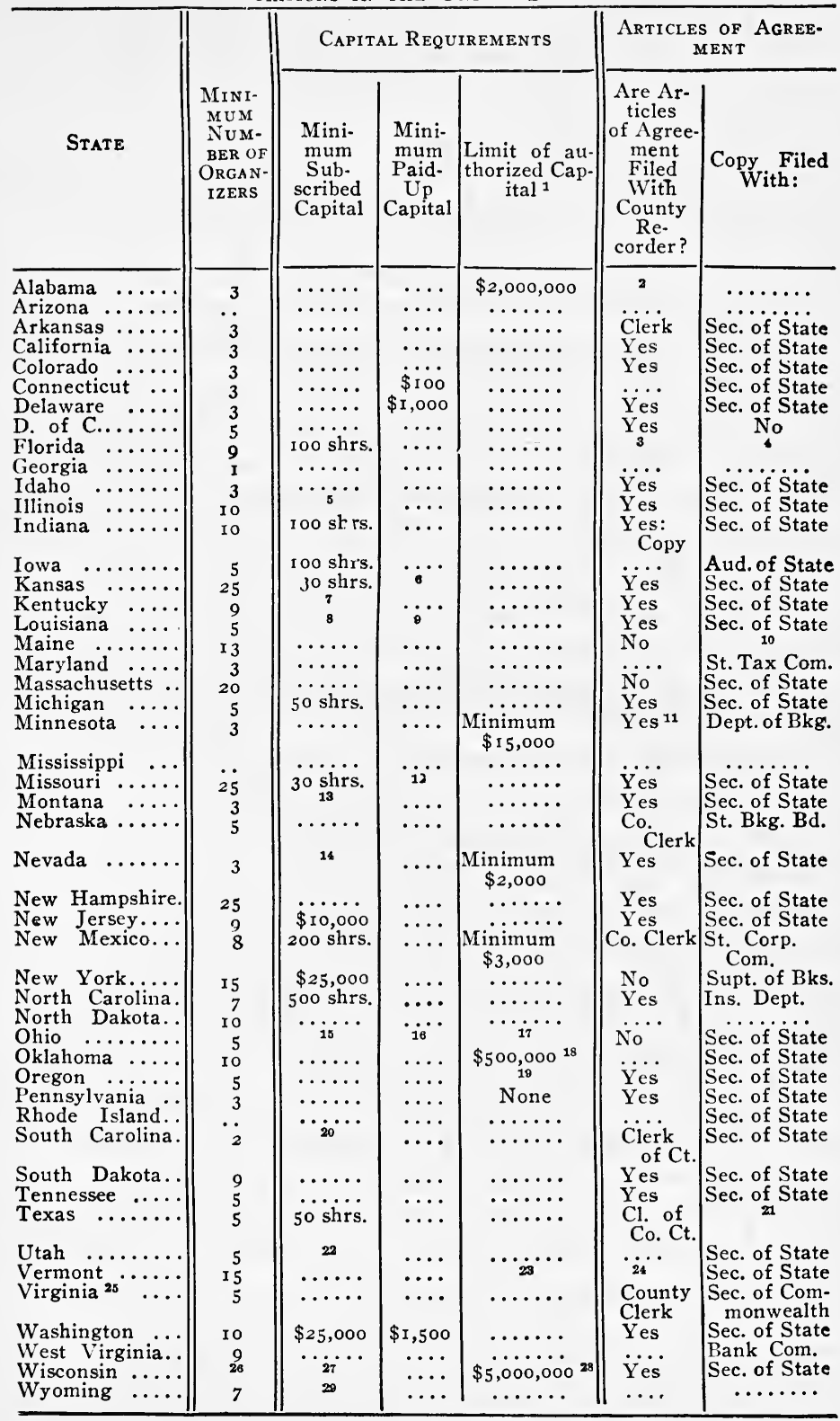


adopted by adjoining states, or by states which have many legislative ideas in common.

Before the passage of the present laws, many associations had been formed as unincorporated companies. In certain districts considerable numbers of these associations continue to do business on their original plans. They resemble partnerships in their form of organization and, therefore, are not subject to all the provisions of the laws which govern incorporated associations in the same localities. The number of such associations is unknown, but they are widely distributed, being particularly noticeable in many parts of the East, including the District of Columbia.

It is a reasonable assumption that the matters not covered by statutes (that is, all questions for which no answers are given in the tables) may be covered by the by-laws of indi'In practically all of the states, the amount of authorized capital is left $t$, the articles of incorporation.

2 Alabama. County Judge of Probate.

Florida. Yes: copies of charter and patent.

- Florida. Governor issues letters patent after articles of agreement are filed with Secretary of State.

- Illinois. 500 shares less than 5 ,000 population.

1,000 shares over 5 , 000 population.

6 Kansas. Óne month's dies on 30 shares.

7 Kentucky. Two hundred shares less than 5,00o population.

Five hundred shares over 5,00o population.

- Louisiana. Towns of 10,000 or less................ \$25,000

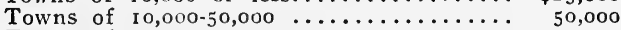

Towns of $50,000-100,000 \ldots \ldots \ldots \ldots \ldots \ldots$ 100,000

Towns over $100,000 \ldots \ldots \ldots \ldots \ldots \ldots \ldots$ 150,000

- Louisiana. Twenty per cent of minimum subscribed capital.

10 Maine. Secretary of State and Bank Commissioner.

11 Minnesota. Recorded with Secretary of State and County Recorder.

12 Missouri. One month's dues on 30 shares.

18 Montana. Five per cent of authorized capital.

14 Nevada. Five per cent of authorizcd capital.

15 Ohio. Five per cent of authorized capital.

${ }^{16}$ Ohio. Five per cent of authorized capital.

17 Ohio. Not less than $\$ 300,000$. If population exceeds 5,000 , must be $\$ 500,000$.

18 Oklahoma. May be increased.

19 Oregon. $\$ 50,000$ if business is restricted to own county.

$\$ 1,000,000$ if business not so restricted.

Amounts may be increased.

south Carolina. Ten per cent of amount named as "initial" capital.

21 Texas. Secretary of State and Insurance Commissioner.

22 Utah. Five per cent of authorized capital.

23 Vermont. Subscribed $\$ 4,000,000$.

Accumulated $\$ 2,000,000$.

24 Vermont. Certificate of Secretary of State filed with town clerk.

${ }^{25}$ Virginia. The Virginia law contains a "joker" section which practically nullifies it.

20 Wisconsin. One hundred in Milwaukee. Law silent for smaller cities.

${ }^{27} \mathrm{Wisconsin}$. Two thousand shares in Milwaukee. Law silent for smaller cities.

28 Wisconsin. May be increased.

20 Wyoming. Five per cent of authorized capital. 
TABLE XXV (B)

Statutory Provisions, January I, 1925, Covering Building and Loan Associations in the United States

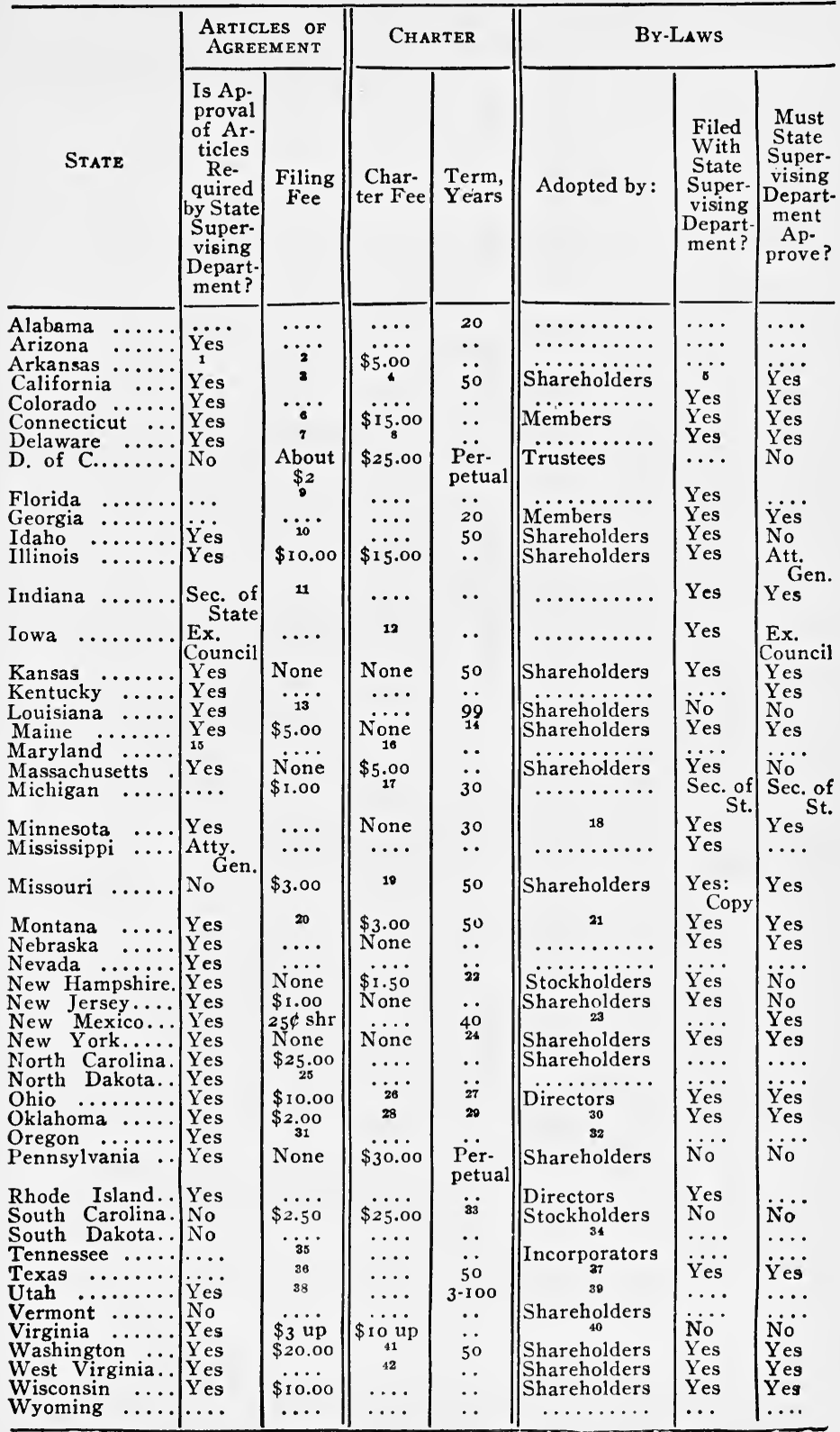


1 Arkansas. See "Blue Sky Law."

2 Arkansas. $\$ 25$ for first $\$ 10,000$ authorized capital.

$\$ 1$ per $\$ 1,000$ authorized capital in excess of $\$ 10,000$. Maximum \$250.

- California. California has three types of fees, including an annual license fee. Minimum fee $\$ 10$ per year up to $\$ 25,000$ capital.

Above $\$ 25,000$, graduated scale.

- California. Annual license fee as assessed by Commissioner.

- California. Yes: a certified copy.

- Connecticut. \$2 recording fee with Secretary of State.

\$3 filing fee with town clerk.

7 Delaware. One cent per line for certificate of incorporation and other papers. $\$ 2$ for annual statement.

8 Delaware. Minimum of $\$ 10$

Ten cents per $\$ 1,000$ authorized capital up to $\$ 2,000,000$.

Five cents per $\$ 1,000$ authorized capital over $\$ 2,000,000$.

- Florida. $\$ 5$ for each $\$ 50,000$ capital.

10 Idaho. $\$ 10$ to $\$ 150$, based on assets.

11 Indiana. $\$ 5$ for each $\$ 50,000$ capital.

12 Iowa. \$25 for domestic associations.

2s Louisiana. Twenty-five cents per 100 words in copying. $\$$ I for certificate of same.

14 Maine. Perpetual.

15 Maryland. Certified by Circuit Judge.

16 Maryland. Twenty cents per $\$ 1,000$ of authorized capital.

17 Michigan. \$50 per \$100,000 capital.

Fifty cents per folio of roo words in making and certifying to articles of association, by-laws, etc.

18 Minnesota. First board of directors (amended by shareholders).

10 Missouri. $\$ 50$ first $\$ 50,000$ capital

$\$ 25$ each additional $\$ 50,000$.

20 Montana. \$1 per $\$ 1,000$ up to $\$ 100,000$ capital.

Graduated thereafter.

21 Montana. Directors or shareholders.

22 New Hampshire. Unlimited.

${ }^{23}$ New Mexico. Stockholders then filed with Corporation Commission and county clerk.

24 New York. Perpetual.

26 North Dakota. $\$ 20$ for first $\$ 100,000$ assets.

$\$$ Io for each additional $\$ 100,000$.

26 Ohio. For filing certificate of subscription, $\$ 2$.

${ }^{-7}$ Ohio. Perpetual.

28 Oklahoma. \$1 per $\$ 1,000$ of authorized capital.

20 Oklahoma. Not to exceed 20 years in charter.

May be extended to 50 years.

${ }^{20}$ Oklahoma. Directors or shareholders.

ar Oregon. Based on amount of authorized capital.

32 Oregon. Directors in first instance.

83 South Carolina. Perpetual.

34 South Dakota. Shareholders (in original by-laws they may confer the power to amend upon the directors).

${ }^{85}$ Tennessee. One-tenth of one per cent of capital stock.

36 Texas. Filing fee $\$ 1$.

Franchise tax $\$$ io

Also pay for two extra certified copies of articles at 50 cents per page and $\$ 1$ for certificate.

$\$ 2$ for approval of by-laws.

37 Texas. Directors or shareholders.

88 Utah. \$2.50 plus 20 cents per folio.

39 Utah. Directors or shareholders.

to Virginia. Stockholders (may delegate this power to the directors, reserving the right to change or repeal).

\& Washington. Based on amount of capital stock.

West Virginia. Based on authorized capital. 
TABLE XXV (C)

Statutory Provisions, January i, 1925, Covering Buildings and Loan Associations in the United States

\begin{tabular}{|c|c|c|c|c|c|c|c|}
\hline \multirow[b]{2}{*}{ State } & \multicolumn{2}{|c|}{ QUORUM } & \multicolumn{5}{|c|}{ VOTING } \\
\hline & $\begin{array}{c}\text { Of } \\
\text { Shares }\end{array}$ & $\begin{array}{c}\text { Of } \\
\text { Mem- } \\
\text { bers }\end{array}$ & $\begin{array}{c}\text { By } \\
\text { Shares }\end{array}$ & $\begin{array}{c}\text { By } \\
\text { Mem- } \\
\text { bers }\end{array}$ & $\begin{array}{l}\text { Is Cu- } \\
\text { mula- } \\
\text { tive } \\
\text { Voting } \\
\text { Per- } \\
\text { mitted? }\end{array}$ & $\begin{array}{c}\text { Vote of } \\
\text { Individual } \\
\text { Limited? }\end{array}$ & $\begin{array}{l}\text { Use of } \\
\text { Proxies } \\
\text { Lim- } \\
\text { ited? }\end{array}$ \\
\hline labama & $\cdots \cdot$ & $\cdots \cdots$ & & $\cdots$ & $\cdots$ & $\ldots \ldots \ldots$ & $\cdots$ \\
\hline & & & & $\ldots$ & & & \\
\hline $\begin{array}{l}s \\
\text { ia }\end{array}$ & $\begin{array}{l}\text { Majority } \\
\text { Majority }\end{array}$ & $\begin{array}{l}\text { Majority } \\
\text { Majority }\end{array}$ & Yes & $\cdots$ & $\ddot{\mathrm{y}}$ & No & No \\
\hline$\ldots \ldots$ & Majority & $\ldots$ & $\ddot{\mathrm{y}} \mathrm{es}$ & $\cdots$ & IeS & $\ddot{\mathrm{Yes}}$ & 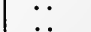 \\
\hline ut $\ldots$ & & $C i$ & No & Yes & $\cdots$ & Yes: I vote & \\
\hline $\begin{array}{l}\text { Delaware } \ldots \ldots \ldots \\
\text { D. of } C . \ldots \ldots \ldots\end{array}$ & $\begin{array}{c}\text { Charter } \\
\ldots \ldots\end{array}$ & $\underset{1}{\text { Charter }}$ & $\begin{array}{l}\text { Yes } \\
\text { Yes }\end{array}$ & $\cdots$ & Yes & $\begin{array}{l}\text { No } \\
\text { No }\end{array}$ & $\begin{array}{l}\text { No } \\
\text { No }\end{array}$ \\
\hline rida $\ldots \ldots \ldots$ & $\ldots$ & $\ldots$ & Yes & $\cdots$ & $\cdots$ & 25 shares & No \\
\hline ia. & 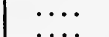 & $\cdots$ & $\mathrm{Y}_{\mathrm{e}}-\mathrm{C}_{2}$ & $\cdots$ & $\ddot{\mathrm{v}}$ & $\ldots \ldots$ & 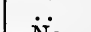 \\
\hline is & Majority & $\cdots$ & $\begin{array}{l}\text { Yes } \\
\text { Yes }\end{array}$ & $\cdots$ & $\begin{array}{l}\text { Yes } \\
\text { Yes }\end{array}$ & ${ }_{\text {No }} \cdots \cdots$ & $\begin{array}{l}\text { No } \\
\text { No }\end{array}$ \\
\hline na $\ldots \ldots$ & $\ldots$ & $\ldots$ & Y̌es & $\cdots$ & $\ldots$ & 20 shares & \\
\hline$\ldots \ldots \ldots$ & $\cdots$ & $\cdots$ & Yes & $\cdots$ & 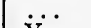 & 2 & No \\
\hline$\cdots \cdots$ & $\cdots$ & $\cdots$ & Yes & $\cdots$ & Yes & No & No \\
\hline na.. & $\cdots$ & $\cdots \cdot$ & $\ddot{3}$ & $\ddot{\theta}_{3}$ & $\ddot{3}_{3}$ & $\cdots \cdots_{i} \cdot$ & No \\
\hline i $\cdots \cdots$ & Mriomitz & $\cdots$ & No & Yes & No & Yes: I vote & \\
\hline isetts $\ldots$ & Majority & & No & Yeo +2 & & & No \\
\hline - & $\cdots$ & & & & & $x \in x^{2}+2 x$ & $\begin{array}{l}\text { For- } \\
\text { bidden }\end{array}$ \\
\hline$\therefore$ & $\cdots$ & $\cdots$ & $\cdots$ & - & • & .. & \\
\hline & . & $\cdots$ & $\ddot{\theta}$ & a & $\ddot{\mathrm{ye}}$ & $\cdots \cdots$ & No \\
\hline$\because$ & 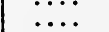 & $\cdots$ & $\ldots$ & $\cdots$ & $\mathrm{Ye}$ & $\cdots_{7} \cdots$ & No \\
\hline & $\ldots$ & $\ldots$ & & & Yes & No & No \\
\hline Ne & $\because$ & $\ddot{*} \cdot$ & Yes & No & Yes & Yes & 8 \\
\hline pshire. & $\ldots$ & $\ldots$ & 10 & $\mathrm{Y}^{10}$ & Yes & yes....... & \\
\hline Tor T & & & & $\mathbf{Y}$ & No & Yes: I vote & $\begin{array}{l}\text { For- } \\
\text { bidden }\end{array}$ \\
\hline $\begin{array}{l}\text { Jew Jersey.... } \\
\text { Jew Mexico.... }\end{array}$ & $\begin{array}{l}11 \\
12\end{array}$ & $\begin{array}{l}11 \\
12\end{array}$ & No & Yes & & Yes: I vote & No \\
\hline Yor & $\ldots$ & $\cdots$ & & • & $\begin{array}{l}\text { Yes } \\
\text { No }\end{array}$ & $\ddot{m}$ & No \\
\hline h $\mathrm{C}$ & $\cdots$ & $\ldots$ & $\ldots$ & $\cdots$ & & & \\
\hline h Dakota... & $\cdots$ & . & i & $\because$ is & & No & No \\
\hline$\cdots \cdots$ & & $\cdots$ & & & No & $\ldots \ldots$ & No \\
\hline$\cdots \cdots$ & $\because$ & & Yes & No & $\cdots$ & . & No \\
\hline sylv & & $\cdots$ & & & $\ddot{\text { Yes }}$ & & No \\
\hline Rhode Island & 15 & 15 & No & Yes & $\cdots$ & Yes: I vote & $\cdots$ \\
\hline $\begin{array}{l}\text { South Carolina. } \\
\text { South Dakota.. }\end{array}$ & $\ddot{m}$ & $\cdots$ & $\mathrm{Ye}$ & No & $\because$ & $\cdots \cdots_{16} \cdots$ & No \\
\hline hessee... . & $\ldots$ & $\cdots$ & Yes & $\ldots$ & $\ldots$ & No & No \\
\hline$\ldots$. & .. & & & & & & \\
\hline & $\cdots$ & $\ldots$ & & & Yes & No & No \\
\hline * & $\ldots$ & $\because$ & Yes & & $\cdot_{i i}$ & No & $\mathrm{No}$ \\
\hline ngt & & & & & & & \\
\hline Virginia.. & $\ddot{\mathrm{Y}} \ddot{\mathrm{es}}$ & $\cdots$ & $\ddot{\mathrm{Y}} \ddot{\mathrm{es}}$ & 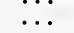 & $\cdots$ & $\cdots$ & $\because$ \\
\hline$n \sin \ldots$ & $\cdots$ & .. & Yes & & $\cdots$ & $\ldots$ & .. \\
\hline oming .. & $\cdots$ & $\cdots$ & $\cdots$ & . & $\cdots$ & & . \\
\hline
\end{tabular}

Notes on p. $39 \mathrm{I}$. 
vidual associations, if the shareholders see fit to make use of them in their business.

An outstanding feature of all the laws is their lack of completeness. To discover the provisions relating to organization, for example, it has been necessary to refer to the general corporation laws of many states, and then to check these with all possible sections of the special building and loan statutes which may nullify them. A single paragraph, or at the most, one page, added to the special act, to cover necessary matters, would save endless confusion, especially for newly appointed supervisors and for men new to the movement who wish to organize associations. The addition of the few necessary paragraphs (by way of repetition, if no change is desired) would not interfere with the administration of the general corporation laws.

As the laws now stand, three persons may organize a new building and loan association in $\mathrm{I}_{3}$ states, at least 5 are required in II states, and in others the number varies, with 9 and Io the most common after 3 and 5 .

Another feature worth mentioning is the merely nominal amount of investment required of directors. For example, in four states directors may qualify if they have subscribed for a single share of stock, two states require the directors to

1 District of Columbia. Such of the stockholders as shall attend after 30 days' published notice.

${ }^{2}$ Iowa. Ten per cent of outstanding shares.

${ }^{3}$ Louisiana. Articles or by-laws.

4 Louisiana. Number of shares owned.

5 Maryland. A majority of all members unless by-laws specifically provide.

- Mississippi. Association may determine number of shares that will entitle member to vote.

${ }^{7}$ Missouri. Shares must be on books 30 days before voting is permitted.

8 Nebraska. $\$ 5,000$ by one person, except that where not less than 50 members are present, sufficient proxies may be voted to represent the majority of stock of the association.

$\rightarrow$ Nevada. Articles or by-laws.

10 Nevada. In absence of by-law provision, each member has one vote.

11 New Jersey. Constitution.

12 New Mexico. Articles or by-laws govern, but if no provision is made, a majority in interest of the stockholders in person or by proxy constitutes a quorum.

${ }^{13}$ New Mexico. Voting privilege irrespective of class or series: I share $I$ vote.

14 Ohio. Constitution.

15 Rhode Island. May be less than a majority.

16 South Dakota. Yes: 20 per cent of outstanding stock.

17 Virginia. Cumulative voting permitted if authorized in certificate of incorporation. 
TABLE XXV (D)

Statutory Provisions, January 1, 1925, Covering Building and Loan Asso. Ciations in the United States

\begin{tabular}{|c|c|c|c|c|c|c|c|}
\hline \multirow[b]{3}{*}{ State } & \multicolumn{6}{|c|}{ Directors } & \multirow{3}{*}{$\mid \begin{array}{c}\text { CoMmIT- } \\
\text { TEES }\end{array}$} \\
\hline & \multirow[b]{2}{*}{$\begin{array}{l}\text { Mini- } \\
\text { mum } \\
\text { Num- } \\
\text { ber }\end{array}$} & \multirow[b]{2}{*}{$\begin{array}{l}\text { Maxi- } \\
\text { mum } \\
\text { Num- } \\
\text { ber }\end{array}$} & \multirow[b]{2}{*}{$\begin{array}{c}\text { Limit } \\
\text { for } \\
\text { Term } \\
\text { of Of- } \\
\text { fice, } \\
\text { Years }\end{array}$} & \multicolumn{2}{|c|}{$\begin{array}{c}\text { Share Ownership } \\
\text { by Directors }\end{array}$} & \multirow[b]{2}{*}{$\begin{array}{l}\text { Are Di- } \\
\text { rectors } \\
\text { Liable for } \\
\text { Neglect? }\end{array}$} & \\
\hline & & & & $\begin{array}{c}\text { Re- } \\
\text { quired? }\end{array}$ & $\begin{array}{c}\text { Mini- } \\
\text { mum } \\
\text { Amount, } \\
\text { Each } \\
\text { Director }\end{array}$ & & \\
\hline Alabama....... & $\cdots$ & $\cdots$ & $\cdots$ & $\cdots$ & …... & $\cdots$ & $\cdots \ldots \ldots$ \\
\hline Arizona $\ldots \ldots \cdots$ & $\cdots$ & $\cdots$ & $\because$ & $\ddot{\text { Yes }}$ & $\cdots \cdots$ & $\ddot{\mathrm{y}}$ & $\cdots \cdots \cdots$ \\
\hline $\begin{array}{l}\text { Arkansas } \\
\text { California }\end{array}$ & $\begin{array}{l}3 \\
3\end{array}$ & $\ddot{m}$ & I & $\begin{array}{l}\text { Yes } \\
\text { Yes }\end{array}$ & 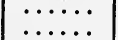 & $\begin{array}{l}\text { Yes } \\
\text { Yes }\end{array}$ & Directors \\
\hline Colorado $\ldots \ldots \ldots$ & 3 & 13 & I & $\ddot{\mathrm{Y}}$ & …. & In $\cdots$ & Directors \\
\hline Connecticut...$\cdots$ & 3 & $\cdots$ & & Yes & I share & In some & Directors \\
\hline $\begin{array}{l}\text { Delaware } \ldots \ldots \ldots \\
\text { D. of C. } \ldots \ldots \ldots\end{array}$ & 3 & $\ddot{i s}$ & $\ddot{I}$ & $\begin{array}{l}\text { No } \\
\text { Yes }\end{array}$ & $\cdots \cdots$ & Yes & $\begin{array}{l}\text { Directors } \\
\text { Trustees }\end{array}$ \\
\hline $\begin{array}{l}\text { D. of } \\
\text { Fiorida }\end{array}$ & $\begin{array}{l}3 \\
9\end{array}$ & $\begin{array}{l}15 \\
\cdots\end{array}$ & $\begin{array}{l}1 \\
3\end{array}$ & $\begin{array}{l}\text { Yes } \\
\text { Yes }\end{array}$ & $\ldots \cdots$ & $\cdots$ & $\begin{array}{l}\text { Trustees } \\
\cdots \ldots\end{array}$ \\
\hline & $\therefore$ & $\therefore$ & $\begin{array}{l}3 \\
\cdots\end{array}$ & & $\cdots \cdots$ & & $\ldots \ldots \cdots$ \\
\hline $\begin{array}{l}\text { Idaho } \ldots \ldots \ldots \ldots \\
\text { Illinois } \ldots \ldots \ldots \ldots\end{array}$ & 3 & 15 & $1-3$ & Yes & $\cdots \cdots$ & Yes 1 & Directors \\
\hline $\begin{array}{l}\text { Illinois } \ldots \ldots \ldots \ldots \\
\text { Indiana } \ldots \ldots \ldots\end{array}$ & $\begin{array}{l}3 \\
5\end{array}$ & $\ddot{2}$ & $\ddot{3}$ & $\begin{array}{l}\text { Yes } \\
\text { Yes }\end{array}$ & I share & Yes & Directors \\
\hline Indrana $\ldots \ldots \cdots \cdots$ & $\begin{array}{c}5 \\
.\end{array}$ & $\cdots$ & $\begin{array}{c}3 \\
1-5\end{array}$ & $\begin{array}{l}\text { Yes } \\
\text { Yes }\end{array}$ & $\ldots \cdots$ & $\ddot{\mathrm{Y}}$ es & $\ldots \ldots \cdots$ \\
\hline$\underset{\text { Kentucky }}{\text { Kansas }} \ldots \ldots \ldots$ & 5 & I 5 & None & Yes & 2 shares & $\begin{array}{l}\text { Yes } \\
\text { Yes }\end{array}$ & …… \\
\hline & 9 & $\cdots$ & 3 & Yes & 5 shares & Yes & \\
\hline $\begin{array}{l}\text { Louisiana } \\
\text { Maine } \ldots \ldots \ldots \\
\end{array}$ & $\cdots$ & 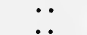 & Non & $\begin{array}{l}\text { Yes } \\
\text { Yes }\end{array}$ & $\cdots \cdots$ & $\ddot{\mathrm{V}}$ & Directors \\
\hline Maryland $\ldots \ldots \ldots$ & $\because$ & $\because$ & $\begin{array}{c}\text { None } \\
\ldots\end{array}$ & & $\cdots \cdots$ & Yes & $\because \cdots \cdots$ \\
\hline Massachusetts $\ldots$ & $\ddot{5}$ & 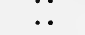 & $\ddot{3}$ & $\ddot{\mathrm{Y}} \ddot{\mathrm{es}}$ & $\cdots \cdots$ & - & Directors \\
\hline Michigan $\ldots \ldots \ldots$ & 5 & $\cdots$ & None & Yes & 8 & $\ddot{\mathrm{Y}} \mathrm{es}$ & President \\
\hline Minnesota $\ldots \ldots$ & 3 & . & 5 & Yes & $\cdots \cdots$ & Yes & Directors \\
\hline $\begin{array}{l}\text { Mississippi } \ldots \ldots \\
\text { Missouri } \ldots\end{array}$ & $\ddot{0}$ & $\because$ & $\because$ & $\ddot{\text { Yes }}$ & $\ddot{2}$ shares & Yes & $\cdots \cdots$ \\
\hline $\begin{array}{l}\text { Missouri } \\
\text { Montana }\end{array} \ldots \ldots \ldots$ & $\ddot{3}$ & $\ddot{25}$ & $\ddot{1}-3$ & $\begin{array}{l}\text { Yes } \\
\text { Yes }\end{array}$ & $\begin{array}{l}2 \text { shares } \\
\text { I share }\end{array}$ & $\begin{array}{l}\text { Yes } \\
\ldots \text {... }\end{array}$ & $\cdots \cdots \cdots$ \\
\hline Nebraska $\ldots \ldots \ldots$ & .. & $\cdots$ & .. & $\cdots$ & ...... & $\cdots$ & $\cdots \cdots \cdots$ \\
\hline ada $\ldots . . . .$. & $\cdots$ & $\cdots$ & .. & $\ddot{0}$ & ...... & Yes & $\cdots \cdots \cdots$ \\
\hline$N$ Hampshire... & $\ddot{5}$ & $\because$ & $\because$ & $\begin{array}{l}\text { No } \\
\text { Yes }\end{array}$ & $\cdots \cdots$ & No & President \\
\hline $\begin{array}{l}\text { New Jersey. } \\
\text { New Mexico. }\end{array}$ & $\begin{array}{l}5 \\
6\end{array}$ & $\ddot{\cdots}$ & $\ddot{I-3}$ & $\begin{array}{l}\text { Yes } \\
\text { Yes }\end{array}$ & I share & Yes & President \\
\hline $\begin{array}{l}\text { New Mexico. } \\
\text { New York... }\end{array}$ & & $\ddot{15}$ & $1-3$ & Yes & $\cdots \cdots$ & Yes & $\ldots \ldots \ldots$ \\
\hline $\begin{array}{l}\text { New York........ } \\
\text { North Carolina... }\end{array}$ & . & .. & . & $\cdots$ & $\ldots \ldots$ & $\begin{array}{l}\text { Yes } \\
\ldots\end{array}$ & $\cdots \cdots \cdots$ \\
\hline North Dakota.... & . & 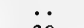 & 3 & $\dddot{x}$ & $\cdots \cdots$ & $\cdots$ & anm \\
\hline$\cdots$ & 5 & 30 & I-3 & Yes & 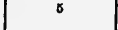 & $\ddot{\mathrm{Y}} \ddot{\mathrm{es}}$ & $\ldots \ldots \ldots$ \\
\hline homa $\ldots \ldots \cdot$. & 5 & $\ddot{i o}$ & 3 & Yes & $\cdots \cdots$ & & $\cdots \cdots$ \\
\hline on & 5 & $\begin{array}{l}\text { I0 } \\
\ldots\end{array}$ & $\begin{array}{l}3 \\
. .\end{array}$ & Yes & $\ldots \ldots$ & Yes & $\cdots \cdots$ \\
\hline $\begin{array}{l}\text { Pennsylvania } . . . \\
\text { Rhode Island..... }\end{array}$ & $\begin{array}{l}3 \\
5\end{array}$ & $\because$ & $\ddot{m}$ & $\cdots$ & $\cdots \cdots$ & & Directors \\
\hline South Carolina... & 2 & $\ddot{1} 5$ & $\ddot{i}$ & Ÿes & ro shares & $\ddot{\text { Yes }}$ & $\ldots \ldots \ldots$ \\
\hline th Dakota..... & 5 & I 3 & I-3 & Yes & $\ldots \ldots$ & & \\
\hline nessee. & 5 & $\ddot{i}$ & $\cdots$ & $\cdots$ & …… & Yes & $\cdots \cdots \cdots$ \\
\hline as $\ldots \ldots \ldots \cdots \cdots$ & 5 & 21 & $\ddot{3}$ & $\because$ & a... & $\begin{array}{l}\text { Yes } \\
\text { Yes }\end{array}$ & Directors \\
\hline$\ldots \cdots \cdots \cdots \cdots$ & $\begin{array}{l}3 \\
0\end{array}$ & 25 & $\begin{array}{l}3 \\
\cdots\end{array}$ & & $\cdots \cdots$ & $\ldots$ & $\begin{array}{l}\text { Directors } \\
\ldots \ldots \ldots\end{array}$ \\
\hline $\begin{array}{ll}\text { Vermont } & \ldots \\
\text { Virginia } & \ldots\end{array}$ & $\begin{array}{l}9 \\
3\end{array}$ & $\begin{array}{r}9 \\
. .\end{array}$ & $\ddot{0}$ & $\cdots$ & $\cdots$ & $\cdots$ & Directors \\
\hline $\begin{array}{l}\text { Virginia } \\
\text { Washington }\end{array}$ & $\begin{array}{l}3 \\
7\end{array}$ & $\ddot{\text { i }} 5$ & $\because$ & $\ddot{\mathrm{Y}}$ es & $\ddot{8}$ & $\ldots$ & \\
\hline West Virginia.... & 5 & 5 & .. & Yes & $\ldots \ldots$ & $\ldots$ & Directors \\
\hline onsin $\ldots \ldots \ldots$ & $\cdots$ & $\cdots$ & . & Yes & ..... & $\cdots$ & $\ldots \ldots \ldots$ \\
\hline Wyoming ........ & $\cdots$ & . & -. & ... & ..... & $\cdots$ & $\cdots \cdots$ \\
\hline
\end{tabular}

Notes on p. 393. 
hold two shares, one requires shares to the amount of \$100, another $\$ 200$, and I 5 states which expect the directors to own shares leave the amount to the by-laws. Of the latter number, seven states permit the directors to amend the by-laws. Can such nominal requirements be of practical importance in associations where the assets frequently run into the milliondollar class?

Fidelity bonds are now almost universally required of officers who handle funds. In only seven states, however, has the law made these mandatory. Fourteen states have given the state supervisor power to approve or disapprove bonds offered, and such authority is now assumed by the supervisor in at least one more state, under the general statutes. The number requiring corporate suretyship appears to be slowly increasing.

Seven states limit share holdings in the hands of individual members.

A most unsettled matter is the permission to charge fees and fines. Five states limit the amount of fees to 25 cents per share, two to 50 cents per share, two $\$ I$, one $\$ I .50$ per $\$ 100$ share, while three states permit fees of $\$ 2$ per share. In 20 other states the size of "possible fees is left to the provisions of the by-laws, and only two states in the Union, Ohio and Mississippi, prohibit the use of fees. There is no regularity about fines, but the best practice seems to be to require that fines be no greater than legal interest on arrearages. Fines on fines are prohibited in most states.

Seventeen states definitely prohibit the forfeiture of dues in case of delinquency, but nine others still permit this unfair practice. In two more states the use of fees would accomplish

1 Idaho. See case of Smith vs. Rader.

2 Indiana. Articles of Association.

3 Michigan. Five saving or installment shares or other shares equal in value to

- New York. Five savings or installment shares or equivalent of one matured share.

- Ohio. Department requires $\$ 100$.

- Pennsylvania. Directors not liable by statute but under common law.

7 Utah. Yes: if association is restricted to Utah.

- Washington. $\$ 200$ in cash must be maintained. 
Statutory Provisions, January 1 , 1925, Covering Building and Loan Associations in the UNited States

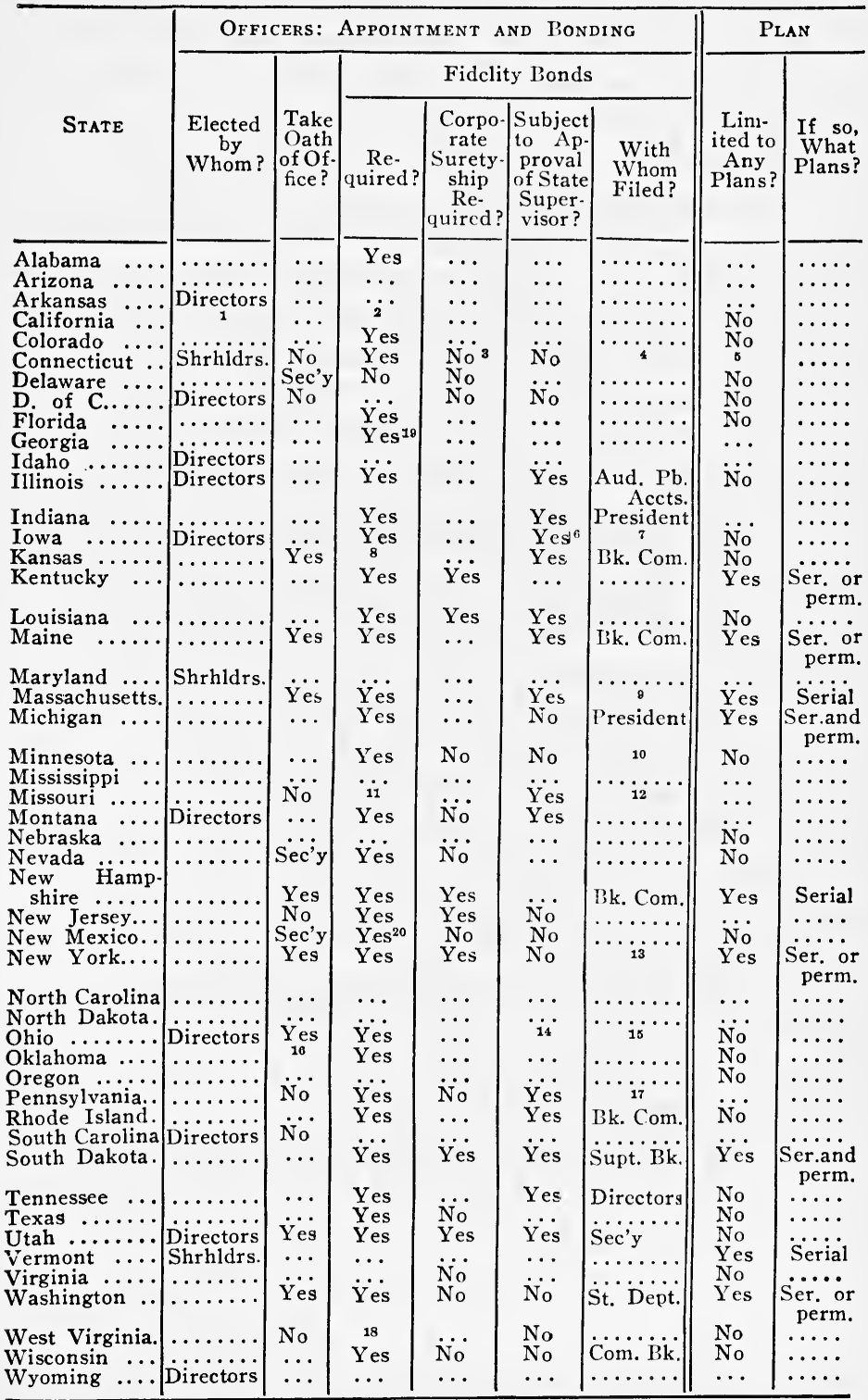


the same result if withdrawal takes place in an early year. Seven states which permit forfeiture of dues have statutory provisions which are supposed to limit the amount of forfeiture, but closer examination shows that but three of these limits are effective.

Twenty states permit the forfeiture of earnings, and only two prohibit such forfeiture. Eleven of the twenty states place a limit upon the amount which may be confiscated, but only three of these provisions are of such a nature as to prevent oppression of members by unscrupulous officers of associations.

Associations are expected to lend their funds under one of the regular building and loan plans, but in practically all of the states they may lend excess funds on straight mortgages if they so desire; and a considerable number of the states specifically provide that loans may be made to other building and loan associations, a provision which is evidently intended to recognize the inherent desirability of the state-wide clearinghouse system. Only four states prohibit lending upon straight mortgages.

The matter of expense is not yet adequately treated in the statutes. Only sixteen states limit the expenses to earnings,a rather remarkable situation when one considers that a busi-

Notes for Table XXV (E) (p. 394):

1 California. Appointed by directors.

2 California. Must be bonded by any class approved by Commissioner.

3 Connecticut. Not required, but usually given.

- Connecticut. Another officer.

- Connecticut. New associations limited to serial plan.

- Iowa. Yes: for domestic associations State Auditor, and for domestic locals Clerk of District Court.

7 Iowa. Domestic associations, State Auditor; domestic locals, Clerk of District Court.

${ }^{8}$ Kansas. State department may require fidelity bond.

- Massachusetts. With Commissioner.

10 Minnesota. Inactive cfficers.

11 Missouri. Yes (except president and vice-president).

12 Missouri. With Commissioner, or depository designated by him.

13 New York. Officers of the association.

14 Ohio. As to amount only.

15 Ohio. Officers of the company.

16 Oklahoma. Officer in election.

17 Pennsylvania. Other officers.

18 West Virginia. Fidelity bonds are required by action of the State Bank Commissioner.

10 Bonds required by Georgia Securities Commission.

${ }^{20} \mathrm{New}$ Mexico. Bonds required of treasurer. 
Statutory Pp visions, January 1, 1925, Covering Building and Loan Associations in the United States

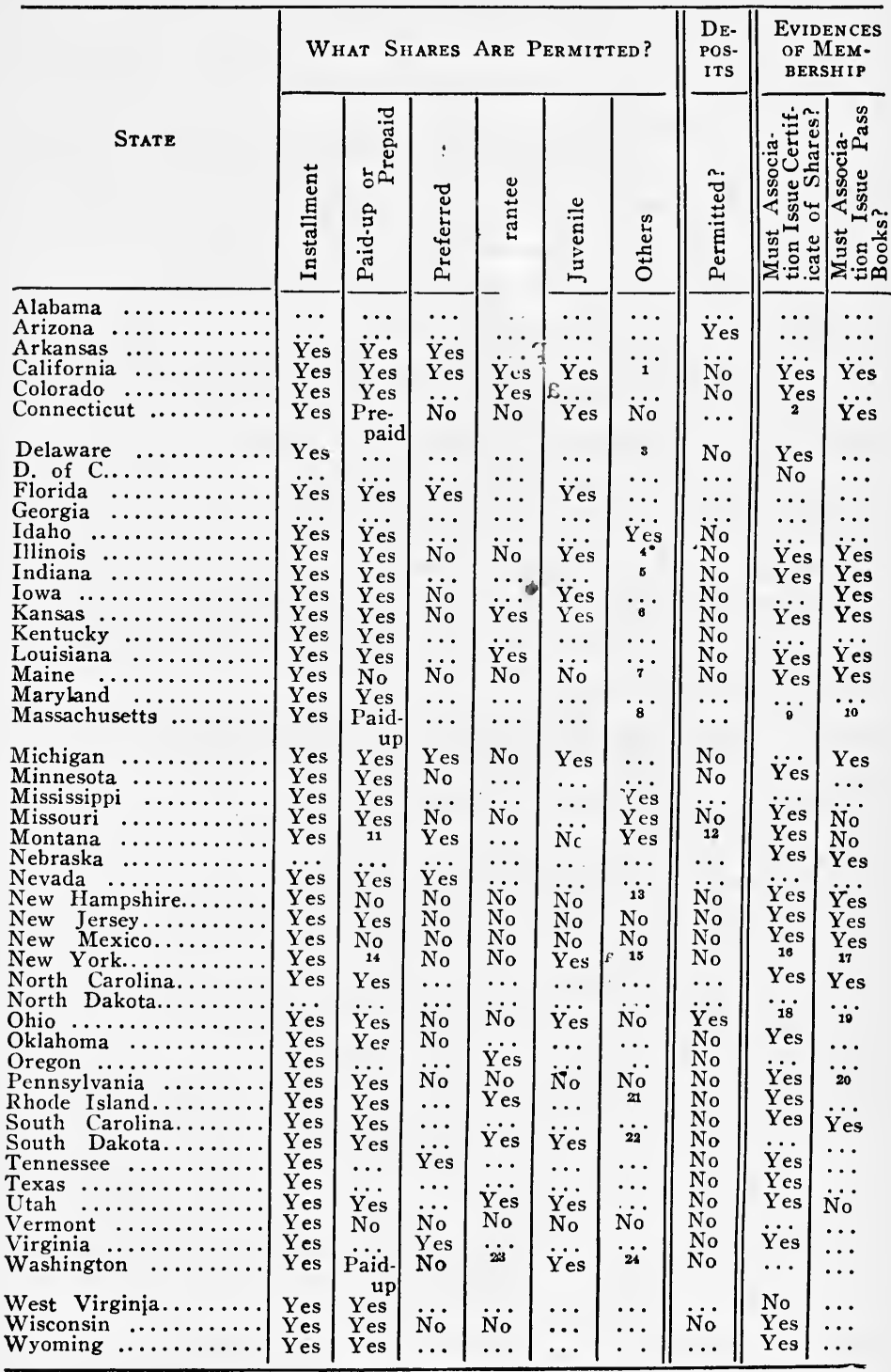


ness is always expected to pay its own way if it be allowed to survive. In all other states it would be possible to charge some portion (at least) of the expenses against dues, unless by-law provision or the arbitrary ruling of the state supervising department definitely prohibits such action. Fortunately this is one of those cases where the business judgment of the directors has kept the work on an equitable basis in spite of loose laws. The number of associations which take advantage of this laxness is negligil Practically all expenses are paid from earnings, and mean wile the laws are being brought into conformity with current ractice.

Contingent reserve $\mathrm{h} s$ not yet been studied with sufficient care by the legislators. Twenty-two of the states require reserves for at least a part of their associations, but the amount required is often inadequate. An association with $\$ 1,000,000$ assets and an average of $\$ 50,000$ net earnings per year, would require twenty years to build up a five per cent contingent reserve if only five per cent of net earnings are deducted each year for that purpose (unless earnings on the fund are added to the principal). One per cent deductions would require a hundred years to build up a fund of a size sufficient to accom-

1 California. Investment certificates.

2 Connecticut. Yes: only in case of serial plan and full-paid shares.

3 Delaware. Matured.

4 Illinois. Matured, not ex'ceeding 20 per cent of assets.

-Indiana. By-laws govern' debentures.

- Kansas. Deposit shares and rural credit shares.

7 Maine. Matured.

8 Massachusetts. Matured.

- Massachusetts. For mitured and paid-up shares.

10 Massachusetts. For serial shares.

11 Montana. Fully paid.

12 Montana. By implication: yes.

13 New Hampshire. Matured not exceeding 20 per cent of assets.

14 New York. Yes: paid-up shares called "income shares."

18 New York. Savings. prepaid shares called "accumulative shares."

10 New York. Yes: on income or accumulative shares only.

May issue pass book or certificate.

$17 \mathrm{New}$ York. May issue pass book or certificate.

18 Ohio. Yes: upon certificates or upon "written subscriptions."

10 Ohio. Yes: on written subscriptions.

20 Pennsylvania. Pass-book or otherwise.

21 Rhode Island. Yes: with approval of Bank Commissioner.

22 South Dakota. Debenture and deposit.

23 Washington. Yes: for associations having such shares prior to this law. (Added

24 Washington. Savings. to law to enable one association from Portland, Oregon, to continue use of such shares.) 
TABLE XXV (G)

Statutory Provisions, January I, i925, Covering Building and Lonn Associations in the United States

\begin{tabular}{|c|c|c|c|c|c|c|c|c|c|c|}
\hline \multirow[b]{2}{*}{ State } & \multicolumn{3}{|c|}{$\begin{array}{c}\text { DUES RESTRIC- } \\
\text { TIONS }\end{array}$} & \multicolumn{7}{|c|}{ Membership Restrictions } \\
\hline & 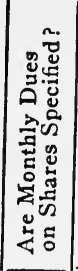 & 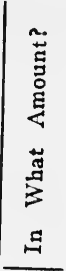 & 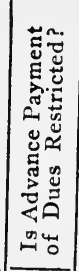 & 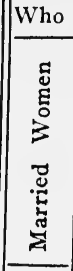 & 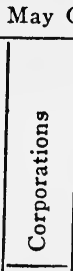 & 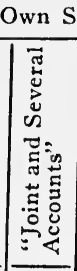 & 总 & 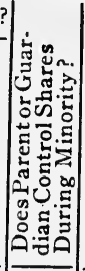 & 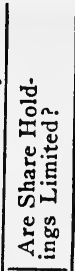 & 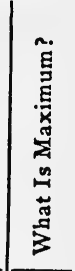 \\
\hline Alabama...$\ldots \ldots$ & $\overline{Y e s}$ & 1 & $\cdots$ & $\cdots$ & $\cdots$ & $\cdots$ & $\cdots$ & $\cdots$ & $\cdots$ & $\cdots$ \\
\hline Arizona...$\cdots \cdots$ & Ne & $\cdots$ & $\cdots$ & $\cdots$ & $\cdots$ & $\cdots$ & $\cdots$ & $\cdots$ & $\cdots$ & $\cdots$ \\
\hline$\underset{\text { California }}{\text { Arkansas }}$. & No & $\cdots$ & $\ddot{\mathrm{No}}$ & $\ddot{Y} \ddot{\text { es }}$ & $\ddot{\mathrm{Y}} \ddot{\mathrm{es}}$ & $\ddot{\mathrm{Yes}}$ & $\dddot{\text { Yes }}$ & $\ddot{\text { Yes }}$ & $\ddot{\mathrm{No}}$ & $\cdots$ \\
\hline Colorado ... & $\ddot{\mathrm{No}}$ & $\because$ & No & Yes & & Yes & Yes & Yes & No & $\cdots$ \\
\hline Connecticut $\ldots$. & Yes & $\$ I$ & No & $\ddot{\mathrm{Yes}}$ & $\begin{array}{l}\text { Yes } \\
\text { Yes }\end{array}$ & Yes & Yes & Yes & No & ... \\
\hline $\begin{array}{l}\text { Delaware } \cdots \cdots \cdots \\
\text { D. of C............ }\end{array}$ & $\begin{array}{l}\text { No } \\
\cdots\end{array}$ & $\cdots$ & $\begin{array}{l}\text { No } \\
\text { No }\end{array}$ & $\begin{array}{l}\text { Yes } \\
\text { Yes }\end{array}$ & $\begin{array}{l}\text { Yes } \\
\cdots\end{array}$ & $\cdots$ & $\begin{array}{l}\text { Yes } \\
\cdots\end{array}$ & $\begin{array}{l}\text { Yes } \\
\cdots\end{array}$ & $\begin{array}{l}\text { No } \\
\text { By. }\end{array}$ & $\cdots$ \\
\hline Florida $\quad \ldots \ldots \ldots$ & $\cdots$ & $\cdots$ & $\cdots$ & Yes & $\cdots$ & & Yes & No & $\begin{array}{l}\text { laws } \\
\text { No }\end{array}$ & $\cdots$ \\
\hline $\begin{array}{l}\text { Georgia } \ldots . . \\
\text { Idaho } \ldots . . .\end{array}$ & $\cdots$ & $\cdots$ & $\begin{array}{l}\cdots \\
\cdots\end{array}$ & $\ddot{\mathrm{Y} e s}$ & $\cdots$ & . & $\ddot{\mathrm{Y}} \ddot{\mathrm{es}}$ & $\ddot{\mathrm{No}}$ & No & $\cdots$ \\
\hline Illinois $\ldots \ldots \ldots \ldots$ & $\cdots$ & $\because$ & $\ddot{N o}$ & Yes & $\ddot{N o}$ & $\ddot{\mathrm{Y}} \mathrm{es}$ & Yes & No & No & $\ddot{\cdots}$ \\
\hline Indiana $\ldots \ldots \ldots$ & $\ddot{\mathrm{N}}$ & ${ }^{2}$ & & Yes & Yes & Yes & Yes & No & No & $\ldots$ \\
\hline $\begin{array}{l}\text { Iowa } \ldots \ldots \ldots \\
\text { Kansas } \ldots . . .\end{array}$ & $\begin{array}{l}\text { No } \\
\ldots\end{array}$ & $\cdots$ & $\begin{array}{l}\text { No } \\
\text { No }\end{array}$ & $\begin{array}{l}\text { Yes } \\
\text { Yes }\end{array}$ & Yes & $\begin{array}{l}\text { No } \\
\text { Yes }\end{array}$ & $\begin{array}{l}\text { Yes } \\
\text { Yes }\end{array}$ & $\begin{array}{l}\text { Yes } \\
\text { No }\end{array}$ & Yes & 8 \\
\hline Kentucky $\quad . . \ldots \ldots$ & $\cdots$ & $\cdots$ & $\cdots$ & $\cdots$ & $\cdots$ & $\cdots$ & Over & No & Yes & $\because$ \\
\hline Louisiana . & & : & & Yes & Yes & No & Yes & No & No & $\cdots$ \\
\hline $\begin{array}{l}\text { Maine } \\
\text { Maryland } \ldots \ldots \ldots\end{array}$ & $\begin{array}{l}\text { Yes } \\
\text { Yes }\end{array}$ & $\begin{array}{l}7 \\
8\end{array}$ & $\begin{array}{l}\text { No } \\
\ldots\end{array}$ & $\begin{array}{l}\text { Yes } \\
\ldots\end{array}$ & $\cdots$ & Yes & Yes & Yes & $\begin{array}{l}\text { No } \\
\text { By- }\end{array}$ & $\cdots$ \\
\hline usetts & Yes & & & Yes & Yes & Yer & $\begin{array}{ll}\cdots \\
Y_{e s}\end{array}$ & . & By- & $\cdots$ \\
\hline $\begin{array}{l}\text { Massachusetts ..... } \\
\text { Michigan ....... }\end{array}$ & $\begin{array}{l}\text { Yes } \\
\ldots\end{array}$ & $\begin{array}{l}\$ 1 \\
11\end{array}$ & No & Yes & $\begin{array}{l}\text { Yes } \\
\text { Yes }\end{array}$ & $\begin{array}{l}\text { Yes } \\
\text { Yes }\end{array}$ & $\begin{array}{l}\text { Yes } \\
\text { Yes }\end{array}$ & No & $\begin{array}{l}\text { Yes } \\
\text { No }\end{array}$ & 10 \\
\hline Minnesota .. & No & $\cdots$ & $\ddot{i} \cdot$ & Yes & Yes & Yes & Yes & No & No & $\cdots$ \\
\hline ssippi & No & $\because$ & $\begin{array}{l}\text { No } \\
\text { No }\end{array}$ & Yes & No & Yee & Yes & Yes & No & ... \\
\hline Montana $\ldots$ & $\begin{array}{l}\text { No } \\
\text { No }\end{array}$ & $\because$ & ... & $\begin{array}{l}y \text { es } \\
\cdots\end{array}$ & $\cdots$ & Yes & $\begin{array}{l}\text { Yes } \\
\text { Yes }\end{array}$ & $\begin{array}{l}\text { Yes } \\
\text { No }\end{array}$ & No & $\cdots$ \\
\hline aska ... & No & $\cdots$ & $\cdots$ & $\ddot{0}$ & $\cdots$ & $\ddot{\mathrm{Yes}}$ & Yes & 12 & Yes & $\ddot{13}$ \\
\hline ada $\ldots . .$. & No & $\because$ & ï. & Art. & Art. & Art. & Art. & Art. & Art. & $\cdots$ \\
\hline Hallpshir & Yes & \$I & No & & Yes & Yes & No & $\cdots$ & Yes & $\begin{array}{l}50 \\
\text { shrs. }\end{array}$ \\
\hline $\begin{array}{l}\text { New Jersey........ } \\
\text { New Mexico..... }\end{array}$ & & & No & Yes & Yes & Yes & Yes & Yes & No & $\cdots$ \\
\hline $\begin{array}{l}\text { New Mexico.. } \\
\text { New }\end{array}$ & Yes & $\$ 225$ & $\mathrm{Yes}_{14}$ & $\begin{array}{l}\text { Yes } \\
\text { Yes }\end{array}$ & $\begin{array}{l}\text { Yes } \\
\text { Yes }\end{array}$ & $\ddot{\mathrm{Y}} \ddot{\mathrm{es}}$ & $\underset{15}{Y \text { es }}$ & $\underset{10}{\mathrm{YeS}}$ & No & $\because$ \\
\hline North Carolina... & Yes & $\ddot{19}^{\circ}$ & No & Yes & $\cdots$ & ... & $\begin{array}{c}\text { Over } \\
12\end{array}$ & No & No & $\cdots$ \\
\hline 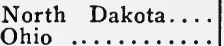 & $\cdots$ & & No & Yes & Yes & $\ddot{\mathrm{Y}} \mathrm{es}$ & Yes & No & No & ... \\
\hline Oklahoma $\ldots . .$. & No & $\cdots$ & No & Yes & $\cdots$ & $\cdots$ & Yes & Un:- & $\begin{array}{l}\text { No } \\
\text { No }\end{array}$ & $\cdots$ \\
\hline & & & & & & & & 14 & & \\
\hline $\begin{array}{l}\text { Oregon } \ldots . . . \\
\text { Pennsylvania }\end{array}$ & $\cdots$ & $\dddot{18}^{\circ}$ & No & Yes & Yes & $\because$ & No & $\cdots$ & No & $\cdots$ \\
\hline de Island..... & $\ddot{\mathrm{N}} \ddot{\mathrm{o}}$ & $\ldots$ & No & $\begin{array}{l}\text { Yes } \\
\text { Yes }\end{array}$ & $\begin{array}{l}\text { Yes } \\
\text { Yes }\end{array}$ & & & $\cdots$ & No & $\cdots$ \\
\hline South Carolina... & No & $\ldots$ & $\ddot{\mathrm{No}}$ & Yes & Yes & Yes & Yes & $\cdots$ & No & \\
\hline & No & $\cdots$ & $\cdots$ & .. & & Yes & Yes & $\cdots$ & No & ... \\
\hline $\begin{array}{l}\text { ennessee } \\
\text { Cexas . . }\end{array}$ & No & $\because 0$ & $\ddot{20} \cdot$ & & Yes & $\cdots$ & $\cdots$ & $\cdots$ & $\ddot{\mathrm{N}}$ & $\cdots$ \\
\hline Itab & & & ... & Yes & $\ddot{\mathrm{Y} e s}$ & No & Yes & $2 i$ & No & $\cdots$ \\
\hline ont & Yes & $\$ I$ & $\cdots$ & es & $\cdots$ & $\cdots$ & Yes & Yes & Yes & $40^{\circ}$ \\
\hline Virginia $\ldots$ & $\cdots$ & ... & No & Yes & Yes & & Yes & Yes & No & $\cdots$ \\
\hline $\begin{array}{l}\text { Washington } \\
\text { West Virginia..... }\end{array}$ & Yes & $\dddot{22}$ & $\ddot{\text { No }}$ & & $\cdots$ & Yes & Yes & No & $\begin{array}{l}\text { No } \\
\text { No }\end{array}$ & $\cdots$ \\
\hline$n \sin .$. & $\cdots$ & 23 & $\begin{array}{l}\text { Yes: } \\
\text { I year }\end{array}$ & Yes & No & Yes & $\ddot{\mathrm{Y}} \ddot{\mathrm{es}}$ & $\begin{array}{l}\text { Un- } \\
\text { der }\end{array}$ & Yes & $\ddot{i i}$ \\
\hline Wyoming & $\ldots$ & $\ldots$ & $\ldots$ & Yes & Yes & Yes & Yes & $\ldots{ }^{14}$ & No & ... \\
\hline
\end{tabular}


plish its intended purpose, if earnings were no greater than this average.

One of the least satisfactory provisions of the present laws is the matter of interest rate, particularly the premium. In some way the legislators have acquired the notion that premium is something different from interest, and in more than half the states the usury law does not apply to the premiums charged by associations. In many of these states the statute requires that interest be no greater than the legal rate. Since interest and premium are merely two forms of the same thing, no limit upon the interest rate will have any effect upon the total charge when the premium is not considered usurious.

The limitation on borrowing from another association or from banks is usually placed at about 20 to 25 per cent of

Notes for Table XXV (G) (p. 398):

1 Alabama. $\$$ I per $\$ 50$ share.

2 Indiana. Limited to 50 cents per week per $\$$ roo.

Iowa. $\$ 10,000$ of stock at par, unless association has assets in excess of $\$ 1,000,000$, when limit becomes one per cent.

- Kansas. Other building and loan associations only, not to exceed 5 per cent of their assets.

${ }^{B}$ Kentucky. Authorized capital $\$ 100,000$ or less. .2 $1 / 2$ per cent of number of shares Authorized capital $\$ 100,000-\$ 500,000 . .2$ per cent of number of shares Authorized capital $\$ 500,000-\$ 1,000,000 . \mathrm{I}^{1 / 2} \mathrm{per}$ cent of number of shares Authorized capital over $\$ 1,000,000 . .$. . I per cent of number of shares

- Louisiana. Twenty-five cents to two dollars and fifty cents.

7 Maine. \$I per month on \$200.

8 Maryland. \$1 per week.

- Massachusetts. At discretion of the board.

10 Massachusetts. 40 unmatured shares, or Io matured shares and

11 Michigan. Not to exceed $\$ 2$.

1o paid-up shares. This practically means $\$ 8,000$.

12 Nebraska. Yes, if under 14.

13 Nebraska. \$5,ooo of investment stock, but loan stock may be carried to limit of loans permitted according to assets of the association.

One borrower limited:

If assets $\$ 200,000-\$ 500,000 \ldots \ldots \ldots \ldots \$ 10,000$

If assets $\$ 500,000-\$ 1,000,000 \ldots \ldots \ldots \ldots$. 15,000

If assets over $\$ 1,000,000 \ldots \ldots \ldots \ldots \ldots, 25,000$

14 New York. Yes: to one year. Interest allowed not exceeding six per cent.

15 New York. Yes: any class.

10 New York. Yes, except juvenile savings shares.

17 North Carolina. Twenty-five cents per week.

\$1 per month.

${ }^{18}$ Pennsylvania. Maximum $\$ 2$.

10 Texas. Maximum $\$ 2$.

20 Texas. "Advance payment certificate," if by-laws provide.

${ }^{21}$ Utah. If parent contributes funds for minor, parent can control shares. If funds belong to the minor, parent cannot control same.

22 West Virginia. Maximum periodical payment $\$ 2$ per share.

23 Wisconsin. Maximum $\$ 2$.

24 Wisconsin. Installment stock $\$ 10,000$.

Paid-up stock.... \$10,000.

(Except to cover loan in excess of $\$ 10,000$.)

${ }^{26} \mathrm{New}$ Mexico. Monthly dues on shares may not exceed $\$ 2$ per share. 
Statutory Provisions, January i, 1925, Covering Building and Loan Associations in the United States

\begin{tabular}{|c|c|c|c|c|c|c|c|c|}
\hline \multirow{3}{*}{ State } & \multicolumn{2}{|c|}{$\begin{array}{l}\text { MEMBERSHIP } \\
\text { OR WITH- } \\
\text { DRAWAL FEES }\end{array}$} & \multicolumn{3}{|c|}{ Fines } & \multicolumn{3}{|c|}{ WITHDRAWALS } \\
\hline & \multirow{2}{*}{ 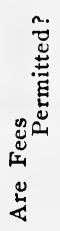 } & \multirow[b]{2}{*}{ 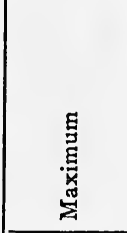 } & \multicolumn{2}{|c|}{$\begin{array}{l}\text { Are Fines } \\
\text { Permitted } \\
\text { on: }\end{array}$} & \multirow{2}{*}{ 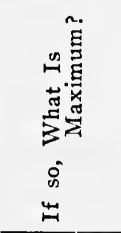 } & \multirow{2}{*}{ 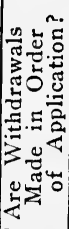 } & \multicolumn{2}{|c|}{$\begin{array}{l}\text { Percentage Used } \\
\text { Without Action } \\
\text { of Directors }\end{array}$} \\
\hline & & & 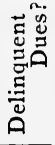 & 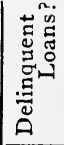 & & & 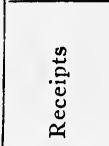 & 点 \\
\hline Alabama .......... & $\cdots$ & $\cdots$ & Yes & Yes & $2 \%$ permo. & $\cdots$ & & $\cdots$ \\
\hline Arizona $\ldots \ldots \ldots$ & $\ldots$ & $\ldots$ & $\cdots$ & $\cdots$ & & & & \\
\hline Arkansas $\ldots \ldots \ldots$ & 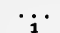 & 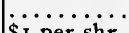 & $\cdots$ & $\cdots$ & & $\ddot{2}$ & $\cdots \cdots$ & $\ldots$ \\
\hline $\begin{array}{l}\text { California } \ldots \ldots \ldots \\
\text { Colorado } \ldots \ldots \ldots \ldots\end{array}$ & $\mathrm{Y}^{1}$ & \$I per & $\ddot{\mathrm{Yes}}$ & $\ddot{\mathrm{Yes}}$ & $\because$ & & One-half & $\ldots \cdots \cdots$ \\
\hline Connecticut ..... & Yes & & Yes & Yes & 6 & Y es & $\ldots \ldots$ & One-half \\
\hline Delaware... & Yes & & Yes & Yes & & & & \\
\hline D. of C........ & Yes & & Yes & Yes & & & & One-half \\
\hline Florida $\ldots \ldots \ldots \ldots$ & Yes & $25 \phi$ per shr. & Yes & Yes & & Yes & One-half & $\ldots \ldots$ \\
\hline $\begin{array}{l}\text { Georgia } \ldots \ldots \ldots \ldots \\
\text { Idaho } \ldots \ldots \ldots \ldots \ldots\end{array}$ & $\cdots$ & $\cdots$ & Yes & $\ddot{\mathrm{Y}} \ddot{\mathrm{es}}$ & $\because$ & $\cdots$ & $\ldots \ldots \ldots$ & $\cdots \cdots \cdots$ \\
\hline Illinois.... . & $\ddot{\mathrm{Yes}}$ & $25 \&$ per shr. & Yes & Yes & 10 & & & One-haiff \\
\hline Indiana $\ldots \ldots \ldots$ & Yes & $50 \%$ per shr. & Yes & Yes & 11 & Yes & One-half & $\ldots \ldots \ldots$ \\
\hline ............. & Yes & $\cdots_{\text {is }}$ & Yes & Yes & 12 & & if & $\ldots \ldots \ldots$ \\
\hline$\underset{\text { Kentucky }}{\text { Kansas }} \ldots \ldots \ldots \ldots$ & Yes & & $\begin{array}{l}\text { Yes } \\
\text { Yes }\end{array}$ & $\begin{array}{l}\text { Yes } \\
\text { Yes }\end{array}$ & $\begin{array}{l}14 \\
15\end{array}$ & $\begin{array}{l}\text { Yes } \\
\text { Yes }\end{array}$ & One-half & One-half \\
\hline Louisiana: & Yes & & Yes & Yes & & Yes & One-haif & \\
\hline Maine $\ldots$ & & & Yes & Yes & & & & One-half \\
\hline Maryland ... & Yes & $\cdots$ & Yes & Yes & & Yes & & \\
\hline Massachusetts & Yes & & Yes & Yes & ${ }_{1} \%$ per mo. $^{17}$ & $\begin{array}{l}\text { Yes } \\
\text { Ye; }\end{array}$ & $\cdots{ }_{18} \cdots$ & One-half \\
\hline Michigan $\ldots \ldots \ldots$ & Yes & & $\begin{array}{l}\text { Yes } \\
\text { Yes }\end{array}$ & $\begin{array}{l}\text { Yes } \\
\text { Yes }\end{array}$ & & $\begin{array}{l}103 \\
\ldots .\end{array}$ & One-half & $\begin{array}{l}\cdots \cdots \\
\cdots \ldots \ldots\end{array}$ \\
\hline $\begin{array}{l}\text { Minnesota ... } \\
\text { Mississippi } . .\end{array}$ & $\ddot{\text { Noo }}$ & & & & & $\cdots$ & $\ldots \ldots$ & $\ldots \ldots \ldots$ \\
\hline Missouri .. & Yes & 18 & Yes & Yes & & Yes & 20 & $\ldots \ldots$ \\
\hline Montana...... & Yes & 21 & Yes & Yes & $\cdots$ & Yes & All & $\cdots \cdots_{22} \cdots$ \\
\hline $\begin{array}{l}\text { Nebraska } \ldots . \\
\text { Nevada .... }\end{array}$ & $\begin{array}{l}\text { Yes } \\
\text { Yes }\end{array}$ & $\cdots$ & $\begin{array}{l}\text { Yes } \\
\text { Yes }\end{array}$ & $\begin{array}{l}\text { Yes } \\
\text { Yes }\end{array}$ & . & & ... & One-half \\
\hline $\begin{array}{l}\text { Nevada } \ldots . . . . . . \\
\text { New Hampshire... }\end{array}$ & Yes & & Yes & Yes & $\ddot{23}$ & Yes & & One-half \\
\hline New Jersey...... & Yes & $25 \phi$ per shr. & Yes & Yes & 24 & Yes & One-half & \\
\hline New Mexico. & No & $\ldots \ldots \ldots$ & & Yes & 41 & Yes &.. & One-half \\
\hline New York.: & Yes & & Yes & Yes & 26 & Yes & $2 / 3$ & $\cdots \ldots \ldots$ \\
\hline North Carolina & Yes & $\ldots$. & Yes & $\begin{array}{l}\text { Yes } \\
\text { Yes }\end{array}$ & .. & $\cdots$ & $\cdots$ & One-half \\
\hline $\begin{array}{l}\text { North Dakota. } \\
\text { Ohio .......... }\end{array}$ & $\begin{array}{l}\text { Yes } \\
\text { No }\end{array}$ & & $\begin{array}{l}\text { Yes } \\
\text { Yes }\end{array}$ & $\begin{array}{l}\text { Yes } \\
\text { Yes }\end{array}$ & & Yes & & Une-inalt \\
\hline Oklahoma $\ldots \ldots \ldots$ & $\begin{array}{l}\text { No } \\
\text { Yes }\end{array}$ & $\$ 2$ per $\$ 100$ & Yes & Yes & & Yes & & One-half \\
\hline gon. & Yes & $\ldots \ldots$ & Yes & & & Yes & One-half & \\
\hline Pennsylvania. & Yes & $\ldots \ldots$ & Yes & Yes & $2 \%$ permo. & Yes & One-half & One-half \\
\hline $\begin{array}{l}\text { Rhode Island. } \\
\text { South Carolina }\end{array}$ & $\begin{array}{l}\text { Yes } \\
\text { Yes }\end{array}$ & & Yes & $\ddot{\text { Yes }}$ & 30 & $\ddot{\mathrm{Y}} \mathrm{es}$ & One-halt & $\cdots \cdots \cdots$ \\
\hline $\begin{array}{l}\text { uth Carolina } \\
\text { uth Dakota. }\end{array}$ & ${ }_{81}^{Y e s}$ & $\ddot{32}$ & $\begin{array}{l}\text { Yes } \\
\text { Yes }\end{array}$ & \begin{tabular}{|l} 
Yes \\
Yes
\end{tabular} & 33 & Yes & $\ddot{m}$ & $\cdots_{8 i} \cdots$ \\
\hline Tennessee .... & & & & & & $\cdots$ & $\cdot \cdot$ & . \\
\hline Texas .. & Yes & & Yes & Yes & r \% permo. & & & \\
\hline$U_{t}$ & Yes & & Yes & Yes & & & $\underset{35}{\text { One-half }}$ & $\ldots \ldots \ldots$ \\
\hline mont .. & Yes & $25 \phi$ per shr. & Yes & Yes & $2 \%$ permo. & Yes & & \\
\hline ginia & $\begin{array}{l}\text { Yes } \\
\text { Yes }\end{array}$ & ........... & Yes & $\mathrm{Yes}_{3 \mathrm{~A}}$ & $\ddot{3}^{\prime} \cdots$ & es & $\cdots \cdots_{38} \cdots$ & $\cdots \cdots$ \\
\hline $\begin{array}{l}\text { Iington } \\
\text { Virgi }\end{array}$ & Yes & $\$ 2$ per & Yes & Yes & 89 & & & \\
\hline Wisconsin & Yes & & Yes & Yes & & $\ldots$ & & One-half \\
\hline Wyoming ... & Yes & -1 & Yes & Yes & & & One-half & $\ldots \ldots$ \\
\hline
\end{tabular}

Notes on p. 40 I. 
the assets. Nine states use this limit; two allow 30 per cent borrowing; two 50; and only one allows up to 80 per cent of the assets; while 2 limit the amount to 5 per cent, and

1 California. Yes: except on pass-book or juvenile shares.

2 California. Yes, but this does not apply if applications on file are more than a year old.

California. One-half. If applications are a year old, all of the receipts may be used.

- Colorado. \$2 per share. \$10 maximum in any one transaction.

Colorado. Five per cent per month first 60 days.

Two per cent per month thereafter.

- Connecticut. Two cents per month on each dollar in arrears, for 6 months.

7 Delaware. Five per cent per month of amount past due for first six months. Thereafter, 6 per cent per year.

8 Florida. Five cents per share for each weekly delinquency.

- Idaho. Cannot be usurious.

10 Illinois. Ten cents per share per month.

1 Indiana. Ten per cent of delinquent payments, or such further sum as shall not exceed five cents per share, and shall be charged only once.

12 Iowa. Three cents per share of $\$$ ioo first month.

Five cents per share of $\$$ roo each month thereafter.

Shall not exceed profits belonging to delinquent.

18 Kansas. Fifty cents per share, or membership fee of $\$ 1$.

14 Kansas. Not to exceed dividends.

15 Kentucky. Ten cents per share per month on dues.

Ten cents per \$10o loan per month on interest.

For period of 6 months.

10 Maine. Two per cent per month for six months.

17 Massachusetts. Not exceeding 2 per cent per month for 6 months, or amount of profits distributed to shares.

18 Michigan. One-half, and for retirement of matured shares, two-thirds.

10 Missouri. Rules of Department fix one.

${ }^{20}$ Missouri. One-half. If unpaid matured shares are outstanding, reduced to one-third.

21 Montana. Withdrawal fee $\$ 2$ per share.

22 Nebraska. One-half, and for matured shares, two-thirds.

23 New Hampshire. Two per cent per month for 6 months.

24 New Jersey. After 3 months' default, 2 per cent per month for a period of 6 months in any one year.

${ }^{25}$ New York. Twenty-five cents per share or \$I per member.

${ }^{20}$ New York. Two per cent per month on monthly payments or one cent per share per week on weekly payments. Not to exceed earnings.

27 Oregon. Ten cents per share for first month.

Fifteen cents per share per month thereafter.

28 Rhode Island. Withdrawal fee of one per cent.

${ }_{20}$ Rhode Island. Five cents per share for 6 months.

30 South Carolina. Ten per cent of amount due.

81 South Dakota. Yes, except on juvenile shares.

32 South Dakota. One and one-half per cent of par value.

sa South Dakota. By-laws govern, but after 3 months' default, cumulative fines shall not be charged in excess of 2 per cent per month on amount in arrears.

8* South Dakota. One-half. Also one-half for matured shares.

85 Vermont One-half; if matured shares await withdrawal, one-third.

One-third on matured shares.

so Washington. Certain serial associations only.

87 Washington. Earnings on delinquent installments.

88 Washington. Two-thirds, except if application for withdrawal and matured shares have been on file for 6 months and unpaid, all receipts may be so used.

so West Virginia. All fines must be uniform. No member may be fined more than once for same default.

$\omega$ Wyoming. Ten per cent of delinquency.

1 New Mexico. Fines on delinquent loans limited to one month's interest and any expense incurred. 
TABLE XXV (I)

Statutory Provisions, January i, 1925, Covering Building and Loan AssoCiations in the United States

\begin{tabular}{|c|c|c|c|c|c|c|c|c|c|}
\hline \multirow{4}{*}{ State } & \multicolumn{4}{|c|}{ Forfeiture } & \multicolumn{5}{|c|}{ LOANS } \\
\hline & \multicolumn{2}{|c|}{ Dues } & \multicolumn{2}{|c|}{ Earnings } & \multirow{3}{*}{ 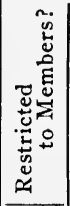 } & \multirow{2}{*}{\multicolumn{2}{|c|}{$\begin{array}{c}\text { Priority } \\
\text { Estab- } \\
\text { lished by: }\end{array}$}} & \multirow{3}{*}{ 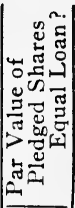 } & \multirow{3}{*}{ 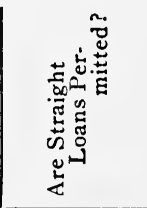 } \\
\hline & \multirow{2}{*}{ 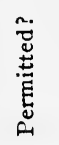 } & \multirow{2}{*}{ 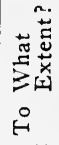 } & \multirow[b]{2}{*}{ 苞 } & \multirow{2}{*}{ 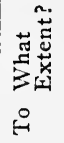 } & & & & & \\
\hline & & & & & & $\stackrel{\infty}{\Xi}$ & 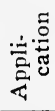 & & \\
\hline labama & 1 & - & & $\cdots$ & Yes & $\cdots$ & $\cdots$ & $\cdots$ & \\
\hline 然 & $\ldots$ & . & .. & $\cdots$ & No & $\ldots$ & $\cdots$ & $\cdots$ & \\
\hline is & $\ddot{2}$ & $\cdots$ & $\ddot{\mathrm{Yes}}$ & $\ddot{3}$ & $\mathrm{No}_{4}$ & $\ddot{N o}$ & $\ddot{N o}$ & $\ddot{B}$ & \\
\hline & a & $\because$ & Yes & & & 0 & Yes & Yes & Excess $f$ \\
\hline cut & $\ldots$ & $\ldots$ & & & 8 & & $\ldots$ & Yes & No \\
\hline & & & & & No & No & $\cdots$ & No & Yes \\
\hline C.. & No & 30 & Yes & & Yes & Yes & $\ldots$ & Yes & \\
\hline Florida ... & $\ldots$ & $\ldots$ & $\cdots$ & $\cdots$ & Yes & $\ldots$ & $\ldots$ & $\cdots$ & \\
\hline gia & $\cdots$ & $\ldots$ & $\cdots$ & $\cdots$ & Yes & $\ldots$ & $\cdots$ & $\cdots$ & $\cdots$ \\
\hline 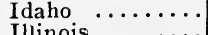 & $\dddot{i}$ & $\cdots$ & $\cdots$ & $\cdots$ & Yes & $\cdots$ & $\cdots$ & Yes & $\cdots \cdots_{10} \cdot$ \\
\hline$\cdots$ & $\begin{array}{l}\text { No } \\
\text { No }\end{array}$ & $\cdots$ & Yes & ... & $\begin{array}{l}\text { Yes } \\
\text { No }\end{array}$ & $\ldots$ & $\cdots$ & $\begin{array}{l}\text { Yes } \\
\text { Yes }\end{array}$ & ${ }^{10}$ Excess fun \\
\hline$\ldots$ & No & $\cdots$ & Yes & $\cdots$ & Yes & $\ddot{N o}$ & $\cdots$ & Yes & xcess \\
\hline $\mathrm{K}$ & No & .. & $\ldots$ & & 11 & $\ldots$ & $\ldots$ & Yes & Excess \\
\hline cky & No & $\cdots$ & $\cdots$ & $\cdots$ & Yes & $\cdots$ & $\cdots$ & Yes & Excess funds \\
\hline ana. & No & $\cdot$ & $\cdots$ & $\because$ & $\begin{array}{l}\text { Yes } \\
\text { Yes }\end{array}$ & $\cdots$ & $\because$ & Yes & $\cdots_{\text {id }} \cdots$ \\
\hline$\therefore \cdots$ & No & .. & $\dot{.}$ & - & & $\ldots$ & $\ldots$ & Yes & \\
\hline isetts & $\ddot{N o}$ & & : & $\cdots$ & Yes & $\cdots$ & $\ldots$ & Yes & \\
\hline & 13 & . & & . & Yes & $\cdots$ & $\cdots$ & Yes & No \\
\hline $\mathrm{M}$ & Yes & . & Yes & & Yes & $\cdots$ & $\cdots$ & Yes & \\
\hline & $\mathrm{V}_{0}$ & $\cdots$ & & . & No & $\cdots$ & $\cdots$ & $\mathrm{Y}$ & \\
\hline$\cdots$ & $\begin{array}{l}\text { Yes } \\
\text { Yes }\end{array}$ & $\because{ }_{14}$ & Yes & $\cdots$ & $\cdots$ & $\cdots$ & $\cdots$ & Yes & ess \\
\hline $\begin{array}{ll}n \operatorname{tana} & \ldots \\
\text { oraska } & .\end{array}$ & $\begin{array}{l}\text { Yes } \\
\ldots\end{array}$ & $\ldots$ & $\cdot$ & $\cdot$ & Yes & $\cdots$ & $\cdots$ & $\cdots$ & \\
\hline $\begin{array}{l}\text { Nebraska } \\
\text { Nevada }\end{array}$ & $\cdots$ & $\cdots$ & - & . & 15 & $\cdots$ & $\cdots$ & $\cdots$ & \\
\hline New Hampshire. & No & .. & Yes & 16 & & Yes & $\ldots$ & Yes & Excess funds \\
\hline New Jers & No & $\ldots$ & Yes & 17 & No & $\ldots$ & $\cdots$ & Yes & Yes \\
\hline $\mathrm{Me}$ & No & . & No & 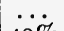 & Yes $^{29}$ & $\cdots$ & $\cdots$ & & 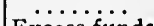 \\
\hline New York. & No & $\cdots$ & Yes & $40 \%$ & & $\cdots$ & $\cdots$ & Yes & Excess $f$ \\
\hline North Caroli & & . & $\cdots$ & $\cdots$ & Yes & $\cdots$ & & Yes & \\
\hline th Dakota & No & . & & . & Yes & 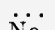 & No & $\dddot{\mathrm{q}}$ & \\
\hline ahoma... & $\begin{array}{l}\text { No } \\
\text { Yes }\end{array}$ & $\ddot{10}$ & & $\because \theta^{\circ}$ & No & No & No & No & $\begin{array}{l}\text { Yes } \\
\text { Excess funds }\end{array}$ \\
\hline & $\hat{\mathrm{Y}} \mathrm{es}$ & 20 & Yes & 21 & Yes & $\ldots$ & $\ldots$ & Yes & \\
\hline$\pi$ & No & & $\mathrm{Y}$ & 22 & & & & Yes & Excess fund \\
\hline de Island. . & Yes & 23 & $\mathrm{Ye}$ & & & & & Yes & \\
\hline $\mathrm{Ca}$ & & & & & No & No & Yes & Yes & \\
\hline South Dakota & Yes & 25 & Yes & 25 & ... & No & Yes & 28 & Excess funds \\
\hline essee $\ldots$ & $\cdots$ & $\cdots$ & & & $\cdots$ & $\cdots$ & $\cdots$ & Y & \\
\hline$\ldots \ldots$ & $\ddot{\text { Yes }}$ & $\because 28$ & $\begin{array}{l}\text { Yes } \\
\text { Yes }\end{array}$ & $\begin{array}{l}27 \\
28\end{array}$ & $\ddot{\text { Yes }}$ & $\ddot{\mathrm{No}}$ & $\ddot{\mathrm{Yes}}$ & es & $\begin{array}{c}\text { Excess fund } \\
\text { Yes }\end{array}$ \\
\hline ont & $\ldots$ & $\ldots$ & Yes & $\ldots$ & Yes & Yes & $\ldots$ & $\ddot{\mathrm{Y}} \mathrm{es}$ & \\
\hline & 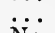 & $\ldots$ & & $\therefore$ & No & $\ldots$ & $\ldots$ & Yes & Excess funds \\
\hline ington & No & . & No & $\cdots$ & & $\cdots$ & $\cdots$ & $\cdots$ & … \\
\hline West Virgini & & . & & & Yes & & & & \\
\hline Wisconsin & No & . & Yes & - & Yes & & $\cdots$ & Yes & No \\
\hline Wyoming .. & Yes & & Yes & & No & Yes & & & \\
\hline
\end{tabular}

Notes on p. 403 . 
one to ro per cent of the assets. All such borrowings are supposed to be for short periods, and the law frequently states that the time limit for notes issued under such conditions shall not be greater than one year. A summary of the provisions relating to borrowing follows:

\section{Borrowing BY Association}

California ...... Permitted.

Colorado ...... Limit-25 per cent of its assets.

Connecticut .... Limit-25 per cent of its assets. (Amounts over ro per cent subject to approval of Bank Commissioner.)

Florida ........ Limit-25 per cent of gross assets.

(Borrowing provisions continued on p. 408.)

1 Alabama. As provided in by-laws.

2 California. No: cxcept entrance or withdrawal fees.

3 California. As provided by directors or by-laws.

- California. No (officers and directors may not borrow).

- California. Yes: in the mutual plan.

- Colorado. Membership or withdrawal fees only.

7 Colorado. \$2 per share. Maximum of $\$ 10$ in any one transaction.

8 Connecticut. No (other building and loan associations).

- Florida. Excess funds over $\$ 5,000$.

10 Illinois. Not to exceed 20 per cent of assets (temporary).

11 Kansas. Yes, unless there is an excess of funds.

12 Maine. Loan to other building and loan associations.

13 Michigan. No. If shares are less than one year old, expense in writing such shares is not to exceed 25 cents per share and may be deducted.

14 Montana. \$2 per share.

18 Nevada. Yes: by implication.

16 New Hampshire. First year, all.

Thereafter, by-laws.

17 New Jersey. During first year no earnings need be paid on withdrawal.

After first year "reasonable share of profits" must be included.

18 North Dakota. Funds idle 30 days loaned as provided in by-laws.

10 Oklahoma. Fines and charges.

20 Oregon. Fees, fines, and expense deduction.

21 Oregon. During first two years, all.

Thereafter, one-fourth of profits.

22. Pennsylvania. On voluntary withdrawals, by-laws decide what proportion of profits and rate of interest is paid.

On involuntary withdrawals, not less than legal interest must be paid.

23 Rhode Island. Losses. Withdrawal fee not exceeding one per cent of par value and (deductions for expense), one-tenth of one per cent per month on par value during first three years.

* Rhode Island. First three years: all earnings may be forfeited.

Fourth year: five per cent interest may be allowed, if earned.

48 th to rooth month: six per cent interest may be allowed, if earned.

After I ooth month: seventy-five per cent of earnings shall be allowed.

28 South Dakota. Fines and charges.

26 South Dakota. Yes: if "mutual" loan.

27 Texas. Lawful charges.

No: if "definite contract" loan.

28 Utah. Fines and charges.

${ }^{29} \mathrm{New}$ Mexico. Loans restricted to shareholders except when there is no demand for funds by shareholders.

so District of Columbia. Failure to pay installments and fines, forfeits stock, but may be returned less fines. 
Statutory Provisions, January 1 , i925, Covering Building and loan Associations in the United States

\begin{tabular}{|c|c|c|c|c|c|c|c|c|}
\hline \multirow[b]{2}{*}{ State } & \multicolumn{3}{|c|}{ ForecLosure } & \multicolumn{2}{|c|}{ ExpENSES } & \multicolumn{2}{|c|}{ Contingent } & Reserve \\
\hline & 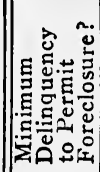 & 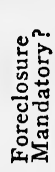 & 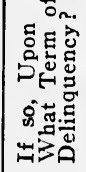 & 苛 & 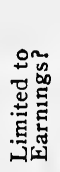 & 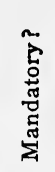 & 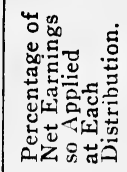 & 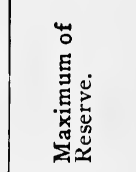 \\
\hline Llabama & & $\ldots$ & $\cdots$ & & $\cdots$ & & & $\cdots$ \\
\hline Arizona & 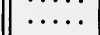 & $\because$ & $\ldots \ldots$ & & $\ldots$ & 1 & $5 \%$ & ...... \\
\hline $\begin{array}{l}\text { Arkansas } \\
\text { California }\end{array}$ & & No & $\cdots \cdots$ & $\begin{array}{l}\text { No } \\
\text { No }\end{array}$ & $\ddot{\text { No }}$ & $\underset{2}{\mathrm{No}}$ & $\cdots \%$ & $\cdots_{8} \cdots$ \\
\hline Colorado & $\begin{array}{l}3 \mathrm{mos} \\
\ldots \ldots\end{array}$ & No & & No & & No & $\begin{array}{l}5 \% \\
\ldots \ldots\end{array}$ & r \\
\hline recticut & $\ldots \ldots$ & No & $\ldots \ldots$ & Yes & Yes & Yes & I \% & \\
\hline Nare.... & $\cdots \cdots$ & No & $\cdots \cdots$ & No & No & & $\cdots \cdots$ & $2 \%$ assets \\
\hline $\begin{array}{l}\text { D. of } C \ldots \ldots \ldots \\
\text { Florida } \ldots \ldots\end{array}$ & $\begin{array}{l}2 \text { mos. } \\
3 \text { mos. }\end{array}$ & $\begin{array}{l}\text { No } \\
\text { No }\end{array}$ & $\ldots \ldots$ & $\begin{array}{l}\text { No } \\
\text { Yes }\end{array}$ & $\begin{array}{l}\text { No } \\
\text { Yes }\end{array}$ & $\mathrm{No}_{\mathrm{O}}$ & $\cdots_{\theta} \cdots$ & 10\% assets \\
\hline Georgia .... & & & . & & $\cdots$ & & $\ldots \ldots$ & $\ldots \ldots$ \\
\hline Idaho $\ldots$ & & No & & No & & $\begin{array}{l}\text { No } \\
\text { Yes }\end{array}$ & $\cdots_{7} \cdots$ & $\cdots_{8} \cdots$ \\
\hline $\begin{array}{l}\text { Illinois } \cdots \\
\text { Indiana }\end{array}$ & $\begin{array}{l}6 \text { mos. } \\
3 \text { mos. }\end{array}$ & $\begin{array}{l}\text { No } \\
\text { No }\end{array}$ & $\ldots$. & Yes & $\ddot{\text { Yes }}$ & Yes & ? & $10 \%$ \\
\hline Iowa. & & $\ldots$ & & 10 & ${ }^{11}$ & & 13 & \\
\hline $\begin{array}{l}\text { Kansas } \\
\text { Kentucky }\end{array}$ & 6 mos. & No & $\ldots$ & Yes & Yes & Yes & $\begin{array}{l}12 \\
14\end{array}$ & None \\
\hline $\begin{array}{l}\text { Kentucky } \\
\text { Louisiana }\end{array}$ & 13 & $\begin{array}{l}\text { No } \\
\text { No }\end{array}$ & & $\ddot{\mathrm{Y}} \mathrm{es}$ & Yes & $\begin{array}{l}\text { Yes } \\
\text { Yes }\end{array}$ & $\begin{array}{l}14 \\
15\end{array}$ & $\begin{array}{c}10 \% \\
10\end{array}$ \\
\hline & 17 & Yes & $12 \mathrm{mos}$. & No & No & Yes & $3.10 \%$ & 18 \\
\hline Maryland .... & $\cdots \cdots$ & & $\cdots \cdots$ & .. & . & No & $\cdots \cdots$ & $\ldots \cdots$ \\
\hline $\begin{array}{l}\text { Massachusetts } \\
\text { Michigan ... }\end{array}$ & 18 & Yes & 20 & $\mathrm{~T}$ & $\because \cdots$ & Yes & I-5\% & ${ }^{21}$ \\
\hline $\begin{array}{l}\text { Michigan } \\
\text { Minnesota }\end{array}$ & $4 \mathrm{mos}$ & No & $\cdots \cdots$ & Yes & $\underset{23}{\mathrm{Yes}}$ & Yes & I \% up & 22 \\
\hline ssippi $\cdots$ & $\cdots \cdots$ & $\ddot{\mathrm{N}}$ & $\ldots \cdots$ & No & & No & -.. & $\cdots \cdots$ \\
\hline souri $\ldots .$. & $6 \mathrm{mos}$ & No & $\ldots \ldots$ & No & & Yes & At least I\% & $\ldots \ldots$ \\
\hline $\tan a \ldots$ & $\ldots \ldots$ & No & $\ldots$ & & 25 & Yes & $5 \%$ mini- & 20 \\
\hline aska & 3 mos. & $\cdots$ & & No & $\cdots$ & 27 & & xo \\
\hline ada & $\cdots \cdots$ & No & None & No & No & So & ...... & $\cdots \cdots$ \\
\hline New Jersey.... & 6 mos. & No & DOAC & Yes & No & 31 & $2 \%$ mini- & $5 \ddot{\%}$ assets \\
\hline New $M$ & $6 \mathrm{mos}$. & No & - & No & $\because$ & No & $\cdots$ & $\cdots$ \\
\hline $\begin{array}{l}\text { New York....... } \\
\text { North Carolina. }\end{array}$ & $\cdots \cdots$ & No & $\ldots \cdots$ & $\begin{array}{l}\text { Yes } \\
\text { No }\end{array}$ & 32 & $\begin{array}{l}\text { Yes } \\
\text { No }\end{array}$ & $\begin{array}{c}{ }^{83} \\
\ldots \ldots\end{array}$ & \\
\hline North Dakota.. & $\ldots \ldots$ & No & : & Yes & 35 & No & & $\cdots$ \\
\hline$\cdots \cdot$ & $\ldots \ldots$ & 30 & & Yes & Yes & 37 & 38 & No limit \\
\hline Oklahoma ..... & $6 \mathrm{mos}$ & No & & No & $\because$ & No & $\ldots \ldots$ & $\ldots \ldots$ \\
\hline $\begin{array}{l}\text { Oregon } \ldots . . . . \\
\text { Pennsylvania } \ldots\end{array}$ & $\because \cdots$ & $\begin{array}{l}\text { No } \\
\text { No }\end{array}$ & & $\begin{array}{l}29 \\
\text { Yes }\end{array}$ & $\stackrel{40}{Y e s}$ & $\begin{array}{l}\text { No } \\
\text { No }\end{array}$ & $\cdots \ldots$ & ${ }_{5} \%$ assets \\
\hline Rhode Island... & $\ldots \ldots$ & No & & & 43 & No & $\cdots$ & $\ldots \ldots$ \\
\hline th Carolina. & $\ldots \cdots$ & No & & No & & No & $\ldots \ldots$ & $\cdots \cdots$ \\
\hline $\begin{array}{l}\text { South Dakota. } \\
\text { Tennessee .... }\end{array}$ & $6 \mathrm{mos}$ & No & & $\mathrm{No}_{0}$ & & Yes & 16 & $\cdots \cdots$ \\
\hline $\begin{array}{l}\text { Tennessee . } \\
\text { Texas ..... }\end{array}$ & 4 mos. & $\begin{array}{l}\text { No } \\
\text { No }\end{array}$ & & Yes & $\ddot{\mathrm{Y} e s}$ & $\begin{array}{l}\text { No } \\
\text { Yes }\end{array}$ & $\cdots_{47} \cdots$ & $\cdots \cdots$ \\
\hline $\mathrm{U}$ & & No & & $\ldots$ & .. & & & $\cdots \cdots$ \\
\hline & $6 \mathrm{mos}$ & No & & • & & No & $5 \%$ maxi- & $\cdots \cdots$ \\
\hline $\begin{array}{l}\text { Virginia } \\
\text { Washing }\end{array}$ & . & No & . & $\mathrm{No}_{48}$ & & No & $\cdots_{\text {io }} \cdots$ & $\cdots_{i 1} \cdots$ \\
\hline $\mathrm{Vi}$ & 3 mos. & $\begin{array}{l}\text { No } \\
\text { No }\end{array}$ & & & & $\mathrm{N}$ & & 82 \\
\hline onsi & $6 \mathrm{mos}$ & No & & Yes & 63 & Yes & 34 & .... \\
\hline oming & $6 \mathrm{mos}$ & No & & . & .. & . & $\cdots \cdots$ & $\ldots \ldots$ \\
\hline
\end{tabular}

Notes on pp. 405 and 407. 
1 Arizona. Yes, if association has no capital stock.

2 California. Yes, unless guarantee capital equals 5 per cent of outstanding loans.

s California. Guarantee association need not maintain reserve in excess of $\$ 50,000$ when stock and reserve equal amount required by law.

- Connecticut. Five per cent of dues capital.

- Florida. Yes, after second year.

- Florida. Two per cent, applied until contingent fund reaches 5 per cent of assets. Not required if dividend would thereby be less than 6 per cent per annum.

${ }^{7}$ Illinois. One to five per cent until five per cent of dues capital is reached.

8 Illinois. Ten per cent of dues capital.

- Indiana. Three per cent until five per cent of assets is reached. Not obliged to reduce its dividend below 6 per cent for contingent fund.

${ }^{10}$ Iowa. Yes: $\$ 8$ for maturing $\$ 100$ of installment stock. $\$ 2$ for full-paid or prepaid stock.

Cannot exceed limits of 3 per cent on $\$ 100,000$ and I per eent on $\$ 1,000,000$.

11 Iowa. Yes, or a "fixed charge" provided in by-laws.

12 Kansas. One per cent until fund reaches three per cent of assets.

${ }^{3}$ Kentucky. Six weeks plus 30 days' notice.

${ }^{14}$ Kentucky. One per cent until fund reaches five per cent of assets.

No association required to reduce its dividends below 5 per cent for that purpose.

${ }^{15}$ Louisiana. Three per cent contingent loss fund. May also set aside 3 per cent of net earnings for a reserve fund up to $2 \frac{1}{2}$ per cent of outstanding loans.

${ }^{16}$ Louisiana. Two and one-half per cent of outstanding loans.

${ }_{17}$ Maine. Six months plus one month's notice.

18 Maine. Five per cent of dues capital.

10 Massachusetts. Four months plus twenty-one days' notice.

${ }_{20}$ Massachusetts. Six months thereafter.

21 Massachusetts. Five per cent of total liabilities. Guaranty fund and surplus not to exceed $5 \frac{1}{4}$ per cent of total liabilities. Not more than one per cent of net earnings may be carried to surplus at any distribution, unless the maximum of 5 per cent has been carried to the guaranty fund.

2 Michigan. Five per cent. If reserve is less than 50 per cent of book value of real estate except that held for office purposes and sold under contract, at least 4 per cent must be set aside annually.

23 Minnesota. No, if expenses are greater than earnings, they may be carried as "Expenses Paid," to be deducted from earliest future net profits.

24 Montana. After 2 years, except loan expense.

25 Montana. After 2 years, yes.

${ }^{28}$ Montana. Five per cent of outstanding loans.

${ }^{27}$ Nebraska. Yes, except certain "serial" associations.

${ }_{28}$ Nebraska. At least 5 per cent until fund reaches 5 per cent of total assets.

${ }^{20}$ Nebraska. Ten per cent of assets with approval of State Banking Board.

20 New Jersey. One per cent of average amount of loans outstanding plus admission or membership fees. (Applies only to associations with assets of $\$ 35,000$ or more.)

${ }^{31} \mathrm{New}$ Jersey. Yes. Law requires payment into contingent reserve only in certain cases.

82 New York. Not to exceed $21 / 2$ per cent per annum of dues and dividends at beginning of year. Association under 40,000, not to exceed $\$ 1,000$.

ss New York. Five per cent until it equals 5 per cent of accumulated capital and 50 per cent of book value of real estate owned.

s4 New York. Together with undivided profits, 15 per cent of capital.

85 North Dakota. No. For expenses (except interest, taxes, and insurance), 17 per cent of dues can be used.

38 Ohio. Yes: where interest has not been paid for one year.

${ }^{37}$ Ohio. Yes, in permanent associations.

38 Ohio. At least 5 per cent until fund reaches 5 per cent of assets.

30 Oregon. By-laws must cover "the charges of management."

to Oregon. No. A maximum of ten cents per share per month may be deducted from dues for expense. 
Statutory Provisions, January 1, 1925, Covering Building and Loan Associations in the United States

\begin{tabular}{|c|c|c|c|c|c|c|c|c|}
\hline \multirow[b]{3}{*}{ State } & \multicolumn{5}{|c|}{ Holding Real Estate } & \multicolumn{3}{|c|}{ INTEREST RATE } \\
\hline & \multirow[b]{2}{*}{ 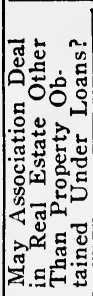 } & \multirow[b]{2}{*}{ 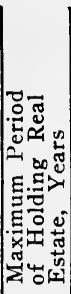 } & \multicolumn{3}{|c|}{ Office Building } & \multirow[b]{2}{*}{ 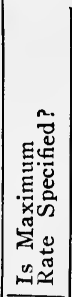 } & \multirow[b]{2}{*}{ 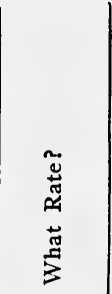 } & \multirow[b]{2}{*}{ 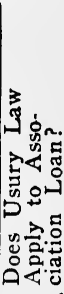 } \\
\hline & & & 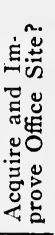 & 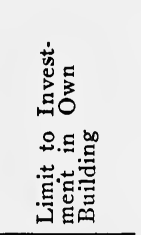 & 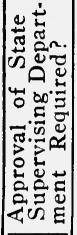 & & & \\
\hline Alabama ... & Yes & - & $\cdots$ & - & $\cdots$ & 1 & I \% per & $\cdots$ \\
\hline Arizona & & 10 & $\cdots$ & & & & mo. & \\
\hline $\begin{array}{l}\text { Arkansas .. } \\
\text { California }\end{array}$ & $\begin{array}{l}\text { Yes } \\
\text { No }\end{array}$ & $\because 5$ & $\ddot{\mathrm{Yes}}$ & $\cdots \cdots$ & Yes & $\begin{array}{l}\text { Yes } \\
\text { Yes }\end{array}$ & $10 \%$ & $\begin{array}{l}\text { Ÿes } \\
\text { Yes }\end{array}$ \\
\hline Colorado . . & No & $\ldots$ & Yes & No & No & No & $\begin{array}{l}12 \% \\
\ldots \ldots\end{array}$ & No \\
\hline Connecticut .. & $\begin{array}{l}\text { No } \\
\text { Yes }\end{array}$ & $\because$ & Yes & 8 & Yes & $\begin{array}{l}\text { Yes } \\
\text { Yes }\end{array}$ & $12 \%$ & No \\
\hline D. of C.......... & No & $\because$ & Yes & None & No & $\begin{array}{l}\text { Yes } \\
\text { Yes }\end{array}$ & $\begin{array}{l}6 \% \\
8 \%\end{array}$ & $\ddot{\text { No }}$ \\
\hline Florida ... & Yes & $\cdots$ & Yes & $\ldots \ldots \ldots$ & ... & $\ldots$ & $\ldots$ & No \\
\hline gia $\ldots$ & $\mathrm{Yes}_{6}$ & $\therefore$ & Yes & $\dddot{\$ 20,000}$ & $\cdots$ & $\begin{array}{c}4 \\
\text { Yes }\end{array}$ & $\begin{array}{l}8 \\
7\end{array}$ & $\begin{array}{l}\text { No } \\
\text { Yes }\end{array}$ \\
\hline is & No & $\ddot{\cdots}$ & Yes & $\begin{array}{l}\$ 20,000 \\
5 \% \text { assets }\end{array}$ & $\cdots$ & $\begin{array}{l}\text { Yes } \\
\text { No }\end{array}$ & $\ldots$ & $\begin{array}{l}\text { Yes } \\
\text { No }\end{array}$ \\
\hline ina & 8 & . & Yes & .......... & & Yes & $\because$ & No \\
\hline & No & & Yes & . & & Yes & $8 \%$ & No \\
\hline as & No & None & Yes & None & No & Yes & $10 \%$ & Yes \\
\hline iana & No & $\begin{array}{r}5 \\
10\end{array}$ & $\begin{array}{l}\text { Yes } \\
\text { Yes }\end{array}$ & No & $\ddot{\mathrm{No}}$ & $\begin{array}{l}\text { No } \\
\text { No }\end{array}$ & $\cdots \cdots$ & No \\
\hline e $\ldots$ & No & 10 & $\cdots$ & $\ldots \ldots \ldots$ & $\cdots$ & Yes & 11 & \\
\hline $\begin{array}{l}\text { land } \ldots \ldots \ldots \\
\text { chusetts } \ldots\end{array}$ & Yes & 13 & $\ddot{\text { Yes }}$ & $\cdots_{\text {ii }} \cdots$ & Yes & $\mathrm{Yes}_{15}$ & & No \\
\hline higan.... & $\ddot{\mathrm{No}}$ & .. & Yes & 16 & No & Yes & Leg. rate & ${ }^{\prime \prime}{ }^{\circ}$ \\
\hline nesota. & Yes & 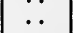 & $\ldots$ & ... & ... & Yes & 18 & No \\
\hline Mississippi & No & & & $\because \cdots \cdots$ & N & Yes & $10 \%$ & $\because 0^{\circ}$ \\
\hline Missouri. & $\begin{array}{l}\text { No } \\
\text { No }\end{array}$ & $\underset{20}{\text { None }}$ & Yes & None & No & No & ….... & $N_{0}^{18}$ \\
\hline $\begin{array}{l}\text { Montana } \\
\text { Nebraska }\end{array}$ & No & 5 & $\begin{array}{l}\text { Yes } \\
\text { Yes }\end{array}$ & ${ }^{\prime} \mathrm{No}_{\mathrm{o}}$ & $\cdots$ & No & $\begin{array}{c}\text { Leg. rate } \\
\ldots . . . .\end{array}$ & No \\
\hline Nevada. & Yes & . & Yes & $\ldots \ldots$ & & No & & \\
\hline New Hampshire & 21 & .. & Yes & $\ldots$ & No & Yes & Leg. rate & No \\
\hline New Jers & Yes & .. & Yes & $5 \%$ assets & & No & $\ldots \ldots$ & No \\
\hline $\begin{array}{l}\text { New Mexic } \\
\text { New York. }\end{array}$ & $\begin{array}{l}\text { No } \\
\text { No }\end{array}$ & $2 \dot{a}$ & $\begin{array}{l}\text { Yes } \\
\text { Yes }\end{array}$ & $\$ 5_{23}^{0,000}$ & $\mathrm{No}_{24}$ & $\begin{array}{l}\text { No } \\
\text { Yes }\end{array}$ & $\cdots 6 \%$ & $\underset{25}{\text { Yes }}$ \\
\hline North Carolina... & $\ldots$ & $\cdots$ & & $\ldots$ & & Yes & $6 \%$ & Yes \\
\hline North Dakota. & & & Yes & No & No & No & & \\
\hline$\ldots$ & No & None & Yes & None & No & Yes & $8 \%$ & No \\
\hline homa & No & 7 & Yes & No & & Yes & $10 \%$ & Yes \\
\hline on. & $\begin{array}{l}\text { Yes } \\
\text { Yes }\end{array}$ & ת & Yes & $\cdots \cdots \cdots$ & & Yes & Leg. rate & No \\
\hline $\begin{array}{l}\text { asylvan } \\
\text { de Isl }\end{array}$ & Yes & Io & $\begin{array}{l}\text { Yes } \\
\text { Yes }\end{array}$ & $\begin{array}{l}\text { No } \\
\text { Io } \% \text { capital }\end{array}$ & . & Yes & Leg. rate & No \\
\hline th Carolina. & Yes & & Yes & & No & $\ddot{\mathrm{No}}$ & $\cdots \cdots$ & $\cdots$ \\
\hline th Dakota. & & 28 & 27 & & & No & ....... & $\ddot{N o}$ \\
\hline Tennessee... . & No & .. & Yes & $\ldots \ldots \ldots$ & $\cdots$ & No & ..... & $\cdots$ \\
\hline as $\ldots \ldots \ldots$ & $\cdots$ & - & & $\ldots \ldots \ldots$ & $\cdots$ & No & $\cdots \cdots$ & $\cdots$ \\
\hline Utah ..... & & & Yes & & & $\begin{array}{l}\text { No } \\
\text { Yes }\end{array}$ & $\cdots_{2 \theta} \cdots$ & $\ddot{\mathrm{No}}$ \\
\hline ginia... & Yes & None & Yes & None & No & Yes & 30 & No \\
\hline hington. : & No & 5 & Yes & $10 \%$ assets & No & Yes & $12 \%$ & \\
\hline Virginia. & 31 & 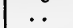 & $\ldots$ & $\ldots \ldots \ldots$ & $\cdots$ & No & $\ldots \ldots$ & No \\
\hline consin $\ldots$ & No & 10 & $\ldots$ & $\ldots \ldots \ldots$ & .. & No & ...... & No \\
\hline oming $\ldots$ & $\ldots$ & .. & $\ldots$ & $\ldots$ & .. & No & & \\
\hline
\end{tabular}

Notes on lower part of p. 407 . 


\section{NOTES TO TABLE XXV (J)-(Continued)}

1 Pennsylvania. First mortgage, 6 months.

Other securities, 3 months.

42 Pennsylvania. Five per cent or less. Interest or dividends payable under involuntary withdrawal may not be reduced thereby.

43 Rhode Island. Earnings plus one-tenth of one per cent per month on par value of shares in force.

44 South Dakota. Yes. No compensation may be paid (agents, etc.), in excess of $1 \frac{1}{2}$ per cent of the shares sold by each.

4 South Dakota. Yes. Earnings and fces so used shall not exceed 2 per cent of average assets for the year except for an association with less than $\$ 40,000$, which may incur expense not exceeding $\$ 1,000$ plus membership fees collected.

46 South Dakota. Five per cent until fund reaches 5 per cent of assets.

${ }^{47}$ Texas. One per cent until fund reaches 5 per cent of assets.

48 Washington. Yes. Two and one-half per cent per annum on average assets; less than $\$ 40,000$ assets, maximum of $\$ 1,000$.

${ }^{40}$ Washington. Yes, except as to associations with paid-up reserve fund stock. ${ }^{\text {so }}$ Washington. At least 5 per cent until fund reaches 5 per cent of amount credited to members.

${ }^{51}$ Washington. Reserve and undivided profits, I 5 per cent.

${ }^{62}$ West Virginia. Eight per cent of outstanding loans.

${ }^{63} \mathrm{~W}$ isconsin. Yes. Not over 2 per cent of dues and dividends at beginning of fiscal year.

Associations with assets of less than $\$ 40,000$, limit $\$ 1,000$.

o4 Wisconsin. At least 5 per cent until fund reaches at least 5 per cent of outstanding loans.

\section{NOTES TO TABLE XXV (K)}

1 Alabama. Yes: interest and premium together.

2 California. Reserve or guarantee stock and surplus.

3 Connecticut. Amount must be approved by Bank Commissioner.

4 Georgia. Yes: for non-shareholders.

${ }^{5}$ Georgia. Eight per cent on entire amount for entire time, divided into equal monthly payments.

- Idaho. Yes. May buy and improve for members-not to exceed $\$ 50,000$.

7 Idaho. Must not be usurious.

8 Indiana. Yes. Contract to sell to stockholders must be made.

- Indiana. Legal contract rate. Loan fees and premiums permitted.

${ }^{10}$ Maine. Five years. May be extended by Bank Commissioner.

11 Maine. Six per cent. With premium up to 8 per cent.

12 Maryland. Six per cent. Premium may be charged.

13 Massachusetts. Five years. May be extended by Bank Commissioner.

14 Massachusetts. Yes. Five per cent of dues capital or $\$ 100,000$, but not to exceed surplus or guaranty fund.

${ }_{15}$ Massachusetts. No. Minimum interest rate, 5 per cent.

10 Michigan. If association's assets are over $\$ 500,000$, it may invest up to 5 per cent of its assets in office site and building.

17 Michigan. As to interest, yes.

As to premium, fines, etc., no.

18 Minnesota. Legal rate 6 per cent.

Contract rate 8 per cent.

${ }^{19}$ Missouri. No. May not be unreasonable or extortionate.

${ }^{20}$ Montana. Five years. May be extended by Examiner.

${ }^{21}$ New Hampshire. Yes, it may purchase houses or land and erect houses thereon and sell or lease same to shareholders.

${ }^{22}$ New York. Five years. May be extended by Superintendent of Banks.

${ }^{23}$ New York. Not to exceed 25 per cent of guaranty fund, without approval of Superintendent of Banks.

${ }^{24}$ New York. Yes, when cost exceeds 25 per cent of guaranty fund.

${ }^{25}$ New York. Interest and premium not to exceed 8 per cent.

${ }^{26}$ South Dakota. Five years. May be extended by Superintendent of Banks.

${ }^{27}$ South Dakota. Yes, if it has a guaranty or permanent capital.

${ }^{28}$ South Dakota. Forty per cent of guaranty or permanent capital.

${ }_{20}$ Vermont. Six per cent plus premium.

${ }^{30}$ Virginia. Six per cent on entire amount entire time.

51 West Virginia. Yes: may erect houses.

32 District of Columbia. Eight per cent interest rate is permitted; associations charge six. 
Borrowing by Association-Continued from p. 403.

Idaho ........ Permitted-pledge its securities.

Illinois ....... Limit-ro per cent of assets. Time limit one year.

Indiana ....... Permitted.

Kansas ........ Limit-15 per cent.

Kentucky ...... Limit-1 5 per cent first $\$ 300,000$ assets. 5 per cent of dues paid in excess of $\$ 300,000$ assets.

Louisiana ..... Limit-50 per cent of mortgage loans. Pledge and assign securities therefor.

Massachusetts .. By vote of $3 \%$ of the directors and consent of Commissioner may borrow from any national bank, etc., for not more than six months, and may pledge any portion of its securities or resources.

Michigan ...... Limit-2o per cent of accumulated capital and one year. Minnesota ..... Limit-80 per cent of assets.

Mississippi ..... Permitted.

Missouri ..... Limit-not more than "6 months' income" from dues and interest and not longer than 2 years.

Montana ..... Limit-2o per cent of assets.

New Hampshire. Limit-set by Bank Commissioners for each association. New Jersey .... Limit-30 per cent of dues paid in and one year plus a renewal of one year.

New York..... Limit-2o per cent of capital and one year.

North Carolina. Limit-30 per cent of dues.

North Dakota.. As provided in by-laws.

Ohio ........ Limit-2o per cent of assets.

Oregon ........ Permitted.

Pennsylvania ... Permitted.

Rhode Island... Permitted.

South Carolina. Permitted.

South Dakota.. Limit-50 per cent of assets. Pledge securities.

Tennessee ...... Permitted.

Washington ... Limit-25 per cent of actual value of securities on deposit with State Auditor.

Wisconsin ..... Limit-20 per cent of assets and one year.

In other states borrowing can probably be authorized in the by-laws.

Other matters of interest in connection with the statutes, but which are not repeated for more than a few states, are listed below. No comment is needed in these various cases, since the notes given are self-explanatory. The provisions listed below are culled from the building and loan statutes 
themselves, and in many cases these items have merely been inserted there to further clarify the practices. Similar provisions may be found in the general statutes of other states which may apply to associations, but the present writers have not had the opportunity to examine the general statutes, except for a few items shown in the formal tables.

\section{SHAREHOLDER'S LiabiLITy}

Arkansas ...... Limited to unpaid balance of subscription.

California ..... Proportionate to par value of shares held.

Connecticut ... Unpaid balance of subscription.

Idaho ........ Unpaid amount on shares subscribed for, but assessment may be levied against paid-up stock.

Kentucky ...... Articles of association shall state whether private property of stockholders shall be liable for corporate debts and if so, to what extent.

New Mexico.... Stockholders liable until subscriptions are fully paid.

Ohio ......... "Double liability" on all shares where the association accepts deposits.

Oregon ........ Stockholders liabie for unpaid subscriptions.

Tennessee ..... Liability of shareholder limited to amount unpaid on his holdings.

Texas ........ Liability of shareholder limited to amount unpaid on his shares.

Utah ......... Liability of shareholder limited to amount unpaid on his shares.

\section{LIFE INSURANCE}

Idaho ........ Association may insure the lives of its members and debtors.

Illinois ....... Board of Directors may require life insurance from borrower assigned to the association. May handle premiums thereon (pay and charge to borrower's account).

\section{Negotiability of Securities}

Colorado ...... Notes and securities not negotiable.

Florida ...... Securities held as pledges, not assignable except on court order.

Indiana ...... Bonds, notes, and mortgages secured by pledge of shares are not transferable except on order of court. Iowa $\ldots \ldots \ldots$. Securities non-negotiable. 
Kansas ....... May assign its securities to other associations to secure needed funds.

Maryland ..... May not repledge or re-hypothecate securities held.

New York..... Mortgages may be assigned to Land Bank.

Wisconsin ..... Mortgages not assignable.

\section{MisdemeANOR}

Kentucky ..... False rumors about solvency of association made a misdemeanor.

Pennsylvania .. To make any untrue derogatory statement (or induce another to make) regarding any financial institution is a misdemeanor.

Washington ... Misrepresentation in advertising a misdemeanor.

Treatment of Borrower in Insolvent Association

D. of C........ In insolvent associations, borrower shall be entitled to credit for such portion of dues paid as is received in common with other shareholders.

New York...... Borrowing member fully participates in assets on voluntary dissolution. On involuntary dissolution receives minimum value of his shares after losses as credit toward his loan.

North Dakota.. Repayment of mortgage by porrower: Shall be credited with amount paid for dues and premiums on stock pledged therefor.

\section{INTEREST ACCRUED AND UNPAID}

Louisiana ..... Interest due and unpaid for six months may not be included in calculation of earnings.

New York...... Interest and premium earned or accrued and unpaid for over one year cannot be carried as an asset.

Ohio ......... Uncollected interest due shall not be considered an asset or be treated as an earning.

Books, Methods, Etc.

Louisiana ..... Association must keep register of capital stock and maintain transfer office.

Maine ........ Accounting methods specified, double-entry required, trial balance at least monthly, all payments made by order, check, or draft.

Massachusetts .. Double-entry bookkeeping and monthly trial balance required.

Nebraska ...... Double-entry bookkeeping and monthly trial balance required. 
Nevada ....... Stock records must be kept.

New Hampshire. Bank Commissioners have power to prescribe form of books for accounting.

Ohio ........ Complete stock and deposit records must be kept.

Oregon ........ Stock books must be kept.

South Dakota... All loan applications shall be registered in a book as received.

\section{Commissions}

Massachusetts .. No loan fee or commission is permitted, under penalty. New Jersey.... No association shall employ agents to solicit members or sell shares on commission.

New York..... No salary or commission for selling shares.

Ohio ........ If premium is charged on stock, it must be placed in reserve intact, and no fees permitted for sale of stock.

Share in Contingent Reserve Fund

New Hampshire. If "surplus" is set aside (as contingent fund) matured or "retired" shareholders must receive their proportion upon compulsory withdrawal.

South Dakota.. By-laws may provide that when stock is matured or withdrawal made, the holder may also receive his net contribution to the contingent fund or surplus.

Washington .... In enforced withdrawal, share in contingent fund to be allotted.

\section{Deposit of Securities}

Oregon ....... All mortgages shall be deposited with Corporation Commissioner or duly chartered and responsible bank or trust company, in trust.

Washington .... All mortgages must be deposited with State Auditor or

a trust company

\section{Branchi Offices Permitted in}

Alabama, Arizona, Arkansas, Colorado, Delaware, Indiana, Iowa (domestic associations only), Kansas, Louisiana (limited), Maryland, Massachusetts, Michigan, Minnesota, Missouri, Montana, Nebraska, North Carolina, North Dakota, Ohio (on approval of State Superintendent which is seldom granted), Oklahoma, Oregon, Virginia.

\section{Foreign Associations Prohibited in}

Georgia, New Hampshire, and New York. (Certain other states effectually prohibit foreign associations from entering their borders by requiring the payment of a prohibitive tax or the deposit of an unusually 
large amount of securities, or both. Although the wording of the laws appears to allow such foreign associations to enter, it is not practicable for them to do so.)

Other provisions of the law relating to building and loan associations of the various states which seem to be worthy of inclusion in this discussion are listed below. Since there is no uniformity among the various states in regard to this matter, they are listed in alphabetical order according to states.

Arizona ...... By-laws must fix rights and privileges and obligations. Arkansas ..... Organization. Same blanks and procedure are used as in organizing other corporations.

Associations must comply with provisions of the Blue Sky Law.

By-laws prescribe details of operation.

California ..... Shares held by any person to extent of $\$ 1,000$ shall be exempt from execution.

Delaware ..... Contingent fund may be used for losses and also for stabilizing maturities.

Association assets exempt from attachment proceedings.

Georgia ...... Recent action by the Georgia Securities Commission has placed building and loan associations offering stock to the public within the supervision of the Commission. This has been accomplished under the existing law by construing mutual associations as dealers in securities based on real estate. A few associations in the state which do not wish to expand but only to lend capital which they have had in hand for many years do not come under such supervision.

Kentucky .... Borrower (after 5 years, and not more than once) may withdraw up to 25 per cent of dues paid in, to pay delinquent taxes or municipal improvements.

"Cancel and endorse" permitted.

Maryland ..... Loans can be made only in money.

Michigan ..... Carry all real estate at actual cost.

Nebraska ...... Association must declare and credit dividends (as earned) at least annually.

Nevada ...... By-laws may provide for control by majority of members of the board of directors, acting individually, if assented to in writing.

Stock owned by non-residents exempt from taxation. 
New York..... Association may pension employees after 20 or 30 years of service.

Junior lien loans permitted under certain conditions. May join Land Bank of New York.

Deposits of savings and loan associations given preference in liquidation of failed state banks and trust companies.

North Carolina. If adapted to use of farmers, may be classed as land and loan associations.

Reserve land and loan associations may be chartered and stock therein taken by local land and loan associations.

Ohio ........ No association shall advertise a larger amount of capital stock than has been subscribed and paid in.

Oklahoma ..... May invest in Federal Farm Loan Bonds.

$\$ 5$ fee for examination of loans authorized.

Oregon ........ Association doing business outside its own county must deposit $\$ 25,000$ in securities with Corporation Commissioner.

Pennsylvania .. Not lawful to collect premiums or fines on straight bond or mortgage.

Rhode Island... Limitation of capital stock applies only to capital actually paid in and an association may issue shares as long as capital paid in is less than authorized capital.

South Carolina. May acquire and transfer property both real and personal including shares of stock in other corporations.

South Dakota.. Upon voluntary liquidation, full participation for all shares in all assets if there is no guarantee or permanent stock.

Vermont ...... All accumulations upon shares held by any person shall be exempt from attachment, etc., to the amount of $\$ 500$.

Virginia ...... Loans may be made on personal property or assignment of wages, not in excess of $1 / 3$ of assets.

Washington .... Agents for sale of shares must be licensed.

Wisconsin .... Trust funds may be invested in paid-up stock of building and loan associations.

Corporations may not borrow from building and loan association.

Wyoming ...... With unanimous consent of trustees, loans may be made on bonds or other personal property. 
Many of the provisions which are unique in the law of a particular state are the evident outgrowth of a desire to favor or to curb particular practices which have developed in certain associations. Other provisions have evidently been blindly copied from the laws of other states regardless of their applicability to existing conditions. It is to be hoped that future legislation affecting building and loan associations may be based on a more thorough understanding of the fundamental principles involved and look toward the creation of standardized practice in handling matters which are of universal application.

\section{REFERENCES.}

Additional discussion in regard to state laws will be found in other chapters of this text-book. See Chap. X for types of security permitted for loans; Chap. XIX for State Regulation; and Chap. XXI Taxation. 


\section{CHAPTER XXI}

\section{TAXATION ${ }^{1}$}

Taxation of associations usually involves double taxation; state taxes against associations, contingent reserve, profits, fees; exemptions; Federal taxes against associations, capital stock, stamp, proxies, powers of attorney; situation regarding guarantee-stock associations; membership taxation and exemption.

With the exception of a few cantons in Switzerland, the United States is the only country in the world still retaining the outworn and inequitable general property tax. This is a type of taxation which may easily be evaded, due to the diffculty in finding the intangible property which comes within its scope and assessing at its proper values, and to the lack of uniformity with which all general property taxes are administered.

The problem as it confronts the building and loan association centers primarily around the avoidance of double taxation and the matter of distribution of profits. Shares in the hands of members may be taxed to-day under the general property tax of many states, but the zeal of the local assessor

The authors have been assisted in writing this chapter by the contributions of many men interested in the movement. Questionnaires were answered by building and loan men in most of the states of the Union. Frank E. Tyler and J. C. Shipley, attorneys of Kansas City, Missouri, devoted a great deal of time and care to the determination of the situation in regard to taxation of shares as personal property and the detailed fees charged by the states (from which we have presented only the maximum and minimum). Walter T. Peterson, of Chicago, wrote a thesis on taxation toward the requirements for his bachelor's degree at the University of Wisconsin in the spring of 1924 under the direction of the authors. Selections from all this material have been condensed into the present chapter. 
determines to a large extent whether or not association members are called upon to pay such taxes.

The Federal Congress and many state legislatures have taken steps to exempt certain phases of the business from taxation on the ground that the accumulation of large funds through coöperative action to be invested primarily in solving the housing situation should not be discouraged by tax burdens. These exemptions are often looked upon by association men as a permanent feature of the business. Where this is true, they will attempt to urge the reënactment of exempting statutes when current laws expire by limitation, for the history of all such bounties shows that the beneficiaries continue to ask for and expect that similar grants will be enacted in their favor in the future. The wisdom of such action is not under investigation in the present chapter. We will merely attempt to present a plain statement of the facts, as they affect both the associations and their members.

\section{State Taxes Levied upon the Association}

Taxes on Real Estate.-All real estate is supposed to be taxed on the same basis in a given locality, whether owned by individuals, by associations, or by other corporations. No attention need be paid to the matter in our present discussion further than to call attention to the fact that state laws vary in regard to the kinds of real estate which an association may own. In practically all parts of the United States the association is permitted by law to own its own office building, if it cares to do so. In addition to this, it is permissible to acquire real estate under foreclosure process. In some states real estate acquired under foreclosure must be disposed of within a definite period, thus preventing the association from including among its assets an unusual amount of real estate which might become a burden upon the members. ${ }^{2}$

2 Disposal is compulsory in Arizona, ro years; California, 5 years; Kentucky, 5 years; Louisiana, ro years; Maine, 5 years; Massachusetts, 5 years; Montana, 5 years; Nebraska, 5 years; New York, 5 years; Okla- 
Separation of Real Estate from Other Assets.-In only four states of the Union (Alabama, Arkansas, California, and Rhode Island) is there no separation of real estate from other assets for the purpose of taxation. In all other states this separation is made. The separation may have considerable influence on the total amount of taxes paid by the association.

Valuing Other Assets.-Where it is the custom for taxes to be levied on the basis of assets, these figures are usually taken from the books of the association. ${ }^{3}$

Taxation of Contingent Reserve.-Iowa taxes associations on their contingent-reserve funds on the general supposition that such funds constitute a permanent fund of capital for the association, very similar in all respects to the capital fund of commercial corporations. Kansas taxes office fixtures and surplus, using the same theory as Iowa, since the surplus is essentially a contingent-reserve fund for the association, to protect it from further loss. In addition, Kansas also lays an assessment upon the difference between the book value and the withdrawal value of free shares.

Profits Tax.-Associations are generally considered to be exempt from taxation upon their profits, since the burden falls upon them from other standpoints. Only in Nebraska and the District of Columbia are the profits of an association known to be taxed. In the District of Columbia profits are taxed at the rate of two per cent on the gross earnings in lieu of all other taxes except the tax on real estate. In Nebraska the tax is at the rate of four mills on the dollar of gross profits.

homa, 7 years; Pennsylvania, Io years; South Dakota, 5 years; Washington, 5 years; Wisconsin, ro years. Several of these periods may be extended by action of the state supervisor.

${ }^{3}$ In twelve states, including Alabama, Arkansas, California, Delaware, District of Columbia, Indiana, Kansas, New Hampshire, Oklahoma, Tennessee, Texas, and Washington, the valuation of assets is determined from the books. In Illinois and Montana the assessor makes an appraisal, probably aided by the figures shown on the association's books. 
Charter Fees.-Practically all of the states require building and loan associations to pay a charter fee based on the amount of their authorized capital at the time they begin doing business. Two states, Pennsylvania and West Virginia, fix their charter fee at a flat sum, regardless of the size of the association. Florida and Georgia substitute a special occupation tax for a charter fee, while Arizona charges only filing fees. In Montana, Wyoming, and certain other states, charter fees are the same for building and loan associations as for ordinary corporations. In North Dakota associations are exempt from state charter fees and do not pay a franchise tax unless they accept deposits.

Most of the states require a filing fee when each annual or special report is filed with the supervising department of the state. This fee is intended in most cases to cover the actual cost of handling, filing (and perhaps publishing) the reports.

License Fee.-In addition to the charter fees, many of the states charge a license fee for the privilege of doing business. This is sometimes known as a franchise tax. Three states use a flat fee for this purpose, while most of the others graduate it according to the amount of business transacted by the association. Six states exempt associations from this form of annual taxation.

Examination Fees.-The state supervising departments of practically all the states are authorized by law to make at least one examination of the books of the association each year. In most cases the cost of this examination is covered by the license or other fees. Six states charge only the actual expense of examination (in the case of Rhode Island a maximum of $\$ 50$ per year is set on the examination); nineteen states at present use a fee based upon assets. Both of these charges vary with the business transacted by the association. The assets fee is rapidly becoming the predominant type. Seven states make an examination charge on a per diem basis, ranging from $\$ 7$ to $\$ 25$. In addition to the per diem fee, the hotel and traveling expenses of the examiner are 
STATE FEES

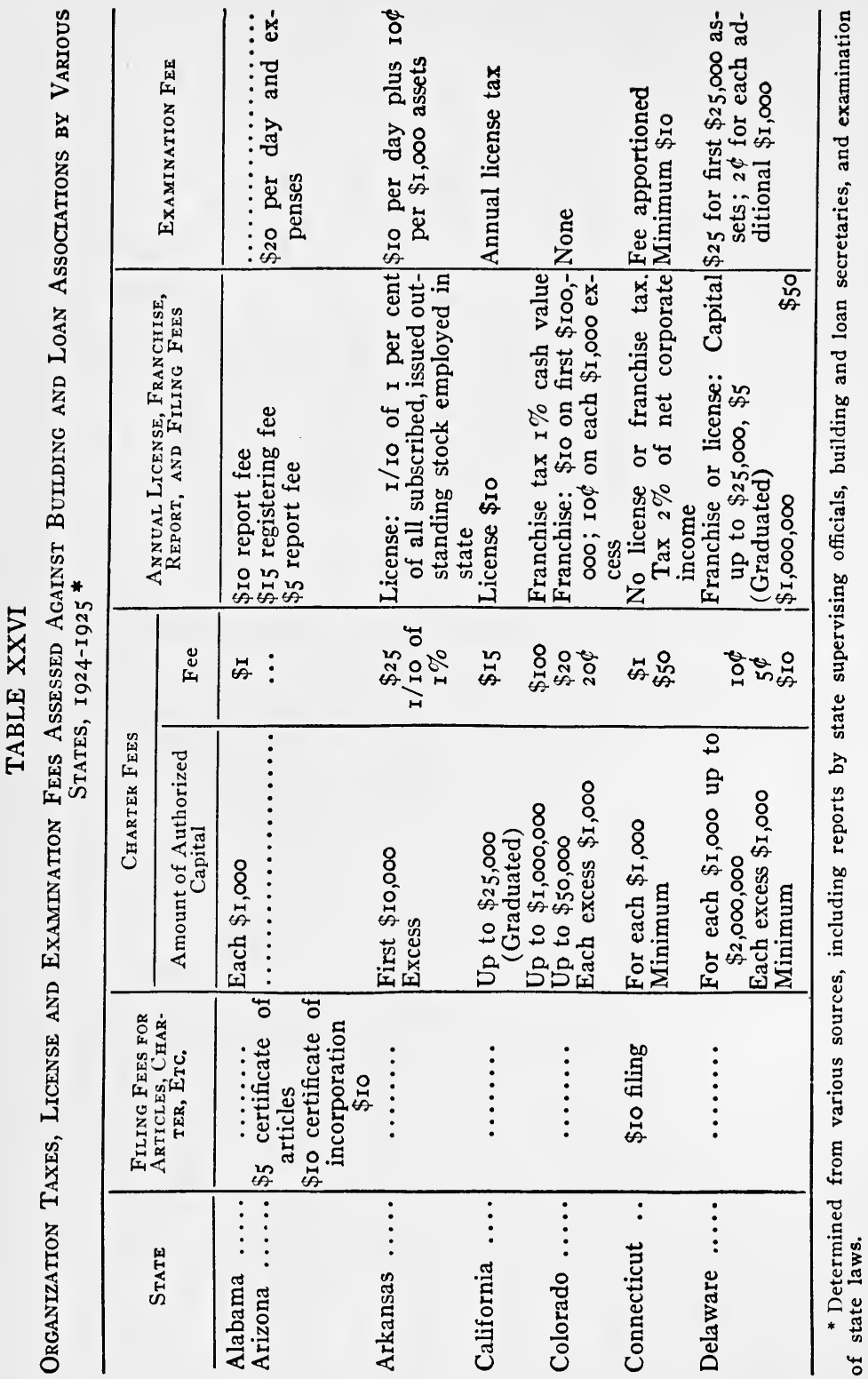




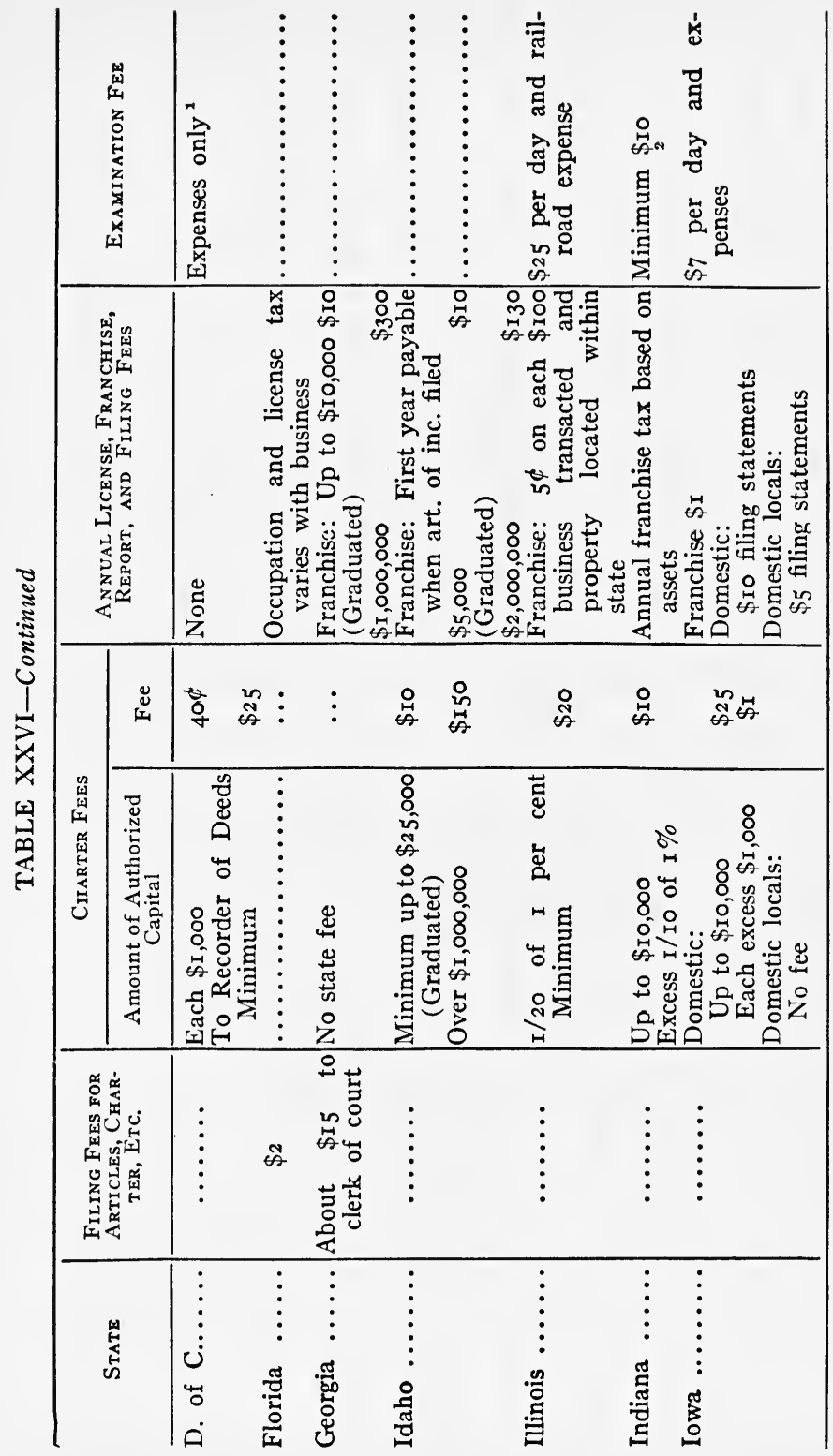




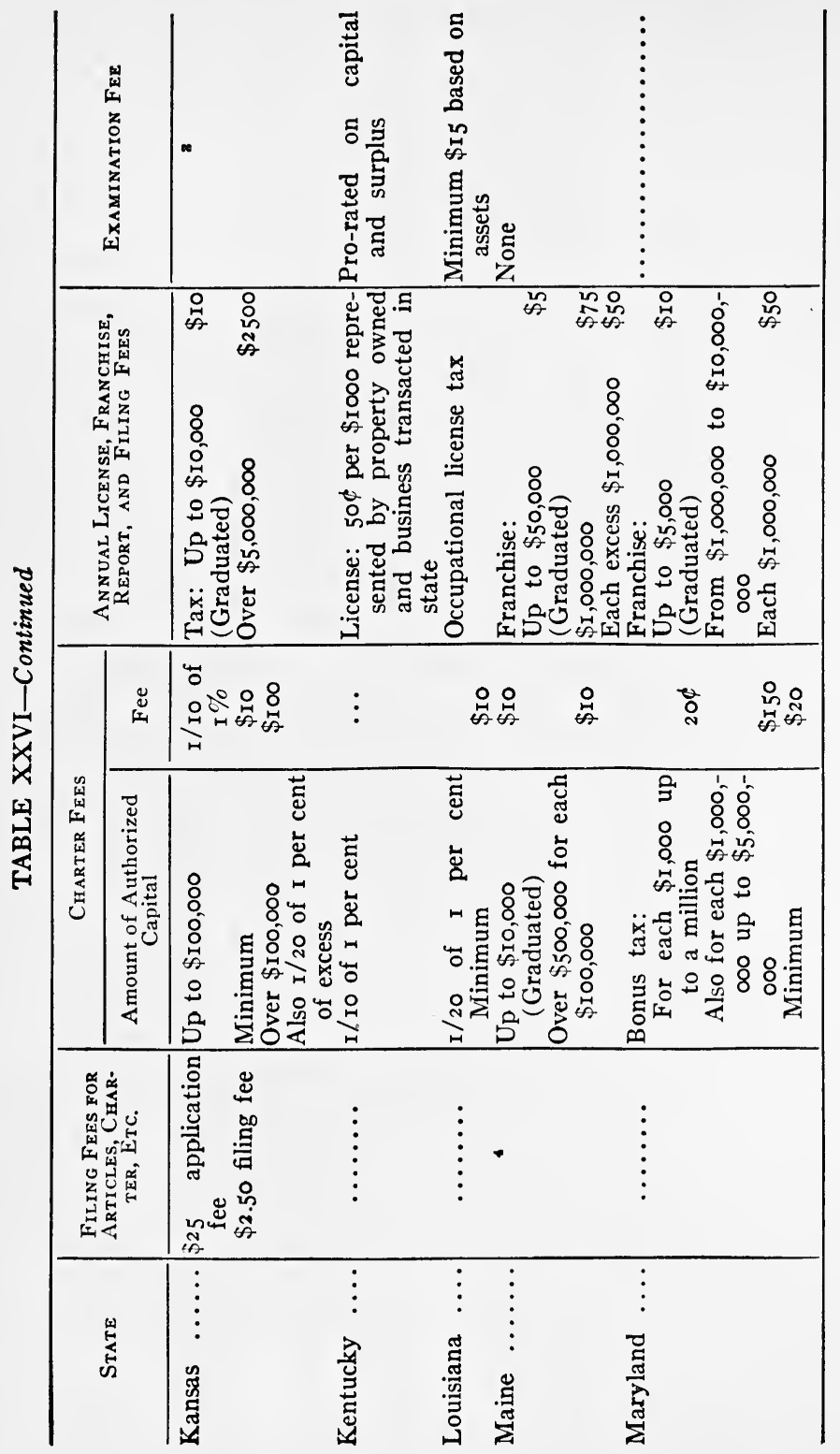




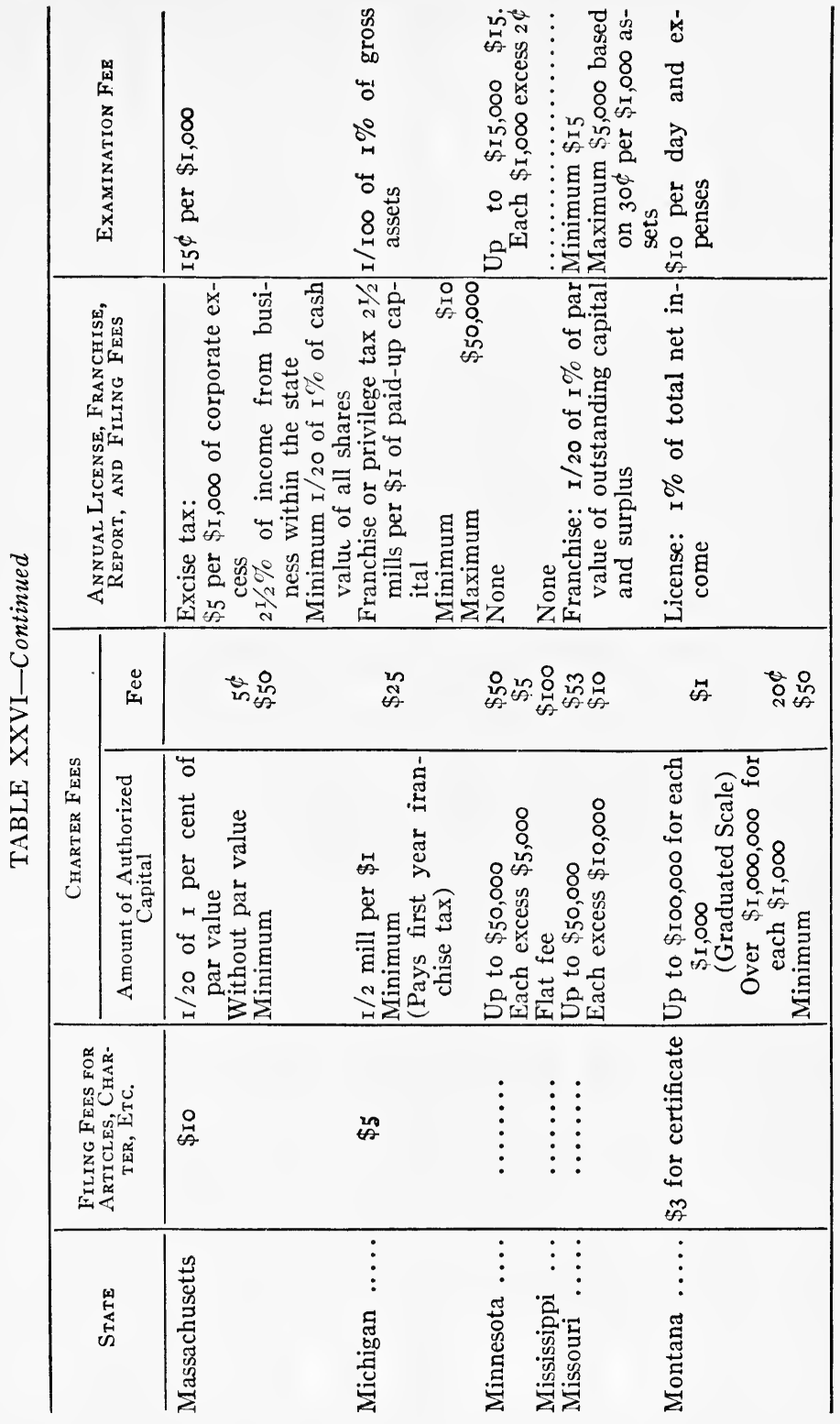




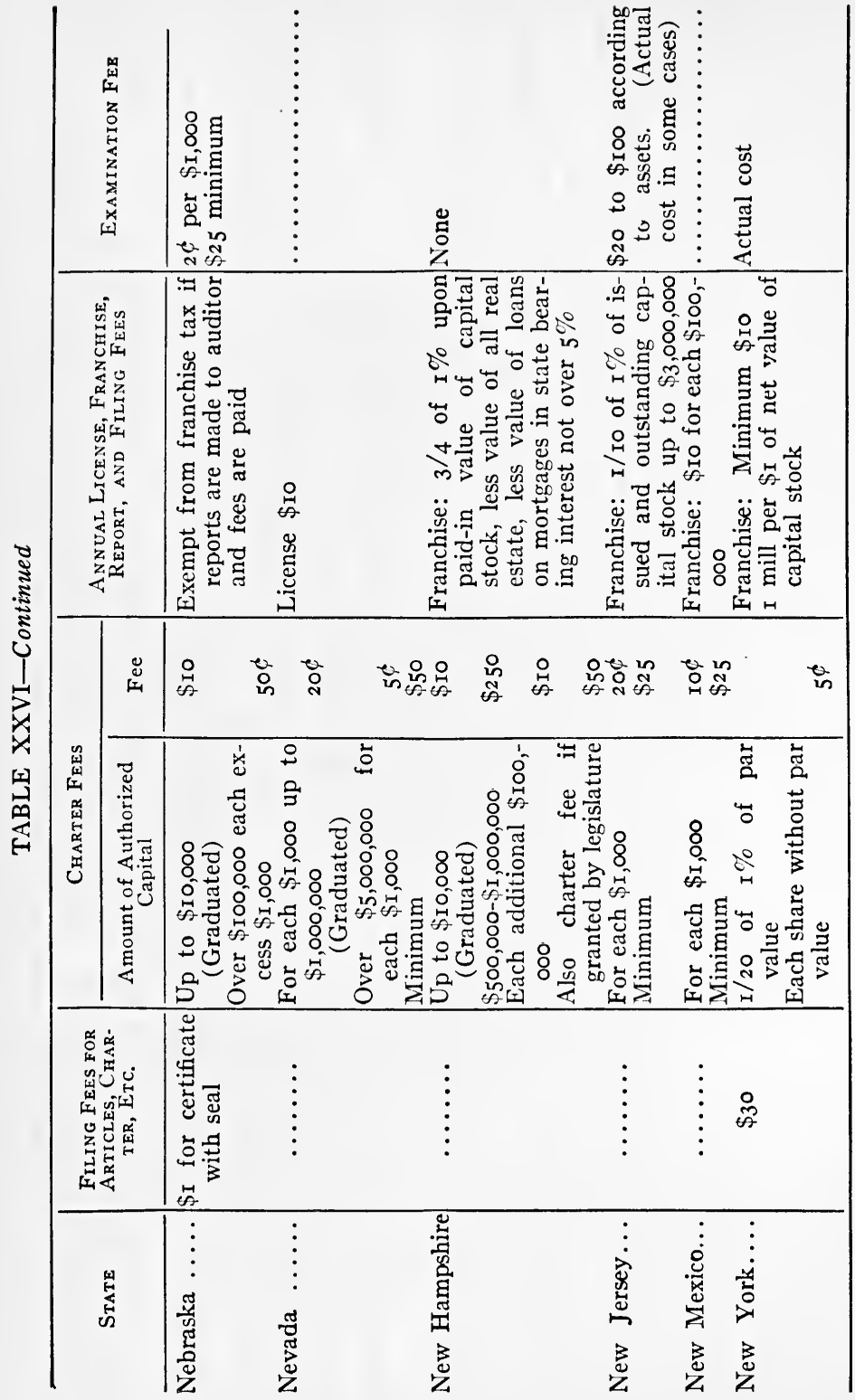




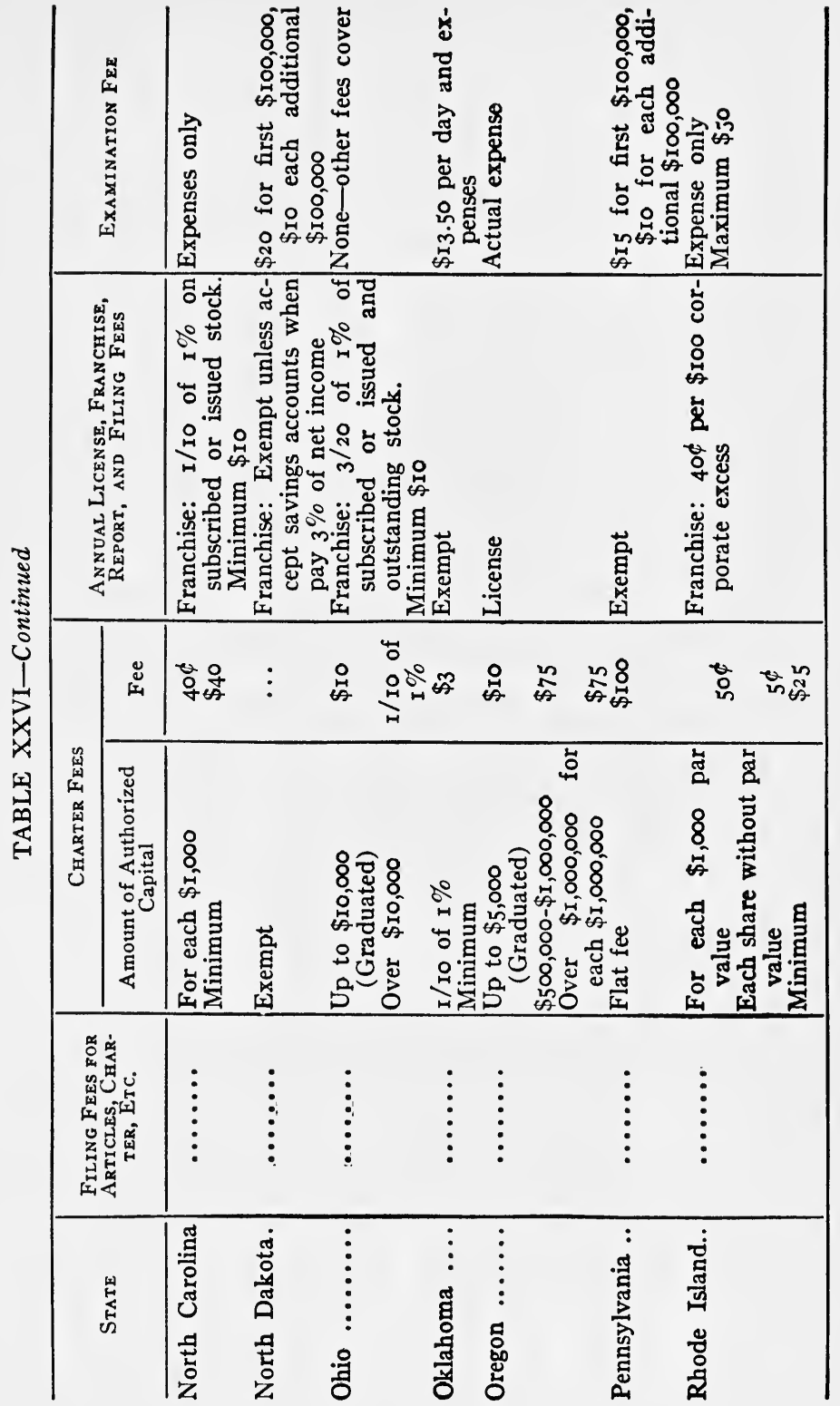


STATE FEES

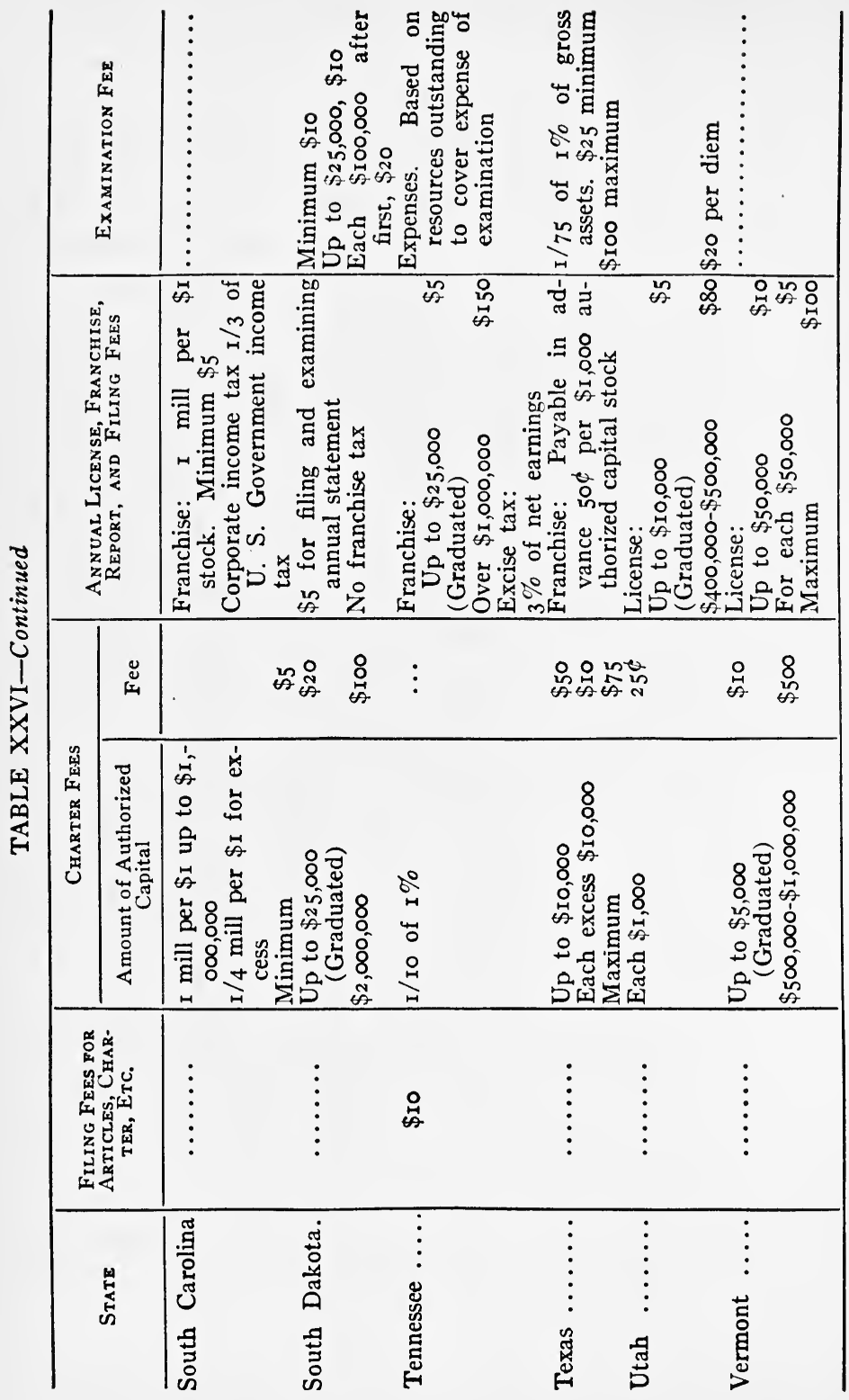




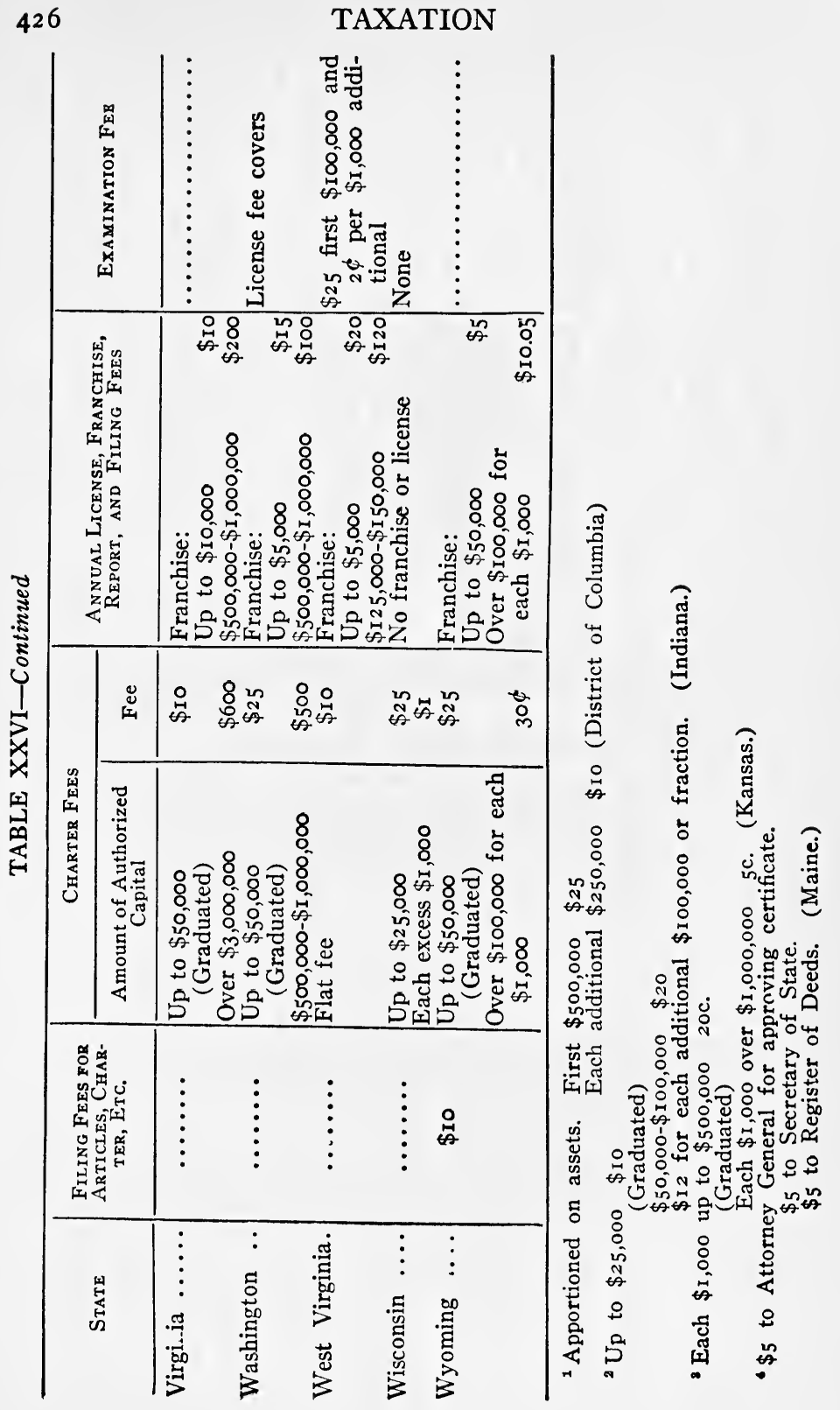


usually paid by the association. In the preceding table are listed the charter fees, license fees, and examination fees charged by the various states. (See also map in Chap. 20.)

\section{Exemptions of the Association from State Taxation}

As already mentioned, some states have found it to their advantage to exempt certain building and loan associations from all forms of taxes, except the tax on real estate, in order to avoid double taxation. New Hampshire grants exemption to all money loaned on 5 per cent mortgages on homes. Vermont gives to associations an exemption from the 7/10 per cent state tax on deposits. Ohio exempts shares on which loans are made. In Kansas, the portion of an association's capital stock which is invested in real estate (of which the fee simple title rests with the association) is deducted from the total stock assessment, since the real estate is already taxed. Rural credit shares in Kansas are also exempt. Missouri gives exemption from the corporation tax; Nebraska grants exemption to 90 per cent of all funds loaned on first mortgages. ${ }^{4}$

Kentucky exempts mortgages; Alabama grants exemption from state privilege taxes; and Washington, Montana, and Oklahoma give exemption to building and loan stock.

In several other states where taxation is possible under existing statutes, the law is not enforced, and no taxation results, either on the association or its members.

In two states (Ohio and Georgia) there appear to be constitutional prohibitions against the granting of exemptions to building and loan associations. We have not had the opportunity to examine the constitutions of all states of the Union, but at least fourteen states have no constitutional prohibition against the granting of exemptions.

- Nebraska taxes the balance under the classification system, at onefourth the rate levied on tangible property. For example, should the tax on $\$ 1,000$ tangible property be $\$ 30$, the tax on $\$ 1,000$ in bank or in any intangible form such as notes, etc., would be $\$ 7.50$. This would make the tax on $\$ 1,000$ in building and loan association shares 75 cents. 


\section{Federal Taxes Charged Against the Association}

Our discussion so far has dealt primarily with the taxes levied by the several states, and by the county and city governments. In addition, the taxes levied by the Federal government must have some consideration. The U.S. Revenue Act specifies the following types of taxes which will apply to building and loan associations and their members:

I. Income Tax.

(a) Individual.

(b) Corporate.

2. Special taxes (including the capital stock tax).

3. Stamp taxes on:

Bonds, debentures, and certificates of indebtedness.

Deeds of conveyance.

Proxies.

Powers of attorney.

We reprint herewith the part of Secretary Cellarius's 1924 Report which covers these taxes.

\section{Revenue Act of $1924^{\circ}$}

The Revenue Bill, H.R. 6715, passed Congress, and became a law, being signed by the President on June 2, r924. It is known as the Revenue Act of 1924. An important feature of the act as far as building and loan associations are concerned, is that all of the provisions descriptive of these associations have been made uniform in accordance with a recommendation of the Legislative Committee of the United States League. In the Revenue Act of 192 I the exemption of $\$ 300$ income derived from dividends or interest applied to associations "operated exclusively for the purpose of making loans to members," while the general exemption and the exemption from capital-stock tax applied to "domestic building and loan associations substantially all the business of which is confined to making loans to members." The exemption from stamp taxes was confined to "coöperative building and loan associations which are organized and operated exclusively for the benefit of their members and make loans only to their shareholders."

${ }^{5}$ Report of H. F. Cellarius, Secretary of the United States League of Local Building and Loan Associations, July, 1924, U. S. League Proceedings, pp. 32-34. 
In the new law all of these exemptions for building associations are retained but they are made to apply uniformly to all "domestic building and loan associations substantially all the business of which is confined to making loans to members."

The following extracts from the new law give the text of the provisions which apply to building and loan associations:

\section{Title VII-Special Taxes}

\section{Capital Stock Tax}

Sec. 700. (a) On and after July I, $\mathrm{r}_{924}$, in lieu of the tax imposed by Section I,008 of the Revenue Act of I92 I-

(I) Every domestic corporation shall pay annually a special excise tax with respect to carrying on or doing business, equivalent to $\$ \mathrm{r} .00$ for each $\$ 1,000$ of so much of the fair average value of its capital stock for the preceding year ending June 30 as is in excess of $\$ 5,000$. In estimating the value of capital stock, the surplus and undivided profits shall be included;

(b) The Taxes imposed by this section shall not apply in any year to any corporation which was not engaged in business (or, in the case of a foreign corporation, not engaged in business in the United States) during the preceding year ending June 30 , nor to any corporation enumerated in Section 23I,

Title VII (called "Special Taxes") effective June 30, r924.

\section{Trtle VIII-Stamp Taxes}

Sec. 8or. There shall not be taxed under this title any bond, note or other instrument, issued by the United States, . . . or stocks and bonds issued by domestic building and loan associations substantially all the business of which is confined to making loans to members.

Title VIII, called "Stamp Taxes," to become effective 30 days after passage of the act.

The tax of two cents on promissory notes is repealed on and after July 3, r924. The tax on bonds of indebtedness, conveyances, deeds, or proxies for voting and powers of attorney remain as in the Revenue Act of $192 \mathrm{r}^{\circ}$

The Revenue Act of I92 I as published by the Treasury Department in Regulations 55 makes the following provisions regarding stamp taxes:

Bonds, Debentures, and Certificates of Indebtedness. Schedule A r. Bonds of indebtedness: On all bonds, debentures, or certificates of in-

- End of quotation from Report of Secretary Cellarius. 
debtedness issued by any person, and all instruments, however termed, issued by any corporation with interest coupons or in registered form, known generally as corporate securities, on each $\$$ roo of face value or fraction thereof, 5 cents: Provided, That every renewal of the foregoing shall be taxed as a new issue: Provided further, That when a bond conditioned for the repayment or payment of money is given in a penal sum greater than the debt secured, the tax shall be based upon the amount secured. (p. r)

Art. 3. Bonds Accompanying Real-Estate Mortgages.-Bonds accompanying real-estate mortgages are taxable as bonds of indebtedness upon the amount secured. (p. r)

Art. ro. Instrument Styled A Bond and Under Seal A Bond, Unless, -An instrument which is styled a "bond" and which is under seal should be held subject to tax as a bond unless it is shown affirmatively that it is not a bond. (p. 2)

Art. I4. Certificates of Indebtedness.-(a) The term "certificates of indebtedness" includes only instruments having the general character of investment securities as distinguished from instruments evidencing debts arising in ordinary transactions between individuals. (p. 2)

Deeds of Conveyance. Schedule A 6. Conveyances: Deed, instrument, or writing, whereby any lands, tenements, or other realty sold shall be granted, assigned, transferred, or otherwise conveyed to, or vested in, the purchaser or purchasers, or any other person or persons, by his, her, or their direction, when the consideration or value of the interest or property conveyed, exclusive of the value of any lien or encumbrance remaining thereon at the time of sale, exceeds $\$ 100$ and does not exceed $\$ 500$, 50 cents; and for each additional $\$ 500$ or fractional part thereof, 50 cents. This subdivision shall not apply to any instrument or writing given to secure a debt. (p. 7)

Art. 53. Who Shall Affix Stamps.-The law requires that the person who makes, signs, or issues any instrument taxable thereunder shall affix and cancel the revenue stamps. It also prohibits any person from accepting such instruments unless they are properly stamped. The grantee in a deed is liable for the tax as well as the grantor. (p. 7)

Art. 54. Actual Value at Time of Conveyance the Measure of the Tax.-Where the consideration for a conveyance of lands, tenements, or other real property is left open, to be fixed by future contingencies, the actual value at the time of conveyance is the measure of the tax upon the the deed, instrument, or writing whereby the conveyance is made. (p. 7)

Art. 67. Deeds of Building and Loan Associations.-Deeds of building and loan associations conveying realty are taxable. (p. 9)

Art. 70. Options and Contracts for Real Estate.-No tax is imposed upon an option for the purchase of real property or upon a contract for the sale of real estate. (p. q) 
Art. 77. Deed to Building and Loan Association.-A deed transferring title to property to a building and loan association for the purpose of securing a loan on the property so conveyed, which property is immediately reconveyed to its owner, is not subject to tax, the deed of reconveyance being likewise exempt. (p. Io)

Proxies. Schedule A ro. Proxy for voting at any election for officers, or meeting for the transaction of business of any corporation, except religious, educational, charitable, fraternal, or literary societies, or public cemeteries, Io cents. (p. 13)

Art. 108. Tax on Proxies Attaches to the Instrument.-The stamp tax on proxies attaches to the instrument and is not measured by the number of grantors and grantees. (p. 13)

Art. rog. Stamp May Be Affixed and Canceled by Either Party to Proxy.-The stamp may be affixed and canceled either by the party who executes the proxy or by the party to whom the proxy is given. (p. I4)

Art. I 10. Directors of Corporations Officers.-Directors of a corporation are officers within the meaning of the clause imposing a tax on proxies for voting at the election for officers of an incorporated company (p. I4)

Art. III. Proxies to Vote Stock of Building and Loan Associations.Proxics for the purpose of voting the stock of building and loan associations are taxable. (p. 14)

Art. II5. Proxies Sent Out by Corporations May Be Stamped After Execution and Delivery.-Where proxies are sent out by a corporation to be executed and returned to the corporation or to the person named in the proxy, such proxies may be stamped after execution and delivery by the person receiving same as the agent of the person executing the proxy. (p. 14)

Powers of Attorney. Schedule A II. Power of attorney granting authority to do or perform some act for or in behalf of the grantor, which authority is not otherwise vested in the grantee, 25 cents. This subdivision shall not apply to any papers necessary to be used for the collection of claims from the United States or from any State for pensions, back pay, bounty, or for property lost in the military or naval service, nor to powers of attorney required in bankruptcy cases nor to powers of attorney contained in the application of those who become members of or policyholders in mutual insurance companies doing business on the inter-insurance or reciprocal indemnity plan through an attorney in fact. (p. I4)

Art. II6. Tax on Power of Attorney, When Due.-The tax on a power of attorney is due when the instrument is executed and delivered. Delivery includes depositing instrument in the mails. (p. 14)

Art. II7. Tax Attaches to the Instrument.-Tax is imposed on the in- 
strument itself, and is not measured by the number of persons joining therein. (p. 14) ${ }^{7}$

A review of the revenue legislation passed during the last thirty years or more shows a settled and consistent policy on the part of Congress to allow building and loan associations exemption from taxation.

Taxation of Guarantee-Stock Associations.-While the Treasury Department may maintain its position in attempting to tax certain associations having in their plans either guarantee, permanent, or contingent-reserve stock, on the ground that these associations closely resemble ordinary corporations in their operation, many of this type have been exempted. In those which may finally be required to pay the tax, the officials may prefer to continue to operate under such plans because of the additional profits which are possible. The same may be said of many Dayton plan associations where higher rates of profit accrue to some members than to others. Regular corporate taxes do not appear to be a very heavy burden upon such associations.

Organizers of new associations which contemplate the use of any of the types of stock whose exemption is in question may not be familiar with the possible necessity of paying taxes when they operate under such plans, and they will do well to investigate this phase of the business before completing their organization. It is possible that their association could be declared non-mutual and not a "domestic building and loan association, substantially all of the business of which is confined to making loans to members; and coöperative banks without capital stock, organized and operated for mutual purposes and without profit." 8

"Where the constitution grants to the legislature authority to exempt from taxation certain persons, corporations, or classes of property, this implies a prohibition against any other or further exemptions. Implied restrictions on the

${ }^{7}$ U. S. Internal Revenue, Treasury Department Regulations 55 (1922 ed.).

Federal Revenue Act, 1921, Title 2, Section 231. 
power of exemption also arise from the constitutional provision requiring equality and uniformity of taxation, from the requirement that all property shall be taxed in proportion to its value, from the declaration in the constitution that every person ought to contribute his proportion of public taxes according to his actual worth, or that no man or set of men are entitled to exclusive separate public emoluments or privileges, but in consideration of public service." 9

\section{Membership TaXation and Exemption}

Exemption from Federal Income Tax.-The shareholders of a building and loan association will enjoy an exemption from the personal income tax until January I, I927, as shown in Sec. 2 I3, Title II, U. S. Revenue Act, I92 I, as amended.

\section{Tithe II-Income TAX}

Gross Income Defined

Sec. 213. (b) The term "gross income" does not include the following items, which shall be exempt from taxation under this title:

(Io) The amount received by an individual before January I, I927, as dividends or interest from domestic building and loan associations, substantially all the business of which is confined to making loans to members, but the amount excluded from gross income under this paragraph in any taxable year shall not exceed $\$ 300$.

\section{Conditional and Other Exemptions of Corporations}

Sec. 23I. The following organizations shall be exempt from taxation under this title:

(4) Domestic building and loan associations substantially all the business of which is confined to making loans to members; and coöperative banks without capital stock organized and operated for mutual purposes and without profit.

Title II (called "income tax" effective as of January I, 1924).

Up to 1927 , therefore, dividends or interest received from building and loan associations not exceeding $\$ 300$ per year are not to be reported as taxable gross income by individuals.

- Cyclopedia of Law and Procedure, William Mack, LL.D., Vol. 37 (The American Law Book Company, 19ri), p. 888. 
With this exception, income of an individual derived from building and loan associations is subject to the same tax as all other kinds of income. The amount of profits or income to be reported is the amount received less the amount paid in. A tax payer is deemed to have received items of gross income which have been credited to or set apart for him without restriction.

It appears that any dividends credited to shareholders have a taxable status as income for the year of the credit, and should be so reported by the shareholder provided they are not subject to deduction.

Where the amount paid in by the shareholder plus the profits is not available to the shareholder until maturity, the dividends are income for the year of the maturity of the share.

Where the subscription was made prior to March I, I9I3, and the share had a cash surrender value on March I, I9I3, and thereafter, over the amount paid in as dues, the profit at the time of cash surrender or at maturity is based on the proceeds in excess of the cash surrender value as of March I, I9I3, plus the aggregate amount paid in subsequently.

A borrowing member is entitled to deduct each year from his gross income the amount he pays the association as interest and premium.

State Taxation of Members.-Shares in the hands of members are reported taxable as personal property or under the general "money and credits" law in nine states, and perhaps such shares might be taxed in this manner in some others, although the matter is in some doubt. In only two states is any effort made to enforce the law covering such taxes, so far as present information shows, and in three others there appears to be partial enforcement. Such provisions seem to be ignored or "winked at" by the assessors, and the laxity in enforcement probably reflects the attitude of the general public toward this type of tax. Wherever partially enforced, it results in great inequality among the various shareholders of the associations in the state and probably 
the matter of enforcement has some influence upon the business of the associations. Very few individuals will be conscientious enough to report to the assessor the amount of money which they have in the bank or the association credits which they hold. It may be assumed that such laws are of small effect, either in gaining revenue for the state or in regulating the investment of citizens.

In the table on pp. 436-7 are listed such data as are available at the present time in regard to this matter. In fourteen states of the Union, income taxes are gradually supplementing or replacing other forms of taxation, and the abandonment of the general property tax which has been recommended for many years may be foreshadowed by this fact. None of these states tax the income from building and loan associations, and four specifically exempt such income from the operation of the tax.

Rate of Taxation.-The rate of tax placed upon shares when they are assessed as personal property varies greatly from state to state. In a recent year they could have been taxed as follows:

Kentucky $\ldots \ldots \ldots \ldots \ldots \ldots$. $\$$ r.oo per thousand. (Only applicable if $1 / 4$ of corporation's property is not taxed in Kentucky.)

Iowa $\ldots \ldots \ldots \ldots \ldots \ldots \ldots, \quad 5.00$

Texas $\ldots \ldots \ldots \ldots \ldots \ldots \ldots, \quad 7.50$ (applicable only when association pays no taxes in Texas.)

Indiana $\ldots \ldots \ldots \ldots \ldots \ldots, \quad 25.00$

Ohio $\ldots \ldots \ldots \ldots \ldots \ldots \ldots \ldots, \quad 28.50$

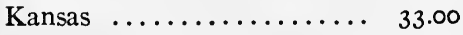

Rural-credit shares are tax exempt in Kansas, and some $\$ 2,000,000$ has been loaned at 6 per cent on such shares in that state.

Methods of Assessment.-Where taxes are assessed against shares in the hands of members, it is possible for the amounts to be placed upon the tax roll either (a) by reports made directly to the assessor by associations, (b) by the assessor having access to the books of the associations and taking therefrom the book values of the shares, the names 


\section{TABLE XXVII}

Taxation of Shares as Personal Property and Practice Regarming ENFORCEMENT

\begin{tabular}{|c|c|c|c|c|}
\hline \multirow[t]{2}{*}{ State } & $\begin{array}{l}\text { Shares } \\
\text { TAXEd As } \\
\text { PERSONAL } \\
\text { PROPERTy }\end{array}$ & $\begin{array}{c}\text { INCOME OF } \\
\text { BUILDING AND } \\
\text { LOAN SHARES } \\
\text { EXEMPT FROM } \\
\text { INCOME TAX }\end{array}$ & $\begin{array}{c}\text { ASSESSOR } \\
\text { HAS ACCESS } \\
\text { TO ASSOCIA- } \\
\text { TION RECORDS }\end{array}$ & $\begin{array}{c}\text { ENFORCEMENT OF } \\
\text { PRESENT TAXES }\end{array}$ \\
\hline & Yes 9 & & $\begin{array}{lr}\text { No } & \text { I6 } \\
\text { Yes } & 6\end{array}$ & $\begin{array}{lr}\text { Enforced } & 13 \\
\text { Ignored } & 7 \\
\text { Partially } & 5 \\
\end{array}$ \\
\hline Alabama ....... & $\begin{array}{c}\text { Depends on } \\
\text { value }\end{array}$ & $\cdots$ & No & Enforced \\
\hline Arizona $\ldots . . .$. & No & & Yes & Ignored \\
\hline Arkansas $\ldots \ldots$ & $\mathrm{No}^{1}$ & No $\operatorname{tax}$ & Yes & Partially \\
\hline California ...... & Exempt & No $\operatorname{tax}$ & No & Enforced \\
\hline Colorado ....... & No & $\because$ & No & Enforced \\
\hline Connecticut $\ldots$. & No & * & & $\cdots \cdots$ \\
\hline Delaware $\ldots \ldots$ & No & * & No & Enforced \\
\hline D. of C...... & No & No $\operatorname{tax}$ & No & Enforced \\
\hline $\begin{array}{l}\text { Florida } \\
\text { Georgia }\end{array} \ldots \ldots \ldots$ & $\mathrm{No}^{2}$ & $\cdots$ & $\begin{array}{l}\cdots \\
\cdots\end{array}$ & $\cdots \cdots$ \\
\hline Idaho $\ldots . . . \ldots$ & $\mathrm{No}^{2}$ & $\ldots$. & & \\
\hline Illinois $\ldots \ldots \ldots$ & No & No tax & No & Ignored \\
\hline Indiana $\ldots . .$. & Yes & No $\operatorname{tax}$ & Yes & Partially \\
\hline Iowa $\ldots \ldots \ldots$ & Yes & $\ldots$ & No & Enforced \\
\hline Kansas ......... & Yes & $\ldots$ & No & Partially \\
\hline Kentucky ...... & $\mathbf{8}$ & $\ldots$ & $\ldots$ & Enforced \\
\hline Louisiana $\ldots .$. & No & ... & $\cdots$ & Ignored \\
\hline Maine $\ldots . . . \ldots$ & No & ... & $\cdots$ & Enforced \\
\hline Maryland ...... & Yes & $\cdots \cdots$ & $\ddot{M}$ & $\cdots \cdots$ \\
\hline Massachusetts .. & No & * Exempt & No & Ignored \\
\hline Michigan ...... & No & $\cdots$ & No & Enforced \\
\hline Minnesota $\ldots \ldots$ & No & $\cdots$ & $\cdots$ & $\cdots \cdots$ \\
\hline Mississippi $\quad \ldots \ldots$ & Yes & * & & $\ldots \ldots$ \\
\hline Missouri $\ldots \ldots$. & 4 & * & No & Ignored \\
\hline Montana ....... & $\mathrm{No}^{\mathrm{s}}$ & * Exempt & No & Enforced \\
\hline Nebraska ..... & Yes $^{7}$ & $\cdots$ & No & Partially \\
\hline Nevada..$\ldots \ldots$ & No & $\ldots$ & $\ddot{i} \cdot$ & $\cdots \cdots$ \\
\hline New Hampshire.. & No & No $\operatorname{tax}$ & No & Enforced \\
\hline New Jersey..... & No & $\cdots$ & $\cdots$ & $\ldots \ldots$ \\
\hline New Mexico.... & Yes & * & $\cdots$ & $\cdots \cdots$ \\
\hline New York...... & No & * & $\cdots$ & $\ldots \ldots$ \\
\hline No. Carolina.... & No & * & $\cdots$ & $\ldots \ldots$ \\
\hline No. Dakota. . & No & * & $\ddot{i}$ & \\
\hline Ohio .......... & Yes & $\cdots$ & Yes & Partially \\
\hline Oklahoma .. & $\underset{\text { mestic }}{\text { No, if do- }}$ & * Exempt & Yes & Ignored \\
\hline Oregon $\ldots$. & No & $\cdots$ & $\cdots$ & ..... \\
\hline Pennsylvania ... & No & $\cdots$ & $\cdots$ & $\ldots \ldots$ \\
\hline Rhode Island. . . . & No & $\cdots$ & $\cdots$ & $\ldots \ldots$ \\
\hline So. Carolina..... & No & $\cdots$ & $\cdots$ & $\cdots \cdots$ \\
\hline So. Dakota...... & $\mathrm{No}^{5}$ & $\cdots$ & $\cdots$ & $\cdots \cdots$ \\
\hline
\end{tabular}


TABLE XXVII-Continued

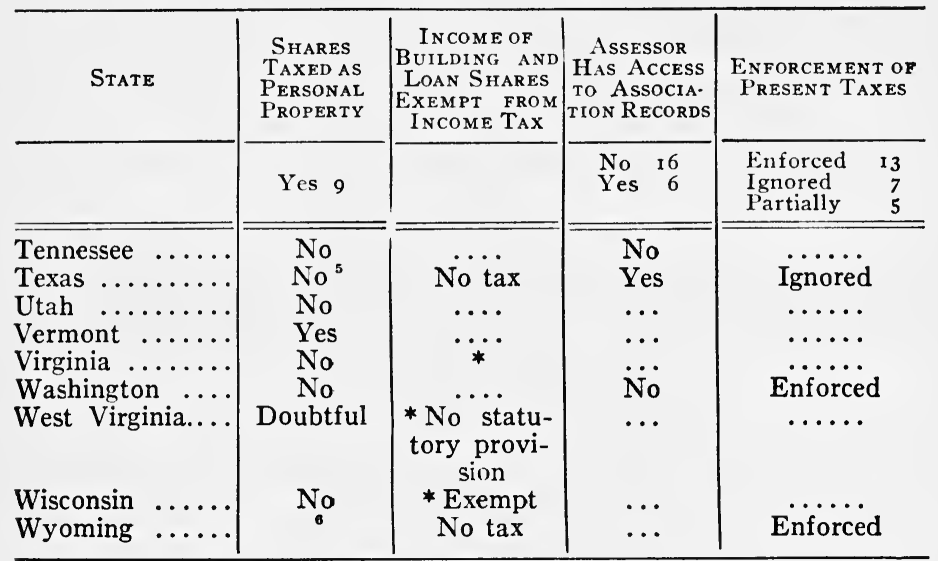

* States having income tax ( 14 in all).

1 Arkansas: Courts have held shares not taxable. 97 Ark. 254.

${ }^{2}$ Georgia, Idaho. Shares not taxable if corporate property is within the state.

${ }^{3}$ Kentucky: Shares not taxable if $1 / 4$ of corporate property is taxed in state.

' In Missouri, free shares must be listed by the individual for taxation as personal property, but shares pledged for loans are exempt.

- Montana, South Dakota, Texas. Shares not taxable if corporate property is taxed in state (see also 67 Tex. 599).

${ }^{\circ} \mathrm{No}$ as to domestic corporations. No as to foreign, if corporation pays any taxes in Wyoming.

${ }_{7}$ Assessors in Nebraska were authorized on April 6, 1925, to list individual holdings at 10 per cent of withdrawal value and tax this amount 5 mills on the dollar.

and address of the members, etc., or (c) by the members themselves reporting the amount of their investment in the associations. In only six states of the Union may the assessor demand access to the records. These include Arizona, Arkansas, Indiana, Ohio, Oklahoma, and Texas. In Arizona, Oklahoma, and Texas no use is made of this privilege, and in the other three states only a few assessors seem to take advantage of the privilege.

In at least sixteen states the assessor cannot demand access to the association records for the purpose of assessment of individual share holdings. Even where this is possible, the assessor may not care to take the trouble, since 
the amount of property involved is usually small and hence the amount of taxes collected would be negligible. Even where the tax is large, few assessors would run counter to public opinion if it has not previously been the custom to assess shares under such conditions. With universal neglect of the law, it would seem that such statutes are entirely useless and might better be removed from the statute books.

\section{SPECIAL REFERENCES}

Taxation (General). Illinois League Proceedings (I920), pp. IOI-I2I; (1922), pp. I0-II, 107-109. Indiana League Proceedings (I921), pp. 20-28. Iowa League Proceedings (I9I2), pp. I2-20; (1923), pp. 20. 25. Kansas League Proceedings (I9I8), pp. 29-30; (I924), pp. I4I6, 35-43, 80-87, 89-98, I22-131, I35-140. Minnesota League Proceedings (1923), p. 12. Missouri League Proceedings (1919), pp. 17-18. Nebraska League Proceedings (1923), pp. 40-41. New York League Proceedings (1922), pp. 15-16, 99-125. Ohio League Proceedings (I9I4), pp. 24-33; (I9I8), pp. 78-93; (I9I9), pp. 5I-77, I36-I69; (I920), pp. IIO-II7; (I92I), pp. 8-II, 39-63; (I922), pp. 20-21, 9I-96; (1923), pp. I46-I63. Oklahoma League Proceedings (1922), pp. 67-72; (1924), pp. 27-28. Utah League Proceedings (1924), pp. 48-5r. U. S. League Proceedings (1900), pp. 90, 93-94; (I902), pp. 26-3I; (I903), pp. 47-60; (I909), pp. I23-I25; (I9II), pp. 24-26, I27-I3I ; (I9I2), pp. I9-2I, I34-I42 ; (I9I3), pp. I62I68; (I9I4), pp. I7-I8; (I9I5), pp. 25-27; (IgI6), p. I4; (I9I7), pp. 32-36; (I918), pp. 29-33; (I919), pp. 24-25; (I920), p. 49; (I921), pp. 26, I53-168; (I922), pp. 22-30; (1923), pp. 33-43. Youngstown Institute Proceedings, April 2, 1924, pp. 6-20.

Taxation-exemption. Iowa League Proceedings (I92I), pp. 56-60. Tax-exempt securities. Missouri League Proceedings (I921), pp. 35-4I. Tax-income. Youngstown Institute Proceedings, February 13, 1924, pp. I-I6.

\section{GENERAL REFERENCES}

Rosenthat, Henry S. Cyclopedia, pp. 77-96.

Sundherm, Joseph H. Law, pp. I94-200.

Statute law of each state and court decisions interpreting the law. 


\section{PART VI}

\section{THE ASSOCIATION AS A BUILDER OF NA- TIONAL THRIFT AND HOME OWNERSHIP}

\section{CHAPTER XXII \\ ECONOMIC CONSIDERATIONS IN BUILDING AND BORROWING}

Purposes of saving; problem of owning a home; determining the size of a home for any family; increase in number and value of homes between 1890 and I920; rôle played by the building and loan associations in this increase; "to build or not to build"; significant principles that the buyer should know; expenses of home ownership; changes in tenancy; multi-family houses; home buying-an economic and personal problem.

Saving is effective only when it is for a definite purpose. To save, one must forego present satisfactions in the hope that the satisfactions which will come in the future will be greater than the present. Many people seem to believe that there is at the present time an increasing preference for spending money on other types of consumption goods rather than on housing. This statement is open to question. Undoubtedly our people are buying many kinds of goods which were unheard of a few years ago. Probably these goods satisfy a demand which did not exist in that day. The diffculty is that most of these things are purchased out of current income with very little, if any, planning. The true incentives for effective saving include saving to buy or build a home, saving for an education, to establish a business, or to provide a cash reserve which will take care of contingencies.

The unmarried man may not be considering acquiring a home, but this may actually become one of the serious prob- 
lems of his life if he has neglected to make some provision in youth. Home ownership has many comforting qualities that promote a family's happiness, and this may quite outweigh all financial considerations. When a family is permanently located, owning a home is an almost absolute necessity, regardless of cost. If there is no assurance of permanent employment on the other hand, or if the breadwinner of the family knows that he must go elsewhere for employment within a year or so, house ownership may be a serious financial handicap. The family should carefully weigh the many advantages of living in their own home against the ease of moving from a rented house, if conditions should compel such a change.

If building and loan development is to fulfill its purpose in the community, it must follow sound economic principles. It cannot encourage borrowing when the money would be put to no useful purpose. Experience of many years has shown that when a man borrows to buy a home after having saved a reasonable amount in the first place, he becomes a more important member of the community; but not all men should buy homes.

Determining the Size of Home.-Among the first economic considerations to be investigated before a man borrows in order to acquire a home is the value of the property that the buyer can pay for while he continues to support his family. The buying process itself may look comparatively simple, but the expenditure involved is not completed by the average buyer until a considerable term of years has expired. When a man has borrowed for this purpose, he is not put to the expense of paying rent for the property of someone else, and, therefore, is enabled to apply his former rent money to the purchase of the house. He is, however, subjected to many additional costs which may not occur to him unless they are called to his attention. It should be a criminal offense to overload a purchaser of a home with payments which he evidently will be unable to meet. A family can usually 
acquire title to a home as good as any they can afford to occupy as tenants, provided the rented house was erected for the purpose of renting. As higher ethical standards are introduced into the real-estate profession, both in selling the property and in providing the funds with which to complete the purchase, buyers will not be asked to undertake obligations which they have small chance of completing.

Mortgages Based on the Right of Private Property.Borrowing as an aid to home ownership is based upon the right of private property. Society has recognized that the rights of individuals in controlling property aid us in providing a firm foundation for the credit structure of the community. Private property involves the exclusive right which society grants the individual to exercise control over some form of economic goods. Houses and lots are included in this category. There is an increasing use of mortgages secured by these rights of private property for buying, building, repairing, and remodeling private residences, and also for the refunding of straight loans.

Increases Shown by the Census.-The accompanying table indicates the increase in the number and value of homes between I 890 and I920, together with the mortgage debt which is reported by the United States Census ${ }^{1}$ as existing against these homes. Part of the increase in value has been due to the marked change in costs of construction within the period. It will be noted, however, that in 1890 the amount of mortgage debt averaged 39.8 per cent of the value of the homes reported, whereas in 1920 this had increased to 42.6 per cent. Since the mortgages are based upon the values of the homes in the two periods, the ratio of debt to value is significant. No longer is a mortgage considered a disgrace, but a definite aid in acquiring a home for those people who are thrifty enough to set aside regularly a specific part of their income for that purpose.

${ }^{1}$ Mortgages on Homes 1920, U. S. Census Monograph, II. See also appendix. 


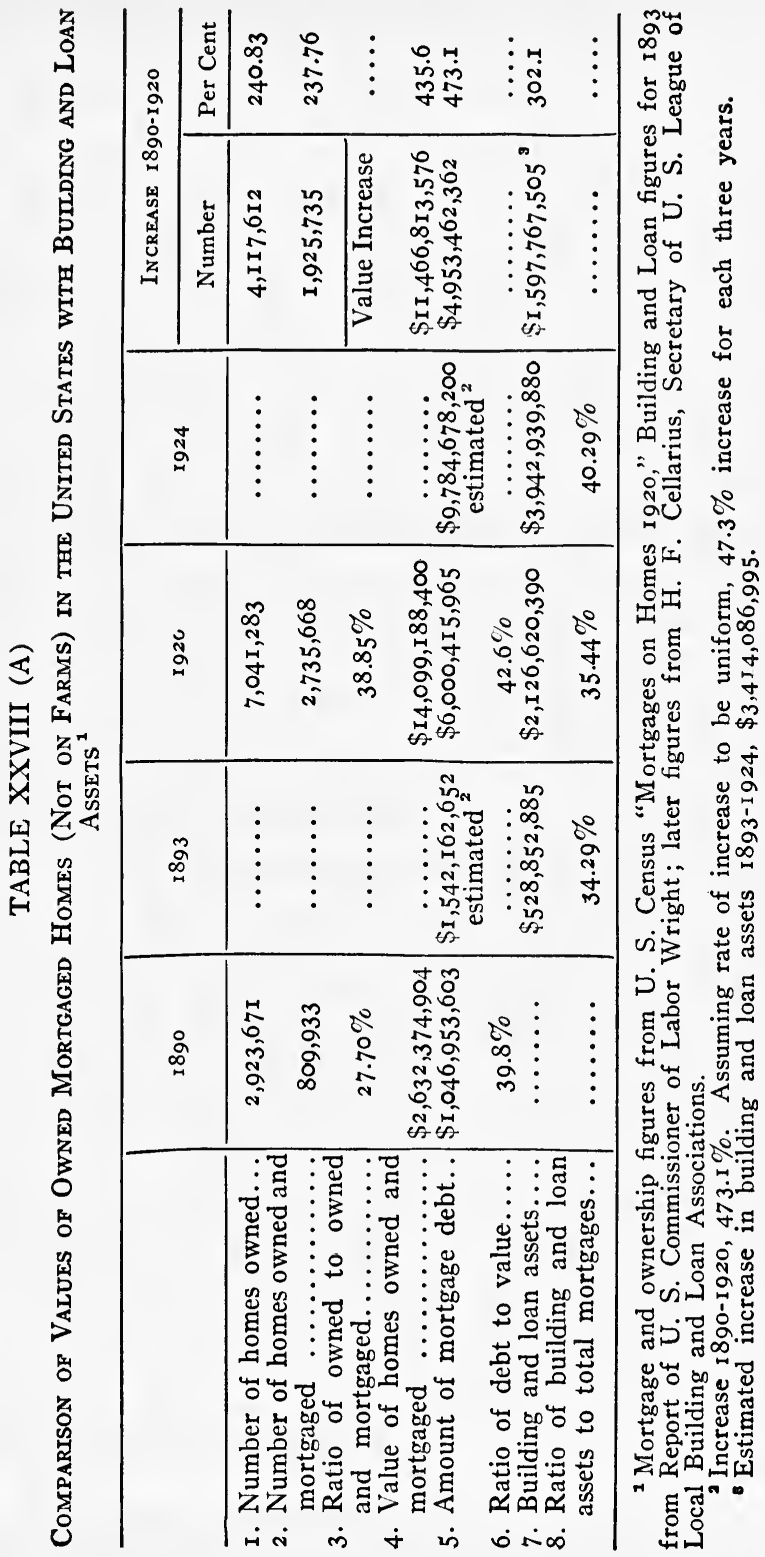


Of great interest in connection with this table is the part which building and loan associations are playing in supplying mortgage money, as indicated by the growth of their assets in comparison to the growth of mortgage indebtedness on homes in the United States. In 1893, the year which gives us the most accurate figures for building and loan associations, their assets appear to have been 34.29 per cent of the amount of mortgage debt, as estimated to be in existence that year. By 1920 , both the mortgage debt and building and loan assets had increased manyfold, and at that time the assets amounted to 35.44 per cent of known mortgages. No accurate figures showing mortgage debt throughout the United States are available since 1920 , but on the basis of the increase from 1890 to 1920 , the figure should be $\$ 9,784,678,200$ in 1924. At that time association assets were 40.29 per cent of this amount. ${ }^{2}$

This is a definite indication that building and loan associations are filling a more important place in the life of the community with the passing years.

To Build or Not to Build.-Whether a man is justified in building or buying depends upon many economic factors. It has frequently been said that all men are better off as home owners, and in general this is true. There are many persons, however, who are not in a position to hold property. The mobility of our urban population in America is extraordinarily great. There is much moving around within the city. It is well known that in some cities certain days are set aside as moving days, at which time a large portion of the population vacates its former dwellings and moves to new locations. Part of this moving is entirely unnecessary, being caused by a spirit of restlessness and discontent, but a large part is due to the desire to live in a place where rents

2 When the figures from the next census are available after 1930, it is possible that this percentage may be somewhat reduced, as mortgage indebtedness probably has increased more in proportion since 1920 than prior to that time. 
are more equitable, where the neighborhood contains a more congenial class of people, or to be nearer a business place, or (which amounts to the same thing) to be nearer better transportation to and from work. People who are renting homes have the opportunity to make such adjustments when they find their first location unsatisfactory, whereas in case of purchase it is necessary to dispose of the property perhaps at a loss, and always with the expense of sale, or to put up with unsatisfactory conditions.

The external flow of population into and out of cities is also an element in the housing situation. Men move to new locations because of changing occupations, seeking better pay or better working conditions, or perhaps because their former industry has passed its usefulness and gone out of existence.

Tenancy and the House Shortage.-Under what conditions should tenancy be encouraged? There are times when a family is better off not to own realty in a location where its members are not satisfied, or where they can no longer make a living. Each case must be decided on its merits.

Examining the housing conditions of the entire United States, we find vast differences among towns. Building and loan association men may be familiar only with prosperous towns, but there are dying villages and static towns where more houses are found than there are jobs. The leaders who founded these towns failed in forecasting their future. Perhaps the only industry located in the town has gone out of business, as in the sawmill towns of the North, and the mining towns scattered throughout many parts of the country. A considerable number of mining towns still contain houses adequate for a population of three or four thousand people or more, while scarcely as many hundred people actually live there. People continue to live in such places in the hope that they will eventually "come back" when mining conditions change.

Such a surplus of houses causes rents to be so low that ownership is not a paying investment. Money invested in houses 
must make a satisfactory return with assured safety, or people will not undertake house ownership. Fortunately these adverse conditions exist in only a comparatively few communities. In many others, a live town has been inadequately planned for expansion, and this acts to retard growth and unsettle values.

The true test of a housing shortage is whether or not all the people desiring homes in a given city are able to get the kind that they want at a price within their income. Vacant large houses are no index of the supply of small houses. The rent, the amount of care necessary to keep up such places, are as definite obstacles to their use as if they did not exist. Houses of the type that people can afford to pay for, and that are satisfactory to live in are the only kind that can be considered in measuring the actual condition.

What the Home Buyer Should Know.-The prospective home buyer needs to learn much about many changing elements in a city before undertaking a purchase.

(I) He should recognize sections where values will continue to be good for years. Since he may purchase a home but once in a lifetime, it is the duty of the real-estate agents and the building and loan men to show him how to recognize such sections.

(2) He must understand something of the types of construction, even though the house is already built. Too expensive construction for a given size of house may result in loss if the property should be resold, but too light construction causes excessive deterioration, which also may result in loss. In other words, the type of construction should be suited to the size and value of the particular residence.

(3) If a house is to be built, staple plans should be selected. The most important of all considerations is preventing mistakes in construction. Architects and builders have done a great deal in the last few years to induce home buyers to eliminate "gingerbread" and "box-type" extremes of construction, and to work for simplicity and convenience of the interior layout of the house. 
(4) The buyers should understand the methods of protecting property rights, both their own and their neighbors', against encroachment or destruction. This includes many items which are not obvious, such as the building of a filling station on an adjoining lot, the maintenance of a nuisance at the rear or side of a lot, etc.

(5) The essentials of comfort, convenience, and beauty should not be overlooked when the property is first purchased.

(6) Many other items can be added to a property as the debt diminishes instead of being included at the time of original purchase. These include things that add greatly to its value and which may be inexpensive, but they also include a long list of fancy items which will have no bearing upon resale value. Cataloguing such items at this point would be useless, since they vary for every part of the country.

Buyers should also remember that there is usually an extra cost involved in purchasing a home when the down payment is too small. In some cases no extra charge is made on account of this, but ordinarily there is greater economy in saving for some years in order to have a fund large enough to command the lowest market price for a property. This is true even though the extra cost is merely an additional commission charged for securing the mortgage money. Loans through building and loan associations ordinarily involve no commissions, but if a second mortgage must be placed in addition to the first, a commission may become necessary. The cost of transferring real estate is also an important item. The commission which real-estate agents receive for the sale of a desirable property appears to be about as great as one or perhaps two years' savings for people of moderate income.

The expenses incident to home ownership begin to accrue from the day the family takes possession, and can never be avoided. These include the cost of accessories of all kinds. They include improvements, repairs, maintenance, depreciation, and obsolescence. 
Improvements are within the control of the owner. When a man has title to a piece of property, he will be interested in adding to it many things that would not be provided by him as a tenant. In fact, during a housing shortage it is to a tenant's disadvantage to make any kind of improvement in connection with the place, because other possible tenants might be attracted to it and thereby tend to increase the rent he would have to pay. If depreciation allowances are not provided for, the owner may be disappointed in the price he is able to realize in the event of resale. Obsolescence is always an unknown factor. The property may go out of fashion within a very few years, but if staple plans have been adopted as suggested above, obsolescence can be reduced to a minimum.

Among the expenses of home ownership are included the cost of complying with building codes, plumbing codes, housing laws, and zoning ordinances. Some of these codes contain very peculiar provisions. For example, one city prohibits the building of a garage within ten feet of the wall of the residence unless both the garage and the house wall are constructed of fire-proof material. But the same city permits the construction of a garage as a part of a house regardless of the material used in construction. One provision actually contradicts the other. Expense can often be avoided by taking advantage of peculiarities in these codes.

Changes in Amount of Tenancy.-The rapid increase in size of large cities ordinarily means a decrease in home ownership, and an increase in the number of dwellings which house more than one family. Philadelphia and Baltimore are examples of great cities which have an unusually large proportion of home ownership. They stand at one extreme, wnile New York stands in the opposite position. It is almost invariably true that more homes are owned in the suburban districts than in the cities proper. Of the cities of from 25,000 to 100,000 population in the United States, two groups were selected for comparison by the Census Bureau. In one 
group of 14 cities, the increase in population between 1890 and 1920 was found to be 200 per cent or more. In this group there has been a much greater increase in home-ownership (in proportion to tenancy) than in another group of 15 cities where in the same period the increase in population has been 50 per cent or less.

Changes in Percentages of Ownership of Homes ${ }^{1}$

\begin{tabular}{|c|c|c|c|c|}
\hline \multirow[t]{2}{*}{ Place } & \multicolumn{2}{|c|}{$\left|\begin{array}{c}\text { Per Cent OF } \\
\text { HOMES OWNED }\end{array}\right|$} & \multicolumn{2}{|c|}{$\begin{array}{c}\text { PER CENT OF } \\
\text { HOMES MORT- } \\
\text { GAGED } \\
\end{array}$} \\
\hline & 1920 & 1890 & 1920 & 1890 \\
\hline 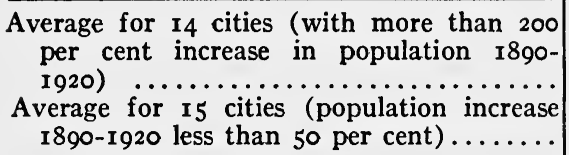 & 37.6 & 32.3 & $\begin{array}{r}48.4 \\
39.8\end{array}$ & 27.1 \\
\hline
\end{tabular}

${ }^{1}$ From Census Monograph II, Mortgages on Homes 1920, pp. 61 and 63 .

In 1920 mortgaged homes in New England and the Middle Atlantic States exceeded the homes free of mortgages. This is the first time that mortgaged homes exceeded homes not mortgaged in any geographical district since the Federal government began collecting statistics. This condition may mean that there is a new group of home owners who have not yet had time enough to repay their loans on account of the "recency of acquisition."

Tenancy increased faster than home ownership between I 890 and I900, but ownership increased faster than tenancy from 1900 to 1920 throughout the country as a whole, and also in the North. In the South, owned homes have continued to increase throughout the past three decades, I890 to I920, while in the West ownership decreased from 1890 to I900, increased from 1900 to I9I0, and decreased from I9Io to 1920. The West was the only section in the country showing a decrease in the decade r9 10 to r920. These facts shown by the Census directly contradict the common statement that tenancy is greatly increasing. In addition they support the 
contention of building and loan men that home ownership is becoming increasingly more attractive to our people.

It is also interesting to note from the Census that the number of mortgages increased in approximately the same proportion as the total number of homes from I893 to I 900 , but increased faster in both succeeding decades, from 1900 to 1920. Table XXVIII (B) on p. 450 presents some interesting statistics in regard to the number of homes owned, rented, and mortgaged in the United States, contrasted with the changes in building and loan assets in the same period, 1890 to 1920. The figures have not been carried farther than 1920 , since that was the date of the last census, and figures for 1893 are taken as equal to 100 per cent, so that all others may be compared with that year.

The average mortgaged home of 1920 is found to be a smaller home than the average for 1890 . This is due to the increased cost of all commodities at the present time.

Houses for Two or More Families.-There is an increasing economy in the use of multi-family houses which a prospective home owner should not overlook. One lot, one foundation, one roof, can adequately house more than one family when the interior arrangements have been properly made for this purpose. The cost per family decreases considerably, and by the use of modern floor plans, several families may be made comfortable with a minimum amount of inconvenience to each other. The rapidly increasing average value of the single family house has focussed attention upon the multi-family unit as never before.

The Problem of Home Buying.-The question of building a property to suit the needs of the buyer instead of buying an existing house hinges upon the adequacy of those which are already available. The stimulation to trade which results from the upbuilding of a community is an important factor. All lines of business feel the beneficial effects of new construction. Taxable values are increased in the community, thus providing more potential revenue for the city, county, 


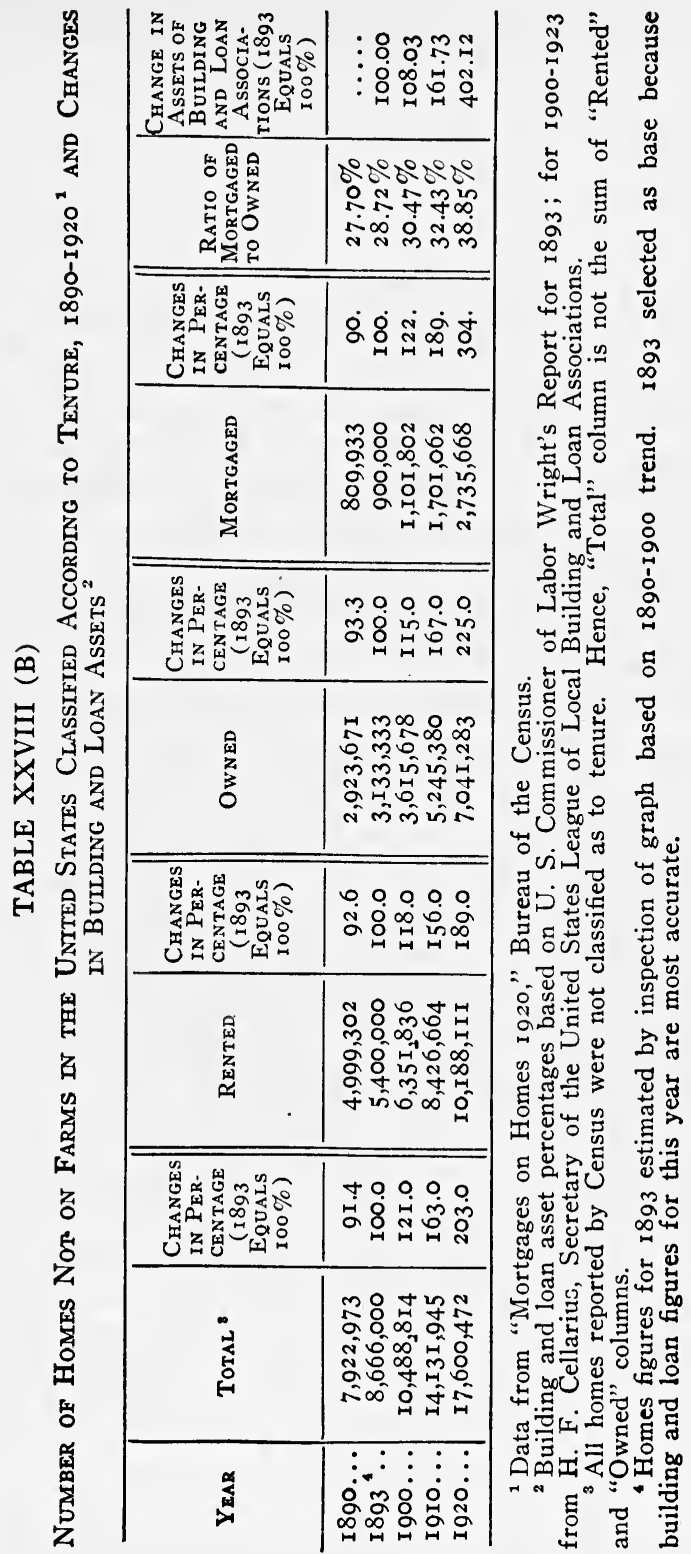


and state. The home builder himself must weigh the effects of postponing the acquisition of his home against the "noneconomic rewards" which come from home ownership. These latter may offset actual money costs. Home ownership for the man with a steady job has frequently converted the careless, inefficient, and thriftless worker into an industrious and thrifty citizen. It tends to stabilize labor turnover because the home owner is less likely to be attracted by a distant job. If, however, employers are unable to provide fairly continuous employment at good wages and proper working conditions, the advantages of home ownership in reducing labor turnover are definitely lost. The plan of the building and loan association in amortizing mortgage debt definitely fosters home ownership for all classes of the community who care to take advantage of its privileges.

\section{SPECIAL REFERENCES}

Economics of building and loan. Kansas League Proceedings (1924), pp.

64-79. U. S. League Proceedings (I901), pp. 84-91.

Home ownership. Nebraska League Proceedings (I923), pp. I3-I4.

Housing question. U. S. League Proceedings (I9I2), pp. 75-84, 84-90;

(I9I3), pp. I70-I79; (I9I4), pp. 39-45; (I9I8), pp. I2I-I40.

Census Monograph II. Mortgages on Homes, 1920. 


\section{CHAPTER XXIII}

\section{HISTORY OF BUILDING AND LOAN ASSOCIATIONS. ${ }^{1}$}

Periods in building and loan development in the United States; early credit societies; the Frankford Association; constitution and by-laws, early activities; pioneers in the work; method of original operation; evolution of the serial plan; growth of the movement in Pennsylvania, Massachusetts, other states; comparative statistics; beginnings of the nationals-methods of operation, effect of the panic of 1893; the crisis; causes of failure of the nationals; slow growth of locals after the national disaster; growth after 1913; development in other countries.

In attempting to discover the less well-known phases of the course of building and loan development, we find that in the United States its history falls into four rather well defined periods:

(I) Early experiment and ultimate success of the local association, $\mathrm{I} 83 \mathrm{I}-\mathrm{I} 885$.

(2) Rise and fall of the national associations, I885-1900.

(3) Reconstruction of public confidence, I900-1910.

(4) Expansion on sound lines, I9ro to the present time.

Only in the United States and in England is a substantial development of coöperative credit found which aims directly to foster home ownership. Methods of the building societies

1 Thanks of the authors are due to many writers from whom the ma terial on which this chapter is based has been collected. Mr. Eugene Ming Shu Shen prepared a thesis on this subject under our direction and submitted it in satisfaction of one of the requirements toward his degree of Bachelor of Arts at the University of Wisconsin. This thesis was awarded honors at Commencement, June, 1924. Others have sent us material from many parts of the United States and from foreign countries. Wherever possible to determine the authorship of particular quu. tations, we have tried to give proper credit. 
of England are quite similar to those of the building and loan associations of the United States, in spite of the fact that there has been very little exchange of information on the subject between the two countries.

Early attempts in both countries were designed in each case to aid one group of people to secure homes. It was supposed that the usefulness of an association would cease when this was accomplished. As a result the originators planned their affairs so that they would "terminate" in about twelve years, not realizing that new troubles would arise in each successive year. The difficulty of keeping a considerable group of members "in step" with each other for so long a term without bringing in new members is now easily understood. At that time it was not so apparent.

The excessive cost of late entrance restricted the usefulness of the early terminating societies, and they were not ultimately successful until placed on a permanent basis by the issuance of shares in series.

Early Credit Societies.-The origin and early history of local building and loan associations is doubtful. A meager form of such societies first took root in China about $200 \mathrm{~B}$. C. During the Han Dynasty, a wealthy official named Pong Koong, instituted a sort of money-lending club called Leehwea, T. meaning interest-receiving society, probably for the Fل double purpose of rendering benevolent assistance to the poor and providing a convenient means of in金 vestment for his money at a fair rate of interest. Any person who was anxious to obtain a loan for useful purposes might call upon his friends and relatives to form such a club. Loans were repaid in installments and the fund was continuously reloaned.

These money-lending societies are still prevalent everywhere in China with regulations varying slightly in different localities. Though they are not organized primarily to finance home building, it is interesting to note that they possess many features in common with local building and loan associations. 
They were mutual in character, they made loans by lot or by competitive bidding, loans were repaid in installments, dues and interest were paid at stated periods, a system of fines was imposed for default in payments, and profits were equally divided.

Development in Great Britain.-Turning to Europe, we

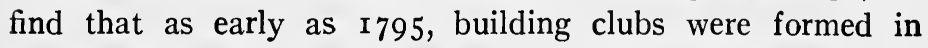
Birmingham in England. At that time it was becoming very difficult for the man in poor circumstances to own any kind of home. Most of the land was passing into the hands of large landed proprietors, and these clubs provided a means by which the working classes could "save themselves into a home." In 1809 the Greenwich Union Building Society was founded and some of its methods have come down to us. Its membership was limited to fifty; it issued 200 shares at $t_{2}$ Io each, each share representing a dwelling house. Houses were built under the supervision of the society, one after another, whenever sufficient funds were available, out of the money paid in by its members in monthly installments. The houses were then distributed among its members by lot. In case of default in payments, a member was subjected to fines and punishments. Here was the skeleton and foundation of the later developed and well-organized building and loan associations.

In I 8 I 5 , another such club was founded under the auspices of the Earl of Selkirk at Kirkcudbright in Scotland. In 1836 building societies gained legal recognition in England by the passing of the first Benefit Building Societies' Act. This act declared it lawful to establish building societies for the purpose of enabling the members to erect and purchase dwelling houses, or acquire other real or leasehold estate, to be mortgaged to the society until the amount or value of the shares should be fully repaid with interest and all other appropriate payments; ${ }^{2}$ and it provided elementary rules for their guidance. Under this act, building societies made considerable develop-

'Johnson's Universal Encyclopedia, Vol. II, p. 530. 
ment. Seeing the beneficial effect of these societies in encouraging the building of homes for the working and lower middle class, the parliament in 1874 passed another Building Societies' Act which greatly enlarged their powers. Under this act the societies were legally established corporations, having perpetual succession and a common seal. Many restrictions, which existed under the law of 1836 , such as those limiting the value of shares to $E_{I} 50$ and subscription to 20 shillings, were done away with. As might be expected, this favorable legislation enabled the organizations to make their plans fit the needs of their members, and building societies in England have ever since made a steady progress.

Enoch Hill, secretary of the Halifax Permanent Building Society, the largest in England, states that the business of these societies has grown at an unprecedented rate in recent years, and that they were never so strong as at present. All of the larger societies are attracting capital to themselves in greater quantity than they can use in financing residence ownership, although the smaller societies do not have so much excess capital available. Surplus funds of the larger societies are being invested temporarily in government and other securities and in bank loans, until they shall be needed for residence purposes.

One great difficulty which they are encountering is the high cost of homes, which is generally regarded as abnormal. These high costs restrict the amount which the societies feel that they can safely lend their members, because a greater margin must be provided between the loan and the present value, since a fall in these values is generally expected. "The greater the reserve which has to be made by building societies in anticipation of a fall in value, the greater is the proportion of the cost which has to be found by the individual builder or purchaser. This can easily become prohibitive in the case of a man of small means, but there is an increasing tendency on the part of men and women of the thrifty artisan class to appreciate the fact that there is no royal road to house owner- 
ship. They realize that house ownership can only be secured by habits of thrift and they have begun to appreciate the fact that the surest and shortest way to acquire a home is to save oneself into it." ${ }^{3}$

At the beginning of the year 1924 these English building societies comprised some 1,300,000 members and depositors.

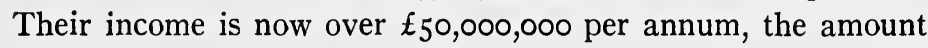
advanced on new mortgages is approximately $\mathfrak{t}_{2} 5,000,000$ per annum, and the reserve funds are well over $t_{5}, 000,000$. "The balance sheets show that all the unsatisfactory mortgages in possession amount to less than one-half of one per cent of the total assets, or, in other words, the portion of the assets

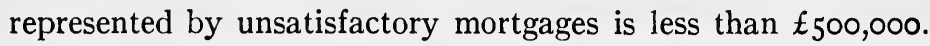
... These properties, moreover, instead of being worthless, are probably of the value of something very near, if not

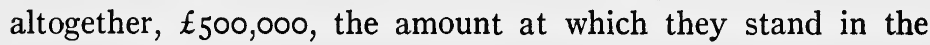
balance sheets." 4

The year 1924 showed further substantial gains and, according to the Building Societies Gazette, the combined working capital was something over $\operatorname{EII}_{7,000,000}$ in the fall of that year (approximately $\$ 569,380,500$ ). Investors receive from $3^{\mathrm{T}} / 2$ to 5 per cent for the use of their money.

United States.-The movement attracted attention very early in the United States, and was already well established in $185^{2}$. In that year, W. P. Smith, in defending the policies of the newly formed Suffolk Mutual Loan and Accumulating Fund Association of Boston, ascribed their origin to the desire of the workingman for a home.

"To the Earl of Selkirk, a Scottish nobleman, the world is indebted for their origin. . . .

"The principle is one that, having taken root, can never be eradicated, and even in the unfruitful soil of England, they

${ }^{3}$ Letter from Enoch Hill, Secretary of the Halifax Permanent Benefit Building Society, Halifax, England, American Building Association News, November, 1923 , p. 501 .

- Letter from Mr. Hill to the American Savings, Building and Loan Institute, February 4, I924. 
have started up in every city, town, and village. . . But the noble scheme of its projector was never fully developed until it reached the United States. Here its appeal was made to an intelligent people, with the means, the fruits of their labor, to give it a fair trial. And what has been the result? Four years ago the first Association was established in New York, and now there are upwards of forty in that city alone. They are established and prospering in many of the large cities throughout the Union." 5

In the United States, the movement has been actively carried on since the earliest association was organized at Frankford, a suburb of Philadelphia, on the 3 rd of January, I8 31 , under the title of the Oxford Provident Building Association of Philadelphia County. ${ }^{6}$ The main provisions of its constitution and by-laws were as follows:

(I) Every member was required to make a payment of $\$ 5$ for membership fee, and a monthly payment of $\$ 3$ for each share having a matured value of $\$ 500$ each.

(2) No member could hold more than five shares; each member was entitled to one vote per share of stock at the semiannual elections.

(3) Loans up to $\$ 500$ per share were allotted to the stockholder offering (in writing) the highest premium for the loan.

(4) Members failing to pay the monthly dues were fined twenty-five cents per share.

${ }^{5}$ W. P. Smith, Building and Loan Associations, Their Character, Operations and Advantages, Boston, 1852.

- We are indebted to Arthur G. Singer of Frankford for much valuable information regarding the early development in Philadelphia. Mr. Singer is the present Secretary of the Decatur Building Association of Frankford, which is the direct successor of the original Oxford Provident. No less than four of the present officers of the Decatur are lineal descendants of organizers of the Oxford Provident Association. The office of Secretary has been occupied by the Singer family since 1877 , the uncle and father of A. G. Singer having occupied it, respectively, from $1877-98$ and 1898-1909. Since its organization this association has matured 9,0421/4 shares, paying out $\$ 1,808,450$ on account of them, and on January 1,1924 , its assets amounted to approximately $\$ 340,000$. 
(5) The association was designed to continue until every member had an opportunity of purchasing a dwelling house, after which the assets were to be divided (the terminating plan).

The original Oxford-Provident Association matured in ten years; but it was subsequently reorganized twice, giving three associations under this name. At the same place, in I845, another similar association, called the "Franklin Building Association" was organized, and in I847 still another in the Kensington District of Philadelphia.

Robert T. Corson, who was closely connected with the associations in northeastern Philadelphia and was solicitor for the Decatur association for many years, tells of their early growth:

"Frankford at that time was (and still is) a manufacturing community, and doubtless the English idea of building associations was brought there by the manufacturers and mill operatives, many of whom came from the mother country about that time.

"On January 3, I83I, according to the [Frankford] 'Call,' 'A meeting of sundry inhabitants of the borough of Frankford was held at the house of Thomas Sidebotham for the purpose of forming an association to enable the contributors thereof to build or purchase dwelling houses.' ... At this meeting forty members signed the constitution, enrolled their names, and subscribed for shares, and at a later meeting by-laws were adopted. At the next meeting held January Io, I83I, the organization was completed by the election of officers. Isaac Whitelock was elected President of the Board of Trustees and Isaac Shallcross, Secretary. ...

"The Constitution and By-Laws, a copy of which is in my possession, is apparently the model upon which all later building associations have been constructed and the points of difference between them and those of a modern building association are surprisingly few. The affairs of the association were not formally wound up until June ro, I84x, but no payments were made after January II, and this, not the former date, is the time of maturity. (Wrigley, in his work on building associations, page 23 , confuses the two dates.) A second association bearing the same name was organized on January 30 , I841, which matured in March, I852, and a third one, also bearing the same name, was organized on January $2 x, 1852$. 
"The partnership feature of building associations, one of their most prominent features, is emphasized by the popular name for the Oxford Provident, viz., that of 'Club,' by which name in Frankford the building associations are popularly known. To this day, in the locality in which they originated and in which almost every man, woman, and child in the community is familiar with them, they are invariably referred to as the 'Building Club.'" ?

Similar statements to the same effect are found in the newspaper files, such as the following, which introduce names of men who have been forgotten as pioneers in the work:

"The ... building and loan association ... idea was brought from England by Samuel Pilling and Jeremiah Horrocks, manufacturers, and Dr. Henry Taylor. . . . The suggestion was submitted by them to Isaac Shallcross, a surveyor and conveyancer, and Jesse Y. Castor, a lawyer, and a club was formed upon a plan as near that of the English 'clubs' as could be arrived at without either written or printed guides." 8

Development after the formation of the first association was slow, being in the nature of a "feeling-out" process to discover the most successful procedure. Judge Dexter, one of the most careful students of early associations, told of their early development at the U. S. League Convention in 1900 as follows:

"In this primitive association there was only a single series of stock issued. . . . Its funds were loaned only to its shareholders, and to no one shareholder could be loaned a greater sum than the matured value of the shares held by him. The only security accepted for a loan was a first mortgage upon real estate or its own shares of stock, the accumulations on which exceeded the amount of the loan made. At the regular monthly meetings of the shareholders, held in the evening, the dues were paid in, and after such payment the funds received were offered in open meeting

${ }^{7}$ From the Address of Robert T. Corson of Philadelphia before the 1899 Convention of the United States League of Local Building and Loan Associations. Mr. Corson was solicitor for the Decatur Building and Loan Association and Treasurer of the United States League until his death in 1921 .

${ }^{8}$ From the Frankford Herald, January 14, 1888. 
and the right to a loan sold to the highest bidder. . . . In the event no one wanted to borrow, parties holding shares upon which no loans had been made were compelled to become borrowers. These were called forced loans.

The reason for forced loans is clear. Under this scheme every shareholder must become a borrower to the matured value of the shares held by him before his shares could mature, except as to the receipts of the last meeting at which the matured value of the shares was reached. The borrower paid interest on his loan same as now, but a very different concept was entertained as to such interest payment from that entertained at the present. It was not called interest, but redemption fees or dues. ... The shareholder who in the early days of the existence of the association was able to obtain the full matured value of his shares, was enabled to build his home at once, and the term 'redemption' of his shares was in use instead of a 'loan' upon his shares, and the sum he paid monthly in addition to his dues, until the shares did actually mature, was called 'redemption fees' or 'dues.' The sum which he paid at the bidding for a redemption of his shares was called a 'premium.' . . . The matured value of shares in this association was $\$ 500$.

"The first change made . . . was in 1847 , in the Franklin Association, organized in Philadelphia, in which dues payable nonthly were placed at $\$ 1.00$ and matured value of shares $\$ 200$. That has continued as the standard form in Pennsylvania. . . Prior to 1850 these associations in Philadelphia were not incorporated. Their property was held by trustees in trust for the shareholders. ...

"The methods of this primitive association seemed ... to have three defects, namely, the dissolution of the association when the stock matured; the large amount of back dues which the new shareholders weuld have to pay who took shares after the association had been running for some time; and lastly, the making of forced loans. . . .

"To overcome these defects the serial method of issuing shares evolved. I have not been able to learn the name or date of the first association conducted that issued its stock on the serial plan, or the first association that evolved the further change of conducting its finances upon the principle of a co-partnership.

"Whoever was responsible for both changes did much to forward the growth and development of this form of coöperation, and their names ought to have place in the history of this movement. ${ }^{9}$ With the application of the principles of co-partnership to the serial plan, naturally the frequency of the issuing of a new series of stock increased, so that associations were formed issuing semiannual, quarterly, bimonthly and even monthly series. And going still further in this direction there evolved

\footnotetext{
- These names have not yet come to light.
} 
in Ohio the so-called permanent plan, whereby stock could be taken at any time, and the shares of each shareholder were dealt with separately in conducting the affairs of the association." 10

In spite of the fact that between I83I and I849 fifty or more associations were organized, none of them were incorporated until 1850 , when the State of Pennsylvania passed a law providing for their incorporation with a limitation of the amount of stock to 500 shares. In 1859 this limit was raised to 2,500 shares of $\$ 200$ each. In 1874 another amendment changed the limit under the Pennsylvania law to an aggregate value of $\$ 1,000,000$ of outstanding shares, regardless of the number, and later laws have made it possible for associations to issue any desired amount of capital stock. Official records show that during the decade 1860 to 1869 inclusive, I 48 associations were chartered in Pennsylvania; from 18701878,370 associations were chartered; in 1876 , there were 450 incorporated associations in the city of Philadelphia alone, and that city now has some 2,000 associations.

From Pennsylvania, the coöperative movement spread into other states at a wonderfully rapid rate. They flourished especially in St. Paul, Minneapolis, and other points in the northwest, although the troubles of the "national" associations following the panic of 1893 caused a severe setback in this region and present development there is less active than in other sections of the country.

The first association in Maryland was organized in 1843 ; in New Jersey, I847; Illinois, I849; New York, I848; Massachusetts, I850; Ohio, I857; Michigan, I86r*; Georgia, I866;

${ }^{10}$ From the address of Hon. Seymour Dexter, Elmira, N. Y., before the United States League of Local Building and Loan Associations, 1900. Judge Dexter was president of the N. Y. State League in 1892 when he called a "World's Congress" of Building and Loan Associations, which assembled in Chicago at the Grand Pacific Hotel, April I4, 1892. From this "Congress" grew the United States League of Local Building and Loan Associations. Judge Dexter was, therefore, the founder of the United States League. He was also the author of the sentiment The American Home-the Safeguard of American Liberty. He died May 5, 1904. 
Texas and Delaware*, I867; Kansas, r868; Minnesota and Arkansas, I869; North Carolina and Iowa, r870; Louisiana and Tennessee, I873; Wisconsin, Utah*, and Maine*, r883; Connecticut, I886*; New Hampshire, I887; Colorado, I889*; Oregon and Oklahoma, I $890 .^{11}$

In Massachusetts the system had a large early growth. Many terminating associations existed between 1856 and 1860 , but due to certain faults in the method of computing maturities, growing out of ignorance of the true building and loan plan, these associations had financial difficulties after a few years of operation. The serial plan was adopted as an alternative and many of the troubles disappeared. The plan of most of the associations now existing in Massachusetts is a modifcation of the serial plan as used in Pennsylvania, New Jersey, and elsewhere. After much opposition, the name "coöperative bank" was substituted in the law of Massachusetts in 1883 for the extremely long name formerly in use. ${ }^{12}$

The modest beginnings in Pennsylvania and other eastern states scarcely presaged the marvelous development of the movement over the country as a whole during the past few years. The sudden upward slope of the curve in Chart Io indicates clearly the way in which these associations have provided additional funds to meet the housing shortage since the Great War.

\section{Few Comprehensive Statistics Available}

In 1893 the first attempt was made by Carroll D. Wright, then U. S. Commissioner of Labor, to make a nation-wide survey of the building and loan associations in the United

11 The date of the first building and loan associations in states marked * were obtained from supervising officials of the respective states. Data in regard to other states are from Bliss, New Encyclopedia of Social Reform (1908), except that of Oklahoma which was taken from a report by W. M. Malone in Proceedings of the Ioth Annual Session of the Oklahoma State League, 1922, p. 53.

${ }^{13}$ Chapter 298 , Massachusetts statutes of 1883 , quoted by D. Eldredge, Massachusetts Coöperative Banks, 1893. 
States. As a result of this investigation, he published the most complete report that has ever been issued on building and loan associations, and the only one available that covers the whole field. No other organization but the government has sufficient funds for such a purpose, and a new report with similar information now would place the statistics of building and loan associations in their proper place with those of other

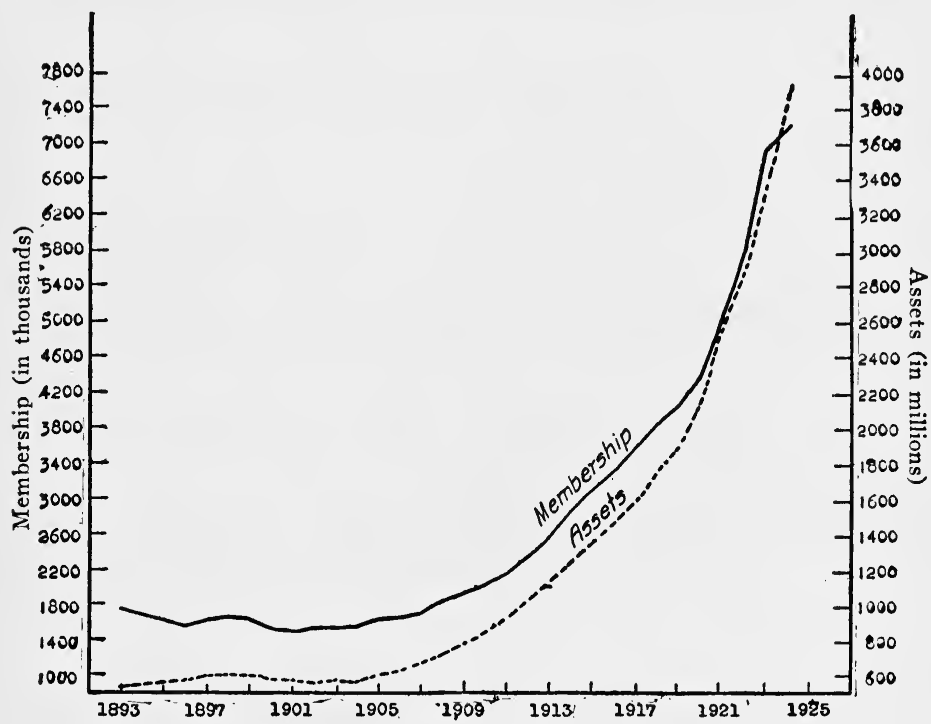

Chart ro.-Changes in membership and assets of building and loan associations, United States, I893-1924. (See also p. 516.)

great financial institutions of the country. Officers of the various leagues are now asking Congress to make such a survey with the facilities of the Census Bureau.

Since I893, H. F. Cellarius, Secretary of the United States League of Local Building and Loan Associations, has prepared as complete information as possible with the funds at his command, but he has been hampered both by lack of funds and lack of help. Association reports in many states are not assembled by any organization, public or private. Wherever 
a properly financed state supervisor of building and loan is at work, these records are being brought up to date, but only a few of the 37 states (and the District of Columbia) which have some measure of supervision have complete figures.

All reports by $\mathrm{Mr}$. Cellarius have been used in preparing the tables in the Appendix from which the summary shown in Table XXIX has been compiled. Probably the figures of greatest significance in Table XXIX are:

(I) The number of people which the associations are reaching (last column).

(2) The average assets which the associations have accumulated based on the number of people in our total population (whether members or not,-column 7).

(3) The average assets per member (column 9).

TABLE XXIX

Assets and Relative Sizes of Local and National Building and Loan Associations in the United States in 1893, I903, I9I3, ANd I923

\begin{tabular}{|c|c|c|c|c|c|c|c|c|c|}
\hline YEAR & $\begin{array}{c}\text { POPU- } \\
\text { LATION } \\
\text { I000'S }\end{array}$ & $\begin{array}{l}\text { No. of } \\
\text { Assns. }\end{array}$ & $\begin{array}{l}\text { No. of } \\
\text { AssNS. } \\
\text { RPTG. }\end{array}$ & Assets & \begin{tabular}{||} 
AvER- \\
AGE As- \\
SETS \\
PER \\
ASSN.
\end{tabular} & \begin{tabular}{|c|} 
AVER- \\
AGE \\
As- \\
SETS \\
PER \\
PER- \\
SON
\end{tabular} & $\begin{array}{c}\text { NUMBER } \\
\text { OF MEM- } \\
\text { BERS IN } \\
\text { ASSNS. }\end{array}$ & $\begin{array}{c}\text { AVER- } \\
\text { AGE As- } \\
\text { SETS } \\
\text { PER } \\
\text { MEM- } \\
\text { BER }\end{array}$ & $\begin{array}{l}\text { MEM- } \\
\text { BERS } \\
\text { PER } \\
\text { IOOO } \\
\text { POPU- } \\
\text { LA- } \\
\text { TION }\end{array}$ \\
\hline $\begin{array}{l}1893 \\
1903\end{array}$ & $\begin{array}{l}62,622 \\
76,303\end{array}$ & $\begin{array}{l}5,838 \\
5,336\end{array}$ & $\begin{array}{r}5,796 \\
. . \ldots\end{array}$ & $\begin{array}{r}\$ 528,852,885 \\
577,228 \text { 0 1 } 4\end{array}$ & $\left|\begin{array}{l}\$ 90,588 \\
108,176\end{array}\right|$ & $\begin{array}{r}\$ 8.45 \\
7.56\end{array}$ & $\begin{array}{l}\mathrm{I}, 745,725 \\
\mathrm{I}, 530,707\end{array}$ & $\begin{array}{r}\$ 303.94 \\
377.10\end{array}$ & $\begin{array}{l}27.87 \\
20.06\end{array}$ \\
\hline 1913 & $91,97 \mathrm{I}$ & 6,273 & $\ldots$ & $\mathrm{I}, \mathrm{1} 37,600,648$ & $18 \mathrm{I}, 348$ & 12.37 & 2516,936 & 451.98 & 27.37 \\
\hline 1923 & 105,707 & 10,009 & $\cdots$ & $3,342,530,953$ & 333,952 & $31.62 \mid$ & 6,864, I $_{4}$ & 486.96 & 64.94 \\
\hline
\end{tabular}

1 Population figures taken for 1890,1900 , 1910 , and 1920 respectively.

The Rise and Fall of the National Associations

Of the associations in existence in 1893 , according to the Wright report, 5,598 were local and 240 national, a total of 5,838 .

STATISTICS FOR 1893

\begin{tabular}{|c|c|c|c|}
\hline Associations Reported & SHAREHOLDERS & Total Assets & $\begin{array}{c}\text { Average } \\
\text { ASSETS } \\
\text { PER MEMBER }\end{array}$ \\
\hline $\begin{array}{r}5,560 \text { locals } \ldots \ldots \ldots \ldots \\
236 \text { nationals } \ldots \ldots \ldots\end{array}$ & $\begin{array}{r}\mathbf{I}, 359,366 \\
386,359 \\
\end{array}$ & $\begin{array}{r}\$ 473,137,454 \\
55,7 \text { I } 5,43 \mathrm{I}\end{array}$ & $\begin{array}{r}\$ 348.06 \\
144.20\end{array}$ \\
\hline 5,796 total $\ldots \ldots \ldots \ldots$ & $1,745,725$ & $\$ 528,85^{2,885}$ & $\$ 302.94$ \\
\hline
\end{tabular}


It was the introduction of the national association which changed the whole trend of the movement and interrupted the development of this type of economic coöperation which had been started so effectively, and nearly caused its downfall.

Coopperative associations have always been difficult to manage because of the large number of members who must be pleased. Possibly continued building and loan success in the local field is due in large measure to the known safety of funds and to the large profits and other benefits which have accrued to the individual member. It is easy to please a member by paying him handsome profits on his investment; and since the operating expenses of the local associations are small, there is a maximum amount available for such profits. But these profits are also attractive to the grasping exploiter, and in the absence of restrictive legislation, men always seek the opportunity for large and easily acquired profits. Had the movement not been so firmly grounded in the fundamentals of justice and coöperation, the effect of the catastrophe that befell the national associations would have been very different.

Such marked success had attended the formation of the original local associations throughout the country that homeseekers everywhere sought to take advantage of this new and successful plan of securing a hoped-for residence. When new associations were formed to do business on a nation-wide scale, people readily joined them and paid in their savings, not realizing that the work undertaken was radically different in character from that of the local associations. Many of the new promotions were merely experiments, trying out new plans. Agents were sent over the country soliciting memberships and loans. Contact between the shareholders and the officials of some of these companies was impossible, and loans were made by mail with no personal inspection of either the security or the individual borrower. As a result, borrowers with poor reputations who were unable to obtain funds from local lenders became the principal customers of the national associations. 
The loans were nearly all of a low grade. Improper security was frequently accepted, and heavy losses occurred.

The period from I 885-I 893 was a boom period in real estate as in other values. Loans made on the basis of inflated values could be no stronger than the real security behind them. When all values crashed with the panic of 1893 , hundreds of lenders on mortgages throughout the country found that the property was not worth as much as the loan, and were obliged to take over the security and liquidate it as best they could. Borrowers in most cases lost all their interest in the mortgaged premises, and even the most conservative lenders had great difficulty in realizing the amount of their loans.

"Strange as it may seem, the financial panic of 1893 gave [the nationals] a new impetus, mainly on account of the tightness of the money market with a consequent unlimited demand for loanable funds. Field agents did a land office business, as it were, in 1894 and 1895 , selling shares and collecting fees on promises of loans." 13

It was impossible to keep the promises in many cases. The 236 nationals are reported to have collected more than $\$ 250,000,000$ and loaned about $\$ 150,000,000$ in the hey-day of their existence. Large expense accounts ate up the difference. Such a state of affairs could not last. Loans made in a period of falling values are always uncertain, and companies entering a community to compete with local funds are less likely to get the cream of the business.

"The writer has been asked on more than one occasion how the national associations succeeded in getting any good risks at twelve per cent interest, when local money went abegging at six and seven per cent. They put this over in two ways: first, they would loan, knowingly or otherwise, up to sixty and seventy-five per cent, of a given valuation. Builders and others would take advantage of this, keep up their payments of \$15.00 and \$16.00 a thousand (monthly) until they had 23 "National Installment Loan Companies," American Building Associa" tion News, October, 1923, p. 460. 
worked the margin down to fifty per cent, then go into a local bank and obtain funds to pay off their loans to the 'foreign' company. No one is going to pay twelve and thirteen per cent for money to build or buy a home on long-time basis when he can get the needed financial help at one-half of these rates.

"Had the 'nationals' been able to mature their shares (all loans carried collateral shares equivalent to their face) in the seven or eight years the agents and the printed matter of the companies represented as the probable time of maturity, or had they been able to mature these $\$ 15.00$ and $\$ 16.00$ monthly payments (of which $\$ 10.00$ and $\$ I I .00$ went for interest and premium) even in 100 months, they might have fared much better. A loan of $\$ 1,000$ at $\$ 15.00$ a month, were it to run out in roo months, would not be a bad investment for the home buyer, but when these loans (or the ten collateral shares) had reached a book value of only $\$ 500$ or $\$ 600$ in seven years, the disaffection of borrowers and free shareholders in a community was sure to manifest itself with no uncertain sound. There were always plenty of local sages to point out to the honest borrower where he stood in the matter of credits on his loan. And the dishonest borrower was usually selling his land and improvement to the obliging foreign bidder-'unloading' in other words." 14

A crash was inevitable, especially when fraud was added to the other evils of the movement. The national associations reached their peak about 1896 . In that year the movement ceased expanding, and the inevitable crash followed the failure of one of the largest of the national concerns in the spring of 1897. This was called the Southern Building and Loan Association, of Knoxville, Tennessee, with $\$ 5,000,000$ of assets on its books. With the first of the nationals in trouble, the others fell after it like a row of dominoes.

Causes of the Fall of the Nationals.-Judge Dexter, the

" "National Installment Loan Companies," American Building Association News, October, 1923, p. 462-3. 
founder of the United States League of Local Building and Loan Associations, believed that both fraud and the too large growth of the individual national associations contributed to the catastrophe.

"The curse and blight of the building and loan association movement in recent years has been the evolution of the national association.

"The issuing of paid-up shares and fixed premiums by permanent associations, conspiring with the enthusiasm of ignorant men in some cases, but in most with the cupidity of designing scoundrels, are responsible for the appearing of this gigantic swindle in our land. . . .

"There were some honest enthusiastic men in the early days of the national association development, that reasoned and believed that if a small association run by wage earners and men untrained in finance could so uniformly make money, a large association run by expert men could make even more money. Many men of financial standing and reputation permitted their names to be associated with their management. These men [did not] clearly perceive that increase of business does not increase profits, and cannot, because every new dollar taken into the business shares in the profits made."15

Judge Dexter did not mean to imply that each new dollar brought into a legitimate association business could not be used profitably. One dollar properly invested by an association will earn the same profits as another. The failure of the nationals was in part due to the fact that they expected to receive an extra profit from each new dollar for themselves and for the existing members by doing a large-scale business and thus reducing expenses. But it is necessary to pay dividends to the savings members first and since they are entitled to all that their money has earned after expenses, there can be no legitimate surplus profit for the organizers. Judge Dexter would be the last to say that mere size hampers the

${ }_{25}^{25}$ Judge Dexter's address in 1900 before the United States League of Local Building and Loan Associations. 
efficiency of a properly conducted association. Until the existing need for loanable funds is met, it is difficult to establish the limit of profitable expansion.

The most complete discussion of the old national associations that is now available may be found in a series of articles published during 1923 and 1924 in the American Building Association News. ${ }^{16}$ The writer of the articles referred to believes that the local building and loan association owes much to the nationals. "The 'locals,' by the way, are surely indebted to the 'nationals' for waking them up to the possibilities of more pep and publicity. . . . The State League of New York and the United States League of Local Building and Loan Associations naturally became alarmed in those peak days by their aggressions. . . . The nationals themselves felt confident, for at that period of their career they had not scored many serious losses." 17

"The exceptions to this experience-the well-managed statewide or regional companies, that had fared better because of more capable and honorable management, and because of a competent system of field supervision of their risks-were not dragged down in the general upheaval. But these companies were few and far between. A half dozen survivors out of a

10 "National Installment Loan Companies," American Building Association News, Vol. XLIII, 1923.
April, pp. 167-171;
July, pp. 31 1-3I 3 ;
May, pp. 210-21 2 ;
September, pp. 4I6-4I9;
June, pp. 254-257 ;
October, pp. 460-463.
"Looking forward from '76," American Building Association News, Vol. XLIV, 1924.
February, 70-72;
October, 448-449;
April, I70-173 ;
November, 492-494 ;
September, 400-403；
December, 542-544.

The writer of this series of articles according to his own statement "went through with them as a journalist of their successes and failures, from their inception to their final collapse."

17 "National Installment Loan Companies," American Building Association News, October, 1923 , p. 460. 
score of dozens, operating on a more than local basis, merely proves the rule that the national loan association movement was a transitory one, carrying the seeds of disintegration in its plans and policies. As a national movement it was foredoomed to failure. As a near-local or state-wide experiment, it has succeeded in a half-dozen states, and those who still contend for its integrity may point with pride to a half-dozen successful companies that were organized in the 9o's and are 'going strong' to-day."18

\section{Period of Expansion}

In spite of the great recent growth of the movement, it appears to have taken twenty years (I893-I9I3) for the associations to find their way back to public favor, after the disastrous effect of the national associations during the 90's. Only by I9I 3 were the same number of people per Ioo० population being reached as in 1893 . The lowest point for membership was in I90r when only $\mathrm{I}, 495,000$ persons were recorded as shareholders, and during the following year (I902) total assets reached their lowest point of $\$ 565,387,000$. It will be remembered that these years marked the culmination of the greatest industrial expansion that the United States has ever known. People were interested only in large and quick profits. With the nervous activity which always accompanies a rapid industrial expansion out of the way in rgor, the local associations had a chance to prove their ultimate reliability. Loans were restricted by practically all associations to property in their immediate locality. The sound common sense of the managers prompted this action, and in addition restrictive laws were passed in many states which made it mandatory. A few states forbade all "foreign" associations to enter. (Associations are known as "foreign associations" when they have their home office in another state.) Others required a deposit of securities to insure the faithful performance of contracts

28 "National Installment Loan Companies," American Building Association News, October, 1923, pp. 462-3. 
made in the state. The local association thus has a fairly free field for its operation.

The swing of the pendulum of public favor away from the associations and back again has been more than made up by the later rush into membership. There is still ample room for extending the usefulness of the associations in every state of the Union, particularly in those states which are below the average. Unfortunately the figures are incomplete because of lack of information in many of those states where there is no state supervision, but the estimates used in compiling the tables are believed to be reliable.

\section{TABLE XXX}

Ciranges in the Business of Building and Loan Associatrons as Shown by Averages of People Reached and the Accumulated Resources ${ }^{1}$

\begin{tabular}{|c|c|c|c|c|c|c|c|c|c|}
\hline \multirow[b]{2}{*}{ YeAR } & \multicolumn{9}{|c|}{ Averages for the United States } \\
\hline & $\begin{array}{c}\text { Mem- } \\
\text { bers } \\
\text { per } \\
\text { Iooo } \\
\text { Popu- } \\
\text { lation }\end{array}$ & $\begin{array}{c}\text { High- } \\
\text { est } \\
\text { State } \\
\text { Re- } \\
\text { ported }\end{array}$ & $\begin{array}{c}\text { Lowest } \\
\text { State } \\
\text { Re- } \\
\text { ported }\end{array}$ & $\begin{array}{l}\text { Assets } \\
\text { Per } \\
\text { Person } \\
\text { of } \\
\text { Popu- } \\
\text { lation }\end{array}$ & $\begin{array}{l}\text { High- } \\
\text { est } \\
\text { State } \\
\text { Re- } \\
\text { ported }\end{array}$ & $\begin{array}{l}\text { Lowest } \\
\text { State } \\
\text { Re- } \\
\text { ported }\end{array}$ & $\begin{array}{c}\text { Assets } \\
\text { Per } \\
\text { Mem- } \\
\text { ber }\end{array}$ & $\begin{array}{l}\text { High- } \\
\text { est } \\
\text { State } \\
\text { Re- } \\
\text { ported }\end{array}$ & $\begin{array}{l}\text { Lowest } \\
\text { State } \\
\text { Re- } \\
\text { ported }\end{array}$ \\
\hline $1893 \ldots$ & 27.87 & 93.90 & 2.29 & $\$ 8.45$ & $\$ 29.2 \mathrm{I}$ & $\$ 0.28$ & $\$ 303.94$ & $\$ 843.4 !$ & $\$ 124.07$ \\
\hline $1903 \ldots$ & 20.06 & 56.59 & 1.26 & $7 \cdot 56$ & 26.68 & .61 & 377.10 & 749.65 & 245.02 \\
\hline $1913 \ldots$ & $27 \cdot 37$ & 97.37 & I. 93 & I 2.37 & 53.52 & .67 & 451.98 & 804.20 & 291.44 \\
\hline $1923 \ldots$ & 64.94 & $2 \mathrm{I} 5.14$ & 2.46 & 31.62 & I I 3.84 & I. 49 & 486.96 & 1014.22 & 228.15 \\
\hline
\end{tabular}

1 The figures in this table are derived from Table XXXV of the Appendix, together with data for intervening years.

A comparison between the number of homes owned and rented and the amount of building and loan assets shows a similar situation. (Chart I I.) As shown in this chart, owned homes increased faster than building and loan assets from I 893 to I9IO. After that and until I9I 7 the associations began to recover their lost ground and since $19 \mathrm{I} 7$ the proportional increase has been very great. The table on which this chart is based will be found in the Appendix (page 5I4).

"The concepts of the promoters of the primitive associations have been enlarged by successive generations of workers, until the concept of the modern association is far different from the primitive one. But the main purpose and object of 
the first has steadily been maintained, to wit, stimulation to the building and owning of homes. The movement has accomplished and is accomplishing a grand work in this direction, and deserves the support and encouragement of every lover of the Great Republic."19

Other Countries.-Meanwhile similar movements have been going on in other countries, though much less vigorously,

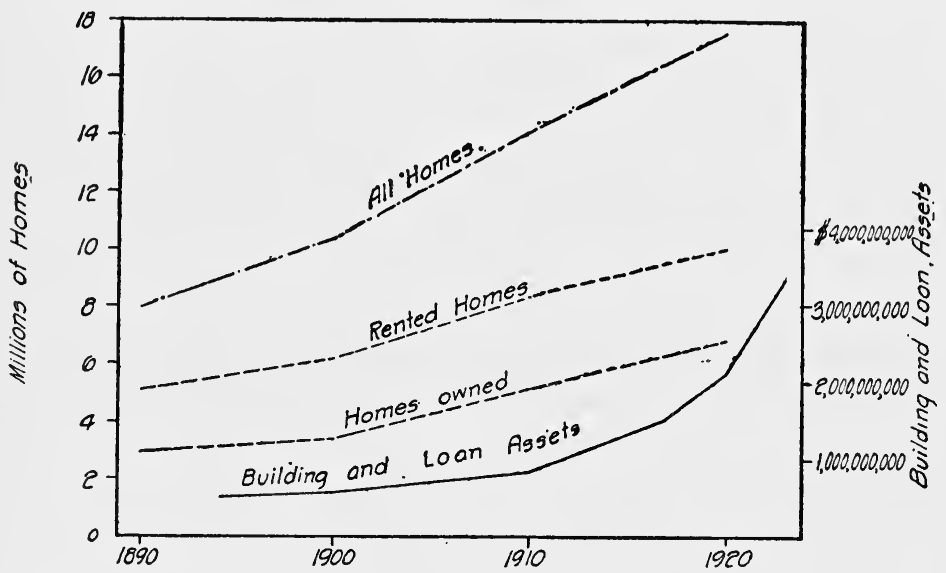

CharT II.-Increase in building and loan assets compared with increase in home ownership in the United States. (Data on ownership from the U. S. Census.)

in the direction of promoting home ownership. There has been very little distinctive building and loan development outside of the United Kingdom and the United States. Coöperative credit elsewhere has been used principally for short-time needs, such as are evidenced by personal notes. "Credit unions" are the outstanding development of this type.

Belgium.--In Belgium a mixed official and philanthropic

19 These closing words of Judge Dexter's address at the convention of the United States League in 1900 apply as well to-day as the day he uttered them. The achievements of the movement in the past are but a stepping stone for the things which it should be able to accomplish for future generations. 
system exists, under which some fifty or sixty "committees of patronage" have been formed for aiding workingmen to borrow. Some of these committees are established directly by the government, and some by local authorities. The Government Savings Bank may be empowered by these committees to make advances to societies of money or credit to enable their members to build homes. The advance is made to the society usually at 3 per cent interest, sometimes at $2 \frac{\mathrm{t}}{2}$ per cent and the borrower pays 4 per cent. The societies are allowed to advance to the borrowers as much as nine-tenths of the value of a house.

Germany.--In Germany coöperative associations are known as "Societies for Self-help," but they are few in number and are overshadowed by a far greater number of coöperative banks or "Compulsory savings-banks" organized by Herman SchulzeDelitzsch (1808-1883), and the Raiffeisen coöperative ruralcredit banks founded by Frederick William Raiffeisen (1818I 888$).^{20}$

"The first coöperative society in Delitzsch was founded for the purpose of purchasing merchandise. Afterwards they formed other societies not only for purchase, but for production and for sale. . . . They also formed societies to build houses for peasants and working people. . . Each member was liable for all the liabilities of the society, which gave the societies a high standing and credit."21

The best methods of operating all these institutions were discovered only by a slow trying-out process, which gradually placed more responsibility on the shoulders of those who benefited by the society.

"One thing Raiffeisen learned from this experiment. $\mathrm{He}$ became forever convinced that the crying need of the poor was not for philanthropic aid, but for some sort of organization

${ }^{20}$ See Roy F. Bergengren, Coöperative Banking-a credit-union book. (N. Y., Macmillan Co., 1923.)

21 "Interviews on the Banking and Currency Systems of ... Germany," National Monetary Commission Report. (Senate Doc. 405, 61st Cong., and Session, 1910, p. 453.) 
which would enable them to obtain credit funds for themselves." ${ }_{22}$

On the whole the German societies have shown a remarkable development, but the greatest amount of coöperative credit has been made available for purposes other than for residence construction.

Scandinavia.-In Scandinavian countries there have been organized many excellent coöperative mortgage banks, which serve to aid in financing home-building and in cheapening and thereby facilitating mortgage credit.

France.-In France the Crédit Foncier has arrangements providing for the repayment of mortgages in monthly installments according to definite plans. Dr. Charles Pranard's work in laying a sound foundation is the outstanding feature of the movement. The French government has recognized the beneficial effects to be derived from it, and passed legislation exempting building societies from taxation and has aided them with investments of government money. Consequently, the number of building societies in France is continually increasing.

In the British colonies, and in Italy, Spain, and Russia also, this coöperative saving and home-building idea has been developed.

Japan.-In Japan, the "Mujin" or Mutual Loan Societies, which are said to be of very ancient origin, have been newly regulated of late by the Mutual Loan Societies Law of r9r5. They were however not primarily organized for financing homebuilding. They are similar in nature to the coöperative banks common in Europe. By I9I7, there were 173 such societies existing in Japan, with an authorized capital of $8,905,000$ yen, of which sum 3, I I I,93 I yen had been paid up. ${ }^{23}$

According to M. Takayanagi, Secretary of the Osaka Chamber of Commerce, "The first coöperative associations in

${ }^{22}$ C. R. Fay, Coöperation at Home and Abroad, quoted by Hector Macpherson "Coöperative Credit Associations in the Province of Quebec." I9ro.

${ }^{23}$ Henry W. Wolff, People's Banks, 4th edition (London, 1919), p. 359. 
Japan were established in 1892 , and the laws regulating the associations were promulgated in $1900 . \ldots$ In 1922 the number of the associations increased to 14,047 , with a total membership of 2,736,947." Most of these were formed for purposes other than home ownership, including "sales, savings, consumption, and utility."

"There are 20I prefectural federations formed by the above associations at present. In addition, in 1905 a central bureau for all the associations was formed in Tokyo for the purpose of aiding in the establishment of similar associations and in the development of the coöperative movement. Last year a Central Kasse for financing the associations was established by the Government." 24

\section{SPECIAL REFERENCES}

England. Iowa League Proceedings (I9I5), p. 34. U. S. League Proceedings (I9I3), pp. I42-I6I; (I9I9), pp. 44-62. Youngstown Institute Proceedings, March 8, I923, pp. 2-5.

France. U.S. League Proceedings (I909), pp. II9-123; (I913), pp. I80I85; (I9I4), pp. I24-I45.

Germany. Bosse, Alwin, Die Forderung des Arbeiterwohnungswesens durch die Landesversicherungsanstalten. Jena, 1907.

History of building and loan. Development of building and loan associations in the United States, Monthly Labor Review, October, I923, v. I7, p. 192. Johns Hopkins University History Studies, History of Coöperation in the United States, Vol. VI, I888. U. S. League Proceedings (I9I4), pp. 83-94; (I9I5), pp. 67-69. Youngstown Institute Proceedings, March 8, I923, pp. 2-8.

Japan. Ogata, Kryoshi, The Coöperative Movement in Japan (1923). National Associations. U. S. League Proceedings (rgoo), pp. II5-ri6; (I924), pp. III-II6.

Status of European Associations as a result of the War. U. S. League Proceedings (I9I6), pp. I23-I37; (I9I7), pp. I69-I78.

\section{GENERAL REFERENCES}

Rosenthal, Henry S. Cyclopedia, pp. IO-I 2 ; 29-34; r40-r4r.

Sundheim, Joseph H. Law, pp. I7-18; 29.

${ }^{24}$ Letter from M. Takayanagi, Secretary, The Osaka Chamber of Commerce, Osaka, Japan, June 4, 1924, to the American Savings, Building and Loan Institute. 


\title{
PART VII
}

\section{COÖPERATION AS THE BASIS OF EXPANSION}

\author{
CHAPTER XXIV
}

\section{LEAGUES, INSTITUTES, AND SYSTEMS}

Need for clearing houses; possible national system; proposed federal home-loan bank; security for movement of funds within a national system; effect of a national system on interest rates; Land Bank of New York; its organization, rural credit possibility, membership requirements, management, conducting the business, limits upon amounts to be borrowed, security delivered; inter-association loans, a step toward clearinghouse organization; league and group action; local and state leagues, United States League; the American Savings, Building and Loan Institute an outgrowth of the educational work of the U.S. League.

The day of individualism in the association movement is definitely past. Our financial structure in the United States is complex, and all financial institutions, except the building and loan associations, are tied together so that they not only interchange information and assist each other in education, but even come to each other's aid, when necessary, by moving funds from parts of the country where they are plentiful to other parts where they are needed. There is a need of a complete structure of the same sort to function for the building and loan associations. It has long been the ideal of leaders in the movement to bring about effective coördination throughout the country.

Need for Clearing Houses.-Just as the building and loan association functions as a clearing house for its members by directing individual savings into a secure type of investment, so the building and loan associations of a given town or state are coming to establish clearing houses among them- 
selves. The latter need not be for the purpose of exchanging only money and securities. The essential thing to accomplish is the exchange of definite information about many items of common interest. These include: (I) valuation of property in each district of a city, (2) methods of appraisement, (3) credit information, including lists of people who have attempted overborrowing on their property or other fraudulent practices, and (4) successful methods of advertising and business development.

Business methods now in use are very diverse. In some places associations are not well enough understood by the people in the community to attract enough savings into this soundest form of real-estate security. In other parts of the country, the association is so well developed that there is often overaccumulation of funds. The excess can easily be transported by a system perfected for that purpose. Where no organization exists, peculiar methods have grown up to dispose of such funds. Money has been loaned sometimes by means of a syndicate, by which the individual association loses control over the investment, placing it through a lawyer or a committee representing a number of associations. Occasionally such syndicated loans are made on poor risks in order to take advantage of the large commissions which accrue to the members of the syndicate. The associations of the country should be tied together as definitely as the Federal Reserve Banks and the Federal Farm Loan and Joint Stock Land Banks in order to obviate unsavory and inequitable practices.

A National System.-Both of the federal banking systems are the outgrowth of long investigations and careful planning extending over a considerable period of time (particularly from 1905-1914). The savings and loan associations of the State of New York were at the same time working out a plan which grew into the Land Bank of that state, and the New York methods were considered by the framers of the federal system of land banks. So successful have the coordinated activities of the Federal Farm Loan Banks become 
that, after only a few years' operation, millions of dollars have been secured for investment in farm mortgages at a very reasonable rate of interest.

The time will no doubt come when all the building and loan associations of the country will work together on a basis similar to that outlined for the Land Bank of New York and the two federal systems. These central banks will function as clearing houses for member institutions. They will secure funds at a minimum of cost in parts of the country where they are available and through the coöperation of other banks will lend them to associations, which in turn can place them upon mortgages in the same way as funds obtained at home. The time is about ripe for such an organization, and it is suggested that building and loan men should renew their efforts for a complete national system with this end in view.

A Federal Home-Loan Bank for this purpose has been proposed at several sessions of Congress, but the bill has failed of passage, probably because tax exemption was asked for the bonds which such a bank system could issue. In I92 I efforts to secure the passage of this bill were postponed by the legislative committee of the United States League, and the committee still has the matter before it.

Security for the Movement of Funds.-Money loaned between associations under a land-bank scheme is secured by individual mortgages and the note or promise of the borrowing association.

It is true that the risks of the individual mortgage may be unknown to the central institution where the mortgages are assigned as security for loans. The central organization, however, can retain the right to investigate and appraise as in the case of the individual association, and it also has the note of the association promising to repay the amount advanced. Bonds issued by the central institution can readily be sold because of the joint security, and an association is thus able to obtain money at rates lower than it must pay to savings members at home. The bonds of the Federal Farm Loan 
Banks at present bear about 4.5 per cent interest, but have been sold during the year 1924 on a 3.75 per cent basis, which means that they are highly regarded by the average investor. Association clearing house bonds such as the Land Bank bonds of the State of New York do not have the advantage of the tax-exemption privilege of the Federal Farm Loan Bonds, and, therefore, the return of interest must be somewhat higher. In spite of this fact, the sale of Land Bank bonds in New York has been ample to take care of the needs of the associations in the state.

A national system of this kind would relieve the high interest rates now prevailing in many parts of the country, because funds secured by bond issues from a central organization could be loaned by individual associations at a rate not greater than the issuing rate by more than one-half of one per cent. In a time when the ostensible rate charged by building and loan associations in the United States runs as high as ro per cent in certain sections of the West (the actual rate in some cases being much higher) while the same type of money is available in other sections at 5 or 6 per cent, the need for such an institution is apparent. By proper organization the sale of these bonds would insure a continual supply of funds to all worthy applicants having good security.

Land Bank of New York State. ${ }^{1}$ - In order to understand definitely the above proposal, it is necessary to get before us the methods used by the Land Bank of the State of New York. This is a clearing house for savings and loan association funds. It is not in any sense a bank which loans directly to individuals on farm mortgages as might be implied by its name. The original name proposed for this Land Bank by E. F. Howell, Sr., after a careful study of European systems and institutions, was "The Clearing House of Building-Loan Associations of the State of New York." In fact, such an

1 The thanks of the writers are due Martin S. Cohen, First Vice-President of the Land Bank of the State of New York, for valuable suggestions in connection with this discussion. 
organization was duly organized and incorporated prior to the passage of the Land Bank Act of I9r4, but for certain reasons it never functioned. Mr. Howell's ideas later crystallized into the Land Bank, and he personally drew up the original by-laws and constitution, as well as the first draft of the law of r9r4. David B. Hutton, now managing director of the Land Bank; Robert B. Van Cortlandt, a banker of New York who had made a study of land credit systems in Europe; Thomas J. Skuse, and George I. Skinner, the deputy state superintendent of banking, were subsequently consulted by Mr. Howell, and after a long period of debate and discussion the bill was finally presented to the New York legislature and passed. The Land Bank idea involved the possibility of rural credit, but the farmer has made no practical use of the facilities so provided.

The funds obtained on Land Bank bonds are loaned to associations which in turn lend them on mortgages on either urban or rural property. According to Mr. Howell's own statement, the farmer can take advantage of these funds by organizing his own savings and loan association, or by making himself known to the existing associations in nearby communities. "It is his duty to make himself acquainted with the coöperative societies, to make the coöperative societies acquainted with him, and so, by intercourse, overcome whatever prejudice may exist against the making of a loan on farm property. This is the only manner in which the Land Bank is going to help the farmers." The original board of directors included men prominent in the study of rural credit, including Mr. Van Cortlandt and John J. Dillon, publisher of the Rural New Yorker.

The savings and loan associations of New York State have the privilege of becoming members of the Land Bank in their own name by owning one or more shares of $\$ 1,000$ each. The Land Bank in turn is directed by a board of fifteen members, who must be bona fide members of savings and loan associations. 
It issues its own securities which must be bonds secured by bonds and mortgages deposited with the Comptroller of the State of New York and countersigned by him. These bonds are issued in series which are amortized in ten years, one-tenth being payable annually. They may be issued in blocks of at least $\$ 50,000$, authorized by the Board of Directors, and can be issued as occasion warrants. By statute these bonds are legal investments for savings banks, trust funds and the sinking funds of the State of New York and of any of its political subdivisions. These securities are sold wherever funds are available for that purpose. The most frequent purchasers are banking institutions, state officials in charge of temporarily idle funds (including the state and city comptrollers), and brokerage and investment houses. A very large proportion of these bonds have found their way into the sinking funds of various state departments. No commission has ever been paid to a broker on these bonds, but the brokerage houses which have bought them have sold the 5 per cent bonds as high as \$102.50.

Whenever the officers of the Bank find that there is a demand from the member associations for funds, they look for available moneys; and when an offer for the purchase of bonds is received, every association in the State of New York is notified by the Managing Director in a circular letter, giving full information in the matter and requesting the associations to send in statements of their needs. This circular is sent to every association in the State of New York as every one of them is considered a potential member of the Land Bank. Upon receiving applications for funds, the Committee of the Land Bank makes allotments according to the amount available. Every association, regardless of its assets, receives an equitable share of the funds, providing its resources warrant the advance. When an association has borrowed money from other sources amounting to less than ro per cent of its accumulated capital, it may pledge 50 per cent of its mortgages as collateral for the advance of a loan; when such indebted- 
ness amounts to more than ro per cent and less than 20 per cent, it may pledge 25 per cent of its mortgages; when such indebtedness exceeds 20 per cent, it can receive no further advance from the Land Bank. With this limitation, for every share which the association owns in the Land Bank, it is entitled to secure an advance of $\$ 20,000$, and for each additional advance of $\$ 20,000$ desired, it may purchase another share in the Land Bank. Capital of the Land Bank thus is ever increasing and the interests of the bond holder are absolutely safeguarded.

Mortgages to the value of 125 per cent of the advance are delivered to the Land Bank as security, being assigned to the Land Bank in absolute form so as to protect the bond holder; and the Land Bank turns the mortgages over to the custody of the State Comptroller, who puts them in escrow until they are redeemed by the association. In addition to the pledge of securities, one year's collections on the mortgages are also paid over, and each association also pledges its total resources for the security of the loan. This provision is based upon the method used to secure issues of our national bank notes (U. S. bonds and the total assets of the issuing bank), and gives to the Land Bank bonds a degree of security which is unequalled in the investment market.

The association must also (a) furnish a sworn statement of its balance sheet, (b) make a true copy of appraisal from its records, (c) furnish the Land Bank with a statement of the present value, amount collected or credited to the repayment of each mortgage pledged, as well as the original amount of the mortgage, and the amount which the association can collect annually on each, and (d) must execute an agreement with the Land Bank to pay interest quarterly on the amount advanced plus one-half of one per cent commission, and agree to pay back annually one-tenth of the amount advanced.

Since its organization, the Land Bank has issued $\$ 5,400,000$ of bonds, of which $\$ 1,002,000$ have been redeemed, leaving outstanding $\$ 4,398,000$. The last issue of bonds, in Decem- 
ber 1924, bears interest at the rate of $4^{1 / 2}$ per cent. Some of the bonds have been sold as low as 4 per cent, but in no case has the bank paid more than 5 per cent interest on its obligations. Should an association fail to pay its obligation to the Land Bank, a receiver could be appointed to liquidate the business of the association, and the mortgages which have been pledged as security need be disturbed or sold to a third party only as a last resort.

Advantages of the Land Bank funds are thus apparent.

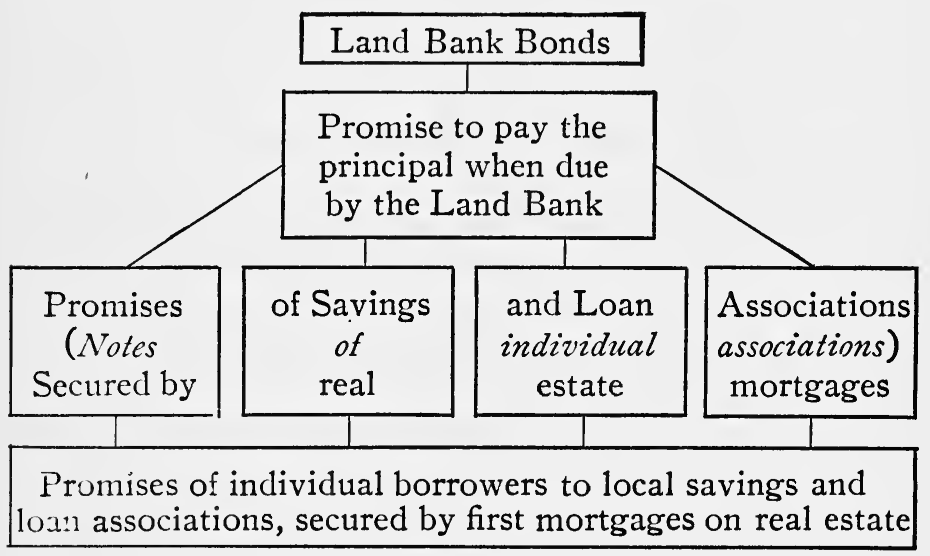

CharT 12.-Security behind the bonds of the Land Bank of the State of New York.

The association in a district where savings members have not been educated to the advantages of ordinary membership may obtain funds through the sale of these bonds by the central institution, and place them on mortgages in its own locality. The growth of an association under such conditions acts as a stimulant for ordinary membership in its own locality, because it establishes confidence. It is particularly desirable in places where the building and loan movement was seriously interfered with due to the malpractice of the national associations organized during the period of the ' 90 's. 


\section{Present Method of Making Inter-Association Loans.} - The extension of such a system to every state in the Union would be desirable, and the establishment of a national clearing house for these central state institutions is an ideal worth working for. The name by which the clearing houses are known is of small importance, so long as they promote the essential functions of building and loan practice.

Already something has been done in this direction in Ohio, Kansas, Louisiana, and a few other states, where the associations have taken advantage of the law which authorizes them to lend excess funds to one another. No bonds are issued in such cases, the associations using their corporate notes, secured in whatever manner is provided by their mutual agreement. At least six states (Colorado, Florida, Indiana, Iowa, Maryland, and Wisconsin) prohibit the assignment or transfer of mortgages owned by associations.

In Kansas, associations borrow on notes which are usually secured by the actual transfer of mortgages. The assignment of the mortgages is without recourse (that is, the endorser is protected from liability to the endorsee and subsequent holders of the instrument). The only charge in connection with such service is a slight adjustment of subsequent interest payments. The association which purchases such notes and mortgages may demand payment only in accordance with the original terms between the borrower and the selling association, and the selling association retains the right to recall these securities without penalty when it has excess funds on hand.

A state-wide clearing house like the Land Bank is only a step beyond.

League and Group Action.-Already there has developed within the movement a large amount of group activity for education of the public to an understanding of the building and loan business as a coöperative financial institution. This includes work for the training of executives and employees within the various association offices, for the adjustment of membership problems and loan problems, to secure adequate 
legislation, and in a minor way for the interchange of funds.

At present the various groups which are functioning most successfully are organized on a geographical basis. That is, the associations in various political subdivisions organize. A large number of city leagues have been established, in which the various associations may interchange ideas on all topics of common interest. County and district leagues include the associations of adjacent cities and towns. State leagues exist in practically every state in the nation, and these embrace a majority of associations in each state. These leagues have played a substantial part in the elimination from the movement of those associations which are not truly coöperative in character. They have investigated the business carried on by associations before admitting them to membership, and they have accomplished much good for the movement. In addition to these, "group conferences" have been arranged which include the associations in several adjoining states where the problems are essentially similar.

The student is recommended to read the convention proceedings of the various leagues in his own state. Recent copies may be obtained from the secretaries of the respective leagues, either for a small fee or without charge. Only in this way is it possible to grasp the full significance of the accomplishments of the past few years. While all such gatherings are characterized by flowery speeches which are intended to please and flatter the audience, much information of real value is contained in the reports of practically every meeting.

Finally, the various state leagues are united in the United States League of Local Building and Loan Associations, which meets annually at different points in the United States. It is the outgrowth of a "Building Association Congress of the World" held in Chicago on April I4, I892, to combat the practices of the national building and loan associations of that day, to bring about the collection and dissemination of 
correct statistical information as to proper methods of organization, security, and management, and to secure greater uniformity in legislation and state supervision. As early as 1888 , Henry S. Rosenthal, editor of the American Building Association News, had suggested the creation of a national league. The meeting in 1802 was attended by representatives of thirteen states, and it adopted a constitution and by-laws for the United States League. 'The latter held its first meeting in Chicago in 1893. Recent meetings have been attended by delegates to the number of about five hundred or more from all parts of the country. Here is centralized all of the more important information regarding legislative and other activities of the entire country for the previous year, and here also the leading men of the movement come together to interchange their ideas in a helpful way.

American Savings, Building and Loan Institute.Growing out of the United States League and formed at its suggestion and under its authorization is the American Savings, Building and Loan Institute, an educational non-profit corporation which disseminates building and loan information independently and without partiality. The United States league being composed of many state leagues committed to ccrtain definite, yet widely different policies, could not very well carry on an educational campaign. 'The Institute is compiling standardized building and loan text-broks, conducting feld work in developing the business of individual associations and communities, aiding individual associations in solving their problems by correspondence, conducting local chapters for the education of building and loan exccutives along the lines of the local chapters of the American Institute of Banking, and finally developing a correspondence course for the benefit of building and loan men who are unable to obtain regular classroom instruction in the work. The present textbook is one of the first pieces of work completed on a large scale under the auspices of the Institute. Many other studies are being marle from time to time which are supplised from 
the office of the Institute upon the application of building and loan men.

The business of the Institute is limited to education and research. By means of a working agreement, the Institute is disseminating building and loan information to others through the Institute for Research in Land Economics and Public Utilities of Madison, Wisconsin, the National Association of Real Estate Boards, and the United Y. M. C. A. schools, and other schools and colleges of commerce.

The outstanding need of the building and loan movement to-day is the coördination of all the activities in various parts of the United States to the end that better methods, more uniform methods, and more equitable methods may be practiced by all associations. When the various institutions mentioned in this chapter are fully functioning, that end will undoubtedly be realized.

\section{SPECIAL REFERENCES}

Bohemian League of Building and Loan Associations. U. S. League Proceedings (1915), Dp. 150-152; (1917), pp. 125-126.

Clearing house. Minnesota League Proceedings (1924), pp. 20-22. North Carolina League Proceedings (1924), pp. 54-61. Ohio League Proceedings (1916), pp. 54-61. U. S. League Proceedings (1914), pp. $145^{-1} 53$.

Coöperative campaigns. New York League Proceedings (1922), pp. 8092.

District conventions. Illinois League Proceedings (1920), pp. 58-63, 6370. North Carolina League Proceedings (1924), 62-63.

Education. U.S. League Proceedings (1924), pp. 99-107; (1924), pp. 180-188; (1924), pp. 246-254.

Ethics. California League Proceedings (1924), pp. 64-68. Kansas League Proceedings (1924), Dp. 18-19. Missouri League Proceedings (1924), pp. 13-16. Oklahoma League Proceedings (1923), p. 16.

Federal Farm Loan Act. Kansas League Proceedings (1919), pp. 33-38. Missouri League Proceedings (1919), pp. 79-92. Ohio League Proceedings (1922), pp. 165-168. U. S. League Proceedings (1916), pp. 15-21.

Federal Building-Loan Bank. Hennessy, C. O., Proposed Federal Euilding-Loan Bank System, National Housing Association Proceedings, 
I920, I92 I, v. 8., pp. 28-34; 235-237. Iowa League Proceedings (г919), pp. 30-33. Illinois League Proceedings (1920), pp. 43-47. New York League Proceedings (1922), pp. 98-99. Ohio League Proceedings (I919), pp. 88-129. U. S. League Proceedings (I919), pp. 74-92.

Land bank. Minnesota League Proceedings (1924), pp. 20-22. New York League Proceedings (1922), pp. 39-40, 132-134. New York League Proceedings (1923), pp. 59-70. U. S. League Proceedings (I9I5), pp. I32-I35; (I9I6), pp. 75-83; (I923), pp. 85-93; (I924). pp. I64-I 66 .

Leagues-sectional. New York League Proceedings (1923), pp. 55-59.

Leagues-state. U. S. League Proceedings (I901), pp. 137-138.

Leagues-U. S. U. S. League Proceedings (I900), pp. 59-72; (I90I), pp. I37-I38; (I922), pp. I07-I24.

State guaranty. Ohio League Proceedings (I9I6), pp. I36-138.

Standardization. Iowa League Proceedings (1916), p. 28. Nebraska League Proceedings (1924), p. 47. Ohio League Proceedings (1914), pp. 53-54. U. S. League Proceedings (I9I7), pp. 80-94. Youngstown Institute Proceedings, March 23, I923, p. 2.

\section{GENERAL REFERENCES}

Rosenthal, Henry S. Cyclopedia, pp. 47-67; 96-98; I64-I66.

Sundheim, Joseph H. Law, p. 23. 


\section{TRAINED LEADERSHIP AS THE SAFEGUARD FOR THE MOVEMENT}

President Coolidge has well said, "The world needs education in order that there may be a better estimation of true values. It is not easy to assemble facts. It is not easy to draw deductions. It is not easy to distinguish between the accidental and the essential. In the complications of modern civilization, these are becoming more and more difficult. If world problems are to be solved, it will be through greater application, through more education, through a deeper faith, and a more complete reliance on moral forces."

If the building and loan movement is to fulfill its destined place in the life of the nation, it will need to equip all its leaders to carry on along equitable lines. Already most of them can see beyond their immediate routine tasks many larger opportunities for service. The effective kinds of service can easily be discovered by a little study and research.

The building and loan student will do well to acquire an educational background which includes thorough courses in elementary economics, money and banking, accounting, and investments. In addition to these, the subjects of, corporation finance, the money market, financial history, commercial correspondence, urban land economics, and advertising are of value in about the order named. For students who wish to pursue a systematic reading course in any of these fields a list of interesting and authoritative books is appended to this chapter.

Institute chapter work has been organized in many parts of the country for those who have the time to attend regular 
classes, and courses by correspondence are now available in all phases of the building and loan work. The latter afford the maximum opportunity for concentration on particular problems, assisting the man who is interested in community service to obtain a thorough grounding in his life work.

A university training for business is of distinct advantage. The close connection between our schools of commerce and the business community is resulting in the development of professional courses which equip men for the "big job ahead" in much less time than is needed where no academic preparation is undertaken. Hundreds of our college men work during their vacations as relief men in the offices and plants where they later expect to begin their business career, and building and loan officials will find such men a real addition to their staff if they care to use them. By placing men of college age on various building jobs, it is possible to lay a solid foundation for later appraisal work.

Limits to the Expansion.--So much has been written and said in recent years on the matter of the economies of largescale production that even building and loan officials have been led to believe that only by having enormous amounts of assets can their work be carried on in the best way. Yet, the experience of ordinary business has shown that there is a definite limit to the expansion of any industrial, commercial, or banking plant. Expansion can be carried no further than the ability of the officials to oversee all essential details of the work. Large-scale production is entirely possible on a sound basis wherever the detailed operations can be repeated with machinelike accuracy by unskilled men. It has never been a success where skilled employees are necessary for all operations, because the expenses of management rise more rapidly than the value of the product. The limit to the size of a building and loan association depends primarily upon the capacity of the appraising officers to make certain that all loans are properly safeguarded, and secondly, on their ability 
to attract new savings. In other words, it is a matter of human skill.

A few men will always be available in all parts of the country who can guide the destinies of very large associations on a sound and conservative basis. The average secretary, however, finds himself handicapped when he attempts to run too large a business. Not understanding the methods of getting other men to handle the detail work for him, he becomes swamped in the mechanics of his records and so loses his perspective. Probably the average secretary cannot handle a business with much more than $\$ 1,000,000$ in assets. A few men can be found with the ability to handle a business of two or three times that amount with the aid of a very small office force. When the business runs into the millions, however, the detailed office work must be handled by a corps of clerks specializing in certain operations under the direction of an efficient office manager. Otherwise the work falls to pieces. The number of secretaries capable of handling such large associations is very limited.

It has already been pointed out in another connection that while practically every dollar in the association can be put to work, there is not enough excess profit on each dollar to enable the association to conduct its affairs on the lines of the ordinary commercial house, if it is to continue to distribute sizable dividends on any of the mutual plans.

It is not possible to set down in detail the exact limit which each association should set for itself. This will depend upon at least one other factor in addition to those which have just been mentioned, namely, the amount of housing needs of the community. The ability of the officials to handle the growing business, however, is always of more importance. In many cases it is better for several associations to divide the business of a community, each taking as much as it can handle, rather than to attempt to combine all of the activities under one corporation.

Safeguarding the Expansion.-As every good thing has 
its enemies and detractors, it is not strange that the building and loan movement should be subjected to repeated attempts at perversion and misuse. Individual greed is responsible for most of the troublesome problems that have arisen in the movement from time to time. Ignorance of the mathematical maturity of shares has caused men to promise impossibilities for the associations which they attempted to start. Failure to predict accurately the demand for loans and the trend of interest rates has caused officials to "count their chickens before they were hatched," and while these items are less serious than some others, they have caused considerable confusion in the minds of the people of the community in which an association has not lived up to expectations. Fortunately these errors are being corrected rapidly.

The outstanding difficulties in the way of a successful development in some sections of the country to-day are the attempts on the part of some officials to charge fees, fines, and forfeitures which they induce the directors to pay over to a favored group of insiders. In other places a few associations are charging much higher interest rates on their loans than they advertise. In a very limited number of cases the borrower is paying interest on the entire loan for the entire time and receiving no credit for the earnings on his dues payments. (The rate in such cases is more than doubled.) In still other parts of the country syndicated loans are being made where surplus savings have accumulated (or where no demand exists for regular loans on residences), and these loans fall short of the coöperative ideal upon which the building and loan association movement has been based. They are unnecessary if the movement is conducted along the lines of the system developed in New York State and the plan for its extension to all parts of the country which has been laid down in the preceding chapter.

Men who are directing the associations cannot afford to ignore the signs of the times, which effectively challenge them to a higher ideal of service than is being realized in certain 
places. The purely mutual character of the fundamental building and loan plan should not be lost through an attempt to commercialize the successful methods of the small association.

No text-book on the subject of building and loan associations could have been issued in years past without mentioning in detail the outrageous methods used by many organizations which have represented themselves as building and loan associations. Most of these, instead of incorporating under the state laws, operated as "common law trusts." They have been commonly known as "housing trusts" or "contract companies." Apparently the last of these institutions has now been definitely put out of business. ${ }^{1}$ The menace of such companies has been beneficial to the building and loan movement in that it tended to arouse and unite association men to the need of presenting their sound methods of development to the people without misrepresentation or fraud. The contracts of the housing trusts allowed the inside management to obtain large rewards for their services. They made impossible promises to return to the investors from I5 per cent up to I50 per cent per annum or more, while at the same time the borrower was supposed to receive the use of the capital at 3 or 4 per cent per annum. The mathematical impossibility of such results was ignored, and thousands of poor, worthy families who were trying to secure their homes were cheated of their savings.

Such external dangers to the movement at the present time are of less importance than internal dangers. In most states the usury law does not apply to the premium, although it is supposed to apply to the interest rate. As a result it is pos-

${ }^{1}$ This result has been obtained largely through the efforts of men like John C. Hall of St. Louis, Missouri; Will G. Akers, Little Rock, Arkansas; Maco Stewart, Galveston, Texas; J. Fred Leghorn, Olympia, Washington; L. E. Roush of Wichita, Kansas; Henry S. Rosenthal, publisher of the American Building Association News of Cincinnati, Ohio, the officers of the U. S. League and of the various state leagues. 
sible to overcharge the borrower by means of premium, and a few associations do this. Fortunately their number is constantly on the decrease, and the savings member and the borrowing member are being treated more equitably than has ever been the case before. The scathing denunciations of extortion voiced at all league meetings will continue to be effective in curbing unsavory practices. Thousands of associations have never abused the borrower, and this should be true of all.

This does not mean that interest rates need be alike in all parts of the country. In newer sections it is impossible to obtain necessary capital to finance loans at rates which are reasonable in other sections where capital accumulations are large. Without the use of some premium, new sections would often be unable to attract capital quickly, and it might be many years before the service is rendered.

The definite tendency toward lower interest rates in any given area tends to change these conditions with the passing years. In the mean time, the association officials themselves would do well to see that the maximum interest rate and premium charged do not violate the usury laws of the state, even in the absence of a statutory provision to that effect. The cloaking of efforts to make large profits for a group of insiders under the guise of philanthropy cannot be too strongly condemned.

Exploitation is the one serious menace to the building and loan movement to-day, as it has been in the past. Probably it is under better control to-day than ever before, but exploitation will always be present when the opportunity for a large profit arises. One of the best ways to combat the tendency to exploitation is to adequately compensate efficient men for the service which they actually perform in making the affairs of the association safe and conducting them along equitable lines. No one should be permitted to pervert the movement for his private advantage. 


\section{SPECIAL REFERENCES}

Dangerous practices. U. S. League Proceedings (IgI4), pp. II4-I24. Future of the association. U. S. League Proceedings (Igor), pp. 36-43. Ideals. California League Proceedings (1924), pp. 46-48. U. S. League Proceedings (I90I), pp. I0I-108; (I9r9), pp. I03-II3; (I92I), pp. ror-ro8.

Investment companies. Nebraska League Proceedings (1924), pp. 6I-69. Obstacles encountered. U. S. League Proceedings (1900), pp. 79-84; (1922), pp. r55-r 59 .

Three per cent companies. Missouri League Proceedings (1922), pp. 3445, 52-59. Ohio League Proceedings (1922), pp. 140-145. Oklahoma League Proceedings (1922), pp. 78-8r. U. S. League Proceedings (r922), pp. I28-I45; (r923), pp. 31-32, I79-192; (1924), pp. 31-32. "Wild cat" schemes. Minnesota League Proceedings (I923), pp. IO-II. Missouri League Proceedings (1919), pp. 18-22. U. S. League Proceedings (I901), pp. 27-30.

\section{GENERAL REFERENCES}

Rosenthal, Henry S. Cyclopedia, pp. I4I-I48.

\section{SUGGESTED LIST OF READINGS IN RELATED TOPICS}

\section{ElEmentary ECONOMics}

Ely, R. T. Outlines of Economics.

TAYLOR, F. M. Principles of Economics.

TAussig, F. Principles of Economics.

Hamilton, W. M. Current Economic Problems.

\section{Money AND Banking}

Dunbar, C. F. Theory and Practice of Banking.

Scort, W. A. Money and Banking.

White. Money and Banking.

Holdswortr. Money and Banking.

Moulton. Financial Organization.

\section{Accountrng}

Hatfield. Modern Accounting (I909).

Paton, W. A. Accounting.

Kester, R. A. Accounting: Theory and Practice. 


\section{SUGGESTED READINGS (continued)}

INVESTMENTS

JORDAN, D. Investments.

Chamberlain, L. Principles of Bond Investment.

LAGERQUIST, W. Investment Analysis.

\section{Corporation Finance}

Dewing, A. S. Financial Policy of Corporations.

Gerstenberg, C. W. Materials of Corporation Finance.

Gerstenberg, C. W. Financial Administration and Management.

FinANCIAL History

Dewey, D. R. Financial History of the United States.

URBAN LAND ECONOMICS

Ely and MoRehouse. Elements of Land Economics. 
APPENDIX

Suggestions for by-laws............................. 497

Table XXXI. Classification of associations according to plans in use, $1924 \ldots \ldots \ldots \ldots \ldots \ldots \ldots \ldots \ldots \ldots . . \ldots \ldots$. 501

Table XXXII. Number of building and loan associations compared with banks and population ................ 504

Determining actual interest rates ..................... 507

Table XXXIV. Summary of foreclosure experience............. $5^{\mathrm{I} 3}$ Table XXXV. Comparison of members and assets 1893 and 1923,

p. $5 \mathrm{r} 4$

Table XXXVI. Growth, 1893-1924 ................. 516 Table XXXVII. Changes in numbers of homes owned and rented in U. S. $1890-1923 \ldots \ldots \ldots \ldots \ldots \ldots \ldots \ldots$............. 517 Corporate names in use by associations in the United States......p. 518

\section{SugGeSTIONS FOR By-LAwS}

One of the problems which confront the organizers of a building and loan association is finding the proper material to include in the by-laws, and another is that of arranging the provisions in a proper sequence in order that their usefulness may be increased.

Before an association may be incorporated, articles of incorporation (or in Louisiana, a notarial act) must be drawn up. On the strength of the proposed articles a state official issues a certificate authorizing the formation of the corporation. This authorization is usually in the form of a charter which brings the association into existence as a legal body. The terms of the charter are similar in some states to the formal legal document called the "constitution," in which case it outlines the powers of the new corporation in some detail. In other states a charter is merely a formal grant of the right to begin business, and a separate constitution must be drawn up, if one is desired. In yet other states (including Rhode Island), a charter can only be secured by special act of the legislature.

Usually the documents of authorization include such basic information as the name of the association, its objects, its powers, its domicile, its capitalization, its term of operation and occasionally some additional matter. The principal guide for the officers in the transaction of their business, however, is found in the by-laws, which are adopted either by the organizers, the directors, or the shareholders, as required by state law. The provisions of these by-laws must not conflict with the laws of 
the state. A few states require special sections to be included, and belor adopting any regulations, organizers should consult the statutes to lea the requirements. Considerable latitude is usually allowed in the formation of by-laws, as the inclusion or exclusion of individual provisions depends upon the ends which the organizers desire to accomplish. It is not possible to submit a form of by-laws that will be applicable everywhere, but certain well-defined rules for the guidance and protection of all who are interested can be laid down here which will enable new associations to start on the right track. These provisions, which are common to all, are presented in the following outline as a suggested basis for the writing of the detailed by-laws themselves.

\section{OUtLINE of By-Laws}

ARTICLE I. Sec. I. Title.

Sec. 2. Object.

Sec. 3. Location.

Sec. 4. Term of charter.

Sec. 5. Capitalization.

This article should include the name, the object (of accumulating savings fund to lend to members for buying, building, or improving of homes, etc.), place of principal office, term, authorized capital stock divided into certain number of shares, having a matured value of so many dollars each. (This article need not be included if the subject matter appears in the charter or constitution, which is also printed for distribution with the by-laws.)

ARTICLE II. Sec. I. Members (shareholders).

Sec. 2. Shareholders' meetings.

Qualifications, duties, and privileges of members or shareholders. If minors or married women are accorded the same privileges as others, this should be mentioned.

Under this same article, shareholders' meetings, classified as annual (or general) and special. In Massachusetts and some other states where officers are elected by members, this section may provide for a meeting to be held a month prior to the annual meeting in order to nominate officers. Such matters as notice of meeting, quorum, method of voting, use of proxies, type of business that may be transacted, etc., may also be included.

ARTICLE III. Sec. I. Directors.

Sec. 2. Directors, meetings.

Sec. 3. Directors, duties.

Qualifications of directors, their number, and (where the system of classification is in vogue) provision for grouping according to term of office or otherwise. 
Time and method for assembling for formal organization; also subseJuent regular or stated and special meetings; provisions concerning notice, quorum, etc.

The directors are in general control of the corporate affairs, and one section should include matter relating to the method of election of officers, provision for fidelity bonds, custody of bonds, method of declaring and filling vacancies in offices, creation of committees. Depository banks should be designated, authorization provided for issuance of shares of various kinds, method of receiving and approving applications for loans, procedure in handling surplus funds, method of authorizing borrowing by the association, execution of legal documents, provision for maintenance of suitable office. If any limitation is placed upon expense, this should be mentioned at this point, as well as the method of determining earnings, creation of a contingent reserve, declaration of dividends, and any other general or special powers the directors may have under the association's charter.

ARTICLE IV. Sec. I. Officers.

Sec. 2. President.

Sec. 3. Vice-president.

Sec. 4. Secretary.

Sec. 5. Treasurer.

Sec. 6. Attorney or counselor.

Sec. 7. Committees.

Sec. 8. Notary (in Louisiana).

Listing the officers to be employed, their respective qualifications, and their powers and duties in such detail as to prevent overlapping of functions. Method of choosing officers, compensation, etc., if not covered in Article III.

ARTICLE V. Sec. I. Stock (shares).

Sec. 2. Matured shares.

Sec. 3. Withdrawals.

Sec. 4. Shares of deceased members.

Kinds of stock or shares to be issued in gathering funds from the members of the association. The place for this provision is not always the same as here shown, as it is frequently found in the first article. It is placed in this position here because it is the most important matter of business transacted and deserves separate treatment. The number of sections to be included under this article will depend upon the number of kinds of shares offered. Methods of issuing and retiring each type of shares should be included, including method of application for shares, limitations, if any, on share ownership, issuance of a certificate and/or pass-book, stating the amount of dues or payments, provision for advance payments and delinquent payments (in serial associations), fines, 
forfeitures, crediting of earnings or dividends of the association, type of shares, methods of withdrawal and crediting accruals (for both voluntary and involuntary withdrawal), contemplated maturities, transfers, loss of certificates, cancellation and reissuance of shares, disposition of shares of deceased members, subjection of shares to lien of association, exemption, if any, of private property of member for debts of the association.

ARTICLE VI. Sec. I. Loans.

Sec. 2. Settlements.

Loans, including persons eligible to borrow, priority of right to borrow, application for loan, character of security required, appraisal, method of approval of security, title procedure, necessary insurance, method of paying for taxes, interest rate, premium if any, expenses in connection with loan, repayment provisions if paid before maturity, method of crediting special payments, penalties for delinquency, foreclosure procedure, special provisions for construction loans (including surety bonds, inspection, etc.), loans on shares or pass-book.

\section{ARTICLE VII. Audit.}

The practice of auditing by a committee of shareholders which was formerly almost the invariable custom has now been discarded by most associations in favor of audit or examination by an experienced accountant, and the method of such audit should be provided in one section in order that adequate periodical inspection of the accounts and securities may be made.

\section{ARTICLE VIII. Contingent reserve.}

While many associations are still operating without a provision for a contingent reserve, there is a constantly growing recognition of the importance of this safeguard. This article should contain the method of creating and maintaining such reserve, including the percentage of net earnings to be diverted to that purpose and the maximum amount to be allowed in the reserve (usually five per cent of total assets, but the total will depend upon local conditions).

ARTICLE IX. Seal.

Provisions for the adoption of a corporate seal.

ARTICLE X. Amendments.

Methods of amending the by-laws. Where the by-laws include items usually found in a charter or constitution, the right to amend is prob- 
ably vested in the shareholders, but where the constitution provides for most of the detailed procedure of the business, leaving only minor matters to the by-laws, it is customary to allow directors to amend the bylaws. The amendment of the constitution in such cases is left to the action of the body of shareholders. In any case, the method of amendment must be in accordance with state law.

Classification According to Plan Used

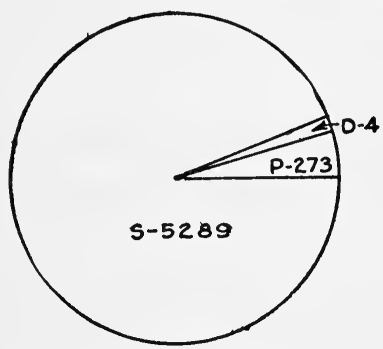

MIDDLE ATLANTIC STATES (5566)

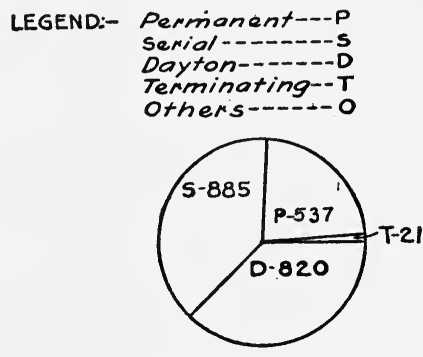

EAST NORTH CENTRAL STATES (2263)

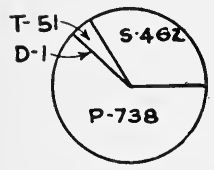

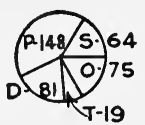

SOUTH ATLANTIC STATE'S (1252)

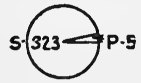

NEW ENGLAND STATES (328)
WEST NORTH CENTRAL STATES (387)
SOUTH CENTRAL STATES (345)

NUMBER AND KINDS OF BUILDING AND LOAN PLANS IN USE IN EACH GEOGRAPHIC SECTION OF THE UNITED STATES. (1924)

CHART 13.-Comparative number of associations using different plans in each section of the United States, 1924. 


\begin{tabular}{|c|c|c|c|}
\hline & $\begin{array}{lll}0 \\
0 \\
0\end{array}$ & & 若 \\
\hline & & & 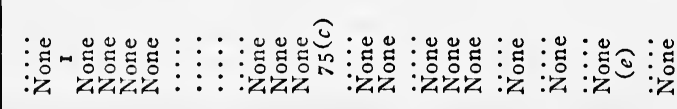 \\
\hline$\stackrel{n}{z}$ & & & 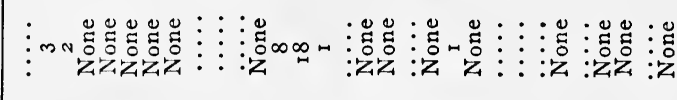 \\
\hline 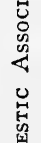 & 节 & 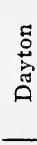 & 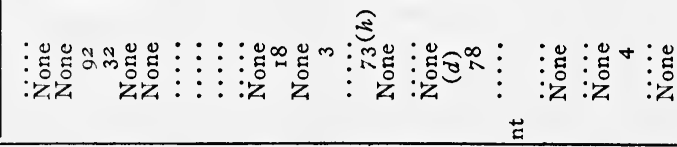 \\
\hline & $\underset{d}{E}$ & 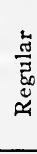 & 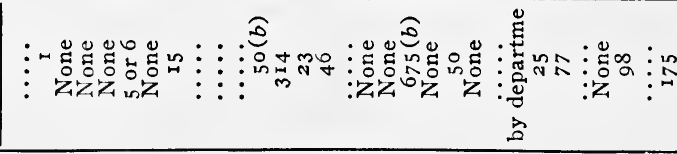 \\
\hline & 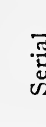 & & 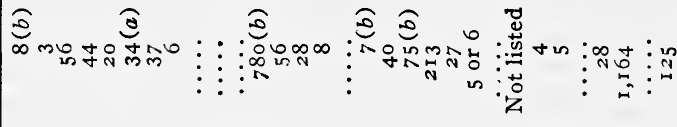 \\
\hline 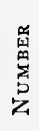 & 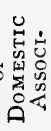 & & | \\
\hline
\end{tabular}

岩。

的参

s

F州

$\circ \underbrace{\infty}$

它设窟

2

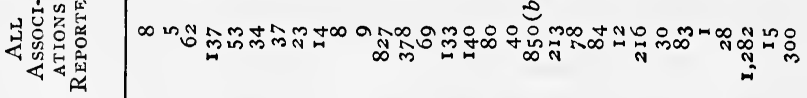

茫

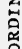

㺃

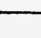

i:

$:::::::::::::::::$

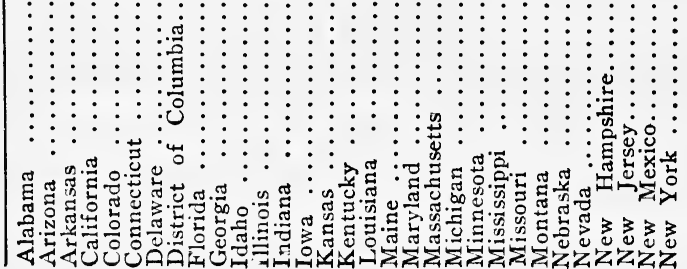




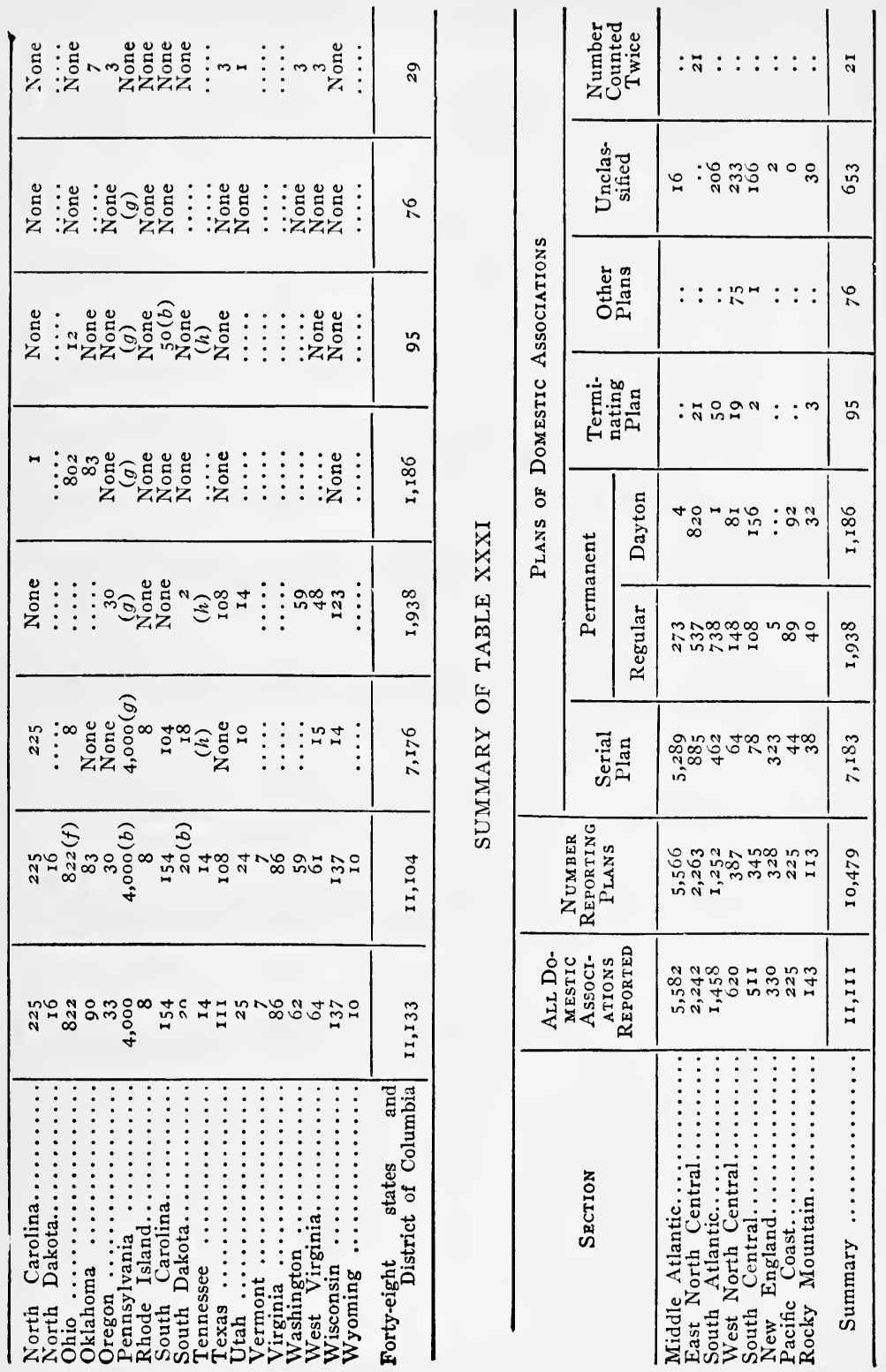




\begin{tabular}{|c|c|c|c|c|c|}
\hline 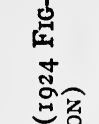 & 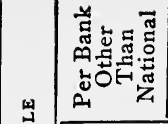 & $\begin{array}{l}n \\
0 \\
\infty \\
f\end{array}$ & 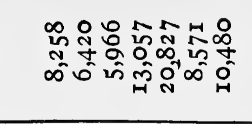 & 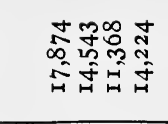 & $\begin{array}{l}\infty \\
\infty \\
0 \\
0\end{array}$ \\
\hline 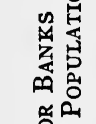 & 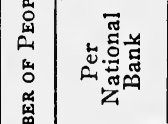 & $\begin{array}{l}\hat{N} \\
\infty \\
\tilde{y} \\
\tilde{H}\end{array}$ & 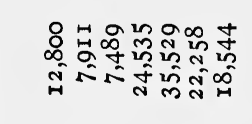 & 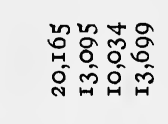 & 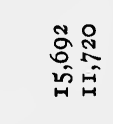 \\
\hline 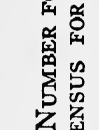 & 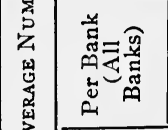 & 品 & 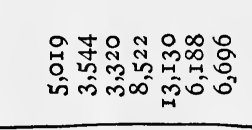 & 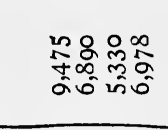 & 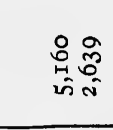 \\
\hline 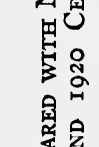 & 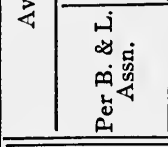 & $\begin{array}{l}\frac{1}{4} \\
2 \\
\alpha\end{array}$ & 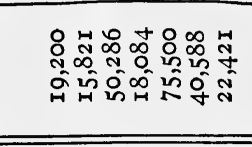 & 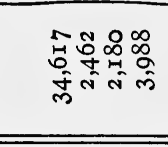 & 足枈 \\
\hline 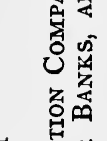 & 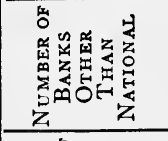 & $\begin{array}{l}\infty \\
\infty \\
\infty \\
-1 \\
N\end{array}$ & 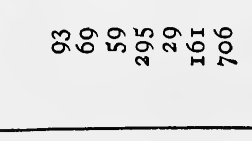 & 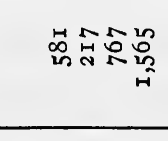 & 옹 \\
\hline 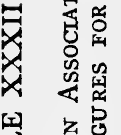 & 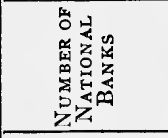 & 离 & 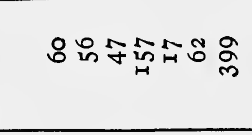 & 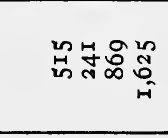 & 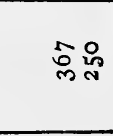 \\
\hline 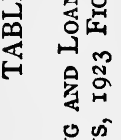 & 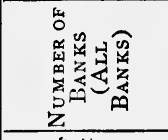 & 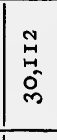 & 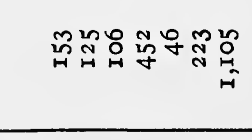 & 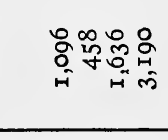 & 吕总 \\
\hline 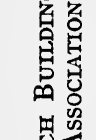 & 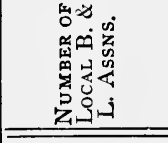 & 总 & 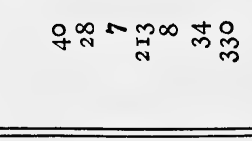 & 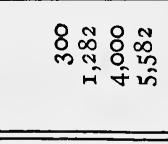 & $\underset{\infty}{N} \underset{m}{\infty}$ \\
\hline 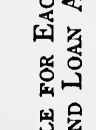 & 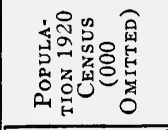 & 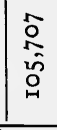 & 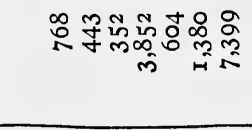 & 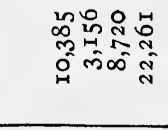 & की \\
\hline 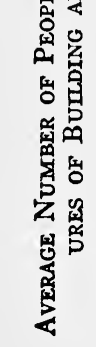 & 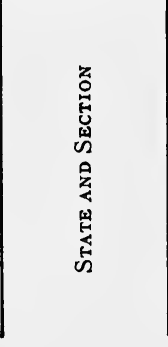 & $\begin{array}{c}\vdots \\
\vdots \\
\vdots \\
\vdots \\
\vdots \\
\vdots \\
\substack{0 \\
0}\end{array}$ & 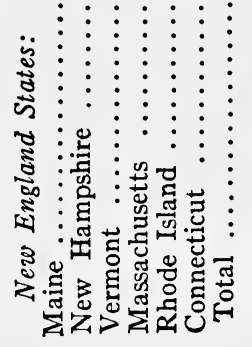 & 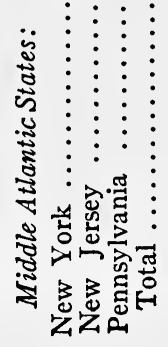 & 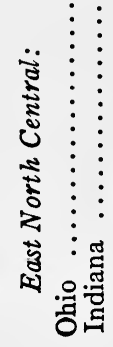 \\
\hline
\end{tabular}




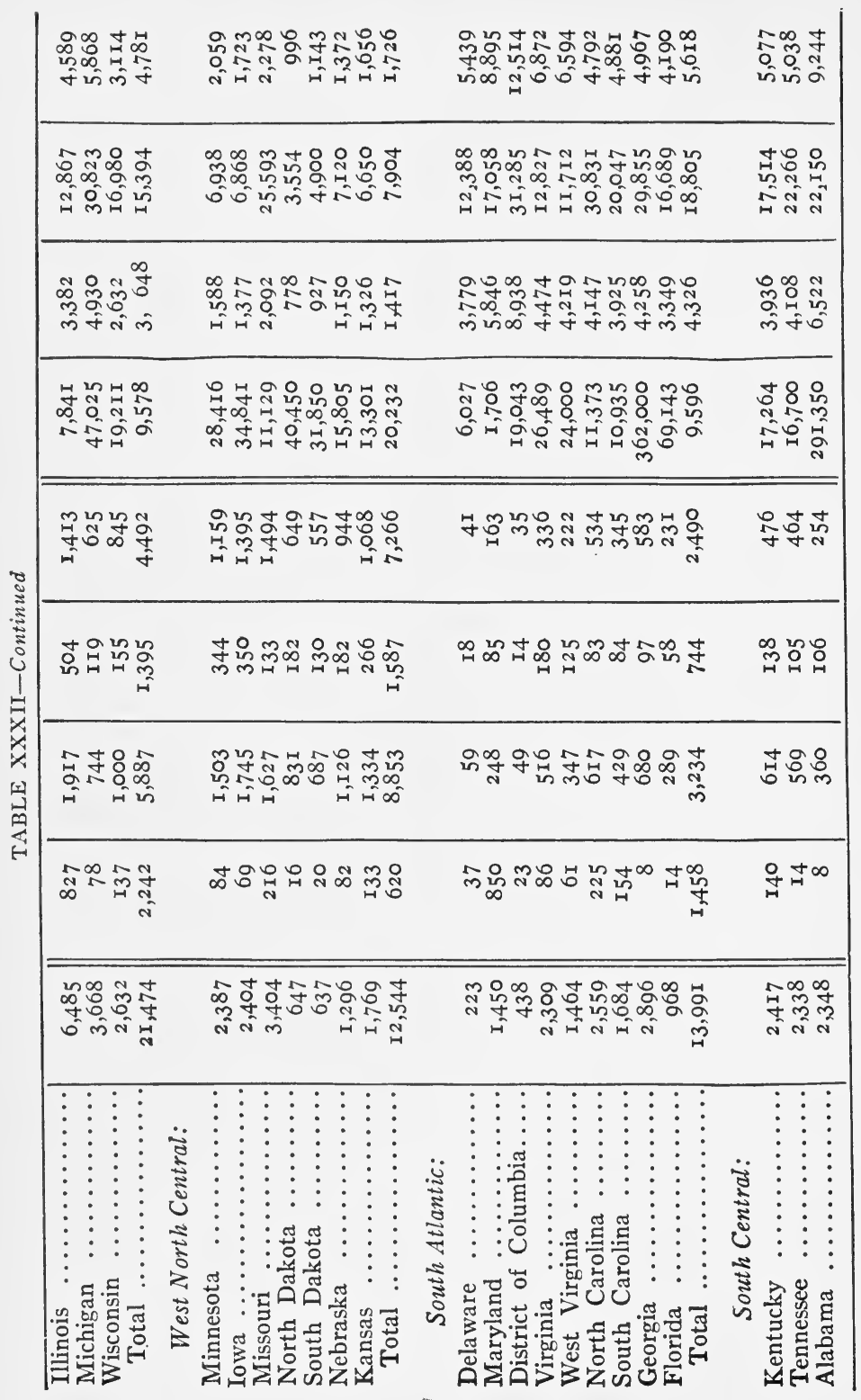




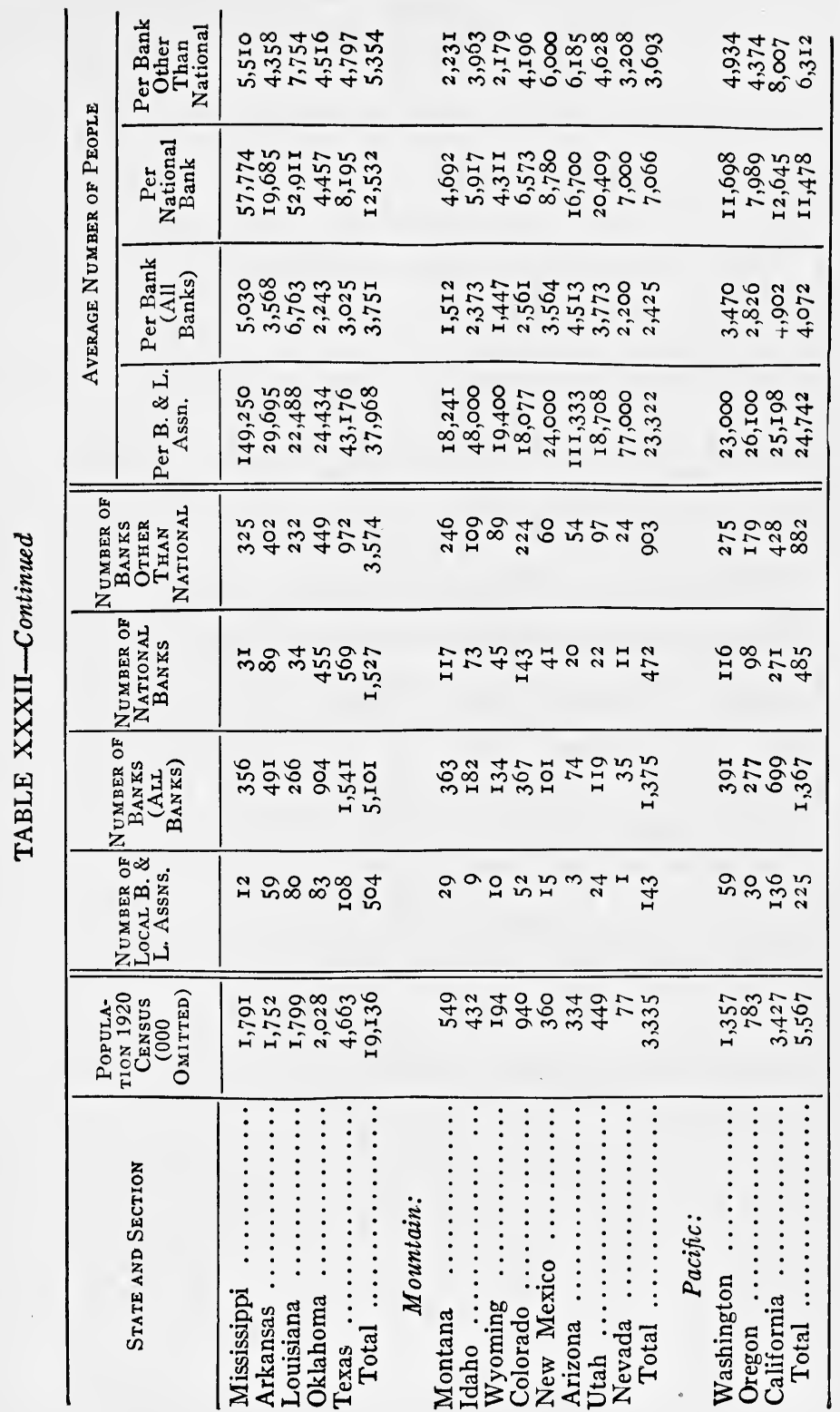




\section{DETERMINING ACTUAL INTEREST RATES}

The actual charges made for a $\$ 1000$ loan by 233 associations scattered throughout the United States have been analyzed by the present writers on the basis of the dollar-month formula referred to in Chapter VIII. These reports have been grouped according to geographic locality and are presented in Table XXXIII. Since various kinds of averages were used in making the computations, these should first be explained.

\section{Averages-The Mode, Mean and Median}

We often hear people speak of the "average man" or an "average day," when they mean something quite different from an "average amount," or an "average balance." The "average man" does not refer to a figure such as all the people divided by their number. The "average man" is the "most usual" man or the "most common" man-the type of man who is most frequently encountered. Statisticians call this kind of average the "mode," or the "modal number." It is the number which occurs most frequently in any given series of items. The "modal interest rate" is, therefore, the rate most frequently used in a given place. The mode supplies a summary figure where the range of sizes is very great, but where repetition occurs at certain points. If repetition occurs at two or more parts of the series, the mode is of little value.

On the other hand the "arithmetic average," "arithmetic mean," or "mean" is the term applied to the average obtained by adding all the

\section{NOTES TO TABLE XXXI (pp. 502-3).}

a) Practically all associations in Connecticut use serial plan.

b) Approximately.

c) Kansas reports seventy-five associations using permanent or guaranty stock, which sell stock to savings members under a definite contract stating the rate of return.

d) Many types of permanent plans are reported in use in Michigan, but supervisor does not separately list them.

e) A short-term double-payment plan is in use in New Jersey.

f) In Ohio, 822 made report the past year. There are 1,043 incorporated in the state.

g) No statistics as to plan, practically all are serial, except in western Pennsylvania where there are perhaps 400 permanent or Dayt on plan associations.

h) "All classes of shares are issued," in Tennessee, but no report is available as to Dayton plan or number using other plans.

The classification of states into geographical sections was made on the following basis: Middle Atlantic: New York, New Jersey, Pennsylvania; East North Central: Ohio, Indiana, Illinois, Michigan, Wisconsin; South Atlantic: Delaware, Maryland, District of Columbia, Virginia, West Virginia, North Carolina, South Carolina, Georgia, Florida; West North Central: Minnesota, Iowa, Missouri, North Dakota, South Dakota, Nebraska, Kansas; South Central: Kentucky, Tennessee, Alabama, Mississippi, Arkansas, Louisiana, Oklahoma, Texas; New England: Maine. New Hampshire, Vermont, Massachusetts, Rhode Island, Connecticut; Pacific Coast: Washington, Oregon, California; Rocky Mountain: Montana, Idaho, Wyoming, Colorado, New Mexico, Arizona, Utah, Nevada.

The number of "foreign" associations shown in this table is to be accepted merely as an "intelligent guess" by the supervising officials.

The number of "domestic" associations is rapidly increasing, as shown in our table of statistics as of Dec. 31, 1924, elsewhere in this book. 
items together and dividing by the number of items. This is the average used for many purposes, and is more commonly understood than other averages. The purpose of any average is to represent all the items in a series as well as any single summary figure can. The arithmetic mean gives weight to every item in the series. If some are much larger than others, these large numbers unduly influence the result. Where the items are similar in size, this difficulty does not arise.

The median average or the "median" is the middle term of a series when all the items are arranged according to size. In the following series the median is $\mathbf{1} 3$ :

2
8
9
12
12
13
14
18
20
21
22

That is, there are as many items larger than the median (I3) as there are smaller than this number.

The median average is very useful when the range of items is great, since it is not influenced by any single item of large size.

In the above series, the mode is 12 (the item which occurs most frequently), while the arithmetic mean is $\mathbf{1 3 . 7 2}$, a number which does not actually occur in the series. The median is the best representative of the above series.

In Table XXXIII, both the arithmetic mean and the mode have been used,- the choice resting on the kind of average which best represents all the numbers in each series. In the case of the ostensible interest rate, the mode was used. The actual rate shown in the last column (col. 6), was obtained for each state or section on the basis of the modal rate for that locality. The method used was as follows: The actual rate for each association was compared with $(a)$ the modal rate for the state in which it was located, and the difference was obtained. If the actual rate proved to be greater than the mode, the "d-viation" was considered as "plus"; if it was less, the "deviation" was "minus." "Plus" deviations were then added together, and the "minus" deviations subtracted therefrom. The resultant figure was divided by the total number of items, in order to obtain the "mean deviation from the mode." (b) The same 


\section{TABLE XXXIII}

Bullding and Loan Interest Rates in United States ig24 (Based on \$IOO0 LOAN) ${ }^{1}$

\begin{tabular}{|c|c|c|c|c|c|}
\hline State and Section & $\begin{array}{c}\text { Total } \\
\text { MONTHLY } \\
\text { PAYMENT } \\
\text { (MODAL } \\
\text { AVERAGE) }\end{array}$ & $\begin{array}{l}\text { FEES PaId } \\
\text { (ARITHME- } \\
\text { TIC MEAN) }\end{array}$ & $\begin{array}{c}\text { OSTEN- } \\
\text { SIBLE INT. } \\
\text { RATE } \\
\text { (MODAL } \\
\text { AVERAGE) }\end{array}$ & $\begin{array}{c}\text { MEAN } \\
\text { DEVIATION } \\
\text { FROM } \\
\text { MODAL. INT. } \\
\text { RATE }\end{array}$ & $\begin{array}{c}\text { ACTUAL } \\
\text { INTEREST } \\
\text { RATE }^{4}\end{array}$ \\
\hline All U. S.......... & $\$ 10.00^{5}$ & $\$ 2 \mathrm{I} .33$ & See Note ${ }^{6}$ & $2.102^{7}$ & See Note \\
\hline All New Eng. & $\$ 10.00$ & $\$ 15.79$ & 6.00 & +.140 & 6.140 \\
\hline 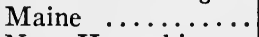 & 10.00 & 10.50 & 6.00 & $+.4 \mathrm{I} 3$ & $6.4 \mathrm{I} 3$ \\
\hline New Hampshire .. & $9.86^{8}$ & 26.67 & 5.00 & +.766 & 5.766 \\
\hline Vermont...$\ldots$. & 10.00 & 4.50 & 6.00 & +.215 & 6.215 \\
\hline Massachusetts .... & 10.00 & $24 \cdot 50$ & 6.00 & $+.12 I$ & $6.12 \mathrm{I}$ \\
\hline Rhode Island ..... & 10.00 & 16.42 & 6.00 & +.595 & 6.595 \\
\hline Connecticut $\ldots \ldots$ & 10.00 & 16.70 & 6.00 & -.322 & 5.678 \\
\hline All Middle Atlantic & I0.00 & 44.50 & 6.00 & +.907 & 6.907 \\
\hline New York ....... & 10.00 & 19.66 & 6.00 & +.533 & 6.533 \\
\hline New Jersey. ....... & 10.00 & 69.50 & 6.00 & +1.013 & 7.013 \\
\hline Pennsylvania .. & 10.00 & 55.42 & 6.00 & +1.283 & 7.283 \\
\hline All South Atlantic & $10 . \infty 0$ & 14.63 & $6 . \infty$ & +1.298 & 7.298 \\
\hline Delaware...... & $10.50^{8}$ & 14.90 & 6.00 & $-\quad .857$ & 5.143 \\
\hline Maryland ..... & $3.70^{\circ}$ & 17.33 & 6.00 & +.935 & 6.935 \\
\hline Dist. of Col... & 10.00 & 8.16 & 6.00 & -.529 & 5.471 \\
\hline Virginia $\ldots \ldots \ldots$ & $4.00^{9}$ & 20.70 & 7.12 & +.906 & 3.026 \\
\hline West $\mathrm{Va}^{10} \ldots \ldots \ldots$ & & & & & \\
\hline No. Carolina ..... & 15.00 & 14.30 & 6.00 & +.704 & 6.704 \\
\hline So. Carolina ...... & I6.66 & 10.00 & 8.00 & +.780 & $8.780^{\circ}$ \\
\hline Georgia $\ldots \ldots \ldots$ & IS.66 & II.67 & 8.00 & -1.348 & 6.652 \\
\hline Florida $\ldots \ldots$ & $10.77^{8}$ & 13.50 & $7 \cdot 50$ & +2.462 & 9.962 \\
\hline All East No. Central & 10.00 & I 2.04 & 6.00 & +.476 & 6.476 \\
\hline Ohio ............. & 10.00 & 8.66 & 6.00 & +.128 & 6.128 \\
\hline Indiana .... & 13.00 & 8.50 & 6.00 & +1.334 & 7.334 \\
\hline Illinois ...... & 10.00 & 10.47 & 6.00 & +.627 & 6.627 \\
\hline Michigan .... & $3.20^{11}$ & 9.45 & 6.24 & +.318 & $6.55^{8}$ \\
\hline Wisconsin $\ldots$ & I $1 . \infty 0$ & 23.40 & 6.60 & -.425 & 6.175 \\
\hline All West North & & & & & \\
\hline Central & 13.00 & I2.39 & 8.00 & +.469 & 3.469 \\
\hline Minnesota ... & I3 & 14.60 & 6.00 & +2.023 & 8.023 \\
\hline Iowa $\ldots \ldots$ & 10.83 & 9.94 & 7.00 & +.044 & 7.044 \\
\hline Missouri .... & I 1.00 & 25.08 & $8.00^{12}$ & +.387 & 8.387 \\
\hline No. Dakota & I 5.00 & 7.80 & 6.00 & +4.571 & $10.57 \mathrm{I}$ \\
\hline So. Dakota .... & I $3.66^{8}$ & 9.17 & 6.00 & +2.772 & 8.772 \\
\hline Nebraska .... & 13.00 & I5.68 & 8.40 & -.720 & 7.680 \\
\hline Kansas ...... & 12.70 & $7.8 \mathrm{I}$ & 9.00 & - .966 & 8.034 \\
\hline
\end{tabular}


TABLE XXXIII-Continued

\begin{tabular}{|c|c|c|c|c|c|}
\hline State and Section & $\begin{array}{c}\text { Total } \\
\text { MONTHLy } \\
\text { PAYMENT } \\
\text { (MODAL }^{2} \\
\text { AVERAGE) }\end{array}$ & $\begin{array}{l}\text { FEES PAID } \\
\text { (ARITHME- } \\
\text { IIC MEAN) }\end{array}$ & $\begin{array}{c}\text { Osten- } \\
\text { SIBLE INT. } \\
\text { RATE } \\
\text { (MIODAL } \\
\text { AVERAGE) }\end{array}$ & $\begin{array}{c}\text { MEAN } \\
\text { DEVIATION } \\
\text { FROM } \\
\text { MODAL INT. } \\
\text { RATE }\end{array}$ & $\begin{array}{c}\text { Actual } \\
\text { INTEREST } \\
\text { RATE }^{4}\end{array}$ \\
\hline All South Central & 15.83 & 29.16 & I0.00 & -.680 & 9.320 \\
\hline Kentucky $\ldots \ldots \ldots$ & $2.30^{9}$ & 21.50 & 6.75 & - .679 & 6.071 \\
\hline Tennessee $\ldots . .$. & II .00 & $74.7 \mathrm{I}$ & 6.00 & +2.574 & 8.574 \\
\hline Alabama ......... & 19.00 & I 4.37 & 6.00 & +5.573 & I I. 573 \\
\hline Mississippi $\quad . . \ldots \ldots$ & I $6.00^{8}$ & $\ldots$ & $8 . \infty 0$ & +0.000 & 8.000 \\
\hline Arkansas .......... & I3.33 & 10.60 & 10.00 & -.524 & 9.476 \\
\hline Louisiana ....... & II $.5^{8}$ & 33.00 & 7.80 & +.400 & 8.200 \\
\hline Oklahoma ........ & I6.30 & 23.50 & 10.00 & $+.55^{2}$ & I0.552 \\
\hline Texas $\ldots . . . \ldots$ & I 5.83 & $24 \cdot 77$ & 10.00 & - .I3I & 9.869 \\
\hline All Rocky Mountain & & & & & \\
\hline States & $15.3 I^{8}$ & I9.63 & 10.00 & +.229 & 10.229 \\
\hline Montana $^{13}$. & & & 10.00 & +3.232 & I3.2.32 \\
\hline Idaho........ & I5.I 7 & 24.05 & 10.00 & -.100 & 9.900 \\
\hline Wyoming $^{14}$.. & & & 10.00 & - .874 & 9.126 \\
\hline Colorado ..... & I3.00 & 28.18 & 10.00 & - I.I 45 & 8.855 \\
\hline New Mexico .. & I8.33 & 6.88 & 10.00 & +1.633 & I I.633 \\
\hline Utah $\ldots \ldots \ldots$ & I $5.82^{8}$ & 9.33 & 10.00 & -1.004 & 8.996 \\
\hline Arizona $^{14} \ldots \ldots \ldots$ & & & 10.00 & +1.216 & II. 216 \\
\hline Nevada $^{10} \ldots \ldots \ldots$ & & & & & \\
\hline All Pacific & I 3.00 & I9.3I & 8.00 & +.937 & 8.937 \\
\hline Washington .. & I 5.00 & 21.08 & 8.00 & +.775 & 8.775 \\
\hline Oregon $: \ldots \ldots \ldots$ & $19.42^{8}$ & 30.50 & 10.00 & +3.300 & 13.300 \\
\hline California ....... & I3.00 & 15.19 & 8.40 & $-.4 \mathrm{II}$ & 7.989 \\
\hline
\end{tabular}

1 Table based on 233 reports made by individual associations to the American Savings, Building and Loan Institute, I924.

${ }^{2}$ For explanation of modal average see page 507 .

${ }^{3}$ For explanation of arithmetic mean see pages $507-8$.

4 Actual interest rate equals modal rate plus or minus average deviation.

- Modal payment for entire country \$1o reported by 20 per cent of associations; arithmetic mean of monthly installments \$I2.I5.

${ }^{\circ}$ Ostensible interest rate reported by 231 associations.

93 reported 6 per cent.

I I reported 7 per cent.

26 reported 8 per cent.

35 reported 10 per cent.

I 3 others reported rates between 6.24 per cent and 6.96 per cent.

I 7 reported rates between 7.02 per cent and 7.8 per cent.

The mode is clearly 6 per cent and by computation the arithmetic mean is found to be 7.463 per cent.

${ }^{7}$ Mean deviation for entire country figured from ostensible rates reported by individual associations. This figure is useful for comparison only. It is not possible to compute an actual rate for the entire country. I 93 associations reported "plus deviations" (actual rate higher than the ostensible rate). 37 reported "minus deviations" (actual rate lower than ostensible rate). [See first line of Table XXXIII, p. 509.] 
process was repeated for each section. The mean deviations were then subtracted from or added to the mode (depending upon their sign), and the "actual interest rate" shown in the sixth column was thus obtained.

Since the fees paid by the borrower are an important part of this interest calculation, the arithmetic mean of such charges on a $\$ I, \infty 00$ loan has been reported in the third column of the same table, and the total monthly payments are also shown. The charges for loans of all sizes are usually the same in a given association. To the extent that this is true, the rates will be less for larger loans than the figures which we present in these tables. A loan of $\$ \mathrm{I}, 000$ was used as a standard, in order to make our computations uniform, and since all associations reported on this basis, no partiality is involved in such a presentation.

\section{A More Accurate Method of Computing the Interest Rate Pam by BORROWER}

The "dollar month" method of computing the actual rate paid is comparatively easy to use, but it lacks the high degree of accuracy which mathematicians demand in much of their work. If it is desired to obtain a rate which will satisfy even the most particular borrower, association officials are referred to the method shown by Professor Skinner in his "Mathematical Theory of Investment" (I924 edition), section 93. In part, his method is as follows:

"Let $C$ be the value to which the stock matures, which is also the face value of the debt, $M$ the monthly dues, $n$ the number of years required for the stock to mature, $k$ the nominal rate charged on loans, $i$ the unknown rate paid by the borrower, and $M_{1}$ the total monthly payment.

$$
\begin{aligned}
& \text { "The monthly interest payment will be } \frac{\mathrm{Ck}}{\mathrm{I} 2} \text {, so that } \\
& \qquad \mathrm{M}_{1}=\frac{\mathrm{Ck}}{\mathrm{I} 2}+\mathrm{M}
\end{aligned}
$$

${ }^{8}$ Mean average taken of monthly payment for New Hampshire, Delaware, Florida, South Dakota, Mississippi, Louisiana, Utah, and Oregon.

${ }^{9}$ Dues payments made weekly.

${ }^{10}$ Insufficient information available to prepare satisfactory statistics.

${ }^{11}$ Mean average of dues payments made weekly.

12 Eight per cent selected as the ostensible rate closest to the mean and median, since it checks closely with rates given in report of Missouri supervisor, I921 (26th Annual Report, Dept. of Finance, Missouri Building and Loan Bureau).

${ }^{13}$ Most Montana associations do not credit dividends on dues payments. Information incomplete as to dues and fees paid.

${ }^{14}$ Wyoming and Arizona information incomplete. 
"The present value of the annuity is the face of the debt and is the same as the value to which the stock matures. It is given by

$$
\mathrm{C}=\mathrm{M}_{1}+\mathrm{I}_{2} \mathrm{M}_{1} \cdot \mathrm{a} \frac{\mathrm{I} 2}{\mathrm{n}} \text { | }
$$

"Equation (3) may be written in the form

$$
\frac{C-M_{1}}{{ }_{12} M_{1}}=a \frac{12}{n} j=\frac{a}{n} i_{j^{p}}^{i}-
$$

where $C$ and $M_{1}$ are both known and the right member contains the unknown rate $i$. The problem of determining $i$ is then similar to the problem of finding the rate received by the investing shareholder."

(The student is referred to the original text for further explanation of these formulas, but the following may be of assistance: $a_{n}$ is the present value of an annuity of $I$ per annum for $n$ years. $j$ is the portion of the annual dividend rate paid at each dividend period. $p$ is the number of times per year that $j$ is paid.)

This problem can be solved without difficulty if tables are available to supply values for each of the complex expressions. Where the figure obtained by substituting values in the formula can not be found in the tables, it is necessary to "interpolate" in order to discover the proper answer. That is, the resultant figure is compared with those in the table, as follows: If the resultant figure were 22.6942518 and the time 36 months, the table shows no such figure. It does show:

$$
\begin{aligned}
& \text { For } 21 / 2 \% \text { at } 36 \text { months.... } 23.55625 \text { II } \\
& \text { And for } 3 \% \text { " " " } \ldots . .21 .8322525 \\
& \text { Leaving a difference of........ } \overline{\mathbf{1 . 7 2 3 9 9 8 6}} \\
& \text { From ......... 23.55625II and from 3\% } \\
& \text { Subtract } \ldots \ldots \cdots, 22.69425 \mathrm{I} 8 \text { and } 21 / 2 \% \\
& \text { Difference ...... } \overline{.8619993} \quad \overline{\mathrm{r} / 2 \%} \\
& \text { Then: } \frac{.8619993}{1.7239986} \times 1 / 2 \%=1 / 4 \% \\
& 3 \%-1 / 4 \%=23 / 4 \%=\text { the rate desired. }
\end{aligned}
$$

In the absence of tables, the solution can be obtained by the use of logarithms. When the time required for maturity is in even years, this method is even simpler than the dollar-month method discussed in Chap. VIII. It happens that very few building and loan association shares mature on the even year, and interpolation which involves a period as long as a year does not give an accurate result. Careful interpolation, however, yields a closer approximation than the dollar-month method, especially for the longer periods of maturity of shares. 


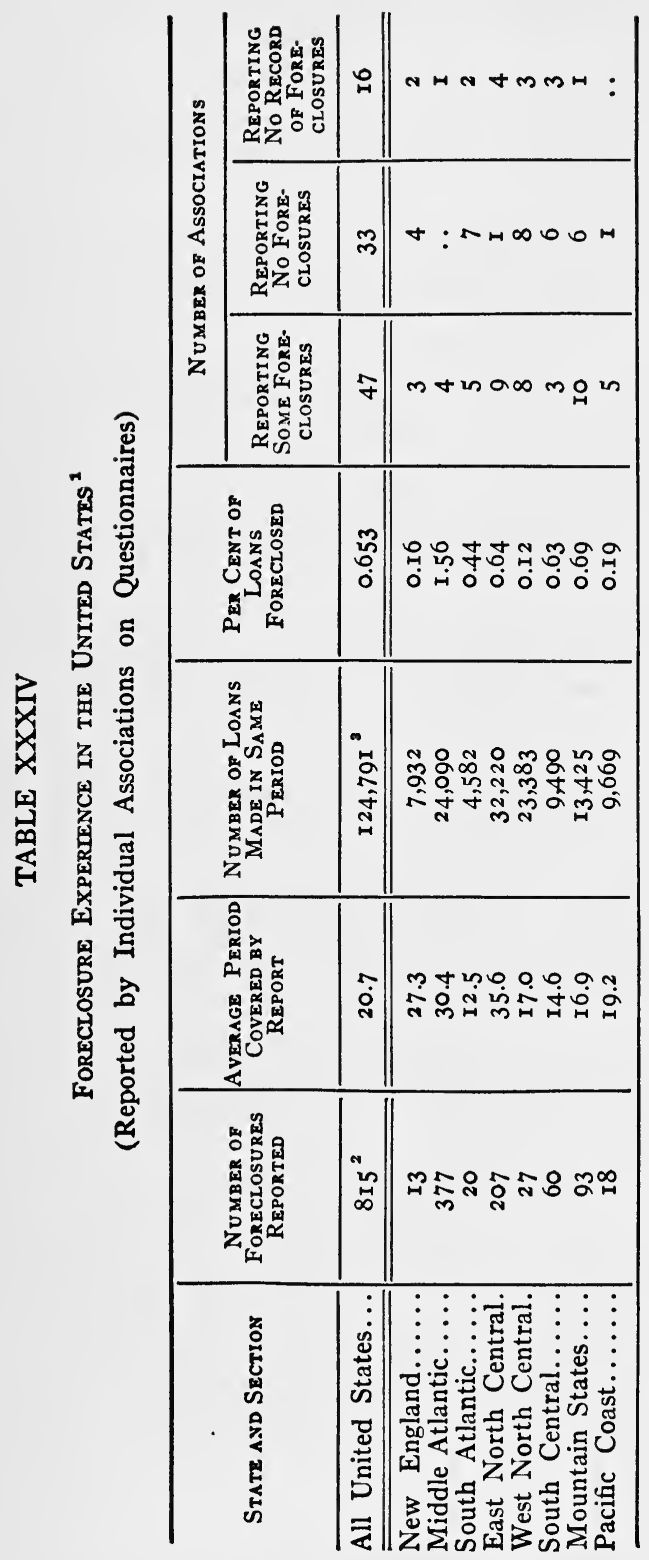

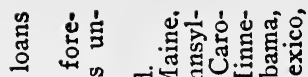

岁 出.川

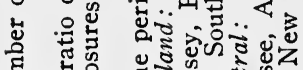

है

ज诺

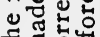

专和

उु जै

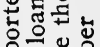

:․ㅡㄹ.

들

तै है山्य

두

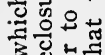

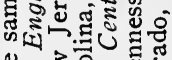

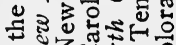

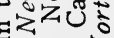

व

\&

․ㅡㅁ

I 3 잉

की

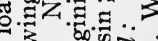

원혀

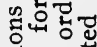

焉.志

ठै. क

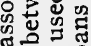

>ㅇ..의

․ํำ

꼬ำำ

泋向

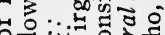

응 प्र

ปั

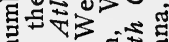

도

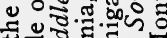

प्र.

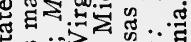

क क

$0 \geqslant 3.004$

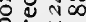

ง

उ ข

이요

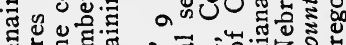

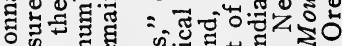
응 च क

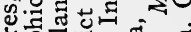

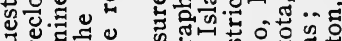
항투

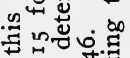
वा क

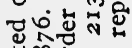

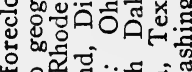
० g.

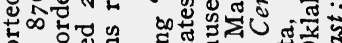

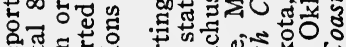

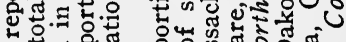

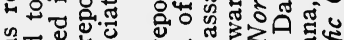
呵顿 원

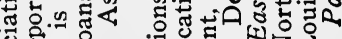

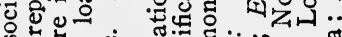
की

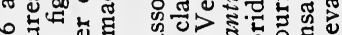
次药然

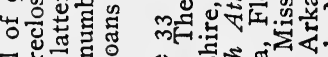

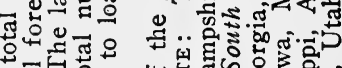

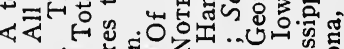
س

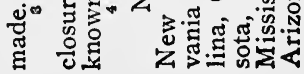




\begin{tabular}{|c|c|c|c|c|}
\hline 过 & 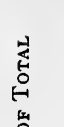 & 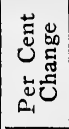 & 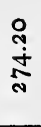 & 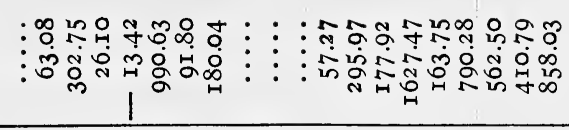 \\
\hline 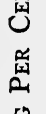 & 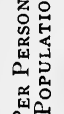 & ָָ & 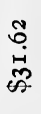 & 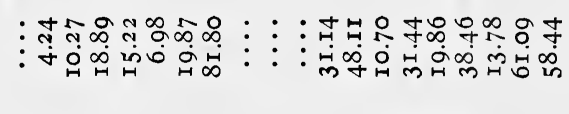 \\
\hline 舀 & 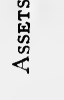 & م్ & $\underset{\substack{\infty \\
\infty}}{\substack{\infty \\
\infty}}$ & 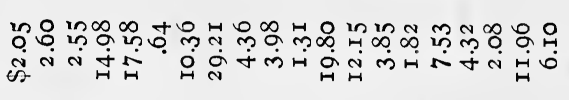 \\
\hline 兽 & 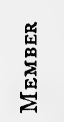 & 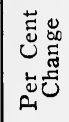 & 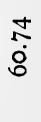 & 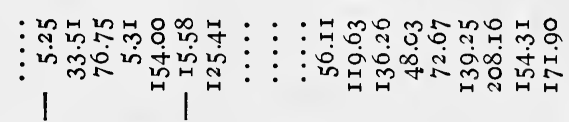 \\
\hline 总 & 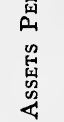 & ָి & 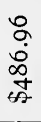 & 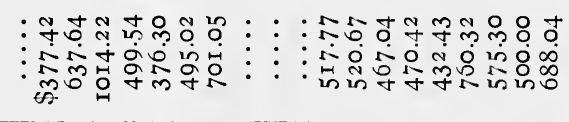 \\
\hline 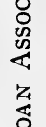 & 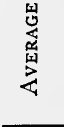 & ふ2 & 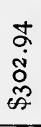 & 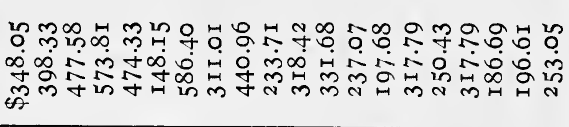 \\
\hline 案 & 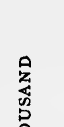 & 岂㟧 & $\stackrel{\leftrightarrow}{\dot{m}}$ & 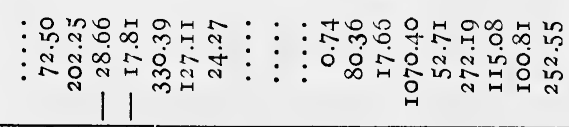 \\
\hline 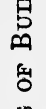 & 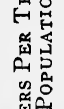 & ָె & $\begin{array}{l}\dot{\Xi} \\
\dot{J}\end{array}$ & 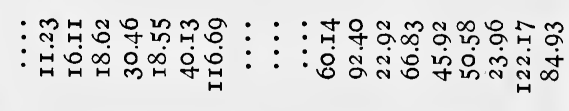 \\
\hline 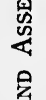 & & 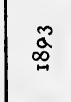 & $\stackrel{\substack{n \\
\infty}}{n}$ & 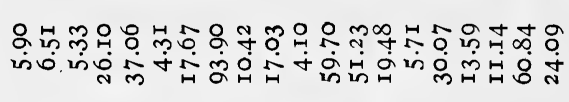 \\
\hline 茎 & & & 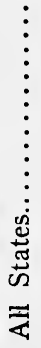 & 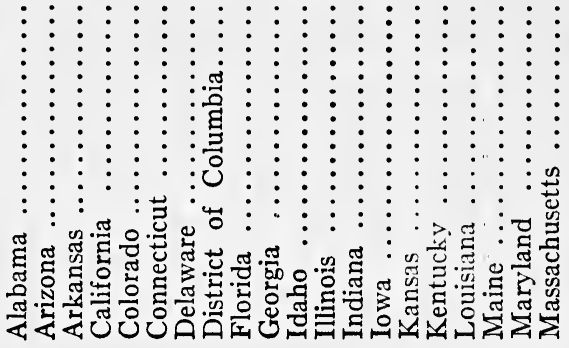 \\
\hline
\end{tabular}




\section{APPENDIX}

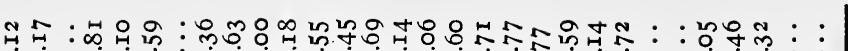
สं

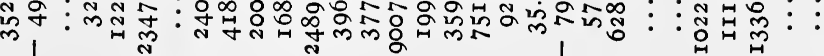

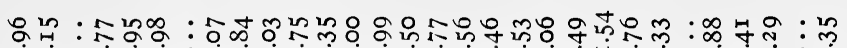

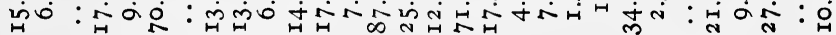
(1)

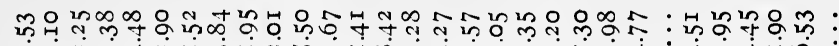

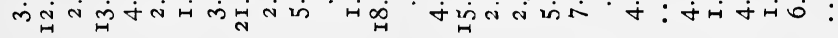

윘

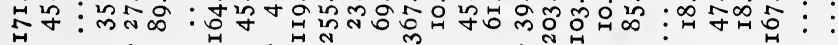

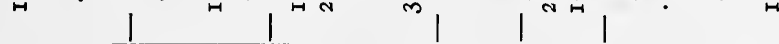

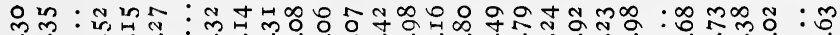

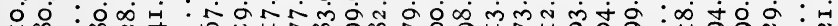

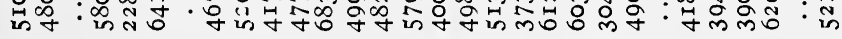

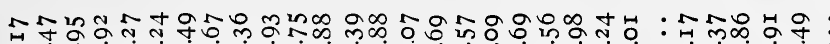

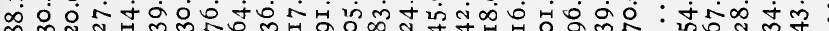
品 लై ₹

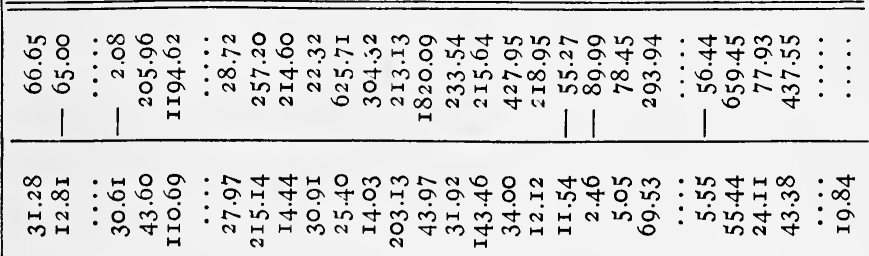

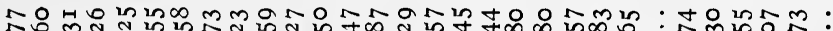
占

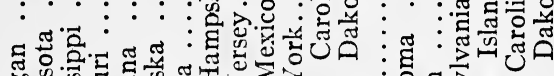

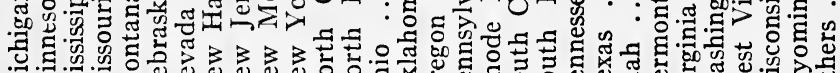

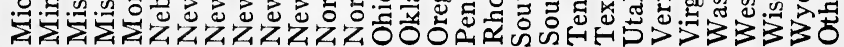




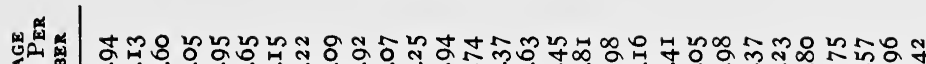
象鱼 ஜ்ம் 密密 $<$ 我 $\leftrightarrow$

要

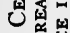

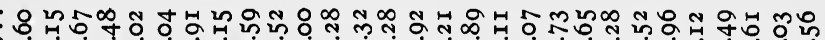
我安究

: व்ற்

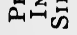

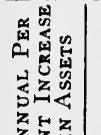

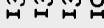

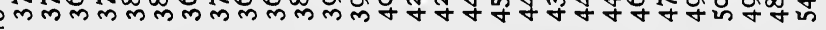
z

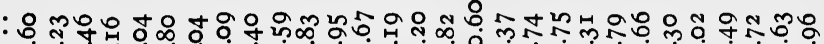

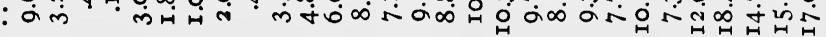

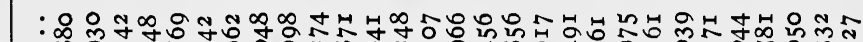
:

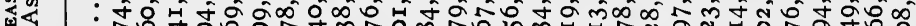

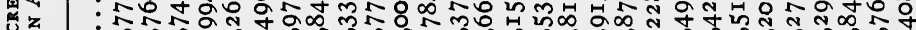

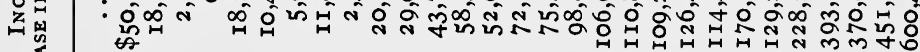
t $t+1|1| 1+t+t+t+t+t+t+t+t+t+t+$ 田 $+++|1| 1++++++++++++++++++++++$ $\lambda$

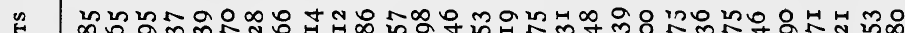

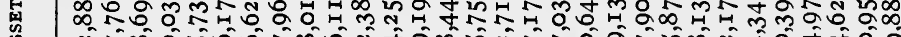
\% तิ
$4 \quad$ एतู
स क

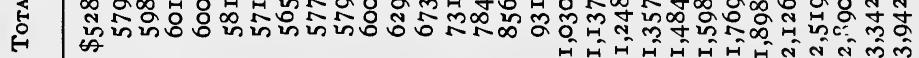

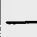

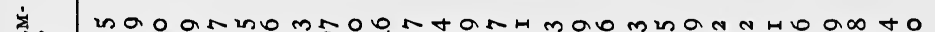

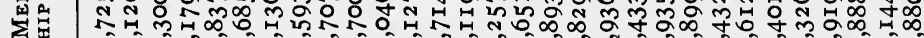

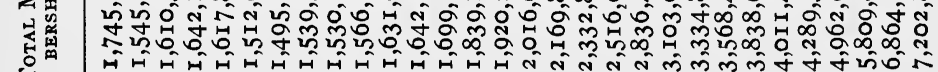

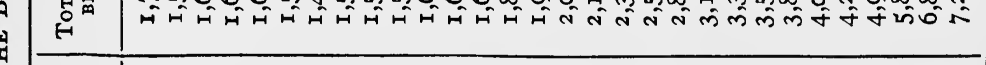

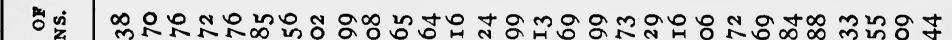
․․

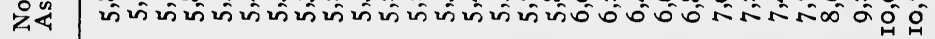


APPENDIX

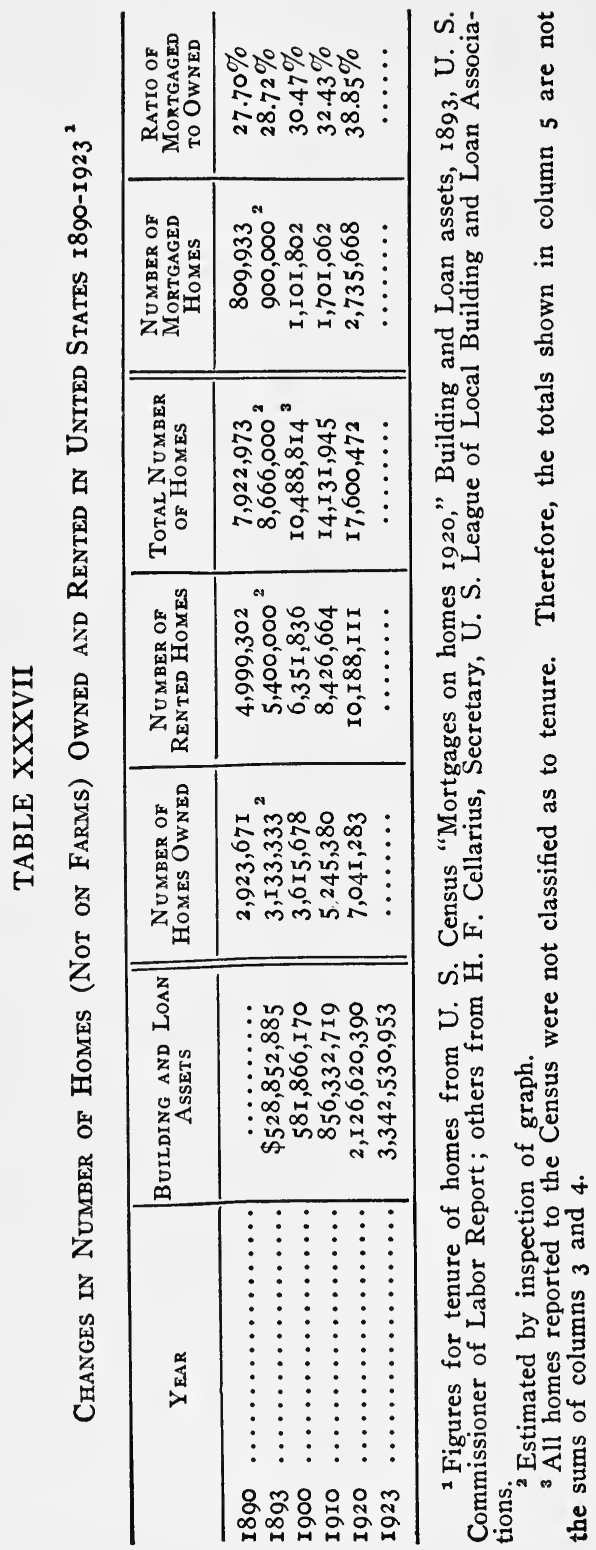




\section{CORPORATE NAMES}

Associations operating on the building and loan plans are not always called by the same title. A list of titles known to be in use in the various states is appended hereto. The great diversity of names causes much confusion among people unfamiliar with association business.

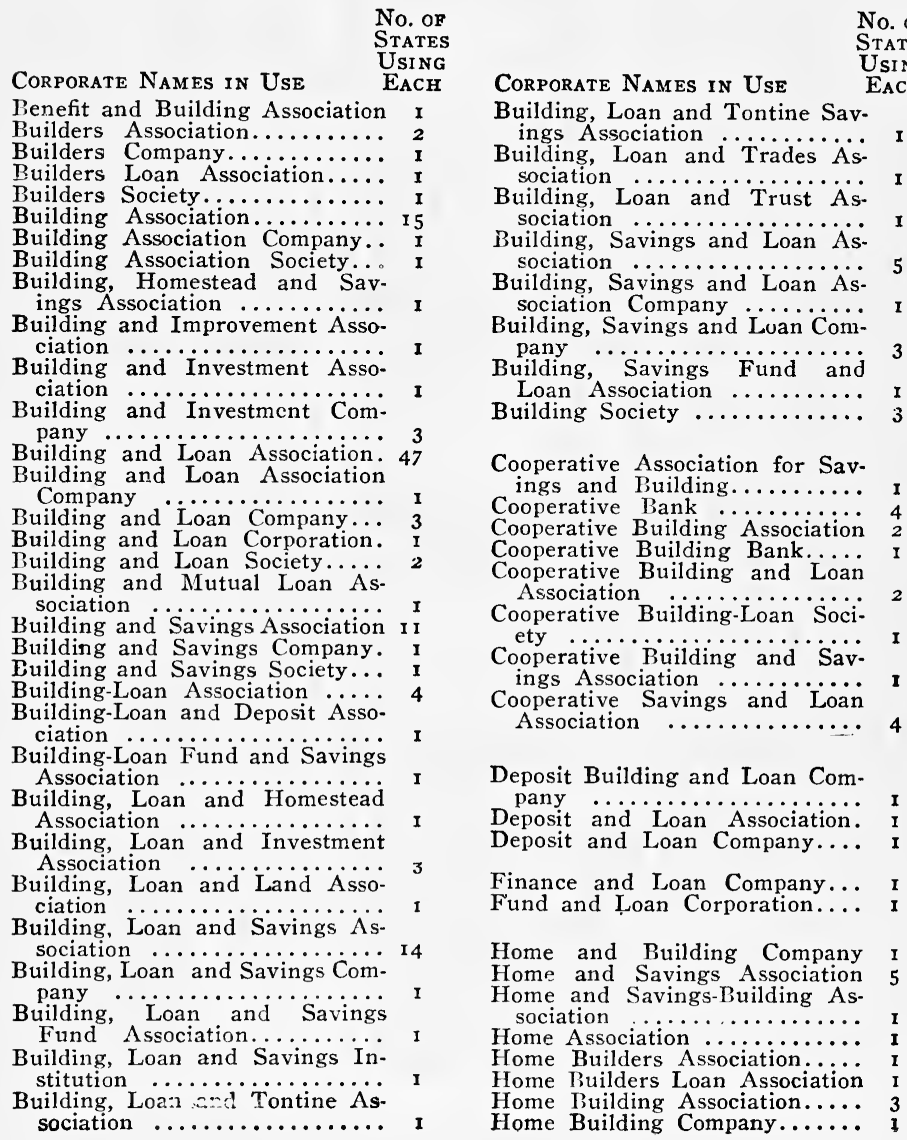


No. of

No. of

STATES

Corporate Names in Use

USING

EACH

Home Building and Loan Association...$\ldots \ldots \ldots \ldots \ldots$.

Home Investment Association..

Home Loan Association.........

Home Loan and Savings Association $\ldots \ldots \ldots \ldots \ldots \ldots \ldots$

Home Owners Corporation.....

ilome Savings and Loan Asso-

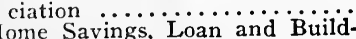
ing Association ...........

Homestead Aid Association.....

llomestead and Loan Association

I Iomestead and Loan Company.

IIomestead Association .......

Homestead Building, Loan and Savings Association .......

Homestead Company .........

Homestead Loan Association...

Improvement Association ......

Improvement Society ........

Investment Association .......

Investment and Building Asso-

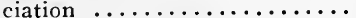

Investment Building and Loan

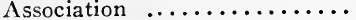

Investment Company $\ldots \ldots \ldots \ldots$

Investment and Loan Association

Investment and Loan Company.

Loan and Deposit Company.... I

Loan Association .......... 7

Loan and Building Association. I4

Loan and Building Association

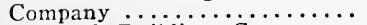

Loan and Building Company..

Loan and Ruilding Society....

Loan and Home Aid Company.

Loan and Homestead Association

Loan and Improvement Associ-

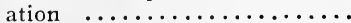

Loan and Insurance Company..

Loan and Investment Association

Loan and Investment Company

Loan and Savings Association..

Loan and Savings Company....

Loan Building and Deposit Com-

Loan Puilding and Savings $\ddot{A}$ s. sociation $\ldots \ldots \ldots \ldots \ldots \ldots$

Loan Company .............

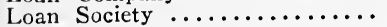

Mutual Benefit Building and Loan Association ...........

Mutual Building Association...

Mutual Building and Loan Asso-

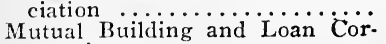
poration Building.............. IIomestead Association ...... Mutual Building, Loan and Savings Association ...........
Corporate Names in Use Using

Mutual Home Association..... I I

Mutual Loan Association...... 2

Mutual Loan and Building Association $\ldots \ldots \ldots \ldots \ldots \ldots$.

Mutual Loan and Savings Association $\ldots \ldots \ldots \ldots \ldots \ldots$

Mutual Savings and Loan Association $\ldots \ldots \ldots \ldots \ldots \ldots \ldots$.

Premium and Loan Association

Rural Credit Building and Loan Association...$\ldots \ldots \ldots \ldots$........

Savings and Building Association Savings and Building and Loan Association $\ldots \ldots \ldots \ldots \ldots$.

Savings and Building Company.

Savings and Building-Loan Asso-

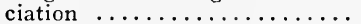

Savings and Farm Loan Com. pany $\ldots \ldots \ldots \ldots \ldots \ldots$

Savings and Homestead Association $\ldots \ldots \ldots \ldots \ldots \ldots \ldots$ r

Savings and Loan Association.. 29

Savings and Loan Association Company $\ldots \ldots \ldots \ldots \ldots \ldots$

Savings and Loan Company......

Savings and Loan Society......

Savings Association ............

Savings Association Company..

Savings, Building and Loan Association $\ldots \ldots \ldots \ldots \ldots \ldots$.

Savings, Building and Loan Company $\ldots \ldots \ldots \ldots \ldots \ldots \ldots$

Savings Company $\ldots \ldots \ldots \ldots \ldots, 3$

Savings Fund Association.......

Savings Fund and Building Association $\ldots \ldots \ldots \ldots \ldots \ldots$

Savings Fund and Loan Association $\ldots \ldots \ldots \ldots \ldots \ldots \ldots$

Savings Investment and Building Association .............

Savings \& Investment Association $\ldots \ldots \ldots \ldots \ldots \ldots \ldots$

Savings Investment Company...

Savings, Loan and Building Association ..............

Savings, Loan and Homestead Association ...............

Savings Society $\ldots \ldots \ldots \ldots \ldots$

Security and Loan Association

Security Loan Corporation.....

Society for Home Building and Savings $\ldots \ldots \ldots \ldots \ldots \ldots \ldots$

Society for Savings ..........

Trust Company $\ldots \ldots \ldots \ldots \ldots$ (This is a regular old time serial Building and Loan Association in North Carolina.)
I 43 different forms of corporate title 


\section{APPENDIX}

No. of
STATES
USING
EACH
47 States
29 “
15 “
14
14 “

Corporate Names in Use

Title: Building and Loan Association used in.....

Title: Savings and Loan Association used in ....

Title: Building Association

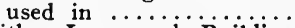

Title: Loan and Building Association used in....

Title: Building, Loan and Savings Association used in $\ldots \ldots \ldots \ldots \ldots \ldots$.

No. of

States

No. or

USING

Corporate Names in Use

Title: Building and Savings

Association used in.....
Title: Savings, Loan and

Building Association used in...$\ldots \ldots \ldots \ldots \ldots$.

Other words used in titles: Aid, Benefit, Farm!, Finance, Improvement, Institution, Insurance, Land, Owners, Premium, Rural Credit, Security, Tontine, and Trades. 


\section{GLOSSARY}

Abstract of Title: A history of the title (not a guarantee).

Amortization: Means "killing off" a debt through the use of periodical payments.

Assured Investment Combination: Combining a life-insurance contract with a savings plan.

Bond of the Borrower: Personal promise of the borrower to repay the loan with the interest and other agreed charges. It is always executed by the borrower under a formal seal.

Building and Loan Plan, Regular: Lending a given sum against real-estate mortgage security, to be repaid by maturing shares of the value of the loan.

Cancel and Endorse Method: Periodical reduction of principal and interest in units of one share. Borrower's note and certificate are endorsed by association officials as each share is canceled.

Certificate of Indebtedness: A direct obligation of the association, establishing .. debtor and creditor relationship.

Certificate of Necessity: A permit for a new association to begin business, issued by the supervisor when he is convinced that the proposed organization is needed in the locality.

Coefficient: As used in the "dollar-month" formula is part of the formula for arithmetical progression.

Company Associations: Operated for the benefit of the employees of a single concern.
Contingent Reserve: Account accumulated from earnings to provide a "buffer" for future losses. Its purpose is primarily to equalize dividends.

Controlling Accounts: Ledger accounts which summarize a number of similar individual accounts.

Credit-Intermediate: Covers the needs of borrowers who wish longer extensions of credit than are possible by commercial banks, but do not wish to give mortgages or other long-time types of security. (Usually runs for 6 months to one year.)

Credit-Long-Time: Type of investment which will be repaid out of profits or income rather than from the entire proceeds of the sale of goods at one time. The basis of association business.

Credit-Short-Time: Self-liquidating credit.

Cumulative Voting: Privilege of casting as many votes as one has shares, multiplied by the number of directors or officers to be elected. The total number of votes may be cast for any one candidate, or may be distributed among several candidates.

Deed of Trust: Differs from mortgage only in the method by which title to property is conveyed in case of default. It provides for a trustee, an outside party, who holds the title during the life of the debt.

Defeasance Clause (in a mortgage): States that the absolute transfer of the property may 
be "defeated" or voided if the borrower pays his debt.

Deposits: In building and loan associations, where accepted, are similar to savings bank deposits, receiving, however, a higher rate of earnings.

Deposits, Machine: School savings accepted through the use of automatic stamp sellers.

Dexter Plan of Distributing Profits: A slight modification of the Partnership plan. It treats past distribution as definitely belonging to each series.

Dollar Months (or Years): Number of months (or years) that the borrower or lender has the use of one dollar.

Equated Time: The average length of time that an investment has been held by an association.

Equilibrium: After the first maturities, the association tends to reach a point of equilibrium, when assets and liabilities show little change although sums to be loaned to new borrowers will be decreased due to the repayment of the principal of maturing shares (unless there is a progressive increase in the sale of shares).

Escrow: The temporary deposit of papers (or the title which those papers represent) into the hands of a third party, or trustee, for delivery upon the completion of some contingent act.

Fees - Membership: Charges made when an individual joins an association, designed to cover expense of handling the business.

Fees-Withdrawal: Deductions from book value when shares are withdrawn before maturity.

Fines: Employed for the purpose of enforcing promptness in making payments by both savers and borrowers; usually consist of regular interest on delinquent payments.
Foreign Associations: Any association is a "foreign" association when it enters another state than that in which it was organized.

Forfeited Shares: When accumulations are uncalled for by delinquent members, the term "forfeited shares" is usually applied to the proceeds. In older usage, shares might be forfeited through fines or other charges. This is no longer practiced.

Forfeiture: Most commonly consists of withho!ding a portion of earnings im case of withdrawal of shares before maturity.

Granting Clause: Gives the mortgage the appearance of an absolute conveyance, but is subject to later clauses.

Group Life Insurance: Insuring the lives of officers by the association.

Habendum Clause (in a Deed or Mortgage): Defines the legal title that the mortgage would convey if the courts construed it literally, in other words, the "size," or legal quantity, of estate granted (usually a fee-simple title).

Income Bonds: Have characteristics of investment certificates, with stipulater rate of dividend.

Interest Rate, Actual: Found by crediting dividends as offsets to interest, deducting all lump charges from gross loan, and calculating cost on net loan for entire period. (Most easily found by "dollar-month" formula.)

Interest Rate-Contract: Rate which no agreement between creditor and borrower may exceed. It is usually three or four per cent higher than the legal rate.

Interest Rate-Legal: Rate set by statute in each state, which applies to loans upon which the borrower has agreed to pay in- 
terest but in which the rate has not been specified.

Investment Certificates: Comparable with ordinary bank certificates of deposit. They are permitted only where guarantee stock or a reserve fund exists to guarantee the contract rate of earnings.

Juvenile Savings: Represented either by special certificates or on pass-books; each child's name being carried as a separate account. Not subject to same restrictions and regulations as shares for adult members.

Land Bank of New York: A clearing house for building and loan associations in the State of New York, by which they secure funds from each other and from outside investors by means of bonds of the Land Bank.

Leasehold: A long-term contract for the use of land.

Local Association: One which confines its business within state or county boundaries.

Machine Deposits: See Deposits.

Maturity of Shares: Installment shares mature when they reach their par value, and are ready to be repaid to the investor.

Mortgage-First: A contingent conveyance of property from borrower to creditor, given as security for loan. This conveyance becomes void when the debt is paid. In case the property is sold to pay the debt, the holder of the first mortgage has first claim.

Mortgage-Real-Estate: Instrument by which title to property is conditionally transferred is security for a loan.

Mortgage-Second: A lender's claim to property which is secondary or "junior" to claim of another lender on same security. Mortgage-Straight: One where no method of repayment is specified; issued usually for three or five year terms.

National Associations: Organizations formed to do business on a national scale, either through agents or by mail. Now practically obsolete except for half a dozen conspicuously successful associations.

Ostensible Rate: Interest rate which association claims to be charging.

Partnership Plan of Distributing Profits: Profits distributed on the assumption that all profits constitute a common pool for all series alike, to be redivided at each dividend date.

Periodic Reduction: Borrower makes uniform payments throughout the life of the loan, part applied to interest, remainder reduces the principal. Interest charged only on balance.

Plan: The type of contract between the association and its members by which money is invested in the business.

Plan-Dayton Permanent: Similar to regular permanent plan, except that no method of enforcing systematic payment is used.

Plan-Guarantee Stock (principally used in California): Consists of a basic stock which is not withdrawable and which is used to guarantee earnings on installr.ent shares or investment certificates. Earnings in excess of the contract liabilities accrue to the benefit of the guarantee shareholders.

Plan-Permanent, R e g u 1 a r : Each shareholder has an independent ledger account, and his shares start and mature without regard to others. Periodical payments are uniform in amount, and regularity is expected and usually enforced.

Plan-Permanent Stock or "Contingent Reserve Stock" (Kansas): Used to guarantee 
earnings to other shareholders. Unlike the guarantee-stock plan, "permanent" stock may be withdrawn under certain conditions.

Plan-Serial: Issues new shares of installment stock at periodic intervals. All shares of each series have uniform value until maturity.

Plan-Terminating: Issues only one group of shares, sells them to savings members, lends proceeds to borrowing members, and at maturity discharges all obligations and "terminates" the association.

Premium: An additional loan charge, originally used to determine precedence in borrowing.

Premium-Gross or Lump Sum: Premium bid by the borrower and deducted from loan in advance.

Premium-Installment: Premium bid by the borrower, which is paid in periodical installments in the same manner as interest and dues.

Premium, Interest: In the "interest premium" plan, the rate of interest to be paid by the borrower is determined by bidding.

Premium, Net: Interest is charged on the amount that the borrower actually receives instead of upon the face value of the loan.

Premium-Unearned: Premium paid in advance which remains in the association's hands after crediting the portion due the association each successive month.

Profits; Unearned or "Unrealized": Money paid to association as interest or premium in advance, not yet earned, and accounted for separately until earned.

Refunding of a Mortgage: Borrowing a similar sum on the same security from another lender, and paying off the first with the proceeds of the second. The term "refinancing" is also used.

Renewal of a Mortgage: Borrowing the same sum on the same security for another period from the same lender.

Self-Liquidating Loans: Loans, the proceeds of which are used to purchase goods which will be used or sold by the borrower before the loan is due, so that the proceeds of the sale may liquidate the loan

Shares, Free: Savings shares which have not been pledged as part of the security for a loan. Proceeds of free shares are paid to members at maturity or when withdrawn.

Shares, Pledged: Shares which have been pledged to the association as part of the security for a loan.

Split Loan: Total loan split into two parts which are then secured by filst and second mortgages.

Stock-Deposit Shares: Used in some states to indicate installment shares held under the Dayton plan.

Stock-Double-Payment: Used in order to mature a given sum more quickly.

Stock-Guarantee: Similar to capital stock in a bank. It is used to guarantee a definite profit to savings members on their investment, and receives excess earnings. It is not withdrawable.

Stock-Installment: Stock with a fixed matured value, on which the shareholder agrees to pay a given amount of money at regular intervals, usually the same amount at each payment, until payments and dividends equal the matured value. The proceeds are then repaid to the investor or converted into paid-up stock. 
Stock-Optional Installment: A term which more aptly describes "deposit shares," where the time and amount of the payments is optional with the shareholder.

Stock-Paid-up or Full Paid: Full par value paid by the member at time of subscription. Stock-Permanent or Contingent Reserve: Similar to guarantee stock except that it may be withdrawn when all contract liabilities for which it is pledged have been liquidated.

Stock-Prepaid: Calls for a lump-sum payment at the time of purchase: the sum which, at the current rate of dividend, compounded, will amount to the matured value in a certain time.

Strawman: A fictitious person or an applicant who is acting for some one else.
Turnover: Number of times a given amount of money is received and paid out.

Undivided Profits: Temporary items transferred to an account so named, or allowed to remain in the profit and loss account, until the directors dispose of them.

Warrant: Sometimes accompanies the bond and mortgage: an authorization signed by the borrower and directed to the attorney of the association, providing that suit may be brought in case of default. It "confesses judgment" or releases to the association all rights which borrower had before default.

Withdrawal Value: Book value of shares at any given time, less charges of a minor nature. 
, 2 


\section{INDEX}

Abstract of title, use, 206.

Acceptance of material bill to avoid liens, 217.

Accounting, 267-302; advance payments, 335; controlling accounts, use of, 278 ; Dayton Plan, 298; guarantee and permanent-stock plans, 298 ; illustrated example of association records, 270; juvenile savings, 327 ; ledger accounts, sample, 280 ; legal requirements, 410 ; permanent plan, 297 ; suggested readings, 495; systems, uniform, 299; uniform, prescribed, 369 .

Accounts, joint and several, 398 .

Advance payments, accounting for, 335 ; legal restrictions, 398 .

Advertising, expense, 34I ; must have news value, 308 ; national coöperative, 318 ; newspaper, 304, 308; restrictions, Ohio, 4I 3 ; use of attractive office, 307 .

Allotment of loans, 203.

American Savings, Building and Loan Institute, 486.

Amortization, advantages, 254; a method of paying off a debt, 5 ; applied to farm loans, 224 ; permits higher percentage loans, I 97.

Amounts of prepayment allowed, 70 .

Application for loan, 204, 300; transfer of, 264 ; priority, legal provisions, 402 .

Appraisal, 230-247 ; before construction, 243; committee, Io6; examination of property, 205 ; copy of, furnished for Land Bank loans, New York, 482; estimates of depreciation, 239; of house, 236 ; "One-Per-Cent rule," applied to rent, 24I; "point system" of comparing values, 234 ; record, 300 .

Appraisor, individual, 230.

Approval of charter by state supervisor at organization, 85 .

Articles of agreement, approval, 388 ; filing, 386 .

Articles of incorporation, fees for, 4ig; (Same as Charter), 86.
Assessment of taxes upon members, 435 .

Assets include contingent reserve, 343 ; list of items, $28 \mathrm{I}$; need for study of plans in use based on assets, 61 ; Table 1893 to 1923 , 5I4; Table r893 to 1924, 516; taxation of association, 417 .

Assistant-Secretary, duties, I02.

Associations compared with banks, 29; compared to population, 80 .

Attachment, exemption of shares from, Vermont, 4 3 .

Attorney, duties, I08; examination of title, 206.

Auditing committee, I07 ; methods, 370.

Authorization for borrowing by association, I 26.

Averages, definitions, 507 .

Balance, trial, 293.

Bank, department as supervisor, 375 ; failures in U. S., 364 ; Land Bank, New York State, 479; portable, for juvenile savings, 325.

Bankers, coöperation in community campaigns, 3 I 4 .

Banking, school savings, 333 ; suggested readings, 495 .

Belgium, history of coöperative credit, 472.

Bidding for loans, legal provisions, 402 ; premium, 36.

Blotter, disbursements record, 284 .

Blue-sky laws, sometimes affect associations, 367.

Bond, accompanying mortgage, form of, 2 Io; approval before purchase of bonds with excess funds, 369.

Bond, fidelity, 394; corporate suretyship, I03; custody, 96, 103; required by law, 393 .

Bond, for proper completion of building, 2 I 8.

Bond, income bonds issued by some associations, 74 .

Bond, Land Bank of New York, I 98,479 ; security for, 483 . 
Bond, mortgage, based on real estate, 25.

Bond, of no value after defalcation, I 04.

Bond, of officers, 94, 102.

Bond, purchase permitted with excess funds, 198 .

Bond, quoted in trust deed, $2 \times 2$.

Bond, real estate mortgage bonds, 25.

Bond, reasons for use with mortgage, 261 .

Bond, rural-credit, Indiana, 226.

Bond, stamp tax, federal, 430 .

Bond, street-improvement bonds, possibility of lien, 233 .

Bond, surety, 102-104; approval by state supervisor, I03; personal, use limited, ro3.

Bookkeeping, see accounting, 267302 ; simplified for juvenile savings, 327 .

Books, required by state law, 4 Io.

Borrower, also a savings member, 64 ; cannot afford to permit foreclosure, 223 ; character of, important in making loan, 202, 249; clear explanation of loan conditions, $22 \mathrm{I}$; credit information regarding, 203; legal treatment in insolvent associations, 410; liability of, 255,263 ; liability under periodical reduction plan, I42; membership requirements, I99203.

Borrowing by association, restrictions, I 26, 403, 408; security for, I 26-127; to meet maturities, I 20 .

Borrowing by corporations from associations, restricted, Wisconsin, 413.

Borrowing, by individuals, economic considerations, 439-451.

Borrowing for seasonal needs, I 25 .

Borrowing to avoid withdrawal fees, $183,252$.

Branch offices, use of, 9 I ; legal provisions, $4 \mathrm{II}$.

Building and loan plan, regular, I 34-I 37 .

Building, appraisal before construction, 243 ; appraisal of, 236.

Building construction,-training officials for appraisal work, 490 .

Building, economic considerations, 439-45 I ; effect of type of building upon value of lot, 235 .

Burglary insurance, 102 .

Business development, methods in use, 304 ; new opportunities, 305 .

Business men, conference for gaining community coöperation, 313 .
Business territory, legal limitations, 90.

By-laws, adoption, 86 ; amendment, 393 ; designed to supplement statutes, 387 ; legal provisions, 388 ; of early associations, extracts from, 458 ; purpose, 35 ; suggestions for, 497 ; withdrawal provisions, 186.

California associations, withdrawal practice, I85; guarantee-stock plan, 47-50; juvenile savings, 329.

Campaigns, community, 304 .

Cancel and endorse method, I43.

Capital attracted by safety, $35 \mathrm{I}$.

Capital fund of association, what this includes, 35 .

Capital, guarantee, California, 47 ; Colorado, 72; Indiana, under rural-credit act, 226.

Capital, loss because of fees, 178 .

Capital, of New York Land Bank, owned by associations, 482 .

Capital requirements, legal, 386.

Capital stock record, 410 ; tax, 429.

Capital, supply and demand curves, 352 .

Cash book, accounting, 270 ; combined with journal, form, $29 \mathrm{I}$ 292.

Cash reserve, advantage of accumulating, $25 \mathrm{I}$.

Census, changes of ownership of homes, 44I, 447.

Certificate of necessity, use of, 368 .

Certificate of shares, legal requirements, 396 .

Certificates, investment, 49, 73 .

Certificates of deposit, 49.

Certificates of indebtedness, 74-75; stamp tax, 430 .

Changes in plans in use, 1893-1923, 6o-6r.

Character of borrower, important in making loan, 202, 249.

Character of secretary, importance, 98.

Charges, effect upon interest rate, I 55-158; withdrawal, 361 ; types in use, $170-179$.

Charter, application for, 85 ; fees, 418; legal provisions, 388; see also suggestions for by-laws, 497 .

Checking appraisal estimates, 236.

Checks, signature of two officers, 284.

Chemung valley, juvenile savings, 326.

Chicago, juvenile savings, 329. 
Circular distribution for advertising, 304-307.

City leagues, functions, 485 .

Classifications of associations, according to plans used, 501-503.

Clearing houses for funds, I98; need for, 476 .

Collection of monthly dues, authorization for draft, 208.

Colorado, guarantee-stock, 72 .

Combination of plans, to care for all savers, 86.

Commercial-bank funds, purpose, 19.

Commissions, for sale of stock, legal restrictions, 4II; not permitted on farm loans, Kansas, 227 ; paid from withdrawal fees, 176 .

Committee, appointments, 392 ; appraisal, duties, 106, 230; auditing, duties, I07; finance, duties, Io8; for community campaigns, 316; membership, duties, 108 ; organization, I05-108; promotion, duties, ro8.

Common law trusts, now eliminated, 493.

Community campaigns, 304 .

Community, effect upon selected, 86 ; coöperation, 3 I I.

Company associations, 89.

Compensation, directors, 88 .

Competition, effect upon interest rates, 152.

Compound interest, advantages, 252.

Computation, equated time, 357 .

Constitution, adoption, 86 ; of early associations, extracts, $45^{8}$; see suggestions for by-laws, 497 .

Construction, appraisal during, 243 ; building, information paid for by fees, I80; loans, 26I ; loans, procedure, 216 ; type of, must be adapted to building, 445 .

Contingent reserve, $342-350$; a necessary expense, 161; effect upon dividends, 355 ; legal requirements, 397,404 ; share of, credited to member on early withdrawal, I7 I; similar to surplus, 290; size, 347 ; source, 346.

"Contingent-reserve" stock, Kansas, $50-53,72$.

Contingent reserve, taxation of, 4I7; withdrawal of, legal requirements, $4 \mathrm{II}$.

Contract companies, elimination, 493.

Contracts, real estate, stamp taxes, 430.
Control, differences among shares in affairs of association, 75 ; legal provisions, Nevada, 4I 2.

Controlling accounts, ledger, 278286.

Conveyance, deeds of, stamp taxes, 430.

Conveyancer, duties of, 108 .

Coöperation, basis of credit, 19 , of borrower necessary for safety, 249; of members in developing business, 304 .

Coöperative bank, name adopted in Massachusetts (same as building and loan association), 462 .

Corning, New York, juvenile savings experience, 325 .

Corporate names in use, 518 .

Corporation commission, as supervisor, 377 .

Corporation, finance, suggested readings, 496 .

Corporation laws, affecting associations, 391.

Corporations, as share owners in associations, 398; borrowing from associations forbidden in Wisconsin, 4I3.

Cost of newspaper advertising, 309 .

Costs, loan, calculation, 257.

Counsel, legal, duties, 108 .

County leagues, functions, 485 .

Covenants, in trust deeds, 212 .

Credit bureaus, 203.

Credit for early payment upon loans, I $25,144$.

Credit, foundations of, 248 ; intermediate, defined, 2I; long time, types of corporations dealing in, 2I-25; used by associations, $2 \mathrm{I}$; meaning of term, 278 ; short-time, defined, 20 ; slow vs. liquidating, I4 societies, probable origin, 453.

Creditors preferred, seldom used by associations, 64.

Criticisms of all plans in use, 54-59.

Cumulative voting, described, 390 .

Customers, treatment, to insure success, 100.

Daily accounting summary for offcers, 287-294.

Dates of organization of early associations, $46 \mathrm{r}$.

Dayton plan, 43-47; accommodates all types of income, 45 ; associations primarily invest in mortgages, same as other associations, 46; bookkeeping, 298; criticism, 57 ; sample ledger page, 
283 ; taxation, 432 ; withdrawal, 169,183 .

Debit, meaning of term, 278 .

Debit slips, 284.

Debts, association, list of items included, 282.

Deed of trust, description, 2 I I-2I 4.

Deeds, stanisp taxes, 430.

Default, use of warrant in case of, 2 II.

Defeasance clause, mortgage, 209.

Defeasance clause, trust deed, 213.

Definite-plan associations, criticized, 58.

Definitions of building and loan association: Rosenthal's, Sundheim's, Treasury Department, 7 .

Delinquency, legal effect upon foreclosure, 404.

Department, supervising, 375 .

Deposit of mortgages by Land Bank of New York as security for bonds, $48 \mathrm{I}$.

Deposit of securities with state official by association, $4 \mathrm{II}$.

Depository for funds, designation of, IOI.

Deposits, certificates of, 49 ; legal restrictions, 396; machine, for juvenile savings, 3.31 ; profits upon, accrue to shareholders, 339 ; shares, similar to Daytonplan shares, 68 ; slips, $27 \mathrm{I}$.

Deposits, use of, 30,45 , I 31 .

Depreciation, 239.

Development, methods in use, 304 .

Dexter plan of dividend distribution, 359.

Directors, action, on loan applications, 205; action to authorize borrowing, 126; compensation, 88; daily information regarding accounts, 287 ; duties, 93 ; investment required, $39 \mathrm{I}$; legal requirements, 392; minutes of meetings, $30 \mathrm{I}$; negligence in bonding officers, I 04; New York Land Bank, 480 ; personal liability, 94 ; responsibility for safety of loans, 197 ; term of office, 88 ; qualification and selection, 87 .

Disbursements, accounting, 270; expected, in new association, 113 I 20 ; list of, 273 ; posting, 284 .

Distribution of circulars as advertising, 307.

Distribution of profits, $35 \mathrm{I}-362$.

District leagues, functions, 485 .

Dividends, actual, compared to expected, in case of early withdrawal, I77; checks, used for education of children, 70 ; credited toward repayment of loan, I37; definite policy, 339 ; distribution, methods, 356 ; rates, 297 ; effect of contingent reserve, 355 ; estimated between periods in case of early withdrawal, 172; for borrowers, 76 ; guaranteestock, definite obligations as. sumed, 47; legal requirements, Nebraska, 412; on juvenile savings, 324 ; on stocks, a source of funds from members, I 12 ; policy, methods of distribution, $35 \mathrm{I}-362$; rate, uniform, 352 ; rate, varying, 360 ; reduced on withdrawal, 173; should be reasonable, I 45; simple interest instead of compound in some cases of early withdrawal, I74; source of, 334 ; Washington associations in case of early withdrawal, 184 .

Dollar-month formula for computing interest rate, $156-158$.

Double-payment shares, 73 .

Draft, authorization for collecting monthly payments, 208 .

Dues, meaning and use, 34 ; authorization for collection by draft, 208 ; average payments in U. S., 509 ; itemized in cash book, 271; legal provisions regarding forfeiture, 402 ; restrictions, 398.

Duties, of directors, 93 .

Duties of secretary, 98-Ior.

Duties of treasurer, I0I-102.

Earnings, 334-34I ; effect upon maturity of shares, 68 ; Dayton plan, credits on early withdrawal, 183 ; determining net from gross, 356 ; excess, on early withdrawal, how credited, I7I; excess, source and use, 339 ; forecasting amount of, 339 ; forfeitures, legal provisions, 395; guaranteed, California plan, 47 ; legal provisions regarding forfeiture, 402; loss prevented by borrowing, 173 ; on early withdrawal, amount reduced, I 7I-I75; paid to last dividend date, I72-173; seldom paid if withdrawal takes place during first year, I70; uniform reduction, I73; varying reduction, I74; when fee is charged, 178 ; withheld, 166 .

Earnings, on juvenile savings, 324 ; serial, partnership plan of distribution, 298 ; source of reserve, 343 ; terminating association, 34 . 
Economic considerations, in borrowing, 439-45 $\mathrm{I}$.

Economics, suggested readings, 495 .

Education, building and loan, under the Institute, 486.

Education, made possible by dividend checks, 70.

Education, readings in topics related to building and loan, 495 .

Election of officers, 394.

Elmira, New York, juvenile savings, 326.

Employers, as successful committee men, 316; advantages in using associations, 16 ; aid in organization of new associations, 89 .

Employment, agency, for members, 180.

Enforcement of payments, 39 .

England, history of building societies, 454.

Envelope system for juvenile saving, 326 .

Equated time, meaning and use in dividend distribution, 357 .

Equilibrium, tendency toward, among $\$ \mathrm{I}, 000,000$ associations, I 13 -I 20.

Equity of borrower, effect upon foreclosure, 223 .

Escrow, meaning of term, 2 r 9.

Examination by state, $363-384$; fees, 372, 418 .

Example of operation of association, 9-I 2.

Execution, exemption of shares from, California, $4 \mathrm{I} 2$.

Exemption, from taxation, federal income tax, 433; from taxation of shares of non-residents, Nevada, 412; rural-credit shares, Kansas, 435 ; state, 427.

Exemption of shares from attachment, Vermont, 413 ; of shares from execution, California, 4 I 2.

Expansion, history of, 470 ; limits to, 490.

Expenditures during construction, control of, 218.

Expenses, covered by fees in some associations, 166 , I 80 ; legal limitations, 404; legitimate, 340 ; limited to earnings, 395 ; of paid salesmen, 3 I I ; of purchasing the home, 446 ; paid from difference between interest and dividend rates, 172; part of financial policy, 160 ; ratio to business transacted, 305.

Explanation of shares, 67-75.
Exploitation of the borrower, continues a menace to the movement, 494 .

Failures, bank, 364; building and loan associations, 365 ; of the "Nationals," 467.

Farm loans, 224; bonds, Indiana, 226 ; Kansas and Nebraska, 226; North Carolina, 413; shares, tax exempt in Kansas, 435.

Farm mortgages, possible use by Land Bank of New York, 480.

Federal taxation, 428 .

Fees, advance payment, 335 ; a part of financial policy, I6I; arguments against, $181-182$; arguments in support of, $180-181$; as earnings, 338 ; average used in U. S., 509 ; avoided by borrowing, I83; charter, state, 388,418 ; effect of use, I 82 ; effect upon cost of loan, 259; effect upon interest rate, 260; examination, state, 418; for filing of articles of agreement, 388 ; for selling shares, 31 i ; for state examination, 372 ; justice of fees, depends upon size, 180 ; legal provisions for, 393-400; license, state, 372 418 ; loan, legal restrictions, 411 ; membership, uniform, 176 ; membership, use of, 40 ; not charged by banks, I8I; returnable to member, 337 ; withdrawal, 40 , 166, 175, 180; withdrawal, avoided by borrowing, 252 ; withdrawal, varying, i 78-180.

Figures showing population for each financial institution in U.S., 504.

Filing fees, 4 I 9.

Filing of fidelity bonds, 394 .

Finance committee, 108 .

Finance, private, definition, 18 .

Financial history, suggested readings, 496; institutions, investments of, 24 ; institutions, U. S., number of people for each in population, 504; policy of associations, 1 34-164.

Fines, 40-4I; a part of financial policy, I6I-162; legal provisions, $393-400$; negligible as a source of funds, 125 .

Fire insurance, 214.

Flat houses, saving involved in use of, 449.

Flow of investment funds among financial institutions, 23.

Forecasting net earnings, 339. 
Foreclosure experience in U. S., 513; legal provisions, 404; possibility, 26I ; use of, 222-224.

Foreign associations, history, 464; legal prohibitions, $4 \mathrm{II}$.

Forfeitures, $4 \mathrm{I}$; as a part of financial policy, I6I; as a source of funds, I 25 ; legal provisions, 145 , 395,402 .

Formula, dollar-month, 156.

France, growth of coöperative credit, 474.

Franchise fees, 4 I 9.

Frankford, location of first building and loan association in America, 457.

Fraud, guarding against, 493.

Free shares, 39 ; retirement, I 19.

Fresno, California, juvenile savings, 329.

Full-paid stock, 69-71.

Fund, contingent reserve, $342-350$; not separate from other assets, 343.

Funds, allottment, by Land Bank of New York, $48 \mathrm{I}$.

Funds, deposited in commercial banks, 28 ; responsibility for, IOI ; source of, I IO-I 33 .

Geographical distribution of plans, 60,501 ; location, no effect upon withdrawal, 169.

Germany, history of coöperative credit, 473 .

Grace, 30 days on early withdrawal, 185.

Granting clause, mortgage, 209; trust deed, 2 I 2.

Great Britain, history of building societies, 454.

Group conferences, functions, 485 .

Growth, city, effect upon values, 236.

Growth of associations, 1893 to $1924,516$.

Guarantee-stock plan, 47-50, 71-72; accounting, 298; Idaho, 72 ; Indiana, under rural-loan act, 225; legal permission to use, 396 ; Louisiana, limited use, 72 ; Oregon, 71; Rhode Island, 72 ; withdrawal practice, 185 .

Habendum clause, mortgage, 209212.

History, financial, suggested readings, 496.

History of associations, 452-475.

Hoards of money, as a source of funds, III.
Homes, see House.

Homestead associations (in Louisiana; same as building and loan association), I 3 .

Homestead associations, limited use of guarantee-stock, 72 .

House, appraisal of, 236 ; appraisal before construction, 243 ; depreciation of, 239 ; determination of size, 440; effect upon value of lot, 235 ; multi-family, advantages of, 253 ; ownership, economic considerations, 439-45I; U. S. Census reports, 517; purchase of, cause of withdrawal, I67; purchase of, financed through associations, 2 ; value, relation to income of owner, 253.

Housing trust, elimination, 493.

Idaho, guarantee-stock, use of, 72 . Ideals, thrift and ownership, 3 .

Idle money, method of placing in new loans, 99.

Improvement of lot, effect upon value, 235 ; of house, 447 ; street, effect upon value of lot, 233 .

Income bonds, as used by associations, 74 .

Income, differences, among shares, 75-78 ; expected, for new association, I I $3-120$; expected, under various plans, I 23-I 24 ; personal, relation to value of home, 239253; property, advantages, 253 ; tax, exemption of dividends on shares, 433.

Incorporation, suggestions for bylaws, 497.

Indiana, farm-loan experience, 225 .

Individual ledger, posting, 282.

Information about association practices, on a national scale, need for, 477 .

Insolvency, associations, 365 ; banks, 364 ; legal provisions regarding borrower, $4 \mathrm{I} 0$.

Inspection of property, for appraisal, $23 \mathrm{I}$.

Installment series, separate accounts for each, 297.

Installment, shares, 67-69; legal permission to use, 396 .

Institute, American Savings, Building and Loan, 486.

Insurance, burglary, 102.

Insurance, combined with savings, I 28-I 31 ; companies, investments of, 24 ; department, organized by an association, I 29-131; fire and wind, "loss payable clause" (to 
association), 214 ; fire and wind, record in office of association, 301; group life, for employees, 104-105; life, provisions of law, some states, 409; of title, 206.

Inter-association loans, methods of making and security given, 483 .

Interest, accrued, legal provisions, 410; important source of earnings, $124-338$; compound, advantages, I I 2-I I 3, 252; compound, effect in wiping out loan, r35I 37 ; increased by premium, 257 ; rate, actual, 155-158; on bonds, a source of funds, I 12 ; rate, calculation of, I 46-152, I 56, 507 ; rate, clear explanation to borrower, 221 ; rate, comparison of various plans, 140 ; rate, effect upon competition, 152 ; rate, farm loans, Kansas, 226; rate, fixed under Dayton plan without premium adjustment, 45 ; rate, high, one cause of withdrawal, I67; rate, legal provisions, 399,406 ; rate, selection of, by directors, I 58; rate, 7 per cent, table showing repayment of loan, I4I ; rate, 6 per cent, table showing repayment of loan, 139; rate, table showing effect of fees, 260 ; rate, used in split loans, r 95 ; saved under building and loan plan, 136; simple, allowed on early withdrawal in some associations, 174 .

Internal dangers, elimination, 493.

Investment certificates, 49,73 .

Investment, individual, legal limitations, 355, 398; long-term, need for educating members, 168 ; of excess funds by association, permitted types of securities, I62, 198 ; of various financial institutions, 24 ; required of directors, 391 ; suggested readings, 496.

Investors, attracted by safety, 351 .

Japan, growth of coöperative credit, 474.

Joint and several accounts, 398 .

Journal, description of, 288 ; with cash book, combined form, 29I292.

Judgment confessed by warrant of borrower in case of default, 211.

Juvenile savings, $73,323-333$; legal provisions, 396 .
Kansas farm loans, 266 ; permanent stock, 50,72 ; statistics of associations, 53; tax exemption of rural-credit shares, 435 .

"Key man," usually the secretary, 97.

Land Bank of New York, 479; bonds, 198 .

Land economics, suggested readings, 496.

Laws, state, affecting building and loan associations, 385-4I4; investments permitted, I 99-201 ; regarding withdrawal provisions, 186-189.

Leadership, need for, $489-496$.

Leagues of associations, functions, 476-488.

Leaseholds, not a desirable basis for investment, 198 .

Leasing clause, trust deed, 213.

Ledger, daily summary for officers, 294; membership, sample page, Dayton plan, 283; Serial plan. 285 ; posting, 277,282 ; trial balance of, 293.

Legal counsel, ro8.

Legislation, effect upon premium charged, 152.

Letters, form, for advertising, 317.

Liabilities, explained, 296.

Liabilities, list of, 282 .

Liability of borrower, 255 ; of directors, 94,392 ; of shareholders, 409.

License fees, $372,418$.

Lien, first, on real property, secured by first record in county office, 192 ; mechanics, avoided by "acceptance" of bill for material and labor, 217 ; of street improvement bonds against property, 233 .

Life insurance, for savings members, I 28-1 31 ; provisions of laws, 409.

Limitations, legal, upon contingent reserve, 348,404 ; upon investment by individual, 355,398 ; upon voting at stated meetings, 390 ; upon withdrawal, 400.

Liquidation, notice of withdrawal, a protection against, 186.

Liquidation, of banks, legal preference of association deposits, New York, 4 is.

Lists, mailing, for advertising purposes, 317.

Loan, allotment, in order of application, 203; amortized, advantages, 254; amount decided by 
directors, I97; amount that may be advanced during construction, 216; application, approval by proper officers, 94; application handling, 204; application, legal requirements, 4II ; application, record, 300; at six per cent interest, table for various repayments, I 39 ; at seven per cent interest, table for various repayments, I4I ; avoiding "strawmen" as borrowers, 202 ; bonds, accompany mortgage or trust deed, 2 10; bonds, permission to purchase by association, r98; borrowing by associations for shorttime needs, 403; canceled by matured shares, 35 ; character of borrower important, 202 ; charges, effect upon interest rate, I55; construction, special procedure and safeguards, 216, 261; costs, calculation, 257 ; costs, effect of fees, 259; costs, table showing effect of fees, 260; determining proportion of value to be loaned, 253 ; farm, 224 ; forced, in early associations to care for accumulated funds, 460 ; foreclosure as an added protection, 222 ; foreclosure experience in U. S., 513 ; insurance of property, 214 ; interassociation, methods of making, 483 ; interest rates in U. S., 509; junior lien, New York, 4I3; legal restrictions, 402; methods of making, in early associations, 457; mortgage form and use, 299 ; need for clear explanation of costs to borrower, 221 ; never made to officers, 202 ; note to accompany mortgage or trust deed, 210 ; offsets, in making reports of condition of association, 374 ; papers, handling, 214; pictures of property, valuable to association, 218.

Loan plan, advantages of periodical reduction, 142; "cancel and endorse," 143; principal reduced periodically, I37-143; regular building and loan, I $34^{-1} 37$.

Loan, procedure in handling, 190 ; rate, Skinner's computation, 5 I I ; refunding other mortgages. 2I9; renewal, avoided by use of amortization, 255 ; re-payment before due, r 20 ; restrictions, in new association, I19; selling, when excess funds occur, 320,395 ; signatures, 216 .
Loan, split, for use with two mortgages, I54; uniform-payment plan, 193-197.

Loan, stock of association as security, I 98,220 ; straight, competition with association loans, I 52 ; to other associations, $48 \mathrm{r}$.

Loan, transfer of, 263 ; application, 264 ; approval, 265 .

Loan, warrant may accompany mortgage and bond, $2 \mathrm{I}$.

Location of association, geographical, small effect upon withdrawal, I 69.

Loss of earnings, by members prevented by borrowing, I73; thorough use of commission and fee, 176.

Loss protected by contingent reserve, 342 .

Loss, shares affected, I 66.

Lot, appraisal of, 232 ; value, effect of house upon, 235 .

Louisiana, guarantee-stock plan, limited use, 72 ; "vendor's privilege and first lien," a form of mortgage, 192.

Machine, bookkeeping, 282 .

Machine, deposits, 331 .

Mail solicitation of business, $3 \mathbf{I} 6$.

Market for mortgages, limited, 26.

Market price, basis of valuation of property, 234 .

Market, "quick close," meaning, 26.

Married women as shareholders, 398.

Massachusetts, adoption of name "coöperative bank," 462 .

Material, base prices, for appraisal of construction, 244 .

Mathematical computation of interest rates, 146-152, 156, 507 .

Matured shares, used to cancel loan, 35 .

Matured value of shares, 67 .

Maturities, provision for, in a new association, II 9 ; unequal, causes of, 335 .

Maturity, expected, for prepaid shares, 69 ; expected, selection of period, 146; not used under Dayton plan, 44; of double-payment shares, $73 ;$ of shares affected by fees, 182 ; of shares, depends upon various factors, 38 ; of shares, time based upon earnings, 68.

Mean, average, defined, 507.

Meaning of terms, see Glossary, 521. 
Median, average, defined, 507 .

Meetings of shareholders periodical, customary in many associations, I6I.

Meetings of shareholders, quorum, 390.

Member, avoidance of loss by borrowing instead of withdrawing, 173 ; benefits by use of contingent reserve, 171 ; ledger account, individual, 282; liability, 409 ; need for education, to type of longterm investment, I68; new, making them feel "at home," 100 ; persistence, affected by fees, 182 ; requirement of "keeping in step" in some associations, 35 ; selection of association by individual, 312.

Membership, changes, 1893 to 1924 , 516 ; committee for securing new members, 108; defined, 201 ; evidences of, 396 .

Membership fee, 40 , r75 ; legal provisions, 400 ; paid to salesman for selling shares in some associations, 3 I I ; returnable, 337 .

Membership, growth 1893 to 1923 , 514; legal restriction upon investment, 355-398; quorum required, 390 ; taxation and exemption, federal, 433 ; taxation, state, 434.

Minors, right to own shares, 398 .

Minutes of meetings, $30 \mathrm{r}$.

Misdemeanor of officers for false statements, legal liability, 4 ro.

Misrepresentation, guarding against, 493.

Mode, defined, 507.

Model average, defined, 507 .

Money advanced during construction only as work progresses, 218 .

Money and banking, suggested readings, 495 .

Mortgage, assignment of, Kansas, 484; basis of security, 441; bonds, real estate, 25 ; credits for borrowers, in insolvency of association, legal provisions, $4 \mathrm{I} 0$.

Mortgage companies, types of investments, 25 .

Mortgage, deposited by associations with state official, 411 ; deposited by Land Bank with state official, New York, 48 I.

Mortgage, first foundation of association business, I9I; foreclosure of, 222; form and explanation, 208-210; increases, shown by U. S. Census, 442,517 ; pledged for
Land Bank loans, New York, 482 ; Real Estate, meaning, 2527 ; reasons for using bonds or notes in addition to mortgage, 261 ; refunding of straight loans, 262 ; release before maturity, 221.

Mortgage, second, I92; uniform payment under split-loan plan, 193-197.

Mortgage, stamp tax, federal, 430; straight, competition with, 152154; straight, legal permission to use, 395,402 ; used by Land Bank of New York, 480.

Mortgagee, defined, I $9 \mathrm{I}$.

Mortgagor, defined, I9I.

Moving from community, a cause of withdrawal, 168.

Multi-family house, advantages, 253, 449.

Names, in use, by associations, 13 , 518.

National associations, history, 464; laws opposed to, 385 .

National system of clearing-houses, for local associations, 477 .

Nebraska, farm loans, 226.

Need for an association, how determined, $79-83$.

Negligence, of directors, in bonding officers, 104.

Negotiability of securities, legal provisions, 409.

Neighborhood, effect upon values of property, 235 .

New Jersey, experience with juvenile savings, 324 ; League leaflets for education, 332 ; use of double. payment shares, 73 .

News, American Building Association, official organ of U. S. League, 486.

Newspaper advertising, 304-308.

News value of advertising necessary, 308.

New York, decision regarding contingent reserve, 344 ; experience with juvenile savings, 324; Land Bank, 479.

Note accompanying mortgage, purpose, 210,261 .

Note, for stock loan, 221.

Notice of withdrawal, 173,185 .

Notices, tax, 2 I 4 .

Number of associations, 1893 to 1924,516 .

Oath of office, directors, 88 ; offcers, 394 .

Objects, of associations, 14-17. 
Office building, legal restrictions, 406 ; branch, 9 I-92; branch, legal provisions, $4 \mathrm{II}$; choice of location, I60; directors, term of, 88 ; staff, 93-109; type of building to use, 307.

Officers, appointment and bonding, 102,394 ; liability for misdemeanor, 410; necessary, for a new association, 95; responsible for appraisal, 230 ; should not borrow from association, 202 .

Ohio, deposits, use of, I 3 I-I33; farm-loan experience, 225 ; juvenile savings, 329 .

"Ohio plan," or Dayton plan, 4347 ; criticism, 57-58.

Oklahoma, juvenile savings, 329.

Operation of association, example, 9-I 2.

Options, real-estate, stamp tax, 430 .

Ordinance, zoning, effect upon appraisal, 245.

Oregon, guarantee-stock, withdrawable, $7 \mathrm{I}$; reserve-fund stock, 72 .

Organization, Arkansas, legal provisions, 4I2; expenses, source, 84 ; fees, 419 ; methods, preliminary, $83-85$; preliminary, for community campaign, 312 .

Organizers required, legal provisions, 386 .

Ownership of homes, economic considerations, 439-45I; 1890 to 1923 from U. S. Census, 44I, 517.

Ownership of Land Bank stock by associations, New York, 482.

Oxford-Provident Association, organized 1831, 457 .

Paid-up shares, 69-7I; legal permission, 396.

Panic, I 893 , a stimulus to association growth, 466.

Partnership plan of distributing profits, 298-359.

Par value of shares, meaning, 67.

Pass-book, credits and withdrawal, $36 \mathrm{I}$; juvenile, 325 ; legal provisions, 396.

Payments, advance, accounting for, 335; uniform, split-loan plan, I 93-197.

Penalties, as earnings, 338 ; membership fees, 40, 176; withdrawal fees, 40 , I66, I 75 .

Pennsylvania laws for early associations, 46r.

Pension, of employees, New York, 4I 3 .
Percentage, of withdrawals, actual results, I 68-1 70 .

Perfection of title, when to insist upon before making loan, 206.

Periodical reduction plan, I 37-143.

Permanent plan, accounts, 297; criticism, 56 ; Dayton or "Ohio," 43-47; regular, 4I-43.

Permanent-stock, Kansas, 50-53, 7273 ; accounting, 298; issued in series or to cover all installment shares, 51-52; withdrawable, 52 .

Personal property, as security for loans, Wyoming, 413.

Personal property taxes, 435; avoided, 214 ; legal restrictions, 436.

Personal suretyship for faithful performance, 103 .

Personnel, organization of, 93-to9.

Pictures of property, useful in checking up loan, 218 .

Place of association in financial organization of U. S., 29.

Plan, choice of, 85 ; comparative number of associations, using different plans, 60, 501-503; "contingent-reserve stock," Kansas, 50-53; Dayton, permanent, 43-47; definition, 32 ; geographical distribution, 60, 501 ; guarantee-stock, 47-50.

Plan, house, necessity for using staple type, 445 .

Plan, Kansas permanent-stock, 5053; legal limitation upon use, 394 ; Ohio, permanent, 43-47; permanent, regular, $4 \mathrm{I}-43$; permanent, entrance of new members, 41 ; permanent, simplification of books, 43 ; serial, 38-41; terminating, 34-38.

Pledging shares for loan, legal provisions, 402.

"Point system" of appraisal, 234.

Pooling of capital, I 9.

Population available for associations in each section of country, $81,504$.

Posting disbursements, accounting, 284.

Posting, individual ledger, accounting, 282 .

Posting, the accounts, 277.

Powers, of attorney, stamp tax, federal, $43 \mathrm{I}$.

Preferred shares, legal provisions. 396.

Premium, advance, 335 ; as added interest, 36 , I 24,256 ; development of, 149-152; gross, 36, 151 ; 
gross, legal provisions for return of, to member on repaying loan before maturity, 337 ; installment, 36, I 51 ; legal restrictions, 399, 410; lump sum, 36, I51; on straight mortgage, forbidden, Pennsylvania, 413; same as interest, 36 ; to determine precedence in borrowing, 36 ; treatment on early repayment of loan, I45; unearned, 335.

Prepaid shares, legal provisions, 69, 396 ; necessary amounts to mature given shares, 70 ; expected maturity, 69.

President, duties of, 95 ; salary of, 96.

Prices, base, for material, in appraising construction, 244 .

Principal reduced on early withdrawal, 175.

Procedure, examination, $37 \mathrm{I}$.

Profits, credited to borrowing members, 35 ; distribution of, $35 \mathrm{I}$ 362 ; taxation of, 4I 7 ; undivided, 356.

Promotion committee, I 08 .

Property, appraisal of, 230-247; personal, as security for loan, Wyoming, 413; private, basis of mortgage, $44 \mathrm{I}$; rights, protection of, 446 .

Proxies, stamp tax, federal, 431; use of, 390 .

Publicity, for business getting, 84 .

Purchaser, liability of, in transfer of mortgaged property, 263 .

Quit claim, use of warrant in protecting loan, $2 \mathrm{I}$.

Quorum of members at stated meetings, 390 .

Rate, dividend, $297,360$.

Rate, interest, actual, I 55-I 58, 507 ; affects withdrawals, I67; compared, 140; determination of, 1 46-152; dollar-month formula, 156-158; effect of competition upon, I 52 ; legal provisions, 406; selection of, for association, 158 ; Skinner's computation, 5 I I.

Rate of taxation, upon shares, 435 .

Readings, in related topics, 495 .

Real estate, legal restrictions on ownership by association, 406 .

Real estate mortgage, foundation of association business, I9I.

Real estate taxes, 4I 6 .

Receipts, accounting for, 270.

Receipts of association, list of, 272 .
Receipts and disbursements, expected, in new association, I I3I 20.

Receipts for taxes, 214, 30I.

Record, accounting, 269; appraisal, 300 ; auxiliary, 299; insurance, 301 ; of association, access for assessment purposes, 437 .

Recording mortgages in county offices, I9I.

Recording procedure, accounting, 275.

Re-financing loans, 320 .

Refunding straight loans, 219, 262.

Register, stock, 299.

Regularity, enforcement of, 34 .

Regularity of income, desirable, 65 .

Regulation by state, $363-384$; the problem, 367 .

Re-investment of funds promptly, 65.

Re-investment of interest and dividends, I I 2.

Release of mortgage, before maturity, 221.

Renewal of loan, avoided by amortization, 255.

Rental of homes, U. S. Census reports, 5 I 7 .

Rent, economic, useful in checking appraisal, 235 .

Rent, "one-per-cent rule" in appraisal, 24 I.

Repayment of loan before maturity, I 2, I 20, I 43 .

Repayment not provided for in straight mortgage loan, 259.

Repayment, policy, I 43 .

Report, fees, 419.

Report of Commissioner Wright, I893, 462 .

Reports, of associations, 293, 374.

Reports of Secretary Cellarius of U. S. League, 463 .

Reports, regarding validity of title, 300.

Reserve, contingent, $342-350$; effect on dividends, 355 ; legal requirements, 397,404 ; portion credited on early withdrawal, I 7 I; similar to surplus, 290 ; size, 347 ; source, 345 ; taxation, 417 ; withdrawal, legal requirements, $4 \mathrm{II}$.

Reserve-fund stock, Oregon, 72.

Reserve, legal interpretation, 344 .

Resolutions, blanket, for borrowing by association, 127 .

Resources, explained, 295 ; list of, 281.

Revenue act of 1924,428 .

Rhode Island, guarantee-stock, 72 . 
Risk, assumption of, 65 ; differences among shares, 75-78.

Rivalry, important in community campaigns for business building, 3 I5.

"Rules of the game" (state laws), 385-4I4.

Safety, increased by high-grade leadership, 489-496; indicated by lower interest rate, 159 ; depends upon title and appraisal, 206; of prime importance in attracting funds, I I O-I I I.

Salaries, individual, as a source of funds, I I ; president, 96 ; restrictions, legal, 4II ; secretary, I 00 ; state supervisors, 373 ; treasurer, ror.

Sale of property, price, basis of valuation for loan, 234 .

Salesmen, paid, use of, 309 .

Savings and loan associations (same as building and loan associations).

Savings, bank funds, use of, 23 .

Savings, effect of withdrawal fees, 178 .

Savings, insured, by use of life insurance, I 28 .

Savings, juvenile, 73, 323-333.

Savings, limitations, 355,398 ; through borrowing instead of withdrawing, 173.

Scandinavia, coöperative credit, 474 .

School savings, 323-333.

Secretary, creation of business, a duty, 99; duties, 98-гог; qualifications, 97 ; salary, 100.

Securities, approval by supervisor before purchase, 369 ; deposit with state official, 4II; commission, as supervising body, 377 ; negotiability, 409; New York Land Bank, 479; purchase of, with excess funds, 162 ; types of, 22 ; use for contingent reserve, 349 .

Security for borrowed money, I 26 ; between associations, 478 .

Selection of plan, 85 .

Selling shares, preliminary, in new association, 84 .

Selling the installment loan, 3 ro.

Serial plan, 38-4I ; criticism of, 55 ; earnings, 298; example of expected income, II $3^{-120}$; sample ledger page, 285 ; use of reserve, 343 .

Series, installment, separate accounts, 297; issuance of shares in, 38 .
Service regarding values and construction, paid for by fees, 180 , 216.

Shareholders, liability, 409; minutes of meetings, $30 \mathrm{r}$.

Shares, advance payments, 335 ; changes in book value during life of loan, 136 ; constitute all of association's capital, 63 ; deposit, 68 ; directors', requirements of law, 392 ; double-payment, 73 ; dues restrictions, 398 ; free, 39 ; full-paid, 60 .

Shares, installment, $34,67-69$; installment, true earnings of, 338 ; installment, withdrawal before maturity, 170.

Shares, limit in hands of individual, 355,398 ; maturity, effect of fees, 182 ; optional installment, 69 ; paid-up, 69 ; paid-up and prepaid, introduction of, I $21-123$; permitted by law, 396 ; pledged for loan, legal provisions, 402 ; prepaid, 69 ; quorum of, 390 ; term, effect upon withdrawal, 169.

Signatures to loan papers, 216.

Sinking fund, to repay loan, 135 .

Size of association, limit, depends upon ability of secretary, 305 .

Size of home, determination of, depends upon income, 440 .

Slips, debit, use of in accounting, 284.

Societies for credit, early history, 453.

Soliciting business by mail, 316 .

Solicitors, paid, r 08, 304, 309 .

Solvency, record of, for banks and building and loan associations, 364-367.

Source of contingent reserve, 346 ; of funds, I 2, I I O-1 33 .

South Dakota, guarantee-stock, use of, 72; law regarding reserve, 345 .

Split loan, 154; Stevens' uniformpayment plan, 193-197.

Stamp-selling machines, for juvenile savings, $33 \mathrm{I}$.

Stamp taxes, federal, 429.

Statement, annual, explained, 295 ; daily, 294.

Starting an association, 79-92; dangers to avoid, 90 ; first regular meeting, $86-87$; income to be expected, I $3-120$; making the decision, 83 ; organizing the personnel, 93-109; prerequisites to success, 88-92; selecting directors, 87 ; selecting the interest 
rate, 158 ; suggestions for bylaws, 497 .

State laws, 385-414; regarding withdrawal, 186-189.

State leagues, functions, 485 .

State supervision, approval of securities purchased with excess funds, 163 ; approval of surety bonds, 103 .

State taxation, 416; of members, 434.

Statistics, as to plans in use, 6o, 501.

Statistics, Kansas, 53.

Statistics, U. S., comprehensive figures lacking since 1893,462 ; estimates 1893 to $1923,514-516$.

Statutes, regarding withdrawals, I 86.

Stevens' split-loan plan, I54; uniform payment, application to any rates, I 93-1 97 .

Stock compared to shares, 34 .

Stock, "contingent-reserve," Kansas, 72 ; guarantee, 71 ; installment, 67 ; Kansas permanent, 72 ; loans, I 98 ; loan, procedure, 220 ; New York Land Bank, ownership by associations, 482 ; prepaid, 69 .

Stock records, legal requirements, 4 I O ; register, 299.

Stock tax, federal, 429.

Straight loans, competition, 152 ; refunding, 219; legal permission to use, 402 .

"Strawmen," dangerous in making loans, 202.

Street improvements, effect upon value, 233 .

Subdivisions, not a good basis for new associations, 90.

Subscription blanks, 84 .

Summarizing accounts, 287, 294.

Supervision, $363-384$; by commissions, 377 ; Georgia, 412 ; methods, 368 .

Supervisor, approval of by-laws, 399 ; approval of fidelity bonds, 394; approval of office building, legal provisions, 406; approval of plan before securing charter, 85 .

Suretyship, corporate, 393; personal, ro3.

Surplus account, use of, 290.

Symbols, useful in appraising house, 237.

Table, amounts of pre-payment required to mature $\$ 100$ in various times, 70 .
Table, effect of fees on loan costs, 260.

Table of expected maturities of shares for different payments, 68.

Table of expected maturities of prepaid shares, 69.

Table, repayment of seven per cent loan, I $4 \mathrm{I}$.

Table, repayment of six per cent loan, 139.

Tables, earnings and losses on early withdrawal, 178 .

Taxation, 4I 5-438; exemption from income tax, federal, 433 ; exemption of rural-credit shares, Kansas, 226, 435; exemption of shares of non-residents, Nevada, 4I2; guarantee stock, taxation of, 432 ; notices and receipts, 214; personal property, avoided, 214 ; personal property, legal restrictions, 436 ; record of receipts, 301 ; state, exemption, 427.

Teachers, coöperation, in obtaining juvenile savings, 332 .

Team work, needed in community campaigns, 315.

Tenancy, and the house shortage, 444.

Tenancy, changes as shown by U. S. Census, 447,517 .

Tenure of homes, U. S. Census report, 450 .

Term, charter, length of, 388 .

Term, holding real estate permitted, 406.

Term of office, directors, 392.

Term of shares, effect upon withdrawal, 169 .

Terminating association, business transacted, 35 .

Terminating plan, $34-38$; failure of, 37.

Terms, meaning of, see Glossary, 521 .

Territory, business, legal limitations, 90.

"Three-per-cent" companies, elimination, 493.

Thrift, 330,439 ; said to be discouraged by fees, 181 ; said to be encouraged by fees, I66, 180 .

Time, equated, use in declaring dividends, 357.

Title, abstract of, 206; defects avoided by trust deed, 211 ; examination by attorney, 206; insurance, 206; problems, 207; record of, 300 .

Titles in use by associations, 518 . 
Tornado insurance, 214.

Training men for appraisal work, 490.

Transfer of loan, 263; application, 264 ; approval, 265.

Transfer of property to avoid foreclosure, with approval of association, 224.

Treasurer, duties, гог; salary, гог.

Trial balance, 293 .

Trust companies, investments of, 24 .

Trust deed, described, $211-214$.

Trustee, needed in refunding loans, 220.

Type of association, effect upon number and amount of witldrawals, 169 .

Uniform accounts, 299, 369 .

Unincorporated associations, legal status, 387.

United States, history of associations, 456 .

U. S. League of Local Building and Loan Associations, history and functions, 485 .

Urban-land economics, suggested reading, 496 .

Usury law, application to association loan, 406.

Utah, guarantee-stock associations, 72.

Vacant property, appraisal of, 232 .

Vacations, for office staff, 105.

Values, intangible, of importance while making appraisal, 246.

$V$ alue, items to be considered, 23I ; of house, cubic foot basis, 242, of house, relation to personal income, 239; of property "OnePer-Cent Rule," applied to income, 24I ; recognition of items before purchase, 445 .

"Vendor's Privilege and First Lien" (type of mortgage used in Louisiana), 192.

Verification of payments, 275 .

Vice-President, duties, 96.
Voting, legal provisions for, 390.

Vouchers, signature, 284 .

Wages as a source of funds, IIr.

Warrant, one of the loan papers in some states, $2 \mathrm{I}$ I.

Washington associations, withdrawal practice, I84; juvenile savings, 329 ; law regarding reserve, 345 ; use of guaranteestock, 72.

Wind insurance, 214.

Wisconsin, decision regarding creation of reserve, 344 .

Withdrawal, 165-189; addition of excess earnings, unusual, I71 ; and pass-book credits, $36 \mathrm{r}$; by borrowing, I44; causes, I 67 ; charges avoided by borrowing, I73; charges, in use, I70-179; credit for estimated earning after last dividend date, 172 .

Withdrawal, Dayton Plan, 183 ; earnings and losses when fees are charged, I78; fees, 40, 175-180; fees, avoided by borrowing, 252 ; fees, legal provisions, 400 ; forced, Washington, 345; guaranteestock associations, 185 ; juvenile savings, 327 ; notice, 185-186.

Withdrawal of Kansas "permanent stock" ("contingent reserve" stock), 52 .

Withdrawal, percentage of, I68; provisions, Kentucky, 4I 2 ; provisions of law, 186; reasons for charging fees, 165-167; returnable fees, 337 .

Withdrawal value, clear explanation to borrower, 22I.

Withdrawal, Washington Associations, 184 .

Women, married, as share owners, 398.

Work sheet, dollar-month formula, I 57 .

Zoning ordinances, effect upon appraisal, 245. 



